Красинский Владислав Вячеславович

\title{
ЗАЩИТА ГОСУДАРСТВЕННОГО СУВЕРЕНИТЕТА
}

Монография

MOCKВА 2017 
Автор выражает глубокую благодарность Алешину Владимиру Васильевичу, Арсеньеву Валерию Васильевичу, Дамаскину Олегу Валерьевичу, Красинской Марине Евгеньевне за помощь и полезные советы при подготовке книги

Aвmop:

Красинский В.B. - профессор кафедры уголовного права Голицынского пограничного института, доктор юридических наук, полковник.

\section{Рецензенты:}

Керимов А.Д. - профессор Института права и национальной безопасности Российской академии народного хозяйства и государственной службы при Президенте Российской Федерации, профессор, доктор юридических наук;

Клеандров М.И. - судья Конституционного Суда Российской Федерации, заслуженный юрист Российской Федерации, заслуженный деятель науки Российской Федерации, доктор юридических наук, профессор, член-корреспондент РАН.

Красинский В.В.

Защита государственного суверенитета: монография. М.: Норма, 2017. - $790 \mathrm{c}$.

В монографии рассматриваются современные концептуальные подходы к защите государственного суверенитета, раскрыты теоретикоправовые, политико-правовые и конституционные аспекты защиты государственного суверенитета Российской Федерации и зарубежных стран, исследована российская национальная система конституционно-правовой защиты государственного суверенитета и даны предложения по ее совершенствованию. Книга предназначена для государственных служащих, сотрудников правоохранительных органов, преподавателей и аспирантов юридических вузов и факультетов, представителей политических партий, СМИ и правозащитных организаций. 
Посвящается моим дорогим родителям -

Красинской (Артюшиной) Татьяне Николаевне и Красинскому Вячеславу Михайловичу 


\section{ОГЛАВЛЕНИЕ}

ВВЕДЕНИЕ

ГЛава 1. ТЕОРИЯ ГОСУДАРСТВЕННОГО СУВЕРЕНИТЕТА И ЕЁ ГЕНЕЗИС: КОНЦЕПТУАЛЬНОЕ ОБОСНОВАНИЕ ЗАЩИТЫ ГОСУДАРСТВЕННОГО СУВЕРЕНИТЕТА .................................................

1.1. Понятие и сущность государственного суверенитета ......................................... 13

1.2. Государственный суверенитет в российской политико-правовой и конституционной доктрине ....................................................................................

1.3. Государственный суверенитет в зарубежной политико-правовой и конституционной доктрине.....

1.4. Концептуальные подходы к защите государственного суверенитета......92

1.5. Механизмы защиты государственного суверенитета...................145

ГЛава 2. ТЕОРИИ И ПРЕДЕЛЫ ОГРАНИЧЕНИЯ ГОСУДАРСТВЕННОГО СУВЕРЕНИТЕТА

2.1. Теоретическое обоснование ограничения государственного суверенитета и доктрина «мирового правительства» 194

2.2. Ограничение государственного суверенитета правами человека 214

2.3. Влияние глобализации на государственный суверенитет 224

2.4. Теории «ограниченного» суверенитета и механизмы государственной интеграции в федеративных государствах.

2.5. Правовые позиции российских и зарубежных органов конституционной юстиции о пределах ограничения государственного суверенитета.............267 Глава 3. КОНСТИТУЦИОННО-ПРАВОВЫЕ МЕХАНИЗМЫ ЗАЩИТЫ ГОСУДАРСТВЕННОГО СУВЕРЕНИТЕТА РОССИЙСКОЙ ФЕДЕРАЦИИ .305

3.1. Понятие и общая характеристика конституционно-правовой защиты государственного суверенитета Российской Федерации ... 305 
3.2. Конституционно-правовая защита государственного суверенитета Российской Федерации в социально-экономической сфере ................409 3.3. Конституционно-правовая защита государственного суверенитета Российской Федерации в политической сфере …………………………………......566 3.4. Конституционно-правовая защита государственного суверенитета Российской Федерации в идеологической сфере................................................681 3.5. Совершенствование конституционно-правовых и иных механизмов защиты государственного суверенитета Российской Федерации.....................738 ЗАКЛЮЧЕНИЕ ................................................ 750

СПИСОК ИСПОЛЬЗОВАННЫХ ИСТОЧНИКОВ И ЛИТЕРАТУРЫ............759

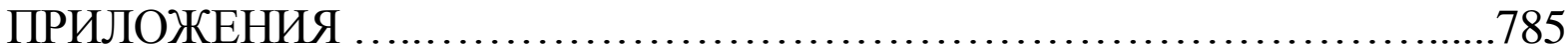




\section{ПЕРЕЧЕНЬ СОКРАЩЕНИЙ}

Евразийский экономический союз - ЕАЭС

Военно-техническое сотрудничество - ВТС

Закрытое административно-территориальное образование - ЗАТО

Защита государственного суверенитета - ЗГС

Защита государственной тайны - ЗГТ

Иностранная некоммерческая неправительственная организация - ИННО

Контртеррористическая операция - КТО

Местное самоуправление - МСУ

Национально-культурная автономия (НКА)

Некоммерческая организация - НКО

Организация Договора о коллективной безопасности - ОДКБ

Собрание законодательства Российской Федерации - СЗ РФ

Совет Безопасности Организации Объединенных Наций - СБ ООН

Содружество Независимых государств - СНГ

Средства массовой информации - СМИ

Российская газета - Рос. газ

Российская Федерация - РФ

Чрезвычайное положение - ЧП

Военное положение - ВП 


\section{ВВЕДЕНИЕ}

Современные тенденции военно-политической и социальноэкономической обстановки в мире находят выражение в формировании комплекса вызовов и угроз для международной безопасности, стабильного и независимого развития многих стран. В качестве объекта прямых и косвенных посягательств нередко выступают суверенитет и конституционный строй государств.

В настоящее время проблема защиты государственного суверенитета в является крайне актуальной для нашей страны. Как отметил Президент РФ В. Путин на заседании Совета Безопасности 22 июля 2014 г., "суверенитет и территориальная целостность - фундаментальные ценности. Речь идет об обеспечении независимости и единства государства, надежной защите территории, конституционного строя, своевременной нейтрализации внутренних и внешних угроз. Однако сегодня в мире все чаще звучит язык ультиматумов и санкций. Само понятие государственного суверенитета размывается. Неугодные режимы, страны, которые проводят независимую политику или просто стоят на пути чьих-то интересов, дестабилизируются"1.

Россия является одной из ведущих мировых держав, которая на протяжении всей своей истории вынуждена защищать свою идентичность и политическую независимость. Новые реалии межгосударственных отношений и внутриполитических конфликтов, повышение фактора комбинированной (военной и "мягкой") силы, трансформация международных норм и институтов требуют использования не только традиционных экономических, политических, военных методов защиты государственного суверенитета, но и развития гибкого конституционноправового инструментария и правоприменительной практики его защиты.

1 Заседание Совета Безопасности. URL: http:// www.kremlin.ru/news/46305 (дата обращения 23.07.2014). 
Необходимость конституционно-правовой защиты российской государственности связана с широким спектром реально существующих внутренних и внешних посягательств на государственный суверенитет РФ.

В современных условиях наиболее опасные угрозы государственному суверенитету РФ внутри страны представлены значительным социальным расслоением и формированием дискриминационной социальной системы на основе неравенства материальных возможностей граждан, расширением масштабов коррупции, теневой экономики, ущемлением законных экономических интересов государства, демографической диспропорцией, вызванной трудовой миграцией, обострением межнациональных и межконфессиональных отношений, сращиванием криминальных структур с органами государственной власти и местного самоуправления, террористической активностью бандподполья на территории Северного Кавказа и других регионов России.

Геополитические условия, влияющие на военно-политическую обстановку в современном мире, способствуют усилению борьбы США и их союзников за сохранение глобального доминирования, с одной стороны, с другой - за формирование многополюсного мира, сохранение государствами суверенитета и национальной самобытности. В условиях турбулентности, продолжающейся девальвации норм международного права складывается практика ограничения мировыми и ведущими региональными державами суверенитетов отдельных государств, навязывания им определенных антиконституционных политических сценариев для решения собственных задач. Между тем, как отмечается в Концепции внешней политики Российской Федерации, утвержденной Указом Президента РФ от 12 июля 2008 года № 1440, "попытки принизить роль суверенного государства как основополагающего элемента международных отношений, ввести в практику разделение государств на категории с различным объемом прав и обязанностей несут в себе угрозу подрыва международного правопорядка, а 
также чреваты произвольным вмешательством во внутренние дела суверенных государств".

Подобные попытки предпринимаются и в отношении России. Политическим руководством США и ЕС против нашей страны развязана беспрецедентная информационная, экономическая и дипломатическая война. Любые события, способствующие укреплению государственного суверенитета РФ, крайне негативно воспринимаются многими западными "партнерами". Выдвигается тезис о "российской угрозе" цивилизованному миру и попытках "реванша" за поражение в "холодной войне". На фоне антироссийских санкций, введенных Соединенными Штатами и их союзниками с целью подрыва экономической и политической систем России, смены высшего политического руководства российского государства все более заметное значение приобретают внешние угрозы государственному суверенитету РФ. В настоящее время спецслужбы и организации США и стран НАТО продолжают агрессивный курс на ослабление позиций России на пространстве СНГ, принимают меры по консолидации радикальных оппозиционных политических сил и дискредитации российских государственных институтов с целью возможного ослабления, изменения или подрыва конституционного строя России. Стратегической целью является подрыв российской политической системы путем спонсирования "цветных революций", инспирирования "протестной" активности, явных или латентных сепаратистских настроений, а также дезинтеграции страны с последующим её расколом на несколько управляемых, слабых в политическом, экономическом и военном отношении государственных образований. C момента осуществления антиконституционного государственного переворота в Украине основная ставка делается на втягивание России в конфликт на Донбассе и ослабление экономики. Для этого используются возможности СМИ, зарубежных и подконтрольных 
национальных неправительственных организаций, информационнопропагандистских структур и диверсионно-террористических формирований.

Многие зарубежные и связанные с ними национальные неправительственные организации и СМИ занимаются целенаправленным сбором информации о социально-политических процессах в России, политических партиях, перспективных представителях общественных организаций, органов власти, формируют выгодное Западу общественное мнение. Спектр угроз государственному суверенитету России существенно расширяется в период организации и проведения федеральных выборов, поскольку возникает реальная опасность использования радикальными оппозиционными силами технологий «цветных революций».

Главные устремления антироссийских сил направлены на формирование оппозиционной коалиции, способной по "украинскому сценарию" инспирировать протестные настроения и в последующем изменить политический курс руководства страны неконституционными методами. Важнейшая роль в этом процессе отводится организации незаконных массовых публичных мероприятий с участием молодежи.

Немалое опасение вызывает целенаправленная деятельность финансируемых Западом сетевых структур по мониторингу ситуации в России. Отмечаются попытки сбора информации об общественнополитическом климате, взаимоотношениях органов власти и бизнеса, федерального Центра и субъектов Федерации, межконфессиональных и межнациональных отношениях, a также о фактах нарушения законодательства с целью дальнейшего тенденциозного их освещения.

Руководство РФ на национальном и международном уровне принимает адекватные меры по защите государственного суверенитета нашей страны. Законодательная власть устанавливает нормативные правовые основы организации и функционирования российского государства, формирования и воспроизводства институтов публичной власти. Органы исполнительной 
власти, спецслужбы и правоохранительные структуры обеспечивают реализацию решений государственных органов и защиту государственной власти в условиях антиконституционных посягательств. Суды осуществляют правосудие по конституционным, гражданским, административным и уголовным делам и принимают постановления, обеспечивающие единство правового пространства на всей территории РФ.

Наряду с перечисленными правотворческими, правоохранительными и правоприменительными мерами особое значение в механизме защиты российской государственности имеет деятельность Конституционного Суда РФ, который осуществляет защиту конституционного строя, восстанавливает конституционную законность и правопорядок, защищает права и свободы граждан, обеспечивает верховенство и прямое действие Конституции. Решения Конституционного Суда РФ обязательны на всей территории РФ для всех представительных, исполнительных и судебных органов государственной власти, органов местного самоуправления, предприятий, учреждений, организаций, должностных лиц, граждан и их объединений. При этом конституционно-правовая защита государственного суверенитета в решениях Конституционного Суда РФ охватывает все сферы жизни российского общества. Не случайно именно органы конституционной юстиции, как показали трагические события 1993 г. в России и 2014 г. в Украине, становятся первоочередным объектом антигосударственных посягательств, направленных на изменение или подрыв конституционного строя ${ }^{1}$.

${ }^{1}$ В 1993 г. антиконституционные действия Президента РФ в отношении законно избранных органов государственной власти привели к прекращению деятельности советов всех уровней и спровоцировали вооруженные столкновения. После того как Конституционный Суд РФ признал действия Президента не соответствующими Конституции, деятельность Конституционного Суда РФ Указом Президента РФ от 7 октября 1993 г. № 1612 была приостановлена. Схожая ситуация сложилась в Украине в 2014 г. 24 февраля 2014 г. Верховная Рада Украины своим постановлением в нарушение законодательных процедур отстранила от должности членов Конституционного Суда Украины, назначенных по квоте Рады, и потребовала увольнения конституционных судей, назначенных Президентом. Тем самым все украинские органы власти, сформированные в 
Современная теория конституционного права, государственное строительство и международные отношения остро нуждаются в концептуальном и политико-правовом обосновании защиты государственного суверенитета.

Конституционное судопроизводство позволяет защищать государственный суверенитет, опираясь на институты гражданского общества, не прибегая к насилию и не задействуя в полном объеме организационно-ресурсную мощь карательного механизма государства. Ценность конституционно-правовой защиты государственного суверенитета, являющейся показателем цивилизованности общества и функциональности государства, неизмеримо выше традиционно силового подавления противников и применения карательных методов воздействия в отношении политических оппонентов. Гибкое и оперативное использование конституционно-правовых механизмов защиты государственного суверенитета позволяет юридически оценить деструктивный потенциал антигосударственных сил и задействовать самый широкий спектр законных средств для реагирования на любые механизмы ослабления и подрыва государственного суверенитета, начиная от тайной подрывной деятельности иностранных государств и инспирирования "цветных революций" и заканчивая другими проявлениями скрытой и прямой агрессии.

C учетом изложенного, исследование вопросов защиты государственного суверенитета в конституционно-правовой доктрине и практике представляется значимым и актуальным.

результате вооруженного государственного переворота, были лишены конституционной легитимности. 
ГЛава 1. ТЕОРИЯ ГОСУДАРСТВЕННОГО СУВЕРЕНИТЕТА И ЕЁ ГЕНЕЗИС: КОНЦЕПТУАЛЬНОЕ ОБОСНОВАНИЕ ЗАЩИТЫ ГОСУДАРСТВЕННОГО СУВЕРЕНИТЕТА

\section{1. Понятие и сущность государственного суверенитета}

Мощь и эффективность государственной власти измеряется в первую очередь ее суверенностью. Проблемы государственного суверенитета всегда находились и продолжают оставаться в центре внимания отечественных и зарубежных государствоведов, политологов и философов. Усилиями ученых и государственных деятелей на протяжении нескольких столетий была разработана теория государственного суверенитета, которая внесла неоценимый вклад в обеспечение национальной общественно-политической стабильности, международного правопорядка, позволила усовершенствовать и приблизить к населению государственные институты власти, повысить их ответственность перед обществом.

В основе данной теории лежат дефиниции, выводные знания и доказательства, предложенные представителями различных политикоправовых и конституционных доктрин.

Теоретико-правовое исследование государственного суверенитета представляется логичным начать с изучения специфики государственной власти, характеристики свойств государственного суверенитета, раскрытия его понятия, сущности и содержания.

Особенности государственной власти связаны с тем, что она отделена от общества, распространяется на всех его членов и осуществляется специальным аппаратом управления и принуждения.

Как и другие разновидности публичной власти, государственная власть осуществляет руководство общественными делами. Но в отличие от предшествовавшей ей родоплеменной власти государственная власть 
возвышается над населением, является единственной по содержанию и организации суверенной властью в обществе и регулирует основные стороны общественной жизни, осуществляя свои властные функции по отношению ко всем субъектам, участвующим в управлении делами общества.

Политическая негосударственная власть не имеет аппарата управления и принуждения. Она обычно опирается на массовые движения или вооруженные отряды.

Как отмечает В.Е. Чиркин, "только государственная власть юридически уполномочена от имени всего общества применять легализованное и в большинстве случаев легитимное принуждение, насилие" ${ }^{\text {. }}$

Только государственная власть обладает юридически (иногда и фактически) верховенством, суверенным свойством, которое реализуется путем установления в обществе единого правопорядка, правоспособности государственных органов и общественных организаций, в наделении правами и обязанностями должностных лиц и граждан. Именно в верховенстве выявляется определяющее положение государственной власти по отношению к любым иным властным проявлениям. Никакие субъекты политической деятельности не могут длительное время противостоять суверенной государственной власти. В государстве не может быть нескольких государственных властей со своими институтами ${ }^{2}$. Наконец, полновластная государственная власть вправе объявить любые общественные властные проявления вне закона.

По мнению государствоведа В.С. Шевцова, "верховенствующее положение государственной власти в обществе реализуется прежде всего в установлении и претворении в жизнь системы правовых норм, основные особенности которых заключаются в том, что они: во-первых, являются прямым порождением государственной власти, воплощают ее политику; во-

1 Чиркин В.Е. Государствоведение. М.: МПСУ, Воронеж, 2012. С. 107.

2 Об этом свидетельствуют события в России в 1993 г. и Украине в 2014 г. 
вторых, обеспечиваются в своем применении в необходимых случаях принудительной силой государства; в-третьих, распространяются на все общество в целом. Устанавливая посредством правовых актов определенный порядок деятельности государственных учреждений, взаимоотношений между государством и гражданином, между различными ведомствами, организациями, предприятиями, определяя основные нормы поведения людей, государство организует экономическую, социально-политическую, культурную жизнь общества таким образом, чтобы обеспечить полное и своевременное удовлетворение объективно возникающих потребностей и способствовать его нормальному функционированию и развитию"1.

В советский период верховенство как суверенное свойство государственной власти учеными-юристами рассматривалось в трех аспектах:

- через универсальность государственной власти, т.е. распространение её властной силы на всю территорию, всё население и все организации страны $^{2}$;

- через полновластие (исключительность): возможность признания государственной властью ничтожным любого проявления всякой другой общественной власти;

- через наличие у государственной власти особых средств воздействия и принудительного механизма реализации государственных предписаний (законодательство, органы принуждения и др.) ${ }^{3}$.

${ }^{1}$ Советское государственное право. М.: Высшая школа, 1978. С. 74. В данном случае государственная власть выступает не как социально-политическое явление, а как институт конституционного права.

2 Суверенная власть государства распространяется на определенное пространство, замкнутое государственными границами, и население, организованное по территориальному признаку.

${ }^{3}$ Проблемы теории государства и права / Под ред. С.С. Алексеева. М.: Юрид. лит., 1979. C. $49,50$. 
Отдельные ученые рассматривали государственный суверенитет с позиций аксиологического подхода: как показатель совершенства, развитости государства ${ }^{1}$.

В настоящее время традиционный подход к пониманию суверенитета государства состоит в том, что наряду с верховенством в конструкцию суверенной государственной власти входит и её независимость, которая понимается как возможность государства самостоятельно решать свои внутренние и внешние задачи и функции ${ }^{2}$. Суверенитет государства в этом случае рассматривается как «специфический признак государства, выражающий верховенство государственной власти по отношению ко всем иным организациям и лицам в стране и независимость ее в сфере взаимоотношений данного государства с другими государствами» ${ }^{3}$.

Если не относить верховенство государственной власти только к внутригосударственным делам, а её независимость - к межгосударственным отношениям (что вполне обоснованно), логическим следствием такой точки зрения выступает позиция, что никакие другие организации внутри страны и за рубежом не могут функционально заменить государство.

Некоторые юристы рассматривают независимость государственной власти не как самостоятельное свойство, а как необходимое условие верховенства ${ }^{4}$. Автор не разделяет эту точку зрения, поскольку независимость как условие выступает внешним явлением объективной реальности, средой для существования верховенства, между тем как свойства суверенитета имманентно присущи ему.

Таким образом, краткий анализ юридической доктрины и понятийнокатегориального аппарата современной теории государственного

${ }_{1}^{1}$ Алексеев С.С. Государство и право. М.: Проспект, 2015. С. 8.

1979. С. 50. конституционно-правовом измерении. Сб. статей и материалов. М.: Рос. газ., 2007. С. 80.

${ }_{4}^{4}$ Сторонником данной точки зрения выступал государствовед В.С. Шевцов. 
суверенитета позволяет сделать вывод о том, что государственный суверенитет непосредственно выражает сущность государственной власти через ее суверенные свойства - верховенство и независимость ${ }^{1}$. Только суверенная государственная власть способна самостоятельно решать любые внутри- и внешнеполитические задачи, обеспечивать реализацию своих властных полномочий в отношении всех субъектов права в пределах своей территориальной юрисдикции.

В структуре государственного суверенитета присутствует искусственная, на наш взгляд, конструкция, в соответствии с которой некоторые теоретики права выделяют внутренние и внешние аспекты суверенитета. Приверженцы данной точки зрения исходят из неоспариваемого посыла, что государственный суверенитет рассматривается как верховенство политической власти и законов внутри страны и за ее пределами, как независимость государства во внешних и верховенство во внутренних делах.

В таком ракурсе суверенитет государства внутри страны (внутренний аспект суверенитета) выражается: в единстве и распределении государственной власти на всё население и общественные организации страны; в общеобязательности решений органов государства для всех, кого они касаются, на территории государства; в прерогативе, т.е. возможности отмены и признания ничтожным любого проявления другой общественной власти ${ }^{2}$.

\footnotetext{
${ }^{1}$ Теория государства и права / Под ред. С.С. Алексеева. М.: Юрид. лит., 1985. С. 41; Теория государства и права / Под ред. В.К. Бабаева. М.: Юристъ, 1999. С. 55; Лазарев В.В., Липень С.В. Теория государства и права. М.: Спарк, 2004. С. 45; Cырых B.M. Теория государства и права. М.: ЗАО Юстицинформ, 2005. С. 21. В.М. Корельский, М.Н. Марченко и В.Е. Чиркин включают в понятие «государственный суверенитет» такие компоненты, как верховенство, единство и независимость государственной власти. См. Проблемы теории государства и права / Под ред. С.С. Алексеева. М.: Юрид. лит., 1979. С. 49, 50; Теория государства и права / Под ред. М.Н. Марченко. М., 1987. С. 39; Чиркин В.E. Государствоведение. М.: МПСУ, Воронеж, 2012. С. 107.

2 Теория государства и права / Под ред. М.Н. Марченко. М., 1987. С. 39.
} 
Суверенитет государства за пределами его территории (внешний аспект суверенитета) проявляется в способности государства выступать полноправным субъектом международного права, самостоятельно формировать и реализовывать внешнюю политику, защищать свою целостность и территориальную неприкосновенность и распространять свою юрисдикцию в пределах экстерриториальности. Внешний суверенитет неразрывно связан с иммунитетом государства от юрисдикции иностранных государств ${ }^{1}$. Это означает, что суверенное государство не подчиняется органам власти иностранных государств. Суверенный иммунитет государства согласно доктрине международного частного права включает несколько элементов ${ }^{2}$ :

- судебный иммунитет (неподсудность государства суду иностранного государства);

- иммунитет от предварительного обеспечения иска;

- иммунитет от принудительного исполнения иностранного судебного решения;

- иммунитет собственности государства - правовой режим неприкосновенности государственной собственности, находящейся на территории иностранного государства.

Логика внутреннего и внешнего суверенитета понятна. Иммунитеты государства встречаются в практике частно-правовых отношений с участием иностранного элемента. Международно-правовые аспекты суверенитета

1 В настоящее время все чаще используют понятие т.н. «функционального (ограниченного) иммунитета» государства, согласно которому все действия государств подразделяются на действия в качестве суверена и в качестве частного лица. Государство пользуется иммунитетом, только если оно выступает как суверенный субъект властвования. Основным международно-правовым документом, регулирующим иммунитеты государства, является основанная на концепции функционального (ограниченного) иммунитета государства Европейская конвенция о государственном иммунитете (Базель, 1972). Концепция функционального (ограниченного) иммунитета иностранного государства и его собственности была законодательно закреплена в Федеральном законе от 3 ноября 2015 г. № 297-Ф3 «О юрисдикционных иммунитетах иностранного государства и имущества иностранного государства в Российской Федерации». Более подробно см. параграф 3.2 данной работы.

${ }^{2}$ Международное частное право / Под ред. Г.К. Дмитриевой. М., 2002. 
рассматриваются в рамках международного публичного права. Однако выделение дополнительных элементов в структуре конституционно-правовой теории государственного суверенитета представляется излишним, поскольку невозможно представить себе суверенное только во внутриполитических или внешнеполитических вопросах государство. Направленность полномочий государства также не является критерием суверенности государственной власти. Только системная взаимосвязь верховенства и независимости государственной власти, характер принятых высшими органами власти решений и мер по их практическому воплощению позволяют судить о наличии либо отсутствии реального государственного суверенитета.

В терминологической системе теории государственного суверенитета на протяжении длительного времени различают государственный, народный и национальный суверенитет. Несмотря на тесную связь между ними, эти понятия различаются ${ }^{1}$.

Если государственный суверенитет - это выражение сущности верховной и независимой государственной власти, то народный суверенитет следует определять как реальное экономическое, социальное и политическое положение народа, позволяющее ему обладать полновластием в обществе и государстве ${ }^{2}$.

Поэтому народный суверенитет определяется как полновластие народа, т.е. обладание народом социально-экономическими и политическими средствами для реального участия в управлении делами общества и государства ${ }^{3}$.

${ }^{1}$ Автор разделяет точку зрения Н.Б.Пастуховой о том, что категории «народный» и «национальный» суверенитет носят скорее политический, нежели юридический характер. См. Пастухова Н.Б. Суверенитет и федеративная организация российского государства в условиях глобализации: конституционно-правовые аспекты. Дис. ... докт. юрид. наук. М.: РАГС при Президенте РФ, 2010. С. 179.

${ }_{2}^{2}$ Советское государственное право. М.: Высшая школа, 1978. С. 77.

3 Румянщев О.Г., Додонов В.Н. Юридический энциклопедический словарь. М.: Инфра-М, 1996. С. 300. 
Некоторые юристы справедливо рассматривают народный суверенитет как качественную сторону власти народа в системной взаимосвязи с принципами конституционного строя. По мнению Б.С. Эбзеева, народный суверенитет есть скорее не сама власть, а важнейший организационнополитический и функциональный принцип конституционного строя государства, реализация которого обеспечивает верховенство и полновластие народа ${ }^{1}$.

Национальный суверенитет - это реальная политическая, социальная, территориальная, культурная, языковая самостоятельность нации, которая проявляется в полноте суверенных прав нации и обеспечивает их наиболее полное осуществление. Суверенная нация самостоятельно решает вопрос о своей национальной организации и национально-государственном устройстве. Она вправе сохранять и свободно развивать свой язык, обычаи, уклад жизни, соответствующие национальные учреждения²

Народный и национальный суверенитет лежит в основе государственного суверенитета, поскольку именно государственный суверенитет выражает и гарантирует как волю народа в целом, так и каждой нации и народности в отдельности.

В.А. Лебедев и В.В. Киреев справедливо отмечают, что «суверенитет государства представляет собой выраженный особыми политико-правовыми средствами суверенитет народа» ${ }^{3}$. Поддерживая данную точку зрения как идеальную, автор всё же склоняется к более реалистичному пониманию взаимосвязи народного и государственного суверенитета. Государственный

1 Эбзеев Б.С. Личность и государство в России: взаимная ответственность и конституционные обязанности. М.: Норма, 2011. С. 54.

${ }_{3}^{2}$ Советское государственное право. М.: Высшая школа, 1978. С. 78.

3 Лебедев B.A., Киреев B.B. Концепция суверенной демократии: парадигма, проблемы, перспективы // Конституционное и муниципальное право. 2007. № 5. Сторонником данной точки зрения является также В.В. Горюнов. См. Горюнов В.B. Суверенитет и демократия - основополагающие принципы конституционного строя России / Суверенная демократия в конституционно-правовом измерении. Сб. статей и материалов. М.: Рос. газ., 2007. С. 184. 
суверенитет должен быть производен от народного, хотя далеко не всегда его полноценно выражает.

Трактовка государственного суверенитета как формы проявления народного суверенитета имеет следующие основания. Во-первых, государство как особая политическая организация общества призвана выражать волю народа и действовать в его интересах, решать общенародные дела. Подвергая справедливой и нередко острой критике отдельные государственные институты, следует осознавать, что другой организации, способной реализовать национальные интересы в полном объеме, просто не существует ${ }^{1}$. Только государство является официальным представителем всего общества. Во-вторых, именно народ располагает правом формировать аппарат государственной власти и воздействовать на него таким образом, чтобы в случае отклонения деятельности субъектов государственного управления от интересов народа привести ее в соответствие с такими интересами ${ }^{2}$. Во-третьих, адекватное выражение народного суверенитета в суверенитете государства является решающим условием самостоятельности внутренней и внешней политики государства, eе эффективности и прагматизма ${ }^{3}$. Именно независимый (суверенный) народ может наделить свое государство качеством суверенитета ${ }^{4}$.

Любопытную аргументацию взаимосвязи государственного и народного суверенитета выдвинул В.В. Горюнов. Ученый справедливо указал ряд случаев, когда прямая связь между суверенитетом государства и суверенитетом народа прерывается. Это происходит тогда, когда система

\footnotetext{
${ }^{1}$ Лебедев В.А., Киреев В.В. Указ соч.

2 Джагарян А.A. Концепция суверенной демократии в конституционном измерении / Суверенная демократия в конституционно-правовом измерении. Сб. статей и материалов. М.: Рос. газ., 2007. С. 139.

3 Лебедев В.А., Киреев В.В. Указ соч.; Лебедев В.А. Российская демократия: национальные особенности, проблемы и решения в глобализирующемся мире // Гражданин. Выборы. Власть. 2014. № 2. С. 99.

4 Горюнов B.B. Суверенитет и демократия - основополагающие принципы конституционного строя России / Суверенная демократия в конституционно-правовом измерении. Сб. статей и материалов. М.: Рос. газ., 2007. С. 176.
} 
формирования государственного аппарата не требует выявления воли народа (например, в условиях абсолютной монархии) либо когда процедуры выявления его воли исключительно формальны и не позволяют обеспечить демократичность деятельности государственных органов (что имеет место, в частности, в тоталитарных государствах $)^{1}$.

Автор разделяет точку зрения С.А. Авакьяна о том, что «государственный суверенитет производен от народного суверенитета и является его логическим продолжением, служит тому, чтобы никакие внутренние и внешние силы не препятствовали выражению воли народа; тем самым государство становится защитником интересов народа, в том числе и на международной арене»².

А. Джагарян также чётко акцентирует внимание на недопустимости внешнего воздействия на волю народа: "верховенство и полновластие народа характеризуется недопустимостью какого бы то ни было внешнего воздействия, в том числе со стороны иностранных государств и организаций, на формирование, принятие и реализацию государственно-властных решений"3.

Заслуживает поддержки позиция М. Соколова о том, что "вопросы властвования и политического преемства должны решаться исключительно внутри - без какого-либо внешнего вмешательства и уж тем более без прямого внешнего арбитража... Исключение внешних инстанций из решения

\footnotetext{
${ }^{1}$ Горюнов В.В. Указ. соч. С. 185.

${ }^{2}$ Авакьян C. A. Точка отсчета - народ // Рос. газ. 2006. 28 октября.

3 Джагарян А.А. Концепция суверенной демократии в конституционном измерении / Суверенная демократия в конституционно-правовом измерении. Сб. статей и материалов. М.: Рос. газ., 2007. С. 139. Именно поэтому действующее законодательство РФ последовательно реализует идею исключения зарубежного влияния на положение дел в стране как через кадровые, так и через структурные меры. См. Ст. 7 и 9 Федерального конституционного закона от 17 декабря 1997 г. № 2-ФКЗ «О Правительстве Российской Федерации», п.3.1 ст. 4 Федерального закона от 12 июня 2002 г. № 67-Ф3 «Об основных гарантиях избирательных прав и права на участие в референдуме граждан Российской Федерации», ч.6 ст. 9, ч.2 ст. 23 и ч.3 ст. 30 Федерального закона от 11 июля 2001 г. № 95Ф3 «О политических партиях».
} 
внутренних политических вопросов всегда являлось принципом всех цивилизованных стран"1 .

Отдельного внимания заслуживает вопрос о сущности государственного суверенитета.

Поскольку сущность государства заключается в том, что оно выступает орудием власти тех или иных классов, сословий или социальных групп, то рассмотрение сущности государственного суверенитета следует вести по пути фактического использования государственной власти в интересах правящих слоёв и эффективности деятельности системы государственных органов по отношению к населению.

В таком контексте государственный суверенитет может служить оценочной характеристикой государственного механизма и существующего политического режима ${ }^{2}$.

Провозглашение в конституции суверенитета народа и государства совсем не означает их реального наличия. В современном мире есть государства, в которых вся полнота и мощь власти, различные звенья государственного механизма направлены на обогащение и защиту коррумпированных чиновников, а централизованный бюрократический государственный аппарат, имеющий узкую социальную базу поддержки, для осуществления управления обществом прибегает к прямому насилию и подавлению. В то же время полновластие государства может успешно использоваться для развития политического, религиозного, национальнокультурного многообразия, расширения и реального осуществления прав и свобод граждан, поддержки независимых от государства и оппозиционных институтов гражданского общества, укрепление законности в деятельности государственных органов и учреждений.

\footnotetext{
${ }^{1}$ Соколов М. Суверенитет и свобода / Рrо суверенную демократию. Сб. М.: Европа, 2007. C. $13,15$.

2 В качестве политического режима в монографии рассматривается совокупность используемых методов осуществления государственной власти.
} 
Ни в коем случае не следует отождествлять государственный суверенитет и народовластие. В истории можно найти множество примеров, когда недемократические государства являлись суверенными в подлинном смысле этого слова. И напротив, значительное число стран с давними демократическими традициями государственным суверенитетом не обладали и не обладают ${ }^{1}$. При этом как суверенные, так и не обладающие реальным суверенитетом государства могут проводить социально ориентированную политику в сфере образования, здравоохранения, культуры, стимулировать технический прогресс, обеспечивать занятость трудоспособного населения. Это обусловлено тем, что современной тенденцией политической жизни любого государства является стремление правящих кругов иметь широкую социальную поддержку проводимой политики и придать своему правлению конституционный характер. В отличие от ранних исторических типов государств (рабовладельческих и феодальных) правящие силы современных государств используют не открытые формы осуществления политического господства подавления, а замаскированную защиту своего политического, экономического и идеологического влияния.

Другой важный момент заключается в том, что коррупционная пораженность, нарушения законности в деятельности государственного механизма и недоверие населения представительным органам власти (что может присутствовать как в демократических, так и в недемократических политических режимах) существенно затрудняет формирование и выражение воли народа, реализацию национальных интересов ${ }^{2}$.

${ }^{1}$ Как правильно отмечает Л.Ю.Черняк, «государственный суверенитет не зависит от государственного режима и формы правления. Привязывая суверенитет к демократии, мы тем самым ошибочно лишаем суверенитета недемократические государства. См. Черняк Л.Ю. Общетеоретические проблемы государственного суверенитета. Дис. ... канд. юрид. наук. Челябинск, 2007. С. 47-48.

2 Недоверие населения может быть вызвано получившими огласку фактами преступной деятельности выборных представителей и должностных лиц, массовыми фальсификациями в ходе выборов, использованием «административного ресурса», отстранением от участия в политической жизни ключевых оппозиционных кандидатов и др. 
Если сущность государственного суверенитета означает целевую направленность фактического использования верховенства и независимости государственной власти правящими слоями, то содержание государственного суверенитета составляет совокупность прав, необходимых для реализации функций государства. Именно в реализации этих правовых возможностей начинают действовать суверенные свойства государственной власти. Другими словами, чем шире спектр применяемых государством полномочий по реализации своих внутренних и внешних функций, тем больше оснований вести речь о глубоком наполнении реального содержания государственного суверенитета.

Права и обязанности являются неотьемлемой частью правоспособности любого государства, Они связаны с самим существованием государств и корреспондируют друг другу. Нарушение прав государства создает угрозу его существованию, а нарушение государством своих обязанностей создает угрозу существованию другого государства (государств) и нормальному функционированию межгосударственного сообщества ${ }^{1}$.

Следует учитывать, что в идеале суверенными правами государства являются только такие права, на осуществление которых его уполномочил народ. Иными словами, суверенные права государства предстают в качестве своеобразной проекции суверенных прав народа ${ }^{2}$. Но для этого население государства должно принимать активное участие в формировании органов власти и влиять на деятельность всех звеньев государственного механизма, что достижимо далеко не везде.

Особенность суверенных прав государства состоит в том, что:

1) кроме государства никакой другой субъект права их реализовать не может;

\footnotetext{
${ }^{1}$ Международное право / Под ред. А.А. Ковалева, С.В. Черниченко. М.: Омега - Л, 2006. С. 158.

${ }^{2}$ Горюнов В.В. Указ. соч. С. 185.
} 
2) речь идет о возможной деятельности государства, которая в разных социально-экономических условиях может отличаться своим содержанием и внешним проявлением.

В традиционный перечень исключительных суверенных прав государства входят: эмиссия, осуществление правосудия и исполнение наказаний, право решать вопросы войны и мира, право на самооборону, участие в межгосударственных объединениях, помилование и амнистия, монополия на правотворчество и налогообложение и др.

Юридически общепризнанного перечня суверенных прав государств не существует. Нормативное закрепление такие права получили лишь в межамериканской системе. В 1933 г. в Монтевидео была заключена Конвенция о правах и обязанностях государств, в которой с позиций декларативной теории признания была дана характеристика международной правосубъектности государств ${ }^{1}$. В Конвенции отмечалось, что "политическое существование государства не зависит от признания другими государствами. ... Признание государства означает, что государство, которое его признает, принимает правосубъектность другого государства со всеми правами и обязанностями, установленными международным правом. Признание является безусловным и бесповоротным".

Позднее положения Конвенции Монтевидео были в значительной степени восприняты в главе IV Устава Организации американских государств (г. Богота, 30 апреля 1948 г.).

В данном международном документе было закреплено, что "государства в юридическом отношении пользуются равными правами, а также имеют равные обязанности. Права государства не зависят от силы,

${ }^{1}$ Наряду с декларативной теорией признания государств, которую поддерживает большинство юристов-международников, истории международного права известны и специальные доктрины признания правительств (доктрины Тобара и Эстрады). Данные доктрины были направлены против государственных переворотов, революций и вмешательства извне во внутренние дела латиноамериканских государств. Подробнее см. Международное публичное право / Под ред. Бекяшева К.А. М.: ТК Велби, Проспект, 2007. C. $147-149$. 
которой оно обладает для их осуществления, а вытекают из факта существования государства как субъекта международного права. ... Каждое государство имеет право на свободное и самостоятельное развитие своей культурной, политической и экономической жизни". Согласно ст. 12 Устава ОАГ даже до своего признания любое государство "имеет право на защиту своей целостности и независимости, на обеспечение своей безопасности и процветания и, исходя из этого, право организовываться, как сочтет необходимым, издавать законы по касающимся его вопросам и руководить различными органами, а также определять юрисдикцию и компетенцию своих судов. Осуществление этих прав не имеет никаких ограничений, кроме уважения прав других государств в соответствии с международным правом"1. При этом, в соответствии с Уставом ОАГ признание означает, что признающее государство признает новое государство в качестве субъекта международного права со всеми правами и обязанностями.

В доктрине высказывались различные точки зрения по поводу природы и перечня прав государств ${ }^{2}$. Автор согласен с В.В. Горюновым в том, что «не может быть некоего универсального и заранее данного для всех государств перечня суверенных прав. Каждое государство в зависимости от конкретных обстоятельств может актуализировать те права, которые необходимы для выполнения его функций в конкретной исторической ситуации, что говорит о неисчерпаемости суверенных прав» ${ }^{3}$.

В соответствии с теорией правоотношений, особым участником которой выступает государство, суверенные права предполагают корреляцию с суверенными обязанностями государства ${ }^{4}$. В связи с этим помимо каталога

1 Устав Организации американских государств (г. Богота, 30 апреля 1948 г.) / Действующее международное право. Т. 2. М.: Московский независимый институт международного права, 1997. С. 305-335.

2 Э. де Ваттель сравнивал суверенные права государства с правами человека и рассматривал их как неотчуждаемые и абсолютные.

3 Горюнов В.В. Указ. соч. С. 185.

${ }^{4}$ В 1996 г. российские ученые-юристы подготовили проект Кодекса основных прав и обязанностей государств. 
суверенных прав содержание государственного суверенитета предполагает наличие обязанностей суверенного государства.

К их числу можно отнести следующие обязанности:

соблюдение конституции и подчинение государственных органов, госслужащих и должностных лиц праву;

добросовестное выполнение международных обязательств;

решение международных споров мирными средствами;

уважение суверенитета, территориальной целостности и

неприкосновенности других государств;

обеспечение эффективной борьбы с преступностью (невзирая на материальное и должностное положение, национальную принадлежность и вероисповедание преступников);

обеспечение военной, продовольственной, финансовой, конституционной и других видов безопасности;

обеспечение политической независимости и территориальной целостности государства;

осуществление активной разведывательной и контрразведывательной деятельности ${ }^{1}$;

защита государственной власти ${ }^{2}$;

осуществление дипломатической и правовой защиты своих граждан независимо от их местонахождения;

1 Главная цель осуществления разведывательной и контрразведывательной деятельности заключается в изменении соотношения сил в политической борьбе с противником (иностранным государством или военно-политическим союзом группы государств) в пользу своего государства путем конспиративного (прямого или косвенного) подрыва сил и средств спецслужб и организаций иностранных государств и защиты от их разведывательной и иной подрывной деятельности. Осуществление разведывательной деятельности неизбежно посягает на суверенитет государствапротивника и установленный в нем правопорядок. См. Теория государства и права / Под ред. д-ра юрид. наук профессора В.Н. Струнникова. М.: ВКШ КГБ СССР, 1987. С. 73.

2 Данная обязанность включает в себя обеспечение безопасности выборов, государственную защиту должностных лиц, судей, сотрудников правоохранительных органов, недопущение захватов и блокирования конституционных органов власти и местного самоуправления, недопущение создания и функционирования, пресечение деятельности альтернативных органов власти, незаконных вооруженных формирований, экстремистских структур и др. 
уголовное преследование и сопровождение выдачи иностранных граждан, лиц с множественным гражданством и апатридов, совершивших преступления в отношении граждан государства за рубежом и на территории государства;

отражение вооруженного нападения на формирования вооруженных сил и органы власти государства, дислоцированные за пределами его территории;

осуществление военной защиты своих граждан в случае агрессии иностранного государства ${ }^{1}$;

оказание гуманитарной помощи своим гражданам и соотечественникам, находящимся в зоне внутренних вооруженных конфликтов, в районах чрезвычайных ситуаций².

эвакуация своих граждан из зон вооруженных конфликтов и районов чрезвычайных ситуаций.

Так же, как и перечень прав, суверенное государство вправе корректировать и дополнять перечень своих суверенных обязанностей перед населением.

Рассмотрев гносеологические вопросы содержания понятия "государственный суверенитет", его предметного статуса, перейдем к сравнительному анализу развития теорий государственного суверенитета в российской и зарубежной политико-правовой и конституционной доктрине.

1 Примером может служить защита российского воинского контингента миротворческих сил от нападения Вооруженных сил Грузии в 2008 г.

2 В 2014 - 2016 гг. данная обязанность государства была реализована в ходе специальных гуманитарных операций сил МЧС России в районах возникновения гуманитарных катастроф в ЛНР и ДНР. 


\section{2. Государственный суверенитет в российской политико- правовой и конституционной доктрине}

В рамках исследования политико-правовых и конституционных идей, касающихся государственного суверенитета и его защиты, введем методологическую оговорку о взаимосвязи политико-правовой и конституционной доктрин государственного суверенитета (его защиты).

Во-первых, защита государственного суверенитета (далее - ЗГС) по своей природе имеет политический характер (в первую очередь, преследует цели защиты, сохранения и удержания государственной власти). Во-вторых, вектор и содержание правового (конституционно-правового) наполнения ЗГС во многом определяются характеристиками существующего в государстве политического режима и интересами господствующих на данном этапе государственного развития политических сил. Наиболее влиятельные и популярные политические концепции, получив поддержку правящих кругов, находят свое закрепление в конституционном законодательстве (концепции народного суверенитета, разделения властей, конституционно-значимого и пропорционального ограничения прав человека, баланса конституционных ценностей и др.). В-третьих, конституционно-правовые требования, обязательные для исполнения всеми субъектами права, действуют во всех сферах общественной жизни и регулируют наиболее важные отношения, в том числе в политической сфере. Для ЗГС правящие силы вправе вводить соответствующие обстановке правовые режимы и использовать различные конституционно-правовые институты (чрезвычайное, военное положение, контрсанкции и др.).

Российская политико-правовая доктрина комплексно разрабатывала вопросы государственной власти, отношений государства, общества и личности, ограничения, защиты и оправдания государственной власти.

Можно выделить несколько теоретических течений, сформировавших политико-правовые идеи государственного суверенитета в России. 
По ценностным приоритетам разработчиков теорий государственного суверенитета можно условно выделить: этатистское и либеральное направления политико-правовой мысли; по идеологическим взглядам: либерализм, консерватизм, марксизм-ленинизм, социал-демократию; по хронологии следует различать: дореволюционные теории государственного суверенитета, советские доктрины государственного суверенитета и постсоветские концепции государственного суверенитета.

На протяжении всей истории российской государственности значимую роль в обосновании и оправдании проводимой государством политики играли сторонники сильного независимого государства (этатистское направление).

Теоретический фундамент суверенного российского государства и верховенства власти его главы (самодержца) заложила концепция псковского монаха Филофея "Москва-Третий Рим"1. Филофей утверждал, что после падения Константинополя ("Второго Рима") центром православного христианского мира стала Москва: "Два Рима пали, третий стоит, а четвертому не бывать". Поэтому российский царь отвечает за судьбу православного мира и вверенного ему Богом государства. По меткому выражению Е.И. Марченко, "абсолютная власть русского государя теперь определялась сквозь призму религиозной духовности"2.

Логическое следствие данной концепции нашло свое выражение в формуле: власть царя священна, московский царь богоизбранный и высокопрестольный, а родословная династии московских царей восходит к римскому императору Константину Великому.

${ }^{1}$ Иванов А.Б. Третий Рим. Русь XIV-XVII вв. М., 1996. Кириллов И.А. Третий Рим. Очерк исторического развития идеи русского мессианства. М., 1996. Лисовой Н.Н. Три Рима. М., 2001; Синищыла Н.В. Третий Рим. Истоки и эволюция русской средневековой концепции. М., 1998; Скрынников Р.Г. Третий Рим. СПб, 1994.

${ }^{2}$ Марченко Е.И. Идея суверенитета в государственно-правовых учениях российских консерваторов второй половины XIX - XX вв. Автореф. дис. ... канд. юрид. наук. Ростовна-Дону, 2009. С. 19. 
Данная концепция стала официальной доктриной в правление Ивана Грозного. В этот период теория царской власти основывалась на следующих ключевых положениях:

Во-первых, самодержавие передается в порядке престолонаследия и исходит из трех источников: власти от Бога, власти от древнеримских императоров и власти от русских великих князей.

Во-вторых, самодержавие - власть единоличная, независимая от духовенства, бояр и других общественных сил.

B-третьих, царь властвует в соответствии с божьими заповедями.

В-четвертых, государственная власть строится на жестоких методах управления ("царь спасает своих людей страхом").

Концепция "Москва-Третий Рим", обосновывающая сильное богоизбранное государство с неограниченной царской властью была ориентирована не только на внутрироссийскую общественно-политическую жизнь, но и решала задачу самоопределения Московской Руси как суверенного государства мирового значения. До конца 17 века концепция "Москва-Третий Рим" являлась фундаментом, на котором были сформированы и закреплены идеи абсолютной власти царя, ответственного перед Богом и за государство, и за православную веру.

В 18 в. идеология абсолютизма продолжила активное развитие в России. Главными ее теоретиками стали Феофан Прокопович и Василий Татищев. Придерживаясь договорной теории происхождения государства, они обосновывали зависимость форм правления от размеров территории государства ${ }^{1}$.

"Республики, - писал Прокопович, - могут существовать только у малых народов и на небольшой территории. В условиях демократии часто происходят мятежи. При аристократии борьба правящих группировок может

${ }^{1}$ В европейских политико-правовых учениях основоположником «географического детерминизма» принято считать Монтескье. 
разрушить государство"1. Поэтому правильной формой правления Прокопович считал монархию.

Татищев предлагал следующие классификации форм правления: демократическая республика;

конституционная монархия;

аристократическая республика;

самодержавие.

Великие и подвергающиеся нападению народы не могут "иначе правиться, как самовластием" (самодержавием)².

Особенностями общественного договора теоретики российского абсолютизма считали решение народа об установлении верховной власти в форме неограниченной монархии, в которой самодержец имеет право и должен регулировать все стороны жизни и быта. Народ же, наделяя властью правителя, добровольно отказывается от всех своих прав и свобод, говоря: "Ты владеешь нами к общей пользе нашей". В трудах Прокоповича теоретические доводы естественно-правовой теории дополняются религиозной аргументацией: "монархи Бози суть", "государь самому токмо Богу ответ дает"'.

В первой половине 19 в. Александр I предпринял попытку преобразования феодального государственного строя Российской империи и провел ряд либеральных реформ. Проекты Сперанского М.М. встретили закономерное сопротивление придворной знати. Реакцией дворянского протеста стала охранительная политико-правовая теория Н.М. Карамзина.

Карамзин осудил попытки учреждения конституции, ограничивающей власть царя. Попытки поставить закон над Государем опасны: "Две власти государственные в одной державе суть два грозных льва в одной клетке,

\footnotetext{
${ }^{1}$ Прокопович Ф. Сочинения. М - Л., 1961.

2 Татищев В.Н. Избранные произведения. Л., 1979.

${ }^{3}$ Прокопович $\Phi$. Указ. соч.
} 
готовые терзать друг друга, а право без власти есть ничто. Самодержавие основало и воскресило Россию. В монархе российском соединяются все

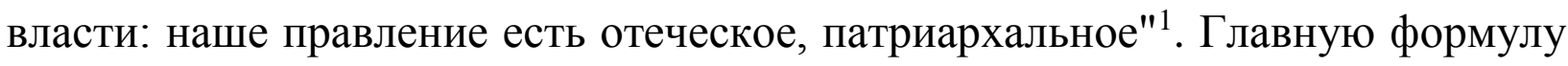
своей консервативной теории Карамзин выразил следующим образом: "Дворянство и духовенство, Сенат и Синод как хранилище законов. Над всеми Государь, единственный законодатель, единственный источник властей. Вот основание Российской монархии"2.

Политико-правовые идеи охранительной теории Карамзина нельзя оценить однозначно. С одной стороны, они выражали взгляды основной массы дворянства, консервировали феодальные порядки в стране и блокировали проведение реформ. С другой стороны, они акцентировали внимание на самобытности российского государства, культуры и общественно-политической жизни.

Религиозно-философское оправдание сильной и справедливой верховной власти, ответственности правителя за судьбу русского государства и народа получило развитие в трудах П.Б. Струве, который дополнил консервативную этатистскую концепцию государственного суверенитета аксиологическими положениями о государственном могуществе как общественной ценности и социально-ответственном государстве.

Ученый считал, что государство желает быть могущественным. Данная черта государства есть обнаружение его сверхразумной природы, поскольку соотношение между силой отдельных личностей и мощью государства покоится не на рациональных, а на религиозных началах.

Сущность государства и его суверенитета Струве рассматривал с мистических позиций: "Жизнь государства состоит во властвовании одних над другими. Давно замечено, что власть и властвование устанавливают

1 Карамзин Н.M. Записка о старой и новой России в ее политическом и гражданском отношениях. М., 1991.

${ }^{2}$ Карамзин Н.М. Указ. соч. 
между людьми такую связь, которая нерациональна и сверхразумна, что власть есть своего рода очарование или гипноз. Наблюдение это совершенно верно, поскольку власть не есть просто необходимое орудие упорядочения общежития, средство рационального распорядка общественной жизни. Поэтому прежде всего и полнее всего оно применимо к власти как орудию государственной мощи. Вот почему мистичность власти обнаруживается так ясно, так непререкаемо на войне, когда раскрывается мистическая природа самого государства, за которое, отстаивая его мощь, люди умирают по приказу власти"1.

Верховенство власти Струве выводил из внешнего аспекта государственного суверенитета: "Личность, особность государства проявляется в отношениях его к другим государствам. Поэтому могущество государства есть его мощь вовне. Обычное рационалистическое воззрение ставит внешнее могущество государства в зависимость от его внутреннего устройства и от развития внутренних отношений. Но мистичность государства и заключается в том, что власть государства над «людьми» обнаруживается в их подчинении далекой, чуждой, отвлеченной для огромного большинства идее внешней государственной мощи"2.

При этом, говоря о подчинении, П.Б. Струве имел ввиду не внешнее и насильственное, а внутреннее и моральное подчинение, признание государственного могущества как общественной ценности.

Ученый поднимал проблему легитимности государственной власти и видел ее решение в строительстве мощного, социально-ответственного и справедливого государства. "Власть есть орудие внешней мощи государства и в качестве такового она держит в подчинении себе людей. Переставая

1 Струве П.Б. Отрывки о государстве / Струве П.Б. Избранные сочинения. М., 1999. C. 202-210.

' Струве П.Б. Указ. соч. С. 202-210. 
исполнять это самое важное, наиболее связанное с мистической сущностью государства назначение, власть начинает колебаться и затем падает.

То, что в новейшее время называют империализмом, есть более или менее ясное постижение того, что государство желает быть и - постольку государство ценно для личности - должно быть могущественно. Всякое живое государство всегда было и будет проникнуто империализмом в этом смысле. Если под империализмом разуметь заботу о внешней мощи государства, а под либерализмом - заботу о справедливости в его внутренних отношениях, то 19 в. и начало 20 в. характеризуется тем, что торжествуют везде те государства, в политике которых наиболее полно слились и воплотились обе эти идеи ${ }^{1}$.

Схожую со Струве этатистскую позицию занимает Н.А. Бердяев в книге «Философия неравенства». Он пишет, что «подчинение Церкви, государству, национальности, высшим реальностям и ценностям - сладостно и благородно» ${ }^{2}$.

Русский религиозный философ Л.П. Карсавин, обосновывая абсолютность идеи власти, в качестве аргумента приводил факт, что все люди инстинктивно признают значение сверх-индивидуальной и надэмпирически абсолютной власти. Общество упорядочивается только со становлением государственности, а государства без власти быть не может. Это имманентный закон социального индивида: не существует утроенного общества без власти, человека - без такого общества, а без человека не существует и самого мира. И если Бог сотворил мир, то человеческий инстинкт государственности - идея власти - соответствует воле самого Бога 3 .

Ценный вклад в построение многогранной теории государственного суверенитета внесли русские либеральные идеологи и ученые - юристы.

1 Струве П.Б. Отрывки о государстве / Струве П.Б. Избранные сочинения. М., 1999. C. 202-210.

Бердяев Н.А. Философия неравенства / Русское зарубежье. Л., 1991. С. 135-151. 193.

${ }_{3}^{3}$ Карсавин Л.П. Государство и кризис демократии / Новый мир, 1991. № 1. С. 183- 
Либеральные аспекты теории государственного суверенитета акцентировали внимание на правосубъектности личности, юридическом ограничении верховенства государственной власти, солидарности государства и общества.

Так, П.И. Новгородцев обратил основное внимание на свойства государственной власти, которые были введены в понятие суверенитета Боденом и его последователями. По мысли Новгородцева, происходившее в Новое время становление суверенного государства означало, прежде всего, устранение сословного неравенства и упразднение разнообразных привилегий. "Новое государство, - писал он об эпохе перехода от средневековья к Новому времени, - призвано было совершить процесс управления общественных элементов и превратить сословное общество в гражданское, построенное на началах равной правоспособности"1.

Сущность суверенитета, полагал Новгородцев, состоит в том, чтобы суверенная власть имела достаточно могущества для того, чтобы явиться правотворящим источником. В условиях преодоления феодальной раздробленности и становления государственности Нового времени понятие суверенитета являлось синонимом национальной и государственной независимости (отождествление государства с Родиной, Отечеством, восходящее к позднему средневековью), однако одно лишь понятие суверенитета, считал государствовед, не способно дать полного определения государства. Суверенитет - только почва для равенства, внешняя рамка для бытия права. По мнению отечественного философа права, суверенитет - это принцип объединения социальных сил на почве общего и равного для всех права ${ }^{2}$.

Судьба суверенитета определялась мыслителем в духе учения Гегеля о всемирной истории и учения Канта о вечном мире. Суверенное государство,

${ }^{1}$ Фролова Е.A. Неокантианская философия права в России в конце XIX - начале XX века. Монография. М.: Юркомпани, 2013. С. 345.

${ }^{2}$ Фролова Е.А. Указ соч. С. 350-351. 
считал Новгородцев, "является великим историческим этапом на пути к всеобщему объединению в духе мира и братства всех народов и стран". Как требование единого и равного для всех права, суверенитет допускает возможность гражданского уравнения своих и чужих и прогрессивный рост международного общения"1 .

Б.Н. Чичерин в качестве идейной основы либеральных преобразований предложил концепцию "охранительного либерализма", суть которой он выразил формулой "либеральные меры и сильная власть". И уточнил: "... либеральные меры, предоставляющие обществу самостоятельную деятельность, обеспечивающие права и личность граждан" и "сильная власть, блюстительница государственного единства, связующая и сдерживающая общество, охраняющая порядок, строго надзирающая за исполнением законов... разумная сила, которая сумеет отстоять общественные интересы против напора анархических стихий и против воплей реакционных партий"2.

Однако в отличие от "охранительной" консервативной теории Н.M. Карамзина, Б. Н. Чичерин опирался не только на сильное государство, но и на активное, самостоятельное гражданское общество.

Убежденным сторонником теории правового государства выступал Б.А. Кистяковский. Эту идею он тщательным образом анализировал в работе "Социальные науки и право: Очерки по методологии социальных наук и общей теории права" и в "Лекциях по государственному праву (общему и русскому)". Государство - правовая организация народа, обладающая во всей полноте своею собственною и первичною, то есть ни от кого не заимствованною властью. Основной признак правового государства, по убеждению ученого, заключается в наличии границ власти, которая носит подзаконный характер. Кроме того, в правовом государстве механизм

\footnotetext{
1 Фролова Е.А. Указ соч. С. 351.
2 Цит по Зорькин В.Д. Право в условиях глобальных перемен. М.: Норма, 2013. С. 40.
} 
осуществления государственной власти таков, что отдельные государственные органы и порядок в обществе функционируют при непосредственной помощи народа ${ }^{1}$.

C особым вниманием государствовед относился к вопросу об оправдании власти. Среди признаков власти (престиж, авторитет, традиция, привычка, сила, внушающая страх и покорность) необходимо выделить наиболее значимый - власть должна быть носительницей какой-либо идеи, должна иметь нравственное оправдание ${ }^{2}$.

Во власти все, что не находит себе оправдания, подлежит изменению в соответствии с нормами должного. Чтобы существовать и быть признаваемой, рассуждал ученый, власть должна себя оправдывать: современному культурному человеку недостаточно простого факта существования власти; мало "необходимости", "полезности", "целесообразности" власти. Признать власть можно только тогда, когда она будет способствовать тому, что должно быть, то есть если она ведет к господству идеи права. Таким образом, по мысли Кистяковского, власть современного государства станет правовой властью ${ }^{3}$

Ученый подчеркивал необходимость ограничения государственной власти в правовом государстве.

В правовом государстве власть должна быть организована таким образом, чтобы не подавлять личность. Наоборот, отдельные граждане и весь народ должны являться субъектом власти. Это возможно, полагал ученый, только в случае народного представительства, когда основная функция государства - законодательство - будет соответствовать народному правосознанию. Престиж конституционной государственной власти заключается, убеждал Кистяковский, не в недосягаемой ее высоте, а в том,

1 Фролова Е.А. Указ соч. С. 392.

2 Кистяковский Б.А. Государственное право (Общее и русское) / Философия и социология права / Сост. В.В. Сапова. СПб: РХГИ, 1998. С. 470.

${ }^{3}$ Фролова Е.А. Указ соч. С. 393. 
что она находит поддержку и опору в народе. В правовом государстве не может возникнуть политического отчуждения: правительство и народ не противопоставляются как нечто чуждое и враждебное друг другу. Власть в этом государстве солидарна с народом, их цели и интересы едины ${ }^{1}$.

Идею солидарности государства и общества поддерживал и либерал А.Д. Градовский. По его мнению, «отношение государства к обществу не есть отношение победителя к побежденному; общество принимает участие в администрации не потому, чтобы оно завоевало себе какие-нибудь права, государство содействует осуществлению разных общественных интересов не во имя своих верховных прав, отнятых им некогда у общества. Все эти силы действуют во имя солидарности всех государственных и общественных целей и во имя недостаточности каждой из них в отдельности»².

Вопросы ограничения государственной власти ставились даже славянофилами. Убежденный монархист И.С. Аксаков призывал видеть общественный и личный идеал выше всякого государства: «Есть целая область отношений, на которую не может простираться чисто внешняя, формулированная, ограниченная в своих средствах деятельность государственная, такая область, куда, как мы сказали однажды, не в силах достать сверху распоряжением никакая самая отважная благонамеренность начальства; есть многочисленные явления духа, которые не могут быть вызваны на всеет Божий указом и которые не терпят никакой извне излагаемой формулы» ${ }^{3}$.

Обобщая развитие дореволюционной политико-правовой доктрины государственного суверенитета, констатируем наличие нескольких теоретических подходов: вера в незыблемость государственных институтов и могущество государства; религиозно-философское и нравственное

${ }_{2}^{1}$ Фролова Е.А. Указ соч. С. 395, 396.

2 Градовский А.Д. О современном направлении государственных наук. / Градовский А.Д. Сочинения. СПб., 2001. С. 17-30.

3 Аксаков И.С. О взаимном отношении народа, государства и общества / Отчего так нелегко живется в России? М., 2002. С. 148-156. 
оправдание сильной и справедливой государственной власти; обоснование ответственности правителя за судьбу русского государства и народа; единое государство как общественная ценность; обоснование правовых границ власти; солидарность общества и государства.

Как отмечает Н.А. Захаров, «политическая эволюция 19 в. совершалась в двояком направлении: с одной стороны, постепенно падала вера в возможность совершенной и безошибочно действующей государственной организации, с другой стороны, функции государства бесконечно расширялись. В то время, как от государства стали требовать несравненно более, в него стали верить гораздо менее» ${ }^{1}$.

Качественно иное содержательное наполнение доктрина государственного суверенитета в России получила после Октябрьской революции.

Идеи государственного суверенитета трансформировались в соответствии с развитием советского государства.

На ранних этапах государственного строительства Советской России суверенитет рассматривался как диктатура господствующего класса. Так, Ф. Сименский и Е. Пашуканис раскрывали природу государственного суверенитета с позиций юридического выражения диктатуры господствующего класса²

После окончания Великой Отечественной Войны и стабилизации советской системы государственного управления значительная часть ученых стала трактовать суверенитет как качество (свойство, характеристику) государственной власти. Данная точка зрения была основана на тезисе, что суверенитет государства проявляется именно в деятельности государственной власти. Так, В.А. Дорогин трактовал государственный

1 Захаров Н.А. Система русской государственной власти. М., 2002. С. 296-311.

2 Пашуканис Е.Б. Очерки по международному праву. М., 1935. С. 79-80. 
суверенитет как "свойство государственной власти"1, а С.Р. Вихарев утверждал, что суверенитет государства "непосредственно воплощен лишь в его политической организации в лице его государственной власти"2.

В.Т. Кабышев предпринял попытку определения суверенитета и как основного элемента государственной власти, и как ее качества (свойства) ${ }^{3}$.

Другой подход был связан с отождествлением государственного суверенитета с верховной (высшей) властью. Например, И.П. Трайнин, раскрывая понятие государственного суверенитета, акцентировал внимание на том, что он представляет собой высшую власть, неограниченную внутри государства и независимую во внешних сношениях ${ }^{4}$. Необходимо отметить, что в современных условиях организация и функционирование неограниченной государственной власти возможны лишь в отдельных формах государства или же при возникновении чрезвычайных условий (война, стихийные бедствия).

В 1990-е гг. сторонники подобного подхода адаптировали его к новым демократическим реалиям и зарубежным конституционно-правовым теориям. Так, Н.И. Лукашук стал рассматривать суверенитет "как исходящую от народа верховную власть, состоящую в самостоятельном осуществлении государством своих функций в рамках национального и международного права"

Ряд советских государствоведов абсолютизировали сущность государственного суверенитета и трактовали его как полновластие. Государственный суверенитет понимался ими как концентрация всех

1 Дорогин В.А. Суверенитет в советском государственном праве. М., 1948. С. 55-56.

${ }_{3}^{2}$ Вихарев С.Р. В.И. Ленин о суверенитете союзных республик. С. $23-24$.

Кабымев B.T. Элементы понятия государственной власти // Проблемы конституционного права / Отв. ред. И.Е. Фарбер. Саратов, 1969. С. 20, 22, 27.

2. C. 75.

4 Трайнин И.П. К вопросу о суверенитете // Советское государство и право. 1938. № Советское государство и право. 1991. № 5. С. 10. 
государственно властных полномочий, всей власти в одних руках ${ }^{1}$. Данная позиция в целом верно отражала роль и место государственного суверенитета в доктрине советского государственного права, но была неприменима к подавляющему большинству буржуазных теорий конституционного права, поскольку отрицала разделение властей.

Существенную роль в разработке конституционно-правовой доктрины государственного суверенитета и его защиты сыграл Конституционный Суд РФ. Деятельность данного органа способствовала последовательному формированию и укреплению надежной национальной системы конституционно-правовой защиты государственного суверенитета.

Можно условно выделить несколько этапов развития конституционноправовой доктрины и изменения статуса органов конституционного правосудия в системе конституционно-правовой защиты государственного суверенитета РФ:

- Формирование всесоюзного и российского квазисудебного органов конституционного контроля (1-й этап).

- Учреждение специализированного органа конституционного правосудия РФ (2-й этап).

- Становление региональной системы конституционного (уставного) правосудия в РФ (3-й этап).

- Автономизация общегосударственного конституционного контроля (4-й этап).

Четкая периодизация генезиса системы конституционно-правовой защиты государственного суверенитета РФ представляется затруднительной, поскольку выделенные этапы в ряде случаев проходили параллельно.

\footnotetext{
${ }^{1}$ Например, сторонниками такого подхода являлись В.С. Шевцов и А.И. Ким.
} 
На первом этапе в рамках демократизации конституционно-правового развития советской государственности был сформирован всесоюзный орган конституционного надзора СССР.

1 декабря 1988 г. в Конституцию СССР были внесены изменения (ст. 125), предусматривающие создание Комитета конституционного надзора СССР, избираемого Съездом народных депутатов СССР сроком на 10 лет и подотчетного Парламенту. В апреле - мае 1990 г. Съездом народных депутатов и Верховным Советом СССР был сформирован состав Комитета. Законодательной базой, регулирующей статус этого органа, стал Закон СССР от 23 декабря 1989 г. «О конституционном надзоре в СССР».

За время своей деятельности Комитет принял более 40 актов, касающихся защиты гражданских и политических прав. Среди наиболее существенных решений Комитета следует отметить его постановления: о прекращении практики издания секретных законодательных актов, ограничивающих права и свободы граждан; о неконституционности ограничения свободы передвижения и выбора места жительства разрешительным порядком т.н. прописки; об отмене Указа Президента СССР, запрещавшего проведение демонстраций в центре г. Москвы и др ${ }^{1}$.

Вместе с тем узость полномочий, отсутствие политического авторитета и большого опыта практической деятельности не позволили Комитету сыграть сдерживающую роль в процессах распада советской государственности в августе-декабре 1991 г. В связи с упразднением Советского Союза и заключением 8 декабря 1991 г. договора о создании Содружества Независимых Государств (СНГ) Комитет конституционного надзора СССР прекратил свою деятельность.

1 Заявление Комитета конституционного надзора СССР от 11 октября 1991 г. // Ведомости ВС СССР. 1991. № 46. Ст. 1308. 
Формирование российского органа конституционного контроля стало закономерным процессом конституционно-правового развития РСФСР и распада СССР.

Создание собственного органа конституционного контроля - Комитета конституционного надзора РСФСР - было предусмотрено статьями 104 и 119 Конституции РСФСР 1978 г. (с изм. от 27 октября 1989 г.).

Проводимые в СССР реформы в полной мере затронули Российскую Советскую Федеративную Социалистическую Республику, ее политическую и экономическую системы. В марте 1990 г. в РСФСР прошли первые свободные конкурентные выборы - выборы народных депутатов РСФСР. Была сформирована российская демократическая избирательная система.

12 июня 1990 г. І Съездом народных депутатов РСФСР была принята Декларация о государственном суверенитете Российской Советской Федеративной Социалистической Республики. В данном документе РСФСР провозглашалась суверенным государством с системой политических, экономических и правовых гарантий суверенитета как естественных и необходимых условий существования государственности России. В статье 5 закреплялся принцип разделения властей на законодательную, исполнительную и судебную. Данная Декларация рассматривалась в качестве основы для разработки новой Конституции РСФСР, заключения Союзного договора и совершенствования республиканского законодательства.

Руководствуясь Декларацией, Верховный Совет РСФСР в целях защиты экономической основы суверенитета РСФСР, стабилизации и развития народного хозяйства РСФСР принял Закон от 31 октября 1990 г. «Об обеспечении экономической основы суверенитета РСФСР».

Земля, ее недра, воздушное пространство, воды, леса, растительный и животный мир, другие природные и сырьевые ресурсы, расположенные на территории РСФСР, ресурсы континентального шельфа и морской экономической зоны РСФСР, художественные и культурные ценности были 
объявлены государственной собственностью РСФСР и национальным богатством народов РСФСР. Законодатель определил долевой характер золотого запаса, алмазного и валютного фондов СССР (РСФСР признало за другими союзными республиками право на принадлежащие им доли в алмазном, валютном фондах и золотом запасе СССР). Вводилось регулирование вопросов собственности, приватизации, передачи имущественных прав в соответствии с законодательством РСФСР. В соответствии со статьями 5-7 Закона любые решения и сделки органов государственной власти и управления СССР в отношении государственного имущества, должностных лиц, предприятий, учреждений, организаций союзного и республиканского подчинения, находящихся на территории РСФСР, требовали согласования с соответствующими органами РСФСР.

Совету Министров РСФСР было предоставлено исключительное право: определять порядок лицензирования и квотирования товаров и услуг, ввозимых или вывозимых с территории РСФСР;

определять таможенные пошлины по экспортно-импортным операциям участников внешнеэкономической деятельности, находящихся под юрисдикцией РСФСР;

регистрировать участников внешнеэкономической деятельности, имеющих юридические адреса на территории РСФСР;

проводить аккредитацию иностранных фирм, банков и других организаций, имеющих свои офисы на территории РСФСР;

присваивать частоты на территории РСФСР.

Данный законодательный акт фактически закрепил конфедеративный характер связей РСФСР с другими союзными республиками в составе СССР и способствовал дальнейшему распаду советской государственности.

Происходящие дезинтеграционные процессы актуализировали необходимость правовой защиты государственного суверенитета и доктринального обеспечения данной деятельности. 
Bmopoŭ эman (этап институционализации специализированного органа конституционного правосудия РФ) характеризовался определением исключительной компетенции органов конституционного правосудия РФ.

Данный этап можно условно разбить на две стадии ${ }^{1}$ :

- с момента принятия в мае 1991 г. первого Закона о Конституционном Суде РСФСР до принятия в декабре 1993 г. Конституции РФ;

- с момента закрепления конституционного статуса органов конституционного правосудия до принятия в 1994 г. Федерального конституционного закона «О Конституционном Суде Российской Федерации».

Первая стадия институционализации российских органов конституционного правосудия связана с формированием законодательной основы деятельности органов конституционной юстиции. 6 мая 1991 г. Верховным Советом РСФСР был принят Закон РСФСР «О Конституционном Суде РСФСР». На V (внеочередном) Съезде народных депутатов РСФСР 2930 октября 1991 г. был сформирован состав Конституционного Суда в составе 13 судей. 14 января 1992 г. Конституционный Суд РСФСР начал рассмотрение первого дела.

Поворотным моментом конституционно-правового развития стал государственный переворот 18-21 августа 1991 г. (т.н. путч). В ночь с 18 на 19 августа 1991 г. в СССР был совершен государственный переворот, организаторами которого являлись члены т.н. Государственного комитета по чрезвычайному положению (ГКЧП). Этот орган в нарушение Конституции СССР и Закона СССР «О правовом режиме чрезвычайного положения» принял решение о введении режима чрезвычайного положения в ряде

1 Рассматривая развитие конституционно-правовой доктрины защиты государственного суверенитета и деятельности Конституционного Суда РФ как ключевого элемента системы конституционно-правовой защиты государственного суверенитета, автор разделяет подход Ведерникова Н.Т. и Петренко Д.С. к хронологии становления конституционного контроля в современной России. См. Ведерников Н.T., Петренко Д.С. Конституционное правосудие (теоретические, исторические и организационные основы). М., 2009. С. 86-111. 
местностей СССР. Действия Президента РСФСР, Верховного Совета и Правительства РСФСР позволили восстановить конституционную власть в стране. Вместе с тем последствия государственного переворота привели к усилению сепаратистских тенденций, подрыву единого правового и экономического пространства и последующему закономерному распаду CCCP.

Постановлением Верховного Совета СССР от 29 августа 1991 г. № 2371-I «O ситуации, возникшей в стране в связи с имевшим место государственным переворотом» было рекомендовано внести «необходимые изменения и дополнения в Конституцию СССР и другие законодательные акты, определяющие правовой механизм защиты конституционного строя〉 ${ }^{1}$.

В соответствии с Законом РФ от 21 апреля 1992 г. № 2708-1 «Об изменениях и дополнениях Конституции (Основного закона) РСФСР» Конституционный Суд стал высшим органом судебной власти по защите конституционного строя ${ }^{2}$. До момента принятия Конституции РФ 1993 г. Конституционным Судом РСФСР было рассмотрено 27 дел, из них 19 - по ходатайствам о проверке на предмет соответствия Конституции нормативных актов различного уровня органов власти и 8 - по индивидуальным жалобам граждан. В результате рассмотрения всех этих дел Судом были признаны неконституционными полностью или частично 2 постановления Съезда народных депутатов РСФСР, 6 законов и постановлений Верховного Совета РСФСР, 8 указов Президента РФ, 2 постановления Правительства РСФСР, 2 постановления Президиума Верховного Совета РСФСР и 4 нормативных правовых акта республик в составе $Р \Phi^{3}$.

\footnotetext{
${ }_{1}^{1}$ Ведомости СНД СССР и ВС СССР. 1991. № 36. Ст. 1038.

2 Рос. газ. 1992. 16 мая.

3 Ведерников Н.T., Петренко Д.С. Конституционное правосудие (теоретические, исторические и организационные аспекты). М., 2009. С. 96.
} 
Начало деятельности Конституционного Суда совпало с периодом острого политического конфликта между главами законодательной и исполнительной властей РСФСР (Р.И. Хасбулатовым и Б.Н. Ельциным). Конституционный Суд обоснованно полагал, что конфронтация законодательной и исполнительной властей представляет реальную угрозу конституционному строю. На это он обращал внимание в послании Верховному Совету от 5 марта 1993 г. «О состоянии конституционной законности в Российской Федерации». Однако ситуация продолжала обостряться, и противостояние политических сил привело к неизбежному конституционному кризису.

Указом Президента РФ от 21 сентября 1993 г. № 1400 «О поэтапной конституционной реформе в Российской Федерации» было прервано «осуществление законодательной, распорядительной и контрольной функций Съездом народных депутатов Российской Федерации и Верховным Советом Российской Федерации», введено в действие Положение о федеральных органах власти на переходный период и Положение о выборах в Государственную Думу Федерального Собрания Российской Федерации» ${ }^{1}$.

Антиконституционные действия Президента РФ в отношении законно избранных органов государственной власти спровоцировали вооруженные столкновения. Президентом были прекращены полномочия советов всех уровней и назначено всенародное голосование по Конституции РФ².

1 Данный Указ Президента был признан 21 сентября 1993 г. Конституционным Судом РФ не соответствующим части второй статьи 1 , части второй статьи 2 , статье 3 , части второй статьи 4, частям первой и третьей статьи 104, части третьей пункта 11 статьи 121 , статье 121, части второй статьи 121, статьям 165, 177 Конституции РФ. См. Заключение Конституционного Суда РФ от 21 сентября 1993 г. № 2-3 «О соответствии Конституции Российской Федерации действий и решений Президента Российской Федерации Б.Н. Ельцина, связанных с его Указом «О поэтапной конституционной реформе в Российской Федерации» от 21 сентября 1993 г. № 1400 и Обращением к гражданам России от 21 сентября 1993 года» // Вестник Конституционного Суда РФ. 1994 . № 6 .

${ }^{2}$ См. также Зорькин В.Д. Право против хаоса. М.: Редакция «Российской газеты», 2016. C. 117-119. 
Дальнейшее становление специализированного органа конституционного правосудия РФ было форсировано принятием Конституции РФ и Федерального конституционного закона «О Конституционном Суде Российской Федерации».

Конституция 1993 г. стала необходимой основой для развития всей правовой системы и суверенной государственности постсоветской России. Как отмечают В.Д. Зорькин и Л.В. Лазарев, «принятие Конституции на всенародном референдуме 12 декабря 1993 г. прервало развитие советского типа организации государственной власти и юридически закрепило восприятие Россией общедемократических ценностей и ориентиров социально-политического и экономического развития» ${ }^{1}$.

Суверенитет РФ получил закрепление в статье 4 Конституции, взаимосвязанные положения которой в системе единого нормативного комплекса Основного Закона позволяют выделить следующие характеристики государственного суверенитета:

1) верховенство государственной власти на территории государства, выражающееся в том, что в рамках территории РФ не существует никакой другой политической власти, которой бы российская государственная власть подчинялась;

2) независимость государства в международных отношениях, означающая, что государство выступает в международных отношениях равноправным субъектом международного права. Никакое другое государство не может издавать обязательные веления и распространять свою юрисдикцию в отношении РФ;

3) юридическая ограниченность государственного суверенитета, предполагающая функционирование государственной власти в правовых рамках и ограничение верховенства власти нахождением РФ в различных

${ }^{1}$ Комментарий к Конституции Российской Федерации (под ред. В.Д. Зорькина и Л.В. Лазарева). М.: Эксмо, 2010. 
международных организациях с передачей им части государственных полномочий. Статья 79 Конституции РФ предусматривает, что РФ может участвовать в межгосударственных объединениях и передавать им часть своих полномочий в соответствии с международными договорами. Конституция ограничивает это право государства двумя условиями: участие в межгосударственных объединениях возможно, если оно не влечет ограничения прав и свобод человека и гражданина и не противоречит основам конституционного строя РФ;

4) единство государственного суверенитета и принадлежность его только РФ в целом. Республики в составе РФ, хотя и называются в статье 5 Конституции государствами, не могут быть ими признаны, так как не обладают суверенитетом: на своей территории по предметам ведения РФ и предметам совместного ведения органы исполнительной власти республики подчиняются федеральным органам исполнительной власти; республики не являются субъектами международного права, то есть не могут самостоятельно вступать в отношения с иностранными государствами. В соответствии с частью 2 статьи 4 Конституция и федеральные законы обладают верховенством на всей территории РФ;

5) целостность и неприкосновенность территории государства в соответствии с общепризнанными принципами международного права. Часть 3 статьи 4 Конституции возлагает на РФ обеспечение целостности и неприкосновенности своей территории.

Конституционно-правовой смысл изложенных положений был подтвержден решениями Конституционного Суда РФ.

Особый статус Конституционного Суда как важнейшего субъекта правовой защиты государственного суверенитета обусловил закрепление его компетенции наряду с компетенцией Президента, Федерального Собрания и Правительства РФ непосредственно в Конституции. 
Полномочия, порядок образования и деятельности высшего органа конституционного контроля были детализированы в Федеральном конституционном законе от 21 июля 1994 г. № 1-ФКЗ «О Конституционном Суде Российской Федерации».

Следует отметить, что компетенция Конституционного Суда РФ была существенно изменена по сравнению с ее регламентацией при учреждении Конституционного Суда РСФСР. С одной стороны, Конституция РФ 1993 г. закрепила за Судом новые важные полномочия (толкование Конституции, рассмотрение конституционных жалоб, запросов судов), с другой стороны, были исключены некоторые полномочия (разрешение дел о конституционности политических партий и иных общественных объединений, проверка ненормативных актов и др.) ${ }^{1}$.

В рамках третьего этапа развития системы конституционно-правовой защиты государственного суверенитета РФ завершилось становление региональной системы конституционного (уставного) правосудия в РФ.

Формирование конституционных (уставных) судов субъектов РФ осуществлялось по усмотрению региональных законодателей, которые самостоятельно устанавливали их компетенцию, сроки полномочий, порядок формирования и обеспечения деятельности.

В законодательстве субъектов РФ были определены полномочия учрежденных органов региональной конституционной юстиции, отличающиеся существенным разнообразием. Объясняется это спецификой исторического развития отдельных субъектов РФ, свойствами сформировавшейся в каждом из них системы разделения властей, региональными политико-экономическими, культурно-правовыми и другими особенностями ${ }^{2}$.

1 Статус Конституционного Суда РФ как субъекта конституционно-правовой защиты государственного суверенитета подробно рассмотрен в параграфе 3.1.

2 См. Мироновский О.Б. Правовой статус конституционных (уставных) судов субъектов Российской Федерации. Автореф. дис. ... канд. юрид. наук. М., 2001. С 16; 
Четвертый эman (2010-2015гг.) был ознаменован укреплением национальных правовых механизмов и независимости конституционного контроля. Автономизация конституционного контроля в РФ была вызвана принятием различными органами международного правосудия (главным образом, Европейским Судом по правам человека (далее - ЕСПЧ) некоторых «конфликтных» решений, посягающих на базовые конституционные принципы и основы национальной правовой системы.

В 1998 г. РФ ратифицировала Конвенцию о защите прав человека и основных свобод 1950 г. (далее - Конвенция) и признала юрисдикцию Европейского Суда по правам человека по вопросам толкования и применения Конвенции и Протоколов к ней${ }^{1}$. Признание вытекающих из Конвенции международных обязательств рассматривалось не только с точки зрения принципов международного права, но и согласно национальным интересам суверенного российского государства, основанным на балансе конституционно защищаемых ценностей в Конституции РФ.

Изначально предполагалось, что Европейский Суд будет рассматривать только конкретные жалобы на предполагаемые (допущенные) нарушения требований Конвенции о защите прав человека и основных свобод 1950 г. (с правом присудить выигравшей стороне «справедливую компенсацию» материального ущерба, морального вреда, а также возмещение издержек и расходов), однако со временем произошло изменение статуса и прецедентной практики Суда. В 2004 г. Европейский Суд в соответствии с Резолюцией Комитета Министров Совета Европы от 12 мая 2004 г. стал издавать т.н. «пилотные постановления» (pilot judgements) о необходимости изменения национального законодательства, правоприменительной и судебной практики, рекомендовать принятие иных мер, влекущих юридические

Ведерников Н.Т., Петренко Д.С. Конституционное правосудие (теоретические, исторические и организационные аспекты). М., 2009. С. 198.

${ }_{1}^{1}$ Федеральный закон от 30 марта 1998 г. № 54-Ф3 «О ратификации Конвенции о защите прав человека и основных свобод и Протоколов к ней». 
последствия ${ }^{1}$. Указанные рекомендации по гармонизации правовой базы и судебной практики можно было бы только приветствовать, если бы они в ряде случаев не подменяли собой контроль национального законодательства, не затрагивали конституционные устои государств и принудительно не обеспечивались контрольным механизмом исполнения решений ЕСПЧ в соответствии со ст. 46 Конвенции.

Подобная эволюция правового статуса Европейского Суда и одностороннее расширение его правосубъектности вызвали закономерную реакцию ряда ведущих конституционных судов Европы (в первую очередь, Германии, Австрии, Италии, Великобритании и России) $)^{2}$

Применительно к России вопрос о коллизии конституционного толкования нормы национального законодательства Конституционным Судом РФ и толкования Конвенции Европейским Судом, при котором оспариваемая норма признается несовместимой с Конвенцией, впервые возник в октябре 2010 года после принятия Европейским Судом по правам человека Постановления по делу «Константин Маркин против России» 3.

В этом определении от 15 января 2009 г. № 187-О-О Конституционный Суд отметил, что российское правовое регулирование, предоставляющее военнослужащим-женщинам возможность отпуска по уходу за ребенком до достижения им трехлетнего возраста и не признающее такое право за военнослужащими-мужчинами, не нарушает положения Конституции о равенстве прав и свобод независимо от пола ${ }^{4}$.

${ }^{1}$ Практика «Пилотных постановлений» ЕСПЧ возникла в 2004 г. после принятия в марте 2004 г. Комитетом Министров Совета Европы резолюции, рекомендовавшей Европейскому суду фиксировать наличие системных проблем и предписывать «меры общего характера», включая принятие и изменение законодательных актов. Resolution $\operatorname{Res}(2004) 3$ of the Committee of Ministers on judgments revealing an underlying systemic problem, 12 May 2004 // URL: Https://wcd. coe. int/ViewDoc. jsp? id=743257

${ }^{2}$ Подробнее см. параграф 2.5 монографии.

3 Постановление Европейского Суда по правам человека от 7 октября 2010 г. по делу «Константин Маркин против Российской Федерации» (Konstantin Markin v. Russia), № 30078/06, judgment of 7 October 2010; Grand Chamber judgment of 22 March 2012 // Бюллетень Европейского Суда по правам человека. Российское издание. 2012. № 6.

${ }^{4}$ Определение Конституционного Суда РФ от 15 января 2009 г. N 187-О-О «Об отказе в принятии к рассмотрению жалоб гражданина Маркина Константина 
Однако ЕСПЧ определил, что «рассматриваемое российское законодательство не является совместимым с Конвенцией и обнаруживает широко распространенную в правовом механизме проблему, касающуюся значительного числа людей» ${ }^{1}$.

Основа национальной конституционно-правовой доктрины ЗГС в РФ была заложена Постановлениями Конституционного Суда РФ от 26 февраля 2010 г. № 4-П и от 6 декабря 2013 г. № 27-П, в которых Конституционный Суд обязал суды в случае выявления коллизии между правовыми позициями ЕСПЧ и Конституционного Суда относительно оспариваемой нормы обращаться с запросом в Конституционный Суд Р $\Phi^{2}$.

Необходимость выработки конкретного механизма преодоления конвенционно-конституционных коллизий побудила Конституционный Суд РФ в Постановлении от 14 июля 2015 г. № 21-П сформулировать ряд условий, при которых государство вправе отказаться от исполнения решения международного суда.

В дополнение к судебному механизму разрешения конвенционноконституционных коллизий (Постановление Конституционного Суда от 6 декабря 2013 г. № 27-П), основанному на запросе суда о проверке конституционности оспариваемой в конкретном деле нормы в случае выявления коллизии между правовыми позициями ЕСПЧ и Конституционного Суда в Постановлении от 14 июля 2015 г. № 21-П был

Александровича на нарушение его конституционных прав положениями статей 13 и 15 Федерального закона «О государственных пособиях гражданам, имеющим детей», статей 10 и 11 Федерального закона «О статусе военнослужащих», статьи 32 Положения о порядке прохождения военной службы и пунктов 35 и 44 Положения о назначении и выплате государственных пособий гражданам, имеющим детей». Текст официально опубликован не был.

1 Постановление Европейского Суда по правам человека от 7 октября 2010 г. по делу «Константин Маркин против Российской Федерации» (Konstantin Markin v. Russia), № 30078/06, judgment of 7 October 2010; Grand Chamber judgment of 22 March 2012 // Бюллетень Европейского Суда по правам человека. Российское издание. 2012. № 6.

2 Постановление Конституционного Суда РФ от 26 февраля 2010 г. № 4-П «По делу о проверке конституционности ч.2 ст. 392 ГПК РФ в связи с жалобами граждан А.А.Дорошка, А.Е.Кота и Е.Ю. Федотовой»; Постановление Конституционного Суда РФ от 6 декабря 2013 г. № 27-П «По делу о проверке конституционности положений статьи 11 и пунктов 3 и 4 части 4 статьи 392 ГПК РФ в связи с запросом президиума Ленинградского окружного военного суда» // Рос. газ. 2013 . 18 декабря. 
предложен несудебный механизм, предусматривающий толкование Конституции по запросу Президента или Правительства РФ. В ситуации, когда Конституционный Суд РФ приходит к выводу о несовместимости решения ЕСПЧ с Конституцией, оно не подлежит исполнению.

Данные правовые позиции, формирующие конституционно-правовую доктрину ЗГС РФ, легли в основу нового подхода к основаниям и пределам ограничения государственного суверенитета. Национальные механизмы конституционного контроля стали базироваться на безусловном верховенстве Конституции и суверенной ответственности в сфере прав человека.

Активная созидательная роль специализированного органа конституционного контроля позволила вывести политико-правовые идеи ЗГС в практическую плоскость и обеспечить их реализацию.

В начале 2000 г. интерпретационная деятельность Конституционного Суда оказала заметное влияние на развитие конституционной доктрины государственного суверенитета. В решениях Конституционного Суда РФ (Постановление от 7 июня 2000 г. № 10-П и Определение от 27 июня 2000 г. № 92-О) было указано на принадлежность суверенитета исключительно РФ, a также выведено доктринальное определение государственного суверенитета ${ }^{1}$.

В Постановлении от 7 июня 2000 г. Конституционный Суд определил, что федеральная Конституция не допускает какого-либо иного носителя суверенитета и источника власти помимо многонационального народа России и, следовательно, не предполагает какого-либо иного государственного суверенитета, помимо суверенитета РФ. Как отмечает В.Д. Зорькин, "эта правовая позиция позволила Суду сделать вывод, что принцип верховенства Конституции Российской Федерации и федеральных законов как выражение суверенитета Российской Федерации, распространяющегося

${ }^{1}$ Горюнов В.В. Указ соч. С. 181. 
на всю ее территорию, означает, в частности, что субъект Российской Федерации не может изменять установленные Конституцией Российской Федерации приоритеты действия законов и иных федеральных нормативных правовых актов, ограничивать их применение, приостанавливать их действие, вводить какие-либо связанные с действием этих актов процедуры и механизмы разрешения коллизий, правовых споров, не предусмотренные Конституцией Российской Федерации и федеральными законами (Определение от 27 июня 2000 г. N 92-O)"1.

Суверенитет РФ как демократического федеративного правового государства, распространяющийся на всю ее территорию, закреплен Конституцией РФ в качестве одной из основ конституционного строя (ч. 1 ст. 4). Носителем суверенитета и единственным источником власти в РФ, согласно Конституции, является ее многонациональный народ (ч. 1 ст. 3), который, сохраняя исторически сложившееся государственное единство, исходя из общепризнанных принципов равноправия и самоопределения народов и возрождая суверенную государственность России, принял Конституцию РФ.

Суверенитет, предполагающий, по смыслу ст. 3, 4, 5, 67 и 79 Конституции РФ, верховенство, независимость и самостоятельность государственной власти, полноту законодательной, исполнительной и судебной власти государства на его территории и независимость в международном общении, представляет собой необходимый качественный признак РФ как государства, характеризующий ее конституционно-правовой статус. Конституция РФ не допускает какого-либо иного носителя суверенитета и источника власти, помимо многонационального народа России, и, следовательно, не предполагает иного государственного суверенитета, помимо суверенитета РФ.

1 Зорькин В.Д. Верховенство права и конституционное правосудие // Журнал российского права. 2005. № 12. 
Таким образом, по мнению Конституционного Суда, суверенитет РФ исключает существование двух уровней суверенных властей, находящихся в единой системе государственной власти, которые обладали бы верховенством и независимостью - то есть не допускает суверенитета субъектов РФ.

Решение проблем укрепления правового единства и территориальной целостности, последовательное восстановление внешнеполитического влияния и экономический рост в РФ в 2000-е гг. вызвали необходимость пересмотра роли и места России в мировой политике и экономике. Руководство страны впервые с момента распада СССР вернулось к политике отстаивания национальных интересов и ЗГС не только внутри страны, но и за ее пределами.

Идеологическим обоснованием нового курса выступила доктрина суверенной демократии, в основе которой лежит идея построения обновленной и независимой от зарубежного вмешательства российской государственности.

Один из разработчиков этой политико-правовой концепции В.Ю. Сурков определил суверенную демократию как "образ политической жизни общества, при котором власти, их органы и действия выбираются, формируются и направляются исключительно российской нацией во всем ее многообразии и целостности ради достижения материального благосостояния, свободы и справедливости всеми гражданами, социальными группами и народами, ее образующими"1.

Конструкция суверенной демократии и ее содержательное наполнение вызвали полемику в научных кругах. Некоторые ученых высказывали опасения, что концепция суверенной демократии может послужить оправданием шагов государства по ограничению демократических прав и

\footnotetext{
${ }^{1}$ Сурков В. Тексты 97-07. М.: Европа, 2008. С.44.
} 
свобод, созданию препятствия для развития институтов гражданского общества. Критики суверенной демократии утверждали, что использование в названии концепции слова "суверенный" - это маскировка нежелания строить в России некую настоящую демократию, говорили о некорректности и надуманности термина, предполагали, что употребление термина "суверенная" отражает стремление российского государства подчеркнуть его исключительность, а также особую избранность нации и народа, а суверенитет демократии необходим власти для того, чтобы творить беззаконие, не допуская спасительной для российского народа помощи государств с "развитыми демократическими институтами"1.

Последовательная политика руководства государства по отстаиванию национальных интересов внутри страны и за рубежом развеяла эти сомнения. Разделяя демократические принципы, принятые во всем мире, Россия строит собственную национальную модель демократии и развития, отвечающую традициям сильного государства и незыблемого суверенитета.

Концепция суверенной демократии в самом широком смысле затрагивает не только вопросы суверенитета и демократии. Она включает в себя и экономические, социальные, правовые, а также ментальные аспекты развития общества и государства ${ }^{2}$.

Теоретики суверенной демократии полагают, что "данная доктрина как политико-правовая идея может иметь неоспоримую социальную ценность ... Эта идея дает возможность всем нам осознать, что российский народ не из тех, кому нужно ходить в школу к зарубежным учителям"3.

Важно отметить, что категория «суверенная демократия» не является изобретением российской политико-правовой мысли. В зарубежной политологии и политической практике термин sovereign democracy

\footnotetext{
1 Лебедев В.А. Российская демократия: национальные особенности, проблемы и решения в глобализирующемся мире // Гражданин. Выборы. Власть. 2014. № 2. С. 95.

2 Лебедев В.А., Киреев В.В. Указ соч.

${ }^{3}$ Горюнов В.В. Указ. соч. С. 191.
} 
применялся давно: впервые он был предложен в 1980 г. для политической идентификации Канады еe тогдашним генерал-губернатором Юджином Форси; позднее этот термин применялся в отношении Китая, Ирландии, ряда других стран ${ }^{1}$.

Сторонники суверенной демократии (Д.А. Медведев, Ю.А. Тихомиров и др.) обосновывают позицию, в соответствии с которой демократия может быть эффективной только в условиях полноценного государственного суверенитета, а суверенитет как независимость государственной власти внутри страны и вне ее может давать свои результаты только в условиях демократического политического режима 2 .

С таким подходом нельзя согласиться, поскольку, как уже отмечалось ранее, никакой особой связи государственного суверенитета и демократии не существует. Государственным суверенитетом могут обладать любые государства, независимо от формы политического режима: как демократические, так и антидемократические. История государства и права имеет множество примеров недемократических суверенных государств (абсолютные монархии, империи и др.).

По мнению С.А. Панкратова, «... политическая доктрина суверенной демократии указывает на неделимость народного суверенитета, сохранение национальной идентичности и апеллирует к консолидации граждан, элит, социальных групп и слоев» ${ }^{3}$.

Признак консолидации, сплоченности элит выделяет и В.Ю. Сурков: «Для суверенной демократии, отличаемой от прочих интеллектуальным

${ }^{1}$ Джагарян А.А. Концепция суверенной демократии в конституционном измерении / Суверенная демократия в конституционно-правовом измерении. Сб. статей и материалов. М.: Рос. газ., 2007. С. 120.

${ }_{2}$ Медведев Д.А. О демократии. Фрагмент стенограммы выступления на встрече Первого заместителя Председателя Правительства РФ Д. Медведева и заместителя Руководителя Администрации Президента РФ В. Суркова с представителями молодежных организаций // Официальный сайт Совета при Президенте РФ по реализации приоритетных национальных проектов и демографической политике (Обращение - 31 января 2007 г.). См. также Тихомиров Ю.А. Указ. соч. С. 90-91.

3 Панкратов С.A. Политическая модернизация России в контексте устойчивого развития (теоретический аспект). С.11.12. Цит по Джагарян А.А. С. 128. 
лидерством, сплоченной элитой, национально ориентированной открытой экономикой и умением защищаться, приоритетна гражданская солидарность как сила, предупреждающая социальные и военные столкновения. Свободное общество не будет мириться с массовой бедностью (на фоне массового же уклонения от уплаты налогов), убожеством социальной защиты, несправедливым распределением общественных доходов. Равно как и не поставит под сомнение (в условиях необъявленной гонки вооружений) необходимость разумных оборонных бюджетов для поддержания престижа и технического переоснащения армии, флота, спецслужб» ${ }^{1}$.

Социальная солидарность является имманентным признаком суверенной демократии. Жизнеспособность суверенной демократии напрямую зависит от солидарности государства и общества, от полноты выражения народных интересов в деятельности государственных институтов.

Нельзя забывать при этом, что в отношениях "народ-государство" главным является народ, и государство только тогда может быть эффективным, когда существует подлинная власть народа, который хорошо осознает, для каких целей эта власть ему нужна².

Следуя этой логике, В.А. Лебедевым и В.В. Киреевым суверенная демократия определяется как политико-правовой режим реализации полновластия народа в независимой от всякой другой власти деятельности государства для обеспечения высокой динамики роста благосостояния граждан, развития свободы личности, свободы предпринимательства и институтов гражданского общества ${ }^{3}$.

Обобщая идеологические конструкции суверенной демократии можно сделать вывод, что отличительной особенностью этой доктрины является

${ }^{1}$ Сурков В.Ю. Национализация будущего / Pro суверенную демократию. Сб. М.: Европа, 2007. С. 403, 404.

2 Лебедев B.A. Российская демократия: национальные особенности, проблемы и решения в глобализирующемся мире // Гражданин. Выборы. Власть. 2014. № 2. С. 98.

3 Лебедев В.А., Киреев В.В. Суверенная демократия или суверенитет демократии // Конституционное и муниципальное право. 2007. № 5. 
ориентации на сильное государство и свободную личность, возврат к идее консолидации общества, солидарности граждан и власти. Суверенная демократия впитала элементы этатизма, либерализма и других теоретических учений о государстве.

В целом необходимо отметить, что политико-правовые и конституционные наработки российских юристов, исследовавших проблемы государственного суверенитета, сформировали теорию государственного суверенитета, комплексно раскрывающую ценностные, психологические, социологические и нормативные аспекты государственной власти. Особенностью российских политико-правовых взглядов, обосновывавших независимость и верховенство государственной власти в разные периоды исторического развития, являлось неизменное позиционирование России как самостоятельного государства мирового значения. 


\section{3. Государственный суверенитет в зарубежной политико- правовой и конституционной доктрине}

Зарубежные теоретико-правовые исследования государственного суверенитета представлены школами этатизма ("политического реализма"), либерализма и "конструктивизма".

Наиболее распространенной является теория "политического реализма", основанная на следующих основных положениях:

- международным отношениям свойственны постоянные противоречия;

- в международных отношениях государства руководствуются своими национальными интересами, характер взаимоотношений государств определяется уровнями их мощи (силы, власти) $)^{1}$;

- для обеспечения своей безопасности и защиты суверенитета государства стремятся мобилизовать доступный им максимум ресурсов;

- государства являются внутренне целостными субъектами внутренней и внешней политики;

- государства сами определяют отношения друг с другом; над уровнем суверенного государства нет никакой более высокой международной власти, которая была бы способна регулировать поведение участников международной системы;

- международные институты, транснациональные корпорации, любые иные надгосударственные и внутригосударственные субъекты не играют в мировой политике значимой роли.

1 Подавляющее число американских специалистов признает силу важнейшим элементом международных отношений. Как отмечает профессор политических наук университета штата Нью-Йорк Г. Бреттон, «сила - главным образом экономическая и военная - объясняет суть международных отношений наиболее удовлетворительным образом». По мнению профессора Калифорнийского университета К. Уолтса, «государство с большим запасом военной силы может с большей уверенностью угрожать и одерживать верх более часто, чем государство с меньшим запасом силы». См. Тимохин П. Военная сила в политике национальной безопасности США // Зарубежное военное обозрение. 2015. № 2. С. 3,4. 
Долгое время "реализм" являлся доминирующей традицией государственного мышления, к наиболее известным представителям которой относят Фукидида, Сунь Цзы, Н. Макиавелли, кардинала Ришелье, Т. Гоббса, Ж. Бодена, Ш. Талейрана, К. Меттерниха, К. фон Клаузевица, О. фон Бисмарка, Ш. де Голля, Г. Киссинджера, 3. Бжезинского и многих других ${ }^{1}$.

Поддерживая важнейшую роль принуждения и военной силы во внешней политике, представители современного реализма исходят из того, что характер государственной мощи изменился и понятие "сила" стало более сложным. Это проявляется, во-первых, в том, что сила перестала быть однородной. Во-вторых, она не отождествляется только с военной мощью. Втретьих, имеет место т.н. "диффузия силы", т.е. ее перераспределение среди участников международных отношений ввиду резкого увеличения их числа и расширения круга вопросов внешней политики. Поэтому считается, что военная сила еще не гарантирует политического влияния и не может обеспечить решение любых внешнеполитических проблем².

Либеральная школа сложилась на рубеже 18 - 19 вв. В зарубежной литературе ее предтечей считается И.Кант с трактатом "К вечному миру", а реальным основоположником и наиболее известным представителем президент США В. Вильсон.

В трактате "К вечному миру" (1795) Кант пишет о полном (вечном) мире, который возможен при объединении всех государств в федерацию (или конфедерацию), основанную на правовых началах. Допуская определенную долю условности, можно утверждать, что мыслитель теоретически обосновал необходимость создания будущей ООН. При этом Кант идеалистически

\footnotetext{
${ }^{1}$ Внешняя политика России. Теория и практика / Под общей ред. С.В. Смульского, О.Д. Абрамовой / Теоретико-методологические подходы к изучению международных отношений. М.: Книга и бизнес, 2013. С. 16.

2 Тимохин П. Военная сила в политике национальной безопасности США // Зарубежное военное обозрение. 2015. № 2. С. 5.
} 
полагал, что большинство государств с республиканской формой правления должны отвергать идею войн.

По мнению В. Вильсона, "на международной арене государства должны ставить перед собой такие же цели, какие они преследуют в своей внутренней политике". В работе "Государство. Прошлое и настоящее конституционных учреждений" В.Вильсон отмечал, что "публичный порядок держится потому, что этот порядок тесно согласуется с самим характером общества"1 .

Основные идеи либерализма могут быть сформулированы следующим образом:

- конфликтная международная система уступает место миру, в котором существует множество возможностей для сотрудничества; государства взаимозависимы и предрасположены к сотрудничеству;

- детерминантами внешней политики государств являются не столько его военные и экономические возможности, сколько социокультурные и политические факторы;

- современные государства осуществляют власть совместно с корпорациями, неправительственными организациями, деловыми структурами и даже индивидами.

Третьей конкурирующей школой является "конструктивизм". По мнению еe сторонников, внешняя политика государств определяется исторически доминирующими в том или ином обществе идеями ${ }^{2}$. Проводимая государством политика представляет собой "социальные конструкты", возникающие на основе общих идей. В рамках внешнеполитического анализа "конструктивисты" особое внимание уделяют

\footnotetext{
${ }^{1}$ Вудро Вильсон. Государство. Прошлое и настоящее конституционных учреждений / Политические институты, избирательное право и процесс в трудах западно-европейских мыслителей XVII - начала XX века: Хрестоматия / Сост. Ю.А. Веденеев, И.В. Зайцев, Л.В. Поляков. М.: РЦОИТ при ЦИК РФ, 2003. С. 690.

${ }^{2}$ Внешняя политика России. Теория и практика / Под общей ред. С.В. Смульского, О.Д. Абрамовой / Теоретико-методологические подходы к изучению международных отношений. М.: Книга и бизнес, 2013. С. 19.
} 
целям государств, международным угрозам, страхам, элементам культуры, идентичности, языку и политической риторике ${ }^{1}$.

По хронологическому критерию в развитии зарубежных политикоправовых идей государственного суверенитета можно выделить ряд этапов:

- обоснование независимости светской власти от духовной и отождествление суверенитета государства с суверенитетом его конкретного носителя (как правило, главы государства) ${ }^{2}$;

- становление государственного суверенитета как особого свойства (характеристики) государственной власти, не связанной с конкретным носителем ${ }^{3}$;

- распространение элементов суверенитета на общество (обоснование гражданского общества как источника "народного суверенитета"), его взаимосвязь либо противопоставление государственному суверенитету;

- распространение суверенитета не только на общество, но и нацию (обоснование "национального суверенитета"), разграничение "государственного", "народного" и "национального" суверенитетов.

Данные этапы развития идей государственного суверенитета (либо их элементы) можно проследить в рамках каждой из перечисленных школ.

Современная концепция государственного суверенитета стала результатом затяжных войн в Священной Римской империи. Права на государственную территорию, верховенство государственной власти, принципы равенства и суверенитета, соблюдения международных договоров были провозглашены участниками Вестфальского мира 1648 г., которым завершилась Тридцатилетняя война и Реформация. После Вестфальского

1 Наиболее видными представителями школы «конструктивизма» являются $\mathrm{H}$. Онуф, А. Вендт, Э. Рингмар.

2 Идея суверенитета государства сформировалась как реакция на ослабление государственных институтов и феодальную раздробленность.

${ }^{3}$ Принято считать, что Гуго Гроций впервые теоретически «отделил» суверенитет государства от суверенитета его конкретных носителей. 
мира начала складываться система национальных суверенных государств, получившая название "вестфальская модель государственного суверенитета".

Рассматривая этатистское направление (школу "реализма"), нельзя обойти вниманием таких теоретиков политико-правового учения, как Ж. Боден и Т.Гоббс.

Принято считать, что именно Ж. Боден разработал теорию государственного суверенитета.

Как полагал Боден, главным признаком государства является суверенитет как абсолютная, единая и постоянная власть.

Абсолютность суверенитета означает, что суверенная власть не подчиняется повелениям других и не ограничивается какими-либо условиями.

Единство (неделимость) суверенитета Боден понимал как невозможность осуществления власти различными политическими силами (монархом, знатью и народом). Один из элементов власти всегда преобладает.

Постоянство суверенитета раскрывается как вечный характер верховной власти.

Суверенитет государства реализуется в следующих важнейших полномочиях:

- издавать, изменять и отменять законы;

- решать вопросы войны и мира;

- назначать должностных лиц и определять их обязанности;

- осуществлять правосудие и помилование;

- чеканить монету;

- определять меры и весы;

- взимать налоги и подати.

Боден теоретически решил вопрос о распределении суверенитета в сложных государствах. На взгляд мыслителя, в федеративных государствах 
субъекты федерации находятся в зависимости от суверена, а в конфедерациях части союзного государства сохраняют свой суверенитет.

Яркое воплощение защита абсолютной политической власти получила в работах Т. Гоббса. По мнению философа, абсолютная власть государства призвана выступать главным гарантом мира и реализации естественных законов. Государство использует силу и средства людей так, как оно считает необходимым для поддержания мира и общей защиты.

Гоббс считал, что "верховная власть не столь пагубна, как отсутствие её, и вред возникает тогда, когда большинство с трудом подчиняется меньшинству". Несмотря на гиперболизацию идеи государственного суверенитета, особенность учения Гоббса заключается в том, что обладающее полновластием государство должно выполнять не только охранные функции, но и гарантировать своим подданным гражданские свободы. Для 17 века подобная характеристика суверенного государства была нетипичной.

Буржуазные революции и развитие естественно-правовых идей способствовали становлению ранних демократических теорий, обосновывающих необходимость ограничения государственной власти. Таким образом, на смену доктринам "абсолютного суверенитета" приходят конституционные теории государственного суверенитета ${ }^{1}$.

Одним из первых разработчиков либеральных идей стал Б. Спиноза.

Спиноза исходил из того, что "право верховной власти не что иное, как естественное право, но определяемое не мощью каждого в отдельности, а мощью народа, руководимого единым духом, т.е. как отдельный человек в естественном состоянии, точно так же тело и дух всей верховной власти имеют столько права, сколько мощи.

1 Основоположником конституционных теорий государственного суверенитета принято считать Д. Локка, который отказался от идеи абсолютной политической власти. 
Если государство уступает кому-либо право, а следовательно, и власть жить по-своему усмотрению, то тем самым оно отказывается от своего права и переносит его на того, кому дало такую власть. Если же оно дало такую власть двум или многим лицам, чтобы именно каждый жил по своему усмотрению, то тем самым оно разделило верховную власть, и если, наконец, оно дало эту власть каждому из граждан, то тем самым оно разрушило само себя и нет уже более государства ${ }^{1}$.

Спиноза раскрывает свое видение суверенных прав государства:

"Только верховная власть имеет право решать, что хорошо, что дурно, что справедливо, что несправедливо, т.е. что следует делать каждому в отдельности или всем вместе или от чего воздерживаться. Таким образом, мы видели, что только ей одной принадлежит право издавать законы, толковать их в каждом отдельном случае, если относительно их возникнет какойнибудь вопрос, и решать, противоречит ли данный случай праву или согласен с ним; решать вопрос о войне или об установлении и предложении условий мира или о принятии предложенных ${ }^{2}$.

Лишь верховной власти принадлежит право судить о поступках каждого, налагать кару на преступников и разрешать вопросы о праве, возникающие между гражданами, или же назначать знатоков действующего права, чтобы они занимались этим вместо нее; затем определять и проводить меры, необходимые для ведения войны и сохранения мира. Только верховной власти принадлежит право заниматься государственными делами или избирать с этой целью должностных лиц.

В отличие от Гоббса, Спиноза не только осуждал абсолютную монархию, но и обосновывал необходимость установления пределов власти (мощи и права) государства внутри страны.

1 Спиноза Б. Политический трактат / Политические институты, избирательное право и процесс в трудах западно-европейских мыслителей XVII - начала XX века: Хрестоматия / Сост. Ю.А. Веденеев, И.В. Зайцев, Л.В. Поляков. М.: РЦОИТ при ЦИК РФ, 2003. C. 63.

${ }^{2}$ Спиноза Б. Указ. соч. С. 65. 
Эту мысль он выразил в трех позициях.

1. Пределы государственной власти устанавливаются требованиями разума, воплощенными в законах.

2. Пределы мощи и права государства определены естественными правами подданных (способностью людей думать, любить, верить в бога, защищать свою жизнь).

3.Мощь и право государства подрываются действиями, вызывающими негодование большинства подданных.

Не останавливаясь на внутреннем аспекте пределов государственного суверенитета, Спиноза определил и пределы права государств в международных отношениях. По его мнению, требования естественного права обязывают государства следовать миру, "чем больше государств заключают вместе мир, тем более они обязаны блюсти условия мира, тем менее они своеправны...".

Вопросы ограничения государственной власти, правовой защищенности личности, гарантии гражданских свобод разрабатывал известный идеолог французского либерализма Бенжамен Констан.

Дискутируя с Руссо и Гоббсом в работе "Принципы политики, пригодные для всякого правления", Бенжамен Констан полагал, что "до тех пор, пока суверенитет не ограничен, нет никакого средства дать индивидам защиту от правления. Впустую будете вы пытаться подчинить правление общей воле...

Народ - суверен в одном отношении, а подданный - в другом; но на практике оба отношения смешиваются. Власти очень легко притеснять народ в качестве подданного, чтобы принудить его в качестве суверена демонстрировать свою волю, продиктованную ему этой же властью.

Никакая политическая организация не способна устранить эту опасность. Напрасно будете вы разделять власти: если общая сумма власти не ограничена, разделенным властям остается лишь создать коалицию - и 
деспотизм будет неизлечим. Для нас важно не то, чтобы наши права не могли быть нарушены какой-либо властью без одобрения другой, но чтобы такое нарушение было запрещено для любой из властей. Нам недостаточно, чтобы исполнители испрашивали дозволения законодателя, нам нужно, чтобы законодатель мог разрешить им совершить действие лишь в законной для них сфере. Нам мало, если исполнительная власть не имеет права действовать без опоры на закон, если мы не установим границ этой опоры, если не провозгласим, что она относится к тем вещам, в отношении которых законодатель не имеет права издавать закон, либо, другими словами, что суверенитет ограничен и что существуют волеизъявления, которые ни народ, ни его представители не имеют права иметь"1.

По мнению Б. Констана, гарантиями ограничения суверенитета являются (общественное - прим. автора) мнение и равновесие (разделение) властей.

Общественное мнение учитывается при наличии в государстве представительной системы правления, которая предполагает постоянное и активное наблюдение за народными представителями и возможность лишения их полномочий в случае злоупотребления.

В "Курсе конституционной политики" Констан выделил 6 конституционных властей, которые призваны ограничивать власть и защищать личную (гражданскую) свободу индивида: королевскую, наследственную, выборную законодательную, исполнительную, судебную и муниципальную власти.

Лейтмотивом политико-правовой идеологии Констана была независимость граждан от государственной власти и подчиненность политической жизни ценностям личной свободы. Эти взгляды он последовательно отстаивал на протяжении всей своей жизни.

${ }^{1}$ Классический французский либерализм. М., 2000. С. 26-37. 
Другой французский либерал, Франсуа Пьер Гийом Гизо, обосновывал идеи гармоничного сочетания сильного, полновластного государства и свободного общества. В центре внимания ученого находились и вопросы суверенитета.

"Подобно тому, как человек творил себе богов, он создавал себе и господ. Он попытался найти место на земле не только для божества, но и для суверенитета. Он пожелал, чтобы им управляла власть, которая бы имела незыблемое и прочное право на его послушание. И в закреплении своего послушания - безграничного и необратимого - он преуспел не меньше, чем в закреплении своей веры. Этим изначальным и безграничным суверенитетом человек наделял то одного человека, то нескольких, здесь - одно семейство, там - касту, а кое-где - и целый народ. Но как только он присваивал им этот суверенитет, то сразу же ощущал потребность оспорить их право на суверенитет, лишить их его. Он хотел, чтобы им управлял абсолютно и навечно легитимный правитель. Но нигде и никогда он не мог повстречать такого. И, тем не менее, человек продолжал искать или верить, что наконецто нашел его"1.

По мнению Гизо, необходимо создать свободное общество, управление которым со стороны государства будет осуществляться не столько на основе принуждения, сколько на поддержке и доверии граждан:

"Ни один народ не признавал власть только из-за ее силы; он хотел верить в ее легитимность, в ее божественность. Ни одна власть не довольствовалась одной только силой; она нуждалась в том, чтобы ее признавали легитимной и божественной.

Принцип правлений, как порядок и власть подлинного закона, вступает в борьбу против изначальных пороков; власть упорядочивается и смягчается; под воздействием событий она постепенно приспосабливается к обществу,

${ }^{1}$ Классический французский либерализм. М., 2000. С. 507-546. 
которое, также в силу необходимости, приноравливается к власти; между ними устанавливаются определенная гармония и законы, способные эту гармонию поддерживать; воздействия силы ослабевают, да и сама сила отходит, уступая место власти права. Наилучшее правление расценивается и как наиболее легитимное; полагаемое легитимным, оно становится и наилучшим: и под воздействием времени, которое одновременно укрепляет легитимность и делает ее более плодородной, предполагаемая легитимность правления подталкивает его к легитимности подлинной, выступающей единственной целью как усилий, так и уважения со стороны общества"1.

Благодаря Гизо в европейской политико-правовой доктрине впервые отчетливо прозвучала идея легитимности государственных институтов, ответственности и взаимосвязанности государства, общества и граждан.

Американская политико-правовая доктрина вопросы государственного суверенитета разрабатывала через призму формы государственного устройства и распределения власти.

Федералисты (Александр Гамильтон, Джон Адамс, Джеймс Мэдисон) рассматривали федеративное устройство государства в качестве барьера от внутренних раздоров и восстаний. Они обосновывали иерархию правовых актов в соответствии с их юридической силой и приоритет федеральных законов над законами штатов. Отстаивали позицию о том, что ни один из законов штатов, противоречащих федеральной Конституции, не может иметь силу.

По мнению федералистов, в федеративном государстве существует вертикальное (федерация - субъекты федерации) и горизонтальное (исполнительная, законодательная и судебная власти) распределение власти, представленное двумя автономными системами управления.

1 Франсуа Пьер Гийом Гизо. Политическая философия: о суверенитете / Политические институты, избирательное право и процесс в трудах западно-европейских мыслителей XVII - начала XX века: Хрестоматия / Сост. Ю.А. Веденеев, И.В. Зайцев, Л.В. Поляков. М.: РЦОИТ при ЦИК РФ, 2003. С. 517. 
Позднее многие их идеи лягут в основу концепций распределения власти в союзных государствах и определения конституционно-правового статуса субъектов федераций.

В конце 19 - начале 20 вв. зарубежные теории права и конституционные доктрины активно развивали идеи народного представительства, солидаризма и правового государства.

В теории представительного мандата суверенитет рассматривался как воля народа, а государственные органы - как носитель народных прав. Примыкающая к ней теория носителя власти допускала возможность самостоятельного осуществления этим носителем властных полномочий, а также возможность их делегирования другим субъектам. Сторонники юридико-органической теории обосновывали наличие в государстве непосредственных (прямых) органов.

Теоретик конституционализма Леон Дюги подвергал критике частноправовое преломление идеи представительства к публично-правовым отношениям и смежную с ней теорию носителя Г. Мейера:

"Называют носителем государственной власти лицо или группу лиц, коим государственная власть принадлежит, как собственное, прирожденное право. Носитель государственной власти вполне может или самолично выполнять принадлежащие ему права власти или заставить выполнять эти права другое лицо от своего имени. Прилагая это представление к различным формам правительства, приходят к следующим выводам: в монархиях божественного права носителем государственной власти является монарх; в теократических аристократиях носитель публичной власти образует группа знати; наконец, в демократиях носителем суверенитета является сама нация ${ }^{1 " .}$

1 Леон Дюги. Конституционное право. Общая теория государства / Политические институты, избирательное право и процесс в трудах западно-европейских мыслителей XVII - начала XX века: Хрестоматия / Сост. Ю.А. Веденеев, И.В. Зайцев, Л.В. Поляков. М.: РЦОИТ при ЦИК РФ, 2003. С. 833. 
Дюги выступал против дуализма в государстве, образования в нем двух лиц: лица нации (носителя публичной власти), и лица государства. Подобная двойственность могла бы привести к размыванию ответственности государства и неисполнению им своих обязанностей перед обществом ${ }^{1}$.

Дюги считал, что основанием публичной власти является осуществление социальной солидарности. Сущность государства не в командовании обществом, а в служении ему. Государство будущего (синдикалистское государство) должно стать федерацией классов, организованных в синдикаты.

В этот же период окончательно сложилась комплексная доктрина правового государства, элементы которой длительное время разрабатывались многими юристами.

С. Гру, А. Рюи Фабри, Н. Рулан различают 3 европейских модели правового государства:

английскую;

французскую;

немецкую.

Английская концепция правового государства (rule of law) сложилась раньше остальных. Начиная с Великой хартии вольностей идея верховенства законов над властью короля получила юридическое закрепление. "Славная революция" ограничила королевскую власть парламентскими институтами. Позднее был учрежден судебный контроль.

В основе французской концепции правового государства лежит принцип разделения властей как подчинения учрежденных властей учреждающей власти, а также идея защиты личности.

Во 2-й половине 19 в. немецкие юристы Шталь, Гнейст, Штейн предложили немецкую модель формального правового государства, в

\footnotetext{
1 Леон Дюги. Указ. соч. С. 841.
} 
соответствии с которой конституционному контролю должны подвергаться процедурные вопросы и правильность исполнения норм ${ }^{1}$. В дальнейшем опыт государственного строительства Третьего Рейха докажет, что формального контроля недостаточно. После окончания II мировой войны немецкая концепция правового государства была дополнена материальными инструментами.

Заметный вклад в разработку идей связанности государства правом, правовой защищенности личности, взаимной ответственности государства и граждан внесли Г. Еллинек и Л. Штейн.

Георг Еллинек предложил теорию "правового самоограничения государства". Он полагал, что власть государства имеет свои юридические границы и обосновал необходимость притязаний индивида к государству с целью предоставления благ, которые он самостоятельно добыть не может. Еллинек назвал их субъективными публичными правами и классифицировал на три группы:

- политические свободы (неприкосновенность личности, жилища, тайна переписки, свобода слова, передвижений и т.п.);

- права личности на участие в управлении государством (избирательные права);

- права личности на положительные действия со стороны государства (судебная и административная защита законных интересов личности).

По мнению юриста, государство не вправе посягать на субъективные права индивидов и должно защищать своих граждан от произвола должностных лиц.

Еллинек рассматривал современное государство в качестве представителя общих интересов народа. При этом акцентировал внимание на

1 Лоренц фон Штейн впервые сформулировал понятие социального государства, предполагающего ответственность публичной власти за обеспечение условий жизни и развития всех граждан. 
том, что "воля народа, как и воля монарха и его учредителей, должна быть внепартийной, выражающей только общий интерес, хотя отнюдь не всегда действительно является таковой. Но и не соответствующая идеалу государственная воля все же остается волею государства"1.

Как и Георг Еллинек, Лоренц фон Штейн полагал, что монарху должны быть чужды интересы какого-либо отдельного класса. Глава государства выражает интересы всего общества, защищает правопорядок, и такая форма правления является "надклассовой монархией". Чтобы избежать потрясений, государство должно из орудия эгоистических интересов собственников превратиться в политический инструмент "общего блага".

Идеи эффективной социальной политики государства в интересах большинства граждан, демократизации политической жизни, децентрализации государственной власти и народного контроля над ней получили последовательное развитие во второй половине 20 в. в концепциях "плюралистической демократии" и "государства всеобщего благоденствия".

К концу 20 в. зарубежная политико-правовая доктрина сконцентрировалась на необходимости участия в политике и управлении широкого спектра социальных групп и организаций, ответственности государства перед обществом, идеях политического плюрализма, защите прав граждан на оппозицию.

В конституциях зарубежных стран идеи государственного суверенитета нашли свое воплощение в нескольких вариациях:

- в характеристике форм государства;

- в положениях о территории государства;

- в положениях о ЗГС в различных сферах общественной жизни и полномочиях специальных государственных институтов (главы государства,

1 Георг Еллинек. Общее учение о государстве / Политические институты, избирательное право и процесс в трудах западно-европейских мыслителей XVII - начала ХХ века: Хрестоматия / Сост. Ю.А. Веденеев, И.В. Зайцев, Л.В. Поляков. М.: РЦОИТ при ЦИК РФ, 2003. С. 690 
правительства, парламента, Вооруженных Сил) по ЗГС.

Значительная часть зарубежных стран провозгласила себя свободными, независимыми и суверенными государствами (ст. 1 Конституции Социалистической Республики Вьетнам, ст.1 Конституции Республики Индонезия, ст. 6 Конституции Республики Никарагуа, ст. 1 Политической конституции Боливии, ст. 1 Конституции Боливарианской Республики Венесуэла, ст. 43 Конституции Республики Перу, ст. 40 Конституции Мексиканских Соединенных Штатов).

При характеристике форм государства в конституциях большинства зарубежных стран указывается на принадлежность суверенной власти народу (ч.1 ст. 2 Конституции КНР, ч.2 ст.1 Конституции Республики Корея, ст.1 Конституции Японии, ст. 2 Конституции Социалистической Республики Вьетнам (далее - СРВ), ч.2 ст.1 Конституции Республики Индонезии, ст. 39 Конституции Мексиканских Соединенных Штатов, ст.2 Конституции Республики Никарагуа, ст.2 Политической Конституции Боливии, ст. 45 Конституции Республики Перу, ст. 5 Политической Конституции Республики Чили и др.). В некоторых Основных законах выделяются свойства государственного суверенитета (например, в ст. 2 Политической Конституции Боливии закреплены неотчуждаемость и неограниченность суверенитета, в ст. 13 Конституции Боливарианской Республики Венесуэла неограниченность суверенитета, в Переходных положениях Конституции Аргентинской Республики - законность суверенитета). Вместе с тем, в зарубежном законодательстве отмечается терминологическое смешение государственного, народного и национального суверенитета: во многих случаях данные понятия используются как синонимы.

Как известно, государственный суверенитет существует и распространяется на определенной территории. В конституционно-правовой доктрине территориальное верховенство выступает основным элементом государственного суверенитета. Не случайно одним из направлений 
реализации потенциала государства является всестороннее развитие и надежная защита национальной территории. В связи с этим в Основных законах зарубежных стран могут быть главы о национальных территориях и дан их перечень. Так, в ст.11 главы 1 Конституции Боливарианской Республики Венесуэла закреплено, что «Суверенитет Республики распространяется на континентальное и островное пространство, озера и реки, территориальное море, внутренние воды, исторически и жизненно необходимые и включающие береговые линии, установленные Республикой; поверхность почвы и все находящееся под ней; воздушное континентальное пространство, прибрежное и морское, а также ресурсы, находящиеся в них, включая и возможные месторождения, в том числе и мигрирующие воды, производимые ими продукты и их неприкосновенные компоненты, которые по природным причинам могут там оказаться. Прибрежное пространство Республики включает в себя архипелаг Лос-Монхес, архипелаг Лас-Авес, архипелаг Лос-Рокес, архипелаг Ла-Орчила, остров Ла-Тортуга, остров ЛаБланкилла, архипелаг Лос-Эрманос, острова Маргарита, Кубагуа и Коче, архипелаг Лос-Театигос, остров де Патос и остров де Авес и, кроме того, острова, скалы и отмели, расположенные или выступающие на поверхности территориального моря, которое покрывает континентальную платформу или находится в границах исключительной экономической зоны. Над пространством, образованным примыкающей морской зоной, континентальной платформой и исключительной экономической зоной, Республика осуществляет суверенные права и юрисдикцию в порядке, определяемом нормами международного права и национальным законодательством. Республика осуществляет свои права в космическом пространстве и в тех зонах, которые являются или могут являться общим достоянием всего человечества в порядке, определяемом международными 
договорами и национальным законодательством» ${ }^{1}$.

В ряде случаев в конституциях провозглашена цель восстановления территориальной целостности и подтверждение суверенитета над спорными территориями. В ч. 3 ст.66 Конституции Республики Корея сформулирована обязанность Президента Кореи «добиваться мирного объединения Родины» ${ }^{2}$ В Переходных положениях Конституции Аргентинской Республики указано: «Аргентинская нация подтверждает свой законный и безусловный суверенитет над Мальвинскими островами, Южной Джорджией и Южным Сандвичем и прилегающими водными и островными пространствами, являющимися неотъемлемой частью государственной территории. Возвращение указанных территорий и осуществление суверенитета над ними в полном объеме при уважительном отношении к образу жизни населяющих их жителей и с соблюдением принципов международного права составляют постоянную и неотчуждаемую от аргентинского народа цель».

Следует иметь в виду, что вопросы территории и установления границ государств традиционно регулируются не только конституционным законодательством, но и общепризнанными нормами и принципами международного права. В этой связи большую ценность представляет практика Международного Суда ООН, в результате которой Суд ООН выявил признаки осуществления государственного суверенитета на спорных территориях, сформулировал международные принципы установления границ и обстоятельства, обеспечивающие справедливую делимитацию ${ }^{3}$

1 Конституции государств Америки / Под ред. Т.Я. Хабриевой.Т.3. Южная Америка. М.: Институт законодательства и сравнительного правоведения при Правительстве РФ, 2006. С. 311.

${ }^{2}$ Конституции государств Азии / Под ред. Т.Я. Хабриевой. Т.3. Дальний Восток. М.: Институт законодательства и сравнительного правоведения при Правительстве РФ: Норма, 2010. С. 996.

${ }^{3}$ См. Решения Международного Суда ООН от 17 ноября 1953 г. «Дело об островах Менкье и Экрихос», от 20 июня 1959 г. «Дело, касающееся суверенитета над некоторыми приграничными землями», от 20 февраля 1969 г. «Дела о континентальном шельфе Северного моря», Консультативное заключение от 16 октября 1975 г. «Западная Сахара», от 20 января 1982 г. «Дело о делимитации морской границы в районе залива Мэн», от 3 июня 1985 г. «Дело о континентальном шельфе между Ливийской Арабской Джамахирией и Мальтой» и др. 
Так, в делах от 17 ноября 1953 г. об островах Менкье и Экрихос, от 20 июня 1959 г. о суверенитете над некоторыми приграничными землями, в консультативном заключении от 16 октября 1975 г. о Западной Сахаре Суд признал, что осуществление в течение длительного времени государственно властных функций является проявлением государственного суверенитета, весомым и достаточным поводом суверенной принадлежности территории.

В решении по делам о континентальном шельфе Северного моря от 20 февраля 1969 г. (делимитация границ континентального шельфа между ФРГ и Данией, с одной стороны, и между ФРГ и Нидерландами - с другой) Международный Суд ООН указал на то, что «при делимитации необходимо действовать по соглашению, следуя принципам справедливости и принимая во внимание все обстоятельства, относящиеся к делу, и тем самым оставить каждой стороне в максимально возможной мере все те части континентального шельфа, которые образуют естественное продолжение ее территории, без вторжения в естественное продолжение сухопутной территории другой стороны; и что если в результате такой делимитации произойдет частичное совпадение территорий, они должны быть разделены между сторонами в согласованных пропорциях либо, в случае недостижения соглашения, поровну, если стороны не примут решения о режиме совместной юрисдикции, совместном пользовании или эксплуатации. При переговорах в число факторов, которые должны быть приняты во внимание, необходимо включить: общую конфигурацию побережья сторон, а также его особые или необычные признаки; известные или легко устанавливаемые характеристики физической и геологической структуры и природные ресурсы континентального шельфа; показатель разумного соответствия между размерами территорий континентального шельфа, принадлежащих каждому государству, и длиной побережья этого государства, измеренной по общему 
направлению береговой линии» ${ }^{1}$.

В решении по делу о континентальном шельфе между Ливийской Арабской Джамахирией и Мальтой от 3 июня 1985 г. Суд учел положения Конвенции ООН 1982 г. по морскому праву и указал современные принципы международного права, применимые к делимитации континентального шельфа:

«Делимитация должна проводиться в соответствии с принципами справедливости с учетом всех обстоятельств. Район континентального шельфа, который должен быть определен как принадлежащий одной из сторон, не должен выходить за пределы 200 мильной береговой линии соответствующей стороны. При обеспечении справедливой делимитации должны учитываться: общая конфигурация побережья сторон, их противолежание и их взаимосвязь в общегеографическом контексте; различия в протяженности соответствующих береговых линий и расстояния между ними; необходимость избегать чрезмерного нарушения пропорциональности между размерами районов континентального шельфа, принадлежащих прибрежному государству, и длиной соответствующей части побережья, измеренной в общем направлении береговой линии» ${ }^{2}$.

Территориальное верховенство и максимальная степень национальной юрисдикции в пределах государственной территории могут иметь принципиальное значение. Не случайно в конституциях некоторых государств содержится прямой запрет на создание (размещение) на национальной территории военных баз иностранных государств (ст. 92

1 Решение Международного Суда ООН от 20 февраля 1969 г. «Дела о континентальном шельфе Северного моря» / Краткое изложение решений, консультативных заключений и постановлений Международного Суда (1948-1991). НьюЙорк: ООН, 1993. С. 94.

2 Краткое изложение решений, консультативных заключений и постановлений Международного Суда (1948-1991). Нью-Йорк: ООН, 1993. С. 187. 


\section{Конституции Республики Никарагуа $)^{1}$.}

Аналогичный запрет содержится в ст. 13 Конституции Боливарианской Республики Венесуэла: «Венесуэльское географическое пространство является зоной мира. На нем запрещено размещать иностранные военные базы или учреждения, которые имеют какие-либо цели военного характера или намереваются их иметь. ...Национальная территория не может быть отчуждена, сдана в аренду или передана каким-либо способом иностранным государствам и другим субъектам международного права»².

В конституционной доктрине и соответствующих учредительных актах можно найти элементы ЗГС в социально-экономической, политической и идеологической сферах общественной жизни.

Согласно ст. 99 Конституции Никарагуа «государство должно гарантировать существование и функционирование мелких и средних производителей». Данную социальную группу законодатель рассматривает как социальную базу экономического суверенитета и развития страны. В целях привлечения иностранного капитала в экономику «без ущерба национальному суверенитету государство обнародует закон об иностранных инвестициях» (ст. 100 Конституции Никарагуа) ${ }^{3}$.

ЗГС в политической сфере предполагает равноправные отношения с другими государствами, недопустимость вмешательства иностранных государств во внутренние дела, разрешение международных споров мирными средствами (Преамбула Конституции Японии, ст. 1 и 2 Конституции Республики Никарагуа, ст. 4 Конституции Федеративной Республики Бразилия).

1 Конституции государств Америки / Под ред. Т.Я. Хабриевой.Т.3. Южная Америка. М.: Институт законодательства и сравнительного правоведения при Правительстве РФ, 2006. С. 599.

2 Конституции государств Америки / Под ред. Т.Я. Хабриевой. Т.3. Южная Америка. М.: Институт законодательства и сравнительного правоведения при Правительстве РФ, 2006. С. 312.

${ }^{3}$ Конституции государств Америки / Под ред. Т.Я. Хабриевой. Т.1. Северная и Центральная Америка. М.: Институт законодательства и сравнительного правоведения при Правительстве РФ, 2006.С. 601. 
В статьях 30 и 33 главы III Конституции СРВ содержатся положения, регламентирующие ЗГС в идеологической сфере: «Строго запрещается пропаганда реакционной и безнравственной идеологии и культуры... любая культурная и информационная деятельность, наносящая ущерб интересам государства и причиняющая вред личности, морали и достойному образу жизни вьетнамских граждан» ${ }^{1}$. Конституция Боливарианской Республики Венесуэла (ст. 15) возлагает на государство обязанность «обеспечивать национальную идентичность» ${ }^{2}$.

Ocобое внимание уделяется защите традиционных религиозных ценностей. Так, в ст. 3 Политической Конституции Боливии указано, что «государство признает и поддерживает римскую апостольскую католическую религию». В Преамбуле Конституции Республики Индонезии упоминается ключевая роль ислама в обретении индонезийским государством суверенитета.

В конституционных актах зарубежных стран содержится обязанность специально уполномоченных государственных органов или государства в целом защищать независимость, суверенитет и территориальную целостность государства. Ст. 15 Конституции Боливарианской Республики Венесуэла и ст. 44 Конституции Республики Перу возлагают эту обязанность на государство, ч.2 ст. 66 Конституции Республики Корея - на Президента, а ст. 30 Конституции Республики Индонезия, 45 Конституции СРВ, ст. 92 Конституции Республики Никарагуа, ст. 208 Политической Конституции Боливии, ст. 217 Конституции Колумбии, ст. 165 Конституции Республики Перу - на Вооруженные силы).

Комплекс полномочий по ЗГС распределен между Главой государства,

${ }^{1}$ Конституции государств Азии / Под ред. Т.Я. Хабриевой. Т.3. Дальний Восток. М.: Институт законодательства и сравнительного правоведения при Правительстве РФ: Норма, 2010. С. 119.

2 Конституции государств Америки / Под ред. Т.Я. Хабриевой. Т.3. Южная Америка. М.: Институт законодательства и сравнительного правоведения при Правительстве РФ, 2006. С. 312. 
Правительством, Парламентом, Вооруженными силами, спецслужбами и судами ${ }^{1}$.

По общему правилу (независимо от формы правления) Глава государства выступает гарантом национального единства, обеспечивает стабильность и преемственность суверенной государственной власти. Реализуя полномочия в сфере обороны и безопасности, Глава государства объявляет состояние войны и мобилизацию, является Верховным Главнокомандующим и руководит Вооруженными силами при отражении иностранной агрессии или выполнении договорных обязательств. В целях ЗГС Глава государства вводит исключительные (чрезвычайные) режимы во всем государстве либо на части территории страны. Глава государства представляет страну на международной арене, подписывает международные соглашения, заключает мир.

В президентских и смешанных республиках Глава государства руководит высшим органом исполнительной власти, принимает конкретные меры в целях обеспечения правопорядка, общественной и государственной безопасности.

В парламентских республиках и монархиях перечень основных полномочий по ЗГС сосредоточен у главы Правительства (фактическое руководство и контроль внутренней и внешней политики государства).

Парламент осуществляет законотворчество в целях ЗГС, уполномочивает Главу государства использовать Вооруженные силы за пределами территории государства, разрешает транзитный проход или пребывание на территории государства военных кораблей, самолетов и техники иностранных государств, ратифицирует международные договоры². Палаты Парламента могут проводить расследования деятельности

${ }^{1}$ Как правило, роль и место спецслужб в защите государственного суверенитета в конституционных актах зарубежных стран не отражается. Данная деятельность регламентируется в законах и подзаконных актах.

2 См. например, ст. 92 Конституции Республики Никарагуа, ст. 76 Конституции Мексиканских Соединенных Штатов. 
спецслужб, в определенной мере контролировать строительство и реформирование Вооруженных сил.

Как уже отмечалось, в большинстве государств мира Вооруженные Силы и спецслужбы являются специализированными государственными организациями, предназначенными для ЗГС, независимости и территориальной целостности. Исключением является Япония. После поражения во Второй мировой войне с подачи американских «юристов консультантов» в ст. 9 Конституции Японии 1947 г. был закреплен отказ государства от войны и создания сухопутных, морских и военно-воздушных сил: «Народ Японии в искреннем убеждении, что международный мир основан на справедливости и порядке, на вечные времена отказывается от войны как суверенного права нации, а также от угрозы или применения вооруженной силы как средства разрешения международных споров. ... Никогда впредь не будут создаваться сухопутные, морские и военновоздушные силы, равно как и другие средства ведения войны. Право на ведение государством войны не признается»» ${ }^{1}$.

Уникальным институтом ЗГС являются суды. С одной стороны, судебные органы выступают на стороне государства (санкционируют проведение розыскных и специальных мероприятий, следственных действий, применение мер пресечения, наказание государственных преступников, запрет антигосударственных организаций). Специализированные органы конституционной юстиции разрешают дела о соответствии конституции и законам не вступивших в силу международных договоров, принимаемых государственными органами нормативных правовых актов, разрешают споры о компетенции.

С другой стороны, суды защищают законные интересы общества, права

${ }^{1}$ Конституции государств Азии / Под ред. Т.Я. Хабриевой. Т.3. Дальний Восток. М.: Институт законодательства и сравнительного правоведения при Правительстве РФ: Норма, 2010. С. 1023. 
и свободы граждан: рассматривают жалобы о нарушениях законности в деятельности правоохранительных органов и спецслужб, о характере и объемах ограничений прав и свобод граждан в период действия исключительных (чрезвычайных) режимов, восстанавливают необоснованно нарушенные права и свободы, компенсируют гражданам и организациям нанесенный незаконными действиями и решениями должностных лиц ущерб.

Специальным элементом механизма ЗГС в зарубежных странах со сложной формой государственного устройства является федеральная интервенция ${ }^{1}$. Данный институт направлен на обеспечение общественного порядка, реализации основополагающих прав и свобод, единства правового пространства государства, территориальной целостности, беспрепятственного осуществления государственной власти во всех субъектах Федерации.

Традиционным институтом ЗГС в зарубежных странах являются исключительные (чрезвычайные) правовые режимы. В Конституциях зарубежных стран закреплены типовые основания введения чрезвычайного положения (далее - ЧП).

По Конституции Республики Боливия (ст.111) режим ЧП объявляется «в случаях серьезной опасности для страны, вызванной внутренней угрозой или международной войной». Аналогичные причины предусмотрены в ст. 137 Конституции Федеративной Республики Бразилии: «серьезные волнения, имеющие последствия на национальном уровне; объявление состояния войны или принятие ответных мер на иностранную военную агрессию» ${ }^{2}$ В соответствии с ч.1 ст. 137 Конституции Республики Перу «ЧП вводится в случае нарушения мира или внутреннего порядка, катастроф или наступления чрезвычайных обстоятельств, представляющих угрозу жизни

\footnotetext{
${ }^{1}$ Более подробно институт федеральной интервенции рассматривается в параграфе 2.4. монографии.

2 Конституции государств Америки / Под ред. Т.Я. Хабриевой. Т.3. Южная Америка. М.: Институт законодательства и сравнительного правоведения при Правительстве РФ, 2006. С. 209.
} 
нации» ${ }^{1}$.

В ряде зарубежных стран закреплено несколько видов ЧП: чрезвычайное положение, чрезвычайное экономическое положение (Венесуэла), состояние внешнего или внутреннего конфликта (Венесуэла), военное положение (Колумбия) ${ }^{2}$.

В Чили система исключительных режимов представлена: состоянием мобилизации, состоянием ЧП, состоянием катастрофы, осадным положением, объявлением нации терпящей бедствие.

Как показывает анализ чрезвычайных конституционных положений, в случае дифференциации видов ЧП сроки введения специальных разновидностей исключительных режимов увязываются с основаниями их введения. Так, в Венесуэле ЧП может быть введено на срок до 30 дней в случае катастроф, стихийных бедствий и др. подобных событий, которые представляют серьезную угрозу безопасности нации, eе граждан. Чрезвычайное экономическое положение может быть провозглашено на срок до 60 дней в случае возникновения чрезвычайных экономических обстоятельств, которые серьезно воздействуют на экономическую жизнь нации. Состояние внешнего или внутреннего конфликта может быть объявлено на срок до 90 дней, если такой конфликт представляет серьезную угрозу безопасности нации, ее граждан.

В Венесуэле, в отличие от большинства государств мира, понятие ЧП сформулировано в тексте самой Конституции Боливарианской Республики. Согласно ст. 337 Конституции, ЧП квалифицируется как «такие обстоятельства социального, экономического, политического, природного или экологического характера, которые серьезно воздействуют на безопасность нации, на ее институты, граждан, при условии, что

${ }^{1}$ Там же. С 824.

2 В январе 2016 г. указом Президента Венесуэлы для зашиты социальных прав граждан было введено чрезвычайное экономическое положение на всей территории страны сроком на 60 дней. 
необходимые меры для ликвидации таких ситуаций являются недостаточными» ${ }^{1}$. Представляется, что подобная регламентация вызвана желанием законодателя исключить возможность избирательного введения ЧП для установления авторитарных режимов, расширения компетенции органов власти и управления, несудебного преследования представителей оппозиционных сил.

Распространенными конституционно-правовыми гарантиями недопустимости противоправного использования исключительных режимов под предлогом ЗГС выступают:

- предельные сроки введения подобных режимов и ограничительных мер (Чили - 15 дней; Бразилия - 30 дней; Венесуэла - 30 дней; Перу - 70 дней; Боливия - 90 дней; Колумбия - 90 дней);

- парламентский контроль (необходимость получения разрешений парламента на введение или продление чрезвычайных режимов; представление отчета о причинах введения ЧП и принятых мерах; возможность проведения парламентских расследований);

- невозможность роспуска парламента в период ЧП.

Одним из звеньев, связующих конституционно-правовую теорию и практику ЗГС, является доктрина пределов государственного суверенитета, закрепленная в некоторых конституциях ${ }^{2}$.

Анализ конституционных актов зарубежных стран позволяет вычленить доктринально-нормативное понимание пределов государственного суверенитета, которое включает несколько элементов.

1. Пределы государственного суверенитета устанавливаются Конституцией и законами в интересах граждан, общества и государства.

1 Конституции государств Америки / Под ред. Т.Я. Хабриевой. Т.3. Южная Америка. М.: Институт законодательства и сравнительного правоведения при Правительстве РФ, 2006. С. 401.

2 Политико-правовые взгляды ведущих ученых и юристов-конституционалистов на природу, содержание и свойства государственного суверенитета с течением времени в той или иной мере нашли свое выражение в конституционной доктрине пределов государственного суверенитета. 
Управляя общественными делами, государство не вправе руководствоваться только своими интересами. Государственная власть должна осуществляться в интересах общества и граждан и основываться на доверии населения (ст. 2 Конституции СРВ, Преамбула Конституции Японии).

2. Внутренние пределы государственного суверенитета неразрывно связаны с основополагающими правами и свободами человека. Произвольное ограничение государством основополагающих прав и свобод недопустимо. Государственные органы, общественные объединения и должностные лица обязаны уважать и обеспечивать реализацию основополагающих прав и свобод (ст. 5 Политической Конституции Республики Чили, ст. 11 Конституции Японии).

3. Внешние пределы государственного суверенитета определяются международной правосубъектностью государства.

4. Ограничение полноты и мощи государственной власти обеспечивается конституционными гарантиями (разделение властей; ответственность должностных лиц разных уровней за присвоение властных полномочий, восстания и мятежи; невозможность неконституционного порядка изменения или отмены Основного Закона и др.) ${ }^{1}$. Законодатели некоторых стран в качестве дополнительной конституционно-правовой гарантии ЗГС от узурпации права его осуществления отдельными лицами или группировками, недопущения неконституционных способов изменения или отмены Конституции предоставили народу право не подчиняться действиям и решениям лиц, пришедшим к власти в результате антигосударственных посягательств (восстаний, мятежей и др.), а также изменить форму правления в целях восстановления конституционного

1 См. ст. 2 Политической Конституции Республики Боливии, ст.ст. 45, 46 Конституции Республики Перу, ст. 127 Конституции Республики Аргентины, ст. 85 Конституции Федеративной Республики Бразилия, ст. 333 Конституции Боливарианской Республики Венесуэла. 
правопорядка и осуществления суверенитета в соответствии с Конституцией ${ }^{1}$.

Подводя итоги анализу конституционно-правовых норм, регулирующих ЗГС за рубежом, необходимо отметить наличие в конституциях иностранных государств специальных разделов или глав, посвященных защите государства и конституционного порядка (Конституция Боливарианской Республики Венесуэла, Конституция Республики Перу, Конституция Федеративной Республики Бразилия).

Полномочия по ЗГС традиционно распределены между Главой государства, Правительством, Парламентом, Вооруженными силами, спецслужбами и судами. Особенности правосубъектности указанных институтов и реальный объем их полномочий по ЗГС зависят от формы правления, государственного устройств, характера политического режима и конкретной общественно-политической ситуации.

Для государств со сложной формой государственного устройства специальным элементом механизма ЗГС может являться т.н. федеральная интервенция.

Распространенным правовым инструментом ЗГС в зарубежных странах выступают исключительные (чрезвычайные) правовые режимы.

Проведенный в данном параграфе анализ политико-правовых доктрин и зарубежного опыта конституционно-правового регулирования ЗГС позволяет выделить наиболее эффективные концептуальные подходы к ЗГС, определить нормативные решения, подходящие для российской правовой системы, и оптимизировать национальные правовые механизмы ЗГС.

${ }^{1}$ Ст. 36 Конституции Аргентинской Республики, ст. 39 Конституции Мексиканских Соединенных Штатов, ст. 46 Конституции Республики Перу. 


\section{4. Концептуальные подходы к защите государственного суверенитета}

Государственный суверенитет как способность государства самостоятельно решать любые внутри- и внешнеполитические задачи, обеспечивать реализацию своих властных полномочий в отношении всех субъектов права в пределах своей территориальной юрисдикции является динамичной характеристикой государства. Он не дается даром и навечно, его необходимо завоевывать и все время защищать. Государственный суверенитет может быть подорван и утрачен. Как справедливо отмечает С.А. Авакьян, - «о своем - государственном - суверенитете обязано заботиться любое государство» ${ }^{1}$.

Учитывая выдвинутое в работе понимание государственного суверенитета, защита государственного суверенитета представляет собой постоянную активную правомерную деятельность государственных и негосударственных организаций, направленную на обеспечение верховенства и независимости государственной власти, беспрепятственную реализацию государственно-властных полномочий во всех сферах общественной жизни, противодействие деструктивной деятельности антигосударственных сил по ослаблению и подрыву государственного суверенитета.

В теории государства и права существует дискуссионность точек зрения по проблеме отнесения защиты (охраны) государственного суверенитета к функциям государства.

Первая группа авторов относит ЗГС к политическим функциям государства (Пиголкин А.С., Дмитриев Ю.А., Радько Т.Н.). При этом А.С. Пиголкин и Ю.А. Дмитриев включают ЗГС в содержание внутренней политической функции государства ${ }^{2}$, а Т.Н. Радько рассматривает защиту

\footnotetext{
${ }_{2}^{1}$ Авакьян C. A. Точка отсчета - народ // Рос. газ. 2006. 28 октября.

2 Теория государства и права / Под ред. А.С. Пиголкина, Ю.А. Дмитриева. М.: Юрайт, 2013. С. 175.
} 
суверенитета в составе комплексной политической функции любого современного государства ${ }^{1}$.

Вторая группа ученых (Матузов Н.И., Малько А.В., Нырков В.В., Шундиков К.В.) рассматривает ЗГС как элемент внешней функции обороны страны и связывает ее с внешними посягательствами ${ }^{2}$.

На наш взгляд, ни одна из приведенных позиций не заслуживает полной поддержки.

Во-первых, ЗГС неразрывно связана со всеми сферами общественной жизни: политической, экономической, социальной и идеологической. Вовторых, ЗГС осуществляется не только внутри страны, но и за ее пределами. В-третьих, ЗГС обеспечивается в ходе реализации всех функций государства с привлечением негосударственных организаций.

Основанием ЗГС выступает деструктивная деятельность внутригосударственных и зарубежных субъектов по его ослаблению и подрыву. Подобную деятельность можно определить как постоянную спланированную подрывную деятельность государственных органов и негосударственных структур иностранных государств, внутренних антигосударственных сил, осуществляемую в нарушение Конституции и других законов государства в целях снижения качественных характеристик и способности государства реализовывать свои функции в наиболее важных сферах общественной жизни, смены политического режима и поддержки принятия выгодных антигосударственным силам политических решений.

Анализ внешних проявлений деструктивной деятельности по ослаблению и подрыву государственного суверенитета позволяет выделить ряд ее особенностей.

${ }_{1}^{1}$ Радько Т.Н. Теория государства и права. М.: Проспект, 2015. С. 411.

${ }^{2}$ Матузов Н.И., Малько А.В. Теория государства и права. М.: РАНХиГС, 2014. С. 60; Малько А.В., Нырков В.В., Шундиков К.В. Теория государства и права. М.: Норма: Инфра-М, 2014. С. 66. 
1. Ослабление и подрыв государственного суверенитета возникают не естественным образом, а в результате целенаправленной, тщательно спланированной и организованной деятельности внешних и внутренних антигосударственных сил ${ }^{1}$.

Антигосударственные силы следует рассматривать как совокупность государственных и негосударственных организаций иностранных государств и внутригосударственных структур, принимающих участие в планировании, финансировании, информационно-пропагандистском, оперативном, аналитическом, ресурсном и боевом обеспечении, организации и непосредственном осуществлении деструктивной деятельности по ослаблению и подрыву государственного суверенитета.

Зарубежные субъекты в современных условиях представлены органами государственной власти, спецслужбами, воинскими формированиями, органами внешних сношений, кредитно-финансовыми учреждениями. Эти структуры планируют, организуют, координируют, финансируют и обеспечивают деструктивную деятельность по ослаблению и подрыву государственного суверенитета. Для непосредственного осуществления и сопровождения указанной деятельности привлекаются СМИ, иностранные фонды, религиозные, научные, националистические, неправительственные и иные организации, участвующие в политической жизни иностранного государства, парамилитарные структуры (т.н. частные военные компании) ${ }^{2}$.

Функции общего руководства антигосударственной деятельностью в зарубежных странах осуществляет глава исполнительной власти (президент или премьер-министр, в зависимости от формы правления в государстве). Свои полномочия он, как правило, реализует через подведомственные

1 Данная методологическая оговорка имеет важное значение, поскольку ослабление государственного суверенитета может быть следствием естественно-

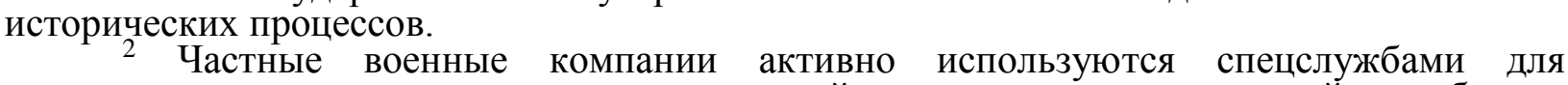
организации военно-политических провокаций и силовых спецопераций «глубокого прикрытия». Их роль особенно проявилась в ходе военных конфликтов США в Боснии и Герцеговине, Ираке и Украине. 
органы (советы национальной безопасности, постоянные комитеты в составе кабинета министров и др.). В ряде случаев, предусмотренных законодательством, решения высшего должностного лица органа исполнительной власти согласуются с парламентом.

Основным зарубежным элементом антигосударственной деятельности являются спецслужбы иностранных государств, которые действуют на правах самостоятельных ведомств либо являются частью отраслевых органов управления.

К числу внутригосударственных субъектов деструктивной деятельности необходимо отнести радикально настроенных лидеров и активистов т.н. "несистемной оппозиции", организованных преступных формирований, националистических, сепаратистских, экстремистских и террористических структур, негосударственные организации различных организационно-правовых форм ${ }^{1}$.

Активное использование при ослаблении и подрыве государственного суверенитета негосударственных организаций позволяет иностранным спецслужбам, с одной стороны, получать и приобретать необходимые прикрытия, расширять свои оперативные возможности, с другой - тщательно маскировать деятельность своего политического руководства и устремления в отношении страны - противника ${ }^{2}$.

2. Эта деятельность направлена против государства, преследует цели ослабления и подрыва государственного суверенитета.

Терминологическая система теории ЗГС предполагает разграничение понятий "ограничение государственного суверенитета", "ослабление государственного суверенитета" и "подрыв государственного суверенитета".

${ }^{1}$ Социальной базой антигосударственной деятельности, как правило, выступает либеральная политическая и культурная элита с космополитическим и проамериканским мировоззрением, не имеющая четких идеологических взглядов, а также представители компрадорского сектора предпринимательских кругов, ориентированные на иностранные капиталы, зарубежные рынки сбыта и контролируемые извне.

${ }^{2}$ Приложение 3. 
Ограничение государственного суверенитета включает теоретическое обоснование, политико-правовое закрепление и практическую реализацию мep, уменьшающих полновластие государства (верховенство и независимость государственной власти).

В качестве ослабления государственного суверенитета предлагается рассматривать снижение качественных характеристик реализации функций государства в наиболее важных сферах общественной жизни. Ослабление государственного суверенитета может быть следствием естественноисторических процессов (существенное снижение потенциала государства из-за экономических проблем, исчерпание полезных ископаемых, влияние глобализации $)^{1}$, а также происходить в условиях специального целевого воздействия (организация или поддержка государственного переворота, понуждение к передаче части суверенных полномочий тем или иным военнополитическим блокам и др.). При ослаблении государственного суверенитета компетентные структуры не в состоянии осуществлять власть в полном объеме на всей территории государства в отношении всех субъектов права. Постепенно это приводит к деградации государственных институтов ${ }^{2}$.

Подрыв государственного суверенитета характеризуется утратой способности государства реализовывать свои функции в наиболее важных сферах общественной жизни, осуществлять самостоятельное управление делами общества и государства. Подрыв государственного суверенитета не происходит случайно. Он всегда готовится и сопровождается. При подрыве государственного суверенитета прерогативы государственной власти целенаправленно присваиваются альтернативными структурами. В конечном

1 Как уже отмечалось, в ряде случаев ЗГС может быть прямо не связана с деструктивной деятельностью внутригосударственных и зарубежных субъектов (например, обеспечение конкурентоспособности национальной экономики или устойчивости финансово-кредитных институтов).

2 Ослабление и подрыв государственного суверенитета, в конечном счете, ведут либо к распаду государственных структур, либо к трансформации государственных органов в авторитарный механизм сохранения власти и защиты корпоративных интересов господствующего класса. 
счете, органы государства перестают быть легитимными, утрачивают доверие и поддержку населения.

Ослабление и подрыв государственного суверенитета указывают на деструктивную направленность и характер деятельности или процессов, происходящих с государством и его властными институтами (отстранение от власти законно избранных должностных лиц, подрыв экономики, нарушение территориальной целостности). Ослабление и подрыв государственного суверенитета могут осуществляться и реализуются на практике вне рамок правового поля и соответствующих процедур. Ограничение государственного суверенитета, как правило, имеет теоретико-правовые основания и позитивное целеполагание (развитие правового статуса личности, укрепление экономических и политических связей, прекращение преступной деятельности, привлечение государства-агрессора и виновных к ответственности). Ограничение государственного суверенитета предполагает обязательное наличие нормативных основ и юридического контроля за применяемыми по отношению к государству санкционными мерами.

Ослабление и подрыв государственного суверенитета осуществляется, главным образом, на плановой основе с участием антигосударственных сил. Для ограничения государственного суверенитета этот признак не характерен.

В современной международно-правовой практике ограничение государственного суверенитета завершается после прекращения государством противоправной деятельности (агрессия, геноцид и др.) и привлечения виновных лиц к ответственности.

В монографии понятия "ограничение", "ослабление" и "подрыв" государственного суверенитета используются с учетом изложенных методологических установок.

3. Рассматриваемая деструктивная деятельность всегда носит противоправный характер, поскольку акции ослабления и подрыва государственного суверенитета нарушают нормы международного права, 
Конституцию и другие законы государства. Противоправные акции по ослаблению и подрыву государственного суверенитета могут планироваться, финансироваться, обеспечиваться и осуществляться на протяжении десятилетий и столетий (например, антигосударственная деятельность США по "сдерживанию" России и развалу СССР, антигосударственная деятельность США по подрыву суверенитета Кубы) вне зависимости от политики государства и действий должностных лиц. В связи с необходимостью обоснования максимально возможного по продолжительности периода действия мер по ослаблению и подрыву государственного суверенитета, данные меры в перспективе всегда претендуют на ограничительно-легальный характер.

Учитывая противоправность, одиозность и реакционность ослабления и подрыва государственного суверенитета, в современных условиях любые государства - участники военно-политического, экономического и идеологического противоборства стремятся придать своей деятельности по ослаблению и подрыву государственного суверенитета стран-противников легитимность, теоретически обосновать и информационно-пропагандистски обеспечить, узаконить ее, трансформировать ее в юридически обязывающие ограничительные меры.

4. Деструктивная деятельность внутригосударственных и зарубежных антигосударственных сил формирует реальные угрозы государственному суверенитету, масштабы и потенциал которых зависит от угрозообразующих факторов ${ }^{1}$.

K наиболее опасным внутренним угрозам государственному суверенитету относятся: низкая конкурентоспособность национальной экономики; низкие демографические показатели и неравномерное распределение населения по территории; наращивание потенциала

\footnotetext{
${ }^{1}$ Приложение 4.
} 
организованной

государственного преступности;

коррупционная пораженность

аппарата; протестная активность и экстремистская деятельность структурных звеньев радикальной оппозиции; устойчивое функционирование вооруженного бандподполья на территории Северокавказского региона и попытки переноса террористической деятельности в другие регионы РФ.

Низкая конкурентоспособность национальной экономики проявляется в высокой зависимости доходной базы консолидированного бюджета от цен на углеводородное сырье, технологическом отставании от ведущих стран, зависимости от поставок современного зарубежного оборудования и программных средств, невысокой производительности труда ${ }^{1}$. Характерными угрозообразующими факторами являются:

- ориентация владельцев средств производства на максимальное извлечение прибыли, вывоз капитала, хищническую эксплуатацию рабочей силы и производственных фондов ${ }^{2}$;

- отсутствие амортизационных отчислений на модернизацию оборудования, программных средств, переподготовку и повышение квалификации персонала;

- недостаточная степень либерализации инвестиций и заимствования передовых иностранных технологий, снижение объема инвестиций в основной капитал ${ }^{3}$;

${ }^{1}$ Сохранение высокой зависимости доходной базы от цен на углеводородное сырье существенно усиливает риски снижения бюджетной устойчивости РФ. Нефтегазовые доходы федерального бюджета в 2015 г. составили 44,5 \% всех его доходов. Значительное снижение цен на нефть, финансово-экономические ограничения, введенные США и странами Западной Европы в отношении российских промышленных предприятий и финансовых учреждений, сокращение доходов от внешнеэкономической деятельности несут угрозу экономической и финансовой стабильности РФ.

2 По данным Росстата, в 2015 г. чистый вывоз частного капитала составил 56,9 млрд. долларов // База данных Росстата Cbsd.gks.ru. (дата обращения 29.12.2015 г.)

Структура и объем инвестиций (менее $20 \%$ ВВП) в основной капитал отражают усиление стагнационных тенденций в российской экономике, недостаточную проработку вопросов территориального и отраслевого планирования экономического развития. 
- низкий уровень развития инфраструктуры (транспортной системы, телекоммуникаций, энергоснабжения, складского хозяйства и распределительной сети);

- остаточное финансирование НИОКР и инновационной деятельности ${ }^{1}$;

- выезд за рубеж высококвалифицированных специалистов;

- недостаточно высокое качество менеджмента в бизнесе (конкурентные стратегии, управление финансами, кадрами, развитие продукта и контроль качества).

Низкие темпы перевода национальной экономики на инновационный путь развития актуализируют вопрос модернизации и повышения конкурентоспособности российской экономики. Автор поддерживает позицию профессора О.Д. Абрамовой, что решение этой задачи стратегического характера "поставило бы нашу страну по уровню благосостояния в ряд наиболее развитых стран и обеспечило ей достойные позиции в мире"2.

Демографическая угроза государственному суверенитету выражается в низких демографических показателях и неравномерном распределении населения по территории ${ }^{3}$. На 1 января 2015 г. по оценке Росстата в России проживало 146267288 жителей. Плотность населения России составила 8,55 человек на км ${ }^{2}$. $68,2 \%$ российских граждан проживают в европейской части РФ (27 человек на км²), представляющей 20,85\% территории государства. В

1 Повышение налоговой нагрузки, высокая неопределенность перспектив внутреннего и внешнего спроса, отсутствие доступных долгосрочных банковских кредитов сдерживают спрос на инновации. Инновационную активность проявляют не более $11 \%$ российских предприятий. Доля инновационной продукции в общем объеме выпуска российской продукции составляет около 5\%, а доля России на мировых рынках высокотехнологичной продукции - менее $0,3 \%$. Статус РФ как мировой научнотехнологической державы неуклонно снижается.

2 Внешняя политика России: теория и практика / Под ред. С.В. Смульского и О.Д. Абрамовой. М.: Книга и бизнес, 2013. С. 147.

3 Слабая заселенность территории означает недостаточную ресурсную и инфраструктурную освоенность государства, низкую демографическую готовность противостоять угрозам военного характера. Государства со значительным демографическим и экономическим потенциалом более устойчивы к возникающим угрозам и вызовам. $\mathrm{KM}^{2}$.

${ }^{4}$ При расчетах учитывалась площадь территории России, составляющая 17125422 
Сибири, площадь которой составляет почти 3/4 территории России, проживает менее $20 \%$ населения ${ }^{1}$.

Угрозообразующими факторами выступают:

- низкая продолжительность жизни трудоспособного населения ${ }^{2}$;

- высокий уровень смертности, заболеваемости населения, распространенность алкоголизма, наркомании, табакокурения;

- недостаточный для расширенного воспроизводства населения уровень рождаемости;

- отсутствие программ профилактики и низкая доступность медицинской помощи для жителей сельской местности и отдаленных районов;

- диспропорции экономического развития и связанный с ними усиленный отток населения ряда регионов ${ }^{3}$;

- дерусификация национальных республик ${ }^{4}$;

- инфраструктурная изоляция и слабая заселенность приграничных районов.

$\begin{array}{cccc}\text { Масштабной угрозой } & \text { государственному } & \text { суверенитету } & \text { становится } \\ \text { наращивание потенциала } & \text { организованной } & \text { преступности } & \text { за счет }\end{array}$

1 Население Сибири и Дальнего Востока в основном сконцентрировано вдоль Транссибирской железной дороги.

2 Основной причиной низкой продолжительности жизни населения в России является высокая смертность граждан трудоспособного возраста. Из общего числа умерших почти 30\% составляют трудоспособные граждане, около $80 \%$ из них - мужчины. Смертность от заболеваний сердечно-сосудистой системы, составляющая $55 \%$ смертности от всех причин, в России в 3-4 раза выше, чем в европейских странах // Концепция демографической политики Российской Федерации на период до 2025 г.

3 Как отмечается в Концепции демографической политики Российской Федерации на период до 2025 г., «в ряде субъектов РФ демографическая ситуация требует немедленного реагирования. За последние 15 лет более чем на $15 \%$ сократилась численность населения в Республике Коми, Камчатском крае, Архангельской, Магаданской, Мурманской и Сахалинской областях. На 10-15\% сократилась численность населения в Республике Карелия, Республике Мордовия и Республике Саха, Приморском и Хабаровском краях, Амурской, Владимирской, Ивановской, Кировской, Костромской, Курганской, Курской, Новгородской, Псковской, Рязанской, Смоленской, Тамбовской, Тверской, Тульской и Читинской областях». В 2015 г. 20 субъектов РФ находились в преддефолтном состоянии, в 34 субъектах был зафиксирован спад промышленного производства. Государственный долг регионов составил 2173 млрд. рублей.

4 Так, за период с 1989 по 2008 гг. субъекты РФ, входящие в состав СевероКавказского федерального округа, покинули около 500 тысяч русских $(37,5 \%$ от общей численности населения). 
проникновения в органы власти, доступа к ключевым отраслям экономики и кредитно-финансовым учреждениям. Представители организованной преступности стремятся контролировать прибыльные сектора экономики, управлять бюджетными средствами, участвовать в принятии решений органами власти, влиять на законотворческий процесс.

Роль преступных организаций (сообществ) в российской политической системе выражается в их функциях, к числу которых относятся:

а) представительство социально-политических интересов определенной части общества;

б) фактическое осуществление отдельных государственно-властных полномочий ("теневая" юстиция, воспитание и трудоустройство подростков из неблагополучных семей и др.);

в) разработка и реализация политической стратегии и тактики борьбы за государственную власть в ходе выборов.

Существующая криминогенная ситуация усугубляется проводимой уголовно-правовой политикой. Современное состояние уголовно-правового законотворчества характеризуется хаотичным и противоречивым подходом к попыткам противодействия преступности, в рамках которого можно выделить ряд угрозообразующих факторов:

- освобождение от уголовной ответственности за совершение широкомасштабных экономических преступлений;

- отказ от реальной борьбы с незаконным обогащением путем конфискации;

- введение системы денежных штрафов, позволяющей пользоваться ею состоятельным гражданам, для освобождения от реального наказания в виде лишения свободы;

- имитация сокращения преступности путем декриминализации общественно опасных деяний. 
Это означает выстраивание дискриминационной социальной системы в уголовно-правовой сфере на основе неравенства материальных возможностей граждан ${ }^{1}$.

Автор разделяет точку зрения А.Д. Керимова, по мнению которого "слабость государственных институтов, проявляющаяся в их неспособности регулировать и контролировать социальные процессы, в демонстрируемой ими беспомощности при необходимости решения разнообразных возникающих перед социумом задач, неизбежно ведет к тому, что эту роль стремятся взять на себя другие силы и структуры"2. Как правило, такими силами являются олигархические структуры и организованные преступные сообщества.

Слабое государство, не располагающее достаточными материальными и финансовыми ресурсами и средствами, не способно эффективным образом регулировать экономику страны, должным образом перераспределять доходы, не в состоянии преодолеть неизбежно возникающее вопиющее социальное неравенство, справиться с унижающей человеческое достоинство бедностью, а зачастую и с грозящей вымиранием значительной части населения нищетой ${ }^{3}$. В этих условиях правящие круги подвержены искушению исправить сложившееся в экономической сфере бедственное положение, прибегнув не к цивилизованным формам и методам ее оздоровления, а к испытанному варварскому средству, т.е. развязыванию агрессивной, захватнической войны ${ }^{4}$.

1 Дамаскин О.В. Криминологические аспекты формирования современной уголовно-правовой политики // Современное право. 2013. № 5.

${ }_{2}$ Керимов А.Д. Государственная организация общественной жизнедеятельности. Вопросы теории. М.: Норма, 2014. С. 67.

${ }^{3}$ Керимов А.Д. Указ. соч. С. 68.

${ }^{4}$ Керимов А.Д. Указ. соч. С. 69 . Примеры таких решений: вторжение вооруженных сил Грузии в Южную Осетию в 2008 г. и карательная операция вооруженных формирований Украины и международных парамилитарных структур в отношении ДНР и ЛНР в 2014-2016 гг. 
В рассматриваемой системе внутренних угроз государственному суверенитету значительную опасность представляет коррупционная пораженность государственного аппарата.

Согласно статистическим данным, в 2012 году в РФ зарегистрировано 49513 преступлений коррупционной направленности и выявлено 13565 лиц, совершивших преступления данной категории. Отмечается рост преступлений, предусмотренных, в частности, ст. 290 УК РФ ("получение взятки"): в 2012 г. зарегистрировано 9,8 тысяч преступлений, в 2013 г. - 11,5 тысяч, в 2014 г. - 11,9 тысяч (с учетом данных по Крымскому федеральному округу). Большинство из них (90,1\%), выявлено органами внутренних дел ${ }^{1}$.

Организованная преступная деятельность на основе коррупционной составляющей осуществляется при участии должностных лиц правоохранительных органов, сотрудничающих с криминальными структурами. При этом, если ранее наиболее высокодоходные сферы незаконной деятельности находились под негласным контролем криминальных авторитетов, то в настоящее время наметилась тенденция к реализации преступных (в том числе коррупционных) схем руководителями крупных коммерческих организаций и должностными лицами органов государственной власти и управления.

В 2014 г. зарегистрировано 75,7 тысяч преступлений в сфере экономики (из них 21,8 тысяч совершены в крупном и особо крупном размере) с участием 32,3 тысяч государственных и муниципальных служащих ${ }^{2}$. Анализ структуры коррупционной преступности показывает рост

1 Статистические данные ГИАЦ МВД России - «Сводный отчет по России о состоянии преступности и результатах расследования преступлений» (форма 494); «Сводный отчет по России о результатах работы правоохранительных (правоприменительных) органов по борьбе с преступлениями, совершенными с использованием служебного положения должностными лицами, государственными служащими и служащими органов местного самоуправления, а также лицами, выполняющими управленческие функции в коммерческой или иной организации» (форма 590); статистические сведения управления правовой статистики Генеральной прокуратуры Российской Федерации (форма К); база данных Росстата.

2 База данных Росстата Cbsd.gks.ru. (дата обращения 25.12.2015г.) Сведения приведены с учетом данных по Крымскому федеральному округу. 
удельного веса мошенничеств, совершенных с использованием служебного положения. Из лиц, привлеченных к ответственности за совершение преступлений коррупционной направленности, большинство (57\%) работали в органах исполнительной власти субъектов РФ; в органах местного самоуправления работали - 21,6\%, в федеральных органах государственной власти - 21,5\%. Среди работников правоохранительных органов, привлеченных к уголовной ответственности за коррупционные преступления, подавляющее большинство (63\%) являлись сотрудниками органов внутренних дел ${ }^{1}$.

Следует констатировать, что к ответственности за коррупционные преступления привлекаются в основном представители низовых звеньев государственного аппарата и органов местного самоуправления. Удельный вес представителей органов государственной власти и управления среди осужденных взяткополучателей составляет менее 1 \%. Доля фактов взяточничества в крупном размере в общем числе выявленных - лишь 7,6\% . Вместо привлечения к уголовной ответственности должностных лиц, допустивших хищение и нецелевое расходование бюджетных средств, злоупотребление полномочиями, получает распространение практика увольнения данных граждан с государственной службы или ротации на другие должности в государственном аппарате.

На коррупционную пораженность государственного аппарата влияют следующие факторы:

- несоответствие уровня заработной платы чиновников объему и сложности выполняемых должностных обязанностей;

- широкие пределы усмотрения чиновников при разрешении административных процедур;

1 Красинский В.В. Организованная преступность на выборах и в российских органах власти. М.: Юрлитинформ, 2014. С.23.

2 Дамаскин О.В. Коррупция: состояние, причины, противодействие. М.: Триумфальная арка, 2009. С. 32. 
- трудновыполнимые требования к гражданам и организациям, создающие условия для коррупционных проявлений;

- возможность необоснованного применения преференций в отношении избранных субъектов права;

- отсутствие надежных правовых гарантий неукоснительного исполнения законов всеми субъектами права, защиты прав собственников и представителей бизнеса;

- различные подходы антикоррупционных законов к оценке материального положения, источников доходов, законности и прозрачности расходов отдельных должностных лиц и правовым последствиям конфликта интересов у данных лиц, непредставления этими должностными лицами сведений о доходах, расходах, имуществе и обязательствах имущественного характера в установленные сроки, а также представления заведомо недостоверных или неполных сведений;

- наличие иммунитетов и изъятий из общего порядка уголовного судопроизводства у ряда должностных лиц федерального, регионального и муниципального уровня ${ }^{1}$.

Перечисленные угрозообразующие факторы дискредитируют органы власти и управления в глазах населения, стимулируют нарушение законных интересов граждан и организаций, негативно влияют на осуществление государственных функций.

Относительно новой угрозой государственному суверенитету можно назвать протестную активность и экстремистскую деятельность структурных звеньев радикальной оппозиции ${ }^{2}$.

${ }^{1}$ Подробно см. Красинский В.В. Организованная преступность на выборах и в российских органах власти. М.: Юрлитинформ, 2014 . С. 58-65, 116-129, 194, 195.

2 В 2014 г. по требованиям Генеральной прокуратуры РФ более чем с 3000 интернет-страниц удалена информация с призывами к осуществлению экстремистской деятельности и участию в несогласованных массовых мероприятиях, проводимых с нарушением установленного законом порядка. 
В отличие от легальной оппозиции, осуществляющей свою деятельность в рамках существующего законодательства, радикальная оппозиция преследует цели насильственного изменения конституционного строя и не ограничивает арсенал своих методов действий, средств и источников финансирования правовым полем. Лидерами и функционерами данных структур используются различные угрозообразующие факторы, в числе которых выступают:

- принятие государственными органами непопулярных политических решений в социально-экономической сфере (реформирование ЖКХ, пенсионная реформа, система налогообложения и др.) ${ }^{1}$;

- наличие очагов социальной напряженности в регионах с высоким уровнем безработицы и неблагоприятной криминогенной обстановкой ${ }^{2}$;

- снижение реально располагаемых доходов населения, девальвация национальной валюты и рост цен из-за санкционного давления США и стран Евросоюза ${ }^{3}$;

- высокая дифференциация населения по уровню денежных доходов ${ }^{4}$;

${ }^{1}$ Повышение тарифов на услуги ЖКХ, рост налогового бремени на физических и юридических лиц, повышение цен на продукты питания, лекарства и товары первой необходимости, увеличение задолженности по заработной плате, неудовлетворенность граждан ситуацией в области медицинского обеспечения, образования и транспорта негативно отражаются на отношении граждан к социально-экономической политике государства.

2 По данным Министерства труда и социальной защиты РФ, в 2015 г. наиболее высокий уровень безработицы отмечался в Республике Ингушетия $(30,7 \%)$, Чеченской Республике $(16,8 \%)$, Республике Тыва $(21,7 \%)$, Республике Калмыкия $(11,4 \%)$, в Забайкальском крае $(10,4 \%)$. Проблемой остается высокий уровень безработицы среди молодежи (24,3\%). Отчетливо проявляется тенденция увеличения количества работников, занятых неполный рабочий день или находящихся в неоплачиваемом отпуске, а также роста безработицы среди граждан в возрасте старше 50 лет $(19,3 \%)$.

3 По данным Росстата, в 2015 г. 40\% населения РФ полагало, что его благосостояние ухудшилось в сравнении с уровнем 2014 г. Реально располагаемые доходы населения снизились на $5,3 \%$, среднемесячная зарплата сократилась на $9 \%$. Доля населения с денежными доходами ниже прожиточного минимума в общей численности населения увеличилась до $14,1 \%$ и составляет 20, 3 млн. человек. Доля детей в семьях с денежными доходами ниже прожиточного минимума составляет 26\%. // База данных Росстата Cbsd.gks.ru (дата обращения 05.05.2016 г.)

4 По данным Росстата, на долю $10 \%$ наиболее обеспеченного населения в РФ приходится 29,4 \% общего объема денежных доходов, а на долю $10 \%$ наименее обеспеченного населения - 2,1 \%. Коэффициент дифференциации денежных доходов в целом по России составляет 14,2. Его самый высокий уровень зафиксирован в Москве, Тюменской и Самарской областях, Ненецком автономном округе, г. Санкт-Петербурге, 
- проблемы и недостатки антикриминальной и антикоррупционной политики государства и др.

Существующие социально-экономические трудности используются для организации и координации различного рода протестных акций ("антикризисных маршей", "антивоенных маршей", "маршей несогласных", "антикоррупционных протестов" и др.), дестабилизации общественнополитической ситуации и смены государственно-политического режима по сценариям "цветных" революций ${ }^{1}$.

На протяжении нескольких десятилетий характер острой угрозы государственному суверенитету носит устойчивое функционирование вооруженного бандподполья на территории Северо-кавказского региона (СКР) и попытки переноса террористической деятельности в другие регионы РФ.

Основными факторами, детерминирующими террористическую деятельность в регионе, являются:

- наличие организационного ядра, структурных звеньев и пособнических сетей незаконных вооруженных формирований (далее НВФ);

- активная вербовочная работа эмиссаров террористического бандподполья и использование информационно-пропагандистской инфраструктуры сети Интернет в террористических и иных экстремистских целях ${ }^{2}$;

минимальные значения - в Тверской, Волгоградской, Костромской областях и Республике Алтай. // База данных Росстата Cbsd.gks.ru. (дата обращения 02.05.2016 г.)

1 Как отмечается в Стратегии противодействия экстремизму в Российской Федерации до 2025 г. (утверждена Президентом РФ 28 ноября 2014 г.), «основным способом дестабилизации социально-политической обстановки в РФ становится привлечение различных групп населения к участию в протестных акциях, в т.ч. несогласованных, которые впоследствии умышленно трансформируются в массовые беспорядки.

2 По данным Генеральной прокуратуры РФ, количество преступлений экстремистской направленности, совершенных с использованием сети Интернет, имеет тенденцию к росту. Для сравнения, в 2014 г. по фактам совершения преступлений с использованием сети Интернет возбуждено 614 уголовных дел (в 2013 г. -361, в 2012 г. - 
- возвращение из мест лишения свободы лиц, осужденных за совершение преступлений террористического характера и вынашивающих намерения по продолжению преступной деятельности;

- возвращение граждан, принимавших участие в вооруженных конфликтах за рубежом либо проходивших (проходящих) обучение в тренировочных лагерях боевиков в Афгано-Пакистанской зоне, Сирии и Ираке

- разрастание масштабов незаконного оборота оружия, боеприпасов, взрывчатых веществ, взрывных устройств, а также анонимных угроз совершения терактов;

- массовая безработица среди местного населения и иждивенческие настроения в молодежной среде;

- арабизация СКР, используемая салафитскими идеологами для пропаганды религиозного экстремизма;

- высокий уровень коррупции в органах государственной власти и управления.

Тактика деятельности НВФ СКР адаптируется к динамике оперативной обстановки и специфике применяемых правоохранительными органами сил, средств, форм и методов работы. Банддвижение способно достаточно быстро восстанавливать конспиративную систему координации террористической деятельности, нарушенную после нейтрализации бандглаварей различного уровня.

231). Другой тенденцией является вовлечение в террористическую и иную экстремистскую деятельность неофитов из молодежной среды славянских этносов.

${ }^{1}$ Возвращение боевиков из регионов с повышенной террористической активностью в страны исхода представляет большую общественную опасность. Указанный контингент способен эффективно противостоять правоохранительным органам. «Возвращенцы» обладают навыками обращения с оружием, изготовления взрывчатых веществ и взрывных устройств, знанием тактических приёмов ведения боевых действий, радикальными взглядами и многочисленными связями в криминальной среде. Кроме того, данная категория лиц выполняет роль модераторов и идейных проводников исламистского радикализма, участвует в вербовке и переправке рекрутов в лагеря подготовки боевиков и зоны вооруженных конфликтов. 
К числу современных тенденций развития террористической деятельности на территории СКР относятся:

- сращивание террористического бандподполья с организованными преступными сообществами, с одной стороны, и коррумпированной частью государственного аппарата СКР, с другой. Данная тенденция проявляется в организации преступных групп общеуголовного характера с целью финансирования бандподполья СКР; создании НВФ, полностью укомплектованных лицами, отбывшими наказание за совершение преступлений террористического характера; формировании «тюремных» «джамаатов» в учреждениях исполнения наказаний, осуществляющих активную религиозно-экстремистскую обработку осужденных и сбор денежных средств в т.н. «бейтумал» («казну мусульман»); использовании членами НВФ связей в криминальной среде для приобретения поддельных документов, оружия, ВВ, наркотиков и др. предметов, изъятых из гражданского оборота; легальном административно-политическом прикрытии и финансировании террористической деятельности (в том числе за счет бюджетных средств) со стороны пособников бандподполья в органах власти и управления;

- создание в субъектах РФ за пределами СКФО автономных боевых групп («джамаатов»), использующих террористов-смертников, с целью расширения зоны подготовки резонансных терактов в местах массового пребывания граждан;

- омоложение социальной базы НВФ за счет формирования «школьных и студенческих джамаатов» и организации т.н. «мусульманских» детских и юношеских лагерей, где под видом военно-спортивной подготовки детям дается радикальная трактовка ислама и прививаются навыки ведения боевых действий ${ }^{1}$;

1 Такие факты отмечались в Республиках Ингушетия, Татарстан, Башкортостан, Дагестан, Ставропольском крае и Ростовской области. 
- создание общественных организаций и привлечение внимания правозащитных структур для легитимации своей деятельности;

- появление устойчивых транзитных каналов переправки рекрутов и боевиков в лагеря подготовки и «горячие точки» для получения боевого опыта и его последующего применения по возвращении в страну пребывания ${ }^{1}$;

- формирование организационных связей ячеек северо-кавказского бандподполья с международной террористической организацией "Исламское государство" и попытки переноса террористической деятельности "Исламского государства" на территорию РФ.

Угрозой государственному суверенитету следует считать длительное отсутствие объединяющей многонациональное государство государственной идеологии.

К числу угрозообразующих факторов можно отнести:

- постепенную деградацию системы государственного образования, проявляющуюся в вытеснении бесплатных услуг платными, снижении доступности вузовского и послевузовского образования;

- длительное отсутствие программ государственного патриотического воспитания;

- пропаганда индивидуализма, корыстолюбия и потребительского образа жизни;

- засилье прозападной массовой культуры;

- популяризация насилия и бездуховности в СМИ;

- отсутствие общегосударственных и региональных "мобилизационных" проектов.

${ }^{1}$ В 2014-2015 гг. отмечался выезд жителей Северо-Кавказского и Приволжского Федеральных округов для участия в вооруженном конфликте в Сирии и Ираке на стороне «Исламского государства» вместе с семьями. 
Существенную опасность представляют внешние угрозы, проявляющиеся как процессы ограничения, ослабления или подрыва государственного суверенитета извне.

В настоящее время наиболее острой внешней угрозой является агрессивная политика США и их союзников в отношении России, которая проявляется в:

- развязывании гонки вооружений, милитаризации околоземного комического пространства, модернизации и развертывании системы ПРО;

- инспирировании дальнейшего расширения НАТО к государственной границе РФ;

- стимулировании провокаций, вооруженных конфликтов и очагов нестабильности в приграничных регионах и сопредельных с Россией государствах;

- попытках смены государственно-политического режима в России루

- дискредитации России и демонизации руководства страны средствами пропаганды;

- организации недружественных коалиций и международной изоляции России;

- разрушении интеграционных связей с Украиной, членами $\mathrm{EC}, \mathrm{CHГ,}$ ЕАЭС, ОДКБ и др;

- попытках недопущения диверсификации российской экономики и развития ее стратегически важных отраслей;

- наращивании санкционного давления и стремлении нанести максимальный экономический ущерб².

1 Реализация данного угрозообразующего фактора возможна путем оказания финансовой и консультативной помощи российским некоммерческим организациям, оппозиционным партиям и движениям, нацеливания их действий на дестабилизацию социально-политической обстановки в России, подрыв авторитета законных органов власти, инициирование протестной активности в обществе.

2 Данный угрозообразующий фактор может быть реализован путем введения дополнительных санкций, создания условий для вывода иностранных инвестиций из 
Стремление США и их союзников к наращиванию наступательных вооружений, модернизации и развертыванию системы ПРО ослабляет систему глобальной безопасности, а также систему соглашений в области контроля над вооружением. На территориях соседних с Россией государств расширяется есть военно-биологических лабораторий США, развиваются процессы милитаризации и гонки вооружений ${ }^{1}$.

Вашингтон не меняет агрессивного характера своей внешней политики, направленной на ослабление международных позиций России и поддержание очагов напряженности вблизи наших границ ${ }^{2}$. Отказавшись от размещения на территории Чехии элементов стратегической системы ПРО, Соединенные Штаты разместили комплексы "Иджис Эшор" в Румынии и Польше, согласовали размещение комплексов THAAD в Республике Корея и завершили формирование компонентов морского базирования ПРО в Европе. Обнародованы планы задействовать Данию в развертываемой системе ПРО.

Параллельно с кампанией по обвинению России в якобы имевших место нарушениях Договора между СССР и США о ликвидации ракет средней и малой дальности, Соединенные Штаты реализуют планы размещения в Европе модернизированных ядерных бомб В 6112 , модификации и переоборудования натовских самолетов "Торнадо" под новые ядерные задачи.

Предпринимаются попытки втянуть в коалицию нейтральную Финляндию. Североатлантический альянс, отказываясь от сотрудничества в сфере договоров по контролю над вооружениями, последовательно расширяет свои функции и зону ответственности. Все отчетливее

российской экономики, дальнейшей девальвации рубля и усиления недовольства населения политикой руководства страны.

1 Стратегия национальной безопасности Российской Федерации (утверждена Указом Президента РФ от 31 декабря 2015 г. № 683) (Раздел II).

2 Агрессивность внешней политики США проявляется не только в стремлении ослабления и подрыва суверенитета РФ, но и в регулярных попытках дестабилизации неугодных политических режимов в государствах СНГ, Азиатско - Тихоокеанского региона, Латинской Америки, Ближнего Востока и Африки. 
просматривается его стремление создать т.н. "буфер безопасности" между ЕС и Россией.

В результате расширения блока НАТО количество стран альянса возросло с 16 до 28, общая площадь территории его государств увеличилась до 24,17 млн. км², а численность населения - до 890 млн. человек. При этом численность регулярных Вооруженных сил НАТО превысила 3,7 млн. человек, а Североатлантический союз получил возможность задействовать в своих целях территорию и инфраструктуру новых членов, что привело к нарушению сложившегося баланса сил в Европе ${ }^{1}$.

В ходе расширения альянса Соединенные Штаты сделали ставку на поиск нового врага, угроза со стороны которого способна сплотить вокруг США как западных, так и восточных союзников. В настоящее время в качестве подобной угрозы рассматривается деятельность российского руководства $^{2}$. В связи с этим один из векторов внешней политики Вашингтона направлен на смену государственно-политического режима в Российской Федерации.

Фактор "нарастающей российской угрозы" Белый дом задействует также в интересах преодоления противоречий внутри НАТО. Главная цель заключается в том, чтобы добиться согласия союзников на существенное увеличение военных расходов, обеспечить постоянное присутствие ВС США в странах Восточной Европы и Балтии, продолжить планомерное приближение военной инфраструктуры блока к государственным границам $\mathrm{P} \Phi^{3}$.

1 За 2015 г. контингент НАТО в странах Балтии, Польши и Румынии увеличился в 8 раз по самолетам и в 13 - по количеству военнослужащих. Петров $B$. $O$ некоторых аспектах расширения НАТО // Зарубежное военное обозрение. 2015. № 6. С. 12.

2 По мнению 3. Бжезинского, расширение НАТО обеспечивает урегулирование восточно-западных отношений, одновременно помогая консолидировать зарождающуюся российскую демократию. См. Бжезинский 3. Стратегический взгляд: Америка и глобальный кризис. М.: Астрель, 2012. С. 155.

${ }_{3}$ Молчанов $\Gamma$. Военно-политическая обстановка в различных регионах мира // Зарубежное военное обозрение. 2015. №1. С. 3. 
Удобным предлогом для достижения поставленных целей послужила возникшая в результате многолетних целенаправленных усилий США кризисная ситуация вокруг Украины. В ней отчетливо проявились попытки Вашингтона дискредитировать Россию в глазах Европы, максимально разрушить ее связи с европейскими государствами, лишить стороны выгод и преимуществ тесного взаимодействия, а также вытеснить с европейского рынка российские энергоносители и обеспечить условия для продвижения на нем интересов американских энергетических компаний ${ }^{1}$.

Следует отметить, что обладание энергетическими ресурсами является важнейшим фактором риска ограничения или полной утраты суверенитета для государства. Концептуальную модель подобного посягательства описал В.А. Лебедев: "Если государство, обладающее энергетическими ресурсами, ослаблено, это генерирует попытки со стороны государств, потребление энергии которыми находится на высоком уровне, присвоить эти ценности либо обеспечить к ним доступ на льготных для себя условиях. Для этого применяется политическое лоббирование, попытки приобретения влияния на общественные объединения, в том числе и на политические партии, в целях вмешательства во внутренние дела государства. Именно таким вмешательством может быть объяснено существование атрибутивных, символических государств, т.е. тех, которые, обладая формальными атрибутами государственной власти, экономической, политической и идеологической самостоятельности не имеют. Фактически многие народы обладают лишь исполнительными государствами, которые, осуществляя в том числе и законодательную деятельность, исполняют политические решения других государств"2.

${ }^{1}$ Молчанов Г. Там же. С. 3. Не способствуют разрешению конфликта поставки США вооружений на Украину, их размещение в непосредственной близости от российской границы и планируемая дислокация на украинской территории иностранных вооруженных контингентов.

2 Лебедев В.А. Российская демократия: национальные особенности, проблемы и решения в глобализирующемся мире // Гражданин. Выборы. Власть. 2014. № 2. С. 101. 
В этом плане РФ, обладающая обширными углеводородными запасами и геополитическими рычагами влияния на постсоветском пространстве, представляет собой зону особой заинтересованности Вашингтона. Наличие значительной по площади неконтролируемой Соединенными Штатами территории с самостоятельным аппаратом власти, стратегическими отраслями экономики и боеспособными вооруженными силами создает Вашингтону проблемы, связанные с завоеванием мирового господства.

Существенной внешней угрозой являются территориальные претензии ряда иностранных государств к РФ, в связи с которыми угрозообразующими факторами выступают:

незавершенность международно-правового оформления государственной границы РФ с отдельными сопредельными государствами; наличие вооруженных конфликтов вблизи государственной границы России (стремление украинского руководства к расширению масштабов карательной операции против Юго-Востока, неопределенность конституционно-правового статуса ПМР, ДНР и ЛНР);

лоббирование необходимости отторжения от России отдельных ее территорий (островов Курильской гряды, Калининградской области, Республики Крым $)^{2}$;

использование неопределенного статуса континентального шельфа в борьбе за Арктическую зонуํㅜㄹ.

1 РФ имеет границы с 18 государствами общей протяженностью 61110 км (сухопутная 14519 , речная - 7381,55, озерная - 470,4, морская - 38738,9 км). Из 23115,2 км государственной границы РФ, подлежащих международно-правовому оформлению, не оформлены 13658,3 км. В международно-правовом отношении государственная граница полностью оформлена с Норвегией, Финляндией, Польшей, Монголией, КНР и КНДР. Не завершена работа по оформлению государственной границы с Латвией, Литвой, Украиной, Казахстаном. Не оформлена граница России с Эстонией, Республикой Беларусь, Абхазией, Грузией, Южной Осетией, Азербайджаном и Японией. Наиболее острой является проблема разграничения морских пространств РФ. Разграничение территориального моря оформлено только с Норвегией, Финляндией, Польшей и КНДР. С Эстонией, Украиной, Абхазией и Японией граница на море не оформлена.

2 Негативное влияние на состояние российско-американских отношений продолжает оказывать отказ США в предоставлении на территории Крымского полуострова услуг, контролируемых американскими корпорациями, и отключение его от американских и европейских интернет-сервисов. 
Заметную угрозу представляет деятельность координируемых из-за рубежа экстремистских объединений и террористических организаций, направленная на: нарушение территориальной целостности; создание сепаратистских анклавов, территорий с "шариатским" правлением; формирование этнически и конфессионально однородных регионов; ликвидацию конституционных органов власти и управления; дестабилизацию социально-политической обстановки в стране.

Факторами, способствующими росту данной угрозы, являются:

- инспирирование антигосударственными силами сепаратистских настроений в среде национальных землячеств и диаспор ${ }^{2}$;

призывы к построению этнически однородного общества;

- расширение географии террористической деятельности международных террористических организаций и экстремистских объединений антироссийской направленности;

- популяризация экстремистских и террористических идей, рост численности неофитов, придерживающихся радикальных взглядов;

- устойчивое функционирование опорной и транзитной инфраструктуры переправки боевиков, возвращение в страну лиц,

\footnotetext{
1 Норвегия не признает статус западной границы российского арктического сектора.

Отмечается деятельность пантюркистских организаций по инициированию сепаратистских проявлений со стороны тюркоязычных диаспор (азербайджанской, узбекской, киргизской, казахской, турецко-месхетинской и др.) в субъектах РФ с преимущественным проживанием тюркоязычного населения, а также инициированию «реформирования» государственного устройства РФ в целях создания различных форм тюркской национальной государственности для последующего отделения от России. Следует обратить внимание на попытки использования черкесскими кланами в борьбе за политическое и экономическое влияние адыго-черкесской сепаратистской проблематики. Деструктивную обработку российских граждан под предлогом «консолидации финноугорских народов» ведут неправительственные и государственные структуры Финляндии, Эстонии и Венгрии (Общество «Финляндия-Россия», «Фенно-Угриа»). Реваншистские организации Германии, Литвы, Эстонии и Финляндии выдвигают требования отторжения от России территорий, отошедших к ней по итогам Второй мировой войны (Калининградская область, Карельский перешеек, северное Приладожье, район Печенги Мурманской области, Пыталовский район Псковской области).
} 
получивших передовой опыт осуществления террористической деятельности за рубежом ${ }^{1}$.

Значительную опасность представляет слабо контролируемая внешняя миграция.

С учетом масштаба рынка труда мигрантов в РФ и сращивания национальных анклавов с криминальными структурами нелегальная рабочая сила стала неотъемлемой частью организованного преступного бизнеса ${ }^{2}$. Под влиянием роста численности этнических диаспор, пополняемых за счет мигрантов, происходит вытеснение коренного населения с рынков труда и формируются предпосылки к возникновению межэтнических и межконфессиональных конфликтов. Неконтролируемый приток иностранцев негативно влияет на криминогенную обстановку в крупных административных и промышленных центрах, серьёзно меняет национальный состав населения ряда регионов страны и ставит под угрозу этническую, культурную и территориальную целостность РФ. Отмечается тенденция проникновения в нашу страну на каналах миграции членов международных экстремистских объединений и террористических организаций.

Реализации рассматриваемой угрозы способствует наличие ряда факторов, к числу которых следует отнести:

1 Целенаправленная вербовочная работа эмиссаров «ИГИЛ» позволила террористам привлечь в свои ряды не менее 3200 российских граждан из 70 регионов РФ. Только в Сирии в боевых действиях участвуют свыше 30 различных террористических группировок, большая часть которых укомплектована выходцами из СКФО и Приволжского федеральных округов РФ. В числе этих структур батальоны «Джохар Дудаев», «Шамиль Басаев», «Амир Хаттаб», джамааты «Адама», «Ахмада», «Абдурахмана», «Сулеймана», «Халида», «Абу Джихада» и др. Следует отметить, что возглавляемые российскими гражданами незаконные вооруженные формирования являются наиболее подготовленными и боеспособными. Наши сограждане представлены и среди руководителей «Исламского государства»: Атабиев И. С. 1980 г.р., Чатаев А. Р. 1980 г.p., Измайлов Ш.М. 1980 г.р. и др. В числе первых лиц МТО «ИГИЛ» выделен специальный координатор по террористической деятельности на территории РФ, который курирует вопросы подготовки и совершения терактов выходцами из России.

2 В 2015 г. на территории РФ органами внутренних дел выявлено 679 этнических преступных группировок общей численностью более 1800 участников, ликвидировано 637 этнических группировок (к уголовной ответственности привлечено более 1900 участников). 
техническую необустроенность и незавершенность договорноправового оформления значительных участков Государственной границы РФ с государствами СНГ;

проявления коррупции в субъектах государственной миграционной политики, способствующие незаконной миграции в $\mathrm{P}^{1}$;

упрощенный порядок въезда на территорию РФ граждан некоторых иностранных государств;

значительно более низкий уровень жизни в сопредельных с Россией государствах (за исключением США и государств ЕС);

ориентацию работодателей на массовое привлечение дешевой рабочей силы за счет трудовых мигрантов;

нежелание приезжих интегрироваться в социальную структуру российского общества, уважать традиции и культуру коренного населения;

лоббирование органами власти некоторых иностранных государств преференций для своих граждан, находящихся на территории РФ, а также попытки усилить влияние на процессы, протекающие в национальных диаспорах ${ }^{2}$;

репрессивная политика ряда государств СНГ, направленная на выдавливание экстремистов и террористов за пределы своей территории;

несовершенство системы миграционного учета и контроля за въездом, выездом и пребыванием иностранных граждан и лиц без гражданства на территории РФ.

${ }^{1}$ В качестве незаконной миграции автор рассматривает незаконный въезд, выезд, пребывание (проживание) или транзитный проезд через территорию государства в целях оседания на постоянное жительство либо временного пребывания на территории той или иной страны.

${ }_{2}$ Особую активность в этом направлении проявляют Таджикистан, Узбекистан и Кыргызстан. Так, властям Таджикистана удалось достичь договоренности с российской стороной о возможности нахождения на территории России граждан Таджикистана без регистрации в течение 14 суток, в то время как прибывающие в Таджикистан российские граждане обязаны встать на регистрационный учет в течение 3 дней. За нарушение данного срока законодательством Таджикистана предусмотрены более строгие санкции, чем в России. Кроме того, Таджикистан, Кыргызстан и Узбекистан регулярно ставят вопрос о снятии ограничений для въезда в РФ своих граждан, ранее нарушавших российское миграционное законодательство. 
Как уже отмечалось, деструктивная деятельность антигосударственных сил по ослаблению и подрыву государственного суверенитета нуждается в легитимности, теоретическом обосновании и информационнопропагандистском обеспечении. С учетом этого представляет интерес типовая аргументация, используемая в целях обоснования ослабления и подрыва государственного суверенитета ${ }^{1}$.

Внешнее посягательство на суверенитет, как правило, осуществляется под предлогом необходимости "защиты демократии" и "борьбы с диктаторскими режимами". Руководство США и стран-сателлитов заявляет в подобных ситуациях о содействии эталонной, подлинной, классической демократии, демократических стандартах и ценностях, позиционируя себя на международной арене как их единственного носителя и выразителя. При этом насильственное распространение "демократии" является основным вектором их внешней политики.

Рассматривая такое обоснование нарушения суверенитета, С.А. Авакьян отмечает, что "периодически одни страны выдают свои представления о демократическом правлении, о справедливом строе за идеальные, желают, чтобы другие страны следовали их моделям, либо навязывают их внешним принуждением. А если не убеждает модель, то можно заявить об угрозе для своей обороны. Таким образом, - приходит к выводу ученый, - признание и за мировым сообществом, и за отдельными странами каких-то исключительных прав и приоритета перед государственным суверенитетом других стран - это очень опасная идея"2.

С этой точкой зрения солидарен О.В. Дамаскин: "Тезис о том, что демократия неполноценна, пока в ней не создано гражданское общество по американскому образцу, представляется не только ошибочным, но и

1 Теории ограничения государственного суверенитета рассматриваются в главе 2 монографии.

2 Авакьян С. Точка отсчета - народ // Рос. газ. 2006. 28 октября. 
опасным. Вера в гражданское общество не должна выражаться в нетерпимости по отношению к демократиям, которые устроены по-другому, что позволяет признать понятие суверенной демократии"1.

В ряде случаев для ограничения суверенитета извне используется предлог "борьбы с терроризмом". В результате политики США и их союзников, направленной на усиление своего влияния на Ближнем Востоке, в условиях жесткой конкуренции за доступ к ресурсам и рынкам их сбыта "борьба с терроризмом" становится одним из инструментов решения геополитических и экономических задач ${ }^{2}$. В течение длительного времени Соединенные Штаты проводят комплекс дипломатических, экономических, информационно-пропагандистских, военных и иных мероприятий в целях установления контроля над странами т.н. Большого Ближнего Востока (от Афганистана, Пакистана до Марокко) $)^{3}$. По этой причине заявленная антитеррористическая борьба постепенно перемещается в другие страны (Афганистан, Пакистан, Ирак, Ливия, Сирия и др.)

Проблема ЗГС в современных условиях неразрывно связана с трансформацией принципа верховенства международного права, который подразумевает уступку государством части национальных суверенных полномочий международной организации ${ }^{4}$. На фоне продолжающейся девальвации международно-правовых норм, усиления зависимости международных институтов от политической воли США и их сателлитов, избирательного соблюдения ими "удобных" норм международного права, подмены гуманитарных международно-правовых аспектов военно-

\footnotetext{
1 Дамаскин О.В. Россия в современном мире: проблемы национальной безопасности. М.: Наука, 2007. С. 47.

2 Более подробно данный механизм ослабления и подрыва государственного суверенитета рассматривается в подразделе «гуманитарные интервенции».

${ }_{3}^{3}$ В регионе Большого Ближнего Востока сосредоточено свыше $60 \%$ разведанных запасов нефти. Поэтому контроль над региональными государствами позволяет обеспечивать доступ транснациональных корпораций к природным запасам углеводородного сырья.

Впервые принцип верховенства международного права получил прямое закрепление в основном законе ФРГ 1949 г. как способ контроля международных организаций за национальными властями послевоенной Германии.
} 
политическими одностороннее соблюдение международных обязательств означает согласие государства на вмешательство в свои внутренние дела и ущемление национальных интересов ${ }^{1}$.

В связи с этим необходимо разделять тенденции ограничения суверенитета вследствие объективных процессов глобализации и вследствие целенаправленной деятельности ряда иностранных государств и их военнополитических блоков ${ }^{2}$.

В результате развития процессов глобализации на национальном уровне образуется некий властный вакуум, куда тут же устремляются многочисленные и постоянно усиливающиеся наднациональные центры влияния. Речь идет о разнообразных межгосударственных альянсах (во многих из которых ведущую роль играют США), транснациональных корпорациях, международных клерикальных объединениях, криминальных структурах и террористических организациях и т.д.

А.Д. Керимов справедливо указывает на две связанные с этим серьезные проблемы ${ }^{3}$.

Во-первых, названные и другие центры влияния далеко не всегда заботятся о всеобщем благе, а зачастую преследуют собственные эгоистические, порой преступные интересы ${ }^{4}$. "Складывающаяся сегодня инфраструктура глобальной власти сочетается с традиционными мотивами использования власти в угоду тем, кто получил в свои руки ее рычаги. Здесь

\footnotetext{
1 Приложение 3. Примером деструктивного использования потенциала международных и региональных организаций для ослабления и подрыва государственного суверенитета может служить противоправное задействование США, ФРГ, Великобританией, Польшей и Украиной структур ООН и ОБСЕ на Донбассе для осуществления разведывательной деятельности в отношении ДНР и ЛНР.

2 Более подробно влияние глобализации на государственный суверенитет рассматривается в параграфе 2.3 данной работы.

${ }_{3}$ Керимов А.Д. Указ. соч. С. 77.

${ }^{4}$ Как отмечает А. Бабаков, «принцип суверенитета имеет системного противника в лице транснациональных корпораций. Государственные границы, национальный суверенитет мешают свободному перемещению капитала, ради которого транснациональные корпорации готовы закрыть глаза на национальную идентичность, национальную культуру любого народа, каким бы количеством тысячелетий они ни исчислялись». См. Материалы круглого стола «Суверенное государство в условиях глобализации: демократия и национальная идентичность» // Рос. газ. 2006. 6 сентября.
} 
власть складывается по принципу соотношения сил (в частности, по итогам "холодной войны") и не может считаться ни демократической, ни легитимной. Совсем не случайно в последнее время наметилась опасная тенденция подмены международных организаций универсального характера ООН, Совета Безопасности, ОБСЕ - инстанциями блокового типа, выражающими волю и интересы отдельных стран и группировок, претендующих на особые права. Все это отражает тенденцию присвоения новых возможностей, вытекающих из глобализации власти, не в интересах мирового сообщества, а в интересах сильных и преуспевших"1.

Во-вторых, наднациональные центры влияния берут на себя властные функции и полномочия, а государства утрачивают власть там, где это нецелесообразно и даже вредно с точки зрения достижения и отстаивания как ближайших, так и перспективных целей и интересов всего человечества, обеспечения прав и свобод отдельной личности. Во многих случаях при решении значительного числа жизненно важных вопросов национальная власть остается незаменимой, и ее дефицит, тем более капитуляция перед натиском власти глобальной несет в себе реальную угрозу наступления деструктивных и регрессивных по своей сути и характеру последствий. Множество процессов и проблем гораздо эффективнее регулируются и решаются на национальном, региональном, местном, а отнюдь не на мировом уровне $^{2}$.

Наибольшую опасность для суверенной государственности представляет целенаправленная деструктивная деятельность иностранных государств и их военно-политических блоков по реализации конкретных механизмов ослабления и подрыва государственного суверенитета странпротивников.

${ }_{1}^{1}$ Панарин А.С. Россия в циклах мировой истории. С. 283.

${ }^{2}$ Керимов А.Д. Указ. соч. С. 78. 
В настоящее время среди таких механизмов можно назвать следующие ${ }^{1}$ :

1. Экономические санкции, блокады, эмбарго и демпинг.

2. "Цветные революции".

3. Тайная и официальная политическая, информационная, материальнотехническая и финансовая поддержка сепаратистских и иных антигосударственных сил.

4. "Гуманитарные" интервенции.

5. Открытое военное вторжение, организованная вооруженная борьба.

Данные механизмы могут применяться самостоятельно, а также реализовываться в комплексе.

Экономические санкции, блокады, эмбарго и демпинг применительно к теме исследования применяются с целью нанесения материального ущерба и подрыва экономической основы суверенитета государства-противника.

Как представляется, следует различать международные санкции как меру ответственности государства - нарушителя норм международного права и санкции "крупных держав" как механизм ослабления и подрыва государственного суверенитета, смены политического режима в странах противниках.

Международные санкции применяются по решению СБ ООН в рамках ст. 41 и 42 Устава ООН в отношении государств, нарушающих нормы международного права. Санкции как форма принуждения применяются только в случае совершения тяжкого международного преступления (например, аннексия Ираком территории Кувейта в 1990 г., геноцид в Руанде в 1994 г. и др.) $)^{2}$. Применение санкций в других случаях нельзя считать

\footnotetext{
${ }^{1}$ Приложение 2.

2 После разгрома вооруженных сил Ирака государство-агрессор принудили отвести войска от территории Кувейта, в отношении Ирака был введен запрет иметь ракетное и
} 
правомерным, поскольку санкции являются реакцией государств (международного сообщества) на умышленное совершение тяжких противоправных действий ${ }^{1}$.

Перед введением международных санкций обязательно должны быть использованы все возможные средства и способы урегулирования. Объем и виды санкций зависят от степени тяжести правонарушения и нанесенного ущерба. Кроме того, международные санкции предполагают точечный характер: наложение ареста на зарубежные активы должностных лиц, ограничение доступа к иностранным финансовым рынкам, эмбарго на поставки оружия и др.

Санкции как механизм ослабления и подрыва государственного суверенитета не имеют международно-правовых оснований и поддержки СБ ООН. Их введение не связано с предварительным использованием примирительных процедур. Сфера действия носит масштабный характер и имеет тенденцию к непропорциональному расширению в целях нанесения максимального материального ущерба противнику.

Применение санкций, блокад и эмбарго в качестве механизма ослабления и подрыва государственного суверенитета имеет давнюю историю.

Так, в 1917-1923 гг. страны Антанты ввели экономическую блокаду (блокирование транспортных каналов) Советской России и запретили любые экономические связи с Советским государством.

В 1960 г. режим эмбарго (полного прекращения торговли) был введен США в отношении Кубы. Предусматривалось задержание судов, грузов, иного имущества и запрет захода судов Кубы в порты Соединенных Штатов.

В 1985 г. США объявили об экономической блокаде Никарагуа

химическое оружие, на территории Ирака международные инспекции наблюдали за ликвидацией ракетного оружия, за передвижением его войск и вооружений.

1 Международное публичное право / Под ред. К.А. Бекяшева. М.: ТК Велби, Проспект, 2007. С. 196. 
(продолжалась до 1990 г.)

В 2006 г. после победы партии "Хамас" на парламентских выборах США и Евросоюз ввели экономические санкции против Палестинской национальной администрации.

В 2014 г. крупномасштабная санкционная кампания была развязана Соединенными Штатами и Евросоюзом в отношении России после проведения референдума в Крыму и принятия в состав Российской Федерации новых субъектов ${ }^{1}$.

Одним из новейших механизмов ослабления государственного суверенитета являются "цветные революции", которые предусматривают дезорганизацию функционирования легитимных органов государственной власти, осуществление контроля за формированием новых выборных и назначаемых институтов власти в «демократически недоразвитых странах».

Несмотря на некоторые особенности в ряде государств, "цветные революции" имеют ряд характерных признаков.

Во-первых, аналогичный состав субъектов управляющего воздействия на политический процесс. Как правило, ключевая роль принадлежит международным неправительственным организациям (Фонд Сороса,

${ }^{1}$ Executive Order 13660 - Blocking Property of Certain Persons Contributing to the Situation in Ukraine // Federal Register. Vol. 79. No. 46. Part I.V. March 10, 2014. URL: http://www.treasury.gov/resource-center/sanctions/Programs/Documents/ukraine_eo.pdf (дата обращения: 10.07.2014); Executive Order 13661 - Blocking Property of Additional Persons Contributing to the Situation in Ukraine//Federal Register. Vol. 79. No. 53. Part I.V. March 19, 2014.URL:http://www.treasury.gov/resourcecenter/sanctions/Programs/Documents/ukraine_eo2. pdf (дата обращения: 10.07.2014); Executive Order 13662 - Blocking Property of Additional Persons Contributing to the Situation in Ukraine // Federal Register. Vol. 79. No. 56. Part I.V. March 24, 2014. URL: http: I/ www.treasury.gov /resourcecenter/sanctions/Programs/Documents/ukraine_eo3.pdf (дата обращения: 10.07.2014); Council Regulation (EU). No. 208. 5 March 2014 concerning restrictive measures directed against certain persons, entities and bodies in view of the situation in Ukraine // Official Journal of the European Union. L 66/1 - L 66/8, 06.03.2014; Council Decision 2014/145/CFSP of 17 March 2014 concerning restrictive measures in respect of actions undermining or threatening the territorial integrity, sovereignty and independence of Ukraine // Official Journal of the European Union. L 78/16 - L 78/21. 17.03.2014; Council Regulation (EU) No. 269/2014 of 17 March 2014 concerning restrictive measures in respect of actions undermining or threatening the territorial integrity, sovereignty and independence of Ukraine // Official Journal of the European Union. L 78/6 - L 78/13. 17.03.2014; Special Economic Measures (Russia) Regulations / P. C. 2014 - 282. March 17, 2014. URL: http://canadagazette.gc.ca/rp-pr/p2/2014/2014-04-09/html/sor-dors58eng.php (дата обращения: 10.07.2014). 
Национальный Фонд поддержки демократии, «Freedom House»). Эти структуры негласно финансируют интересующих их кандидатов и политические партии, обучают активистов для участия в акциях протеста, оказывают информационную, правовую, техническую, методическую помощь отдельным избирательным штабам, консультируют кандидатов и их доверенных лиц, оказывают давление на иностранных и международных наблюдателей.

Международные неправительственные организации и представители оппозиции активно используют студенческие организации в качестве мобильных и радикально-настроенных участников «революционных» событий. Так, выдающуюся роль в агитации против С. Милошевича и организации массовых беспорядков на улицах г. Белграда в 2000 г. сыграла студенческая организация «Отпор». Организатором массовых акций в Грузии в 2003 г. выступила радикальная студенческая организация «Кмара». В 20042005 гг. в Украине действовала студенческая организация «Пора», инициировавшая акции протеста на Майдане.

Во-вторых, общим признаком "цветных революций" является применение схожих технологий оппозиционной борьбы. Можно назвать их «катализирующими» технологиями, поскольку их использование направлено на обострение социально-политической напряженности в стране, вовлечение в политическую борьбу максимального количества участников, привлечение внимания мировой общественности К происходящим событиям. Используемые для этого противоправные действия (несанкционированные митинги, захваты и блокирование государственных органов, организация массовых беспорядков, создание незаконных военизированных формирований, вмешательство в работу избирательных комиссий и т.п.), как правило, остаются безнаказанными, поскольку имеют выраженную политическую окраску и осуществляются под прикрытием оппозиционной 
борьбы ${ }^{1}$. Первостепенное значение имеет постоянная пропаганда оппозиционной правящему политическому режиму идеологии. Возможен захват организаций телевидения и радиовещания.

В-третьих, для захвата политической власти и смены государственнополитического режима применяется т.н. «внешнее голосование» ${ }^{2}$. В избирательном процессе данная технология используется при повторном голосовании или после официального объявления итогов выборов в случае незначительного перевеса голосов, поданных за того или иного кандидата. Полученный перевес можно объяснить массовыми нарушениями, допущенными кандидатом-оппонентом, официально обжаловать их в суд и обратиться к мировой общественности (в лице США и ЕС) с просьбой о непризнании итогов выборов. Если поводом для "цветной революции" стало иное общественно-значимое событие (например, решение правительства Украины о приостановке подготовки к подписанию Соглашения об ассоциации между Украиной и ЕС в ноябре 2013 г.), антигосударственные силы обращаются к иностранным субъектам с просьбой о помощи "демократическим" силам в евроинтеграции, поддержке в "борьбе с тиранией" и коррумпированным режимом и др ${ }^{3}$.

В отличие от "цветных революций", являющихся инновациями политической подрывной работы, в которых иностранное участие не маскируется, тайная политическая, информационная, материальнотехническая и финансовая поддержка сепаратистских и иных

${ }^{1}$ Один из идеологов «цветных революций» Джин Шарп в работе «От диктатуры к демократии» в числе 200 методов ненасильственных действий для смены государственной власти называет следующие противоправные действия: общественное неповиновение, всеобщая забастовка, отказ от уплаты налогов и кредитов, распространение литературы и агитация с призывами к сопротивлению, отказ в помощи силам правопорядка, перекрытие дорог, захват земли и ценностей, изготовление фальшивых документов, политически мотивированное изготовление фальшивых денег, мятеж, создание параллельного правительства. http: //www.aeinstein.org/wp-content/ uploads/ 2013/10/FDTD

2 См.: Кара-Мурза С.Г. Экспорт революции. Ющенко, Саакашвили... М.: Изд-во Алгоритм, 2005. С. 254, 260.

3 В настоящее время опыт «цветных революций» обогатился примером Бразилии, где в мае 2016 г. под предлогом коррупционного скандала оппозицией при поддержке США был отстранен Президент Дилма Русеф. 
антигосударственных сил как механизм ослабления и подрыва государственного суверенитета традиционно и на протяжении длительного времени используется в конспиративной враждебной деятельности иностранных государств.

Так, сразу после Октябрьской революции 1917 г. британский кабинет министров, обсуждая политику в отношении Советской власти, высказался за финансовую и иную поддержку любых антисоветских сил при условии, если последние "дадут гарантию следовать в фарватере политики союзников". Английскому послу в России Д. Бьюкенену было разрешено истратить около 10 млн рублей на развитие контрреволюционного движения в России ${ }^{1}$

Одним из ярких свидетельств тайной деструктивной деятельности по ослаблению и подрыву государственного суверенитета Советской России с использованием диверсионно-террористических методов со стороны британского и французского правительств стал "заговор послов". После разоблачения заговора народный комиссар по иностранным делам Г.В. Чичерин 7 сентября 1918 г. заявил: "Дипломатические и военные представители Англии и Франции пользуются своим званием для организации на территории РСФСР заговоров, направленных к захвату Совета Народных Комиссаров с помощью подкупа и агитации среди войсковых частей, к взрыву мостов, продовольственных складов и поездов "2.

В 1921 г. крупнейшей антисоветской организацией за рубежом стал "Народный союз защиты родины и свободы", который был сформирован при содействии польских властей и представителей французской военной миссии

${ }^{1}$ Голинков Д.Л. Крушение антисоветского подполья в СССР. Книга 1. М.: Изд-во полит. лит-ры, 1986. С. 123. С 1 января 1918 по 31 марта 1921 гг. Англия израсходовала на антисоветскую деятельность 89,7 млн. фунтов стерлингов. См. Вопросы истории. 1968. № 12. С. 74,75 .

2 Международная политика новейшего времени в договорах, нотах и декларациях. М., 1926. Ч.2. С. 170. 
в Варшаве" 1 Фактически "Союз" стал вспомогательным органом польской разведки.

В докладе ВЧК о деятельности "Народного союза защиты родины и свободы" говорилось: "Роль польского генерального штаба сводится к следующему: а) разрешению и содействию организации на территории Польши партизанских отрядов и перевозке их по железной дороге за счет польского военного министерства; б) снабжению этих отрядов оружием; в) содействию вербовке в лагерях военнопленных и интернированных организаторов антисоветских групп и отправке их в Россию; г) содействию реорганизации и приведению в боевую готовность остатков интернированных армий Булак-Балаховича, Перемыкина и Петлюры"2.

Почти все агенты Савинкова состояли одновременно на службе польской разведки и контрразведки. Военные и политические сведения, доставлявшиеся из России, курьеры Савинкова передавали в польский генштаб и французскую военную миссию, откуда организация Савинкова и получала финансирование.

Тайная антигосударственная деятельность проводилась не только в отношении Советской России и СССР. Вашингтон и его союзники предпринимали неоднократные попытки свержения социалистических и революционных правительств по всему мируํ․

Наряду с конспиративной враждебной деятельностью, направленной на ослабление и подрыв государственного суверенитета, государства и их союзы используют официальные механизмы политической,

\footnotetext{
${ }^{1}$ Председателем «Народного союза защиты родины и свободы» был избран Борис Савинков.

2 Голинков Д.Л. Крушение антисоветского подполья в СССР. Книга 2. М.: Изд-во полит. лит-ры, 1986. С. 128-129.

${ }_{3}^{3}$ В свою очередь, СССР и страны социалистического лагеря активно участвовали в антиколониальных войнах 1960-1970-х гг. В частности, повстанцы Анголы, ГвинеиБиссау и Мозамбика получали военную поддержку от СССР и Китая. Поддержка национально-освободительных движений и обеспечение благоприятных условий для укрепления мировой социалистической системы выступали компонентом политики ведущих социалистических государств.
} 


\section{информационной, материально-технической и финансовой поддержки} сепаратистских и иных антигосударственных сил. В качестве элементов такой деятельности выступают: создание и поддержка "антиправительственных блоков" и "коалиций друзей"; признание этнических групп и народов, компактно проживающих в сепаратистских регионах, воюющей стороной; признание организаций сопротивления и правительств в эмиграции; оказание сепаратистским силам, частным военным компаниям и иным участникам вооруженных конфликтов военнотехнической помощи и финансирования; предоставление политического или дипломатического убежища террористам и главарям экстремистских организаций ${ }^{1}$. Официальная поддержка антигосударственных сил может использоваться отдельными государствами (союзами государств) для легитимации одиозных функционеров и активистов сепаратистских, экстремистских и национал-радикальных организаций, узаконивания государственных переворотов, принуждения государственных органов к передаче части суверенных полномочий, скрытой аннексии части территории государства. В качестве примера официальной поддержки антигосударственных (сепаратистских) сил можно привести признание США и Евросоюзом одностороннего провозглашения независимости Косово от Сербии в нарушение резолюции СБ ООН от 10 июня 1999 г. № 1244,

1 Так, Великобритания в ноябре 2003 г. отказала РФ в выдаче А. Закаева, обвиняемого в совершении тяжких преступлений, в том числе террористических актов, на территории России, а затем предоставила ему политическое убежище. В отказе лондонского суда по делу А.Закаева отмечалось, что «деяния, которые были бы квалифицированы как преднамеренное убийство, не должны рассматриваться в качестве преступления, за которое лицо подлежит экстрадиции, на основании того, что данное обвинение может выдвигаться лишь в условиях «королевского мира». Убийство противника в условиях войны не может считаться преступным деянием и квалифицироваться как преднамеренное убийство. Те преступные деяния, которые совершались с целью захватить определенную часть Чечни с помощью оружия и оказания сопротивления властям, не являются преступлениями, за которые лицо может быть подвергнуто экстрадиции, поскольку деяния, совершенные в подобных обстоятельствах, в данной стране не считались бы преступными». Основываясь на этом, судья Тимоти Уоркман отклонил пункты обвинения 7, 8, 9 и 13, связанные с участием А. Закаева в терроризме. Решение судьи Тимоти Уоркмана по делу «Правительство Российской Федерации против Ахмеда Закаева» (офиц. пер.) // http: // grani.ru / Invisible/ Zakaev/50673.html (дата обращения 7 января 2013 г.) 
согласно которой Косово не может рассматриваться в качестве государства, обладающего правосубъектностью. "Косовский прецедент", позднее легитимизированный консультативным заключением Международного Суда ООН от 22 июля 2010 г., позволил другим самопровозглашенным государствам добиваться международного признания ${ }^{1}$.

Эффективным механизмом ослабления и подрыва государственного суверенитета, подмены гуманитарных международно-правовых аспектов военно-политическими являются т.н. "гуманитарные" интервенции.

Одно из наиболее полных определений "гуманитарной" интервенции было дано в совместном докладе двух голландских неправительственных организаций - Консультативного комитета по правам человека и внешней политике и Консультативного комитета по вопросам публичного международного права. В докладе "гуманитарная" интервенция определяется как "угроза или использование силы одним или более государством в пределах территории другого государства с единственной целью остановить или предотвратить крупномасштабные, серьезные нарушения основных прав человека, которые имеют место или совершение которых в ближайшем будущем очевидно, независимо от гражданства, причем к таким правам в особенности относится право индивидов на жизнь, в случаях, когда угроза или использование силы осуществляются либо без предварительного получения полномочий от компетентных органов ООН, либо без разрешения законного правительства страны, на территории которой интервенция имела место"2. Большинство юристов-международников под гуманитарной

${ }^{1}$ После вооруженной агрессии Грузии и попытки геноцида населения Республики Южная Осетия в 2008 г. руководство РФ признало Республику Южную Осетию и Республику Абхазию как суверенные и независимые государства. См. указы Президента РФ от 26 августа 2008 г. № 1260 и 1261.

2 The Use of Force for Humanitarian Purposes. Enforcement Action for Humanitarian Purposes and Humanitarian Intervention // Advisory Committeeon Human Rights and Foreign Policy and Advisory Committee on Issues of Public International Law. Report 5. 1992. Цит. пo Тарасова Л.Н. К дискуссии о правомерности гуманитарной интервенции // Вестник Волгогр. гос. ун-та. Сер. 5, Юриспруд. 2011. № 1. С. 100. 
интервенцией понимают использование вооруженной силы без согласия законных властей государства.

Современная концепция "гуманитарных" интервенций предполагает различные форматы (введение бесполетных зон, бомбардировки, оккупации) применения вооруженных сил против государств, нарушающих права человека, без разрешения СБ ООН и согласия законного правительства данного государства. С юридической точки зрения, отсутствие мандата ООН характеризует любые "гуманитарные" интервенции как военную агрессию1. Устав ООН разрешает применять силу только в порядке самообороны (ст. 51 Устава ООН) или по решению Совета Безопасности для восстановления международного мира и безопасности (ст. 42 Устава ООН $)^{2}$.

Еще в апреле 1949 г., в ответ на утверждение о возможности использования доктрины гуманитарной интервенции, Международный Суд ООН в своем решении "Дело о проливе Корфу" (Соединенное Королевство Великобритании и Северной Ирландии против Албании) указал: "Якобы существующее право на вмешательство Суд может рассматривать только как проявление политики силы, такое, которое в прошлом вело к наиболее серьезным злоупотреблениям и которое не может, каковы бы ни были дефекты организации международного общения, найти место в международном праве... Интервенция, возможно, еще менее допустима, если

1 В связи с действиями США по поддержке никарагуанских «контрас» Международный Суд ООН в решении от 27 июня 1986 г. по делу «Никарагуа против Соединенных Штатов Америки» указал, что международное право не санкционирует использование государством вооруженной силы для исправления ситуации с нарушениями в области прав человека в другом государстве без одобрения Совета Безопасности ООН. Суд установил, что «применение силы как реакция на нарушения прав человека не является подходящим методом контроля или обеспечения соблюдения таких прав». См. Краткое изложение решений, консультативных заключений и постановлений Международного Суда (1948-1991). Нью-Иорк: ООН, 1993. С. 207-208.

2 Примечательно, что в ст. 16 Федерального закона «О юрисдикционных иммунитетах иностранного государства и имущества иностранного государства в Российской Федерации» законодательно закреплен режим непризнания Россией т.н. «гуманитарных интервенций», проводимых без санкции СБ ООН. 
ее осуществляют могущественные державы, так как это может привести к извращению всей системы отправления международного правосудия"1 .

В мае 2010 г., выступая перед офицерами военной академии (ВестПойнт), Президент США Б. Обама заявил: "Соединенные Штаты будут использовать военную силу и в одностороннем порядке, если это необходимо, когда наши интересы потребуют этого - когда угрожают нашим людям, когда речь идет о наших жизнях, когда безопасность наших союзников в опасности. ... Международное мнение имеет значение, но Америка никогда не должна испрашивать разрешения на то, чтобы защищать своих людей, свою родину и свой образ жизни"2.

Таким образом, американским политическим руководством на высшем уровне была заявлена готовность начинать и проводить военные действия по собственному усмотрению, не запрашивая санкции СБ ООН.

Следует отметить, что Соединенные Штаты и их военно-политические союзники по блоку НАТО давно занимают лидирующие позиции в апробации и легализации механизма "гуманитарных" интервенций.

Вторжение США в Панаму в 1989 г. в целях смены правящего режима, стремящегося проводить независимый от Вашингтона политический курс, является первой в истории "гуманитарной" интервенцией Соединенных Штатов, для обоснования которой использовались лозунги "восстановления демократии". В результате вторжения США правительство Панамы было свергнуто.

Первой крупномасштабной военной акцией НАТО стала операция "Обдуманная сила" (август - сентябрь 1995 г.). "Гуманитарная" интервенция

${ }_{2}^{1}$ International Court of Justice. Reports. The Corfu Channel Case. 1949. 9 april.

2 В 2014 г. в США был принят закон, дающий «право» в случае осуждения гражданина США Международным трибуналом в Гааге вводить войска в соответствующую страну, чтобы воспрепятствовать отправлению правосудия и отбыванию совершившему преступление американцу тюремного срока на ее территории. См. Тимохин П. Военная сила в политике национальной безопасности США // Зарубежное военное обозрение. 2015. № 2. С. 8. 
НАТО сыграла значимую роль в поражении сербов в Боснии и заставила их руководство подписать Дейтонские соглашения в декабре 1995 г.

В 1999 г. силами НАТО против Союзной Республики Югославия была проведена очередная "гуманитарная" интервенция (операция "Союзная сила"). В качестве предлога для военной агрессии были названы этнические "чистки" в Косово.

В 2001 г. с целью свержения режима талибов вооруженные силы США вторглись в Афганистан. Декларируемые цели военной интервенции были достигнуты.

В 2003 г. с целью свержения правительства Саддама Хусейна Соединенные Штаты и страны-союзники начали военную операцию против Ирака. Официальным поводом к началу военных действий была заявлена связь правящего режима с международным терроризмом и поиск оружия массового поражения ${ }^{1}$. Результатом "гуманитарной" интервенции стала смена власти в Ираке и установление американского контроля над нефтяными месторождениями.

В 2008 г. РФ впервые применила механизм "гуманитарной" интервенции при проведении операции по разъединению враждующих сторон и принуждению Грузии к миру для защиты миротворческого контингента и своих граждан, проживающих в зоне грузино-юго-осетинского конфликта. Однако, в отличие от операций США и блока НАТО, конфликт был локализован на ограниченной территории, применение Вооруженных сил РФ носило пропорциональный характер и не преследовало цель смены правящего в Грузии политического режима.

В августе 2014 г. под предлогом защиты национальных меньшинств в Ираке Вашингтон санкционировал проведение в Ближневосточном регионе

1 Доказательства наличия у С.Хуссейна оружия массового поражения были сфальсифицированы официальными представителями США и Великобритании. Так было и во время «гуманитарной» интервенции НАТО в Ливии, когда глобальные СМИ транслировали сфабрикованные свидетельства о «зверствах армии Каддафи против собственного народа». 
военной операции "Непоколебимая решимость" против террористической организации "Исламское государство" и приступил к нанесению ракетнобомбовых ударов по Ираку. В сентябре было принято решение о расширении масштабов операции и нанесении ударов по территории Сирии ${ }^{1}$.

Учитывая низкую эффективность воздушных ударов по мобильным группам боевиков "Исламского государства", США предпринимают меры по созданию наземной группировки. Военная операция позволяет легитимизировать использование против Дамаска военной силы, а затем свергнуть правительство Б. Асада. Кроме того, стремясь еще больше ослабить возможности сирийского руководства по противодействию оппозиции и вызвать недовольство населения властями, коалиционная авиационная группировка под предлогом уничтожения позиций и объектов "Исламского государства" планомерно выводит из строя экономическую инфраструктуру Сирии².

Анализ обстановки в регионе свидетельствует, что под вывеской борьбы с террористической группировкой "Исламское государство" осуществляется агрессия против Сирии. Имитируя борьбу с "Исламским государством", США создают повод для переноса ударов по правительственным войскам САР, после чего любое недовольство Б. Асада действиями США можно расценивать как пособничество террористам.

С момента начала военной операции Воздушно-космическими силами России в Сирии ситуация в зоне конфликта заметно изменилась ${ }^{3}$. Авиаудары

\footnotetext{
${ }^{1}$ После первых бомбардировок, состоявшихся 22-23 сентября 2014 г., сирийские власти заявили о недопустимости авиаударов иностранных государств по боевикам «Исламского государства» на территории Сирии без согласия Дамаска. Министр иностранных дел САР Валид Муаллем заявил, что подобные действия будут расцениваться как «агрессия». См. Зарубежное военное обозрение. 2015 . № 1. С. 66.

${ }_{2}$ Молчанов $\Gamma$. Военно-политическая обстановка в различных регионах мира // Зарубежное военное обозрение. 2015. № 1. С. 12.

${ }^{3}$ Антитеррористическая операция ВКС России против действующих на территории Сирии международных террористических организаций началась 30 сентября 2015 г. Ее целью являлась поддержка сухопутного наступления правительственных войск и разрушение инфраструктуры террористов. После выполнения задач, поставленных перед Министерством обороны, 14 марта 2016 г. Президент РФ приказал начать вывод основных сил РФ из САР.
} 
ВКС России нарушили материально-техническое обеспечение террористических структур на линии соприкосновения с сирийскими войсками и позволили правительственным силам развернуть наступление. Следует отметить, что операция российских Вооруженных сил в Сирии была ограничена во времени и масштабах, легитимна с точки зрения международного права и согласована со всеми заинтересованными сторонами.

В качестве элемента механизма "гуманитарных" интервенций можно рассматривать создание разного рода международных трибуналов и следственных комиссий по расследованию серьезных нарушений гуманитарного права, имеющих сомнительную правовую природу, приоритет по отношению к юрисдикции национальных судов и создающих процессуальные нормы собственной деятельности ${ }^{1}$.

Наиболее острый и непримиримый характер имеет механизм открытого военного вторжения, организованной вооруженной борьбы. Данный механизм предполагает применение крайних и последних мер воздействия на государство-противника. В отличие от "гуманитарных" интервенций открытое военное вторжение даже не маскируется необходимостью "защиты прав человека", "борьбы с международным терроризмом" и "демократизации"2. Применение военных мер на практике

${ }^{1}$ Международный трибунал по бывшей Югославии (МТБЮ) и Международный трибунал по Руанде (МТР) были созданы решениями Совета Безопасности ООН от 25 мая 1993 г. № 827 и от 8 ноября 1994 г. № 955. Вместе с тем, Устав ООН не содержит правомочий Совета Безопасности ООН создавать международные трибуналы. У многих юристов вызывают возражения положения ст. 9, 29 Устава МТБЮ, ст.8 и 28 Устава МТР, предполагающие преимущественное положение трибуналов перед национальными юстициями, что прямо затрагивает суверенные права государств. Наконец, юридический нонсенс представляет ситуация, когда судьи трибуналов принимают правила процедуры и доказывания для досудебного этапа разбирательств, принятия доказательств, защиты потерпевших и свидетелей, создают процессуальное право собственной деятельности. См. Международное право / Под ред. А.А. Ковалева, С.В. Черниченко. М.: Омега - Л, 2006. С. 577.

2 Причиной «гуманитарных» интервенций и открытого военного вторжения может быть не деструктивная деятельность антигосударственных сил, направленная на ослабление и подрыв государственного суверенитета, а реализация узкокорпоративных интересов правящей группы. Так, военное положение может вводиться правящими силами для получения чрезвычайных властных полномочий, подавления оппозиции, 
требует существенных экономических и людских ресурсов, ведет к расширению конфликтного пространства и провоцирует дальнейшую напряженность. Кроме того, в отличие от иных механизмов ослабления и подрыва государственного суверенитета вооруженные конфликты детально регламентируются международным гуманитарным правом, которое устанавливает четкие ограничения на право выбора сторонами методов и средств войны ${ }^{1}$. Поэтому в современных условиях данный механизм официально применяется редко.

Одной из крупномасштабных войн, развязанных "Объединенной Европой" против России, стало нападение Наполеона на Российскую империю. Агрессивная политика Наполеона в отношении европейских государств, проводимая без учета интересов России, уверенность в продолжении серии военных успехов Франции, отказ России от континентальной блокады Великобритании, послужили причинами военного вторжения армии Французской империи в Россию. Стратегический расчет французского командования был связан с разгромом русской армии в генеральном сражении, подписанием мирного договора и завершением кампании в Смоленске и Минске. Однако в Отечественной войне 1812 г. русская армия не только отстояла суверенную государственность России, но и в ходе контрнаступления нанесла поражение французским войскам, а затем в ходе преследования довершила их разгром.

Из всех войн начала эпохи империализма наиболее значительной была первая мировая война. Борьба за колонии, столкновение торговоэкономических интересов "великих" держав (Германии и Великобритании,

ликвидации независимых СМИ, отмены предстоящих выборов главы государства и представительных органов власти с нежелательным результатом. «Победоносная» война или «гуманитарная» интервенция также могут быть инициированы правящим режимом в целях сплочения общества перед внешним врагом, хищнического захвата сырьевых ресурсов, дешевой рабочей силы и колонизации оккупированных районов.

Данный принцип впервые закреплен в Брюссельской конвенции 1874 г. и подтвержден в Протоколе I к Женевским конвенциям от 12 августа 1949 г. 
Германии и Франции, Германии и России, России и Австро-Венгрии) стали причинами первой мировой войны.

Война была наиболее выгодна американским империалистам, поскольку она привела к ослаблению всех европейских государств и тем самым способствовала стремлению правящих кругов США к мировому господству. Максимальные потери от войны понесли Германия, Россия, Франция и Австро-Венгрия (66,6\% всех потерь). На долю США пришлось всего 1,2 \% общих потерь. Американские монополии больше всего нажились на войне (прибыли за 1914-1918 гг. составили 3 млрд. долларов) и упрочили экономическое могущество Соединенных Штатов ${ }^{1}$.

После победы Октябрьской революции в России, как уже отмечалось, крупнейшие империалистические государства начали открытую дипломатическую, экономическую, а затем и вооруженную борьбу с Советской Республикой.

В годы становления Советской власти и Гражданской войны правящие круги Великобритании, США, Франции, Германии и Японии, рассчитывающие на расчленение России и ликвидацию советского политического режима, осуществили открытое военное вторжение на территорию России. В марте 1918 г. в Мурманске высадились английские и французские войска, в апреле - Владивосток захватили японские, английские, американские и французские воинские части. 2 августа англичане захватили Архангельск, а 4 августа - Баку.

Пользуясь тяжелым положением России, немцы весной и летом 1918 г. оккупировали Грузию, Крым, Новороссийск, Таганрог, Ростов, вторглись в Донскую область. Союзница Германии Турция захватила Армению. В декабре 1918 г. финские войска захватили ряд пограничных волостей в Советской Карелии.

${ }^{1}$ История военного искусства / Под ред. члена-корреспондента АН СССР генераллейтенанта П.А. Жилина. М.: Военное издательство, 1986. С. 61, 62. 
Открытые военные интервенции дополнялись всеми формами поддержки антигосударственных сил. При поддержке иностранных интервентов на территории бывшей Российской империи образовывались антисоветские "правительства". На оккупированных территориях формировались монархические и националистические организации и воинские подразделения, которые при содействии и помощи иностранного военного командования забрасывались в советский тыл и вели там подрывную работу, нападая на красноармейские части ${ }^{1}$.

В 1941 г. Германия на пути к завоеванию мирового господства осуществила вероломное нападение на Советский Союз.

Идеологически нападение нацистской Германии на Советский Союз обосновывалось концепцией «Lebensraum» («Жизненного пространства») немцев. В Приложении № 2 к Приказу командующего 4 танковой группой в связи с предстоящими боевыми действиями на Востоке отмечалось: «Война против России является важнейшей частью борьбы за существование немецкого народа. Это - давняя борьба германцев против славян, защита европейской культуры от московско-азиатского нашествия, отпор еврейскому большевизму. Эта борьба должна преследовать цель превратить в руины сегодняшнюю Россию, и поэтому она должна вестись с неслыханной жестокостью. Каждый бой должен быть организован и проводиться с железной волей, направленной на безжалостное и полное уничтожение противника»².

В соответствии с Директивой Верховного Главнокомандования Вооруженных Сил Германии от 18 декабря 1940 г. № 21 (План «Барбаросса») «германские вооруженные силы должны быть готовы разбить Советскую Россию в ходе кратковременной кампании еще до того, как будет закончена

${ }^{1}$ Голинков Д.Л. Крушение антисоветского подполья в СССР. Книга 1. М.: Изд-во полит. лит-ры, 1986. С. 103.

2 Преступные цели гитлеровской Германии в войне против Советского Союза. Сб. документов. С. 62. 
война против Англии... Основные силы русских сухопутных войск должны быть уничтожены в смелых операциях посредством глубокого, быстрого выдвижения танковых клиньев. Отступление боеспособных войск противника на широкие просторы русской территории должно быть предотвращено. Путем быстрого преследования должна быть достигнута линия, с которой русские военно-воздушные силы будут не в состоянии совершать налеты на имперскую территорию Германии. Конечной целью операции является создание заградительного барьера против Азиатской России по общей линии Волга - Архангельск ${ }^{1} \gg$.

В своих расчетах гитлеровское командование исходило из организации внезапного удара и стратегии тотальной и "молниеносной" войны, теория которой предусматривала достижение быстрой и полной победы над противником в одной кампании, чему должна содействовать внезапность нападения.

Руководители фашистской Германии разработали целую систему мероприятий по политическому, экономическому и идеологическому закабалению народов СССР, физическому истреблению значительной части советских людей, что нашло свое выражение в заблаговременно утвержденном высшими политическими и военными инстанциями Германии генеральном плане "Ост"2.

Наступление фашистских войск сопровождалось активной диверсионно-разведывательной и карательной деятельностью. На советскогерманском фронте были сосредоточены основные силы и средства мощного аппарата разведки, контрразведки и диверсионные подразделения фашистской Германии, такие, как: военная разведка и контрразведка (Abwehr); органы имперской безопасности (RSHA), основу которых

\footnotetext{
${ }^{1}$ См. Дашичев В.И. Банкротство стратегии германского фашизма. Т.2. С. 86-89.

2 История военного искусства / Под ред. члена-корреспондента АН СССР генераллейтенанта П.А. Жилина. М.: Военное издательство, 1986. С. 164.
} 
составляли полиция безопасности (Gestapo) и служба безопасности (SD); разведка министерства иностранных дел, иностранного отдела министерства пропаганды. На оккупированной советской территории оперативные группы гестапо и SD организовывали массовые облавы и проводили карательные акции против советских партизан ${ }^{1}$.

В 1960-х гг. в целях ликвидации зоны советского влияния на Кубе и подрыва суверенитета Кубинской Республики механизмы организованной вооруженной борьбы активно применялись Соединенными Штатами. Так, в апреле 1961 г. кубинские эмигранты при поддержке ЦРУ и МО США высадили вооруженный десант в заливе Свиней с целью спровоцировать массовое восстание против социалистического правительства Кубы (операция «Запата»). Однако вооруженная интервенция не нашла поддержки среди населения и была успешно пресечена Революционными вооруженными силами Кубы. В 1962 г. МО США спланировало очередное вооруженное вторжение на Остров Свободы и свержение правительства Фиделя Кастро (операция «Нортвудс»). Операция предполагала осуществление террористических актов на территории Кубы, США и других стран, имитацию враждебных действий под иностранным флагом, угоны самолетов $^{2}$. Только в 1986 г. американские историки официально признали, что операция США в 1961 г. являлась вооруженным вмешательством во внутренние дела иностранного государства и актом агрессии США против Кубы ${ }^{3}$.

Наиболее известной вооруженной интервенцией США стала военная кампания во Вьетнаме (1965 - 1973 гг.), развернутая с целью сдерживания коммунистического движения и поддержки проамериканского режима в Южном Вьетнаме. С 1965 по 1969 гг. ВС США проводили

${ }^{1}$ Органы государственной безопасности СССР в Великой Отечественной Войне. Начало. 22 июня - 31 августа 1941 г. / Сб. документов. М.: Академия ФСБ России: Русь, 2000. C. V.

${ }^{2}$ Сергеев Ф. Тайная война против Кубы. М.: Прогресс, 1982. С. 44, 101.

${ }^{3}$ Вопросы истории. 1987. № 7. С. 157-164. 
крупномасштабные наступательные операции в Южном Вьетнаме, направленные на обнаружение и уничтожение подразделений северовьетнамской армии. В ходе боевых действий ВВС США распыляли токсичные дефолианты над джунглями, что было признано одной из крупнейших акций военного экоцида. Активно применялись фугасные бомбы, напалм, фосфор и другие запрещенные виды вооружений. Происходило массовое уничтожение мирных жителей, хозяйственной инфраструктуры, практиковалось разрушение ирригационных сооружений, приведение сельхозугодий в негодность. Однако длительная военная кампания, не имеющая четких военно-политических целей, повлекшая значительные потери среди военнослужащих ВС США, вызвала массовое антивоенное движение в Соединенных Штатах, которое вынудило американское руководство в 1973 г. вывести свои войска из Вьетнама.

В настоящее время ключевая роль военной силы для решения политических задач Вашингтона закреплена в Стратегии национальной безопасности США 2015 г. и Стратегических указаниях по обороне 2012 г. Стратегия национальной безопасности США закрепляет "готовность применить военную силу в любой точке мира".

Приведенные примеры свидетельствуют об активном использовании в политическом противоборстве государств всего арсенала механизмов ослабления и подрыва суверенитета стран-противников. Вместе с тем, в современных условиях, учитывая информационную открытость общества, массовое распространение информационно-телекоммуникационных систем и средств связи, официальные механизмы открытого военного вторжения вытеснены "гуманитарными" интервенциями либо скрытым введением ограниченных воинских контингентов (парамилитарных структур иностранного государства) на территории оперативной заинтересованности.

Следует отметить, что в период существования СССР значительная часть описанных механизмов ослабления и подрыва государственного 
суверенитета иностранных государств, реализуемых США и их союзниками, компенсировалась СССР и странами социалистического лагеря. После распада Советского Союза экспансия США и глобальное доминирование единственной сверхдержавы приобрели неограниченный характер и повлекли крайне негативные последствия. Миропорядок утратил элементы стабильности и предсказуемости. Как и в Средневековье, в мировой политике и межгосударственных отношениях стало господствовать "право сильного".

Поскольку объективных причин и предпосылок для сворачивания политики глобального доминирования и односторонних силовых военнополитических акций Соединенных Штатов в краткосрочной и среднесрочной перспективе не просматривается, на фоне декларативных заявлений о готовности к диалогу, необходимости урегулирования разногласий дипломатическим путем следует ожидать наращивания давления Вашингтона на государства, стремящиеся проводить независимую внешнюю и внутреннюю политику, претендующие на роль центров формирующегося многополярного мира. Рассмотренные деструктивные механизмы будут задействоваться антигосударственными силами для проведения выгодного США политического курса, смены форм правления, политических режимов и форм государственного устройства государств - противников официального Вашингтона.

В связи с этим актуализируется задача формирования специализированного институционального механизма, подконтрольного обществу, способного противостоять долгосрочным угрозам ослабления и подрыва государственного суверенитета. 


\section{5. Механизмы защиты государственного суверенитета}

Противодействие деструктивным механизмам ослабления и подрыва государственного суверенитета нуждается в адекватных механизмах ЗГС.

Как представляется, понятие "механизм защиты государственного суверенитета" следует рассматривать в нескольких аспектах.

В организачионно-управленческом аспекте механизм ЗГС предполагает функционирующую в рамках определенных организационных форм систему элементов оценки обстановки, планирования, организации взаимодействия и контроля, при помощи которых гарантируется верховенство и независимость государственной власти, беспрепятственная реализация государственновластных полномочий в наиболее важных сферах общественной жизни, противодействие деструктивной деятельности антигосударственных сил по ослаблению и подрыву государственного суверенитета.

В правовом аспекте механизм ЗГС включает нормативное регулирование, правоприменение и юрисдикционную деятельность, направленные на обеспечение верховенства и независимости государственной власти, беспрепятственную реализацию государственновластных полномочий в наиболее важных сферах общественной жизни, противодействие деструктивной деятельности антигосударственных сил по ослаблению и подрыву государственного суверенитета.

В институциональном аспекте механизм ЗГС состоит из системы уполномоченных субъектов, с помощью которых обеспечивается верховенство и независимость государственной власти, беспрепятственная реализация государственно-властных полномочий в наиболее важных сферах общественной жизни, противодействие деструктивной деятельности антигосударственных сил по ослаблению и подрыву государственного суверенитета. 
В функиионально-технологическом аспекте механизм ЗГС подразумевает совокупность правовых, организационно-управленческих, информационно-пропагандистских, социально-экономических и силовых методов воздействия на антигосударственные силы и собственное население ${ }^{1}$.

В связи с изложенным, в работе в зависимости от контекста понятие "механизм защиты государственного суверенитета" используется и в единственном, и во множественном числе.

ЗГС начинается с оценки обстановки в сфере государственного управления и строительства, которая предполагает получение своевременной и объективной информации, необходимой для выработки эффективных мер государственного реагирования, на основании ряда показателей. Как отмечает Н.Б. Пастухова, "фиксация такой качественной характеристики трансформации государственной системы, как укрепление или ослабление централизации, способно показать, в какую сторону идет процесс - к укреплению суверенного государства или к его разрушению"2.

Показатели ослабления и подрыва государственного суверенитета являются общими для большинства механизмов ЗГС, поскольку они сигнализируют о тенденциях развития обстановки, подготовке и реализации тех или иных деструктивных механизмов ослабления и подрыва государственного суверенитета (или их взаимосвязанной совокупности) и позволяют компетентным государственным органам выбрать и использовать необходимые объекты, субъекты, формы и методы ЗГС.

1 В отличие от поощрительных (стимулирующих) методов воздействия на собственное население, применяемых государством для защиты своего суверенитета, методы воздействия на антигосударственные силы, как правило, носят пропорциональный негативный характер.

2 Пастухова Н.Б. Суверенитет и федеративная организация российского государства в условиях глобализации: конституционно-правовые аспекты. Дис. ... докт. юрид. наук. М.: РАГС при Президенте РФ, 2010. С. 79. 
Методика оценки степени устойчивости (ослабления или подрыва) государственного суверенитета может быть основана на трех группах показателей ${ }^{1}$ :

социально-экономических;

политических;

культурно-идеологических.

Анализ характерных признаков, свидетельствующих об ослаблении и подрыве государственного суверенитета, позволяет отнести к числу социально-экономических показателей следующие:

- высокий уровень массовой безработицы ${ }^{2}$;

- высокий уровень бедности ${ }^{3}$;

- высокий уровень роста потребительских цен;

- низкий индекс потребительской уверенности населения;

- низкая покупательная способность населения;

- непрерывная положительная динамика трудовой миграции населения (прежде всего, высококвалифицированных специалистов) за рубеж ${ }^{4}$;

- увеличение количества молодежи в возрасте от 16 до 28 лет ${ }^{5}$;

${ }^{1}$ Приложение 5.

2 Уровень безработицы в Тунисе накануне «жасминовой революции» 2010 г. достигал $30 \%$.

3 Для всех государств, в которых прошли «цветные революции» или были предприняты их попытки, характерен высокий уровень бедности. Так, в 2003 г. в Украине $26,6 \%$ населения проживало за чертой бедности, в 2008 г. в Армении - 23,5\%, в 2009 г. в Кыргызстане - 31,7 \%, в Египте в 2011 г. уровень бедности составил 25,2\% населения страны. См. Россия и страны мира. Электронная база данных Росстата gks.ru (дата обращения: 16 июля 2016 г.).

${ }^{4}$ Так, в преддверии «оранжевой революции» в Украине около 7 млн. украинцев находились на заработках за рубежом. Аналогичные миграционные процессы происходили в Грузии: население страны сократилось с 5,4 млн. чел. в 1989 г. до 3,09 млн. в 2003 г. Отрицательные коэффициенты миграционного прироста (на 1000 чел. населения) накануне «цветных революций» были характерны для Киргизии (-5,8 в 2009 г.) и Армении $(-1,9$ в 2007 г.). См. Россия и страны мира. Электронная база данных Росстата gks.ru (дата обращения: 16 июля 2016 г.)

5 Данный показатель присутствовал в Тунисе, Египте, Йемене и Кыргызстане, где основной движущей силой «цветных революций» выступила молодежь. Так, около 50\% египетских безработных входили в возрастную группу от 20 до 24 лет. Свыше 43\% египетских безработных имели высшее образование. О роли молодежи в смене политических режимов см. Бжезинский 3. Стратегический взгляд:Америка и глобальный кризис.М.: Астрель, 2012. С. 48-50. 
- уровень государственного внешнего и внутреннего долга (более 75\% от ВВП);

- закредитованность государства и зависимость предоставления финансовой помощи от выполнения требований международных финансовых институтов в сфере законодательства и проведения экономической политики;

- существенные объемы вывода капитала из страны;

- отрицательное сальдо внешнеторгового баланса ${ }^{1}$;

- одноукладный характер национальной экономики (гипертрофированное развитие сельского хозяйства, добывающих отраслей промышленности, деформированная товарная структура экспорта) $)^{2}$;

- устойчивый рост общеуголовной и коррупционной преступности;

- рост численности устойчивых ("хронических") очагов социальной напряженности со сложной криминогенной обстановкой и зон повышенной протестной активности, в которых затруднено нормальное функционирование органов власти и управления³

- прекращение (ограничение) таможенных и бюджетно-финансовых взаимоотношений между государством и его отдельными регионами, введение в этих территориальных образованиях иностранных денежных единиц в качестве платежного средства ${ }^{4}$;

${ }^{1}$ Для всех государств, в которых произошли «цветные революции» или их попытки с 2005 по 2013 гг. (Армения, Египет, Грузия, Кыргызстан, Молдова, Украина), было характерно отрицательное сальдо внешнеторгового баланса. См. Россия и страны мира. Электронная база данных Росстата gks.ru (дата обращения: 16 июля 2016 г.)

2 В Армении и Молдове, где в 2008 и 2009 гг. были предприняты попытки «цветных революций», значительный объем в товарной структуре экспорта занимала продукция пищевой и добывающей промышленности (в Армении - 34, 3\%, в Молдове $48,1 \%$ ), в Египте - минеральное топливо (44\%). См. Россия и страны мира. Электронная база данных Росстата gks.ru (дата обращения: 16 июля 2016 г.).

3 Данный показатель одновременно является и политической характеристикой ослабления и подрыва государственного суверенитета.

4 Так, Республика Черногория, входившая в состав Союзной Республики Югославия, до проведения референдума о независимости (2006 г.) ввела таможенную границу с Сербией и с 2000 г. перешла на немецкую марку. С 2002 г. официальной денежной единицей Черногории стал евро. 
- юридическое закрепление особого конституционно-правового или экономического статуса отдельных государственных территорий ${ }^{1}$.

В качестве политических показателей, свидетельствующих об ослаблении и подрыве государственного суверенитета, могут рассматриваться:

- замещение правовых норм, создаваемых государством, иными социальными регуляторами (религиозными нормами, обычаями, корпоративными нормами тех или иных кланов и доминирующих социальных групп);

- клановость системы государственного управления ${ }^{2}$;

- разработка и утверждение правовых актов органами власти третьих стран либо международными организациямиㅜㅜ

- ограничение юрисдикции и иммунитетов государства иностранными судами, органами власти и управления;

- приобретение жителями гражданства иностранного государства 4 ;

- создание и функционирование на территории страны альтернативных государственным органам властных структур ${ }^{5}$;

- легальное зарубежное финансирование деятельности органов внешних сношений, разведки, контрразведки, полиции, отдельных спецподразделений Вооруженных Сил государства ${ }^{1}$;

1 Данный показатель одновременно является и политической характеристикой ослабления и подрыва государственного суверенитета.

2 Данный показатель ослабления государственного суверенитета в совокупности с длительным безальтернативным нахождением у власти одного главы государства был характерен для политической обстановки в Египте, Йемене, Кыргызстане, Грузии и Украине накануне «цветных» революций.

${ }^{3}$ Примером может служить Конституция Боснии и Герцеговины, разработанная как приложение к Дейтонскому соглашению.

4 Примерами могут служить приобретение большинством населения Абхазии российского гражданства, а Молдовы - румынского.

5 Один из идеологов «цветных революций» Джин Шарп считал формирование системы «двойного суверенитета» (создание альтернативных социально-экономических, общественно-политических и параллельных властных структур) эффективным методом ослабления и подрыва государственного суверенитета. Позднее данный метод использовался во всех «цветных революциях», а также в ходе тайной и официальной поддержки антигосударственных сил. Д. Шарn. От диктатуры к демократии. http: //www.aeinstein.org/wp-content/ uploads/ 2013/10/FDTD 
- финансирование и официальная реализация зарубежных программ стажировок и повышения квалификации депутатов, госслужащих, муниципальных служащих, сотрудников правоохранительных органов, связанное с этим процессом формирование иностранного лобби в органах власти, управления, правоохранительных структурах, СМИ, отраслях экономики, имеющих стратегическое значение для обороны и безопасности государства ${ }^{2}$;

- количество и уровень активности международных и иностранных некоммерческих неправительственных организаций, участвующих в политической деятельности либо влияющих на ее осуществление ${ }^{3}$;

- ограничение монополии государства на применение насилия при наличии законных оснований под воздействием международных организаций, иностранных государств, оппозиционных партий и движений; - создание и деятельность незаконных вооруженных формирований ${ }^{4}$; - негативная динамика межнациональных и межконфессиональных конфликтов, сепаратистских проявлений, а также фактов нарушения территориальной целостности государства ${ }^{5}$;

1 Данный показатель ослабления государственного суверенитета был характерен для Грузии и Украины.

2 Данный показатель характерен для таких механизмов ослабления и подрыва государственного суверенитета, как тайная и официальная поддержка антигосударственных сил и «цветные революции».

3 Так, в преддверии «евромайдана» на территории Украины функционировали свыше 1800 иностранных некоммерческих неправительственных организаций общественно-политической направленности. Развертывание значительного числа международных и иностранных некоммерческих организаций характерно и для тайной и официальной поддержки антигосударственных сил как механизма ослабления и подрыва государственного суверенитета.

4 В 2004 г. для охраны палаточных лагерей и участия в массовых беспорядках в ходе «оранжевой революции» оппозицией были сформированы незаконные вооруженные структуры (организация «Народная самооборона»). В 2013 г. в ходе «евромайдана» для защиты оппозиции и силовой поддержки антиконституционных действий по смене государственной власти были созданы «сотни» Самообороны Майдана. Наряду с отрядами Самообороны для участия в насильственных акциях привлекались радикальные националистические структуры («Правый сектор»).

5 Для Грузии, Сербии и Украины до фактического распада государств было характерно существование слабо контролируемых официальными властями независимых государственных образований (Абхазия и Южная Осетия, провинция Косово-Метохия и Автономная Республика Крым соответственно). 
- деятельность международных вооруженных радикальных группировок и иностранных частных военных компаний в отдельных регионах государства ${ }^{1}$;

- деятельность органов принуждения иностранных государств в отдельных регионах государства";

- уровень ежегодного обновления вооружения, военной и специальной техники, обеспеченности военными кадрами;

- осуществление на государственной территории силовых операций ("гуманитарной интервенции") иностранных воинских контингентов (специальных служб) без мандата ООН и согласия государства ${ }^{3}$.

Культурно-идеологические показатели ослабления и подрыва государственного суверенитета представлены:

- масштабами распространения различных антигосударственных идеологий;

- охватом населения образованием;

- низким уровнем обеспеченности ресурсами культуры, образования и науки в процентном отношении к ВВП ${ }^{4}$;

- разработкой, финансированием и контролем образовательных программ иностранными государствами и неправительственными организациями ${ }^{5}$;

${ }^{1}$ В период «евромайдана» в Украине на стороне оппозиции помимо незаконных вооруженных формирований действовали частные военные компании США и Польши. Данные структуры были задействованы в ходе вооруженных провокаций и столкновений с военнослужащими и сотрудниками правоохранительных органов Украины, выполнявших функции по защите Конституции и охране правопорядка. Позднее иностранные частные военные компании были переброшены на Донбасс для участия в карательной операции.

2 Показательным примером может служить создание тайных тюрем ЦРУ США в ряде государств Восточной Европы.

3 Данный показатель был характерен для Сербии («гуманитарные бомбардировки» Сербии и размещение контингента НАТО в Косово в 1999 г.)

4 Речь идет об «остаточном» финансировании культурно-образовательных учреждений и научных организаций, особенно на региональном и муниципальном уровнях

5 После распада СССР в бывших союзных республиках началась активная деятельность фонда Сороса, Фридриха Наумана, Британского совета, Германской службы академических обменов и др. зарубежных структур, которые занимались «развитием» 
- отсутствием регулярных программ государственного патриотического воспитания;

- массовым тиражированием и масштабами распространения космополитических установок, идей об отсутствии национальных достижений, необходимости копирования западных ценностей.

Уполномоченные государственные структуры обязаны своевременно обнаруживать, анализировать и документировать эти показатели (индикаторы), выявлять подготовку конкретных антигосударственных сценариев и принимать адекватные меры реагирования: ослаблять воздействие или нейтрализовывать угрозообразующие факторы, инициировать ответные механизмы подрыва или ослабления государственного суверенитета.

Перечисленные показатели в диалектическом единстве являются обобщающей характеристикой степени устойчивости и защищенности государственного суверенитета, с одной стороны, и его ослабления и подрыва, с другой. Показатели как категория «целое» основаны на признаках, без системы которых нельзя судить и о показателях ${ }^{1}$. Чем больше обнаружено признаков подготовки и реализации определенных механизмов ослабления и подрыва государственного суверенитета в различных сферах, тем рельефней показатели и уязвимей система общественных отношений, подлежащих защите.

Для вскрытия деструктивных механизмов ослабления и подрыва государственного суверенитета наиболее удобным является анализ демаскирующих признаков подготовки и реализации конкретных антигосударственных механизмов.

гуманитарного образования, изданием учебников, грантовой поддержкой молодых преподавателей и ученых, академическими обменами. Данные неправительственные организации занимались подбором и изучением талантливой молодежи, внедрением в сознание перспективной аудитории культурных и нравственных ценностей Запада, привлекательности его идеологической системы, экономических и политических институтов.

1 В отличие от показателей, признакам присущи индивидуальные свойства. 
Применительно к механизму экономических санкций, блокад, эмбарго, демпинга демаскирующими признаками подготовки и реализации деструктивной деятельности могут выступать:

программные заявления должностных лиц, выступления с угрозами принятия специальных экономических мер в отношении того или иного иностранного государства, иностранных организаций или граждан в МИД, Парламенте, на международных форумах;

публикации должностных лиц в СМИ с обоснованием целесообразности принятия специальных экономических мер и подготовки соответствующих правовых актов Правительства или Главы государства (союза государств), планирующих введение экономических санкций;

экстренные заседания и внеочередные совещания в МИД, аппаратах Главы государства, Правительства, Парламента, связанные с выработкой санкционной политики в отношении «недружественного» государства;

утечки информации о подготовке санкционных списков физических и юридических лиц, проектов правовых актов в профильных министерствах и ведомствах, аппаратах Главы государства и Правительства;

консультации Глав государства и Правительства с лидерами государств - союзников, руководителями международных экономических, торговых и финансовых организаций, представителями государственных монополий и крупного национального бизнеса о характере экономических санкций, конкретных мерах, сроках, основаниях изменения и отмены;

проработка вопросов о формировании специализированных органов (комитетов, комиссий и др.) для наложения, изменения и отмены санкций, контроля за их исполнением;

дипломатическое признание и поддержка заинтересованными иностранными государствами (союзом иностранных государств) и 
международными организациями введения экономических санкций, блокад, эмбарго ${ }^{1}$.

Признаками подготовки и реализации механизма «ц̧ветных револющчий» выступают:

активизация деятельности международных и иностранных некоммерческих неправительственных организаций, участвующих в политической деятельности либо влияющих на ее осуществление;

визиты зарубежных высококвалифицированных специалистов по «ненасильственным» политическим технологиям и смене политических режимов, а также курирующих антигосударственные проекты сотрудников иностранных спецслужб для встреч с лидерами ведущих оппозиционных организаций, национально ориентированных и молодежных структур, журналистами оппозиционных СМИ;

выступления общественных деятелей, оправдывающие необходимость обострения противоречий и конфликтов;

массовое тиражирование идей о необходимости копирования зарубежного опыта, «демократических» ценностей, интеграции с «цивилизованным» миром и т.п.;

появление экстремистских и иных антиконституционных положений в программах общественно-политических движений и объединений, призывов к свержению легитимных органов власти и противодействию правоохранительным органам;

активизация пропагандистской работы представителей националистических, сепаратистских и иных экстремистских организаций в государственных и образовательных учреждениях, местах массового

1 Указанные автором признаки подготовки и реализации деструктивной деятельности применительно к данному и другим механизмам ослабления и подрыва государственного суверенитета не являются исчерпывающими. Их перечень зависит от множества факторов. 
скопления граждан и осуществление ими подстрекательства к участию в публичных антиконституционных и экстремистских акциях;

обучение (идеологическое, боевое, диверсионное) и экипировка участников протестных акций, активизация организаторов массовых беспорядков;

сбор сведений о состоянии охраны оружия и боеприпасов, готовности органов власти и правоохранительных структур к пресечению массовых беспорядков и иных антиобщественных акций;

трансформация санкционированных митингов в массовые беспорядки;

вмешательство в работу избирательных комиссий и других государственных органов;

организация суточных дежурств оппозиционеров, формирование палаточных лагерей и обустройство баррикад;

инициирование захватов военных арсеналов, зданий органов государственной власти и управления;

создание незаконных вооруженных формирований и развертывание деятельности на территории государства иностранных частных военных компаний;

выступления руководителей заинтересованных иностранных государств и лидеров международных организаций о необходимости ограничения законной монополии государства на применение насилия для пресечения антиконституционных и иных экстремистских действий;

возникновение устойчивых зон повышенной протестной активности, в которых затруднено нормальное функционирование органов власти и управления;

формирование на территории страны альтернативных государственным органам властных структур;

выдвижение требований к законным властям о добровольной отставке и немедленной передаче власти лидерам оппозиции; 
дипломатическое признание заинтересованными иностранными государствами (союзом иностранных государств) и международными организациями легитимности антиконституционных действий и антиобщественных акций организаторов и участников «цветных революций».

Признаками механизма тайной политической, информационной, материально-технической и финансовой поддержки антигосударственньх сил являются:

активизация деятельности международных и иностранных некоммерческих неправительственных организаций, участвующих в политической деятельности либо влияющих на ее осуществление;

тайные визиты зарубежных высококвалифицированных специалистов по массовым акциям протеста и неповиновения правоохранительным органам, а также курирующих антигосударственные проекты, действующих под прикрытием сотрудников иностранных спецслужб для встреч с лидерами ведущих оппозиционных организаций, национально ориентированных и молодежных структур, журналистами оппозиционных СМИ;

появление массовых информационных материалов (в т.ч. фейковых), дискредитирующих органы власти и должностных лиц, дестабилизирующих социально-политическую обстановку в стране и отдельных регионах;

прибытие эмиссаров зарубежных структур экстремистского, националистического и сепаратистского толка для оказания методической, практической и иной помощи представителям антигосударственных сил;

инспирирование межнациональных и межконфессиональных конфликтов, сепаратистских проявлений, нарушения территориальной целостности государства;

выступления общественных деятелей, оправдывающие необходимость обострения противоречий и конфликтов; 
массовое тиражирование идей о необходимости копирования зарубежного опыта, «демократических» ценностей, интеграции с «цивилизованным» миром и т.п.;

активизация пропагандистской работы представителей националистических, сепаратистских и иных экстремистских организаций в государственных и образовательных учреждениях, местах массового скопления граждан и осуществление ими подстрекательства к участию в публичных антиконституционных и экстремистских акциях;

активизация организаторов массовых беспорядков;

формирование палаточных лагерей и обустройство баррикад;

создание незаконных вооруженных формирований и развертывание деятельности на территории государства иностранных частных военных компаний;

тайная переброска вооружений, экипировки и военной техники представителям антигосударственных сил, диверсионная, боевая и иная подготовка активистов незаконных вооруженных формирований;

блокирование органов государственной власти и управления;

возникновение устойчивых зон повышенной протестной активности, в которых затруднено нормальное функционирование органов власти и управления;

выдвижение требований к законным властям о добровольной отставке и немедленной передаче власти лидерам оппозиции.

К признакам, которые могут свидетельствовать о подготовке и осуществлении механизма «гуманитарной» интервенции, относятся:

широкомасштабное распространение сообщений зарубежных правозащитных групп, мониторинговых миссий и представителей международных организаций («врачи без границ» и др.) о грубых и массовых нарушениях прав человека в государстве или отдельных регионах страны; 
выступления, публикации, заявления общественных деятелей и представителей оппозиции с обвинениями органов власти в систематических нарушениях прав человека и необходимости вмешательства международного сообщества;

заявления и высказывания иностранных органов внешних сношений (Государственный департамент, МИД) с критикой законных властей государства и обоснованием возможности «гуманитарной» интервенции для защиты прав человека;

активизация пропагандистской работы по созданию враждебного образа определенного государства - «грубого нарушителя прав человека», его «антидемократического руководства» и «антинародных органов власти» среди населения и личного состава вооруженных формирований государства (коалиции иностранных государств), осуществляющих «гуманитарную» интервенцию;

пропагандистская обработка населения и личного состава вооруженных формирований, правоохранительных и иных органов государства, выступающего объектом «гуманитарной» интервенции;

формирование коалиционных вооруженных сил из различных родов войск для осуществления «гуманитарной» интервенции;

наращивание интенсивности оперативно-боевой подготовки вооруженных формирований государства - агрессора (коалиции иностранных государств) при отсутствии явного противника;

перевод вооруженных формирований государства - агрессора (коалиции иностранных государств) на усиленный режим службы или отмена отпусков военнослужащих;

введение в штаты воинских подразделений государства - агрессора (коалиции иностранных государств) переводчиков с определенным иностранным языком; 
проведение государством - агрессором (коалицией иностранных государств или военно-политическим блоком) крупномасштабных маневров и длительных учений в приграничных районах государства, выступающего объектом «гуманитарной» интервенции;

концентрация в приграничных районах соединений всех родов войск государства - агрессора (коалиции иностранных государств);

дезинформирование с целью скрытного сосредоточения и переброски войск государства - агрессора (коалиции иностранных государств);

переброска диверсионно-разведывательных и агентурно-боевых групп на территорию государства, выступающего объектом «гуманитарной» интервенции;

концентрация беспилотных летательных аппаратов государстваагрессора в приграничных районах;

усиление орбитальной группировки государства - агрессора (коалиции) для наблюдения за территорией государства, выступающего объектом «гуманитарной» интервенции;

заявления официальных лиц государства - агрессора (коалиции) с обоснованием возможности и необходимости «гуманитарных» интервенций;

формирование международной поддержки (легитимация) агрессивных действий либо международной изоляции правящего режима государства, выступающего объектом «гуманитарной» интервенции;

«гуманитарные» бомбардировки и ракетные удары по отдельным объектам стран-союзников и (или) государства;

ввод ограниченных контингентов Вооруженных Сил государства агрессора (коалиции иностранных государств) в отдельные районы государства, выступающего объектом «гуманитарной» интервенции, с последующим наращиванием группировки в зоне оперативной заинтересованности; 
создание военных баз и размещение объектов военной инфраструктуры государства - агрессора (коалиции иностранных государств) на территории государства, выступающего объектом «гуманитарной» интервенции, без мандата ООН и (или) согласия государства;

дипломатическое признание заинтересованными иностранными государствами (коалицией иностранных государств или военнополитическим блоком) и международными организациями «гуманитарной» интервенции.

Применительно к механизму открытого военного вторжения демаскирующими признаками служат:

активизация пропагандистской работы по созданию враждебного образа определенного государства, его руководства и органов власти среди населения и личного состава вооруженных формирований государства агрессора (коалиции государств);

пропагандистская обработка населения и личного состава вооруженных формирований, правоохранительных и иных государственных органов государства, выступающего объектом агрессии;

наращивание интенсивности оперативно-боевой подготовки вооруженных формирований государства - агрессора (коалиции иностранных государств);

дезинформирование с целью скрытного сосредоточения и переброски войск государства - агрессора (коалиции иностранных государств);

развертывание крупномасштабных и долгосрочных учений в приграничных районах государства, выступающего объектом агрессии;

совершенствование структуры и переоснащение воинских соединений государства - агрессора (коалиции иностранных государств);

формирование коалиционных сил для проведения военной операции против государства, выступающего объектом агрессии; 
совершенствование транспортной инфраструктуры, примыкающей к границе государства, выступающего объектом агрессии (оборудование аэродромов, ремонт железнодорожных и автомобильных мостов, доставка переправочных средств и др.);

введение уплотненного графика движения железнодорожных эшелонов;

создание государством - агрессором (коалицией) запасов горючесмазочных материалов;

усиление орбитальной группировки государства-агрессора (коалиции) для наблюдения за территорией государства;

концентрация беспилотных летательных аппаратов государстваагрессора в приграничных районах;

активизация добывания государством - агрессором (коалицией) разведывательной информации с легальных и нелегальных позиций;

пограничные инциденты и провокации парамилитарных структур государства - агрессора (коалиции);

экстренные заседания координационных и совещательных органов государства - агрессора (коалиции иностранных государств) по вопросам обороны и безопасности;

заявления официальных лиц государства (коалиции иностранных государств), содержащие обоснование агрессивных действий;

формирование международной поддержки (легитимация) агрессивных действий либо международной изоляции правящего режима государства, выступающего объектом агрессии.

Владение реальной обстановкой, своевременное и объективное информирование руководства высших органов власти о признаках подготовки и инициирования антигосударственных сценариев способствует своевременному выявлению (обнаружению и вскрытию) и предупреждению деструктивной деятельности (конкретных механизмов ослабления и подрыва 
государственного суверенитета). Это позволяет специализированным государственным органам перегруппировать силы и средства, продумать необходимые мероприятия для задействования адекватных форм и методов защиты на стадии самых ранних проявлений применения механизмов ослабления и подрыва государственного суверенитета.

В любых условиях ЗГС должна носить плановый характер и осуществляться на основе выделенных объектов, вскрытых угроз и показателей (индикаторов) ослабления и подрыва государственного суверенитета, что предполагает разработку перспективных (стратегических), проблемно-целевых и текущих (тактических) планов ЗГС с конкретными целями и задачами, а также комплексом взаимосвязанных мероприятий уполномоченных субъектов, соответствующих выявленным угрозам.

Перспективные (стратегические) планы разрабатываются для решения стратегических задач на длительные сроки ${ }^{1}$.

Проблемно-целевое планирование направлено на решение отдельных сложных проблем или групп взаимосвязанных проблем (например, противодействие реализации антигосударственными силами механизмов "цветных революций" в условиях выборов).

Текущие (тактические) планы разрабатываются для решения тактических задач ЗГС. Примером может служить решение задачи противодействия перерастания отдельных протестных акций в массовые беспорядки.

Немаловажную роль в функционировании любых механизмов ЗГС играет организация взаимодействия и контроля деятельности уполномоченных субъектов.

1 Стратегическими задачами по ЗГС могут являться: противодействие дискредитации государства, организации недружественных коалиций и международной изоляции; обеспечение конкурентоспособности передовых отраслей национальной экономики и др. 
Для повышения уровня взаимодействия между различными субъектами, усиления слаженности совместной работы целесообразно совместное планирование и функционирование оперативных штабов для решения сложных проблем или их взаимосвязанных групп.

Контроль деятельности уполномоченных субъектов ЗГС имеет многоцелевой характер. Он осуществляется для:

- определения своевременности и целесообразности принятия того или иного решения по защите верховенства и независимости государственной власти;

- прогнозирования результатов и последствий принимаемых решений;

- обеспечения исполнения принятых решений, оценки их реализации;

- своевременного выявления факторов, препятствующих решению поставленных задач по ЗГС;

- внесения необходимых коррективов в деятельность субъектов защиты государственного суверенитета.

Другими словами, эффективный контроль за деятельностью субъектов ЗГС предполагает проверку и настройку работы механизмов, компенсирующих деструктивную антигосударственную деятельность, определение реального положения дел и выработку предложений по повышению эффективности ЗГС.

Обобщение исторического опыта обеспечения верховенства и независимости государственной власти, беспрепятственной реализации государственно-властных полномочий в наиболее важных сферах общественной жизни свидетельствует о том, что большинством государств длительное время создавались и использовались два типовых механизма ЗГС: административно-командный (репрессивный) и либеральный.

Административно-командный (репрессивный) механизм предполагает опору на поддержку армии и развитый аппарат специальных служб, управляемых судов и пенитенциарной системы; использование 
пропагандистской машины для формирования общественного мнения под контролем и в интересах правящих сил, камуфлирования угрозообразующих факторов и проблем общественного развития; легальное ограничение (запрет) оппозиционной деятельности; запрет иностранного вмешательства в политическую жизнь и ограничения на иностранные инвестиции в стратегические и иные отрасли национального сектора экономики; применение принудительных и карательных методов воздействия (главным образом, несудебных респрессий) в отношении политических оппонентов.

Либеральный механизм ЗГС характеризуется опорой органов власти на поддержку институтов гражданского общества; слабым влиянием армии и спецслужб на политическую жизнь в стране; зависимостью политического влияния и результатов электоральной борьбы партийных и региональных лидеров от размера их состояния и финансовой базы организаций-спонсоров; осуществлением оппозиционной деятельности при соблюдении минимальных формально-юридических ограничений; свободой распространения любой, в том числе экстремистской информации; минимальным ограничением иностранного вмешательства в политическую и экономическую жизнь общества; использованием убеждения в качестве превалирующего метода воздействия на политических оппонентов и противника.

Необходимо отметить, что динамика современного общественнополитического развития, сложившаяся расстановка сил на международной арене, обострение экономического и военно-политического противоборства между государствами вызвали необходимость государственного регулирования экономических процессов и вмешательства в информационную и идеологическую сферы жизни общества. Поэтому в настоящее время в ведущих западных странах получил распространение т.н. смешанный механизм ЗГС. 
Такой механизм сочетает опору правящих сил на силовой блок (армия и спецслужбы), судебную систему и общественный сектор; СМИ не навязывают те или иные взгляды, однако, несмотря на отсутствие цензуры, искусно манипулируют общественным мнением; оппозиционная деятельность гарантируется государством, но лидеры и активисты оппозиции действуют в правовых рамках и контролируемых государством условиях; иностранное вмешательство в политику запрещено, но экономические связи и зарубежные инвестиции поощряются; основным методом воздействия на оппонентов является т.н. "мягкая" сила (Soft Power) ${ }^{1}$.

Исследователи подчеркивают, что в смешанном механизме ЗГС институты гражданского общества и элементы государственного аппарата осуществляют взаимный контроль. По мнению В.В. Гончарова и С.Ю. Пояркова, "проблема организации и осуществления взаимного контроля гражданского общества и государственного механизма обусловлена необходимостью, с одной стороны, ограничить произвол государственных чиновников и подчинить их деятельность исключительно закону, а с другой стороны, поставить деятельность институтов гражданского общества под пристальный контроль органов власти с целью недопущения проникновения в институты гражданского общества агентов иностранного влияния с целью подрыва государственного суверенитета, независимости государственной власти, насильственной смены политического режима, подрыва обороноспособности, экономической мощи государства в интересах иных государств, межгосударственных и международных организаций"2.

1 Концепция использования «мягкой» силы была разработана американским политологом Джозефом С. Наем. По его мнению, «мягкая» сила позволяет добиваться желаемых результатов на основе привлекательности. При задействовании «жесткой» силы превалирует экономическое и военное давление. Nye. J. Soft Power. The means to success in World Politics. New York: Public Affairs, 2004. P.10

2 Гончаров В.В., Поярков С.Ю. Взаимодействие государства и гражданского общества в контексте конституционализма: теоретико-методологические проблемы и пути их разрешения // Современное право. 2015. № 5. С. 23. 
Как уже отмечалось, в структуру механизмов ЗГС также входят объекты, субъекты, формы и методы ЗГС ${ }^{1}$.

Основными объектами ЗГС выступают: обороноспособность государства; безопасность, легитимность и бесперебойное функционирование (в том числе путем выборов) органов власти и управления; независимость и легитимность партийных и общественнополитических структур; независимость СМИ и интегративный, национальноориентированный характер информационного и культурно-идеологического поля; устойчивость кредитно-финансовых институтов; технологическая независимость и конкурентоспособность передовых отраслей национальной экономики ${ }^{2}$.

Представляется, что эффективный механизм ЗГС предполагает защиту всех перечисленных объектов.

К субъектам ЗГС следует отнести: главу государства, органы законодательной, исполнительной и судебной власти.

Институты гражданского общества (органы местного самоуправления, политические партии, СМИ, общественные объединения) могут рассматриваться как структуры, оказывающие содействие государственным органам в решении задач ЗГС.

Глава государства определяет основные направления внутренней и внешней политики по ЗГС во всех сферах общественной жизни; осуществляет общее руководство спецслужбами и органами безопасности; обладает правом законодательной инициативы по регламентации общественных отношений, связанных с ЗГС. При главе государства, как правило, функционирует консультативный орган - Совет обороны (безопасности), который проводит работу по оценке угроз государственному

\footnotetext{
${ }^{1}$ Приложение 1.

2 Перечень объектов защиты не является исчерпывающим.
} 
суверенитету, готовит рекомендации и решения главы государства по вопросам ЗГС.

Органы законодательной власти формируют законодательную базу ЗГС; принимают государственный бюджет, предусматривающий специальные статьи расходов на ЗГС; ратифицируют (денонсируют) международные соглашения, в том числе по вопросам ЗГС; осуществляют парламентский контроль за деятельностью субъектов ЗГС.

Органы исполнительной власти организуют реализацию государственной политики по ЗГС; разрабатывают и исполняют бюджет для осуществления конкретных целевых программ ЗГС; управляют стратегическими отраслями государственного сектора экономики; исполняют законы и решения главы государства по ЗГС; привлекают структуры гражданского общества к оказанию содействия в решении проблем ЗГС.

В системе исполнительной власти заметную роль в ЗГС играют Вооруженные силы, полиция и органы безопасности.

Важнейшими задачами Вооруженных сил являются сдерживание в интересах предотвращения военной агрессии, миротворческая деятельность и обеспечение исключительных правовых режимов.

Полиция обеспечивает правопорядок и общественную безопасность, выявляет, предотвращает и пресекает массовые антиконституционные посягательства на государственный суверенитет, расследует преступления экстремистской направленности.

Органы безопасности в мирное и военное время осуществляют:

- выявление, предупреждение и пресечение угроз государственному суверенитету;

- вскрытие устремлений, сковывание и парализацию деятельности антигосударственных сил, в первую очередь, иностранных спецслужб;

- гласное и негласное противодействие механизмам ослабления и подрыва государственного суверенитета. 
Органы судебной власти занимаются судопроизводством по гражданским, уголовным, административным и конституционным делам, затрагивающим правоотношения в сфере 3ГС; обобщают судебную практику в целях единообразного применения законодательства по вопросам ЗГС; осуществляют судебный контроль за деятельностью субъектов ЗГС.

Всеобъемлющая и полноценная ЗГС возможна лишь при активном сотрудничестве государственных органов с институтами гражданского общества, которые имеют широкий арсенал инструментов воздействия на общественное сознание и в ряде случаев могут действовать даже более эффективно, чем государственные структуры. Невозможно защитить суверенитет государства, опираясь только на государственные структуры и силовые методы. Необходимо совместно с общественными структурами своевременно выявлять, оценивать, предупреждать и устранять угрозы государственному суверенитету, оказывать адекватное воздействие на их носителей, привлекать резервы общественных организаций к устранению причин и условий, способствующих подрыву и ослаблению государственного суверенитета. Значительным потенциалом обладает участие представителей институтов гражданского общества в проведении научных исследований, подготовке аналитических и справочных материалов по изучению зарубежного опыта ЗГС (в частности, реагирования органов власти на террористические и экстремистские проявления, межнациональные и межконфессиональные противоречия).

Таким образом, в качестве основных задач уполномоченных субъектов ЗГС следует выделить:

- профилактику, выявление и нейтрализацию угроз государственному суверенитету;

- пресечение, сковывание и парализацию деятельности внутригосударственных и зарубежных антигосударственных сил; 
- выявление и противодействие конкретным деструктивным механизмам ослабления и подрыва государственного суверенитета;

- формирование, обеспечение функционирования и развитие адекватных возникающим угрозам механизмов ЗГС;

- реализацию внутренней и внешней политики по ЗГС во всех сферах общественной жизни.

Успешное решение этих задач позволяет обеспечивать функциональность, легитимность и политическую независимость правящих политических режимов, удовлетворять реальные потребности граждан и гарантировать поддержку общественности.

В зависимости от интенсивности воздействия на угрозы государственного суверенитета и содержания применяемых государством мер можно различать пассивную и активную формы ЗГС.

В рамках тех или иных форм ЗГС используются соответствующие методы защиты, которые дифференцируются применительно к используемым антигосударственным силам механизмам ослабления и подрыва государственного суверенитета. Данные методы могут быть сведены к нескольким основным группам: правовые, организационноуправленческие, информационно-пропагандистские, социальноэкономические и силовые.

Упомянутые методы ЗГС нормативно закреплены в законодательных и подзаконных актах, подробный анализ которых проведен в главе 3 монографии ${ }^{1}$.

${ }^{1}$ Автор полагает необходимым сделать следующее методологическое допущение. В качестве мер по тексту работы будет пониматься совокупность действий, нацеленных на решение задач определенного класса. Методы выступают основаниями этих действий. В то же время, учитывая терминологическую неупорядоченность использования понятий в нормативных правовых и политико-правовых актах стратегического планирования (Концепции, Доктрины, Стратегии и т.п.) в методологическом поле решения задач защиты государственного суверенитета упоминаемые в текстах политических и правовых документов меры и методы, исходя из контекста будут рассматриваться как синонимы и использоваться единообразно в формате конструкции «методы». 
Государствовед А.Б. Венгеров справедливо указывал, что "установление оптимального соотношения методов воздействия на общественные отношения для обеспечения наибольшей эффективности государственной деятельности представляет собой сложную научную и практическую задачу"1. В рамках проводимого исследования вопрос о методах будет рассмотрен применительно к используемым антигосударственным силам механизмам ослабления и подрыва государственного суверенитета.

При форматировании необходимых механизмов ЗГС важно иметь в виду, что любой из механизмов ослабления и подрыва государственного суверенитета реализуется в рамках нескольких этапов: подготовки, непосредственного осуществления и закрепления результатов.

Этап подготовки предполагает планирование, финансирование, кадровое обеспечение, обучение, вооружение и экипировку, переброску (сосредоточение) антигосударственных сил, подготовку общественного мнения и маскировку подготовительных действий по ослаблению и подрыву государственного суверенитета.

Этап непосредственного осуществления охватывает: принятие политических деклараций и правовых актов, инициирование захватов органов власти, массовые беспорядки, задействование диверсионноразведывательных формирований и частных военных компаний, ввод войск, блокады, бомбардировки, информационное сопровождение и дипломатическое признание заинтересованными иностранными государствами акций ослабления и подрыва государственного суверенитета.

На этапе закрепления результатов осуществляются: смена политического руководства, изменения конституции и текущего законодательства, реорганизация органов власти, спецслужб,

\footnotetext{
${ }^{1}$ Венгеров А.Б. Теория государства и права. М.: Омега-Л, 2014. С. 279.
} 
правоохранительных органов и Вооруженных сил, заключение (приостановка или денонсация) международных соглашений, присоединение (выход) из военно-политических и иных союзов, создание военных баз и размещение объектов военной инфраструктуры заинтересованных зарубежных стран на территории государства.

Указанные в работе формы и методы ЗГС могут применяться как параллельно прохождению тех или иных этапов реализации механизмов ослабления и подрыва государственного суверенитета, так и асимметрично (предупреждая последовательное негативное развитие механизмов ослабления и подрыва суверенитета, купируя их на ранних этапах, сковывая и парализуя деятельность антигосударственных сил). При этом подготовка и реализация механизмов ЗГС осуществляются с некоторыми закономерностями, к числу которых следует отнести:

влияние целей и характера антигосударственных сил на стратегию и тактику действий субъектов ЗГС, выбор форм и методов ЗГС;

зависимость форм и методов ЗГС от возможностей субъектов ЗГС и условий обстановки ${ }^{1}$;

массированное и комплексное применение возможностей субъектов ЗГС на определенных этапах и в конкретных зонах ослабления и подрыва государственного суверенитета;

четкое взаимодействие и исключение параллелизма в деятельности субъектов ЗГС и др.

Рассмотрим взаимодействующие механизмы ослабления - подрыва и ЗГС в ракурсе адекватных им форм и методов защиты.

1 Так, определенные формы и методы ЗГС могут использоваться только в особых условиях обстановки (например, при введении чрезвычайного или военного положения или объявлении контртеррористической операции). 
Для противодействия экономическим санкциям, блокадам, эмбарго и демпингу в рамках пассивной формы защиты суверенитета могут применяться такие методы, как:

квотирование аудиторской, консультационной и других видов деятельности иностранных юридических и физических лиц ${ }^{1}$;

квотирование или запрет на приватизацию государственных предприятий иностранными физическими и юридическими лицами;

установление квот на выдачу иностранным гражданам приглашений на въезд в целях осуществления трудовой деятельности루

установление квот на выдачу иностранцам разрешений на работу;

установление допустимой доли иностранных работников в различных отраслях экономики ${ }^{3}$;

отказ в выдаче и аннулирование иностранцам разрешений на работу현

гибкая бюджетная политика и предоставление дополнительных полномочий органам власти регионов;

увеличение объемов государственного субсидирования бюджетообразующих предприятий и организаций;

проведение оффшорной амнистии участников внешнеэкономической деятельности и др.

В рамках активной формы защиты суверенитета применяются следующие методы:

дипломатические ноты и демарши по официальным и неофициальным каналам;

1 Применительно к государствам - членам ЕАЭС данный метод ЗГС РФ не применяется.

2 Данный метод ЗГС предусмотрен статьей 18.1 Федерального закона от 25 июля 2002 г. № 115-Ф3 «О правовом положении иностранных граждан в Российской Федерации».

3 Данный метод ЗГС предусмотрен статьей 18.1 Федерального закона от 25 июля 2002 г. № 115-Ф3 «О правовом положении иностранных граждан в Российской Федерации».

4 Данный метод ЗГС предусмотрен статьей 18 Федерального закона от 25 июля 2002 г. № 115-Ф3 «О правовом положении иностранных граждан в Российской Федерации». 
понижение уровня дипломатических отношений (закрытие дипломатического представительства, отзыв посла государства, установившего или поддерживающего экономические санкции и др.);

создание экономических (валютных, торговых) союзов;

усиленное государственное финансирование импортозамещения производства и технологической модернизации;

введение (усиление мер) валютного контроля (обеспечение обязательной продажи части валютной выручки, активное использование резервных требований по капитальным валютным операциям и др.);

гибкая тарифная политика и оперативное нетарифное регулирование в секторе внешнеэкономической деятельности (вывозные, ввозные таможенные пошлины, компенсационные, специальные, антидемпинговые пошлины) ${ }^{1}$;

введение налогообложения вывоза капитала с последующим возмещением для импортных операций или установление высоких налоговых ставок на вывоз капитала;

нормативное снижение доли иностранных денежных единиц в транзакциях;

предоставление предприятиям "малого" и "среднего" бизнеса налоговых льгот и налоговых амнистий;

введение налоговых каникул в отношении венчурных предприятий, наукоемких производств и технопарков, реализующих приоритетные направления экономической политики государства;

запрет на въезд отдельным иностранным гражданам и лицам без гражданства, представляющим угрозу государственному суверенитету ${ }^{2}$;

${ }^{1}$ Применение данных методов ЗГС РФ предусмотрено Федеральным законом от 8 декабря 2003 г. № 165-Ф3 «О специальных защитных, антидемпинговых и компенсационных мерах при импорте товаров», Федеральным законом от 30 декабря 2006 г. № 281-Ф3 «О специальных экономических мерах».

2 Данный метод ЗГС предусмотрен подпунктом 7 части 1 статьи 27 Федерального закона от 15 августа 1996 г. № 114-Ф3 «О порядке выезда из Российской Федерации и 
национализация имущества иностранных государств, организаций и отдельных лиц, представляющих угрозу государственному суверенитету, приостановление деятельности находящихся под их контролем юридических лиц ${ }^{1}$;

замораживание счетов, арест имущества, финансовых и иных активов иностранных государств, отказ в проведении операций с денежными средствами и иным имуществом организаций и отдельных лиц, проводящих недружественную политику по ослаблению и подрыву государственного суверенитета ${ }^{2}$;

запрет на любые сделки с собственностью и инвестициями отдельных иностранных граждан и лиц без гражданства, представляющих угрозу государственному суверенитету ${ }^{3}$;

экспортное и импортное эмбарго в отношении иностранных государств и организаций, проводящих недружественную политику по ослаблению и подрыву государственного суверенитета и др ${ }^{4}$.

В целях противодействия "цветным революциям" в рамках пассивной формы защиты государственного суверенитета используются методы запрета зарубежного финансирования выборных кампаний, референдумов и других разновидностей политической деятельности;

въезда в Российскую Федерацию», а также Федеральным законом от 28 декабря 2012 г. № 272-Ф3 «О мерах воздействия на лиц, причастных к нарушениям основополагающих прав и свобод человека, прав и свобод граждан Российской Федерации».

1 В статье 16 Федерального закона от 25 февраля 1999 г. № 39-Ф3 «Об инвестиционной деятельности в Российской Федерации, осуществляемой в форме капитальных вложений» предусмотрена возможность национализации капиталовложений в России при условии предварительного и равноценного возмещения государством убытков, причиненных субъектам инвестиционной деятельности.

2 Данный метод ЗГС РФ предусмотрен Федеральным законом от 28 декабря 2012 г. № 272-Ф3 «О мерах воздействия на лиц, причастных к нарушениям основополагающих прав и свобод человека, прав и свобод граждан Российской Федерации», статьей 3 Федерального закона от 30 декабря 2006 г. № 281-Ф3 «О специальных экономических мерах», статьей 3.1 Федерального закона от 23 мая 2015 г. № 129-Ф3 «О внесении изменений в отдельные законодательные акты Российской Федерации».

3 Данный метод ЗГС РФ предусмотрен Федеральным законом от 28 декабря 2012 г. № 272-Ф3 «О мерах воздействия на лиц, причастных к нарушениям основополагающих прав и свобод человека, прав и свобод граждан Российской Федерации».

${ }^{4}$ В 2012 г. в ответ на экономические санкции США и Евросоюза против Исламской Республики Президент Ирана М. Ахмадинежад приостановил поставки нефти в Великобританию и Францию. 
регистрации некоммерческих организаций, выполняющих функции иностранных агентов, обязательного информирования об этом статусе в СМИ и Интернете; запрета на заключение сделок общественно-политических организаций и политических партий с некоммерческими структурами, выполняющими функции иностранных агентов; запрета на производство и распространение информационных материалов, изданных иностранными или международными организациями, осуществляющими (поддерживающими) недружественную политику по ослаблению и подрыву государственного суверенитета $^{1}$; ограничений на проведение митингов и демонстраций, шествий и пикетирования, а также иных массовых общественнополитических акций и собраний в очагах социальной напряженности и зонах повышенной протестной активности; запрета забастовок и иных способов приостановления или прекращения деятельности организаций и органов власти ${ }^{2}$; ограничений на допуск иностранных граждан и представителей экстремистских сил к замещению должностей на военной, гражданской, правоохранительной и муниципальной службе ${ }^{3}$; ограничений передвижения иностранных граждан и апатридов, лиц, имеющих судимость за совершение преступлений экстремистской направленности и террористического характера, по территории государства ${ }^{4}$.

При активной форме защчиты суверенитета могут применяться:

${ }^{1}$ Данный метод ЗГС предусмотрен статьей 3.1 Федерального закона от 23 мая 2015 г. № 129-Ф3 «О внесении изменений в отдельные законодательные акты Российской Федерации». Данным законодательным актом в систему конституционно-правовой защиты государственного суверенитета РФ введен институт нежелательности на территории РФ деятельности иностранных и международных неправительственных организаций.

2 Данный метод ЗГС РФ закреплен в статье 11 Федерального конституционного закона от30 мая 2001 г. № 3-ФКЗ «О чрезвычайном положении».

${ }^{3}$ Статья 7 Федерального закона «О Федеральной службе безопасности», статья 17 Федерального закона «О внешней разведке», статья 18 Федерального закона «О государственной охране», статья 40.1 Федерального Закона «О прокуратуре Российской Федерации», статья 25 Федерального закона «О полиции».

4 Данный метод ЗГС РФ закреплен в статье 11 Федерального конституционного закона от 30 мая 2001 г. № 3-ФКЗ «О чрезвычайном положении». 
дипломатические ноты и демарши по официальным и неофициальным каналам;

понижение уровня дипломатических отношений (закрытие дипломатического представительства, отзыв посла государства, инициировавшего или поддержавшего "цветную революцию" и др.) $)^{1}$;

создание общественно-политических организаций патриотической направленности, материальная и информационно-пропагандистская поддержка их деятельности;

создание "организаций-ловушек" для контроля каналов финансирования, ресурсного обеспечения, вскрытия планов и устремлений иностранных государств, организаций и отдельных лиц, представляющих угрозу государственному суверенитету;

запрет на въезд отдельным иностранным гражданам и лицам без гражданства, представляющим угрозу государственному суверенитетуㄹ;

принятие решения о нежелательности пребывания (проживания) в государстве отдельных иностранных граждан и лиц без гражданства, представляющих угрозу государственному суверенитетуㅜㅜㄹ

замораживание счетов, арест имущества, финансовых и иных активов иностранных государств, организаций и отдельных лиц, проводящих

1 Данный метод ЗГС широко распространен в практике межгосударственных отношений. Так, В 2008 г. в связи с грубым вмешательством во внутренние дела Боливарианской Республики посол США в Венесуэле был объявлен персоной нон-грата. В декабре 2010 г. Президент Венесуэлы отозвал согласие на назначение посла США в Каракас. В августе 2012 г. в связи с антигосударственной политической деятельностью из Минска был выслан посол Швеции. В 2012 г. после введения Советом ЕС санкций в отношении граждан и юридических лиц Республики Беларусь, причастных, по мнению EC, к нарушениям прав человека, МИД Республики Беларусь рекомендовал послам Польши и ЕС покинуть страну для консультаций.

21 марта 2015 г. Президент Венесуэлы Николас Мадуро в интересах защиты государственного суверенитета ввел запрет на въезд в страну ряда государственных деятелей США. В РФ данный метод ЗГС предусмотрен статьей 27 Федерального закона от 15 августа 1996 г. № 114-Ф3 «О порядке выезда из Российской Федерации и въезда в Российскую Федерацию», а также Федеральным законом от 28 декабря 2012 г. № 272-Ф3 «О мерах воздействия на лиц, причастных к нарушениям основополагающих прав и свобод человека, прав и свобод граждан Российской Федерации».

${ }^{3}$ Подпункт 7 части 1 статьи 27 Федерального закона от 15 августа 1996 г. № 114-Ф3 «О порядке выезда из Российской Федерации и въезда в Российскую Федерацию». 
недружественную политику по ослаблению и подрыву государственного суверенитета ${ }^{1}$;

запрет на любые сделки с собственностью и инвестициями отдельных иностранных граждан и лиц без гражданства, представляющих угрозу государственному суверенитету, приостановление деятельности находящихся под их контролем юридических лиц ${ }^{2}$;

приостановление деятельности и ликвидацию организаций, осуществляющих подрыв и ослабление государственного суверенитета ${ }^{3}$;

проведение наступательных информационно-пропагандистских мероприятий и операций по компрометации главарей, спонсоров и идеологов террористического и иного экстремистского бандподполья, расколу антигосударственных сил и разложению антиконституционных структур;

уголовное преследование и привлечение к ответственности главарей, активных членов и пособников террористического и сепаратистского бандподполья, спонсоров и организаторов антиконституционных акций и массовых беспорядков;

отказ в выдаче либо аннулирование разрешения на временное проживание иностранному гражданину (апатриду), представляющему угрозу государственному суверенитету ${ }^{4}$;

отказ в выдаче либо аннулирование вида на жительство иностранному гражданину, представляющему угрозу государственному суверенитету ${ }^{1}$;

${ }_{1}^{1}$ Данный метод ЗГС РФ предусмотрен Федеральным законом от 28 декабря 2012 г. № 272-Ф3 «О мерах воздействия на лиц, причастных к нарушениям основополагающих прав и свобод человека, прав и свобод граждан Российской Федерации», статьей 3 Федерального закона от 30 декабря 2006 г. № 281-Ф3 «О специальных экономических мерах».

2 Данный метод ЗГС РФ предусмотрен Федеральным законом от 28 декабря 2012 г. № 272-Ф3 «О мерах воздействия на лиц, причастных к нарушениям основополагающих прав и свобод человека, прав и свобод граждан Российской Федерации».

${ }_{3}^{3}$ Данный метод ЗГС РФ предусмотрен Федеральным законом от 28 декабря 2012 г. № 272-Ф3 «О мерах воздействия на лиц, причастных к нарушениям основополагающих прав и свобод человека, прав и свобод граждан Российской Федерации», статьей 12 Федерального конституционного закона от 30 мая 2001 г. № 3-ФКЗ «О чрезвычайном положении».

4 Данный метод ЗГС РФ предусмотрен статьями 6 и 7 Федерального закона от 25 июля 2002 г. № 115-Ф3 «О правовом положении иностранных граждан в Российской Федерации». 
сокращение срока временного пребывания иностранному гражданину (апатриду), представляющему угрозу государственному суверенитету, и установление срока его выезда из государства ${ }^{2}$;

продвижение общественных инициатив в области патриотического воспитания и антиэкстремистской пропаганды и др.

Для противодействия тайной и официальной политической, информационной, материально-технической и финансовой поддержке сепаратистских и иных антигосударственных сил в качестве целесообразных методов пассивной формы защуиты суверенитета можно рассматривать:

принятие законодательных и политических актов, устанавливающих дополнительные гарантии единства государственной власти, политической независимости и территориальной целостности страны;

введение ограничений на проведение митингов и демонстраций, шествий и пикетирования, а также иных массовых общественнополитических акций и собраний в очагах социальной напряженности и зонах повышенной протестной активности ${ }^{3}$;

запрет забастовок и иных способов приостановления или прекращения деятельности организаций и органов власти ${ }^{4}$;

запрет на производство и распространение информационных материалов, изданных иностранными или международными организациями,

1 Данный метод ЗГС РФ закреплен статьей 9 Федерального закона от 25 июля 2002 г. № 115-Ф3 «О правовом положении иностранных граждан в Российской Федерации».

2 В России такой метод ЗГС применяется на основании пункта 1 статьи 5.1 Федерального закона от 25 июля 2002 г. № 115-Ф3 «О правовом положении иностранных граждан в Российской Федерации».

3 Данный метод ЗГС РФ закреплен в статье 11 Федерального конституционного закона от30 мая 2001 г. № 3-ФКЗ «О чрезвычайном положении». ${ }^{3}$

4 Данный метод ЗГС РФ закреплен в статье 11 Федерального конституционного закона от 30 мая 2001 г. № 3-ФКЗ «О чрезвычайном положении». 
осуществляющими (поддерживающими) недружественную политику по ослаблению и подрыву государственного суверенитета';

приостановление программ в области экономического (в том числе торгового и инвестиционного), а также военно-технического сотрудничества ${ }^{2}$;

отмена визитов делегаций;

ограничение передвижения иностранных граждан и лиц без гражданства, лиц, имеющих судимость за совершение преступлений экстремистской направленности и террористического характера, по территории государства ${ }^{3}$;

закрытие государственной границы или ее отдельных участков и др.

В рамках активной формы защчиты суверенитета уполномоченные государственные органы могут применять следующие методы защиты суверенитета:

дипломатические ноты и демарши по официальным и неофициальным каналам ${ }^{4}$;

$\begin{array}{rrrr}\text { понижение } & \text { уровня } \quad \text { дипломатических } & \text { отношений } & \text { (закрытие } \\ \text { дипломатического } & \text { представительства, отзыв }\end{array}$
совершившего недружественные действия и др.);

1 Данный метод ЗГС РФ предусмотрен в статье 12 Федерального конституционного закона от 30 мая 2001 г. № 3-ФКЗ «О чрезвычайном положении», статье 3.1 Федерального закона от 23 мая 2015 г. № 129-Ф3 «О внесении изменений в отдельные законодательные акты Российской Федерации». ${ }^{1}$

2 Данный метод ЗГС РФ предусмотрен статьей 3 Федерального закона от 30 декабря 2006 г. № 281-Ф3 «О специальных экономических мерах».

3 Данный метод ЗГС РФ закреплен в статье 11 Федерального конституционного закона от 30 мая 2001 г. № 3-ФКЗ «О чрезвычайном положении». ${ }^{3}$

${ }^{4}$ В феврале 2010 г. в связи с оружейной сделкой США и Тайваня в МИД КНР был вызван посол США в Китае, которому вручили ноту протеста с перечислением списка мер в ответ на недружественные действия. В данный перечень ответных мер вошли: замораживание военных связей с Пентагоном, отмена переговоров по проблемам нераспространения и контроля за вооружениями, экономические санкции в отношении участвующих в сделке американских компаний Boeing, United Technologies, Lockheed Martin и Raytheon. В декабре 2015 г. аналогичный демарш был предпринят МИД и Минобороны КНР после получения информации об очередной оружейной сделке США и Тайваня. 
обращение в международные органы правосудия с целью прекращения нарушений суверенитета, всех форм тайной и официальной поддержки антигосударственных сил ${ }^{1}$;

формирование военно-политических и экономических союзов и привлечение союзников к коллективной обороне;

проведение военных акций демонстрации силы (военно-морские, военно-воздушные и сухопутные учения, тренировки сил ПВО, пуски континентальных ракет и др.);

создание общественно-политических организаций патриотической направленности, материальная и информационно-пропагандистская поддержка их деятельности;

создание "организаций-ловушек" для контроля каналов финансирования, ресурсного обеспечения, вскрытия планов и устремлений иностранных государств, организаций и отдельных лиц, представляющих угрозу государственному суверенитету;

запрет на въезд отдельным иностранным гражданам и лицам без гражданства, представляющим угрозу государственному суверенитету루

1 Известным примером использования данного метода ЗГС является дело, возбужденное Республикой Никарагуа против Соединенных Штатов Америки, в отношении спора, касающегося ответственности за военные и военного характера действия США в Никарагуа и против Никарагуа. В своем решении от 27 июня 1986 г. Международный Суд ООН установил, что помощь контрас (обучение, вооружение, оснащение, финансирование и снабжение провиантом, иная поддержка); прямые нападения на порты Никарагуа, нефтяные промыслы и военно-морскую базу; установка мин в портах Никарагуа; неразрешенный пролет территории Никарагуа, а также интервенционистские действия с применением силы, которые уже представляют собой нарушение принципа неприменения силы, являются также нарушением принципа уважения территориального суверенитета. Суд обязал США немедленно прекратить все интервенционистские действия и возместить Никарагуа нанесенный ущерб. См. Дело о военной и военизированной деятельности в Никарагуа и против Никарагуа (Никарагуа против США) / Краткое изложение решений, консультативных заключений и постановлений Международного Суда. Нью-Йорк: ООН, 1993. С. 198-213.

2 Данный метод ЗГС РФ предусмотрен статьей 27 Федерального закона от 15 августа 1996 г. № 114-Ф3 «О порядке выезда из Российской Федерации и въезда в Российскую Федерацию», а также Федеральным законом от 28 декабря 2012 г. № 272-Ф3 «О мерах воздействия на лиц, причастных к нарушениям основополагающих прав и свобод человека, прав и свобод граждан Российской Федерации». 
принятие решения о нежелательности пребывания (проживания) в государстве отдельных иностранных граждан и лиц без гражданства, представляющих угрозу государственному суверенитету ${ }^{1}$;

отказ в выдаче либо аннулирование разрешения на временное проживание иностранному гражданину (апатриду), представляющему угрозу государственному суверенитету루

отказ в выдаче либо аннулирование вида на жительство иностранному гражданину, представляющему угрозу государственному суверенитету ${ }^{3}$;

сокращение срока временного пребывания иностранного гражданина (апатрида), представляющего угрозу государственному суверенитету, и установление срока выезда из государства ${ }^{4}$;

приостановление деятельности и ликвидация организаций, осуществляющих подрыв и ослабление государственного суверенитета 5 ;

замораживание счетов, арест имущества, финансовых и иных активов иностранных государств, организаций и отдельных лиц (главарей и активных членов бандподполья, идеологов, финансовых спонсоров и функционеров, участвующих в проведении антигосударственной деятельности), проводящих недружественную политику по ослаблению и подрыву государственного суверенитета ${ }^{6}$;

1 Данный метод ЗГС предусмотрен подпунктом 7 части 1 статьи 27 Федерального закона от 15 августа 1996 г. № 114-Ф3 «О порядке выезда из Российской Федерации и въезда в Российскую Федерацию».

2 Данный метод ЗГС РФ предусмотрен статьями 6 и 7 Федерального закона от 25 июля 2002 г. № 115-Ф3 «О правовом положении иностранных граждан в Российской Федерации».

3 Данный метод ЗГС РФ закреплен статьей 9 Федерального закона от 25 июля 2002 г. № 115-Ф3 «О правовом положении иностранных граждан в Российской Федерации».

${ }_{4}^{4}$ В России такой метод ЗГС применяется на основании пункта 1 статьи 5.1 Федерального закона от 25 июля 2002 г. № 115-Ф3 «О правовом положении иностранных граждан в Российской Федерации».

5 Данный метод ЗГС РФ предусмотрен Федеральным законом от 28 декабря 2012 г. № 272-Ф3 «О мерах воздействия на лиц, причастных к нарушениям основополагающих прав и свобод человека, прав и свобод граждан Российской Федерации».

${ }_{6}^{6}$ Данный метод ЗГС РФ предусмотрен Федеральным законом от 28 декабря 2012 г. № 272-Ф3 «О мерах воздействия на лиц, причастных к нарушениям основополагающих прав и свобод человека, прав и свобод граждан Российской Федерации», статьей 3 Федерального закона от 30 декабря 2006 г. № 281-Ф3 «О специальных экономических мерах». 
запрет на любые сделки с собственностью и инвестициями граждан, представляющих угрозу государственному суверенитету, приостановление деятельности находящихся под их контролем юридических лиц ${ }^{1}$;

проведение наступательных информационно-пропагандистских мероприятий и операций по компрометации главарей, спонсоров и идеологов террористического и иного экстремистского бандподполья, расколу антигосударственных сил и разложению антиконституционных структур;

дискредитация лидеров и функционеров антигосударственных центров, поддерживающих их неправительственных организаций;

проведение профилактических специальных и контртеррористических операций в отношении главарей, идеологов и спонсоров бандподполья, представителей пособнических сетей ${ }^{2}$;

уголовное преследование и привлечение к ответственности главарей, активных членов и пособников террористического и сепаратистского бандподполья, спонсоров и организаторов антиконституционных акций и массовых беспорядков ${ }^{3}$;

продвижение общественных инициатив в области патриотического воспитания и антиэкстремистской пропаганды.

При подготовке и реализации антигосударственными силами механизма "гуманитарных" интервенций в рамках пассивной формы

${ }_{1}^{1}$ Данный метод ЗГС РФ предусмотрен Федеральным законом от 28 декабря 2012 г. № 272-Ф3 «О мерах воздействия на лиц, причастных к нарушениям основополагающих прав и свобод человека, прав и свобод граждан Российской Федерации».

2 Так, по данным Национального антитеррористического комитета в 2015 г. на территории РФ задержано 814 боевиков и их пособников. В ходе специальных и контртеррористических операций нейтрализовано 170 боевиков, в том числе 39 бандглаварей.

${ }^{3}$ В 2015 г. следственными органами возбуждены уголовные дела в отношении 1150 российских граждан, подозреваемых в участии в боевых действиях на стороне международных террористических организаций за рубежом. Из их числа 198 уничтожены во время боевых действий за границей. Из 216 вернувшихся в Российскую Федерацию боевиков 100 осуждены (в том числе 22 вербовщика), остальные арестованы и ожидают назначения уголовного наказания. См. Егоров И. Боевики на экспорт // Рос. газ. 2015. 16 декабря. 
защуить государственного суверенитета целесообразно применение таких методов, как:

инициирование и принятие международно-правовых актов, осуждающих "гуманитарные" интервенции как агрессивные действия и предусматривающих меры по обеспечению политической независимости и территориальной целостности страны;

приостановление и прекращение программ в области торгового, экономического, военно-технического сотрудничества ${ }^{1}$;

приостановление и прекращение действия договоров в сфере ограничения вооружений, обороны и безопасности, сотрудничества в борьбе с терроризмом;

отмена визитов делегаций;

полное или частичное прерывание железнодорожного, морского, воздушного, почтового, телеграфного и других средств сообщения;

запрет или установление ограничений на осуществление финансовых и внешнеэкономических операций с участием иностранных физических и юридических лиц ${ }^{2}$;

запрет на производство и распространение информационных материалов, изданных иностранными или международными организациями, осуществляющими (поддерживающими) недружественную политику по ослаблению и подрыву государственного суверенитета ${ }^{3}$;

усиление охраны общественного порядка и обеспечения общественной безопасности, охраны военных, важных государственных и специальных объектов, объектов, обеспечивающих жизнедеятельность населения, функционирование транспорта, коммуникаций и связи, объектов энергетики,

${ }^{1}$ В РФ данный метод ЗГС предусмотрен статьей 3 Федерального закона от 30 декабря 2006 г. № 281-Ф3 «О специальных экономических мерах».

2 В РФ данный метод ЗГС предусмотрен статьей 3 Федерального закона от 30 декабря 2006 г. № 281-Ф3 «О специальных экономических мерах».

3 Данный метод ЗГС предусмотрен статьей 3.1 Федерального закона от 23 мая 2015 г. № 129-Ф3 «О внесении изменений в отдельные законодательные акты Российской Федерации». 
а также объектов, представляющих повышенную опасность для жизни и здоровья людей ${ }^{1}$;

запрет или ограничение проведения собраний, митингов и демонстраций, шествий и пикетирования, а также иных массовых мероприятий ${ }^{2}$;

запрет забастовок и иных способов приостановления или прекращения деятельности организаций ${ }^{3}$;

ограничение передвижения иностранных граждан и лиц без гражданства, лиц, имеющих судимость за совершение преступлений экстремистской направленности и террористического характера, по территории государства;

закрытие государственной границы или ее отдельных участков;

запрет или ограничение захода в порты и использования воздушного пространства или его отдельных участков судами иностранных государств, предпринимающих (поддерживающих) недружественные действия по ослаблению и подрыву государственного суверенитета ${ }^{4}$.

Активная форма защуиты государственного суверенитета предполагает следующие методы:

дипломатические ноты и демарши по официальным и неофициальным каналам;

понижение уровня или прекращение дипломатических отношений (закрытие дипломатического представительства и отзыв посла государства, инициировавшего или поддержавшего недружественные действия);

1 Данный метод ЗГС РФ закреплен пунктом 2 статьи 7 Федерального конституционного закона от 30 января 2002 г. № 1-ФКЗ «О военном положении».

Данный метод ЗГС РФ закреплен пунктом 2 статьи 7 Федерального конституционного закона от 30 января 2002 г. № 1-ФКЗ «О военном положении». Данный метод ЗГС РФ закреплен пунктом 2 статьи 7 Федерального конституционного закона от 30 января 2002 г. № 1-ФКЗ «О военном положении».

4 В РФ данный метод ЗГС предусмотрен статьей 3 Федерального закона от 30 декабря 2006 г. № 281-Ф3 «О специальных экономических мерах». 
обращение в международные органы правосудия с целью прекращения нарушений суверенитета;

формирование военно-политических союзов и привлечение союзников к коллективной обороне;

создание военных баз (размещение средств разведки) на территории иностранных государств;

проведение военных акций демонстрации силы (военно-морские, военно-воздушные и сухопутные учения, тренировки сил ПВО, длительные походы, пуски континентальных ракет и др.);

отказ в выдаче либо аннулирование разрешения на временное проживание иностранному гражданину (апатриду), представляющему угрозу государственному суверенитету;

запрет на въезд отдельным иностранным гражданам и лицам без гражданства, представляющим угрозу государственному суверенитету ${ }^{2}$;

принятие решения о нежелательности пребывания (проживания) в государстве отдельных иностранных граждан и лиц без гражданства, представляющих угрозу государственному суверенитетуㅜㅜ

отказ в выдаче либо аннулирование вида на жительство иностранному гражданину, представляющему угрозу государственному суверенитету ${ }^{4}$;

сокращение срока временного пребывания иностранному гражданину (апатриду), представляющему угрозу государственному суверенитету, и установление срока его выезда из государства ${ }^{1}$;

1 Данный метод ЗГС РФ предусмотрен статьями 6 и 7 Федерального закона от 25 июля 2002 г. № 115-Ф3 «О правовом положении иностранных граждан в Российской Федерации».

2 Данный метод ЗГС РФ предусмотрен статьей 27 Федерального закона от 15 августа 1996 г. № 114-Ф3 «О порядке выезда из Российской Федерации и въезда в Российскую Федерацию», а также Федеральным законом от 28 декабря 2012 г. № 272-Ф3 «О мерах воздействия на лиц, причастных к нарушениям основополагающих прав и свобод человека, прав и свобод граждан Российской Федерации».

3 Данный метод ЗГС предусмотрен подпунктом 7 части 1 статьи 27 Федерального закона от 15 августа 1996 г. № 114-Ф3 «О порядке выезда из Российской Федерации и въезда в Российскую Федерацию».

${ }^{4}$ Данный метод ЗГС РФ закреплен статьей 9 Федерального закона от 25 июля 2002 г. № 115-Ф3 «О правовом положении иностранных граждан в Российской Федерации». 
прекращение деятельности организаций, осуществляющих деятельность по ослаблению и подрыву государственного суверенитета ${ }^{2}$;

замораживание счетов, арест имущества, финансовых и иных активов иностранных государств, организаций и отдельных лиц (главарей и активных членов бандподполья, идеологов, финансовых спонсоров и функционеров, участвующих в проведении антигосударственной деятельности), проводящих недружественную политику по ослаблению и подрыву государственного суверенитета ${ }^{3}$;

национализация имущества иностранных государств, организаций и отдельных лиц, представляющих угрозу государственному суверенитету, прекращение деятельности находящихся под их контролем юридических лиц ${ }^{4}$;

уголовное преследование и привлечение к ответственности главарей, активных членов и пособников террористического и сепаратистского бандподполья, спонсоров и организаторов антиконституционных акций и массовых беспорядков;

дискредитация лидеров и функционеров антигосударственных центров, поддерживающих их неправительственных организаций;

1 В России такой метод ЗГС применяется на основании пункта 1 статьи 5.1 Федерального закона от 25 июля 2002 г. № 115-Ф3 «О правовом положении иностранных граждан в Российской Федерации».

2 Данный метод ЗГС РФ закреплен пунктом 2 статьи 7 Федерального конституционного закона от 30 января 2002 г. № 1-ФКЗ «О военном положении», статьей 3.1 Федерального закона от 23 мая 2015 г. № 129-Ф3 «О внесении изменений в отдельные законодательные акты Российской Федерации».

3 Данный метод ЗГС РФ предусмотрен Федеральным законом от 28 декабря 2012 г. № 272-Ф3 «О мерах воздействия на лиц, причастных к нарушениям основополагающих прав и свобод человека, прав и свобод граждан Российской Федерации», статьей 3 Федерального закона от 30 декабря 2006 г. № 281-Ф3 «О специальных экономических мерах»».

${ }^{4}$ Согласно ч. 3 ст. 35 Конституции РФ принудительное отчуждение имущества для государственных нужд может быть произведено только при условии предварительного и равноценного возмещения. 
приостановление полномочий и роспуск представительных органов власти, создание временных органов прямого управления в регионах со сложной обстановкой ${ }^{1}$;

отстранение местных и региональных должностных лиц, руководителей государственных и негосударственных организаций от исполнения служебных обязанностей²;

законодательное замещение (лишение местных и региональных органов правотворческих полномочий, приостановление действия правовых актов региональных и муниципальных органов) и др ${ }^{3}$.

В условиях открытого военного вторжения, организованной вооруженной борьбы в рамках пассивной формы защчиты государственного суверенитета применяются следующие методы защциты:

прекращение всех дипломатических отношений между воюющими сторонами;

прекращение действия договорных обязательств политического характера между воюющими сторонами;

перевод органов власти и организаций на работу в условиях военного времени и введение дополнительных мер, направленных на усиление режима секретности

усиление охраны общественного порядка и обеспечения общественной безопасности, охраны военных, важных государственных и специальных объектов, объектов транспорта, коммуникаций, связи и энергетики, а также

\footnotetext{
1 Данный метод ЗГС РФ закреплен статьей 22 Федерального конституционного закона от 30 мая 2001 г. № 3-ФКЗ «О чрезвычайном положении».

2 Данный метод ЗГС РФ закреплен статьей 13 Федерального конституционного закона от 30 мая 2001 г. № 3-ФКЗ «О чрезвычайном положении».

3 Данный метод ЗГС РФ закреплен статьей 15 Федерального конституционного закона от 30 мая 2001 г. № 3-ФКЗ «О чрезвычайном положении».

4 Данный метод ЗГС РФ закреплен пунктом 2 статьи 7 Федерального конституционного закона от 30 января 2002 г. № 1-ФКЗ «О военном положении», статьей 2 Федерального закона от 26 февраля 1997 г. № 31-ФЗ «О мобилизационной подготовке и мобилизации в Российской Федерации».
} 
объектов, представляющих повышенную опасность для жизни и здоровья людей ${ }^{1}$;

введение особого режима работы объектов транспорта, коммуникаций, связи и энергетики, а также объектов, представляющих повышенную опасность для жизни и здоровья людей и для окружающей природной среды ${ }^{2}$;

создание государственных запасов материальных ценностей ${ }^{3}$;

эвакуация объектов хозяйственного, социального и культурного назначения, а также временное отселение жителей в безопасные районы ${ }^{4}$;

введение и обеспечение особого режима въезда на территорию, на которой введено военное положение, и выезда с нее, а также ограничение свободы передвижения по ней ${ }^{5}$;

полное или частичное прерывание железнодорожного, морского, воздушного, почтового, телеграфного и других средств сообщения;

приостановление деятельности политических партий, других общественных объединений, религиозных объединений, ведущих пропаганду и (или) агитацию, а равно иную деятельность, подрывающую в условиях военного положения суверенитет государства ${ }^{6}$;

введение временных ограничений на осуществление экономической и финансовой деятельности, оборот имущества, свободное перемещение товаров, услуг и финансовых средств, на поиск, получение, передачу, производство и распространение информации ${ }^{7}$;

1 Данный метод ЗГС РФ закреплен пунктом 2 статьи 7 Федерального конституционного закона от 30 января 2002 г. № 1-ФКЗ «О военном положении».

2 Данный метод ЗГС РФ закреплен пунктом 2 статьи 7 Федерального конституционного закона от 30 января 2002 г. № 1-ФКЗ «О военном положении».

3 В РФ данный метод ЗГС предусмотрен статьей 2 Федерального закона от 26 февраля 1997 г. № 31-Ф3 «О мобилизационной подготовке и мобилизации в Российской Федерации».

4 Данный метод ЗГС РФ закреплен пунктом 2 статьи 7 Федерального конституционного закона от 30 января 2002 г. № 1-ФКЗ «О военном положении».

5 Данный метод ЗГС РФ закреплен пунктом 2 статьи 7 Федерального конституционного закона от 30 января 2002 г. № 1-ФКЗ «О военном положении».

6 Там же.

7 Там же. 
введение особого порядка распределения продуктов питания и предметов первой необходимости ${ }^{1}$;

временное изменение форм собственности организаций, порядка и условий процедур банкротства, режима трудовой деятельности и установление особенностей финансового, налогового, таможенного и банковского регулирования²;

изъятие необходимого для нужд обороны имущества у организаций и граждан с последующей выплатой государством стоимости изъятого имущества ${ }^{3}$;

введение военно-квартирной обязанности для расквартирования воинских частей и учреждений ${ }^{4}$;

запрет или ограничение выбора места пребывания либо места жительства ${ }^{5}$;

запрет или ограничение выезда граждан за пределы территории государства

запрет или ограничение проведения собраний, митингов и демонстраций, шествий и пикетирования, а также иных массовых мероприятий ${ }^{7}$;

запрет работы приемопередающих радиостанций индивидуального пользования, введение военной цензуры за почтовыми отправлениями и сообщениями, а также контроля за телефонными переговорами루

1 В РФ данный метод ЗГС предусмотрен статьей 2 Федерального закона от 26 февраля 1997 г. № 31-Ф3 «О мобилизационной подготовке и мобилизации в Российской Федерации».

2 Данный метод ЗГС РФ закреплен пунктом 1 статьи 8 Федерального конституционного закона от 30 января 2002 г. № 1-ФКЗ «О военном положении», статьей 2 Федерального закона от 26 февраля 1997 г. № 31-Ф3 «О мобилизационной подготовке и мобилизации в Российской Федерации».

3 Данный метод ЗГС РФ закреплен пунктом 2 статьи 7 Федерального конституционного закона от 30 января 2002 г. № 1-ФКЗ «О военном положении».

4 В РФ данный метод ЗГС предусмотрен статьей 10 Федерального закона от 26 февраля 1997 г. № 31-Ф3 «О мобилизационной подготовке и мобилизации в Российской Федерации».

5 Данный метод ЗГС РФ закреплен пунктом 2 статьи 7 Федерального конституционного закона от 30 января 2002 г. № 1-ФКЗ «О военном положении».

6 Там же.

${ }^{7}$ Там же. 
запрет забастовок и иных способов приостановления или прекращения деятельности организаций ${ }^{2}$;

запрет нахождения граждан на улицах и в иных общественных местах в определенное время суток ("комендантский час") ${ }^{3}$;

запрет продажи оружия, боеприпасов, взрывчатых и ядовитых веществ, установление особого режима оборота лекарственных средств и препаратов, содержащих наркотические и иные сильнодействующие вещества, спиртных напитков ${ }^{4}$;

изъятие оружия, боеприпасов, взрывчатых, ядовитых и радиоактивных веществ, боевой и учебной военной техники ${ }^{5}$;

введение контроля за работой объектов, обеспечивающих функционирование транспорта, коммуникаций и связи, за работой типографий, вычислительных центров и автоматизированных систем, СМИ, использование их работы для нужд обороны и др

Активная форма защчиты включает следующие методы защчитьл государственного суверенитета:

непосредственное вооруженное отражение агрессии, направленной против государства;

блокада портов или берегов государства - противника;

осада гарнизонов и населенных пунктов государства - противника;

бомбардировка территории иностранного государства - противника;

интернирование (изоляция) граждан иностранного государства противника или союзных государств ${ }^{7}$;

1 Данный метод ЗГС РФ закреплен пунктом 2 статьи 7 Федерального конституционного закона от 30 января 2002 г. № 1-ФКЗ «О военном положении».

Там же.

3 Там же.

4 Там же.

5 Там же.

${ }^{6}$ Там же.

7 Там же. 
выселение из местности, где введено военное положение, лиц, имеющих судимость за тяжкие преступления, а также находящихся под административным надзором;

прекращение работы иностранных и международных организаций, осуществляющих антигосударственную деятельность, направленную на подрыв государственного суверенитета;

национализация имущества иностранных государств, организаций и отдельных лиц, представляющих угрозу государственному суверенитету;

замораживание счетов, арест имущества иностранных государств и организаций, проводящих недружественную политику по ослаблению и подрыву государственного суверенитета и др ${ }^{1}$.

Обоснование перечисленных форм и методов ЗГС требует некоторых оговорок. Во-первых, необходимо иметь в виду сложности отнесения тех или иных методов к активным или пассивным формам защиты суверенитета. В отдельных случаях приведенная автором классификация является весьма условной. Во-вторых, приведенные методы ЗГС не являются исчерпывающими. Определяя набор конкретных форм и методов ЗГС, органы власти исходят из особенностей обстановки и адекватности применяемых форм и методов реальным угрозам государственному суверенитету $^{2}$. В-третьих, ряд методов ЗГС может быть применим для противодействия различным деструктивным механизмам ослабления и

${ }^{1}$ В РФ данный метод ЗГС предусмотрен Федеральным законом от 28 декабря 2012 г. № 272-Ф3 «О мерах воздействия на лиц, причастных к нарушениям основополагающих прав и свобод человека, прав и свобод граждан Российской Федерации», статьей 3 Федерального закона от 30 декабря 2006 г. № 281-Ф3 «О специальных экономических мерах»"$\dot{2}$

2 Так, в случае с актом агрессии Вооруженных сил Турецкой Республики в отношении российского бомбардировщика СУ-24, сбитого над территорией Сирии в ноябре 2015 г., руководством РФ с учетом особенностей политической ситуации не объявлялась мобилизация и не вводился режим военного положения. Вместе с тем в качестве реакции на агрессивные действия иностранного государства - члена НАТО для ЗГС были использованы специальные экономические методы. 
подрыва государственного суверенитета ${ }^{1}$. Наконец, упомянутые методы могут применяться как в комплексе, так и самостоятельно.

Рассмотрев наиболее распространенные в российской и мировой практике механизмы ЗГС, подведем некоторые итоги:

Противодействие деструктивным механизмам ослабления и подрыва государственного суверенитета нуждается в адекватных механизмах ЗГС.

ЗГС ведущих государств мира не может быть организована и обеспечена никем, кроме них самих.

Защита внутринациональных элементов государственного суверенитета взаимосвязана с защитой внешних элементов. Состояние национальной экономики, политическая стабильность и гражданская активность общества, уровень культуры и духовное состояние народа - все это в совокупности определяет авторитет страны в мире и ее влияние на международные отношения. В свою очередь, позиции государства в мировом сообществе оказывают существенное воздействие на решение внутренних проблем ${ }^{2}$.

В зависимости от интенсивности воздействия на внутренние и внешние угрозы государственному суверенитету и содержания применяемых государством мер можно различать пассивную и активную формы ЗГС.

В рамках тех или иных форм ЗГС используются соответствующие методы ЗГС, которые дифференцируются применительно к используемым антигосударственным силам механизмам ослабления и подрыва государственного суверенитета.

Обобщение исторического опыта обеспечения верховенства и независимости государственной власти, беспрепятственной реализации

1 Дипломатические ноты, принятие решения о нежелательности пребывания (проживания) на территории государства иностранцев, представляющих угрозу государственному суверенитету, замораживание счетов, арест имущества иностранных организаций, используемых в деструктивных целях, могут применяться для защиты от нескольких различных механизмов ослабления и подрыва государственного суверенитета.

${ }_{2}^{2}$ Внешняя политика России. Теория и практика / Под общей ред. С.В. Смульского, О.Д. Абрамовой М.: Книга и бизнес, 2013. С.118. 
государственно-властных полномочий в наиболее важных сферах общественной жизни свидетельствует о том, что большинством государств длительное время создавались и использовались два типовых механизма ЗГС: административно-командный (репрессивный) и либеральный. Основное различие между ними состоит в степени вмешательства государства и масштабах применения принудительных и карательных методов воздействия в отношении политических оппонентов правящего режима.

В контексте развития конституционных прав и свобод граждан, сотрудничества с общественными институтами и в тоже время необходимости противодействия агрессивной политике иностранных государств предпочтительным является формирование смешанного механизма ЗГС и применение активных организационных форм защиты. Гибкое применение арсенала целесообразных для государства в той или иной обстановке мер воздействия и реализация принципа наступательности при ЗГС составляют основу прочности и реальной независимости государства.

На современном этапе государственного строительства ставка на преимущественное использование силовых механизмов подавления, пассивного ситуативного реагирования и открытой государственной пропаганды дает лишь ограниченный, временный эффект. Исключительного господства силы государственного аппарата недостаточно: необходима поддержка органов власти со стороны населения и признание гражданами этой силы.

ЗГС нуждается в профилактике, целевом воздействии на причинноследственный комплекс и субъекты ослабления и подрыва государственного суверенитета, качественном изменении уклада общественной и государственной жизни. Все это невозможно без опоры на сильную экономику, реальные потребности граждан и поддержку общественности. 
Глава 2. ТЕОРИИ И ПРЕДЕЛЫ ОГРАНИЧЕНИЯ ГОСУДАРСТВЕННОГО СУВЕРЕНИТЕТА

\section{1. Теоретическое обоснование ограничения государственного суверенитета и доктрина «мирового правительства»}

В 2014 г. произошли важнейшие события, которые заставили переосмыслить роль отдельных стран в системе международной и региональной безопасности.

В связи с вступлением Крыма в состав РФ, провозглашением ДНР и ЛНР на Юго-Востоке Украины в отношении РФ, ряда должностных лиц и организаций, якобы причастных к дестабилизации ситуации в Украине, Соединенными Штатами и ЕС в нарушение норм международного права были введены ограничительные политические и экономические меры ${ }^{1}$. Инициатором введения санкций стало руководство США, под давлением которого к санкциям присоединился Евросоюз.

По мере углубления разногласий между Москвой и официальным Вашингтоном отмечается нарастание интенсивности и остроты антироссийских информационно-пропагандистских акций в западных СМИ. Вместо объективного освещения событий населению подается искусно созданная виртуальная реальность: нежелательные для западной общественности сведения либо полностью замалчиваются, либо грубо искажаются ${ }^{2}$. Экспансионистские цели и оправдание гонки вооружений

${ }^{1}$ В апреле 2014 г. не признавшие легитимность антиконституционного переворота в Киеве жители Донецкой и Луганской областей провозгласили создание «народных республик» и объявили о своем суверенитете. Власти Украины начали в Донбассе карательную операцию против жителей региона.

2 Весьма характерными являются попытки придания легитимности новым правителям Украины, пришедшим к власти в результате государственного переворота. В соответствии с политикой «двойных стандартов» силовые действия радикальной оппозиции и неофашистских сил на Евромайдане подаются как мирные демонстрации, а гражданские акции протеста жителей Донбасса - как «незаконные и сепаратистские действия». Одновременно чиновниками зарубежных правительственных структур и межгосударственных органов, иностранными СМИ осуществляется широкомасштабная 
маскируются рассуждениями о необходимости защиты от «внешней агрессии». Наиболее активно такие приемы используются в ходе освещения гражданской войны на Юго-Востоке Украины.

Зарубежные СМИ и политическое руководство США, Канады и Западной Европы вернулись к агрессивной риторике «холодной войны». Было предложено «изолировать» Россию и возродить «демократическую коалицию Запада времен «холодной войны» с главенствующей ролью Соединенных Штатов. По мнению лидеров США стран блока НАТО, новое мироустройство и система безопасности должны обеспечиваться Организацией Североатлантического договора, которая, в отличие от неэффективной ООН, способна предотвращать конфликты, осуществлять контроль за нераспространением оружия массового поражения и оперативно проводить «гуманитарные» силовые акции. Эти программные заявления «удачно» совпали с наращиванием финансирования и размещением в Европе дополнительных воинских подразделений НАТО, заявлениями о необходимости расширения Альянса за счет Украины, Грузии и Молдавии.

Попытки экономического давления и политической изоляции России связаны с тем, что российское государство является объективным препятствием для передела мира по американской модели, а наличие у России ядерного оружия, уникальные сырьевые и энергетические ресурсы, частично контролируемое информационное пространство затрудняют Соединенным Штатам глобальное доминирование. Неудавшаяся попытка «цветной революции» и неспособность «единой оппозиции» подготовить смену политического режима в России при поддержке извне не оставили антигосударственным силам другого пути, кроме открытого ослабления и подрыва ее государственного суверенитета ${ }^{1}$.

кампания по обвинению России в попытках дезинформировать мировое сообщество относительно собственных планов в отношении Украины.

${ }^{1}$ В этой связи особого внимания заслуживает инициатива Федерального Конгресса США по принятию в 2014 г. законопроекта «Russian Agression Prevention Act 2014» («Акт 
Важно иметь в виду, что ограничение государственного суверенитета нуждается в подробном теоретическом обосновании. С одной стороны, разрабатываемые специалистами концепции, стратегии, доктрины должны содержать аргументацию необходимости усиления ведущей роли США в международных отношениях. С другой стороны, новые, более утонченные и разнообразные формы поддержания мирового лидерства Соединенных Штатов должны быть основаны на постепенном ограничении суверенитета и использовании потенциала (ресурсы, рынки, кадры, технологии) интересующих американское руководство государств.

Несмотря на то, что государственный суверенитет как верховенство и независимость государственной власти внутри страны и за ее пределами является обязательным признаком любого государства, далеко не каждое государство им фактически обладает. В истории известны многочисленные примеры ограниченного суверенитета государств: колонии; вассальные государства (Румыния и Сербия до 1878 г., Болгария до 1908 г., индийские княжества до 1947 г); протектораты (Марокко и Тунис до 1956 г.), капитуляции (Турция до 1923 г., Иран до 1928 г., Египет до 1937 г., Китай до

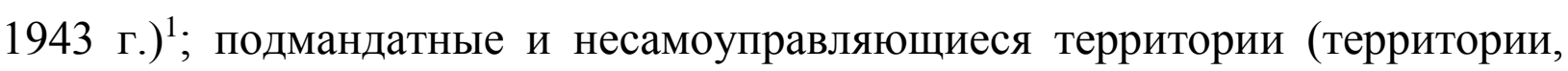
отторгнутые от Германии и Турции в итоге Первой мировой войны $)^{2}$; международные сеттльменты и сервитуты и др. ${ }^{3}$.

о предотвращении агрессии со стороны России 2014»), предусматривающего ежегодное выделение 10 млрд. долларов в период 2015-2017 гг. на «развитие демократии» в РФ.

${ }^{1} \mathrm{O}$ режиме капитуляций см. решение Международного Суда ООН от 27 августа 1952 г. по делу, касающемуся прав граждан США в Марокко / Краткое изложение решений, консультативных заключений и постановлений Международного Суда (19481991). Нью-Йорк: ООН, 1993. С. 31.

2 Статья 22 Устава Лиги Наций предусматривала возможность предоставления тому или иному государству международного мандата от Лиги Наций на управление той или иной страной или территорией. Мандаты были выданы: Англии - на Ирак, Камерун, Палестину, Трансиорданию и Западную Африку; Франции - на Сирию, Ливию, Того; Бельгии - на Руанда-Урунди; Японии - на острова Океании; Австралии и Новой Зеландии - на острова Новой Гвинеи, Самоа и ряд др. Мандатная система Лиги Наций рассматривалась в решении Международного Суда ООН от 21 декабря 1962 г. по делам о Юго-Западной Африке / Краткое изложение решений, консультативных заключений и постановлений Международного Суда (1948-1991). Нью-Йорк: ООН, 1993. С. 78-81.

3 Помимо перечисленных открытых форм зависимости государств необходимо различать скрытые формы экономической зависимости государств. Не случайно в 
Вопрос об ограничении государственного суверенитета остро встал в эпоху деколонизации. Государства-монополии, пытаясь вернуть утраченные ресурсы, рынки, политическое влияние, разрабатывали различные доктрины, умаляющие или отрицающие суверенность стран, освободившихся от колониальной зависимости. На практике это проявилось в формировании различных военных союзов с эксколониями, размещении там военных баз и осуществлении экономической экспансии (предоставление финансовых займов на кабальных политических и экономических условиях, неэквивалентный экономический обмен).

Ограничение государственного суверенитета является одним из традиционных средств расширения сфер влияния государств, претендующих на мировое лидерство. Американская политическая доктрина на протяжении $\mathrm{XX-XXI} \mathrm{вв.} \mathrm{является} \mathrm{ярким} \mathrm{тому} \mathrm{подтверждением.} \mathrm{Рост} \mathrm{экономического}$ могущества, политического, культурного и идеологического влияния США в мире в начале XX в. способствовал поиску идей, теоретически обосновывающих появление и существование новой мировой империи. А поскольку интересам США противоречило существование региональных держав-конкурентов, проводящих относительно независимую внутреннюю и внешнюю политику, в качестве альтернативы государственным суверенитетам была предложена идея единого «мирового правительства». Эта доктрина, обосновывающая слияние всех государств в единое образование во главе с «мировым правительством», позднее получила известность под названием «мондиализм». Наиболее активную разработку она в различных вариациях приобрела после окончания Второй мировой войны. Весомый вклад в создание теорий ограничения суверенитета и доктрины мирового правительства внесли американские теоретики

Стратегии Национальной Безопасности США 2015 г. выделены «слабые государства», «неустойчивые страны» (со слабо управления) и «государства-банкроты».

функциональной системой государственного 
Бжезинский, Вейгарт, Вилкокс, Гарднер, Дейч, Джессеп, Кларк, Кельзен, Киссинджер, Леви, Мейер, Мерриэм, Митрани, Сон, Спикмен, Фальк, Харрисон, Холл, Эциони и др.

Концептуально доктрина «мирового правительства» основана на координации политики в мировом масштабе и принижении роли суверенных государств в международных отношениях. Создание доминирующего мирового центра под эгидой США является стратегической целью, а многочисленные теории ограничения государственного суверенитета выступают тактическим средством достижения этой цели. Теоретический блок концепций ограничения государственного суверенитета состоит из геополитической, экономической, коммуникативной и юридической составляющих.

Значительная часть теорий «ограничения государственного суверенитета» уходит корнями в геополитику. В работах «Американская стратегия в мировой политике» и «География мира» одного из первых американских геополитиков Спикмена обозначены десять критериев, на основании которых следует определять геополитическое могущество государства. К их числу относятся ${ }^{1}$ :

1) территория государства;

2) природа границ;

3) население;

4) наличие полезных ископаемых;

5) экономическое и технологическое развитие;

6) финансовая мощь;

7) этническая однородность;

8) уровень социальной интеграции;

9) политическая стабильность;

1 Дугин А. Основы геополитики. Геополитическое будущее России. Мыслить пространством. М., 1999. С. 63. 
10) национальный дух.

На взгляд Спикмена, если государство по этим критериям оценивается невысоко, оно должно вступить в общий союз и уступить часть своего государственного суверенитета ради мирового геополитического порядка.

Другие американские ученые (Харрисон, Вейгарт) обосновывали ограничение государственного суверенитета с экономических позиций и увязывали его с лидирующим положением США. Они пытались доказать, что малые страны экономически нежизнеспособны и должны добровольно отказаться от «экономического суверенитета», подчинившись большим державам. Макроэкономическое управление в этом случае должно осуществляться Соединенными Штатами, а малые страны будут выполнять лишь роль поставщиков сырья. Видными представителями экономической составляющей теории ограничения государственного суверенитета являются Гарднер и Митрани. Гарднер возлагал надежду на подчинение США остальной части человечества за счет развитого предпринимательства, определяющего мировой порядок (worldorder business). Митрани в качестве важнейшего фактора мировой интеграции рассматривал контролируемые США международные финансовые институты.

Некоторые американские теоретики (Дейч, Киссинджер, Снайдер) выступают с позиций коммуникативного подхода к обоснованию необходимости ограничения государственного суверенитета и создания мирового правительства. По мнению сторонников данного подхода, одним из основных факторов отрицания государственного суверенитета является межгосударственная взаимозависимость и международные контакты.

Юридическая составляющая теорий «ограничения государственного суверенитета» представлена «теорией международных границ» Холла, теорией «мирового гражданства», теорией компетенции, международноправовыми теориями Адлера, Джессепа, Кельзена. По мнению Холла, «международная граница» проходит там, где сталкиваются интересы великих 
держав. Поэтому все территории на Земле входят в сферу верховенства той или иной великой державы ${ }^{1}$. Данная теория использовалась для обоснования создания военных баз США в иностранных государствах ${ }^{2}$.

Другой разновидностью юридических теорий «ограничения государственного суверенитета» является теория «мирового гражданства». Согласно этой теории государственное гражданство должно быть ликвидировано и заменено единым для всех людей «мировым гражданством». Таким образом, индивиды признавались бы полноценными субъектами международного права. Пропаганда подобных идей направлена на обоснование ликвидации суверенных прав государств по определению правового статуса своего населения, а также возможности вмешательства во внутренние дела.

Следующая правовая вариация ограничения государственного суверенитета связана с теорией компетенции. Сторонники данной теории (Кельзен) заменяют территорию государства пространственной компетенцией и утверждают, что в мире не существует территорий, находящихся под исключительной властью одного государства.

Особый блок теоретического обоснования ограничения государственного суверенитета составляют концепции некоторых американских юристов-международников (Адлер, Джессеп, Кельзен) $)^{3}$.

${ }^{1}$ Например, Берлинская конференция 1885 г. о разделе сфер влияния в Африке приняла решение, по которому каждое государство, завладевшее какой-либо территорией, обязано было объявить другим государствам об этом факте. Брюссельский институт международного права в своей декларации 1888 г. по вопросу о завладении новыми территориями указал, что завладение территории должно осуществляться от имени государства и сопровождаться нотификацией всем государствам. Кроме того, такое завладение должно сопровождаться установлением местной государственной власти, обеспечивающей порядок и управление. В истории известны и другие договоры об установлении сфер влияния (например, Англии с Португалией 1890 г., Англии с Италией 1891 г., Англии с Францией 1898 г.).

2 Лазарев М.И. За ликвидацию военных баз США на чужих территориях. М., 1959; Лазарев М.И. «Теория компетенции» - апология военных баз США на чужих территориях // Правоведение. 1960. № 1. В советском международном праве создание военных баз за рубежом рассматривалось как скрытая форма приобретения чужих территорий. См. Лисовский В.И. Международное право. М.: Высшая школа, 1970. С. 142.

3 Ф. Джессеп в работе «Современное международное право» предложил заменить понятие «Государственный суверенитет» понятием «суверенитет международной 
Суверенитет государства понимается ими исключительно как мотив и предпосылка войн. Отмена государственного суверенитета позволит обеспечить мир на Земле. Вместо конкуренции государств должно быть установлено «господство международного права» ${ }^{1}$. Признание принципа верховенства международного права над национальным связывают с именем Кельзена и его трудами «Проблема суверенитета», «Мир с помощью права». Последователи Кельзена выдвинули жесткую альтернативу: либо признавать суверенитет одного государства, исключающий суверенитет других государств, либо отменить государственный суверенитет вообще.

В последних версиях теорий ограничения государственного суверенитета прямо не утверждается о мировом господстве Соединенных Штатов. Данная цель преследуется опосредованно. Предлагается реорганизовать ООН и осуществить верховенство права в глобальном масштабе с помощью США².

Как уже отмечалось, многие теории ограничения государственного суверенитета призваны обслуживать концепцию «мирового правительства», а мировое правительство, в свою очередь, должно стать средством осуществления политики США. Доктрина мирового правительства предусматривает формирование мировой системы финансового контроля, единое мировое законодательство, международную конституционную

\footnotetext{
организации» и заявлял, что «цена государственного суверенитета - война». Цит. по Лисовский В.И. Международное право. М.: Высшая школа, 1970. С. 64.

${ }^{1}$ Можно «проследить общую тенденцию: сторонники примата международного права чаще всего представляли интересы великих держав, которые в течение длительного периода оказывали значительное влияние на развитие международного права и в силу этого в определенном смысле являлись международными законодателями. Таковыми выступали в первую очередь юристы США, Великобритании и Франции». См. Тункин Г.И., Талалаев А.Н., Шибаева Е.А. и др. Международное право. М.: Юрид. лит., 1994. С. 128-129.

Как отмечает В. Чуркин, в настоящее время стал делаться упор на создании под эгидой ООН некой глобальной системы «измерения приверженности государств верховенству права на национальном уровне», были предложены т.н. «индикаторы верховенства права ООН» и концепция «глобального рейтинга верховенства права». См. Современный мир и геополитика. М.: Канон плюс, 2015. С. 201.
} 
юстицию, создание наднациональных организаций и надгосударственных образований (Бжезинский, Кларк, Мерриэм, Сонн, Эциони).

В период международного экономического кризиса 2008 г. концепции «мирового правительства» и неоглобализации вновь активировались. Известный французский политик и теоретик «нового мирового порядка» Ж. Аттали для вывода мира из глобального кризиса предложил создать «глобальную регулирующую систему» и реализовать «глобальный суверенитет» ${ }^{1}$ путем создания мирового правительства, мирового парламента, мировых полиции, суда и юстиции, введения единой мировой валюты и мирового контроля за финансовыми рынками.

Ж. Аттали и другие сторонники универсального глобализма видят корень зла в самом государстве. Помимо создания наднациональных органов из национальной компетенции изымаются и передаются под международный контроль ядерное оружие, ядерная энергетика, ракетно-космическая техника, а также все богатства недр нашей планеты. Разумеется, государственные суверенитеты в этом случае должны быть нивелированы, а действующие конституции и национальные правовые системы выброшены «на свалку истории» ${ }^{2}$.

Идеологи управления глобальным обществом по сетевому принципу (netoкраты Ж. Ришар, А. Бард, Я. Зондерквист) делают ставку на демонтаж современного политико-правового мироустройства как в его национальном, так и в международном аспекте. Они считают, что люди на всей планете попали в зависимость от мировых рынков. Экономическая глобализация влечет «денационализацию» экономики путем установления транснациональных сетей производства, торговли и финансов. Традиционные национальные государства становятся своего рода коммерческими единицами мировой политики. Глобализация порождает 
новые формы социальной организации, которые вытесняют и постепенно вытеснят национальные государства как первичные экономические и политические образования мирового сообщества. Соответственно, сетевым управлением будут вытеснены внутригосударственные и международный правопорядки, созданные Объединенными Нациями ${ }^{1}$.

Первые попытки практического воплощения доктрины мирового правительства относятся к двадцатым годам XX века. В 1921 г. с целью создания мировой системы финансового контроля, предназначенной для управления глобальными политическими и экономическими процессами, был учрежден Совет по международным отношениям (Council on Foreign Relations). В 1937 г. в США начала свою деятельность первая организация (International Campaign for World Government), основной целью которой было формирование мирового правительства. В ноябре 1945 г. к работе приступил комитет по созданию Всемирного правительства, который к 1948 г. подготовил первый проект всемирной конституции (вошедший в историю как «чикагский проект», поскольку 6 из 9 составителей всемирной конституции были преподавателями Чикагского университета). Чикагский проект описывал всемирную федеративную президентскую республику. Президент всемирного государства наделялся не только исполнительными, но и судебными полномочиями в качестве Верховного судьи и председателя Верховного суда. Предусматривалось создание вооруженных сил всемирной республики. Контроль за ними передавался одной из палат всемирного федерального собрания - палате наблюдателей под председательством Президента. Провозглашался один мировой язык. В 1954 г. образован Бильдербергский клуб, занимающийся планированием и координацией

${ }^{1}$ Ришар Ж.Ф. Двадцать лет спустя. Глобальные проблемы и способы их решения // Россия в глобальной политике. 2003. № 2. С. 164; Бард А., Зондерквист Я. Nеtократия. Новая правящая элита и жизнь после капитализма. Стокгольмская школа экономики в Санкт-Петербурге. 2004. С.12. См. также Weiss Th., Thakur R. The UN and Global Governance: An Idea and its Prospects. University of Indiana Press, 2003. Цит. по Зорькин В.Д. Право в условиях глобальных перемен. М.: Норма, 2013. С. 382. 
деятельности олигархических структур в различных странах мира. В 1973 г. Советом по международным отношениям была создана Трехсторонняя комиссия (Trilateral Comission) по урегулированию широкого спектра вопросов взаимодействия американской, европейской и тихоокеанской экономических $30 \mathrm{H}^{1}$. Одним из этапов на пути реализации глобальной американской стратегии создания мирового государства стало оформление политической компоненты Европейского Союза. Таким образом, теоретическая доктрина «мирового правительства» и «нового мирового порядка» превратилась в реальность.

Конец XX века ознаменовался ликвидацией двухполюсной глобальной системы. В связи с устранением Советского Союза безоговорочное доминирующее экономическое, военно-политическое и идеологическое положение в мире стали занимать Соединенные Штаты. Как отмечает Бжезинский в работе «Великая шахматная доска», американское мировое превосходство породило новый международный порядок, который воспроизводит черты американской политической системы: систему коллективной безопасности (НАТО, Американо-японский договор о безопасности); региональное экономическое сотрудничество (APEC, NAFTA) и специализированные глобальные организации (Всемирный банк, МВФ, ВТО); демократическое членство в ключевых союзах и процедуры совместного принятия решения при доминировании Соединенных Штатов; глобальную систему конституционной юстиции ${ }^{2}$.

По мнению Бжезинского, «в случае сознательного или непреднамеренного отказа Америки от своего статуса единственной сверхдержавы реальной альтернативой американскому лидерству в обозримом будущем может быть только анархия в международном

1 Римский клуб. История создания, избранные доклады и выступления, официальные материалы / Сост. Гвишиани Д.М., Колчин А.И. и др. М., 1997. С. 31.

2 Бжезинский 3. Великая шахматная доска. Господство Америки и его геостратегические императивы. М.: Международные отношения, 1998. С. 41. 
масштабе» ${ }^{1}$. Хотите Вы это или нет, Америка несет ответственность за судьбы мира и устанавливает правила поведения для всех остальных государств. «Америка стоит в центре взаимосвязанной вселенной, такой, в которой власть осуществляется через постоянное маневрирование и стремление к формальному консенсусу, хотя эта власть происходит в конце концов из единого источника, а именно: Вашингтон, округ Колумбия. И именно здесь должны вестись политические игры в сфере власти, причем по внутренним правилам Америки» ${ }^{2}$. Приведенная цитата Бжезинского содержит весьма откровенное выражение сути мондиалистской модели мирового устройства, согласно которой «мировое правительство» становится единственным центром власти, а суверенной является только империя «нового мирового порядка».

Американское глобальное доминирование и политика ограничения отдельных государственных суверенитетов сложились не за один день. Этот результат стал закономерным следствием мирового политического развития в XX веке и системного взаимодействия экономических, политических и идеологических факторов.

В числе экономических факторов, способствующих укреплению гегемонии США, можно назвать: долларизацию значительной части национальных экономик, привязку мировых цен на сырье к американской валюте, предоставление контролируемыми США финансовыми институтами кредитов отдельным странам³, льгот в области торговли, налогообложения, таможенных сборов под условиями проведения определенных реформ, выгодных американской администрации, портфельные инвестиции

${ }_{1}^{1}$ Бжезинский 3. Указ. соч. С. 231.

${ }^{2}$ Бжезинский 3. Указ. соч. С. 40-41.

3 Руководствуясь геополитическими интересами, Соединенные Штаты в ряде случаев подрывают правовые устои мировой экономики. Так, обладая преимуществом голосующих позиций в МВФ, США настояли на принятии МВФ решения в отношении Украины о запрете на кредитование стран, которые отказываются признавать и выплачивать собственный суверенный долг. 
американских кампаний и частных лиц в национальные экономики и отрасли, установление экономических санкций за сотрудничество с отдельными государствами, стремящимися проводить независимую от Вашингтона политику, искусственное поддержание экономической отсталости ряда государств за счет ограничения их в доступе к передовым технологиям и разработкам, навязывание кредитов МВФ и кабальных экономических проектов.

К политическим факторам относятся: принятие важнейших политических решений на форумах ограниченного состава под председательством США, осуществление односторонних военных акций, нарушающих нормы международного права, монополия на миротворческую деятельность в ряде регионов мира, легитимация Соединенными Штатами результатов выборов, проходящих в мире, избирательное использование международно-правового института признания государств в качестве инструмента проведения внешней политики, участие США в законодательной деятельности иностранных государств, принятие Конгрессом США законов для других стран мира, требования к иностранным государствам об экстрадиции, противоречащие национальному законодательству этих стран, игнорирование судебных иммунитетов иностранных государств, незаконное обращение взысканий на имущество иностранных государств, экстерриториальность и неподсудность американских военнослужащих и гражданского персонала, обслуживающего военные базы США за границей.

Идеологические факторы доминирования Соединенных Штатов в глобальном масштабе представлены: международным характером английского языка, монополией американских информационных агенств и СМИ на формирование и распространение информации в мире, стимулированием отъезда в США высококвалифицированных специалистов, ученых, деятелей культуры и искусства, ускорением научно-технического, 
технологического и информационно-телекоммуникационного отрыва Соединенных Штатов от других государств мира.

Согласно рейтингу ведущих мировых университетов, составленному Шанхайским университетом Цзяотун, восемь университетов из первой десятки, находятся в США, равно как и семнадцать из первой двадцатки. Эти вузы обеспечивают США научно-техническую и образовательную базу, благодаря которой Америка удерживает экономическое и военное лидерство в освоении промышленных технологий. Кроме того, они способствуют сосредоточению человеческого капитала в стране, поскольку ведущие ученые - исследователи, инженеры и предприниматели со всего мира иммигрируют в США, стремясь реализовать свой потенциал ${ }^{1}$.

Особого комментария с точки зрения ограничения государственных суверенитетов заслуживают участие США в законодательной деятельности иностранных государств и принятие Конгрессом США законов для других стран мира.

В законотворчестве иностранных государств, представляющих интерес для Соединенных Штатов, главное внимание уделяется таким приоритетным сферам правового регулирования, как порядок организации и проведения выборов органов государственной власти, судоустройство и охрана правопорядка, деятельность неправительственных организаций, СМИ, свобода вероисповедания. Так, в подразделе 5 C раздела 2 Закона о демократии в России 2002 г. (Russian Democracy Act of 2002) официально признано, что «финансируемые Правительством США программы внесли вклад в развитие независимой судебной системы, в разработку нового уголовного кодекса, гражданского кодекса, закона о банкротстве, поддержку неправительственных организаций в Российской Федерации» 2 .

1 Бжезинский 3. Стратегический взгляд: Америка и глобальный кризис. М.: Астрель, 2012. С. 91.

2 Электронный pecypc URL: http:// www.access.gpo.gov/nara/publaw/107publ.html (дата обращения 20.03.2016). В частности, большую заинтересованность в разработке и 
В преддверии выборов в Армении 2007-2008 гг. Соединенные Штаты поддержали разработку и модернизацию избирательного законодательства Республики Армения. В Комитет Государственной Думы по делам религии Агентством США по международному развитию вносились предложения об изменении федеральных законов, регулирующих свободу вероисповедания и религиозную деятельность в России. Аналогичные призывы о пересмотре законов поступали от США Узбекистану, Казахстану и руководству ряда др. государств - участников СНГ.

Нужно отметить, что США являются единственным государством, которое не только помогает национальным парламентам принимать внутригосударственные законодательные акты, отвечающие стратегическим интересам американской демократии, но и само принимает законы для других стран мира. Примером распространения юрисдикции Соединенных Штатов в отношении других государств является Закон о свободе вероисповедания в странах мира от 27 января 1998 г., Закон о демократии в России 2002 г., Закон о демократии в Беларуси от 20 октября 2004 г.

Закон о свободе вероисповедания в странах мира 1998 г. предписывает проведение Соединенными Штатами ежегодного анализа положения дел со свободой вероисповедания во всем мире и определение стран, которые «совершили или допустили особенно серьезные нарушения свободы вероисповедания» в отчетный период. После включения какого-либо государства в список «стран, вызывающих особую озабоченность» Государственный секретарь США принимает решение о том, какие действия (в том числе санкции) следует предпринять в отношении данной страны.

\footnotetext{
принятии УПК РФ проявлял Государственный Департамент США. При его непосредственном участии в российский УПК были введены чуждые нашему уголовному процессу американские институты судопроизводства - сделка о признании, право защитника собирать доказательства, ориентация на договоренность сторон, существенно затруднившие работу органов предварительного расследования. В то же время был упразднен институт судьи с двумя народными заседателями. За активную работу по принятию УПК РФ отдельные российские юристы получили американские государственные награды.
} 
В соответствии с подразделом b2 раздела 3 Закона о демократии в России 2002 г. развитие демократии в России отнесено «к сфере интересов национальной безопасности США. В связи с этим Правительству Соединенных Штатов следует продолжать и наращивать поддержку, оказываемую демократическим силам Российской Федерации, включая независимые СМИ, местные администрации, политические партии демократической ориентации и неправительственные организации» ${ }^{1}$.

Аналогичную политико-правовую природу имеет Закон о демократии в Беларуси 2004 г., предусматривающий помощь белорусским политическим партиям, неправительственным организациям и независимым СМИ и устанавливающий запрет правительственным агентствам США на предоставление кредитов и инвестиций правительству Беларуси.

В 2006 г. сенатский комитет США по юридическим вопросам единогласно проголосовал за законопроект, запрещающий зарубежным государствам создавать нефтяные и газовые картельные организации по типу ОПЕК. Закон давал разрешение администрации США преследовать правительства таких государств в судебном порядке. В проекте отмечалось: «Незаконными и нарушающими требования настоящего акта будут коллективные или иные совместные действия в форме картеля или иной ассоциации ... со стороны любого зарубежного государства, инструмента или агента любого зарубежного правительства по ограничению добычи нефти, природного газа или сохранению цен на нефть, природный газ или иной нефтепродукт, а также по любым ограничениям на торговлю нефтью, природным газом или другим нефтепродуктом» ${ }^{2}$. Тем самым иностранные государства - экспортеры энергоносителей лишались права «ограничивать добычу нефти и газа, устанавливать или сохранять цены на них». Важно

1 Электронный pecypc URL: http:// www.access.gpo.gov/nara/publaw/107publ.html (дата обращения 20.03.2016). 23 мая.

${ }_{2}^{2}$ Батчиков С. Суверенная демократия как новая стратегия России // Завтра. 2007. 
иметь ввиду, что впервые в мировой истории данный законопроект в интересах Соединенных Штатов обосновал правомерность выведения природных ресурсов из-под суверенитета того или иного государства.

В 2012 - 2015 гг. США инициировали создание двух крупнейших торгово-экономических блоков - Транстихоокеанского торгового партнерства (Trans-Pacific Partnership) и Трансатлантического торгового и инвестиционного партнерства (Transatlantic Trade and Investment Partnership). В эти партнерства, по замыслу их участников, должны войти страны, производящие более 70\% мирового валового продукта. Данные формы зоны свободной торговли должны со временем заменить Всемирную торговую организацию и фактически упразднить ее правовые нормы.

На фоне секретного обсуждения этих соглашений с потенциальными странами-участниками президент США Б. Обама не раз заявлял, что только Америка, в силу своей исключительности, имеет право создавать новые нормы для глобальной торговли ${ }^{1}$

Еще одним элементом американской «универсальной» юрисдикции стал «закон Магнитского» (Sergei Magnitsky Rule of Law Accountability Act of December 2012), который основывается на голословных заявлениях о систематическом нарушении в России основополагающих прав человека. Данный закон позволяет властям США оценивать деятельность российских официальных и частных лиц, выдвигать обвинения в адрес российских граждан, ущемлять во внесудебном порядке их имущественные и иные законные интересы на основании обвинений в нарушении национальных, иностранных и международных правовых норм². 12 апреля 2013 г. Минфин США опубликовал список из 18 представителей правоохранительных

${ }^{1}$ Цит. по Зорькин В.Д. Право против хаоса. М.: Редакция «Российской газеты», 2016. Вып. 13. С. 44.

2 Нормы «закона Магнитского» предоставили Администрации США легальную возможность контролировать зарубежные активы российского крупного и среднего бизнеса, побуждать данную категорию российских граждан к лояльности США и отказу от любых действий, противоречащих интересам Соединенных Штатов. 
органов и судебной системы России, которым закрыт въезд в США. В 2014 г. данный список дополнен 12 фамилиями.

В марте 2014 г. власти США, не согласные с действиями России в ходе украинского кризиса, ввели персональные санкции в отношении ряда российских госслужащих, парламентариев и представителей бизнеса ${ }^{1}$. В июле 2014 г. точечные антироссийские санкции были усилены секторальными.

В декабре 2014 г. в целях развития демократии за рубежом в США был принят Закон «О защите прав человека и гражданского общества Венесуэлы», а также Закон «О поддержке свободы на Украине».

Однако распространением демократии во всем мире, регулированием международной энергетической и сырьевой политики, формированием правовых устоев глобальной торговли роль Соединенных Штатов не исчерпывается. Настойчивые попытки американского руководства удержать доминирующее положение Соединенных Штатов в качестве мирового лидера вполне объяснимы, если проанализировать, какие возможности предоставляет выборочное ограничение отдельных государственных суверенитетов Америке.

С точки зрения экономики принижение роли суверенных государств во имя доминирующего мирового центра под эгидой США дает: форсирование вывоза капитала, приобретение (расширение) рынков сырья (в первую

${ }^{1}$ Executive Order 13660 - Blocking Property of Certain Persons Contributing to the Situation in Ukraine // Federal Register. Vol. 79. No. 46. Part I.V. March 10, 2014. URL: http://www.treasury.gov/resource-center/sanctions/Programs/Documents/ukraine_eo.pdf I 2014. (дата обращения: 10.07.2014); Executive Order 13661 - Blocking Property of Additional Persons Contributing to the Situation in Ukraine // Federal Register. Vol. 79. No. 53. Part I.V. March 19, 2014. URL:http://www.treasury.gov/resourcecenter/sanctions/Programs/Documents/ukraine_eo2.pdf (дата обращения: 10.07.2014); Executive Order 13662 - Blocking Property of Additional Persons Contributing to the Situation in Ukraine // Federal Register. Vol. 79. No. 56. Part I.V. March 24, 2014. URL: http://www.treasury.gov/resource-center/sanctions/Programs/Documents/ukraine_eo3.pdf обращения: 10.07.2014).Treasury Sanctions Additional Individuals For Threatening The Territorial Integrity Of Ukraine / Sanctions Target Seven Separatists in Ukraine // U.S. Department of the Treasury. 20.06.2014. URL: http://www.treasury.gov/press-center/press-releases/Pages/j12438.aspx (дата обращения: 10.07.2014). Постановлением Конституционного Суда РФ от 19 марта 2014 г. № 6-П подписанный 18 марта 2014 г. международный договор между Российской Федерацией и Республикой Крым о принятии в Российскую Федерацию Республики Крым и образовании новых субъектов по порядку подписания, ратификации и вступления в силу, а также по содержанию норм признан соответствующим Конституции. 
очередь, энергоносителей) и сбыта продукции, снятие торговых ограничений, облегчение выноса экологически опасных производств и отраслей из США.

С точки зрения политики: формирование во всех регионах мира проамериканских политических режимов с контролируемой системой органов государственной власти и отвечающей национальным интересам США системой законодательства, размещение военных баз во всех стратегических районах земного шара; формирование новой системы международного права, ориентирующейся на потребности Соединенных Штатов и предоставляющей Америке исключительные преференции.

С точки зрения идеологии: формирование в общественном сознании ощущения безграничного превосходства американской науки, культуры и искусства, распространение мировоззренческих ценностей американского образа жизни, консолидация американского общества по внешнеполитическим вопросам, затрагивающим национальные интересы США.

С точки зрения социальной сферы: направление на социальные программы Соединенных Штатов денежных средств, полученных за счет снижения издержек производства, вывоза капитала в другие страны, гибкое сдерживание внутреннего потребления и роста жизненного уровня населения.

К чему приводило ограничение государственных суверенитетов для потерпевшей стороны всем известно. Унизительные условия Версальского мирного договора для Германии послужили одной из причин Второй мировой войны. Мюнхенская конференция 1938 г., на которой представителям Чехословакии не было позволено обсуждать принятые решения, привела к уничтожению Чехословацкого государства. Показательные «гуманитарные» бомбардировки Югославии в 1999 г. повлекли за собой изгнание более 200 тысяч сербов из провинции КосовоМетохия и отторжение края в 2008 г. Гуманитарная оккупация Ирака под 
предлогом поиска оружия массового поражения вызвала всплеск непрекращающегося насилия и терроризма. Интервенция в Ливии (2011-2012 гг.) и поддержка антиконституционного переворота в Украине (2014 г.) с целью смены политического режима привели к гражданской войне и распаду государственности.

Стремление к глобальной гегемонии, империалистическая политика «экспорта демократий», «гуманитарных интервенций», «борьбы с диктаторскими режимами», попытки построить на основе НАТО новый мировой порядок по-американски и юридически оформить его представляют непосредственную угрозу и для России. По большинству параметров современные политические и военные установки НАТО (расширение блока за счет Украины, Грузии и Молдавии, развертывание позиционных районов системы ПРО в Европе, Азиатско-Тихоокеанском регионе и космосе, принятие новой стратегической концепции НАТО, предусматривающей ведение силовых операций вне зоны действия Вашингтонского договора без санкции СБ ООН и др.), противоречат интересам безопасности РФ.

Как представляется, современная система международной безопасности и практика межгосударственных отношений должны базироваться не на конфронтационных подходах «холодной войны», а на принципах уважения суверенитета, равноправия, независимости, доверия и взаимовыгодных отношениях государств в международных делах.

Будущее межгосударственных отношений основано на прагматизме, многовекторности, поиске решений актуальных проблем в рамках многосторонней дипломатии и коллективных усилий. 


\section{2. Ограничение государственного суверенитета правами} человека

Конституционно-правовое развитие современных государств невозможно представить без декларирования и правовой регламентации основополагающих прав и свобод человека.

В юридических исследованиях преобладает понимание прав человека как политико-правовой категории, которая выражает правовые возможности личности иметь, пользоваться и приобретать материальные, социальные и духовные блага для удовлетворения своих интересов и потребностей ${ }^{1}$. С точки зрения подобного подхода права человека выступают как неотъемлемые, юридически зафиксированные свойства личности, обеспечивающие ее разнообразные притязания.

Отталкиваясь от сущности прав человека, отметим, что в настоящее время данный институт можно рассматривать в нескольких аспектах:

- как основу правового статуса личности и основу конституционного строя государства (совокупность гарантированных прав и свобод);

- как элемент буржуазно-демократической идеологии, выступающий критерием демократичности политического режима, позволяющий отграничить демократические режимы от недемократических (взгляды на роль индивидуума в общественно-политической жизни общества и государства, характеристика взаимоотношений человека, общества и государства);

- как объект защиты т.н. мирового сообщества, позволяющий оспорить суверенные полномочия государства по регулированию социальных и

\footnotetext{
${ }^{1}$ Глухарева Л.И. Права человека. М., 2002. С. 8-9.
} 
внутриполитических процессов и принудительно навязать внешний правопорядок ${ }^{1}$.

Другой подход связан с определением сферы и круга субъектов воздействия. По сфере воздействия можно различать права человека как формально-правовой институт, охватывающий все категории лиц (граждане государства пребывания, иностранные граждане, апатриды и лица с множественными гражданством), которые находятся на территории государства (права человека в абстрактном смысле) и как реальный объем правомочий определенного индивидуума (права конкретного человека).

Существующие подходы к пониманию прав человека зависят от мировоззрения и правосознания их идеологов и выразителей, а также целеполагания.

История развития института прав человека неразрывно связана с постоянными попытками ограничить полновластие суверенного государства, ввести взаимную ответственность государства и личности, повысить роль гражданского сектора в управлении делами общества ${ }^{2}$.

Оценивая влияние основополагающих прав и свобод человека на адаптацию конституционно-правовой доктрины государственного суверенитета к современным реалиям, необходимо отметить, что оно в целом носит конструктивный характер.

Во-первых, права и свободы человека лежат в основе конституционного строя современного государства. Любое государство стремится гарантировать не только их формальное закрепление в законодательстве, но и фактическую реализацию.

1 Примером могут служить требования международных организаций и иностранных государств о проведении повторных референдумов и выборов под предлогом нарушений демократических прав, введение экономических и визовых санкций в отношении официальных должностных лиц, т.н. гуманитарные интервенции и др.

2 В современной литературе взаимная ответственность государства и личности рассматривается как обязательный признак правового государства. 
Во-вторых, соблюдение прав и свобод человека всеми субъектами права (государственными и негосударственными организациями, гражданами) способствует укреплению режима законности во всех сферах общественной жизни. Государственные органы, общественные объединения и должностные лица обязаны уважать и обеспечивать реализацию основополагающих прав и свобод.

В-третьих, объем реальных и гарантированных прав человека фиксирует рамки политической свободы и индивидуальной самодеятельности, показывает действительное положение человека в обществе, что позволяет рассматривать институт прав человека как критерий демократичности политических режимов. Как отмечает И.С.Филиппова, «права человека как юридическая конструкция являются отражением конкретно исторического признания места и роли индивида в обществе, устанавливают механизм взаимоотношений человека и государства и в этом качестве являются проявлением самоограничения государственной власти» ${ }^{1}$.

Отрицание или выхолащивание прав человека приводит к формированию бюрократических институтов публичной власти и антидемократических режимов.

С другой стороны, концепция прав человека в силу своей надзаконной природы нередко выступала как субъективная оценочная категория. Если требовалось идеологически оправдать какой-либо политический режим или стабилизировать общественные отношения, существующая правовая система и государственный строй объявлялись единственно возможными и соответствующими правам человека. Если ставилась цель общественных преобразований, критики существующих порядков, смены власти, конституционный строй и правовое регулирование провозглашались несоответствующими правам человека и несправедливыми.

1 Филиппова И.С. Концепции ограничения государственной власти: теоретикоправовое исследование. Дис. ...канд. юрид. наук. Н-Н., 2006. С. 174. 
Надзаконность и оценочность европоцентричной концепции прав человека, некритичное принятие общественным мнением псевдогуманитарных идей нередко приводили к злоупотреблениям и манипулированию данным институтом ${ }^{1}$.

Характерными недостатками института прав человека можно назвать его выборочное использование государствами Запада для критики тех или иных государств, тенденциозное освещение выявленных нарушений прав человека за рубежом при замалчивании аналогичных нарушений внутри собственной страны (в государствах-союзниках $)^{2}$.

Конструкция прав человека была доведена до логического абсурда в рамках реализации т.н. «гуманитарных интервенций», противопоставляющих государственный суверенитет защите прав человека.

Как представляется, противоправные вооруженные действия, нарушающие нормы международного права и подрывающие суверенитет государства, не могут являться корректным юридическим обоснованием предотвращения нарушений прав человека. Для пресечения одних правонарушений совсем не обязательно совершать другие. Кроме того, соразмерность причиненного «гуманитарными» интервенциями вреда не пропорциональна предотвращенному боевыми интервенционистскими действиями вреду. Наконец, юридическая несостоятельность подобного рода инструментов силового навязывания внешнего правопорядка подтверждена органами международного правосудия.

1 Абсолютизация навязанных извне гуманитарных идей, двойные стандарты в области измерения прав человека, манипулирование массовым протестным потенциалом на Майдане, легализация неонацистских группировок в целях осуществления антиконституционного государственного переворота, последующее приостановление действия Европейской конвенции по правам человека в зоне т.н. «АТО», политические убийства депутатов и журналистов, блокада и прекращение социальных выплат жителям ДНР и ЛНР серьезно подорвали веру в демократические ценности, свободу СМИ и неотчуждаемость основополагающих прав и свобод.

2 Так, Соединенными Штатами, государствами Евросоюза, Советом Европы и другими правозащитными структурами практически оставлены без внимания заявления официальных властей Украины и Турции о приостановлении на их территории действия Европейской конвенции по правам человека. 
Так, международный суд ООН в решении от 27 июня 1986 г. по делу «Никарагуа против Соединенных Штатов Америки» указал, что международное право не санкционирует использование государством вооруженной силы для исправления ситуации с нарушениями в области прав человека в другом государстве без одобрения Совета Безопасности ООН. Суд установил, что «применение силы как реакция на нарушения прав человека не является подходящим методом контроля или обеспечения соблюдения таких прав» ${ }^{1}$.

Общеизвестные факты произвола, грубых нарушений принципов международного права под флагом защиты и абсолютизации прав человека потребовали смягчения отдельных идеологических постулатов и маскировки отрицательного «правозащитного» опыта.

В качестве альтернативы европоцентризму и субъективизму в понимании прав человека и гуманитарных ценностей был заявлен некий «единый» каталог прав человека, встроенный в систему нового глобального управления миропорядком.

Следует отметить, что необходимость разработки «единого» каталога прав человека, который помог бы определить общие и сблизить существующие подходы в гуманитарной сфере, имеет важное значение и самим фактом своего появления в информационном и научном поле оказывает положительное воздействие на общественное мнение. В то же время второстепенный характер правозащитных элементов по отношению к политологическим, геополитическим, пропагандистским, военным и иным составляющим «универсальности» теории прав человека снижает аксиологическую и идеологическую значимость этой теории. Фактически идеи глобального управления маскируют скрытые интересы руководства США по созданию наднациональных механизмов контроля над

1 Краткое изложение решений, консультативных заключений и постановлений Международного Суда (1948-1991). Нью-Йорк: ООН, 1993. С. 207-208. 
общемировым развитием, в которых стратегия отдельных стран была бы незаметно подчинена целям оформления нужного идеологического, политического и экономического облика мира. При этом не просто ограничивается, а размывается государственный суверенитет. В то же время Запад под эгидой США выстраивается как единое геополитическое, экономическое, военное и культурное консолидированное общество ${ }^{1}$.

Учитывая, что глобальное управление требует открытости всех обществ мира, наличия «управляющих» и обоснования привилегированного права на управление, «закрытые общества» необходимо было подтолкнуть к трансформации, а мировое общественное мнение - подготовить к замене традиционных принципов государственного суверенитета и невмешательства во внутренние дела государств на принцип управления мировым развитием в интересах т.н. «мирового сообщества». Эта стратегическая задача была успешно решена с помощью обновленной идеологии «защиты прав человека».

Сущностью глобального управления должна была стать дискредитация и последующее ограничение государственных суверенитетов по принципам западной цивилизации, т.е. построение «нового мирового порядка», в котором критерием демократичности и права на существование того или иного государства выступало бы соблюдение неких «единых» стандартов прав и свобод человека.

Как известно, при выработке любых правовых стандартов должны учитываться и согласовываться интересы всех субъектов правового регулирования. Однако критики доктрины юснатурализма и практики ее реализации в глобальном масштабе справедливо обращают внимание на то, что современные представления о неотчуждаемых правах человека формируются не путем согласования воль различных субъектов

1 Дамаскин О.B. Россия в современном мире: проблемы национальной безопасности. М.: Наука, 2007. С. 219. 
международного взаимодействия посредством демократической процедуры, а привносятся в сферу глобальных отношений из евро-атлантического пространства. А это значит, что для мирового сообщества права человека предстают не как нормы, в выработке которых все субъекты международного взаимодействия принимали равноправное участие, а как стандарты, предписанные откуда-то «свыше» некими «учителями жизни», которые предлагают всем свою интерпретацию идеологии естественных прав человека ${ }^{1}$.

Как отмечает Л.Н. Тарасова, «показательно, что проблема прав человека серьезно поднимается лишь в отношении тех государств, которые проводят политику, противоречащую интересам трансатлантического сообщества. Все это говорит об отсутствии легитимности в действиях гуманитарных интервентов» ${ }^{2}$.

Так называемая «борьба за права человека», отстаивание гуманитарных ценностей стали активным предлогом для вмешательства во внутренние дела государств, посягательства на их суверенитет. Роль высших судей, которые могут оценивать степень реализации и защищенности прав человека в том или ином государстве и выносить «приговоры», присвоили себе западные страны во главе с Соединенными Штатами ${ }^{3}$. Предполагается, что любое государство, прежде всего, обязано проводить проамериканскую политику и не препятствовать геополитическим планам США по управлению миром, иначе его демократия будет немедленно объявлена ненастоящей, а само государство тоталитарным ${ }^{4}$.

Критически оценивая «универсальные» правозащитные конструкции, зададимся вопросом: возможны ли «единые» стандарты прав человека, их реализация и защита в большинстве государств мирового сообщества? Даже

1 Зорькин В.Д. Право в условиях глобальных перемен. М.: Норма, 2013. С. 405.

2 Тарасова Л.Н. К дискуссии о правомерности гуманитарной интервенции // Вестник Волгоград. ун-та. Сер. 5, 2011. № 1.

${ }_{3}$ Пастухова Н.Б. Указ. соч. С. 169.

${ }^{4}$ Пастухова Н.Б. Указ. соч. С. 171-172. 
без учета неоднозначного характера выборочного использования концепции прав человека для провоцирования напряженности, внутренних и внешних конфликтов, ослабления и подрыва государственного суверенитета отдельных стран (СССР, Куба, КНР, Сербия, Ливия, Сирия и др.) адаптация этой концепции ко всем типам политических режимов и всем правовым системам представляется скорее идеалом.

По ряду причин невозможно разработать единый каталог прав человека и обязать мировое сообщество следовать ему:

1. В современном мире представлены совершенно разные общественные уклады. Место и роль человека в этих укладах и социумах заметно отличается в зависимости от стадии развития общества. Права человека в племени никогда не будут совпадать с правами человека в постиндустриальном обществе.

2. Теоретически допуская возможность равенства всех людей независимо от этнонациональной и государственной принадлежности, общих для большинства людей этических норм, сложно представить абстрактных универсальных людей с одинаковыми ценностями и традициями, которые будут одинаково понимать, ценить и повсеместно поддерживать именно права человека.

3. Права человека неразрывно связаны с этическим и религиознонравственным контекстом. Они не могут существовать и развиваться в вакууме, сами по себе. К примеру, права женщин в мусульманских странах по понятным причинам не будут совпадать с правами женщин в светских государствах. Права ЛГБТ вызывали и будут вызывать противоположную реакцию в «толерантных» протестантских европейских социумах и традиционных православных или исламских обществах. И никакие постановления ЕСПЧ, резолюции ПАСЕ, экономические санкции или 
бомбардировки НАТО не изменят в обозримом будущем эти оценки, укоренившиеся в общественном сознании ${ }^{1}$.

4. Заметно дифференцировано не только понимание прав человека, но и существующих механизмов и пределов их защиты. Где-то права и интересы защищаются главой семьи, где-то старейшиной, где-то в судах наложением штрафа, где-то на общем сходе - побиванием камнями и отрубанием руки. В ряде государств праву на жизнь органично корреспондирует запрет смертной казни, в других странах такой взаимосвязи нет.

Несмотря на свою неоднозначность, права человека позиционируются как «универсальный ограничитель» государственного суверенитета, определяющий пределы полноты и мощи государственной власти.

При этом не только права человека ограничивают государственный суверенитет, но и государственная власть обладает законной прерогативой ограничения прав человека в целях ЗГС.

Можно выделить несколько типичных ситуаций правомерного ограничения прав человека в целях ЗГС:

1. Введение исключительных правовых режимов (чрезвычайного положения, военного положения, контртеррористической операции).

2. Применение мер безопасности в общественных интересах (личный досмотр, досмотр вещей в местах массового скопления граждан и др.)

3. Санкционирование оперативно-розыской, разведывательной, контрразведывательной и уголовно-процессуальной деятельности спецслужб и правоохранительных органов.

4. Прекращение злоупотребления правом (запрет создания террористических структур, пресечение экстремистской пропаганды и др.).

1 Постановление ЕСПЧ о неправомерности запретов гей-парадов в Сербии и последующее решение национальных властей о возможности их проведения привело к беспорядкам и гибели значительного числа людей. 
5. Ограничение прав как мера наказания (например, лишение избирательного права как основное или дополнительное уголовное наказание, которое носит личный характер и назначается судом с учетом общественной опасности правонарушения).

По своей сути ЗГС допускает легитимную возможность подавления антиобщественных преступных элементов (ограничение прав членов террористических организаций, недопущение правонарушителей на выборные должности и др). при условии недопустимости произвольного ограничения государством основополагающих прав и свобод человека.

Таким образом, государственный суверенитет и права человека находятся в неразрывной взаимосвязи. Полновластие государства носит формально-бюрократический характер, если органы власти и управления не пользуются доверием граждан и не ориентированы на повышение народного благосостояния, улучшение условий жизни и труда граждан, здравоохранения, образования, культуры - другими словами, на формирование и развитие личности, наполнение ее потенциала и правосубъектности реальным содержанием. С помощью института прав человека может происходить сближение государства с обществом.

В то же время только сильное независимое государство может обеспечить и защитить права человека. Суверенитет и функциональность государства предполагают не только гарантирование максимально возможного объема прав и свобод, реализацию разнообразных потребностей и интересов, но и ответственность граждан и взаимные обязательства государства и членов общества по отношению друг к другу. 


\section{3. Влияние глобализации на государственный суверенитет}

Происходящие в современном мире процессы (либерализация законодательства, укрепление межгосударственных торговых связей, развитие транспорта, информационно-телекоммуникационных технологий, интегрированность валютных и фондовых рынков в мировую экономику, институционализация транснациональных корпораций и др.) объективно способствуют сближению государств. В различных регионах мира подобное сближение осуществляется в разных темпах и с соответствующими особенностями. Формой данного сближения выступает глобализация.

По своей сущности глобализация представляет собой высшую форму развития межгосударственной кооперации в форме частичного слияния отраслевых сегментов национальных экономик в интересах снижения себестоимости конечного продукта потребления.

Процесс глобализации охватывает все сферы общественной жизни:

- в социально-экономической сфере глобализация способствует развитию транснациональных корпораций и формированию обособленного класса «транснациональных» капиталистов;

- в политической сфере глобализация ведет к транснационализации политических элит, ориентированных на надгосударственное управление;

- в культурно-идеологической сфере способствует выработке и распространению коммерциализированной космополитической идеологии, унификации локальных культур.

Система мировой экономики в условиях глобализации организована в виде нескольких тесно связанных между собой групп сообществ: сообщества «центра», сообщества периферии и полупериферии. Внутри сообществ «центра» мировой экономики устанавливаются отношения кооперации и конкуренции. Между центром и периферией - отношения эксплуатации и зависимости. Полупериферия находится с центром и периферией в 
отношениях смешанного типа. Таким образом, сложившееся после окончания «холодной войны» условное деление стран по уровням экономического развития на «первый», «второй» и «третий» миры трансформировалось в классификацию государств, способных быстро адаптироваться к новым экономическим реалиям, и государств не готовых к этому.

Экономики готовых к адаптации государств стали ориентироваться на создание наукоемких и высокотехнологичных производств, продукции с высокой добавочной стоимостью и упрочили свои конкурентные преимущества. «Отстающие» страны не смогли в полной мере диверсифицировать собственные производственные мощности и фактически закрепили свое зависимое экономическое положение.

Более широкое понимание сущности глобализации сформулировал Б.С. Эбзеев, по мнению которого глобализация - «это длительный исторический процесс, сопровождающийся глобальной конкурентной борьбой, в которой активно используются средства политического, экономического, информационного и даже военного давления и по-разному распределяются ее негативные последствия и предоставляемые ею блага» ${ }^{1}$.

Ученый справедливо подчеркнул, что «характерные для современного мира конституционализация международных отношений и интернационализация внутригосударственного правопорядка, как и глобальные и региональные инфраструктуры и оформляющие их правовые системы, не в состоянии сами по себе гарантировать интересы участвующих в интеграционных процессах государств или блокировать экономическую или политическую экспансию отдельных государств или их группировок»².

1 Эбзеев Б.С. Личность и государство в России: взаимная ответственность и конституционные обязанности. М.: Норма, 2011. С. 17.

2 Эбзеев Б.С. Указ. соч. С. 17. 
Любое государство, претендующее на более заметную роль в глобальной экономике, должно отвечать определенным «стандартам» международных рыночных отношений. Процесс ассимиляции национальной экономики в глобальную систему мировых рыночных отношений основан на следующих ограничениях:

- государство обязано поддерживать низкий уровень инфляции;

- основой экономики должны стать предприятия частного сектора;

- государство обязано сократить расходы на содержание бюрократического аппарата;

- должны быть сокращены ввозные пошлины на импорт;

- должны быть сняты ограничения на иностранные инвестиции;

- должны децентрализироваться внутренние монополии;

- должен произойти отказ от квотирования на импортную продукцию;

- нерезидентам (иностранцам) должно предоставляться право осуществления сделок с ценными бумагами госкорпораций и естественных монополий и т.д.

Идеологами глобализации основы современного государственного планирования и национальные экономические приоритеты представляются избыточными. Во главу угла ставятся интересы «избранного» меньшинства транснациональных капиталистов как основы нового мирового правительства. Вот как описывает транснациональную элиту 3. Бжезинский: «Представители этой элиты свободно говорят по-английски и пользуются этим языком для ведения дел; эта новая глобальная элита характеризуется высокой мобильностью, космополитическим образом жизни; ее основная привязанность - место работы, обычно это какой-либо транснациональный бизнес или финансовая корпорация» ${ }^{1}$.

1 Бжезинский 3. Выбор: мировое господство или глобальное лидерство. М.: Международные отношения, 2010. С. 162. 
Обладая транснациональной лояльностью и высокими доходами, международная элита в наибольшей степени подготовлена к разрыву со своими государствами и переходу к глобальному управлению. Ресурсы, находящиеся в руках этих людей, предоставляют им практически неограниченные возможности для проведения своей политики, а интересы в значительно меньшей степени связаны с государственным суверенитетом ${ }^{1}$.

Рассматривая влияние глобализации на суверенные государства нельзя обойти вниманием общие положительные и отрицательные последствия глобализации для функционирования и развития государств в современных условиях.

В числе положительных последствий необходимо упомянуть: ускорение внедрения и распространение технических достижений и современных методов управления, новые экономические перспективы для государств и отдельных лиц, возможности обеспечения более высокого уровня жизни и т.п

О.В. Дамаскин указывает на положительные последствия адаптации национального государства к условиям глобализации с использованием стратегий выхода, сотрудничества и объединения:

«Выход государства из тех сфер, где его вмешательство не требуется, облегчает его деятельность и в тоже время дает ему возможность более решительно действовать в основных сферах политики. Элементы такой стратегии мы видим в процессе приватизации государственных предприятий, передачи полномочий на нижестоящий уровень.

Сотрудничество государств позволяет объединять ресурсы для осуществления проектов. Наиболее перспективной формой сотрудничества

${ }^{1}$ Брега А., Копылов И. Транснационализация политической элиты и влияние этого процесса на суверенитет государства // Россия и мусульманский мир: Научно - инф. бюллетень / РАН. ИНИОН. М., 2015. № 7 (277). С. 6.

2 Пастухова Н.Б. Глобализация и государственный суверенитет / Суверенная демократия в конституционно-правовом измерении. Сб. статей и материалов. М.: Рос. газ., 2007. C. 150. 
является разработка международных политических систем с участием лиц из сферы экономики и других негосударственных сфер, особенно в рамках ООН и ВТО.

Стратегия объединения основывается на официальной передаче суверенных прав наднациональным институтам. Наиболее развитой формой такого объединения является Европейский Союз. Практикуемая интеграция позволяет в большей степени объединять ресурсы национальных государств и регламентировать межгосударственные отношения, чем это было в рамках сотрудничества» ${ }^{1}$.

В тоже время глобализацию как процесс всемирной универсализации нельзя оценивать только в положительном смысле. Ее отрицательные проявления и последствия очевидны уже сегодня, и на них нужно своевременно реагировать. В числе негативных последствий глобализации можно вести речь:

a) о жестком давлении транснациональных корпораций на развитие национальных экономик, на процессы принятия политических и экономических решений;

б) об акценте на финансово-прибыльной стороне и недооценке социальных аспектов. Это ведет к массовым протестам и движению антиглобалистов, обеспокоенных перемещением центров принятия решений ${ }^{2}$;

в) о подавлении основ национального права и даже сокрушении отдельных институтов и отраслей законодательства под давлением «мировых императивов»;

1 Дамаскин О.В. Россия в современном мире: проблемы национальной безопасности. М.: Наука, 2007. С. 54-55.

${ }_{2}^{2}$ Н.Б. Пастухова указывает на растущее неравенство, когда получаемые выгоды и возможности концентрируются в относительно небольшом числе стран и неравномерно распределяются в самих этих странах, на связанное с этим нарастание уязвимости и маргинализации многих государств. См. Пастухова Н.Б. Указ. соч. С. 151. 
г) об ослаблении суверенитета государств путем ограничения возможностей их свободной деятельности и сокращения перечня традиционных внешних функций государства;

д) о жестких требованиях уставов межгосударственных объединений к национальным законодательствам ${ }^{1}$.

Важнейшим последствием глобализации стало ослабление роли национальных государств и критический пересмотр содержания государственного суверенитета.

Противоречие заключается в том, что современная международная система, создавшая условия для развития процесса глобализации, под его воздействием сама постепенно стала устаревать, а сформированные послевоенные институты международного сообщества оказались неготовыми эффективно функционировать в условиях глобального мира ${ }^{2}$. Закономерной реакцией на уменьшение роли и «вымывание» (hollowing out) государств стали концепции глобального управления (governance) и постсуверенного мирового порядка, в которых обосновывается т.н. «глобальная квазигосударственность» и «теряющие суверенность государства»³.

В.Д. Зорькин в качестве наиболее заметного направления глобализации рассматривает глобализацию труда, технологий и капитала, порождающую потоки трудовых мигрантов и беженцев и комплекс связанных с ними проблем социокультурного характера. Чем больше в ходе глобализации становится таких мигрантов, тем острее встает вопрос об их социальной, экономической, политической, нормативно-правовой интеграции в «коренную» социальную общность ${ }^{4}$.

${ }^{1}$ Тихомиров Ю.А. Указ. соч. С. 97.

2 Пастухова Н.Б. Указ. соч. С. 151.

3 Чешков М.А. Глобальный контекст постсоветской России. М., 1999; Хестанов Р. Россия без Ялты: Современный мир требует частичного отказа от суверенитета // Политический журнал. 2005. № 16 (67). С. 63-65.

4 Зорькин В.Д. Право в условиях глобальных перемен. М.: Норма, 2013. С. 423. 
Оценка основных результатов глобализации позволяет сделать следующие выводы:

- открыто декларируемые принципы и цели глобализации в государствах «центра» мировой экономики не применяются (ограниченно применяются) применительно к лидерам глобализации. При навязывании всему миру максимальной открытости экономики, децентрализации и дерегулирования в ведущих капиталистических государствах фактически выстраивают централизованный и суверенно регулируемый рыночный механизм, интересы которого обеспечиваются и защищаются мощным государственным аппаратом, кредитно-финансовыми инструментами, информационной и военной инфраструктурой;

- процессы глобализации усиливают мировое неравенство и приводят к маргинализации государств с развивающейся экономикой;

- продолжающееся закрепление отсталости, исключение из экономической модернизации государств с развивающейся экономикой ведут к росту социальной напряженности, миграционным процессам, эскалации этнонациональных и сепаратистских конфликтов, терроризму;

- процессы глобализации предоставляют криминальным структурам и террористам возможности доступа к современной технике и передовым технологиям;

- условием исключительности и процветания развитых стран в условиях глобальной экономики становится поддержание высокого уровня экологической безопасности, что предусматривает освобождение территории данных государств от загрязняющих веществ, перенос «вредных» производств и захоронений токсичных отходов на территорию развивающихся стран;

- острой проблемой глобализации является выхолащивание гуманистического начала, рекультуризация, кризис ценностей. Наиболее 
активная часть населения в этих условиях примыкает к разного рода антиглобалистским протестным движениям.

Включение суверенных государств в глобальные процессы протекало по-разному и зависело от множества факторов (общественно-политической стабильности, экономического потенциала, структуры экспортно-импортных операций, степени интегрированности национальных сегментов производства и финансово-кредитной системы в западно-европейские и американские институты (МВФ, МБРР, G-7 и др.).

Включение России в процесс экономической глобализации также имело несколько особенностей ${ }^{1}$. Во-первых, Россия 1990-х гг. встала на путь интеграции в мировое сообщество в период коренных перемен своего общественно-политического и экономического уклада. Во-вторых, приобщение России к мировым и региональным интеграционным процессам проходит в условиях, когда уже сложилась система международных организаций, регулирующих международные экономические, финансовые и торговые отношения. В силу этого РФ приходится играть по правилам, в разработке которых она не участвовала. В-третьих, страна вступила в современный этап глобализации резко ослабленной по сравнению с Советским Союзом, особенно в сфере экономики.

Данные обстоятельства привели к тому, что в отличие от внешнеполитической сферы, позиции России в глобальной экономике весьма скромны. Более того, слабая конкурентоспособность отечественных производителей, недостаточная государственная поддержка ряда отраслей экономики, санкции со стороны США и их союзников, претензии со стороны стран-членов ВТО на принятые Россией защитные (ограничительные) меры стали реальными угрозообразующими факторами, обусловившими рецессию основных экономических показателей и индикаторов, падение курса

${ }^{1}$ Внешняя политика России. Теория и практика / Под общей ред. С.В. Смульского, О.Д. Абрамовой М.: Книга и бизнес, 2013. С.119. 
национальной валюты, отток капитала, значительный рост стоимости импортных товаров, услуг и кредитов, сокращение рабочих мест.

Оценивая влияние глобализации на функционирование и развитие российского государства, необходимо подчеркнуть, что в настоящее время можно вести речь о формировании и реализации ряда вызовов государственному суверенитету Российской Федерации, связанных с процессами глобализации в социально-экономической, политической и культурно-идеологических сферах.

В качестве вызовов государственному суверенитету Российской Федерации, вызванных глобализацией в социально-экономической сфере, необходимо рассматривать:

слабость торгово-экономических позиций Российской Федерации в системе мирохозяйственных связей и мировом разделении труда;

дискриминацию российских товаров, услуг, инвестиций, экспортеров на международных рынках;

попытки «интернационализировать» природные богатства России под предлогом неэффективности их освоения на национальном уровне при остром дефиците жизненно-важных ресурсов и территорий в приграничных регионах;

критическую зависимость объектов экономики, транспорта и связи от иностранной программной и элементной базы, отсутствие конкурентоспособных национальных средств телекоммуникации, операционных систем и систем управления базами данных.

К вызовам государственному суверенитету Российской Федерации, связанным с глобализацией в политической сфере, можно отнести:

подрыв легитимности, снижение авторитета и координирующей роли универсальных международных организаций путем игнорирования США и их союзниками прерогатив СБ ООН, применения односторонних 
экстерриториальных санкций и мер силового воздействия против «государств-изгоев», включая вооруженную агрессию;

ревизию норм международного права под видом концепции «ответственности по защите», ориентированной на оказание политического давления, вмешательство во внутренние дела, дестабилизацию обстановки и смену политических режимов в суверенных государствах;

попытки навязывания России и ее союзникам дискриминационного сотрудничества с иностранными государствами, межгосударственными объединениями, международными организациями и форумами с использованием возможностей международных институтов с традиционным влиянием США, Западной Европы и Канады;

стремление США и их союзников к одностороннему наращиванию наступательных потенциалов на евро-атлантическом и азиатскотихоокеанском пространстве, обеспечению собственной безопасности за счет ущемления интересов внеблоковых государств.

Глобализация в культурно-идеологической сфере формирует следующие вызовы государственному суверенитету Российской Федерации:

соперничество ценностных ориентиров и попытки навязывания англосаксонских и европо-центристских подходов к демократии, правам человека, новейшей истории;

деструктивное использование правозащитных концепций для манипулирования общественным мнением и сознанием;

распространение массовой культуры, ориентированной на примитивные потребности маргинальных слоев и коммерческую прибыль.

Перечисленный комплекс вызовов государственному суверенитету России негативно влияет на устойчивое развитие общественных и государственных институтов, препятствует наращиванию национальной конкурентоспособности и превращению РФ в одну из лидирующих мировых держав. 
Рассматривая влияние глобализации на государственный суверенитет, необходимо подчеркнуть, что глобализация, как любое сложное, многомерное явление, носит диалектический характер и, наряду с вызовами, создает новые возможности. Положительный потенциал глобализации может использоваться суверенными государствами для продвижения конкурентной продукции национальных производителей, развития сферы услуг и коммуникаций, технологического перевооружения, вложения активов в перспективные коммерческие проекты, привлечения инвестиций.

В глобализирующемся мире условиями устойчивого развития государств являются: социально-политическая стабильность в стране; функциональность, многоукладность, инновационность и гибкость национальных секторов экономики; укомплектованность производства, сферы услуг, культурно-образовательных и медицинских учреждений, оборонно-промышленного комплекса квалифицированными кадрами и менеджментом, высокотехнологичным оборудованием; наличие эффективно функционирующих механизмов защиты государственного суверенитета (органы власти, суды, армия, полиция, разведка, контрразведка и др.); четкое формулирование и последовательная защита национальных интересов на разноформатных международных форумах и диалоговых площадках; уважение и учет взаимовыгодных интересов других государств; минимизация репрессивных и силовых мер принуждения в сфере внутренней и внешней политики. Развитие любых государств в современных условиях сопровождается глобализацией, воздействие которой может приводить к отрицательным или положительным последствиям для государственных и общественных институтов. Своевременное прогнозирование и адекватный учет возникающих вызовов, гибкое использование преимуществ глобальной экономики препятствуют формированию и реализации угроз государственному суверенитету, создают предпосылки для всестороннего развития государства, гражданского общества и личности. 


\section{4. Теории «ограниченного» суверенитета и механизмы} государственной интеграции в федеративных государствах

Развитие федеративных отношений требует осмысления государственного суверенитета с учетом особенностей федеративного государственного устройства.

Вопрос о суверенитете в союзном (федеративном) государстве имеет как теоретический, так и практический аспекты ${ }^{1}$. Решение этого вопроса предполагает различное распределение компетенции между федеральными и региональными органами государственной власти, их взаимоотношения, пределы прав Федерации в отношении ее субъектов и субъектов в отношении Федерации.

Степень правовой и политической самостоятельности членов федерации диктуется экономическими, историческими или национальными особенностями жизни общества. При наличии тенденций интеграционного или дезинтеграционного характера эта степень самостоятельности может либо способствовать, либо препятствовать укреплению или развалу федерации ${ }^{2}$.

Автор считает справедливой точку зрения Черняк Л., по мнению которой «суть государственного суверенитета остается неизменной вне зависимости от формы государственного устройства» ${ }^{3}$.

Необходимо отметить, что существование суверенитета как единой, верховной и независимой государственной власти ставится под сомнение сторонниками деления государственного суверенитета в федеративном государственном устройстве, в связи с чем проблема делимости (единства)

1 Унитарное государство участвует в международных отношениях как единый субъект международного права, в связи с чем вопрос о правосубъектности его составных частей не возникает.

${ }_{2}^{2}$ Международное право / Под ред. А.А. Ковалева, С.В. Черниченко. М.: Омега - Л, 2006. C. 155.

${ }_{3}$ Черняк Л.Ю. С. 119. 
государственного суверенитета в федеративных государствах является одной из наиболее дискуссионных.

Существует несколько теоретических подходов к делению суверенитета между федерацией и ее составными частями (субъектами).

Классическая теория «делимости» суверенитета допускает разграничение суверенитетов по территории и по предметам ведения. По мнению сторонников данной теории (Мэдисон, Токвиль, Вайц), федеральные власти и власти субъектов параллельно действуют на одной территории, но каждая из них осуществляет собственные полномочия и в пределах своего предмета ведения одинаково суверенна. Правовым аргументом «делимости» суверенитета стало решение Верховного Суда США 1793 г., в котором было закреплено, что «любой штат в Союзе, в котором его суверенитет не был делегирован Соединенным Штатам, также является полностью суверенным, как и Соединенные Штаты в отношении переданных им прав. Соединенные Штаты суверенны в отношении всех полномочий власти, переданных им; каждый штат в Союзе суверенен в отношении всех зарезервированных за ним полномочий» ${ }^{1}$.

Указанный подход подвергся обоснованной критике.

Как отмечал Г. Еллинек, «суверенитет логически представляет собой превосходную степень; он не поддается раздроблению и терпит рядом с собой только однопорядковые величины того же вида» ${ }^{2}$. Данную позицию разделяет А.В. Зиновьев: «суверенитет - категория недробная: либо он есть в полном объеме, либо его нет совсем. Дозировка суверенитета исключена» ${ }^{3}$. Последовательным противником «ограниченного суверенитета» выступает

1 Willowghby G. The fundamental concepts of public law. № 5, 1924. P. 225.

${ }^{2}$ Еллинек Г. Общее учение о государстве. СПб., 2004. С. 477-478.

3 Зиновьев А.В. Федеративное устройство России: проблемы и перспективы // Правоведение. 1997. № 3. С. 10. 
Б.А. Страшун: «Если суверенитет, т.е. верховенство власти, ограничен, то он уже не является суверенитетом» ${ }^{1}$.

Современное конституционное право исходит из того, что субъекты федерации, даже обладающие значительными полномочиями, не являются суверенными государствами, поскольку эти полномочия добровольно переданы им и осуществляются на основе принципов, установленных федерацией. Субъект федерации не может обладать важнейшими признаками государственного суверенитета: верховенством и независимостью. Регионы не обладают верховенством власти на своей территории и не могут быть самостоятельными участниками международных отношений ${ }^{2}$. Кроме того, государственный суверенитет нельзя отождествлять с компетенцией государственных органов. Разделение компетенции не означает деления государственного суверенитета. Как отмечает Н.Б.Пастухова, «вместо «делимости суверенитета» в федеративных государствах правильней говорить о делегировании полномочий»»»³.

По мере развития федеративных отношений возникли новые теории государственного суверенитета, которые можно условно объединить под названием «теории единства государственного суверенитета». Как полагают сторонники данного подхода, субъекты федерации не обладают государственным суверенитетом и не могут называться государствами, т.к. народ субъекта представляет часть народа федерации, территории субъектов включены в территорию федеративного государства, а региональная власть подчиняется федеральному центру. Роль и место субъектов федерации проявляется в участии в формировании и реализации общегосударственного суверенитета.

${ }^{1}$ Конституционное (государственное) право зарубежных стран. Общая часть / Под ред. Б.А. Страшуна. М.: БЕК, 1997. С. 703.

2 Только Федерация в целом является субъектом международного права. Как отмечается в ст. 2 Межамериканской конвенции о правах и обязанностях государств 1933 г., «федеративное государство составляет только одно лицо перед международным правом».

${ }^{3}$ Пастухова Н.Б. С. 280. 
Возникновение различных типов федераций, расширение внешних региональных связей обусловило появление теорий «ограниченного» государственного суверенитета субъектов Федерации или союзного государства в целом. Большинство последователей данных теорий исходит из того, что суверенитет принадлежит Федерации, а ее субъекты обладают «ограниченным» («остаточным»), «мягким» государственным суверенитетом, лимитированным общегосударственными целями Федерации ${ }^{1}$. Сторонники «ограниченного» суверенитета Федерации исходят из необходимости международно-правового «ограничения» суверенитета федерального государства в интересах гармонизации международных отношений ${ }^{2}$. Признание двух взаимообусловленных, дополняющих друг друга суверенитетов на территории одного государства означает игнорирование сущности государственного суверенитета и представляется несостоятельным. Суверенитет является имманентным свойством государства в целом, поэтому признание «ограниченного суверенитета», «номинального суверенитета», «остаточного суверенитета» и т.п. суверенитетов субъектов федеративного государства нарушает саму природу государственного суверенитета. Не может быть «ограниченного» государственного суверенитета внутри «полного» государственного суверенитета. Ограничение суверенитета федеративного государства является признаком разрушения союзной государственности и деградации федеративных отношений.

Анализируя последствия применения теорий «ограниченного суверенитета» против России, А.Н. Кольев отмечает, что данная концепция,

1 См. Енгибарян Р.В., Тадевосян Э.В. О некоторых дискуссионных теоретикометодологических вопросах курса конституционного права // Государство и право. 2001. № 1. С. 20; Тадевосян Э.В. К вопросу о характере государственной власти // Государство и право. 2002. № 3. С.22; Шахрай С.М. Конституционное правосудие в системе российского федерализма: Монография. СПб: Санкт-Петербургский университет МВД России, 2001. С. 29; Тэпс Д. Концептуальные основы федерализма. СПб., 2002. С. 126.

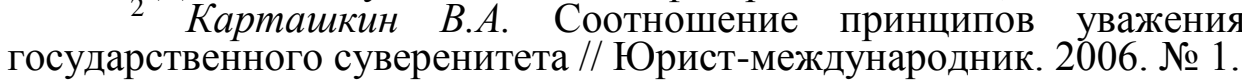

прав человека и 
прежде всего, связывается с размыванием понятия «суверенитет», с попытками поставить под вопрос наличие верховной власти в государстве: «Во внутренней политике это стимулирует конфедерализацию, во внешней все большую открытость страны для разного рода «гуманитарных» организаций, вмешивающихся в государственные дела...1». В результате исследования проблем государственного суверенитета в федеративных государствах А.Н. Кольев приходит к выводу, что «обусловленность концепций «мягкого» суверенитета политической коньюнктурой делает их сомнительными и опасными для национальной безопасности большинства государств» ${ }^{2}$.

Обобщение перечисленных теоретических подходов свидетельствует, что наиболее приемлемыми и жизнеспособными являются теории единства государственного суверенитета федеративных государств, которые фиксируют интегративную роль Федерации и отражают свойство союзного государства быть единственной политической организацией, управляющей делами общества и обладающей верховенством внутри страны и за ее пределами.

Наряду с тематикой «деления» государственного суверенитета между федерацией и ее составными частями, актуальными представляются вопросы разграничения предметов ведения и полномочий в федеративных государствах.

Как правило, полномочия субъектов федерации закрепляются по «остаточному принципу», после перечня исключительных полномочий федерации и совместных полномочий федерации и ее субъектов.

Субъекты федерации не обладают государственным суверенитетом, хотя в отдельных конституциях (Мексика, Швейцария) предусмотрен

${ }^{1}$ Кольев А.Н. Нация и государство. Теория консервативной реконструкции. М.: Логос, 2005. С. 246.

${ }^{2}$ Кольев А.Н. Указ соч. С. 263. 
суверенитет субъектов «во внутренних делах» (при решении вопросов местного значения).

Согласно ст. 71 Конституции РФ в ведении РФ находятся:

принятие и изменение Конституции РФ и федеральных законов, контроль за их соблюдением; федеративное устройство и территория РФ; регулирование и защита прав и свобод человека и гражданина; гражданство; регулирование и защита прав национальных меньшинств; установление системы федеральных органов законодательной, исполнительной и судебной власти, порядка их организации и деятельности; формирование федеральных органов государственной власти; федеральная государственная собственность и управление ею; установление основ федеральной политики и федеральные программы в области государственного, экономического, экологического, социального, культурного и национального развития РФ; установление правовых основ единого рынка; финансовое, валютное, кредитное, таможенное регулирование, денежная эмиссия, основы ценовой политики; федеральные экономические службы, включая федеральные банки; федеральный бюджет; федеральные налоги и сборы; федеральные фонды регионального развития; федеральные энергетические системы, ядерная энергетика; федеральные транспорт, пути сообщения, информация и связь; деятельность в космосе; внешняя политика и международные отношения РФ, международные договоры РФ; вопросы войны и мира; внешнеэкономические отношения РФ; оборона и безопасность; оборонное производство; определение порядка продажи и покупки оружия, боеприпасов, военной техники и другого военного имущества; производство ядовитых веществ, наркотических средств и порядок их использования; определение статуса и защита государственной границы, территориального моря, воздушного пространства, исключительной экономической зоны и континентального шельфа РФ; судоустройство; прокуратура; уголовное и уголовно-исполнительное законодательство; амнистия и помилование; 
гражданское законодательство; процессуальное законодательство; правовое регулирование интеллектуальной собственности; федеральное коллизионное право; метеорологическая служба, стандарты, эталоны; геодезия и картография; государственные награды и почетные звания РФ; федеральная государственная служба.

Автор разделяет точку зрения Т.С. Мелешкиной, что предмет исключительного ведения РФ составляют т.н. «неотчуждаемые права Федерации, потеря которых означает лишение государством статуса государственного суверенитета» ${ }^{1}$. Именно исключительная компетенция Федерации обеспечивает единство союзного суверенитета, экономическую, политическую, правовую, социально-культурную целостность федеративного государства.

В совместном ведении РФ и субъектов РФ находятся:

а) обеспечение соответствия конституций и законов республик, уставов, законов и иных нормативных правовых актов краев, областей, городов федерального значения, автономной области, автономных округов Конституции РФ и федеральным законам;

б) защита прав и свобод человека и гражданина; защита прав национальных меньшинств; обеспечение законности, правопорядка, общественной безопасности; режим пограничных зон;

в) вопросы владения, пользования и распоряжения землей, недрами, водными и другими природными ресурсами;

г) разграничение государственной собственности;

д) природопользование; охрана окружающей среды и обеспечение экологической безопасности; охрана памятников истории и культуры;

е) общие вопросы воспитания, образования, науки, культуры, физической культуры и спорта;

1 Мелешкина T.C. Политико-правовые механизмы защиты государственного суверенитета российского государства. Дис. ...канд. юрид. наук. Р-н-Д, 2008. С. 66. 
ж) координация вопросов здравоохранения; защита семьи, материнства, отцовства и детства; социальная защита;

з) осуществление мер по борьбе с катастрофами, стихийными бедствиями, эпидемиями, ликвидация их последствий;

и) установление общих принципов налогообложения и сборов в РФ;

к) административное, административно-процессуальное, трудовое, семейное, жилищное, земельное, водное, лесное законодательство, законодательство о недрах, об охране окружающей среды;

л) кадры судебных и правоохранительных органов; адвокатура, нотариат;

м) защита исконной среды обитания и традиционного образа жизни малочисленных этнических общностей;

н) установление общих принципов организации системы органов государственной власти и местного самоуправления;

о) координация международных и внешнеэкономических связей субъектов РФ, выполнение международных договоров РФ.

Вне пределов ведения РФ и полномочий РФ по предметам совместного ведения РФ и субъектов РФ субъекты РФ обладают всей полнотой государственной власти.

Конституциями большинства федеративных государств допускается осуществление (при обязательном соблюдении конституционного принципа единства внешней политики государства) внешних связей.

Так, Основной закон ФРГ предоставляет возможность землям в той мере, в какой они обладают законодательной компетенцией, и согласия федерального правительства заключать договоры с иностранными государствами (ч.3 ст. 32). Раздел 10 ст. 1 Конституции США допускает возможность договорных отношений штатов с другими штатами или иностранной властью при согласии Конгресса. 
Принципиально иное решение содержится в параграфе 1 статьи 127 и параграфе 1 статьи 130 Конституции Бельгии: субъекты бельгийской федерации (сообщества и регионы) обладают в пределах своих полномочий правом заключения международных договоров, которое не обусловлено согласием федеральных органов ${ }^{1}$.

Согласно пункту «о» ч.1 ст. 72 Конституции РФ координация международных и внешнеэкономических связей субъектов РФ относится к совместному ведению РФ и ее субъектов.

Автор разделяет точку зрения С.О. Алехновича, что «применительно к международной деятельности субъектов Федерации российское законодательство не случайно использует термин «связи», а не «отношения», подчеркивая тем самым неполитический характер этой деятельности»².

В соответствии с Федеральным законом от 4 января 1999 г. (с изм. от 13 июля 2015 г.) № 4-Ф3 «О координации международных и внешнеэкономических связей субъектов Российской Федерации» субъекты РФ обладают правом на осуществление международных и внешнеэкономических связей с субъектами иностранных федеративных государств, административно-территориальными образованиями иностранных государств, а также на участие в деятельности международных организаций в рамках органов, созданных специально для этой цели. С согласия Правительства РФ такие связи могут осуществлять и с органами государственной власти иностранных государств.

Согласно Определению Конституционного Суда РФ от 27 июня 2000 г. № 92-О «республика не может быть субъектом международного права в качестве суверенного государства и участником соответствующих межгосударственных отношений». Как отмечают Г.В. Игнатенко и О.И.

\footnotetext{
${ }^{1}$ Международное право / Под ред. Г.В. Игнатенко, О.И. Тиунова. М.: Норма, 2002. C. 77.

2 Алехнович С.О. Международные связи регионов и экономическая безопасность России // Законодательство и экономика. 2003. № 2.
} 
Тиунов, при толковании этого положения допустим акцент именно на отрицании суверенного статуса субъектов Федерации, что означает признание и осуществление не основанных на суверенитете международных и внешнеэкономических связей ${ }^{1}$.

Отсутствие государственного суверенитета (самостоятельной международной правосубъектности) субъектов РФ подтверждается следующими взаимосвязанными нормативными положениями:

- полномочия по осуществлению международных и внешнеэкономических связей устанавливаются Конституцией РФ и федеральными законами;

- координация международных и внешнеэкономических связей субъектов РФ возлагается на федеральные органы исполнительной власти в порядке, устанавливаемом Президентом РФ по предложению Правительства РФ;

- права субъектов РФ заключать соглашения с иностранными партнерами (за исключением органов государственной власти иностранных государств), иметь свои представительства на территориях иностранных государств и давать согласие на открытие на своей территории представительств иностранных федеративных государств и административно-территориальных образований иностранных государств предоставляются по согласованию с МИД России ${ }^{2}$;

- право осуществлять международные и внешнеэкономические связи предоставляется субъектам Федерации с согласия Правительства РФ;

\footnotetext{
C. 77 .

${ }^{1}$ Международное право / Под ред. Г.В. Игнатенко, О.И. Тиунова. М.: Норма, 2002.

2 В соответствии с п.6.1 Приказа МИД России от 22 ноября 2011 г. № 21341 «Об утверждении Положения о территориальном органе - Представительстве Министерства иностранных дел Российской Федерации на территории Российской Федерации» представительства МИД России на территории РФ обеспечивают соблюдение принципа единства внешней политики РФ и установленного федеральным законодательством общего порядка координации международных связей субъектов Федерации.
} 
- органы государственной власти субъекта Федерации заблаговременно уведомляют соответствующие федеральные органы исполнительной власти о вступлении в переговоры о заключении соглашений об осуществлении международных и внешнеэкономических связей и согласуют проекты таких соглашений с заинтересованными федеральными органами исполнительной власти;

- соглашения, заключенные органами государственной власти субъекта Федерации, подлежат обязательной государственной регистрации в порядке, установленном Правительством РФ. Незарегистрированные соглашения не вступают в силу;

- вступившие в силу соглашения, в случае их противоречия Конституции РФ, федеральным законам, нормам международного права и международным договорам РФ, могут оспариваться в судебном порядке;

- действие соглашений, содержащих положения, которые противоречат Конституции РФ, федеральным законам, нормам международного права и международным договорам РФ, могут в соответствии с Конституции РФ приостанавливаться до решения этого вопроса соответствующим судом;

- соглашения, заключенные органами государственной власти субъекта РФ, независимо от формы, наименования и содержания не являются международными договорами;

- представительства субъектов Федерации на территориях иностранных государств, а также иностранные представительства на территории субъекта Федерации не обладают статусом дипломатических представительств, на них не могут быть возложены консульские или дипломатические функции. Работники указанных представительств не пользуются дипломатическими привилегиями и иммунитетами.

Дополнительные правомочия субъектов РФ в области внешнеэкономических связей предусмотрены Федеральным законом от 8 
декабря 2003 г. № 164-Ф3 «Об основах государственного регулирования внешнеторговой деятельности» ${ }^{1}$. В соответствии со ст.8 данного закона к их числу отнесены следующие полномочия:

- проведение переговоров и заключение соглашений об осуществлении внешнеэкономических связей с субъектами иностранных федеративных государств, административно-территориальными образованиями иностранных государств, а также с согласия Правительства РФ с органами государственной власти иностранных государств;

- содержание своих представителей при торговых представительствах РФ в иностранных государствах за счет средств бюджетов субъектов РФ по согласованию с уполномоченными федеральными органами исполнительной власти (Минпромторг России и МИД России);

- открытие представительств в иностранных государствах в целях реализации соглашений об осуществлении внешнеэкономических связей;

- формирование и реализация региональных программ внешнеторговой деятельности;

- информационное обеспечение внешнеторговой деятельности на территории субъекта РФ;

- создание страховых и залоговых фондов в области внешнеторговой деятельности на территории субъекта РФ.

В целях полноценного учета региональных интересов и обеспечения единства суверенитета федеративного государства законом (ст. 9) определено, что проекты планов и программ развития внешнеторговой деятельности, разрабатываемые Минпромторгом России, затрагивающие интересы субъектов РФ, согласовываются с органами исполнительной власти субъектов РФ. В свою очередь, органы исполнительной власти субъектов РФ обязаны информировать Минпромторг России обо всех действиях,

\footnotetext{
${ }^{1}$ СЗ РФ. 2003. № 50. Ст. 4850.
} 
предпринятых субъектом РФ по вопросам совместного ведения РФ и субъектов РФ в области внешнеторговой деятельности.

Взаимоотношения федеральных и региональных органов власти в рамках реализации внешнеэкономических и внешнеторговых связей, как правило, в достаточной степени урегулированы законодателем и соответствуют конституционным принципам. Проблемные аспекты возникают, главным образом, в связи с прямыми контактами иностранных органов государственной власти с региональными.

Как отмечает С.О. Алехнович, «политика ведущих иностранных государств по вопросам, касающимся российского федерализма и международных связей субъектов РФ, весьма избирательна. Внешне она вполне корректна - на официальном уровне США и другие западные государства высказываются за сохранение территориальной целостности России, укрепление политических и экономических основ ее федеративного устройства, выражают готовность этому содействовать. В сотрудничестве с субъектами РФ эти страны придерживаются в основном российских норм и правил, регулирующих внешние связи регионов. Реализуемые проекты приносят субъектам РФ определенную пользу. В то же время во внешней политике ведущих зарубежных государств в отношении России в последнее время прослеживается стремление задействовать ее региональную составляющую путем обхода федерального центра, устанавливать и развивать связи с органами государственной власти субъектов РФ, региональными политиками, ориентировать свои деловые круги на сотрудничество с предпринимателями на местах» ${ }^{1}$.

Вопросы государственного суверенитета в федеративных государствах предполагают не только распределение компетенции, наличие двойной системы государственного аппарата, законодательства и налогов, но и

${ }^{1}$ Алехнович С.О. Международные связи регионов и экономическая безопасность России // Законодательство и экономика. 2003. № 2. 
создание организационно-правовых механизмов защиты единства союзного государства. В большинстве федераций к таким механизмам относятся институты федерального вмешательства, принуждения или интервенции ${ }^{1}$.

Сущность федеральной интервенции состоит в понуждении органов власти (должностных лиц) субъектов федерации к исполнению конституционных обязанностей по осуществлению властных полномочий, защите законных прав и интересов граждан, обеспечению единства правового и экономического пространства, территориальной целостности и общегосударственной суверенности.

Федеральная интервенция допускается конституцией при наличии ряда оснований (массовые беспорядки, отсутствие конституционных властей в субъекте, иностранное вторжение в субъект федерации, систематическая неуплата субъектом федеральных налогов и др.).

В.Е Чиркин выделяет несколько форм федерального принуждения²:

1) введение чрезвычайного положения в субъекте федерации (ограничиваются его права, могут создаваться федеральные органы управления в субъекте);

2) введение президентского правления (законодательные и исполнительные органы государственной власти субъекта распускаются, а их полномочия осуществляет представитель президента) ${ }^{3}$;

3) назначение уполномоченного федерального правительства для управления в субъекте (ФРГ);

4) приостановление собственного управления субъекта и передача управления субъектом на определенный срок одному из министров ${ }^{1}$;

1 Организационно-правовые механизмы защиты единства союзного государства предполагают не только институты федерального вмешательства, но и участие субъектов в решении общегосударственных вопросов. Этому служит представительство субъектов в федеральном парламенте, при органах исполнительной власти, участие в заключении международных договоров, затрагивающих интересы субъектов.

2 Сравнительное конституционное право / Под ред. В.Е. Чиркина. М.: Международные отношения, 2002. С. 284.

З Конституцией Индии предусмотрено введение президентского правления в штатах на срок до 2 лет. 
5) применение Вооруженных сил для восстановления конституционного порядка в субъектах федерации ${ }^{2}$;

6) резервирование законов субъекта на усмотрение главы государства ${ }^{3}$;

7) федеральное законодательное замещение (федерация издает законы по вопросам компетенции субъектов федерации (Австрия, Германия).

Нам близка позиция А.Н. Добрина о том, что институт федеральной интервенции «определяется самой природой федеративного устройства, которая предполагает не только разграничение предметов ведения, но и диктует необходимость обеспечения единства экономической и политикоправовой организации союзного государства, закрепления механизмов государственной интеграции, объединяющей субъекты федерации. Институт федеральной интервенции является, таким образом, признаком подлинно федералистских отношений в федеративном государстве ${ }^{4}$ ».

Федеральная интервенция не сводится исключительно к принудительным мерам по отношению к органам власти и должностным лицам субъектов Федерации ${ }^{5}$, а означает, в первую очередь, механизм взаимного контроля и ответственности Федерации и регионов.

Для обеспечения государственной интеграции Федерация передает субъектам отдельные властные полномочия, осуществляет их финансовое

${ }^{1}$ В Папуа - Новой Гвинее предусмотрена возможность передачи управления субъектом на срок до 9 месяцев.

2 Допускается в федерациях Латинской Америки (Аргентина, Бразилия и др.) (Индия, Пакистан)

Закон субъекта федерации не вступает в силу без согласия главы государства

4 Домрин А.Н. Режим чрезвычайного положения. Опыт правового регулирования в зарубежных странах. М., 1992. С. 103-104.

${ }^{5}$ Необходимость укрепления федеральной власти вызвана рядом причин. В первую очередь, без федеральной власти невозможно само существование федерации. Федеральный центр задает общенациональные стандарты в различных сферах, которые призваны создать равные условия жизни для всех граждан федеративного государства, обеспечить реализацию прав и свобод человека и гражданина, а также единообразные правила для предпринимательской деятельности, исключающие региональные барьеры. Защита окружающей среды, создание системы глобальной безопасности, решение других проблем мирового значения требуют усиления роли федеральных органов власти. См. Фарукшин A.M. Проблемы федеративных отношений в решениях конституционных судов // Журнал российского права. 2007. № 8. 
обеспечение и контроль. Реализацию данного механизма можно рассмотреть на примере Российской Федерации.

В соответствии с Федеральным законом от 6 октября 1999 г. (в ред. от 5 октября 2015 г.) № 184-Ф3 «Об общих принципах организации законодательных (представительных) и исполнительных органов государственной власти субъектов Российской Федерации» полномочия органов государственной власти субъекта РФ по предметам совместного ведения осуществляются данными органами самостоятельно за счет средств бюджета субъекта РФ. Осуществление указанных полномочий может дополнительно финансироваться за счет средств федерального бюджета и государственных внебюджетных фондов РФ, в том числе в соответствии с федеральными целевыми программами.

Федеральными законами органам государственной власти субъектов РФ могут передаваться полномочия РФ по предметам ведения РФ, а также полномочия РФ по предметам совместного ведения РФ и субъектов РФ. Финансовое обеспечение полномочий, переданных органам государственной власти субъектов РФ, осуществляется за счет субвенций из федерального бюджета. Дополнительно в пользование либо в собственность субъектов Федерации может передаваться федеральное имущество.

В целях выравнивания уровня бюджетной обеспеченности субъектов РФ в составе федерального бюджета предусматриваются дотации на финансовую поддержку субъектов. Для долевого финансирования инвестиционных программ и проектов развития инфраструктуры регионального значения бюджету субъекта РФ из федерального бюджета может предоставляться финансовая помощь в виде субсидий.

Организацию, контроль и мониторинг эффективности и качества осуществления переданных органам государственной власти субъектов РФ полномочий осуществляют федеральные органы исполнительной власти, которые вправе: 
- вносить высшему исполнительному органу государственной власти субъекта РФ предписания (представления) об устранении нарушений, выявленных при осуществлении переданных полномочий;

- вносить высшему должностному лицу субъекта РФ представления об освобождении от занимаемой должности его заместителей и руководителей соответствующих органов исполнительной власти субъекта РФ, ответственных за осуществление переданных полномочий, в случаях их ненадлежащего исполнения (неисполнения);

- давать высшим должностным лицам субъектов РФ обязательные для исполнения указания по вопросам осуществления переданных полномочий, в том числе в случаях, если требуется координация их осуществления органами государственной власти нескольких субъектов РФ.

Показатели (критерии) оценки эффективности и качества осуществления органами исполнительной власти субъектов РФ переданных полномочий устанавливаются Правительством РФ.

Автор критически оценивает делегирование полномочий РФ по предметам ведения РФ органам государственной власти субъектов Российской Федерации.

Во-первых, передача исключительных полномочий Федерации в ведение субъектов выхолащивает саму суть суверенных прав союзного государства и фактически приводит к сокращению правосубъектности федерального государства.

Во-вторых, делегирование исключительных федеральных полномочий (даже если теоретически допустить возможность изъятия части правосубъектности союзного государства без ущерба для суверенитета Федерации) нарушает баланс в разграничении предметов ведения и полномочий.

В-третьих, если исключительные полномочия Федерации передаются отдельным субъектам, это приводит к неравенству (асимметрии) 
конституционно-правового статуса различных частей Федерации и стремлению остальных субъектов Федерации к получению дополнительных прав и преференций. Если федеральные полномочия перераспределяются между всеми субъектами, подобный конституционно-правовой «эксперимент» означает ползучую трансформацию федеративных отношений в конфедеративные с перспективой последующего усиления сепаратистских тенденций ${ }^{1}$.

Вариантом решения данной проблемы может служить выравнивание конституционно-правового статуса всех частей Федерации вместо раздачи «избранным» регионам общегосударственных властных полномочий в ущерб остальным субъектам.

Отдельные полномочия органов государственной власти субъекта РФ могут быть временно возложены на федеральные органы государственной власти и (или) должностных лиц, назначаемых федеральными органами государственной власти, в случаях, если²:

а) в связи со стихийным бедствием, с катастрофой, иной чрезвычайной ситуацией органы государственной власти субъекта РФ отсутствуют и не могут быть сформированы;

б) возникшая вследствие решений, действий или бездействия органов государственной власти субъекта РФ просроченная задолженность субъекта РФ по исполнению долговых и (или) бюджетных обязательств превышает 30\% собственных доходов бюджета субъекта РФ в последнем отчетном году;

${ }^{1}$ Правовая позиция Конституционного Суда РФ, сформулированная в пункте 1 Постановления от 7 июня 2000 г. № 10-П по делу о проверке конституционности отдельных положений Конституции республики Алтай и Федерального закона «Об общих принципах организации законодательных (представительных) и исполнительных органов государственной власти субъектов РФ», закрепляет недопустимость передачи полномочий РФ по предметам ее ведения субъектам РФ.

Правовой режим временного осуществления федеральными органами государственной власти отдельных полномочий органов государственной власти субъекта РФ установлен в статье 26.9 Федерального закона от 6 октября 1999 г. (в ред. от 5 октября 2015 г.) № 184-Ф3 «Об общих принципах организации законодательных (представительных) и исполнительных органов государственной власти субъектов Российской Федерации». 
в) при реализации полномочий, осуществляемых за счет предоставления субвенций из федерального бюджета, исполнительным органом государственной власти субъекта РФ допускается нарушение Конституции РФ, федерального закона, нормативных правовых актов Президента и Правительства РФ, если такое нарушение установлено соответствующим судом.

В случае отсутствия или невозможности формирования органов государственной власти субъекта РФ временное осуществление федеральными органами государственной власти полномочий органов государственной власти субъекта РФ осуществляется по решению Президента, согласованному с Советом Федерации. При этом на федеральные органы государственной власти не могут быть возложены полномочия органов государственной власти субъекта РФ по принятию конституции (устава) субъекта РФ и поправок к ней (нему), по установлению системы органов государственной власти субъекта РФ, по изменению статуса субъекта РФ и по изменению границ между субъектами РФ.

При наличии просроченной задолженности в субъекте РФ по ходатайству Правительства решением Верховного Суда РФ вводится временная финансовая администрация. Временная финансовая администрация принимает меры по реструктуризации просроченной задолженности субъекта РФ, подготавливает проект бюджета субъекта на очередной год, представляет данный законопроект в законодательный орган государственной власти субъекта РФ, обеспечивает контроль за исполнением бюджета субъекта РФ и осуществляет иные полномочия, предусмотренные Бюджетным кодексом РФ.

В случае нарушения порядка реализации полномочий за счет субвенций из федерального бюджета, подтвержденного судом, решение о временном осуществлении полномочий федеральными органами 
исполнительной власти принимается Правительством РФ с одновременным изъятием соответствующих субвенций из бюджета субъекта Федерации.

Институт федеральной интервенции неразрывно связан с конституционно-правовой ответственностью органов государственной власти субъекта РФ.

В соответствии со ст. 29 Федерального закона от 6 октября 1999 г. (в ред. от 5 октября 2015 г.) № 184-Ф3 «Об общих принципах организации законодательных (представительных) и исполнительных органов государственной власти субъектов Российской Федерации» Президент РФ вправе приостановить действие нормативного правового акта высшего должностного лица субъекта РФ, а также действие нормативного правового акта органа исполнительной власти субъекта РФ в случае противоречия этого акта Конституции РФ, федеральным законам, международным обязательствам РФ или нарушения прав и свобод человека и гражданина до решения этого вопроса соответствующим судом.

Если судом установлено несоответствие изданного нормативного правового акта Конституции, федеральным законам или международным обязательствам, а высшее должностное лицо субъекта РФ в течение 2 месяцев со дня вступления в силу решения суда либо в течение иного предусмотренного судом срока не приняло мер по исполнению судебного решения, Президент РФ выносит предупреждение высшему должностному лицу субъекта ${ }^{1}$.

Аналогичное предупреждение Президента выносится в случае уклонения высшего должностного лица в течение 2 месяцев со дня издания указа Президента РФ о приостановлении действия нормативного правового

${ }^{1}$ Согласно п.3.2 ст.29.1 Федерального закона от 6 октября 1999 г. (в ред. от 5 октября 2015 г.) № 184-Ф3 «Об общих принципах организации законодательных (представительных) и исполнительных органов государственной власти субъектов Российской Федерации» неисполнение решения Конституционного Суда РФ в отношении нормативного правового акта высшего должностного лица субъекта РФ является основанием для отрешения Президентом высшего должностного лица субъекта РФ от должности. 
акта высшего должностного лица либо органа исполнительной власти субъекта РФ от издания нормативного правового акта, предусматривающего отмену приостановленного нормативного правового акта, или от внесения в указанный акт изменений, если в течение этого срока высшее должностное лицо не обратилось в суд для разрешения спора.

Если в течение месяца со дня вынесения Президентом предупреждения высшему должностному лицу субъекта РФ указанное лицо не приняло мер по устранению причин, послуживших основанием для вынесения предупреждения, Президент РФ отрешает высшее должностное лицо субъекта РФ от должности.

Президент РФ вправе отрешить высшее должностное лицо субъекта РФ от должности в связи с выражением ему недоверия законодательным органом государственной власти субъекта РФ, с утратой доверия Президента (при выявлении фактов коррупции или неурегулированного конфликта интересов), за ненадлежащее исполнение своих обязанностей (в том числе по осуществлению переданных полномочий РФ).

Федеральный закон от 6 октября 1999 г. (в ред. от 5 октября 2015 г.) № 184-Ф3 «Об общих принципах организации законодательных (представительных) и исполнительных органов государственной власти субъектов Российской Федерации» (пункт 4 статьи 9) определяет возможность досрочного прекращения полномочий законодательного (представительного) органа государственной власти субъекта РФ в случае принятия правовых актов, противоречащих Конституции РФ, федеральным законам, создания препятствий в реализации полномочий федеральных органов государственной власти, органов местного самоуправления, нарушения прав и свобод человека и гражданина. Данные нарушения устанавливаются в судебном порядке и предусматривают определенный срок на их устранение, после истечения которого Президент своим указом выносит предупреждение законодательному (представительному) органу 
государственной власти субъекта РФ. Если в течение 3 месяцев со дня вынесения предупреждения указанный орган не принял в пределах своих полномочий мер по исполнению решения суда (в том числе не отменил противоречащий федеральному законодательству нормативный правовой акт), Президент РФ вправе распустить законодательный (представительный) орган государственной власти субъекта РФ.

Возможности приостановления действия противоречащих федеральным законам нормативных правовых актов органов государственной власти субъектов РФ и досрочного прекращения полномочий данных органов в случае ненадлежащего исполнения обязанностей по приведению этих актов в соответствие служат интересам укрепления единства общегосударственного правового пространства и законности в деятельности региональных органов государственной власти.

Как представляется, актуальная конструкция механизма ЗГС федеративных государств предполагает развитие и укрепление единства федеративного государства с помощью:

- Гармонизации конституционно-правовых отношений между федеральным центром и субъектами, с одной стороны, а также субъектов между собой, с другой. Для формирования оптимального баланса федеральных и региональных интересов необходимо четкое определение круга полномочий федеральных органов государственной власти, которые обеспечивают защиту интересов федеративного государства и в то же время не ограничивают самостоятельности субъектов по предмету их ведения. Чрезвычайно важно обеспечить реальное конституционно-правовое равенство субъектов федерации (равенство прав регионов в их отношениях с федеральными органами государственной власти, равенство полномочий субъектов в сферах совместного ведения).

- Обеспечения единства правового пространства путем приведения действующих и вновь принимаемых нормативных правовых актов субъектов 
в соответствие с федеральным законодательством и общегосударственной Конституцией, прекращения договорных отношений с отдельными регионами ${ }^{1}$, учета интересов и соблюдения прав субъектов в ходе подготовки и принятия федеральных нормативных правовых актов, повышения ответственности региональных органов власти перед населением субъектов. Важными прерогативами Федерации для обеспечения конституционной законности могут служить права отмены региональных правовых актов, резервирования региональных законов на усмотрение главы государства и федеральное законодательное замещение, если правотворчество субъекта нарушает общегосударственную конституцию и федеральные законы, ущемляет права и свободы граждан. Особая роль здесь принадлежит органам конституционного правосудия.

- Обеспечения единства экономического пространства путем установления правовых основ единого рынка, федерального регулирования государственной собственности на природные ресурсы, бюджетного устройства, таможенного регулирования, денежной и кредитно-финансовой системы, стимулирования экономической активности на всей территории федеративного государства (в сочетании с поддержкой отдельных регионов), выравнивания уровня социально-экономического развития регионов, сбалансированности региональных бюджетов, формирования во всех субъектах многоукладной экономики, развития межрегиональной инфраструктуры.

- Обеспечения реализации прав и свобод человека на всей территории государства.

Сохранения территориальной целостности федеративного государства.

1 Договорная практика с отдельными субъектами Федерации способствует перераспределению конституционно-правовых предметов ведения и полномочий в формате конфедеративных связей и «размывает» государственный суверенитет федеративного государства. 
Любые механизмы ЗГС в конечном счете предполагают обеспечение единства и территориальной целостности государства, что, в свою очередь, актуализирует необходимость выработки подходов к решению проблемы сецессии.

Существующие теоретические представления о сецессии позволяют рассматривать ее в нескольких смыслах:

как сепаратизм и угрозу государственному суверенитету;

как признак суверенитета;

как одну из форм реализации права народов на самоопределение.

В большинстве государств сецессия воспринимается как угроза государственному суверенитету и проявление сепаратизма. Во многих странах попытки выхода из федерации пресекались вооруженным (например, в Швейцарии в 1847 г., США в 1861-1865 гг., Нигерии в 1967-1970 гг., России в 1995 г.) или судебным путем (Западная Австралия в 1938 г.). Вооруженная сецессия удалась в Восточном Пакистане, где в 1971 г. было провозглашено государство Бангладеш.

В большинстве случаев сецессия влекла за собой нарушение исторически сложившихся связей, снижение жизненного уровня населения, а нередко и массовые жертвы ${ }^{1}$.

Практика государственного строительства и ЗГС свидетельствует, что для предотвращения дезинтеграции федеративного государства, как правило, используются две основные стратегии. Одна из них заключается в конституционном запрете сецессии и организации централизованного территориального контроля за политическими движениями и партиями, заявляющими о стремлении к независимости, автономии, децентрализации, самоопределению. Вторая стратегия предполагает пропагандистскую работу по разъяснению негативных последствий сецессии, инвестирование в

1 Сравнительное конституционное право / Под ред. В.Е. Чиркина. М.: Международные отношения, 2002. С. 281. 
инфраструктуру «проблемных» регионов и передачу части властных полномочий с целью институционализации региональных автономий.

Понимание сецессии как признака суверенитета было характерно для советского государственного права. Право союзных республик на выход из СССР рассматривалось «как постоянно действующий конституционный фактор, гарантирующий добровольный характер членства республики в союзном государстве, а также ее суверенное равенство в Федерации» ${ }^{1}$.

Право сецессии является одной из форм реализации права народов на самоопределение, предполагающей дезинтеграцию государства и самостоятельное государственное строительство. Право на самоопределение относится к числу принципов современного международного права. Оно закреплено в Уставе ООН, Международном пакте о гражданских и политических правах, Международном пакте об экономических, социальных и культурных правах, Заключительном акте СБСЕ 1975 г., а также в решениях Международного суда $\mathrm{OOH}^{2}$.

Решение проблем территориального самоопределения, связанных с отделением от государства, осложняется требованием соблюдать территориальную целостность государств, что порождает коллизии данных международно-правовых принципов. Как справедливо указывает А.А. Алексанян, «в зависимости от политических интересов приоритетным выступает то принцип территориальной целостности, то право народов на самоопределение» ${ }^{3}$.

${ }_{1}^{1}$ Шевциов В.С. Государственный суверенитет. М.: Наука, 1979. С. 228.

2 В решении по делу, касающемуся Восточного Тимора (Португалия против Австралии) от 30 июня 1995 г., Международный суд ОOН указал, что «право на самоопределение, вытекающее из Устава и практики ООН, имеет характер erga omnes.. Принцип самоопределения народов признан в Уставе ООН и практике Суда; он является одним из основополагающих принципов современного международного права». См. East Timor (Portugal v. Australia), Judgment, ICJ Reports 1995, Para. 29.

Алексанян A.A. Реализация права народов на самоопределение в контексте принципа территориальной целостности государств // Вестник Пермского университета. Юрид науки. 2013. Вып. 4. 
В работе А. Бьюкенена «Сецессия. Право на отделение, права человека и территориальная целостность государства» отмечается, что «для современных правовых государств все более характерна политика предоставления потенциально сепаратистским меньшинствам территориальной автономии и широких культурных и языковых прав, создания для них условий, при которых их стремления могут найти удовлетворение в рамках единого (или даже формально единого) государства, что дает возможность избежать конфликтов и проблем, связанных с отделением» ${ }^{1}$.

Право сецессии допустимо лишь при определенных обстоятельствах (незаконность включения территории в государство, систематические нарушения прав человека в отношении жителей отделяющейся территории, дискриминационное перераспределение ресурсов, геноцид (блокада региона) или угроза существованию национальной культуры отделяющихся) ${ }^{2}$.

Незаконность включения территории в государство может быть аргументирована аннексией со стороны существующего (ранее существовавшего) государства. Слабость данного подхода к обоснованию сецессии состоит в том, что его последовательное применение приведет к региональной и глобальной политической нестабильности, а введение какихлибо временных ограничений (в рамках которых совершенные государствами несправедливость и беззаконие не принимаются во внимание «за истечением срока давности») будет произвольным.

${ }^{1}$ А. Бьюкенен. Сецессия. Право на отделение, права человека и территориальная целостность государства. М.: Рудомино, 2001. С. 3.

${ }^{2}$ В литературе отсутствует единство точек зрения по вопросу оснований сецессии. См. А. Бьюкенен. Сецессия. Право на отделение, права человека и территориальная целостность государства. М.: Рудомино, 2001. С. 2; Алексанян А.А. Реализация права народов на самоопределение в контексте принципа территориальной целостности государств // Вестник Пермского университета. Юрид науки. 2013. Вып. 4; Сидоренко A. Сецессия: способен ли федерализм предотвратить угрозу? // Власть. 2010. № 5; Корнишова H.B. К вопросу о праве на сецессию //: $\mathrm{http} /$ /pravmisl.ru/index.php?id=1612option=com_contenttask=view. B представлена авторская позиция. 
Нарушения прав человека в отношении жителей отделяющейся территории могут использоваться как предлог для ограничения государственного суверенитета «международным сообществом» в связи с необходимостью соблюдения прав человека. Данная аргументация является наиболее уязвимой в связи с выборочным (коньюнктурным) использованием концепции прав человека для провоцирования напряженности, внутренних и внешних конфликтов, ослабления и подрыва государственного суверенитета отдельных стран.

Сецессия может оправдываться стремлением избежать «дискриминационного перераспределения» ресурсов, т.е. реализации схем налогообложения, политики регулирования, экономических программ и т.П., которые служат инструментом перераспределения ресурсов с одной территории на другую ${ }^{1}$.

Геноцид как основание сецессии представляет собой наиболее веское основание для выхода из состава государства. В этом случае образование нового независимого государства является важнейшим условием для выживания нации перед угрозой геноцида ${ }^{2}$. В качестве разновидности геноцида можно рассматривать транспортную и продовольственную блокаду государства или региона, влекущую бедственное положение и гибель проживающего там населения ${ }^{3}$.

Угроза существованию национальной культуры как аргумент оправдания сецессии предполагает необходимость поддержания культурного разнообразия, связанного с потребностью определенной нации в собственной территории и сохранении памятников культурного наследия. При этом 2010. № 5 .

${ }^{1}$ Сидоренко A. Сецессия: способен ли федерализм предотвратить угрозу? // Власть.

2 Данная аргументация лежала в основе признания Россией республик Абхазия и Южная Осетия после этнических чисток и попыток насильственного присоединения Грузией данных регионов. См. указы Президента РФ от 26 августа 2008 г. № 1260 «О признании Республики Абхазия» и от 26 августа 2008 г. № 1261 «О признании Республики Южная Осетия».

3 В настоящее время фактическая транспортная и продовольственная блокада установлена Украиной в отношении ДНР и ЛНР. 
культура должна находиться на грани исчезновения, а иные способы ее сохранения должны быть недоступны (недостаточны).

Несмотря на попытки распространить режим сецессии на федерации и административно-территориальные образования унитарных государств, необходимо учитывать, что в строгом смысле право сецессии является правовым признаком конфедерации (союза суверенных государств).

С юридической точки зрения о праве сецессии в федеративном государстве можно условно говорить в двух случаях:

- если право сецессии предусмотрено в конституции государства или в других законах;

- если народ (нация) субъекта федерации подпадает под принцип самоопределения народов (наций) ${ }^{1}$.

Право сецессии было законодательно закреплено только в Конституциях СССР, СФРЮ и Эфиопии, и после распада социалистических государств в конституционных актах практически не встречается.

Самоопределение народов предполагает различные формы и не отождествляется с выходом из состава федерации и созданием самостоятельного государства. Как уже отмечалось, территориальное обособление является наиболее радикальной формой самоопределения, которая реализуется в случаях геноцида, политической, экономической и культурной дискриминации, блокады региона, влекущих бедственное

${ }^{1}$ По мнению А.В. Маргиева, одним из условий сецессии республик в составе РФ является наличие у титульных наций республик исторической «национальной» территории. См. Маргиев А.B. О праве выхода республик из состава Российской Федерации / Вестник Адыгейского гос. ун-та. 2005. № 2. С. 131-137.

Не оценивая юридическую безосновательность такой точки зрения, отметим, что данный подход вызывает сомнение и с точки зрения теории: на территориях республик проживают различные нации (национальности); принадлежность территории и ее демографический состав меняются с течением времени; попытки восстановления «исторической несправедливости» и искусственного выделения различных «национальных» территорий ведут к межнациональной розни и ликвидации федеративной государственности. 
положение и гибель проживающего там населения, принудительную ассимиляцию ${ }^{1}$.

Значимую роль в защите федеративной природы государств играют органы конституционного правосудия. По мнению А.М. Фарукшина, «главным средством решения этой задачи является обеспечение соответствия всех законов и подзаконных нормативных правовых актов в границах юрисдикции федеративного государства федеральной конституции. Именно этим гарантируются суверенитет и целостность государства, единство его политического, экономического и правового пространства, одинаковый конституционно-правовой статус субъектов федерации, основанное на законе строгое и последовательное разграничение предметов ведения и полномочий между властями федерального и регионального уровней и одновременное их сотрудничество, искоренение политико-правового сепаратизма и местничества» ${ }^{2}$.

В разных странах роль конституционных судов в укреплении и развитии федеративных отношений неодинакова. Она зависит от социальнополитической и экономической обстановки в стране, характера взаимоотношений федерального центра и субъектов федерации, политической культуры, менталитета населения и др. обстоятельств.

Так, в истории развития американского федерализма специалисты выделяют 3 периода ${ }^{3}$. На первом этапе (с момента образования США до 1937 г.) Верховный Суд США, как правило, решал споры по поводу полномочий в пользу штатов. В период с 1937 по 1985 гг. Суд поддерживал расширение федеральных полномочий. В рамках третьего этапа (с 1990-х гг. по н.в.) Верховный Суд установил пределы федерального законодательного

\footnotetext{
${ }^{1}$ Характерно, что ни одно западное государство в XX веке не позволило применить к себе «право народов (наций) на самоопределение». См. Пастухова Н.Б. Указ. соч. С. 186.

2 Фарукшин А.M. Проблемы федеративных отношений в решениях конституционных судов // Журнал российского права. 2007. № 8.

${ }_{3}^{3}$ Фарукшин А.М. Указ соч.
} 
регулирования (ограничения власти Конгресса) и встал на защиту суверенного иммунитета штатов ${ }^{1}$.

Как было отмечено в зарубежной научной литературе, в конце 1990-х начале 2000-х гг. Верховный Суд США признал недействительными целый ряд принятых Конгрессом законов на том основании, что «они вторгались в защищенные сферы суверенитета штатов или превышали полномочия, делегированные Конгрессу Конституцией. Эти решения были тем более значительными, поскольку в течение большей части предшествовавших шестидесяти лет Суд всегда был энергичным агентом централизации управления со времен так называемой революции в интерпретации Конституции в период Нового Курса»².

Так, в решении по делу «New York v. United States» Суд указал, что Конгресс не может просто управлять законотворчеством штатов, «заставляя их непосредственно предписывать и осуществлять федеральные правотворческие программы. Хотя Конгресс имеет существенные полномочия в непосредственном управлении государством, включая сферы, близко касающиеся штатов, никогда не считалось, что Конституция наделяет Конгресс способностью требовать от штатов осуществлять управление в соответствии с инструкциями Конгресса». В другом деле «Prinz v. United States» Верховный Суд США заявил, что «федеральное правительство не может ни издавать директивы, требуя от штатов заняться конкретными проблемами, ни командовать чиновниками штатов»³.

Высший Суд Австралии (High Court), напротив, своими решениями по делам «Amalgamated Society of Engineers v. The Adelaide Steamship Co. Ltd.»,

1 Рассмотренные Верховным Судом США дела касались разных вопросов: распоряжения ядерными отходами, контроля над оборотом оружия, свободы вероисповедания, индейских игровых казино и др. Но все они затрагивали определение сферы суверенитета штатов и ограничение круга полномочий Конгресса, предусмотренных в ст. 1 Конституции США и XIV поправке к ней.

2 Conlan T.J., Vergniolle de Chantal F. The Rehnquist Court and Contemporary American Federalism // Political Science Quarterly, 2001. Vol.116. No. 2. P. 253-254.

${ }^{3}$ Фарукшин А.М. Указ. соч. 
«Koowarta», «Tasmanian Dam», «Tauh» и др. санкционировал значительное расширение полномочий Содружества в сферах защиты прав человека, равенства полов, интересов коренного населения и окружающей среды.

Наиболее значимым конституционно-правовым решением в сфере защиты федеративного государственного устройства стало дело Верховного Суда Канады о правовых основаниях выхода провинции Квебек из состава Канады.

Федеральное правительство обратилось в Верховный Суд с запросом о законности одностороннего отделения Квебека.

В принятом в 1998 г. постановлении Верховный Суд Канады пришел к выводу, что ни канадская Конституция, ни современное международное право не признают одностороннего выхода субъектов из состава федерации. В данном решении была закреплена возможность односторонней сецессии колоний, получающих независимость, а также сформулирована правовая позиция о необходимости учета интересов остающихся субъектов и федерации в целом: «Если большинство жителей Квебека недвусмысленно сделает выбор в пользу отделения, на федеральное правительство и другие провинции будет возложена обязанность вступить в переговоры. При этом стороны переговорного процесса должны учитывать интересы других провинций, федерального правительства, Квебека и право всех канадцев, проживающих как в пределах Квебека, так и вне их, и особенно права меньшинств» ${ }^{1}$.

Другие случаи односторонней сецессии признаны Судом незаконными.

В своем решении Верховный Суд Канады также постановил, что «государства, чьи правительства представляют весь народ в пределах их территории на основе равенства и без дискриминации и уважают принципы

${ }^{1}$ Judgment of the Supreme Court of Canada Concerning Certain Questions Relating to the Secession of Quebec from Canada, 1998, para. 130. http://scc.lexum.org/decisia-scc-csc/scccsc/scc-csc/en/item/1643/index.doc (дата обращения 08.09.2014). 
самоопределения по своим внутренним установлениям, управомочены на защиту своей территориальной целостности по международному праву».

Важное место в защите федерализма и его конституционных принципов занимает деятельность Конституционного Суда РФํ․

Защищая принципы федерализма (суверенитет и государственную целостность РФ, единство системы государственной власти, разграничение предметов ведения и полномочий, единство правового и экономического пространства, обеспечение обороны страны и безопасности государства) Конституционный Суд РФ неоднократно признавал противоречащими Конституции РФ и федеральным законам и не подлежашими применению нормативные правовые акты субъектов РФ, а также ставил вопрос об ответственности органов государственной власти субъектов РФ за нарушение конституционных обязанностей.

Решение вопросов государственного суверенитета с учетом особенностей федеративного устройства зависит от множества факторов и обстановки в конкретном государстве. Вместе с тем ключевыми элементами механизма защиты государственного суверенитета любого федеративного государства являются формирование оптимального баланса федеральных и региональных интересов, гармонизация отношений между субъектами федерации, обеспечение единства экономического и правового пространства, реализация основополагающих прав и свобод человека на всей территории государства, сохранение территориальной целостности.

${ }^{1}$ Конституционно-правовые механизмы защиты государственного суверенитета РФ в различных сферах общественной жизни рассмотрены в главе 3. 


\section{5. Правовые позиции российских и зарубежных органов} конституционной юстиции о пределах ограничения государственного суверенитета

Вопросы коллизионности национальных и международных правовых норм и юрисдикций, возможности и пределов ограничения государственного суверенитета, уступок юрисдикции зарубежным правовым системам давно вызывают научный и практический интерес. Данная проблематика приобрела актуальность по нескольким причинам:

- в связи с законодательным закреплением в ряде национальных законов (в т. ч. российских) положений о «верховенстве» («первичности») международно-правового регулирования над национальным;

- в связи с регулярными попытками ведущих государств англосаксонской правовой системы расширить свою юрисдикцию, осуществлять функции международного законотворчества и правосудия;

- в связи с принятием различными органами международного правосудия (главным образом, Европейским Судом по правам человека (далее - ЕСПЧ) некоторых «конфликтных» решений, посягающих на базовые конституционные принципы и основы национальных правовых систем.

Рассмотрим перечисленные проблемы взаимоотношений национальных и международных правовых систем.

В настоящее время нет норм международного права, которые бы устанавливали, каким образом должны решаться противоречия между внутригосударственным и международным правом в случае расхождения между ними. Вопрос оставлен на усмотрение законодателя и правоприменительных органов каждого государства ${ }^{1}$.

\footnotetext{
${ }^{1}$ Международное право / под ред. А.А. Ковалева, С.В. Черниченко. М.: Омега - Л, 2006. С. 102. Степень монистичности или дуалистичности государств в части соотношения международного и внутригосударственного права зависит от подхода к введению международных норм в национальное право. Некоторые государства (Нидерланды, Япония, Австрия) предоставляют международным договорам приоритет перед своими конституциями. В большинстве стран (Франция, Испания, Россия и др.) международные договоры имеют более высокий статус, чем обычные законы, но
} 
Вместе с тем, как отмечают российские государствоведы, на волне ультралиберальной идеологии руководства РФ в 90-х гг. ХХ в. в ряде федеральных законов были закреплены монистические положения, прямо или косвенно предусматривающие первичность (надконституционность) международно-правовых норм в регулировании конкретных сфер общественных отношений в РФ¹.

Сложившаяся ситуация вызвала у специалистов ожидаемые дискуссии о необходимости определения соотношения международно-правового и конституционно-правового регулирования, выработки подходов к основаниям и пределам ограничения государственного суверенитета, разработке рациональных юридических механизмов разрешения конфликтов между наднациональными и национальными органами․

Высказывались мнения, что такое регулирование напрямую противоречит принципам верховенства и прямого действия Конституции РФ (ч.2 ст.4, ч.1 ст. 15 Конституции), подрывает государственный суверенитет. В качестве дополнительной аргументации приводились правовые положения ч. 1 ст. 17 Конституции РФ, которая закрепляет требование соответствия признания и гарантирования РФ прав и свобод человека и гражданина меньший, чем Конституция, в ряде государств (Великобритания, США) - статус обычного закона.

${ }^{1}$ К примеру, ст. 2 Трудового кодекса РФ, ч.3 ст.3 Уголовно-исполнительного кодекса РФ, ст. 6 Федерального закона «О государственной политике Российской Федерации в отношении соотечественников за рубежом», ст.1 Федерального закона «Об основах обязательного социального страхования», ч.1 ст. 4 Федерального закона «Об общих принципах организации местного самоуправления в Российской Федерации». Данная позиция обосновывалась буквальными трактовками монистической теории примата международного права над внутригосударственным. См. Киселев А. О пределе уступчивости // ЭЖ-Юрист. 2013. № 49; Пузанов И. Между Конвенцией и национальным законодательством // ЭЖ-Юрист. 2011. № 6.

2 Авакьян С.А. Конституция России: природа, эволюция, современность. М., 1997. С. 205-206; Будылин С.Л. Конвенция или Конституция? Международное право и пределы государственного суверенитета // Закон. 2013. № 12; Дюсагарян А.А. Концепция суверенной демократии в конституционном измерении Суверенная демократия в конституционно-правовом измерении. Сб. статей и материалов. М.: Рос. газ., 2007. С. 141, 143; Зорькин В. Предел уступчивости // Рос. газ. 2010. 29 октября; Зорькин В.Д. Право в условиях глобальных перемен : монография. М.: Норма, 2013. С. 176, 180, 190; Садреддин $O$. Европейская Конвенция по правам человека и национальные правовые системы стран членов Совета Европы. Роль Комитета Министров // Юрист - международник. 2005. № 2; Худолей K.M. Конституционность решений ЕСПЧ и их исполнимость // Вестник Пермского университета. Юридические науки. 2013. Вып. 2. 
Конституции; норм ст. 79 и п. «Г» ч. 2 ст. 125 Конституции РФ, исключающих принятие Россией международных договоров, положения которых расходились бы с основами конституционного строя ${ }^{1}$.

Вопрос соотношения национального и международного права, возможностей и пределов ограничения государственного суверенитета неразрывно связан с готовностью конкретного государства добровольно допустить международный элемент в сферу своей юрисдикции и тем самым самостоятельно ограничить содержание национальной юрисдикции ${ }^{2}$.

Следует отметить, что источником международного правового регулирования является суверенная власть государств - участников межгосударственных отношений, которые добровольно возлагают на себя политические или юридические обязательства. Международные договоры, обязательные для РФ, сообщения МИД России о вступлении в силу международных договоров, заключенных от имени РФ и от имени Правительства РФ, официально публикуются в Собрании Законодательства Российской Федерации или в Бюллетене международных договоров и размещаются на «Официальном интернет-портале правовой информации» (www.pravo.gov.ru).

Непосредственное действие и применение в РФ норм международного права (за исключением jus cogens) нуждаются в государственном санкционировании. Согласно ч. 3 ст.5 Федерального закона «О международных договорах Российской Федерации» положения официально

1 Эбзеев Б.С., Айбазов Р.А., Краснорядиев С.Л. Глобализация и государственное единство России. М.: Формула права, 2006. С. 7, 184; Джсагарян А.А. Концепция суверенной демократии в конституционном измерении / Суверенная демократия в конституционно-правовом измерении. Сб. статей и материалов. М.: Рос. газ., 2007. С. 142.

${ }_{2}^{2}$ Как отмечали Е.И. Козлова и В.С. Шевцов, «принципы и нормы международного права, заключенные государством международные соглашения, с одной стороны, и внутреннее законодательство государства, с другой, имеют равную юридическую силу. Обеспечивая это равенство, каждое государство, заинтересованное в полном и неуклонном исполнении своих обязательств по международному праву, приводит свое собственное законодательство в точное соответствие с этими обязательствами, постоянно следит в своей нормотворческой деятельности, чтобы не возникали противоречия между законодательством и международными обязательствами». См. Советское государственное право. М.: Высшая школа, 1978. С. 141. 
опубликованных международных договоров РФ, не требующие издания внутригосударственных актов для применения, действуют в РФ непосредственно $^{1}$. Для осуществления иных положений международных договоров РФ принимаются соответствующие правовые акты (федеральные законы или подзаконные акты).

РФ не вправе заключать международные договоры, не соответствующие Конституции. При этом компетентные органы государственной власти при соотнесении внутреннего законодательства с обязательствами по международным договорам обязаны: во-первых, соблюдать и защищать права и свободы человека и гражданина; во-вторых, не допускать нарушения основ конституционного строя.

По мнению С.А Авакьяна, «какими бы прогрессивными не были те или иные нормы, о которых договорилось мировое сообщество, государство оставляет за собой их оценку, и прежде всего в своем Основном Законе. В соответствии с Федеральным законом «О международных договорах Российской Федерации», если международный договор содержит правила, требующие изменения отдельных положений Конституции РФ, решение о согласии на его обязательность для РФ возможно только в форме федерального закона только после внесения соответствующих поправок в Конституцию РФ или пересмотра ее положений в установленном порядке»².

Как справедливо отмечает Б.С. Эбзеев, «международный договор, как и международное право в целом, обладает не общим приматом, он имеет приоритет в применении перед законом в случае их коллизии. Нормы закона, предусматривающие иные правила, чем установленные договором,

${ }^{1}$ Пункт 5 Постановления Пленума Верховного Суда РФ от 31 октября 1995 г. № 8 «О некоторых вопросах применения судами Конституции Российской Федерации при осуществлении правосудия» // Рос. газ. 1995. 28 декабря.

2 Авакьян С.А. Конституция России: природа, эволюция, современность. М.: Рос. юрид. изд. дом, 1997. С. 205-206. 
сохраняют свою юридическую силу, но не применяются» ${ }^{1}$. Конституция же всегда обладает безусловным верховенством в силу ч.1 ст. 15.

Приоритет национальной Конституции и находящихся с ней в неразрывном нормативном единстве положений федерального законодательства перед международным правом последовательно отстаивает и Председатель Конституционного Суда РФ В.Д. Зорькин: «Конституционный Суд является высшим арбитром в коллизиях российского законодательства с международными правовыми нормами... Конституционный Суд исходит из того, что согласно Российской Конституции международное право стоит выше российских законов, но не выме самой Конституцчии в части защиты прав и свобод человека и гражданина. ... Другими словами, Конституция Российской Федерации закрепляет приоритет своих положений над любыми иными правовыми предписаниями, в том числе и над актами международно-правового характера в части, касающейся возможности более полной защиты прав и свобод человека и гражданина в Российской Федерации» ${ }^{2}$.

Так, признав в своем Постановлении от 30 ноября 2000 г. № 15-П неконституционными ряд положений Устава Курской области о региональном государственном контроле над местным самоуправлением, Конституционный Суд РФ указал, что на оценку конституционности оспариваемых положений не влияет то, что отдельные из них, по существу, воспроизводят положения пунктов 2 и 3 статьи 8 Европейской хартии о местном самоуправлении. Конституция и федеральные законы, по мнению Суда, закрепляют более высокий, чем это предусмотрено международными обязательствами России, уровень гарантий самостоятельности местного самоуправления, который субъекты РФ не вправе занижать или

1 Эбзеев Б.С., Айбазов Р.А., Краснорядиев С.Л. Глобализация и государственное единство России. М.: Формула права, 2006. С. 184.

2 Зорькин В.Д. Право в условиях глобальных перемен : монография. М.: Норма, 2013. С. 176, 180, 190; Зорькин В.Д. Право против хаоса. М.: Редакция «Российской газеты», 2016. С. 16. 
ограничивать ${ }^{1}$.

Данный аргумент был принят во внимание и Верховным Судом РФ. Как отмечается в п.3 Постановления Пленума Верховного Суда РФ от 27 июня 2013 г. № 21 «О применении судами общей юрисдикции Конвенции о защите прав человека и основных свобод от 4 ноября 1950 г. и Протоколов к ней», «законодательство Российской Федерации может предусматривать более высокий уровень защиты прав и свобод человека в сравнении со стандартами, гарантируемыми Конвенцией и Протоколами к ней в толковании суда. В таких случаях судам, руководствуясь ст. 53 Конвенции, необходимо применять положения, содержащиеся в законодательстве Российской Федерации»².

Конституционный Суд РФ не поддерживает данное ЕСПЧ толкование Конвенции о защите прав человека и основных свобод, если именно Конституция РФ как правовой акт, обладающий высшей юридической силой в правовой системе России, более полно по сравнению с соответствующими положениями Конвенции в их истолковании ЕСПЧ обеспечивает защиту прав и свобод человека и гражданина, в том числе в балансе с правами и свободами иных лиц (ч.3 ст. 17 Конституции) $)^{3}$.

Признание юрисдикции международных организаций и обязательности соответствующих стандартов не противоречит целям достижения внутренних

${ }^{1}$ Постановление Конституционного Суда РФ от 30 ноября 2000 г. № 15-П «По делу о проверке конституционности отдельных положений Устава (Основного Закона) Курской области в редакции закона Курской области от 22 марта 1999 г. «О внесении изменений и дополнений в Устав (Основной Закон) Курской области» // СЗ РФ. 2000. № 50. Ст. 4943.

2 Рос. газ. 2013. 5 июля.

3 Пункт 4 Постановления Конституционного Суда РФ от 14 июля 2015 г. № 21-П «По делу о проверке конституционности положений статьи 1 Федерального закона «О ратификации Конвенции о защите прав человека и основных свобод и Протоколов к ней», пунктов 1 и 2 статьи 32 Федерального закона «О международных договорах Российской Федерации», частей 1 и 4 статьи 11, пункта 4 части 4 статьи 392 Гражданского процессуального кодекса Российской Федерации, частей 1 и 4 статьи 13, пункта 4 части 3 статьи 311 Арбитражного процессуального кодекса Российской Федерации, частей 1 и 4 статьи 15, пункта 4 части 1 статьи 350 Кодекса административного судопроизводства Российской Федерации и пункта 2 части 4 статьи 413 Уголовно-процессуального кодекса Российской Федерации в связи с запросом группы депутатов Государственной Думы» (далее - Постановление Конституционного Суда РФ от 14 июля 2015 г. № 21-П) // Рос. газ. 2015. 27 июля. См. также Зорькин В.Д. Право против хаоса. М.: Редакция «Российской газеты», 2016. С. 16. 
национальных интересов суверенного государства, основанных на балансе конституционно защищаемых ценностей в его Конституции. Международное право, будучи инкорпорированным по воле государства в его национальную правовую систему, не должно игнорировать цели и принципы данной правовой системы. В связи с этим нормы международного права должны толковаться и применяться на внутригосударственном уровне как с точки зрения целей и принципов международного права, так и согласно соответствующим ориентирам внутригосударственного права ${ }^{1}$.

Таким образом, распространенная точка зрения о «верховенстве» международного права является весьма поверхностной и упрощенной. Речь идет о только приоритете международного договора в применении перед законом в случае их коллизии. Что касается Конституции, то она занимает доминирующее положение в любых коллизионных ситуациях.

Разрешая дела, суды непосредственно применяют Конституцию РФ:

а) когда закрепленные нормой Конституции положения, исходя из ее смысла, не требуют дополнительной регламентации и не содержат указания на возможность ее применения при условии принятия федерального закона, регулирующего права, свободы, обязанности человека и гражданина и другие положения;

б) когда Конституционным Судом РФ выявлен пробел в правовом регулировании либо когда пробел образовался в связи с признанием не соответствующими Конституции нормативного правового акта или его отдельных положений с учетом порядка, сроков и особенностей исполнения решения Конституционного Суда РФ, если они в нем указаны². В случаях, когда статья Конституции является отсылочной, суды применяют закон, регулирующий соответствующие правоотношения.

${ }^{1}$ Борисов И.Б. Электоральный суверенитет. М.: РОИИП, 2010. С. 121-122.

2 Пункт 2 Постановления Пленума Верховного Суда РФ от 31 октября 1995 г. № 8 «О некоторых вопросах применения судами Конституции Российской Федерации при осуществлении правосудия» // Рос. газ. 1995. 28 декабря. 
Ко второй группе проблем, актуализирующих вопросы коллизионности национальных и международных правовых норм, возможности и пределов ограничения государственного суверенитета в ходе взаимодействия национальных и зарубежных правовых систем, относятся регулярные попытки ведущих государств англо-саксонской правовой семьи необоснованно расширять свою юрисдикцию и осуществлять функции международного законотворчества и правосудия.

Нужно отметить, что США являются единственным государством, которое не только «помогает» национальным парламентам принимать внутригосударственные законодательные акты, но и само принимает законы для других стран мира. Примерами распространения юрисдикции Соединенных Штатов на другие государства являются Закон о требованиях иностранных лиц, касающихся нарушения их прав (Alien Tort Claims Act) 1789 г., Закон о защите жертв пыток (Torture Victim Protection Act) 1992 г., Закон о свободе вероисповедания в странах мира от 27 января 1998 г., Закон о демократии в России 2002 г., Закон о демократии в Беларуси от 20 октября 2004 г. Экстерриториальное действие имеют Законы США «О коррупции за рубежом» (Foreign Corrupt Practices Act) 1977 г., «Об усилении борьбы с терроризмом в США и за их пределами» 1993 г., Закон Великобритании «О взяточничестве» (United Kingdom Bribery Act) 2010 г.

Размышляя о проблеме совершенствования международной юстиции, В.Д. Зорькин отмечает настойчивое распространение на сферу международных отношений норм прецедентного англосаксонского права ${ }^{1}$ Речь идет об использовании американских и британских судебных решений для преследования подозреваемых вне национальной территории. Данными нормами пытались юридически обосновать убийство Усамы бен Ладена в

1 Зорькин В.Д. Право против хаоса. М.: Редакция «Российской газеты», 2016. Вып. 13. С. 68. Следует отметить, что ЕСПЧ, о котором речь пойдет далее, также является институтом прецедентной системы права. См. пункт 1 статьи 28 Конвенции о защите прав человека и основных свобод. 
Пакистане, применение англосаксонской нормы «провоцирования на преступление» в ходе ареста в Таиланде и последующей экстрадиции в США гражданина России В. Бута ${ }^{1}$.

Юристы Великобритании и США предпринимают активные попытки распространения этих судебных «прецедентов» на практику международного правосудия. Для этого используются решения Международного уголовного суда в отношении руководителей Судана, Малави, Чада и Ливии, которые якобы выступают достаточными прецедентными основаниями для аналогичных решений по любым «диктаторам» из любых государств ${ }^{2}$. «Прецедент» Ливии рассматривается ими как легальная основа для насильственного отстранения от власти с помощью «международной коалиции» Президента Сирии Б. Асада.

Автор разделяет позицию В.Д. Зорькина, что «такая трансформация международного правосудия неизбежно ведет к его замене тривиальным сведением счетов, произволом, облеченным в форму судебных вердиктов»³.

Третья группа проблем, актуализирующих необходимость осмысления характера взаимоотношений национальных и наднациональных органов, выработки новых подходов к основаниям и пределам ограничения государственного суверенитета, относится к принятию ЕСПЧ «конфликтных» решений, посягающих на базовые конституционные

1 Зорькин В.Д. Право в условиях глобальных перемен : монография. М.: Норма, 2013. C. 415.

2 Warrant of Arrest for Omar Hassan Ahmad Al Bashir. Situation in Darfur, Sudan. No.: ICC02/05-01/09. Date: 4 March 2009. In the case of The Prosecutor v. Omar Hassan Ahmad Al Bashir («Omar Al Bashir») // http: // www.icc-cpi.int/iccdocs/ doc/doc639078.pdf; Second Warrant of Arrest for Omar Hassan Ahmad Al Bashir. Situation in Darfur, Sudan. No.: ICC-02/05-01/09. Date: 12 July 2010. In the case of The Prosecutor v. Omar Hassan Ahmad Al Bashir («Omar Al Bashir») // http: // www.icc-cpi.int/iccdocs/ doc/doc907140.pdf ; Warrant of Arrest for Muammar Mohammed Abu Minyar Gaddafi. Situation in the Libyan Arab Jamahiriya. No.: ICC-01/11. Date: 27 June 2011// http: // www.icc-cpi.int/iccdocs/ doc/doc1099321.pdf; Decision Pirsuant to Article 87 (7) of the Rome Statute on the Failure by the Republic of Malawi to Comply with the Cooperation Requests Issued by the Court with Respect to the Arrest and Surrender of Omar Hassan Ahmad Al Bashir. Situation in Darfur, Sudan. No.: ICC-02/05-01/09. Date: 12 December 2011. In the case of The Prosecutor v. Omar Hassan Ahmad Al Bashir («Omar Al Bashir») // http: // www.icc-cpi.int/iccdocs/ doc/doc1013912.pdf.

3 Зорькин В.Д. Право в условиях глобальных перемен : монография. М.: Норма, 2013. C. 265. 
принципы и основы национальных правовых систем.

Изначально при создании ЕСПЧ предполагалось, что Европейский Суд будет рассматривать только конкретные жалобы на предполагаемые (допущенные) нарушения требований Конвенции о защите прав человека и основных свобод 1950 г. (далее - Конвенция) (с правом присудить выигравшей стороне «справедливую компенсацию» материального ущерба, морального вреда, а также возмещение издержек и расходов), однако со временем произошло изменение статуса и прецедентной практики Суда. В 2004 г. Европейский Суд в соответствии с Резолюцией Комитета Министров Совета Европы от 12 мая 2004 г. стал издавать т.н. «пилотные постановления» (pilot judgements) о необходимости изменения национального законодательства, правоприменительной и судебной практики, рекомендовать принятие иных мер, влекущих юридические последствия ${ }^{1}$. Указанные рекомендации по гармонизации правовой базы и судебной практики можно было бы только приветствовать, если бы они в ряде случаев не подменяли собой контроль национального законодательства, не затрагивали конституционные устои государств и принудительно не обеспечивались контрольным механизмом исполнения решений ЕСПЧ в соответствии со ст. 46 Конвенции.

Подобная эволюция правового статуса Европейского Суда и одностороннее расширение его правосубъектности вызвали закономерную реакцию ряда ведущих конституционных судов Европы (в первую очередь, Германии, Австрии, Италии, Венгрии, Великобритании и России).

Одним из первых вырабатывать конституционно-правовую доктрину защиты государственного суверенитета и формировать пределы его

${ }^{1}$ Практика «пилотных постановлений» ЕСПЧ возникла в 2004 г. после принятия в марте 2004 г. Комитетом Министров Совета Европы резолюции, рекомендовавшей Европейскому суду фиксировать наличие системных проблем и предписывать «меры общего характера», включая принятие и изменение законодательных актов. Resolution $\operatorname{Res}(2004) 3$ of the Committee of Ministers on judgments revealing an underlying systemic problem, 12 May 2004 // URL: Https://wcd. coe. int/ViewDoc. jsp? id=743257 
ограничения начал Федеральный Конституционный Суд Германии.

В нескольких своих постановлениях - от 29 мая 1974 г., от 11 октября 1985 г., от 14 октября 2004 г. и от 13 июля 2010 г. Федеральный Конституционный Суд ФРГ сформулировал и обосновал правовую позицию «об ограниченной правовой силе постановлений Европейского Суда». Согласно этой позиции государство обязано исполнять постановление ЕСПЧ в рамках участвующих в рассмотрении дела лиц и в отношении конкретного предмета спора, рассмотренного ЕСПЧ. Однако «государство вправе не учитывать решение Европейского Суда в случаях и в частях, противоречащих конституционным ценностям, защищаемым Основным законом Германии» ${ }^{1}$.

В решении от 29 мая 1974 г. (известном как Solange-1) Федеральный Конституционный Суд заявил о том, что намерен сохранять свою компетенцию по проверке норм права ЕС и решений Европейского Суда справедливости на предмет их соответствия правам человека, изложенным в Основном законе ФРГ, до тех пор, пока Европейские сообщества не будут обладать собственным каталогом прав человека, который был бы адекватен каталогу прав, установленному Основным законом².

Аналогичный подход использовал Конституционный Суд Итальянской Республики, не согласившись с выводами ЕСПЧ относительно трансграничных пенсионных выплат, которые были сформулированы в Постановлении от 31 мая 2011 г. по делу «Маджо (Maggio) и другие против Италии» (Maggio Case). В частности, в Постановлении от 19 ноября 2012 г. по делу № 264/2012 он указал, что соблюдение международных обязательств не может являться причиной снижения уровня защиты прав, уже заложенного во внутреннем правопорядке, но, напротив, может и должно

1 Зорькин В.Д. Право в условиях глобальных перемен : монография. М.: Норма, 2013. C. 463.

Исполинов A.C. Требуются прагматики: Конституционный Суд России и евразийский правопорядок // Сравнительное конституционное обозрение. 2014. № 5. С. 18. 
представлять собой действенный инструмент расширения этой защиты; как следствие, противоречие между защитой, предусмотренной Конвенцией, и конституционной защитой основных прав должно разрешаться в направлении максимального расширения гарантий и при условии обеспечения надлежащего соотношения с иными интересами, защищаемыми конституцией, т.е. с другими конституционными нормами, гарантирующими основные права, на которые могло бы повлиять расширение отдельно взятой гарантии ${ }^{1}$.

В решении от 12 октября 1993 г. Федеральный Конституционный Суд ФРГ проверил конституционность Договора о Европейском Союзе (Маастрихтского договора) на предмет его соответствия нормам ст. 38 Основного закона ФРГ, которая гарантирует гражданам ФРГ, имеющим право голоса, право принимать участие в выборах депутатов германского Бундестага ${ }^{2}$. Заявитель полагал, что Маастрихтский договор сокращает полномочия и задачи Бундестага и сужает его возможности влиять на легитимацию и осуществление властных полномочий на уровне государства, что, в свою очередь, нарушает принцип демократии. Федеральный Конституционный Суд ФРГ, хотя и признал оспариваемый Договор конституционным, сформулировал важнейшие правовые позиции о соотношении международных обязательств и государственного суверенитета.

Во-первых, по мнению Суда, принцип демократии не препятствует ФРГ быть членом в каком-либо межгосударственном объединении, организованном на национальной основе. Однако предпосылкой такого членства является обеспечение исходящей от народа легитимации и влияния,

${ }^{1}$ Judgment No. 264. 19 November 2012 // http: // www.cortecostituzionale.it/ documenti/ download/ doc/recent_judgments/ S2012264 Quaranta_Morelli_en.pdf; См. также Пункт 4 Постановления Конституционного Суда РФ от 14 июля 2015 г. № 21-П.

2 Постановление Федерального Конституционного Суда ФРГ от 12 октября 1993 г. Maastricht-Urteil des Bundesverfassungsgerichtes vom 12.10.1993 // http:

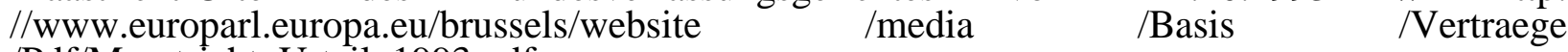
/Pdf/Maastricht_Urteil_1993.pdf 
в том числе и в рамках межгосударственного объединения. Поскольку в основе Договора о ЕС лежит осуществление процесса все более тесного объединения народов Европы, организованных в виде государств, а не создание общеевропейского государства, опирающегося на общеевропейский народ, то именно народы государств - членов Союза, действуя через свои национальные парламенты, являются источником демократической легитимации для осуществления властных полномочий Европейским союзом ${ }^{1}$. Расширение задач и полномочий европейских межгосударственньх объединений ограничивается на основе демократического принцииа. При этом существенные задачи и полномочия остаются в компетенции Бундестага.

Во-вторых, Суд указал, что ст. 38 Основного закона ФРГ будет нарушена в том случае, если закон, который открывает правопорядок Германии для непосредственного действия и применения правовых норм Европейского сообщества, не будет с достаточной точностью определять порядок реализации переданных властных полномочий и программу запланированной интеграции ${ }^{2}$.

В-третьих, Суд подчеркнул, что поскольку властные полномочия Европейского Сообщества в отношении Германии производны от волеизъявления еe народа, выраженного посредством парламентской процедуры в форме национального закона, Суд осуществляет проверку того, насколько правовые акты европейских учреждений и органов находятся в границах предоставленных им властных полномочий и не выходят ли они из

${ }^{1}$ Пункты 2 и 3 Постановления Федерального Конституционного Суда ФРГ от 12 октября 1993 г. по делу Maastricht. Maastricht-Urteil des Bundesverfassungsgerichtes vom 12.10.1993 // http: //www.europarl.europa.eu/brussels/website /media /Basis /Vertraege /Pdf/Maastricht_Urteil_1993.pdf. См. также Джагарян А.А. Указ соч. С. 146.

2 Пункт 5 Постановления Федерального Конституционного Суда ФРГ от 12 октября 1993 г. по делу Maastricht. Maastricht-Urteil des Bundesverfassungsgerichtes vom 12.10.1993 // http: //www.europarl.europa.eu/brussels/website/media /Basis/Vertraege /Pdf/Maastricht_Urteil_1993.pdf. 
этих рамок ${ }^{1}$.

В решении по делу Maastricht Федеральный конституционный суд ФРГ оставил за собой, а не за ЕСПЧ право решать вопросы о соответствии норм ЕС той компетенции, которая передана на уровень ЕС, и объявлять акты ЕС ultra vires, т.е. принятыми в нарушение полномочий.

Еще более жесткая правовая позиция была сформулирована Федеральным Конституционным Судом ФРГ в постановлении от 14 октября 2004 г. по жалобе Гергюлю (Goerguelu). По мнению Федерального Конституционного Суда, «Основной закон ФРГ имеет целью интеграцию Германии в правовое сообщество мирных свободных государств, но не предусматривает отказа от суверенитета. Следовательно, не противоречит цุели приверженности международному праву, если законодатель, в порядке исключения, не соблюдает право международньх договоров при условии, что это является единственно возможным способом избежать нарушения основополагающих конституцฺионных приничипов» ${ }^{2}$.

Кроме того, Федеральным конституционным судом ФРГ было определено соотношение статуса ЕСПЧ и национальной судебной системы государств-участников Конвенции. В частности, было указано на отсутствие в Конвенции оснований для установления примата решений ЕСПЧ над решениями национальных судов ${ }^{3}$.

Вместе с тем, Федеральный конституционный суд ФРГ указал, что правовая природа обязательств, возникающих у государственных органов в связи с решениями ЕСПЧ, полностью зависит от сферы их компетенции и

${ }^{1}$ Пункты 2 и 5 Постановления Федерального Конституционного Суда ФРГ от 12 октября 1993 г. по делу Maastricht. Maastricht-Urteil des Bundesverfassungsgerichtes vom 12.10.1993 // http: //www.europarl.europa.eu/brussels/website /media /Basis /Vertraege /Pdf/Maastricht_Urteil_1993.pdf. См. также Джагарян A.A. Указ соч. С. 147.

${ }^{2}$ Параграф 30 (часть I C) Order of the Second Senate of 14 October 2 BvR 1481/04 (официальный сайт Федерального конституционного суда ФРГ http://www.bundesverfassungsgericht.de/en/decisions/rs20041014_2bvr148104en.html)

3 Параграф 18 (подпункт «b» пункт 4 части I A) Order of the Second Senate of 14 October 2 BvR 1481/04 (официальный сайт Федерального конституционного суда ФРГ http://www.bundesverfassungsgericht.de/en/decisions/rs20041014_2bvr148104en.html) 
той широты полномочий, которая предоставлена соответствующим органам законом. При этом на национальные суды при любых обстоятельствах налагается обязанность принимать во внимание решения ЕСПЧ, касающиеся ранее рассмотренных ими дел, а в случае если суды наделены правом повторного рассмотрения таких дел, - выносить решение с учетом имеющейся позиции ЕСПЧ при условии недопустимости нарушений материального права соответствующего государства ${ }^{1}$.

Таким образом, Федеральный конституционный суд ФРГ вновь подтвердил, что положения Конвенции и акты ЕСПЧ являются дополнительным источником толкования содержания и объема основных прав, закрепляемых Основным законом ФРГ, и подлежат внутригосударственному контролю.

В решении от 30 июня 2009 г. по делу Lissabon-Vertrag о конституционности Лиссабонского договора Федеральный Конституционный Суд заявил, что компетентен рассматривать акты ЕС на предмет их соответствия «конституционной идентичности» Основного закона ФРГ и не только разрешать, но и обязывать правительство не исполнять акты ЕС и предпринимать меры для защиты конституционной идентичности. Увидев обеспокоенность других государств - членов ЕС, Федеральный Конституционный Суд был вынужден в решении Honeywell скорректировать свою позицию, разработав ограничительный подход к решению вопроса о наличии в конкретном случае ultra vires co стороны органов ЕС. По мнению Федерального Конституционного Суда, акты ЕС не должны применяться на территории страны в том случае, если они очевидно противоречат разделению компетенции между ЕС и государствами членами, а также ведут к «значительному структурному сдвигу в

${ }^{1}$ Параграф 30 (часть I C) Order of the Second Senate of 14 October 2 BvR 1481/04 (официальный сайт Федерального конституционного суда ФР 
распределении компетенции в пользу ЕС» ${ }^{1}$.

Из недавних примеров можно упомянуть правовую позицию Федерального Конституционного Суда в ответ на решение ЕСПЧ по делу Fransson. В этом решении ЕСПЧ принял расширительное толкование сферы применения Хартии Европейского Союза об основных правах (Страсбург, 12 декабря 2007 г.), по сути, заявив, что будет считать себя верховным арбитром в вопросах защиты основных прав человека в ЕС. Федеральный Конституционный Суд в решении от 24 апреля 2013 г. по делу о соответствии Основному закону ФРГ компьютерной базы данных по антитеррору упомянул дело Fransson, отметив, что ЕСПЧ не является надлежащим судьей в чисто внутригосударственных вопросах ${ }^{2}$.

Схожие подходы можно встретить и в конституционно-судебной практике других европейских государств.

В 1987 г. к выводу о правовых пределах действия постановлений ЕСПЧ пришел Конституционный Суд Австрии. Отметив необходимость учитывать судебную практику и решения ЕСПЧ, австрийский Конституционный Суд в то же время указал, что обязан руководствоваться принципами национальной Конституции и потому не может допустить применения решений и правовых позиций Европейского Суда, которые противоречат конституционным принципам ${ }^{3}$.

Конституционный Суд Венгерской Республики в решении от 22 января 1997 г. $^{4}$, рассматривая вопрос о соотношении Основному закону установления только предварительного конституционно-судебного контроля международных договоров, исключающего возможность возбуждения

1 Исполинов A.C. Требуются прагматики: Конституционный Суд России и евразийский правопорядок // Сравнительное конституционное обозрение. 2014. № 5. С. 19.

${ }^{2}$ Federal Constitutional Court. Judgment of 24 April 2013, 1 BvR 1215/07.

3 Постановление Конституционного Суда Австрии от 14 октября 1987 г. по делу № В 267/86. См. Зорькин В.Д. Право в условиях глобальных перемен : монография. М.: Норма, 2013. С. 463. 1997-1-001

${ }^{4}$ HUN-1997-1-001 http://www.codices.coe.int/gateway.dll/codices/full/eur/hun/ger/hun- 
гражданами процедур последующего конституционного контроля в отношении таких актов, пришел к выводу, что в силу конституционного принципа всеобщности конституционного контроля и подконституционного характера актов международного права оспариваемые нормы, определяя дополнительную процедуру конституционного правосудия, не препятствуют гражданам обжаловать положения международных договоров точно также, как и любых иных норм внутреннего права ${ }^{1}$.

Верховный Суд Соединенного Королевства Великобритании и Северной Ирландии в решении от 16 октября 2013 г. отметил неприемлемость для британской правовой системы выводов и толкования Конвенции в Постановлении Европейского Суда по правам человека от 6 октября 2005 г. по делу «Херст (Hirst) против Соединенного Королевства» (Hirst v. United Kingdom) в отношении ограничения избирательных прав осужденных ${ }^{2}$. Согласно правовой позиции Верховного Суда Соединенного Королевства решения ЕСПЧ не воспринимаются как подлежащие безусловному исполнению, - по общему правилу, они «принимаются во внимание»; следование этим решениям признается возможным только в том случае, если они не противоречат основополагающим материальным и процессуальным нормам национального права ${ }^{3}$.

Применительно к России вопрос о коллизии конституционного толкования нормы национального законодательства Конституционным Судом РФ и толкования Конвенции Европейским Судом, при котором оспариваемая норма признается несовместимой с Конвенцией, впервые возник в октябре 2010 года после принятия Европейским Судом по правам

1 Джагарян А.А. Указ соч. С. 147-148.

2 Постановление Европейского суда по правам человека от 30 марта 2004 г. «Дело Херст (Hirst) против Соединенного Королевства» (Hirst v. United Kingdom) (№ 74025/01) // Бюллетень Европейского Суда по правам человека. Российское издание. 2006. № 4.

${ }^{3}$ В соответствии со ст. 2 Закона Соединенного Королевства о правах человека 1998 г., рассматривая дела о правах человека, британские суды должны «принимать во внимание» практику ЕСПЧ // Human Rights Act 1998. Art 2. 
человека Постановления по делу «Константин Маркин против России»ํ․

Как отмечает Тузмухамедов Б.Р., «впервые Европейский суд в жесткой правовой форме подверг сомнению решение Конституционного суда РФ» ${ }^{2}$. В этом определении от 15 января 2009 г. № 187-О-О Конституционный Суд отметил, что российское правовое регулирование, предоставляющее военнослужащим-женщинам возможность отпуска по уходу за ребенком до достижения им трехлетнего возраста и не признающее такое право за военнослужащими-мужчинами (они могут воспользоваться лишь кратковременным отпуском), не нарушает положения Конституции о равенстве прав и свобод независимо от пола ${ }^{3}$.

Однако ЕСПЧ определил, что предоставление права на отпуск по уходу за ребенком военнослужащим-женщинам при одновременном отказе в этом праве военнослужащим-мужчинам «лишено разумного обоснования». В связи с этим беспрецедентным является вывод ЕСПЧ о том, что «рассматриваемое российское законодательство не является совместимым с Конвенцией и обнаруживает широко распространенную в правовом механизме проблему, касающуюся значительного числа людей» 4 .

Четкую позицию о соотношении международных договоров и конституционных принципов, разрешении коллизии между ними сформулировал Председатель Конституционного Суда РФ В. Зорькин.

${ }^{1}$ Постановление Европейского Суда по правам человека от 7 октября 2010 г. по делу «Константин Маркин против Российской Федерации» (Konstantin Markin v. Russia), № 30078/06, judgment of 7 October 2010; Grand Chamber judgment of 22 March 2012 // Бюллетень Европейского Суда по правам человека. Российское издание. 2012. № 6.

${ }_{3}^{2}$ http://www.ng.ru/politics/2010-10-13/3_kartblansh.html

3 Определение Конституционного Суда РФ от 15 января 2009 г. N 187-О-О «Об отказе в принятии к рассмотрению жалоб гражданина Маркина Константина Александровича на нарушение его конституционных прав положениями статей 13 и 15 Федерального закона «О государственных пособиях гражданам, имеющим детей», статей 10 и 11 Федерального закона «О статусе военнослужащих», статьи 32 Положения о порядке прохождения военной службы и пунктов 35 и 44 Положения о назначении и выплате государственных пособий гражданам, имеющим детей». Текст официально опубликован не был.

4 Постановление Европейского Суда по правам человека от 7 октября 2010 г. по делу «Константин Маркин против Российской Федерации» (Konstantin Markin v. Russia), № 30078/06, judgment of 7 October 2010; Grand Chamber judgment of 22 March 2012 // Бюллетень Европейского Суда по правам человека. Российское издание. 2012. № 6. 
Анализируя Постановление Европейского суда от 7 октября 2010 года по делу «Константин Маркин против России», в котором было подвергнуто сомнению Определение Конституционного Суда Российской Федерации от 15 января 2009 г. № 187-О-О о конституционности российского правового регулирования, предоставляюего военнослужащим-женщинам возможность отпуска по уходу за ребенком до достижения им трехлетнего возраста и не признающего такое право за военнослужащими-мужчинами, В.Зорькин задаёт острые вопросы:

«Может ли Европейский суд, исходя из статьи 46 Конвенции, в решении по конкретному делу рекомендовать (а фактически указать) государству-ответчику внести необходимые изменения в законодательство притом что суд неоднократно подчеркивал в своих же решениях приоритет государства-ответчика в выборе необходимых мер для исправления нарушения? Не является ли такое указание суда прямым вторжением в сферу национального суверенитета, явно выходящим за рамки предусмотренных Конвенцией прав и полномочий, и с этой точки зрения - явно выходящим за рамки компетенции, установленной Конвенцией? И насколько тогда такое решение подлежит исполнению с учетом того, что вопрос о наличии проблемы конституционности данной нормы, не устроившей Европейский суд, был уже решен Конституционным судом в рамках конституционного судопроизводства?» .

В своей статье «Предел уступчивости» В. Зорькин даёт аргументированные ответы на актуальные вопросы об ограничении государственного суверенитета:

«Принципы государственного суверенитета и верховенства Конституции в правовой системе России относятся к основам еe конституционного строя. Конвенция как международный договор России

1 Зорькин В. Предел уступчивости // Рос. газ. 2010. 29 октября. 
является составной частью ее правовой системы, но она не выше Конституции. Конституция в статье 15 устанавливает приоритет международного договора над положениями закона, но не над положениями Конституции. Монополия на истолкование положений Конституции и выявление конституционного смысла закона принадлежит Конституционному суду. И поэтому истолкование Конституции, данное высшим судебным органом государства, не может быть преодолено путем толкования Конвенции, поскольку ее юридическая сила все-таки юридическую силу Конституции не превосходит...

Каждое решение Европейского суда - это не только юридический, но и политический акт. Когда такие решения принимаются во благо защиты прав и свобод граждан и развития нашей страны, Россия всегда будет безукоснительно их соблюдать. Но когда те или иные решения Страсбургского суда сомнительны с точки зрения сути самой Европейской конвенции о правах человека и тем более прямым образом затрагивают национальный суверенитет, основополагающие конституционные принципы, Россия вправе выработать защитный механизм от таких решений» ${ }^{\text {. }}$

Развитие конституционно-правовой доктрины ЗГС РФ осуществлялось не только в рамках теоретических конституционно-правовых исследований и судебной практики, но и в формате законотворческой деятельности. В июне 2011 г. в Государственную Думу был внесен проект федерального конституционного закона № 564346-5 «О внесении изменений в отдельные законодательные акты Российской Федерации», целью которого являлось «устранение возможных противоречий между результатом оценки конституционности закона Российской Федерации, данной Конституционным Судом Российской Федерации, и выводами Европейского Суда по правам человека о нарушении Конвенции о защите прав человека и

\footnotetext{
1 Зорькин В. Предел уступчивости // Рос. газ. 2010. 29 октября.
} 
основных свобод вследствие применения данного закона» ${ }^{1}$. Предлагаемые в законопроекте изменения предусматривали право суда, в который подано заявление о пересмотре ранее вынесенного им судебного акта в связи с установлением Европейским Судом нарушения Конвенции, связанного с применением федерального закона, не соответствующего положениям данной Конвенции, обратиться в Конституционный Суд РФ с запросом о конституционности указанного закона.

Только после такой оценки, основанной на комплексном рассмотрении вопроса через призму части 4 статьи 15 и части 1 статьи 17 Конституции РФ, которые не предполагают сохранение в правовой системе страны положений, противоречащих международным обязательствам, за исключением случаев, когда сами эти обязательства не согласуются с положениями Конституции РФ, Конституционным Судом РФ должно было приниматься окончательное решение о возможности применения соответствующей нормы закона или иного нормативного правового акта.

Сформулированный российским законодателем подход нашел свое выражение в практике конституционного судопроизводства.

В Постановлениях от 26 февраля 2010 г. № 4-П и от 6 декабря 2013 г. № 27-П Конституционный Суд РФ сформулировал следующие правовые позиции ${ }^{2}$ :

- В процессе производства по пересмотру вступившего в законную силу судебного постановления суд общей юрисдикции может прийти к выводу о невозможности исполнения Постановления ЕСПЧ без отказа от применения положений законодательства РФ, ранее признанных

1 Заключение Комитета Государственной Думы по конституционному законодательству и государственному строительству по проекту федерального конституционного закона № 564346-5.

2 Постановление Конституционного Суда РФ от 26 февраля 2010 г. № 4-П «По делу о проверке конституционности ч.2 ст. 392 ГПК РФ в связи с жалобами граждан А.А.Дорошка, А.Е.Кота и Е.Ю. Федотовой»; Постановление Конституционного Суда РФ от 6 декабря 2013 г. № 27-П «По делу о проверке конституционности положений статьи 11 и пунктов 3 и 4 части 4 статьи 392 ГПК РФ в связи с запросом президиума Ленинградского окружного военного суда». 
Конституционным Судом РФ не нарушающими конституционные права заявителя в его конкретном деле. В таком случае перед судом общей юрисдикции встает вопрос о конституционности указанных законоположений, повлекших нарушение Конвенции в их интерпретации ЕСПЧ.

- Выявление неконституционных законоположений и их исключение из числа действующих правовых норм может являться только совокупным результатом взаимодействия судов различных видов юрисдикции с учетом разграничения их компетенции, предполагающего, с одной стороны, реализацию судом общей юрисдикции правомочия поставить вопрос о конституционности соответствующих норм перед Конституционным Судом РФ, а с другой - обязанность Конституционного Суда РФ окончательно разрешить этот вопрос.

- В целях устранения коллизии внутригосударственных и наднациональных норм суд общей юрисдикции приостанавливает производство и обращается с запросом в Конституционный Суд РФ о проверке соответствия Конституции РФ примененных в деле норм, нарушающих положения Конвенции.

Другими словами, Конституционный Суд РФ обязал суды в случае выявления коллизии между правовыми позициями ЕСПЧ и Конституционного Суда относительно оспариваемой нормы обращаться с запросом в Конституционный Суд РФ.

В соответствии с пунктом 5.1 Постановления Конституционного Суда от 14 июля 2015 г. № 21-П приведенные правовые позиции имеют универсальный характер и распространяются на гражданское, арбитражное, административное и уголовное судопроизводство.

В июне 2014 г. предусмотренный в Постановлении Конституционного Суда РФ от 6 декабря 2013 г. № 27-П механизм разрешения коллизий внутригосударственных и конвенционных норм был закреплен в 
Федеральном конституционном законе «О внесении изменений в Федеральный конституционный закон «О Конституционном Суде Российской Федерации» ${ }^{1}$. Статья 101 данного Закона была дополнена положением о том, что суд при пересмотре дела в связи с принятием межгосударственным органом по защите прав и свобод человека решения, в котором констатируется нарушение в РФ прав и свобод человека при применении закона либо отдельных его положений, придя к выводу, что вопрос о возможности применения соответствующего закона может быть решен только после подтверждения его соответствия Конституции РФ, должен обращаться с запросом в Конституционный Суд РФ о проверке конституционности этого закона.

Необходимо подчеркнуть, что качество решений ЕСПЧ зависит не только от политической беспристрастности и соблюдения принципа субсидиарности, но и напрямую связано с методологическими, организационными и юрисдикционными проблемами в его деятельности.

В настоящее время основные проблемы деятельности ЕСПЧ можно сгруппировать следующим образом:

1. Методологические проблемы толкования Европейским Судом содержания Конвенции.

2. Организационные проблемы деятельности ЕСПЧ.

3. Проблемы правового статуса решений Европейского Суда и их исполнения.

В.Д. Зорькин выделяет методологические проблемы деятельности Европейского Суда ${ }^{2}$ р расширительную интерпретацию конвенционных положений, а также непоследовательное или противоречивое использование

${ }^{1}$ Федеральный конституционный закон от 4 июня 2014 г. № 9-ФКЗ «О внесении изменений в Федеральный конституционный закон «О Конституционном Суде Российской Федерации» // Рос. газ. 2014. 6 июня.

2 Зорькин В.Д. Право в условиях глобальных перемен : монография. М.: Норма, 2013. C. 274. 
методов эволюционного толкования ${ }^{1}$.

Расплывчатость (неопределенность) закрепленных в Конвенции прав, приводит к практически неограниченной дискреции судей, когда положения Конвенции расширяются в контексте, явно не соответствующем первоначальному содержанию. Это порождает проблему легитимности такого расширительного толкования.

В работах В.Д. Зорькина можно найти убедительную критику решений ЕСПЧ, не учитывающих конкретно-исторические условия и особенности развития той или иной страны, принятие которых может повлечь негативные последствия для всего европейского правового поля.

Примером может служить решение Большой палаты ЕСПЧ от 17 мая 2010 г. по делу партизана-антифашиста Кононова, которым палата признала правомерным осуждение Кононова судами Латвии ${ }^{2}$. В этом решении Большая палата признала допустимой ссылку национальных судов Латвии на положения принятых лишь в 1949 г. Женевских конвенций, мотивируя это тем, что уже к 1944 г. соответствующий указанным Конвенциям правовой режим якобы уже «фактически сложился». То есть фактически решение Большой палаты ЕСПЧ исходит из обязанности заявителя предвидеть в 1944 г. возможность дальнейшей квалификации его действий как военных преступлений (в рамках Нюрнбергского процесса). Это, во-первых, означает ретроспективное применение закона, ухудшающего ответственность лица, и во-вторых, основано на очень спорном расширительном толковании результатов Нюрнбергского процесса. Знаменательно, что Большая палата не

${ }^{1}$ Концепция эволюционного толкования Конвенции впервые применена ЕСПЧ в Постановлении от 25 апреля 1978 г. по делу «Тайрер (Tyrer) против Соединенного Королевства» и нашла развитие в Постановлении от 11 июля 2002 г. по делу «Кристин Гудвин (Christine Goodwin) против Соединенного Королевства». Там было указано, что «Конвенция - это живой инструмент, который должен толковаться с учетом современных условий» // Бюллетень Европейского Суда по правам человека. Российское издание. 2003. № 1.

2 Постановление Европейского Суда по правам человека от 17 мая 2010 г. по делу «Кононов против Латвии» (Kononov v. Latvia), № 36376/04. // Бюллетень Европейского Суда по правам человека. Российское издание. 2010. № 8. 
приняла во внимание ссылку адвоката Кононова на ч.2 ст.11 Всеобщей декларации прав человека (ей корреспондирует ст.7 Конвенции), согласно которой «никто не может быть осужден за преступление на основании деяния или за бездействие, которые во время их совершения не составляли преступления по национальным законам или по международному праву» ${ }^{1}$.

В данном случае особо важно то, что решение Большой палаты ЕСПЧ по делу «Кононов против Латвии», пренебрегающее историческим контекстом и юридически сомнительное, создает прецедент фактического уравнивания воинов-антифашистов с гитлеровскими преступниками. А это открывает дорогу глобальному пересмотру политических итогов Второй мировой войны ${ }^{2}$.

Подобное произошло с постановлением ЕСПЧ от 3 ноября 2009 г. по делу «Лаутси против Италии», в котором сделан вывод, что размещение распятия в классах итальянских государственных школ является нарушением права на образование. Это постановление было принято без анализа и учета религиозной и социально-нравственной нормативной традиции в государстве-ответчике. Италия опротестовала это постановление, причем протест поддержали около 20 европейских стран. В итоге Большая палата ЕСПЧ, рассмотрев протест с привлечением в качестве третейских участников судебной процедуры представителей Армении, Болгарии, Кипра, Греции, Литвы, Мальты, Монако, Румынии и России, пересмотрела первоначальное решение ЕСПЧ³

Методология эволюционного толкования, по справедливому замечанию В.Д. Зорькина, также вызывает множество вопросов: «Во что сегодня превращается Конвенция, при толковании норм которой не

1 Зорькин В.Д. Право в условиях глобальных перемен : монография. М.: Норма, 2013. C. 257.

2 Зорькин В.Д. Указ. соч. С. 190, 191.

3 Постановление Европейского Суда по правам человека от 18 марта 2011 г. по делу «Лаутси и другие против Италии» (Lautsi and others v. Italy), № 30814/06. // Бюллетень Европейского Суда по правам человека. Российское издание. 2011. № 6; Зорькин В.Д. Указ. соч. С. 257. 
учитывается ее первоначальное содержание? Насколько обосновано с точки зрения международного права возложение на страны-участницы обязательств, существенно отличающихся от тех, о которых они когда-то договорились? Оправдывается ли такое изменение одной лишь ссылкой на статью 32 Конвенции, наделяющую ЕСПЧ исключительными полномочиями по толкованию ее положений? Можно ли с определенностью сказать, какой именно документ применяет Европейский Суд сегодня?

Кроме того, подход ЕСПЧ к учету первоначального смысла норм Конвенции в целом отличается непоследовательностью: если в одних делах необходимость такого учета была прямо отвергнута (в частности, в постановлении по делу «Голдер против Великобритании» и в постановлении Young, James and Wester v. UK), то в других случаях, например, вывод Суда обосновывается такой необходимостью (дело Bankovic v. Belgium and others о бомбардировках НАТО в бывшей Югославии) ${ }^{1} »$.

Ключевой организаџионной проблемой деятельности ЕСПЧ можно назвать противоречивость идеи «текущего консенсуса».

Как известно, один из критериев, используемых ЕСПЧ для развития собственной практики, - это наличие «текущего консенсуса» большинства государств - членов по рассматриваемому вопросу.

В этой связи В.Д. Зорькин задает несколько острых вопросов: «С какого числа государств этот консенсус начинается? Какой диапазон действий государств по тому или иному вопросу (законодательное регулирование, правоприменение, сложившееся обыкновение или требование общественной морали) он охватывает» ${ }^{2}$ ?

Не отличается последовательностью подход ЕСПЧ и в том, как этот консенсус влияет на пределы свободы усмотрения государств. Если в одних

1 Зорькин В.Д. Право в условиях глобальных перемен : монография. М.: Норма, 2013. C. 275.

Зорькин В.Д. Указ. соч. С. 279. 
решениях ЕСПЧ указывает на зависимость свободы усмотрения от наличия консенсуса, то в других - приводит противоположную аргументацию. Наконец, позиция ЕСПЧ о консенсуальной природе обоснования своих решений вызывает сомнение с точки зрения либерально-демократической сущности Конвенции. Не означает ли следование «текущему консенсусу» государств по острым вопросам регулирования и правоприменения навязывание воли большинства, от которого Конвенция и должна защищать?

Важное значение имеют проблемы правового статуса решений ЕСПЧ $u$ ux исполнения, к которым можно отнести проблемы расширения сферы действия Конвенции, исполнения уже упомянутых «пилотных постановлений» (pilot judgements) ЕСПЧ и необходимости принятия общих мер с формулированием требований к национальному законодателю.

Анализ практики ЕСПЧ свидетельствует о расширении традиционной сферы действия Конвенции на вооруженные конфликты, «гуманитарную» интервенцию, социальные и трудовые права, a также расширение территориальных пределов ее действия (на территорию стран, которые не являются участниками Конвенции). При всем признании роли ЕСПЧ в развитии общечеловеческих ценностей нельзя не заметить, что развитие подобной практики вызывает все больше неоднозначных вопросов к его деятельности.

Другой проблемой являются рекомендации Суда об устранении недостатков правового регулирования в том или ином государстве, что можно рассматривать как определенное вмешательство Суда в полномочия национального законодателя.

Соотношение данного полномочия Суда с суверенными полномочиями национального законодателя не вполне понятно. В.Д. Зорькин указывает на то, что «в отличие от национальных судов, осуществляющих нормоконтроль, ЕСПЧ не встроен в какую-либо систему сдержек и противовесов... Европейская конвенция не предполагает изначально наличия 
наднационального правотворческого органа, уполномоченного на принятие норм общего характера, которые были бы предметом контроля ЕСПЧ. А те нормы, которые издаются национальными законодателями, по смыслу Конвенции также не входят в предмет прямого контроля Суда - они подчиняются другим критериям проверки и в других, национальных процедурах» ${ }^{1}$.

По мнению С.Л. Будылина, «попытки ЕСПЧ искусственно ускорить прогресс в области прав человека в Европе, фактически принимая на себя не предусмотренные Конвенцией полномочия всеевропейского законодателя, могут иметь печальные последствия. Принимая решения, не следующие из буквы Конвенции, без учета мнения властей и граждан стран - участниц, ЕСПЧ ставит в крайне затруднительное положение и правительства, и суды, и парламенты соответствующих стран, тем более в тех случаях, когда от государства требуется изменить положения соответствующей Конституции» ${ }^{2}$.

В ряде случаев необходимость принятия государствами общих мер следует не из пилотных постановлений, а из значительного числа индивидуальных постановлений ЕСПЧ, устанавливающих однотипные нарушения конвенционных норм.

Выбор и принятие мер, посредством которых исполняются решения ЕСПЧ, относятся к сфере усмотрения национальной правовой системы (компетенции законодательных, судебных и исполнительных органов). Комитет министров Совета Европы только контролирует исполнение решений ЕСПЧ. Это неоднократно подчеркивал и сам Европейский Суд (Постановления ЕСПЧ от 13 июля 2000 г. по делу «Скоццари и Джунта (Scozzari and Giunta) против Италии», от 30 июня 2005 г. по делу «Ян (Jahn) и

1 Зорькин В.Д. Право в условиях глобальных перемен : монография. М.: Норма, 2013. C. 272.

2 Будылин С.Л. Конвенция или Конституция? Международное право и пределы государственного суверенитета // Закон. 2013. № 12. 
др. против Германии», от 29 марта 2006 г. по делу «Скордино (Scordino) против Италии», от 3 июля 2008 г. по делу «Мусаева против России» (Musayeva v. Russia), от 3 июля 2008 г. по делу «Руслан Умаров против России» (Ruslan Umarov v. Russia) и др.). Поэтому формулирование конкретных требований к законодателю с указанием перечня необходимых правовых актов является вторжением в суверенные полномочия национальных органов законодательной власти, которое не предусмотрено Конвенцией.

Характерным примером наиболее очевидного расхождения с положениями Конституции РФ служит Постановление Европейского Суда по правам человека от 4 июля 2013 г. по делу «Анчугов и Гладков против России», в котором наличие в российском законодательстве ограничения избирательного права лиц, осужденных по приговору суда, было признано нарушением статьи 3 Протокола № 1 к Конвенции, что прямо противоречит ч.3 ст. 32 Конституции РФ, согласно которой не имеют права избирать и быть избранными граждане, содержащиеся в местах лишения свободы по приговору суда ${ }^{1}$. Согласие РФ на исполнение такого постановления означало бы нарушение ею статей 15 (часть 1), 32 (часть 3) и 79 Конституции РФ либо - в силу ее статьи 135 - необходимость принятия новой Конституции РФ².

Необходимость выработки механизма преодоления конвенционноконституционных коллизий, связанных в том числе с методологическими проблемами толкования Европейским Судом содержания Конвенции, побудила Конституционный Суд РФ в Постановлении от 14 июля 2015 г. №

${ }^{1}$ Постановление Европейского Суда по правам человека от 4 июля 2013 г. по делу «Анчугов и Гладков против России» (Anchugov and Gladkov v. Russia), №№ 11157/04, 15162/05 // Бюллетень Европейского Суда по правам человека. Российское издание. 2014. № 2 .

2 Ранее в прецедентной практике Европейского Суда уже возникала коллизия конституционно-конвенционных норм. В Постановлении от 22 декабря 2009 г. по делу «Сейдич и Финци против Боснии и Герцеговины» («Sejdic and Finci v. Bosnia and Herzegovina») ЕСПЧ признал положения Конституции Боснии и Герцеговины противоречащими Конвенции. См. Бюллетень Европейского Суда по правам человека. Российское издание. 2010 № 5. 
21-П сформулировать ряд условий, при которых государство вправе отказаться от исполнения решения международного суда:

1. ЕСПЧ толкует Конвенцию в ином, нежели обычном, значении либо осуществляет толкование вопреки объекту и целям Конвенции.

2. Согласие на обязательность для государства международного договора было выражено им в нарушение того или иного положения его внутреннего права, касающегося компетенции заключать договоры, если данное нарушение было явным.

3. Толкование нормы международного договора, на котором основано решение, нарушает предписания норм внутреннего права особо важного значения (положения Конституции).

4. Безусловное исполнение решений межгосударственного органа, принятых в несогласующемся с Конституцией истолковании, может повлечь нарушение ее положений, которые являются очевидными для любого субъекта международного права.

В дополнение к судебному механизму разрешения конвенционноконституционных коллизий (Постановление Конституционного Суда от 6 декабря 2013 г. № 27-П), основанному на запросе суда о проверке конституционности оспариваемой в конкретном деле нормы в случае выявления коллизии между правовыми позициями ЕСПЧ и Конституционного Суда в Постановлении от 14 июля 2015 г. № 21 -П был предложен несудебный механизм, предусматривающий толкование Конституции по запросу Президента или Правительства РФ в ситуации, когда Конституционный Суд РФ приходит к выводу о несовместимости решения ЕСПЧ с Конституцией, оно не подлежит исполнению.

При этом Конституционный Суд РФ использует «право на возражение» в редчайших случаях и готов к поиску «правомерного компромисса», но определение степени своей готовности он оставляет за собой.

Более того, в практике отечественного конституционного правосудия с 
самого начала утвердился подход, согласно которому общепризнанные принципы и нормы международного права используются в качестве наднационального эталона, сообразуясь с которым в РФ осуществляются права и свободы человека и гражданина, закрепленные Конституцией. Основываясь на этом, Конституционный Суд прибегает к международноправовой аргументации как для дополнительного обоснования своих правовых позиций, так и для разъяснения значения конституционных норм, а также выявления конституционно-правового смысла тех или иных законов ${ }^{1}$.

Как полагает С.Д. Князев, «логичным результатом этого процесса является упрочение взаимодействия российского и международного права, активно поддерживаемое Конституционным Судом и получающее последовательное подтверждение в его многочисленных решениях»².

Причинами неисполнения (ненадлежащего исполнения) решений ЕСПЧ также могут быть различные подходы международных и национальных органов правосудия к проблеме системных нарушений прав человека, отсутствие у государства необходимых ресурсов и финансирования, большой масштаб требуемых институциональных преобразований. В итоге процесс имплементации европейских стандартов в правовых системах национальных государств может затянуться на годы или даже десятки лет ${ }^{3}$.

По мнению специалистов, применительно к предмету исследования особого внимания заслуживает разработка инструментария для повышения эффективности исполнения ${ }^{4}$ :

- мер индивидуального характера: определение случаев, когда необходим /возможен пересмотр судебных решений, а когда необходимо

1 Зорькин В.Д. Современный мир, право и Конституция. М., 2010. С. 485.

${ }^{2}$ Князев С.Д. Конституционный Суд в правовой системе Российской Федерации // Журнал российского права. 2013. № 12.

3 Шуберт Т.Э. Имплементация решений ЕСПЧ в национальном законодательстве // Журнал российского права. 2015. № 6. С. 136-143.

4 Зорькин В.Д. Право в условиях глобальных перемен : монография. М.: Норма, 2013. C. 291. 
использование иных способов восстановления нарушенных конвенционных прав;

- мер общего характера: определение обязательств государства, вытекающих из постановления, предполагающего принятие общих мер; выработка процедуры такого принятия и его последствий ${ }^{1}$.

В РФ наиболее значительная часть общих мер инициируется в ходе конституционного судопроизводства путем рассмотрения обращений о проверке конституционности тех или иных норм. Следует отметить, что Конституционный Суд РФ рассматривает дела только в пределах оспариваемых норм, что не всегда позволяет комплексно и оперативно разрешать существующие правовые проблемы. Кроме того, как справедливо указывает С.Д. Князев «в решениях Конституционного Суда РФ не могут даваться оценки конституционности других норм, даже если они находятся в неразрывной взаимосвязи с оспоренными положениями, образуя по существу единый нормативный комплекс»².

В настоящее время государства ЕС в целях гармонизации европейского правового поля и национальных правовых систем добровольно принимают во внимание постановления ЕСПЧ по жалобам против других государств, с изменением своего законодательства. Однако на эту рецепцию государства идут до тех пор, пока ЕСПЧ в своем постановлении не затрагивает чувствительных вопросов и не нарушает пределов государственного суверенитета ${ }^{3}$.

Конституционное правосудие идет по пути сближения с Евросоюзом

${ }^{1}$ В случае наделения Конституционного Суда РФ такими полномочиями механизм исполнения общих мер, определяемых Конституционным Судом РФ на основе постановления ЕСПЧ, мог бы быть аналогичным механизму исполнения решений Конституционного Суда РФ.

${ }^{2}$ Князев С.Д. Конституционный Суд в правовой системе Российской Федерации // Журнал российского права. 2013. № 12.

3 В Постановлении от 19 апреля 2016 г. № 12-П Конституционный Суд РФ признал невозможным исполнение Постановления ЕСПЧ от 4 июля 2013 г. по делу «Анчугов и Гладков против России» в части изменений в российское законодательство и в части мер индивидуального характера в отношении граждан Анчугова и Гладкова. 
на основе доброй воли и общих ценностей. Но международный гуманитарный консенсус, предусматривающий единство в понимании прав и свобод человека и гражданина и обязательств государств по их защите, не влечет отказа от государственного суверенитета ${ }^{1}$.

Автор разделяет мнение В.Д. Зорькина о том, что «эффективное взаимодействие европейского и конституционного правопорядков невозможно в условиях субординации. Только диалог и сотрудничество между различными правовыми системами является основой их надлежащей согласованности и равновесия» ${ }^{2}$.

Как полагает Б.С. Эбзеев, «процесс формирования однородной со странами «старой» демократии национальной правовой системы России может занять достаточно длительный период. В связи с этим конвенционное закрепление общих для Европы стандартов прав человека и участие РФ в нем не исключает значительную дискреционную свободу государства-участника, предопределяемую его суверенитетом, на что, интерпретируя Конвенцию, неоднократно в своих решениях указывал Европейский Суд по правам человека. Ослабление суверенных прав государства с неизбежностью ведет к ослаблению ответственности, которую международное сообщество может требовать от публичной власти, осуществляющей эти права ${ }^{3}$. Напротив, особое внимание наднациональных органов к базовым элементам национальной конституционной идентичности (внутригосударственным нормам о фундаментальных правах и правовым основам конституционного строя) «позволит снизить вероятность конфликта между национальным и наднациональным правом, что, в свою очередь, во многом будет определять - при сохранении конституционного суверенитета государств -

1 Эбзеев Б.С. Личность и государство в России: взаимная ответственность и конституционные обязанности. М.: Норма, 2011. С. 28.

2 Зорькин В.Д. Право против хаоса. М.: Редакция «Российской газеты», 2016. С. 113.

3 Эбзеев Б.С. Указ. соч. С. 39. 
эффективность всей европейской системы защиты прав и свобод человека и гражданина и дальнейшую гармонизацию европейского правового пространства в этой области» ${ }^{1}$.

На современном этапе гармонизация международной и национальных правовых систем, сближение правотворческой, правоприменительной и судебной практики нуждаются в обновленной концепции государственного суверенитета, предусматривающей вопросы национальной юрисдикции государств, вопросы юрисдикции наднациональных органов и международных организаций, а также перечень исчерпывающих оснований для международного вмешательства.

Выработка такой концепции возможна лишь в формате $\mathrm{OOH}$ с привлечением всех заинтересованных государств. В согласованном документе целесообразно закрепить предмет национальной юрисдикции государств, в который могли бы войти следующие вопросы:

- описание и порядок официального использования флага, герба и гимна;

- определение статуса и защита государственных границ;

- защита суверенитета и территориальной целостности государства;

- определение структуры и статуса Вооруженных Сил, порядка их применения;

- обеспечение правопорядка и государственной безопасности;

- разработка и осуществление внешней политики;

- вступление в международные и наднациональные организации, приостановление участия и выход из них; нейтралитет;

- заключение международных соглашений, их приостановление и денонсация;

- законотворчество, разрешительные и контрольно-надзорные

${ }^{1}$ Пункт 6 Постановления Конституционного Суда РФ от 14 июля 2015 г. № 21-П // Рос. газ. 2015. 27 июля. 
административные процедуры;

- судоустройство и осуществление правосудия;

- амнистия и помилование;

- определение системы национальных органов публичной власти, порядка ее формирования и особенностей функционирования в государстве;

-определение порядка и характера взаимоотношений общегосударственных и региональных органов власти и управления;

- государственное устройство;

- закрепление гарантий и определение порядка защиты прав человека и гражданина с учетом национальных традиций и особенностей;

- закрепление гарантий и определение порядка защиты прав национальных менышинств и коренных малочисленных народов;

- сохранение истории и защита традиционных для государства религиозных норм и культурных ценностей;

- защита семьи, брака и общественной морали;

- награждение государственными наградами и почетными званиями;

- экономическая и бюджетная политика;

- денежная эмиссия и чеканка монет;

- налогообложение;

- социальная политика;

- государственная собственность и управление ею.

В содержание юрисдикции наднациональных органов и международных организаций можно было бы включить:

- содействие в развитии международных аспектов защиты прав человека и гражданина;

- содействие в создании условий для сохранения и развития этнической, культурной, языковой и религиозной самобытности национальных меньшинств и коренных малочисленных народов;

- защита прав беженцев и перемещенных лиц; 
- защита прав лиц без гражданства;

- помощь государствам по их запросам в ликвидации последствий стихийных бедствий, техногенных катастроф, реализация программ гуманитарной помощи;

- совместная борьба с эпидемиями и эпизоотиями;

- разрешение международных споров, помощь в мирном урегулировании межгосударственных и региональных конфликтов;

- вопросы обеспечения международной и коллективной безопасности;

- регулирование отношений, возникающих в период военных действий и вооруженных конфликтов;

- коллективные меры для предотвращения и устранения угроз миру и подавления актов агрессии (миротворческие операции);

- демилитаризация и нейтрализация территорий;

- координация усилий по вопросам разоружения, сокращения вооружений и укрепления мер доверия;

- содействие в развитии внешнеэкономического сотрудничества, создании благоприятных условий для торговли и инвестиций;

- содействие в искоренении бедности;

- координация усилий по вопросам защиты окружающей среды и внедрения возобновляемых источников энергии;

- развитие межгосударственных образовательных и культурных связей;

- развитие взаимодействия в области науки и техники;

- развитие взаимодействия в области спорта, олимпийского и параолимпийского движения;

- совершенствование транзитного потенциала и развитие туризма;

- развитие правовой базы межгосударственного сотрудничества;

- координация борьбы с преступлениями международного характера (пиратство, работорговля, наркоторговля, организованная транснациональная преступность, торговля оружием, международный терроризм и др.); 
- регулирование деятельности международной информационнотелекоммуникационной сети «Интернет»;

- международные воздушные сообщения;

- сотрудничество в мирном освоении космоса;

- режим и сотрудничество в Антарктике;

- совместные исследования Мирового океана;

- совместный поиск в решении глобальных проблем.

Вопросы юрисдикции, не относящейся к наднациональным органам и международным организациям, следовало бы закрепить за государствами.

Как представляется, обновленная концепция государственного суверенитета должна предусматривать и исчерпывающий перечень оснований для международного вмешательства. К их числу могли бы быть отнесены:

1. Вооруженная агрессия.

2. Геноцид.

3. Экоцид.

4. Апартеид.

5. Государственный терроризм (официальная поддержка, финансирование, вооружение, оснащение и подготовка международных террористических организаций).

6. Транспортная и продовольственная блокада государства или региона, влекущая бедственное положение и гибель проживающего там населения.

7. Плебисцит о выходе региона из состава государства.

8. Разрушение памятников мирового культурного наследия.

Субъектом международного вмешательства должны выступать не государства и их военно-политические союзы, а международные организации универсального характера. В отличие от механизмов подрыва и ослабления государственного суверенитета, исчерпывающий перечень форм 
международного вмешательства должен быть:

- юридически закреплен в универсальных международных договорах, имеющих обязательный характер;

- должен сопровождаться исчерпанием всех возможных процедур мирного урегулирования;

- должен санкционироваться только Советом Безопасности ООН и осуществляться под его контролем;

- должен отвечать критериям пропорциональности действиям государства и их последствиям;

- должен действовать на временной основе и носить исключительный характер;

- не должен преследовать целей насильственного отстранения высших должностных лиц государства от власти, замены законных государственных органов альтернативными властными структурами, подрыва экономики, нарушения территориальной целостности государства.

Реализация предложенного согласованного подхода к определению правосубъектности государств, юрисдикции наднациональных органов и международных организаций, пределов ограничения государственного суверенитета, разработки исчерпывающих оснований для международного вмешательства во внутренние дела государств позволит избежать «двойных» стандартов в международных отношениях и оптимизировать существующие механизмы разрешения конфликтов между наднациональными и национальными органами. 


\section{ГЛАва 3. КОНСТИТУЦИОННО-ПРАВОВЫЕ МЕХАНИЗМЫ ЗАЩИТЫ ГОСУДАРСТВЕННОГО СУВЕРЕНИТЕТА РОССИЙСКОЙ ФЕДЕРАЦИИ}

\section{1. Понятие и общая характеристика конституционно-правовой защиты государственного суверенитета Российской Федерации}

Защита суверенитета любого государства нуждается в необходимом правовом обеспечении, и прежде всего, со стороны ведущей отрасли национальной системы права - конституционного права.

Конституционное право закрепляет важнейшие государственные полномочия в сфере внутренней и внешней политики, содержание и реализация которых позволяют вести речь о государственном суверенитете. Основы конституционного строя, правовое положение личности и общественных институтов, система государственных органов, национальногосударственное устройство, другие важнейшие характеристики суверенного государства определены в конституционные актах. Конституционные акты содержат исходные начала для уголовно-правовой, административноправовой и гражданско-правовой защиты государственного суверенитета. Конституционно-правовые принципы лежат в основе разработки, осуществления и совершенствования государственной политики в сфере защиты государственного суверенитета, являются базовыми началами для подготовки необходимых концептуальных документов и правовых актов.

Особенности конституционно-правовой защиты государственного суверенитета зависят от условий (степень интеграции государства в международную экономическую и политическую систему, демографические особенности, религиозный и национальный состав государства, форма государства и т.п.) и причин антигосударственной деятельности по ослаблению и подрыву государственного суверенитета (интересы и идеология антигосударственных сил, интенсивность и специфика их 
деструктивных действий, реализация конкретных механизмов ослабления и подрыва государственного суверенитета и т.д.), cpeды (международная обстановка, потенциал стран - противников, возможности союзников и т.д.) и потенцииала государства - участника военно-политического, экономического и идеологического противоборства (конкурентоспособность национальной экономики, обеспеченность вооружением, ресурсами и кадрами, уровень патриотического воспитания населения и др.).

Конституционно-правовая защита государственного суверенитета имеет ряд признаков:

во-первых, она представляет собой объединенную единым замыслом юридическую (правотворческую, правоприменительную и правоохранительную) деятельность государства в формате механизмов правотворчества, правореализации и государственного принуждения;

во-вторых, она сопровождает реализацию всех функций государства во всех сферах общественной жизни;

в-третьих, она направлена на преобразование общественной жизни в интересах государства и всегда порождает правовые последствия;

в-четвертых, она обеспечивает неотьемлемые качественные характеристики суверенитета государства (верховенство и независимость государственной власти, полноту иммунитетов государства, беспрепятственную реализацию государственно-властных полномочий в отношении всех субъектов права в пределах территориальной юрисдикции) и противодействие деструктивной деятельности антигосударственных сил по ослаблению и подрыву государственного суверенитета.

Таким образом, конституционно-правовая защита государственного суверенитета представляет собой объединенную единым замыслом и порождающую правовые последствия юридическую деятельность государства (правотворческую, правоприменительную и правоохранительную), сущность которой состоит в обеспечении 
верховенства и независимости государственной власти, полноты иммунитетов государства, беспрепятственной реализации государственновластных полномочий во всех сферах общественной жизни, противодействии деструктивной деятельности антигосударственных сил по ослаблению и подрыву государственного суверенитета.

Целями конституционно-правовой защиты государственного суверенитета РФ выступают:

- обеспечение верховенства Конституции РФ, единства правового и экономического пространства государства;

- модернизация российского законодательства и повышение национального уровня правовой защиты в соответствии с решениями Конституционного Суда РФ по проблемам государственного суверенитета;

- обеспечение независимости национальной правовой системы, гарантирование верховенства национальной юрисдикции и полноты иммунитетов государства от попыток насильственного ограничения государственного суверенитета иностранными судами, органами власти и управления, международными и региональными организациями;

- обеспечение устойчивого функционирования и развития государственных и общественных институтов;

- противодействие деструктивной деятельности антигосударственных сил по ослаблению и подрыву государственного суверенитета.

Средствами конституционно-правовой защиты государственного суверенитета являются нормативные правовые акты и правоприменительные акты (решения судов и других государственных органов, акты прокурорского реагирования, официальные предостережения органов безопасности и др.). Нормативные правовые акты устанавливают единый, государственновластный порядок регулирования социально значимых отношений, действуют в отношении неопределенного круга субъектов права и обеспечиваются мерами государственного принуждения. 
Правоприменительные акты как средства конституционно-правовой защиты государственного суверенитета имеют свою специфику: они регулируют не типовые, а индивидуальные отношения; адресованы конкретному субъекту права; предполагают однократную реализацию.

Правовые акты, составляющие фундамент конституционно-правовой защиты государственного суверенитета РФ, могут быть классифицированы по нескольким критериям.

По юридической силе следует выделить иерархическую систему следующего вида: Конституция РФ, ратифицированные и признанные РФ международные правовые акты, законы и подзаконные акты РФ.

В зависимости от сфер правового регулирования рассматриваемые правовые акты могут включать фрагменты, затрагивающие общественные отношения в сферах экономики, обороны, безопасности, государственного управления и др.

По времени действия можно различать акты постоянного действия (о противодействии терроризму, экстремистской деятельности, организованной преступности и др.) и временные акты, связанные с обострением внутриполитической обстановки или недружественными действиями иностранных государств (союзов) ${ }^{1}$.

По кругу лиц и содержанию предписаний возможна классификация на нормативно-правовые акты (например, о порядке ликвидации организаций иностранных агентов или о специальных защитных мерах) и индивидуальноправовые акты (о нежелательности пребывания или проживания конкретных лиц на территории государства и др.). Критерием разграничения данных документов является их нормативный или индивидуальный характер.

В основе разработки, осуществления и совершенствования государственной политики в сфере ЗГС лежит ряд конститущионно-правовых

${ }^{1}$ К ним относятся акты о введении чрезвычайного положения, специальных и ответных мер и др. 
принципов, которые служат базовыми началами для подготовки необходимых концептуальных документов, принятия правовых актов и соответствующих решений: верховенства Конституции, федерализма, системности, комплексности, оперативности, конституционной законности и адекватности применяемых правовых средств ЗГС, уважения прав и свобод человека и гражданина.

Принциип верховенства Конституц̧ии означает приоритетное положение и высшую юридическую силу Конституции РФ в системе законодательных актов, регулирующих ЗГС.

Принциип федерализма основан на оптимальном сочетании централизации и децентрализации в государственно-правовых отношениях Центра и регионов для обеспечения согласованных действий государственных органов, территориальной целостности, единого правового и экономического пространства, единства государственной власти.

Принциип системности предполагает, что конституционно-правовая защита государственного суверенитета является частью общегосударственного механизма (российской национальной системы) ЗГС в РФ, который рассматривается как упорядоченное множество взаимосвязанных элементов, образующих определенную целостность.

Принциип комплексности проявляется в решении конкретных практических проблем ЗГС путем четкого обеспечения единства различных сторон деятельности, целей, организации и взаимодействия сил и средств конституционно-правовой защиты государственного суверенитета.

Принции оперативности реализуется в своевременном реагировании элементов конституционно-правовых механизмов ЗГС на формирующиеся и существующие угрозы государственному суверенитету.

Принц̧ип конституц̧ионной законности и адекватности применяемых правовых средств защчиты государственного суверенитета проявляется в неуклонном и обязательном соблюдении Конституции и законов всеми 
субъектами ЗГС, использовании ими только допустимых и достаточных правовых средств для достижения социально значимой цели воздействия на общественные отношения.

Принциип уважения прав и свобод человека и гражданина заключается в том, что государство не только провозглашает, но и фактически гарантирует конституционные права и свободы, юридически защищает граждан от злоупотреблений властными полномочиями и иных посягательств со стороны государственных органов и отдельных должностных лиц, выполняющих функции по ЗГС.

Перечисленные принципы являются теоретическим обобщением опыта ЗГС и в силу этого обладают методологическим содержанием.

Конституционно-правовые механизмы ЗГС включают: правовые институты, субъекты конституционно-правовой защиты государственного суверенитета, формы их взаимодействия и правовые режимы ЗГС.

К правовым институтам конституционных механизмов ЗГС относятся обособленные группы согласованных правовых норм, регулирующих определенные разновидности общественных отношений в сфере ЗГС: институт основ конституционного строя; институт правового положения личности; институт национально-государственного устройства; институт государственных органов; институт выборов; институт политических партий; институт общественных организаций; институт СМИ; институт органов местного самоуправления ${ }^{1}$.

Ведущим институтом являются основы конституционного строя. Термин «основы конституционного строя» часто формулируется через категорию принципов ${ }^{2}$.

1 Отдельные институты состоят из субинститутов. Так, в рамках института правового положения личности можно выделить институты гражданства, прав и свобод человека и др.

${ }^{2}$ См. Конституция Российской Федерации: Энциклопедический словарь / Под ред. В.А. Туманова, В.Е. Чиркина, Ю.А. Юдина. М., 1997; Большой юридический энциклопедический словарь. М., 2005. С. 410; Гальвина И.Н. Охрана и защита 
В Большом юридическом энциклопедическом словаре дается следующее определение: «основы конституционного строя - находящаяся под защитой государства система принципов, определяющих и регламентирующих общественные отношения, являющиеся объектом конституционно-правового регулирования; общие основополагающие начала конституционно-правовой регламентации конституционного строя» ${ }^{1}$.

Основы конституционного строя как конституционно-правовой институт закрепляют исходные принципы организации государства и гражданского общества, характер взаимодействия человека, общества и государства. Данный институт является ведущим в конституционноправовой защите государственного суверенитета, поскольку он определяет конституционно-правовое развитие всей системы общественных отношений, а государственный суверенитет является одной из основ конституционного строя. Государственный суверенитет выражает сущностные признаки государства, обладающего особыми возможностями решения наиболее сложных общественных проблем во всех сферах общественной жизни. Установленные Конституцией РФ основы конституционного строя обладают рядом специфических черт, к числу которых относят: их фундаментальное значение; политико-правовой характер; нормативность; юридическое верховенство ко всем остальным положениям конституции и других нормативных правовых актов; общепризнанность; целостность; устойчивость; особый порядок изменения.

Институт правового положения личности в контексте конституционноправовой защиты государственного суверенитета имеет двоякую сущность. С одной стороны, он развивает комплекс взаимосвязанных правовых норм, направленных на соблюдение, обеспечение и охрану конституционных прав

конституционного строя Российской Федерации. Автореф. дис. ... канд. юрид. наук. Челябинск, 2006; Новинский B.B. Основы конституционного строя как система конституционных принципов // Российский юридический журнал. 2004. № 1. С. 9-15.

${ }^{1}$ Большой юридический энциклопедический словарь / Под ред. А.Б. Барихина. М.: Книжный мир, 2005. С. 410 
и свобод, выступающих в качестве высшей конституционной ценности; с другой, - определяет конституционные ограничения прав и свобод в целях ЗГС, правовые основания и законные способы их осуществления (обязанности, запреты, меры ответственности и др.).

Институт национально-государственного устройства закрепляет внутреннюю структуру организации государства, его состав, государственнотерриториальное, национально-территориальное и административнотерриториальное деление. Решение вопросов конституционно-правовой защиты государственного суверенитета с учетом особенностей государственного устройства предполагает распределение компетенции между органами государственной власти и управления и специфику их взаимоотношений. В РФ ключевыми элементами конституционно-правовой защиты государственного суверенитета являются: формирование оптимального баланса федеральных и региональных интересов, гармонизация отношений между субъектами федерации, обеспечение единства экономического и правового пространства, реализация основополагающих прав и свобод человека на всей территории государства, сохранение территориальной целостности.

Институт государственных органов юридически закрепляет принципы построения и деятельности органов государственной власти в РФ, виды государственных органов, взаимоотношения между ними, порядок их образования, компетенцию, формы деятельности и другие важнейшие элементы их правового положения ${ }^{1}$. Данный институт обеспечивает разграничение задач и компетенции государственных органов, необходимое

\footnotetext{
1 Общие принципы построения и деятельности, компетенция органов государственной власти в РФ закреплены в Конституции, федеральных конституционных законах от 21 июля 1994 г. № 1-ФКЗ «О Конституционном Суде Российской Федерации», от 31 декабря 1996 г. № 1-ФКЗ «О судебной системе Российской Федерации», от 17 декабря 1997 г. № 2-ФКЗ «О Правительстве Российской Федерации», Федеральном законе от 6 октября 1999 г. № 184-Ф3 «Об общих принципах организации законодательных (представительных) и исполнительных органов государственной власти субъектов Российской Федерации» и др.
} 
для полного и эффективного осуществления внутренних и внешних функций государства во всех сферах общественной жизни, беспрепятственной реализации его суверенитета.

Институт выборов представляет собой закрепленную в Конституции форму непосредственного народовластия, посредством которой граждане реализуют свое право избирать и быть избранными в органы государственной власти и органы местного самоуправления, участвовать в управлении делами государства как непосредственно, так и через своих представителей. Выборы имеют ключевое значение для ЗГС. Периодическое проведение выборов выступает гарантом стабильности институтов государственной власти и местного самоуправления. Приход к власти представителей тех или иных политических сил с помощью выборов обусловливает определенной состояние ЗГС и задает параметры государственной политики. От решений, принимаемых органами народного представительства и выборными лицами, зависит степень реализации конституционных прав и свобод граждан, характер средств и методов осуществления государственной власти. Выборы выступают альтернативой силовому сценарию завоевания государственной власти. Выборы служат важнейшим индикатором доверия народа к власти и средством активизации населения. В то же время, в силу социально-политической значимости выборов, они могут являться объектом противоправных устремлений организованных преступных групп, террористических и иных экстремистских организаций и отдельных лиц, а для ряда иностранных государств являются объектом устремлений, направленных на ослабление или подрыв государственного суверенитета.

Выборы тесно связаны с существующей в государстве партийной системой.

Институт политических партий в ракурсе конституционно-правового регулирования играет существенную роль в обеспечении идеологического 
многообразия и развитии основополагающих прав и свобод. Конституционно-правовой статус партий позволяет им выступать инструментом организации избирательных кампаний и реализации народного представительства ${ }^{1}$. Состояние функционирования и авторитет политических партий (в том числе оппозиционных) имеют важнейшее значение для легитимности политической системы в целом и демократичности еe институтов. Законодателем запрещены создание и деятельность экстремистских политических партий. В контексте конституционно-правовой защиты государственного суверенитета предпринимаемые государством меры по запрету или роспуску политических партий, пропагандирующих насилие или выступающих за свержение конституционного строя путем вооруженной борьбы, террористических актов или иной подрывной деятельности, носят чрезвычайный и пропорциональный характер.

Институт общественных организаций рассматривается как совокупность правовых норм, регулирующих организацию и деятельность негосударственных и непартийных объединений граждан, воздействующих на государственную власть. В отличие от государства, общественные организации объединяют в рамках своей деятельности не все население, а определенные группы граждан. Специфика правового положения общественных организаций заключается в том, что они не ставят задачу завоевать государственную власть, а оказывают на нее давление. Общественные организации участвуют в управлении государственными и общественными делами, в решении политических, социальноэкономических, культурных и иных вопросов. В целях исключения возможностей иностранного влияния на политическую деятельность под видом поддержки общественного сектора государством установлены

1 Правовое положение политических партий в РФ определяется Федеральным законом от 11 июля 2001 г. № 95-Ф3 «О политических партиях». 
ограничения в деятельности некоммерческих организаций, выполняющих функции иностранных агентов ${ }^{1}$.

Институт СМИ устанавливает принципы поиска, получения, производства и распространения информации; регулирует порядок организации и контроля деятельности СМИ; определяет конституционные гарантии свободы информации и ответственность за злоупотребление ею 2. Законодательные положения не допускают пристрастное отношение, тенденциозную подачу информации, неравный доступ к СМИ, цензуру и другие ущемления свободы информации, которые дискредитируют возможности выражения мнений, свободу собраний и объединений. В тоже время ЗГС обязывает государство принимать меры по пресечению злоупотреблений свободой слова и массовой информации: призывов к насильственному захвату власти, насильственному изменению конституционного строя и нарушению территориальной целостности государства, пропаганды войны, террористических и иных насильственных действий, призывов к социальной, расовой, национальной, этнической, религиозной ненависти и вражде. В интересах ЗГС установлен запрет на производство и распространение информационных материалов иностранными или международными неправительственными организациями, признанными нежелательными на территории государства ${ }^{3}$. Важную роль в обеспечении свободы и независимости СМИ играет создание правовых гарантий защиты журналистов и другого персонала СМИ от нападений, запугивания и иных форм давления (в том числе со стороны представителей органов власти).

Институт местного самоуправления (далее - МСУ) определяет принципы МСУ, порядок формирования, структуру и компетенцию органов

${ }^{1}$ Подробнее см. параграф 3.3 .

2 Правовой основой деятельности СМИ в РФ является Конституция и Закон РФ от 27 декабря 1991 г. № 2124-1 «О средствах массовой информации».

3 Статья 3.1 Федерального закона от 23 мая 2015 г. № 129-Ф3 «О внесении изменений в отдельные законодательные акты Российской Федерации». 
МСУ, его гарантии ${ }^{1}$. Конституционный институт МСУ необходимо рассматривать как особую форму организации и осуществления населением публичной власти на местах, которая выражает право граждан (жителей определенной территории) на самостоятельное ведение дел и решение вопросов местного сообщества. В нормативном комплексе МСУ значимую роль играют полномочия органов МСУ по обеспечению соблюдения законов, поддержанию порядка, содействию органам правосудия, прокуратуры и юстиции в охране прав и свобод граждан, защите нарушенных прав и законных интересов. В закрытых административно-территориальных образованиях органы МСУ координируют деятельность охраны, полиции, гражданской обороны при угрозе возникновения чрезвычайных ситуаций; совместно с органами безопасности участвуют в определении пропускного режима; дают разрешения на въезд в закрытое образование, а также выезд из него $^{2}$. Несмотря на организационно-правовое обособление института МСУ от механизма государства, органы МСУ и их должностные лица на самом близком к населению, базовом уровне создают условия для деятельности специализированных государственных органов по ЗГС и оказывают им необходимое содействие.

Перечисленные правовые институты - элементы конституционноправовых механизмов ЗГС воздействуют друг на друга. К основным формам их взаимодействия можно отнести унификацию и специализацию.

Унификация представляет собой обобщение правовых предписаний и выработку единообразных правовых норм, регулирующих сходные отношения. Она направлена на сближение правового регулирования на внутригосударственном и наднациональном уровнях. Примером унификации на внутригосударственном уровне можно считать закрепление в интересах

1 Федеральный закон от 6 октября 2003 г. № 131-Ф3 «Об общих принципах организации местного самоуправления в Российской Федерации».

2 Закон РФ от 14 июля 1992 г. № 3297-1 «О закрытом административнотерриториальном образовании». 
ЗГС ограничений правосубъектности, связанных с наличием гражданства иностранного государства, в законодательстве о выборах, политических партиях, государственной, военной и правоохранительной службе, СМИ. На наднациональном уровне происходит унификация конституционного, уголовного, военного, административного, гражданского и иных видов законодательства в рамках модельных законов Межпарламентской Ассамблеи СНГ, Парламентской Ассамблеи ОДКБ, таможенного законодательства в рамках ЕАЭС и др.

Специализация означает обособление правовых установлений, позволяющее учитывать специфику регулируемых отношений. Применительно к ЗГС специализация проявилась в виде выделения субинститута специальных защитных и экономических мер, контрсанкций, а также организаций с особым правовым статусом (иностранных или международных неправительственных организаций, признанных нежелательными и некоммерческих организаций, выполняющих функцию иностранного агента).

Рассмотрев юридический аспект конституционно-правовой защиты государственного суверенитета (правовые институты, регулирующие наиболее важные отношения в сфере ЗГС), обратимся к институциональному аспекту - специализированным государственным органам, с помощью которых обеспечивается верховенство и независимость государственной власти, беспрепятственная реализация государственно-властных полномочий, противодействие деструктивной деятельности антигосударственных сил по ослаблению и подрыву государственного суверенитета. Назовем их субъектами конституцчионно-правовой защчитьл государственного суверенитета.

Место субъектов в системе конституционно-правовой защиты государственного суверенитета определяется спецификой общественных отношений, с которыми связана их деятельность, а также характером 
взаимосвязей друг с другом.

Перечень

субъектов

конституционно-правовой

защиты

государственного суверенитета в законодательных и подзаконных актах не определен. Для отграничения специальных государственных органов, осуществляющих ЗГС, от других элементов государственного механизма целесообразно использовать юридический и функциональный критерии. В соответствии с юридическим критерием в конституционно-правовых актах, регулирующих деятельность государственных органов, должна быть закреплена обязанность самостоятельной или совместной реализации правомочий, ориентированных на обеспечение беспрепятственного и независимого осуществления функций государства в области ЗГС ${ }^{1}$ Функциональный критерий предполагает реализацию соответствующим государственным органом функции по защите принципов, порядка формирования и функционирования государственной власти, участие в противодействии деструктивной деятельности по ослаблению и подрыву государственного суверенитета.

С учетом особенностей государственного устройства и разграничения предметов ведения и полномочий в системе государственной власти РФ конституционно-правовая защита государственного суверенитета находится в ведении федеральных и региональных органов власти. Эти органы выступают от имени государства и наделены правом использовать средства конституционно-правовой защиты государственного суверенитета (могут издавать нормативные правовые и правоприменительные акты), а также применять (санкционировать применение) меры государственного принуждения.

По объему компетенции и полномочий в сфере ЗГС можно выделить

1 В данной работе общественные структуры не рассматриваются как субъекты непосредственной защиты суверенитета государства. Общественные институты оказывают разноплановое содействие специализированным государственным органам в решении задач ЗГС, но не выступают носителями правомочий и обязанностей в сфере ЗГС. 
субъекты общуей компетенциии (Президент, Федеральное Собрание, Конституционный Суд, Верховный Суд, Правительство, Центральный банк, ЦИК России) и субъекты спещиальной компетенциии (Вооруженные Силы Российской Федерации, МИД, органы внешней разведки, органы безопасности, таможенные органы, органы внутренних дел, органы МЧС, Росфинмониторинг, налоговые органы, прокуратуру, Министерство юстиции, ФСИН, Министерство культуры и Минобрнауки и др.). Ключевое отличие правового статуса данных категорий субъектов конституционноправовой защиты государственного суверенитета заключается том, что субъекты общей компетенции формируют высшие органы государственной власти и определяют направления политики государства по ЗГС, а субъекты специальной компетенции реализуют эту политику в рамках специального предмета ведения.

С учетом обстоятельств принятия действующей Конституции и закрепленных в ней особенностей формы российского государства (централизация властных полномочий, сильная президентская власть) наиболее значимое воздействие на преобразование общественных отношений оказывает Президент РФ.

Часть 2 статьи 80 Конституции определяет статус Президента РФ как гаранта Конституции РФ, прав и свобод человека и гражданина. В установленном Конституцией порядке он принимает меры по ЗГС РФ, ее независимости и государственной целостности, обеспечивает согласованное функционирование и взаимодействие органов государственной власти.

Президент РФ определяет основные направления внутренней и внешней политики государства. Как глава государства Президент представляет Россию внутри страны и за ее пределами.

В интересах ЗГС Президент принимает меры по обеспечению единства 
правового пространства РФํ․ Глава государства обладает правом отклонения федеральных законов, отмены актов Правительства РФ, приостановления актов органов исполнительной власти субъектов РФ, нарушающих положения Конституции, федеральных законов и международных обязательств.

Президент вправе обратиться в Конституционный Суд РФ с запросом о соответствии Конституции РФ федеральных законов, нормативных правовых актов Президента, Совета Федерации, Государственной Думы, Правительства РФ, конституций республик, уставов, а также законов и иных нормативных правовых актов субъектов РФ.

Президент может вынести предупреждение законодательному (представительному) органу государственной власти субъекта РФ и высшему должностному лицу субъекта РФ, направленное на обеспечение исполнения судебных решений, вынесенных в связи с принятием органами государственной власти субъектов РФ нормативных актов, противоречащих Конституции и федеральным законам.

Президент РФ вправе внести в Государственную Думу проект федерального закона о роспуске законодательного органа государственной власти субъекта РФ в связи с уклонением от исполнения судебных решений об отмене нормативного акта, нарушающего положения Конституции и федеральных законов и влекущего конституционно значимые последствия (неправомерный нормативный акт повлек массовые и грубые нарушения прав и свобод человека и гражданина, угрозу единству, территориальной целостности, национальной безопасности, обороноспособности, единству правового и экономического пространства РФ).

Президент отрешает высшее должностное лицо субъекта РФ от

${ }^{1}$ Указ Президента РФ от 10 августа 2000 г. № 1486 «О дополнительных мерах по обеспечению единства правового пространства Российской Федерации» // С3 РФ. 2000. № 33. Ст. 3356. 
должности: в связи с выражением ему недоверия законодательным органом государственной власти субъекта РФ; в связи с его незаконными действиями и решениями (в связи с утратой доверия Президента РФ); в связи с ненадлежащим исполнением своих обязанностей; в связи с неисполнением им решения Конституционного Суда РФ в отношении нормативного акта высшего должностного лица субъекта РФ, нарушающего положения Конституции и федеральных законов.

Возможность применения Президентом перечисленных мер федерального воздействия является эффективным юридическим инструментом реализации Главой государства своих функций по защите Конституции, государственного суверенитета и обеспечению единства правового пространства РФ.

Значимым фрагментом правосубъектности Главы государства является его участие в правотворческой деятельности. Президент наделен правом законодательной инициативы и в пределах своей компетенции сам издает правовые акты нормативного характера, регламентирующие отношения по ЗГС.

Президент РФ принимает решение о применении специальных экономических мер в отношении иностранных государств, иностранных организаций и граждан, лиц без гражданства для защиты государственного суверенитета РФ, а также прав и свобод российских граждан с обязательным незамедлительным информированием Совета Федерации и Государственной Думы о таком решении ${ }^{1}$.

Важным элементом конституционно-правового статуса Президента как субъекта ЗГС выступают полномочия в сфере обороны, военного

1 Указ Президента РФ от 6 августа 2014 г. № 560 «О применении отдельных специальных экономических мер в целях обеспечения безопасности Российской Федерации» // Рос. газ. 2014. 7 августа; Указ Президента РФ от 28 ноября 2015 г. № 583 «О мерах по обеспечению национальной безопасности Российской Федерации и защите граждан Российской Федерации от преступных и иных противоправных действий и о применении специальных экономических мер в отношении Турецкой Республики» // Электронный ресурс URL: https://www.pravo.gov.ru (дата обращения 05.12.2015). 
строительства и введения особых правовых режимов.

Президент является Верховным Главнокомандующим Вооруженными Силами РФ, утверждает военную доктрину РФ, назначает и освобождает высшее командование Вооруженными Силами.

Президент вводит на территории РФ или в отдельных ее местностях особые правовые режимы (чрезвычайное положение или военное положение) с незамедлительным сообщением об этом Совету Федерации и Государственной Думе. При введении чрезвычайного положения Президентом РФ могут полностью или частично приостанавливаться полномочия органов исполнительной власти субъекта (субъектов) РФ, а также органов местного самоуправления. В случаях агрессии против РФ или непосредственной угрозы агрессии, возникновения вооруженных конфликтов, направленных против РФ, Президент объявляет общую или частичную мобилизацию с незамедлительным сообщением об этом палатам Федерального Собрания РФ. Глава государства издает нормативные правовые акты в области мобилизационной подготовки и мобилизации и устанавливает режим работы органов государственной власти, органов местного самоуправления и организаций в период мобилизации и в военное время ${ }^{1}$.

Реализуя конституционные полномочия по ЗГС в условиях военного времени, Президент:

- осуществляет руководство организацией обеспечения режима военного положения;

- определяет меры по обеспечению режима военного положения и контролирует их применение;

- определяет задачи и устанавливает порядок привлечения Вооруженных Сил, других войск, воинских формирований и органов для

1 Статья 4 Федерального закона от 26 февраля 1997 г. № 31-Ф3 «О мобилизационной подготовке и мобилизации в Российской Федерации». 
обеспечения режима военного положения;

- приостанавливает деятельность политических партий, других общественных объединений, религиозных объединений, ведущих пропаганду и (или) агитацию, а равно иную деятельность, подрывающую в условиях военного времени оборону и безопасность государства;

- устанавливает запреты или ограничения на проведение собраний, митингов и демонстраций, шествий и пикетирования, а также иных массовых мероприятий в условиях военного положения;

- устанавливает запреты на проведение забастовок и на приостановление или прекращение деятельности организаций в условиях военного времени;

- принимает необходимые меры по прекращению или приостановлению действия международных договоров РФ и иностранными государствами (группой государств), совершившим (совершивших) акт агрессии против РФ и (или) государствами, союзными с ним (ними) ${ }^{1}$;

- прекращает деятельность в РФ иностранных и международных организаций, в отношении которых правоохранительными органами получены достоверные сведения о том, что указанные организации осуществляют деятельность, направленную на подрыв обороны и

${ }^{1}$ После того, как 24 ноября 2015 г. турецким истребителем на территории Сирии был сбит российский бомбардировщик СУ-24, что являлось актом агрессии против РФ, Указом Президента РФ от 28 ноября 2015 г. № 583 «О мерах по обеспечению национальной безопасности Российской Федерации и защите граждан Российской Федерации от преступных и иных противоправных действий и о применении специальных экономических мер в отношении Турецкой Республики» с 1 января 2016 г. было приостановлено действие Соглашения между Правительством Российской Федерации и Правительством Турецкой Республики об условиях взаимных поездок граждан Российской Федерации и граждан Турецкой Республики от 12 мая 2010 г. в части поездок граждан Турецкой Республики - обладателей общегражданских заграничных паспортов. По поручению Президента Правительством РФ была приостановлена деятельность Смешанной межправительственной Российско-Турецкой комиссии по торговоэкономическому сотрудничеству, приостановлен переговорный процесс с турецкой стороной по проекту Соглашения между Правительством РФ и Правительством Турецкой Республики о торговле услугами и инвестициях, проекту Среднесрочной программы торгово-экономического, научно-технического и культурного сотрудничества между Правительством РФ и Правительством Турецкой Республики на 2016-2019 гг., а также по созданию Российско-турецкого совместного фонда по финансированию инвестиционных проектов в РФ и Турецкой Республике. 
безопасности РФ;

- устанавливает на территории, на которой введено военное положение, особый режим работы объектов, обеспечивающих функционирование транспорта, коммуникаций и связи, объектов энергетики, а также объектов, представляющих повышенную опасность.

Особая группа президентских полномочий в сфере ЗГС связана с противодействием террористической и иной экстремистской деятельности.

Президент определяет основные направления государственной политики в области противодействия терроризму и экстремизму. По решению Президента сформированы коллегиальные органы, координирующие деятельность федеральных органов исполнительной власти, органов исполнительной власти субъектов РФ и органов местного самоуправления по противодействию терроризму и экстремизму ${ }^{1}$. Глава государства принимает решение об использовании за пределами территории РФ формирований Вооруженных Сил и подразделений специального назначения для борьбы с террористической деятельностью, осуществляемой против РФ либо граждан РФ или апатридов, постоянно проживающих в РФ².

Глава государства обращается с посланиями к Федеральному Собранию, в которых определяются приоритетные направления государственной политики РФ и конкретные задачи по ЗГС.

Президент осуществляет общее руководство подведомственными государственными органами, обеспечивающими ЗГС, и определяет их

${ }^{1}$ В соответствии с Указом Президента РФ от 15 февраля 2006 г. № 116 (в ред. от 27 июня 2014 г.) «О мерах по противодействию терроризму» для координации субъектов противодействия терроризму в России образован Национальный антитеррористический комитет. В целях реализации государственной политики в области противодействия экстремизму на основании Указа Президента РФ от 26 июля 2011 г. № 988 (в ред. от 17 февраля 2016 г.) «О Межведомственной комиссии по противодействию экстремизму в Российской Федерации» создана Межведомственная комиссия по противодействию экстремизму в РФ.

230 сентября 2015 г. Президент РФ внес на рассмотрение Совета Федерации предложение о принятии Постановления о согласии на использование контингента Вооруженных Сил РФ за рубежом для проведения антитеррористической операции в Сирийской Арабской Республике. Данное предложение было поддержано. 
компетенцию (Министерство обороны Российской Федерации, МИД России, СВР России, ФСБ России, Федеральная служба войск национальной гвардии РФ, МВД России, МЧС России, Росфинмониторинг, Министерство юстиции) $)^{1}$.

В соответствии с п. «ж» ст. 83 Конституции РФ Президент формирует и возглавляет Совет Безопасности РФ, статус которого определяется федеральным законом. Данный орган обеспечивает реализацию конституционных полномочий Главы государства по защите прав и свобод человека и гражданина, ЗГС РФ, ее независимости и государственной целостности, организации взаимодействия органов государственной власти, определению основных направлений внутренней и внешней политики государства. Совет безопасности готовит предложения Президенту для принятия Главой государства решений по ЗГС РФ и вопросам внутренней и внешней политики.

Важнейшим субъектом конституционно-правовой защиты государственного суверенитета выступает высший законодательный и представительный орган государственной власти Российской Федерации Федеральное Собрание РФ. Особенности конституционно-правового статуса данного органа заключаются в том, что он обладает исключительным правом на принятие законов, на законодательном уровне устанавливает регламентацию общественных отношений, связанных с ЗГС, а также определяет компетенцию большинства других субъектов, реализующих полномочия по ЗГС.

Федеральное Собрание: принимает федеральные конституционные и федеральные законы, регламентирующие весь спектр деятельности государства в сфере ЗГС РФ; рассматривает расходы на оборону, на защиту

1 Перечень федеральных органов исполнительной власти, которыми непосредственно руководит Президент РФ, закреплен в Указе Президента РФ от 21 мая 2012 г. (с изм. от 5 апреля 2016 г.) № 636 «О структуре федеральных органов исполнительной власти». 
государственной тайны, на содержание субъектов ЗГС (органов полиции, безопасности, внешней разведки и др.), принимает федеральный бюджет; устанавливает гарантии правовой и социальной защиты военнослужащих и сотрудников государственных органов, относящихся к субъектам ЗГС; осуществляет парламентский контроль деятельности субъектов, осуществляющих ЗГС; направляет парламентские запросы и проводит парламентские слушания, в том числе по проблемам ЗГС; проводит парламентские расследования.

Совет Федерации утверждает указы Президента РФ о введении военного положения и чрезвычайного положения на территории РФ или в отдельных ее местностях, a также решает вопрос о возможности использования Вооруженных Сил за пределами территории РФ. Совет Федерации вносит предложения Президенту о применении специальных экономических мер для защиты интересов, обеспечения безопасности РФ, а также защиты прав и свобод российских граждан; рассматривает принятые Государственной Думой федеральные законы по вопросам обеспечения режима военного положения; рассматривает принятые Государственной Думой федеральные законы по вопросам прекращения или приостановления действия международных договоров РФ с иностранным государством (группой государств), совершившим (совершивших) акт агрессии против РФ, и государствами, союзными с ним (ними).

Государственная Дума вносит предложения Президенту о применении специальных экономических мер в отношении иностранных государств, иностранных организаций и граждан, а также лиц без гражданства; принимает федеральные законы по вопросам обеспечения режима военного положения; принимает федеральные законы по вопросам прекращения или приостановления действия международных договоров РФ с иностранным государством (группой государств), совершившим (совершивших) акт агрессии против РФ, и государствами, союзными с ним (ними). 
Государственная Дума заслушивает доклад Министра юстиции о деятельности некоммерческих организаций, выполняющих функции иностранного агента, об участии их в политической деятельности на территории РФ, о поступлениях и расходовании денежных средств и о результатах контроля за их деятельностью.

Значимую роль в ЗГС играют органы правосудия, уполномоченные применять государственное принуждение. Особое место в системе судебной власти занимает Конституционный Суд РФ, который обеспечивает верховенство Конституции РФ и выступает высшим органом конституционного контроля в РФ. Он осуществляет свои функции посредством особой процедуры конституционного судопроизводства.

Конституционно-правовая защита государственного суверенитета осуществляется Конституционным Судом в рамках реализации его полномочий, установленных Федеральным конституционным законом от 21 июля 1994 г. (с изм. и доп. от 8 июня 2015 г.) № 1-ФКЗ «О Конституционном Суде Российской Федерации» ${ }^{1}$.

Конституционный Суд РФ:

а) разрешает дела о соответствии Конституции РФ:

- федеральных законов, нормативных актов Президента, Совета Федерации, Государственной Думы, Правительства РФ;

- конституций республик, уставов, а также законов и иных нормативных актов субъектов РФ, изданных по вопросам исключительного ведения органов государственной власти РФ и совместного ведения органов государственной власти РФ и органов государственной власти субъектов РФ;

- договоров между органами государственной власти РФ и органами государственной власти субъектов РФ, договоров между органами государственной власти субъектов РФ;

\footnotetext{
${ }^{1}$ Рос. газ. 1994. 23 июля.
} 
- не вступивших в силу международных договоров РФ;

б) разрешает споры о компетенции между федеральными органами государственной власти; между федеральными и региональными органами государственной власти; между высшими государственными органами субъектов РФ;

в) по жалобам на нарушение конституционных прав и свобод граждан проверяет конституционность закона, примененного в конкретном деле;

г) по запросам судов проверяет конституционность закона, подлежащего применению соответствующим судом в конкретном деле;

д) дает толкование Конституции РФ;

е) дает заключение о соблюдении установленного порядка выдвижения обвинения Президента РФ в государственной измене или совершении иного тяжкого преступления;

ж) проверяет на соответствие Конституции РФ вопрос, выносимый на референдум РФ;

3) выступает с законодательной инициативой по вопросам своего ведения.

В разделе III Федерального конституционного закона «О Конституционном Суде Российской Федерации» определены особенности конституционного судопроизводства по отдельным категориям дел, среди которых в ракурсе конституционно-правовой защиты государственного суверенитета особое значение имеют:

- дела о соответствии Конституции РФ нормативных актов органов государственной власти и договоров между ними;

- дела о соответствии Конституции не вступивших в силу международных договоров РФ;

- дела по спорам о компетенции;

- дела о конституционности законов по жалобам граждан и запросам судов; 
- дела о толковании Конституции РФ;

- дела о даче заключения о соблюдении установленного порядка выдвижения обвинения Президента РФ в государственной измене или совершении иного тяжкого преступления.

Итогом рассмотрения дел, принятых Конституционным Судом РФ к производству, могут являться:

признание нормативного акта, договора или отдельных их положений соответствующими или не соответствующими Конституции;

подтверждение или отрицание полномочия соответствующего органа издать акт или совершить юридически значимое действие, послужившие причиной спора о компетенции;

утрата силы актов или их отдельных положений, признанных неконституционными;

невозможность введения в действие и применения не вступивших в силу международных договоров РФ, признанных не соответствующими Конституции;

неисполнение и пересмотр в установленных федеральным законом случаях решений судов или иных органов, основанных на актах, дисквалифицированных Конституционным Судом;

отмена положений нормативных правовых актов, основанных на нормативных правовых актах неконституционными, либо воспроизводящих оспариваемые положения ${ }^{1}$.

Вклад Конституционного Суда в функционирование системы конституционно-правовой защиты государственного суверенитета РФ неоценим. Решения Конституционного Суда по проблемам ЗГС способствуют гармонизации российского законодательства и повышению внутригосударственного уровня правовой защиты. Благодаря практике

1 Если признание нормативного правового акта создало пробел в правовом регулировании, применяется непосредственно Конституция. 
конституционного судопроизводства обеспечиваются независимость российской правовой системы и верховенство национальной юрисдикции.

Существенную роль в ЗГС играет Верховный Суд РФ.

Полномочия Верховного Суда РФ закреплены в статье 2 Федерального конституционного закона от 5 февраля 2014 г. № 3-ФК3 «О Верховном Суде Российской Федерации».

Верховный Суд является высшим судебным органом по гражданским делам, по разрешению экономических споров, уголовным, административным и иным делам, а также осуществляет судебный надзор за деятельностью судов.

В качестве суда первой инстанции Верховный Суд рассматривает следующие категории дел, имеющие непосредственное отношение к ЗГС:

- об оспаривании нормативных правовых актов Президента, Правительства, федеральных органов исполнительной власти, Генеральной прокуратуры РФ, Следственного комитета РФ, Судебного департамента при Верховном Суде РФ, Центрального банка РФ, ЦИК России, государственных внебюджетных фондов, а также государственных корпораций;

- об оспаривании ненормативных правовых актов Президента, Совета Федерации и Государственной Думы, Правительства РФ, Правительственной комиссии по контролю за осуществлением иностранных инвестиций в РФ, Министерства обороны и иных федеральных органов исполнительной власти, в которых федеральным законом предусмотрена военная служба;

- о приостановлении деятельности политических партий, общероссийских и международных общественных объединений, о ликвидации политических партий, общероссийских и международных общественных объединений, о ликвидации централизованных религиозных организаций, имеющих местные религиозные организации на территориях двух и более субъектов РФ; 
- о прекращении деятельности СМИ, продукция которых предназначена для распространения на территориях двух и более субъектов РФ;

- об оспаривании решений (уклонения от принятия решений) ЦИК России (независимо от уровня выборов, референдума), за исключением решений, оставляющих в силе решения нижестоящих избирательных комиссий, комиссий референдума;

- об отмене регистрации кандидата на должность Президента РФ, об отмене регистрации федерального списка кандидатов, об отмене регистрации кандидата, включенного в зарегистрированный федеральный список кандидатов, а также об исключении региональной группы кандидатов из федерального списка кандидатов при проведении выборов депутатов Государственной Думы;

- о прекращении деятельности инициативной группы по проведению референдума РФ, инициативной агитационной группы;

- о расформировании ЦИК России;

- по разрешению споров между федеральными органами государственной власти и органами государственной власти субъектов РФ, переданных на рассмотрение в Верховный Суд РФ Президентом РФ в соответствии со статьей 85 Конституции РФ;

- по разрешению экономических споров между федеральными органами государственной власти и органами государственной власти субъектов РФ, между высшими органами государственной власти субъектов РФ.

Верховный Суд РФ осуществляет право законодательной инициативы по вопросам своего ведения, а также разрабатывает предложения по совершенствованию законодательства по вопросам своего ведения.

Анализ полномочий Верховного Суда позволяет выделить несколько форм его участия в конституционном контроле: 
a) обращение в соответствии с частями 2 и 4 статьи 125 Конституции РФ в Конституционный Суд РФ с запросами о проверке конституционности законов, иных нормативных правовых актов и договоров,

б) обращение с запросом о проверке конституционности закона, подлежащего применению в деле, рассматриваемом Верховным Судом в любой инстанции.

Верховный Суд выступает элементом механизма реализации конституционной ответственности Президента РФ: выносит заключение о наличии в действиях Президента признаков преступления при выдвижении Государственной Думой обвинения Президента в государственной измене или совершении иного тяжкого преступления.

В рамках ЗГС в сфере международных отношений Верховный Суд РФ разрешает в пределах своей компетенции вопросы, связанные с международными договорами РФ.

Особого внимания заслуживают решения Верховного Суда РФ о признании ряда организаций, в том числе иностранных и международных, террористическими и запрете их деятельности на территории РФ. Такие решения принимались Верховным Судом РФ 14 февраля 2003 г., 2 июня 2006 г., 13 ноября 2008 г., 8 февраля 2010 г. и 29 декабря 2014 г.

1 Решение Верховного Суда РФ от 14 февраля 2003 г. № ГКПИ 03-116 «О признании террористическими организаций «Высший военный Маджлисуль Шура Объединенных сил моджахедов Кавказа», «Конгресс народов Ичкерии и Дагестана», «База» («Аль-Каида»), «Асбат аль-Ансар», «Священная война» («Аль-Джихад» или «Египетский исламский джихад»), «Исламская группа» («Аль-Гамаа аль-Исламия»), «Братья-мусульмане» («Аль-Ихван аль-Муслимун»), «Партия исламского возрождения» («Хизб ут-Тахрир аль-Ислами»), «Лашкар-И-Тайба», «Исламская группа» («Джамаат-иИслами»), «Движение Талибан», «Исламская партия Туркестана» (бывшее «Исламское движение Узбекистана»), «Общество социальных реформ» («Джамият аль-Ислах альИджтимаи»), «Общество возрождения исламского наследия» («Джамият Ихья ат-Туразаль аль-Ислами»), «Дом двух святых» («Аль-Харамейн») и запрещении их деятельности на территории Российской Федерации; Решение Верховного Суда РФ от 2 июня 2006 г. № ГКПИ 06-531 «О признании организаций «Джунд аш-Шам» и «Исламский джихад Джамаат моджахедов» террористическими и запрете их деятельности на территории Российской Федерации; Решение Верховного суда РФ от 13 ноября 2008 г. № ГКПИ 081956 « признании международной организации «Аль-Каида в странах исламского Магриба» террористической и запрете ее деятельности на территории Российской Федерации»; Решение Верховного Суда РФ от 8 февраля 2010 г. № ГКПИ 09-1715 «О признании международной организации «Имарат Кавказ» («Кавказский Эмират») 
Однако без органов исполнительной власти, непосредственно реализующих правовые предписания законодателя и судебные постановления, конституционно-правовая защита государственного суверенитета была бы недейственной. Именно Правительство РФ и другие органы исполнительной власти разрабатывают и осуществляют меры по обеспечению обороны страны, государственной безопасности, реализации внешней политики, ведут борьбу с преступностью, обеспечивают законность, права и свободы граждан, охрану общественного порядка.

Правительство РФ в пределах своей компетенции участвует в законодательном обеспечении различных направлений ЗГС:

- обладает правом законодательной инициативы;

- дает заключения на законопроекты о введении или об отмене налогов, об освобождении от их уплаты, о выпуске государственных займов, об изменении финансовых обязательств государства и на законопроекты, предусматривающие расходы, покрываемые за счет средств федерального бюджета;

- представляет Государственной Думе федеральный бюджет и отчет о его исполнении.

Правительство определяет компетенцию субъектов ЗГС - федеральных органов исполнительной власти, руководство деятельностью которых оно осуществляет.

Правительство РФ осуществляет меры по обеспечению обороны страны и несет ответственность за состояние и обеспечение Вооруженных Сил, других войск, воинских формирований и органов; организует их оснащение вооружением и военной техникой, обеспечение материальными средствами и другими ресурсами; организует выполнение государственных

террористической и запрете ее деятельности на территории Российской Федерации»; Решение Верховного Суда РФ от 29 декабря 2014 г. № АКПИ 14-1424С «О признании международных организаций «Исламское государство» и «Джебхат ан-Нусра» террористическими и запрете их деятельности на территории Российской Федерации». 
программ вооружения и развития оборонно-промышленного комплекса; устанавливает мобилизационные задания федеральным органам исполнительной власти; определяет порядок выполнения органами исполнительной власти, органами местного самоуправления, организациями, а также гражданами военно-транспортной обязанности, подготовки граждан к военной службе, воинского учета, призыва на военную службу, проведения военных сборов; принимает решение об установлении особого режима безопасного функционирования организаций и объектов в закрытых административно-территориальных образованиях; ведет международные переговоры по вопросам военного сотрудничества и заключает межправительственные соглашения; реализует иные полномочия по ЗГС ${ }^{1}$.

В пределах своих полномочий Правительство участвует в деятельности по противодействию терроризма: организует разработку и осуществление мер по предупреждению терроризма, минимизацию и ликвидацию последствий терроризма; организует обеспечение деятельности субъектов противодействия терроризму необходимыми силами, средствами и ресурсами; устанавливает требования к антитеррористической защищенности объектов, категории таких объектов; в случае выполнения Вооруженными Силами задач по пресечению международной террористической деятельности за рубежом Правительство по поручению Президента направляет за пределы территории РФ гражданский персонал, определяет районы действий, задачи, срок пребывания, порядок замены указанного персонала.

Конституционно-правовая защита государственного суверенитета в сфере исполнительной власти проявляется в закреплении:

- единой системы исполнительной власти в пределах ведения и

1 Правительство РФ вносит предложение Президенту РФ о применении специальных экономических мер в отношении иностранных государств, иностранных организаций и граждан, а также лиц без гражданства для ЗГС РФ, а также прав и свобод российских граждан. 
полномочий РФ по предметам совместного ведения РФ и субъектов РФ;

- механизма обеспечения федеральных и региональных интересов по предметам совместного ведения, урегулирования разногласий между федеральными и региональными органами исполнительной власти;

- контроля Правительства за деятельностью органов исполнительной власти.

Согласно ст. 43 Федерального конституционного закона от 17 декабря 1997 г. № 2-ФКЗ «О Правительстве Российской Федерации» Правительство РФ в целях обеспечения сочетания интересов РФ и субъектов РФ по предметам совместного ведения РФ и субъектов РФ в сфере осуществления исполнительной власти координирует деятельность органов исполнительной власти субъектов РФ.

Проекты решений Правительства по предметам совместного ведения РФ и субъектов РФ подлежат согласованию с законодательными (представительными) и исполнительными органами государственной власти субъектов РФ. Предложения законодательных (представительных) и исполнительных органов государственной власти субъектов РФ по таким проектам в обязательном порядке рассматриваются Правительством.

Правительство РФ разрешает споры и устраняет разногласия между федеральными органами исполнительной власти и органами исполнительной власти субъектов РФ. Для этого создаются согласительные комиссии из представителей заинтересованных сторон.

Контрольные полномочия Правительства распространяются на деятельность федеральных органов исполнительной власти, а по предметам совместного ведения РФ и субъектов РФ - на деятельность органов исполнительной власти субъектов РФ. Правительство вносит предложения Президенту о приостановлении действия актов органов исполнительной власти субъектов РФ в случае их противоречия Конституции РФ, федеральным законам, международным обязательствам или нарушения прав 
и свобод человека и гражданина.

Правительство РФ вправе обратиться в Конституционный Суд с запросом о соответствии Конституции Российской Федерации федеральных законов, нормативных правовых актов Президента РФ, Совета Федерации, Государственной Думы, Правительства РФ, конституций республик, уставов, а также законов и иных нормативных правовых актов субъектов РФ.

Подобный механизм ЗГС в сфере исполнительной власти способствует обеспечению основополагающих прав и свобод, укреплению федеративных отношений, единству правового и экономического пространства, территориальной целостности государства.

Чувствительным направлением деятельности Правительства РФ является экономическая политика, от которой в определяющей степени зависит ЗГС.

В ходе разработки основных направлений единой государственной денежно-кредитной политики и направлений развития финансового рынка Правительство тесно сотрудничает с другим субъектом ЗГС - Центральным банком РФ (Банком России) 1 .

Банк России и Правительство РФ информируют друг друга о предполагаемых действиях, имеющих общегосударственное значение, координируют свою политику, проводят регулярные взаимные консультации.

Согласно ст. 3 Федерального закона от 10 июля 2002 г. № 86-Ф3 «О Центральном банке Российской Федерации (Банке России)» целями деятельности Банка России являются:

защита и обеспечение устойчивости рубля;

развитие и укрепление банковской системы РФ;

${ }^{1}$ Роль Центрального банка РФ как субъекта ЗГС подчеркнута в п. 109 Стратегии национальной безопасности Российской Федерации (утверждена Указом Президента РФ от 31 декабря 2015 г. № 683), где указано, что «деятельность Центрального банка Российской Федерации как участника стратегического планирования осуществляется в целях обеспечения национальных интересов и реализации стратегических национальных приоритетов». 
обеспечение стабильности и развитие национальной платежной системы;

развитие финансового рынка РФ;

обеспечение стабильности финансового рынка РФ.

Банк России во взаимодействии с Правительством РФ разрабатывает и проводит единую государственную кредитно-денежную политику посредством поддержания ценовой стабильности, в том числе для формирования условий сбалансированного и устойчивого экономического роста.

К прерогативам Банка России относятся эмиссия наличных денег, организация их обращения и изъятие из обращения.

Банк России осуществляет надзор и развитие национальной платежной системы, управление золотовалютными резервами, организует и осуществляет валютное регулирование и валютный контроль.

Банк России является органом банковского регулирования и банковского надзора. Надзорные функции Банка России осуществляются в целях поддержания стабильности банковской системы РФ и защиты интересов вкладчиков и кредиторов.

Банк России принимает решение о государственной регистрации кредитных организаций, выдает кредитным организациям лицензии на осуществление банковских операций, приостанавливает их действие и отзывает их.

Банк России проводит анализ состояния экономики РФ (в том числе анализ денежного обращения и кредита, финансового рынка РФ, валютного положения и платежного баланса РФ, национальной платежной системы) и прогнозирует ее развитие; осуществляет контроль и надзор за соблюдением эмитентами требований законодательства об акционерных обществах и ценных бумагах; осуществляет контроль за соблюдением требований законодательства о противодействии неправомерному использованию 
инсайдерской информации и манипулированию рынком.

По решению Президента Банк России во взаимодействии с Правительством РФ устанавливает перечень специальных экономических мер по ЗГС РФ и в пределах компетенции обеспечивает их реализацию1.

Значительный вклад в ЗГС при формировании и воспроизводстве представительных органов государственной власти вносит Центральная избирательная комиссия РФ (ЦИК России).

Статус и полномочия ЦИК России как субъекта конституционноправовой защиты государственного суверенитета закреплены в Федеральном конституционном законе «О референдуме Российской Федерации» (статья 30), Федеральном законе «Об основных гарантиях избирательных прав и права на участие в референдуме граждан Российской Федерации» (статья 21), Федеральном законе «О выборах Президента Российской Федерации» (статья 19), Федеральном законе «О выборах депутатов Государственной Думы Федерального Собрания Российской Федерации» (статья 25).

ЦИК России является федеральным государственным органом, организующим подготовку и проведение выборов и референдумов в РФ. ЦИК России действует на постоянной основе и состоит из 15 членов: пять членов ЦИК России назначаются Государственной Думой, пять членов назначаются Советом Федерации, пять членов назначаются Президентом РФ.

Полномочия ЦИК России в сфере защиты государственного суверенитета можно разделить на несколько основных групп:

- полномочия в сфере организации и проведения выборов и референдумов;

- полномочия по установлению обязательных нормативов и образцов избирательных (референдумных) документов и технологического оборудования;

${ }^{1}$ Статья 4 Федерального закона от 30 декабря 2006 г. № 281-Ф3 «О специальных экономических мерах». 
- полномочия в сфере правового регулирования избирательного (референдумного) процесса;

- контрольные полномочия;

- полномочия по определению результатов выборов и легитимации избирательного (референдумного) процесса.

Полномочия в сфере организациии $и$ проведения выборов $u$ референдумов охватывают деятельность ЦИК России по подготовке и проведению выборов в федеральные органы государственной власти (выборов депутатов Государственной Думы, выборов Президента РФ), подготовку и проведение референдума РФ.

ЦИК России руководит деятельностью избирательных комиссий и комиссий референдума, обеспечивает реализацию всего комплекса мероприятий, связанных с подготовкой и проведением выборов и референдумов.

ЦИК России регистрирует доверенных лиц и уполномоченных представителей политических партий, федеральные списки кандидатов в депутаты Государственной Думы, регистрирует кандидатов на должность Президента РФ, инициативную группу по проведению референдума РФ и инициативные агитационные группы.

ЦИК России назначает и организует повторные выборы депутатов Государственной Думы Федерального Собрания РФ, организует повторные выборы Президента РФ и повторное голосование по выборам Президента РФ.

Полномочия ЦИК России по установлению обязательных нормативов и образцов избирательных (референдумных) документов и технологического оборудования включают: установление нормативов, в соответствии с которыми изготавливаются списки избирателей, участников референдума и др. избирательные документы; утверждение форм документов, связанных с подготовкой и проведением выборов; определение способов защиты 
избирательного бюллетеня, открепительного удостоверения, списка избирателей и др. документов; установление нормативов технологического оборудования; утверждение образцов печатей избирательных комиссий и комиссий референдума. Данная группа полномочий позволяет обеспечивать единые на всей территории Российской Федерации требования к изготовлению, защите и использованию избирательных документов (документов референдума), а также единообразно применять технические средства подсчета голосов и технические средства ГАС «Выборы».

Oсобое место в системе конституционно-правовой защиты государственного суверенитета занимают полномочия ЦИК России в сфере правового регулирования избирательного (референдумного) процесса.

Компетенция ЦИК России по изданию нормативных правовых актов носит ограниченный характер и, как правило, прямо предусмотрена в соответствующих федеральных законах о выборах. В соответствии с подпунктом 1 пункта 2 статьи 6 Федерального закона «О Государственной автоматизированной системе Российской Федерации «Выборы» ЦИК России устанавливает порядок использования ГАС «Выборы» при подготовке и проведении выборов и референдумов в части, не урегулированной федеральными законами. Принятие некоторых нормативных правовых актов ЦИК России прямо предусмотрено пунктом 11 статьи 16, пунктом 7 статьи 57, пунктами 14 и 15 статьи 64 Федерального закона «Об основных гарантиях избирательных прав и права на участие в референдуме граждан Российской Федерации».

Специфика нормотворческой деятельности ЦИК России заключается в том, что согласно пункту 13 статьи 20 Федерального закона «Об основных гарантиях избирательных прав и права на участие в референдуме граждан 
Российской Федерации» для вступления в силу нормативных актов ЦИК России их государственная регистрация не требуется ${ }^{1}$.

Важным аспектом деятельности ЦИК России в сфере правового регулирования является участие в устранении коллизий между региональным и федеральным законодательством о выборах 2 .

Ключевым элементом правосубъектности ЦИК России в сфере ЗГС выступают контрольные полномочия.

ЦИК России осуществляет контроль за соблюдением избирательных прав и права на участие в референдуме граждан Российской Федерации

ЦИК России контролирует соблюдение конституционно-правовых ограничений на выдвижение и регистрацию кандидатов в депутаты и на выборные должности, что позволяет предотвращать проникновение криминальных и экстремистских элементов в органы государственной власти, ставленников иностранных государств и международных неправительственных организаций.

ЦИК России осуществляет контроль: за целевым использованием бюджетных средств, выделенных на подготовку и проведение выборов и референдумов, на обеспечение деятельности избирательных комиссий (комиссий референдумов), на обучение организаторов выборов и избирателей; за финансированием деятельности инициативной группы по проведению референдума, инициативных агитационных групп; за целевым использованием средств, поступивших в избирательные фонды кандидатов;

${ }^{1}$ По мнению некоторых ученых - юристов, изъятие нормативных правовых актов избирательных комиссий из процедуры государственной регистрации является продолжением принципа независимости от органов государственной власти, в частности, от Министерства юстиции РФ. См. Волков В.П., Дамаскин О.В., Шапиев С.М. Некоторые проблемы и пути их решения для обеспечения законности избирательного процесса в Российской Федерации. М.: РЦОИТ, 2009. С. 36.

2 Согласно пункту 14 статьи 21 Федерального закона «Об основных гарантиях избирательных прав и права на участие в референдуме граждан Российской Федерации» ЦИК России вправе давать заключения о соответствии законов и иных нормативных правовых актов субъектов РФ федеральным законам о выборах и референдуме. 
за соблюдением законодательных требований при финансировании избирательных кампаний кандидатов.

ЦИК России совместно с избирательными комиссиями субъектов Российской Федерации осуществляет проверку сводных финансовых отчетов и сведений о поступлении и расходовании средств политических партий, контроль за источниками и размерами имущества, получаемого партиями в виде вступительных и членских взносов, пожертвований граждан и юридических лиц.

ЦИК России контролирует соблюдение правил информирования избирателей (участников референдума), проведения предвыборной агитации на территории Российской Федерации.

ЦИК России рассматривает жалобы на решения и действия (бездействие) избирательных комиссий субъектов Российской Федерации, их должностных лиц и принимает по жалобам мотивированные решения.

Непосредственное отношение к ЗГС имеют полномочия ЦИК России по определению результатов выборов и легитимации избирательного (референдумного) прочесса.

Именно ЦИК России определяет результаты референдума Российской Федерации, выборов Президента РФ, депутатов Государственной Думы Федерального Собрания РФ, осуществляет их официальное опубликование и выдает избранному Президенту РФ (депутатам Государственной Думы) удостоверения об избрании.

Полномочия по легитимации избирательного (референдумного) процесса направлены на обеспечение законности избирательного (референдумного) процесса, доверия и признания населением государства результатов выборов (референдумов), готовности граждан подчиняться требованиям представительной власти. Легитимация результатов выборов (референдумов) со стороны общества (внутренний аспект) является главным условием политической стабильности и незыблемости конституционного 
строя. Внешний аспект легитимации избирательного (референдумного) процесса обусловлен признанием результатов выборов иностранными (международными) мониторинговыми миссиями, а также поддержкой сформированной в условиях избирательных кампаний политической власти со стороны государственных органов иностранных государств и международных организаций.

Представляется, что внешняя легитимация избирательного (референдумного) процесса, подменяющая волеизъявление граждан, подрывает основы народовластия и государственный суверенитет. Политическая власть, опирающаяся, главным образом, на внешнюю поддержку, не имеет долгосрочных перспектив и устойчивости. Органы публичной власти, образованные в ходе «гуманитарных» интервенций, «цветных революций» и «управляемых» избирательных кампаний при вмешательстве иностранных государств и международных организаций, выражают, в первую очередь, интересы метрополий, марионетками которых они и являются.

Рассмотрев систему субъектов общей компетенции, определяющих принципы и основные направления конституционно-правовой защиты государственного суверенитета, акцентируем внимание на субъектах специальной компетенции, которые выполняют основной объем работы по реализации конституционно-правовых норм в сфере ЗГС. В качестве субъектов, непосредственно осуществляющих ЗГС, выделим Вооруженные Силы, МИД России, органы внешней разведки, ФСБ России, таможенные органы, МВД России, Федеральную службу войск национальной гвардии, Росфинмониторинг, МЧС России, налоговые органы, прокуратуру РФ, Минюст России, ФСИН России, Министерство культуры и Минобрнауки 
России ${ }^{1}$.

Вооруженные Силы РФ предназначены для отражения агрессии, направленной против РФ, для вооруженной защиты целостности и неприкосновенности территории РФ, а также для выполнения задач, возложенных законодательством и международными договорами РФ.

В случаях агрессии или непосредственной угрозы агрессии против РФ, возникновения вооруженных конфликтов, направленных против РФ, Вооруженные Силы, другие войска, воинские формирования и органы выполняют задачи в области обороны. В этих целях реализуются мероприятия по охране и обороне военных, важных государственных и специальных объектов, объектов жизнеобеспечения населения, транспорта, коммуникаций и связи, энергетики, объектов повышенной опасности, по борьбе с диверсионно-разведывательными формированиями иностранных государств и незаконными вооруженными формированиями, по выявлению, предупреждению, пресечению и ликвидации последствий их диверсионной, разведывательной и террористической деятельности.

Мероприятия в области обороны требуют существенных расходов на создание объектов военной инфраструктуры, оснащение вооружением и военной техникой, обеспечение войск материальными средствами, топливом и другими ресурсами, создание и развитие мобилизационных мощностей. В связи с этим для удовлетворения потребностей государства и нужд населения в военное время формируется государственный материальный резерв и вводятся в действие мобилизационные планы экономики РФ, экономики субъектов РФ и экономики муниципальных образований.

В соответствии с пунктом 2.1 статьи 10 Федерального закона от 31 мая 1996 г. № 61-Ф3 «Об обороне» в целях защиты интересов РФ и ее граждан,

1 Данный перечень субъектов ЗГС периодически корректируется в связи с изменением структуры федеральных органов исполнительной власти и компетенции соответствующих государственных органов. 
поддержания международного мира и безопасности формирования Вооруженных Сил РФ могут оперативно использоваться за пределами территории России в соответствии с общепризнанными принципами и нормами международного права, международными договорами РФ для решения следующих задач:

1) отражение вооруженного нападения на формирования Вооруженных Сил РФ, другие войска или органы, дислоцированные за пределами территории РФ;

2) отражение или предотвращение вооруженного нападения на другое государство, обратившееся к РФ с соответствующей просьбой;

3) защита граждан РФ за пределами территории РФ от вооруженного нападения на них;

4) борьба с пиратством и обеспечение безопасности судоходства.

Решение об использовании Вооруженных Сил РФ за пределами территории России принимается Президентом на основании постановления Совета Федерации. Глава государства определяет общую численность формирований Вооруженных Сил, районы их действий, боевые задачи и срок использования за пределами территории РФ.

Статьей 10 Федерального закона «О противодействии терроризму» предусмотрена возможность применения вооружения с территории РФ против находящихся за ее пределами террористов и (или) их баз, а также использования формирований Вооруженных Сил для выполнения задач по пресечению международной террористической деятельности за рубежом ${ }^{1}$.

Головным государственным органом, осуществляющим функции по реализации государственной политики и нормативному правовому регулированию ЗГС в сфере международных отношений, выступает

\footnotetext{
${ }^{1}$ Решения о таком применении принимаются Президентом РФ.
} 


\section{Министерство иностранных дел РФ (МИД России).}

Правосубъектность МИДа России по ЗГС представлена несколькими группами полномочий ${ }^{1}$.

Первая группа полномочий связана с разработкой стратегии внешней политики и реализащией внешнеполитического курса Российской Федераџии. Сюда можно отнести: разработку и представление Президенту и в Правительство РФ предложений по вопросам международных отношений РФ; участие в реализации государственной политики в области торговоэкономических и финансовых связей, научно-технического, культурного и иного обмена, связей с соотечественниками, проживающими за рубежом; внесение Президенту и в Правительство проектов федеральных конституционных законов, федеральных законов, актов Президента и Правительства по вопросам компетенции МИДа России и Россотрудничества; издание нормативных правовых актов, обязательных для исполнения всеми участниками международных контактов; разработка проектов международных договоров РФ, представление Президенту и в Правительство предложений о подписании и выражении согласия РФ на обязательность для нее международных договоров, а также предложений о прекращении и приостановлении действия международных договоров РФ; заключение международных договоров межведомственного характера по вопросам компетенции МИДа; ведение переговоров с иностранными государствами и международными организациями.

Вторая группа полномочий представлена защщттой дипломатическими и международно-правовыми средствами государственного суверенитета, безопасности, территориальной целостности Российской Федерации, законных прав и интересов российских граждан. В нее можно включить:

внешнеполитическое и международно-правовое обеспечение защиты

1 Указ Президента РФ от 11 июля 2004 г. № 865 «Вопросы Министерства иностранных дел Российской Федерации». 
Государственной границы РФ;

реализацию усилий РФ по обеспечению международного мира, глобальной и региональной безопасности ${ }^{1}$;

содействие повышению роли РФ как члена мирового сообщества в решении глобальных и региональных проблем²;

обеспечение представительства РФ при рассмотрении споров с другими государствами или международными организациями;

уведомление Генеральных секретарей $\mathrm{OOH}$, Совета Европы и сопредельных государств о введении исключительных правовых режимов (чрезвычайное и военное положение), основаниях их введения, об объеме ограничений прав и свобод граждан и дате предполагаемого прекращения указанных отступлений от международных обязательств;

защиту законных прав и интересов соотечественников, проживающих за рубежом;

поддержку российских участников внешнеэкономической деятельности, защиту их законных интересов за рубежом.

Третью группу полномочий можно назвать координирующими полномочиями по реализации единой политической линии Российской Федерации в отношениях с иностранными государствами (международными организачиями) и реализачии международных прав и обязательств Российской Федеращии. Эти полномочия объединяют:

координацию международной деятельности федеральных и

1 Так, усилия России по решению иранской «ядерной проблемы», легитимные антитеррористические действия и поиск путей политического урегулирования в Сирии способствовали укреплению российских позиций на международной арене.

${ }_{2}^{2}$ В 2015 г. усилиями МИД России в ООН принят ряд резолюций, направленных на урегулирование конфликтных ситуаций под эгидой ООН на основе принципов независимости и территориальной целостности государств, непризнания государственного переворота как метода смены власти и исключения из международного общения попыток незаконного давления одних государств на другие, включая экстерриториальное применение национального законодательства. Российскими дипломатами был нейтрализован ряд деструктивных инициатив в Совете Безопасности ООН (создание «международного» квазитрибунала по расследованию крушения самолета «Боинг» в июле 2014 г., размещение миротворцев ООН в ДНР и ЛНР и другие), блокировались несбалансированные модели реформирования СБ ООН. 
региональных органов государственной власти;

координацию международных связей субъектов РФ;

координацию распространения за рубежом информации о внешней и внутренней политике РФ, социально-экономической, культурной и духовной жизни страны.

Четвертая группа представлена контрольными полномочиями МИДа России. К ним относятся:

контроль за соответствием законодательству РФ и международным правовым нормам проектов международных договоров РФ;

контроль за соответствием нормативных правовых актов РФ ее международным обязательствам;

контроль за работой зарубежных представителей (представительств) федеральных органов исполнительной власти, органов исполнительной власти субъектов РФ, российских государственных учреждений, организаций и предприятий;

контроль за соблюдением дипломатических и консульских привилегий и иммунитетов.

Пятая группа полномочий связана с содействием реализации отдельных направлений защуиты государственного суверенитета. В нее входят:

обеспечение совместно с другими федеральными органами исполнительной власти безопасности и эвакуации граждан, учреждений и других объектов РФ за рубежом, в том числе в условиях кризисных и чрезвычайных ситуаций, включая угрозы или акты международного терроризма;

принятие решений о выдаче виз иностранным гражданам и лицам без гражданства;

участие в решении вопросов гражданства;

ведение списка граждан иностранных государств, которым 
запрещается въезд в РФ, и организаций, деятельность которых приостановлена в связи с участием в политической деятельности на территории РФ и получением иностранного финансирования, а также реализацией проектов и программ, представляющих угрозу государственному суверенитету;

участие в противодействии терроризму.

Таким образом, конституционно-правовой статус МИД России позволяет: осуществлять ЗГС с помощью дипломатических и международноправовых средств; проверять соответствие национальному законодательству и международному праву проектов международных договоров РФ, соответствие национального законодательства международным обязательствам РФ; готовить решения Президента и Правительства о прекращении и приостановлении действия международных договоров в интересах ЗГС, безопасности, территориальной целостности РФ, законных прав и интересов российских граждан; координировать и контролировать реализацию единой политической линии РФ.

Деятельность МИД России по ЗГС в сфере международных отношений тесно связана с работой органов внешней разведки.

Особенности ЗГС органами внешней разведки связаны с целями, содержанием, тайным характером и специальными средствами осуществляемой ими разведывательной деятельности.

В соответствии с Федеральным законом от 10 января 1996 г. № 5-Ф3 «О внешней разведке» целями разведывательной деятельности являются:

1) обеспечение Президента, Федерального Собрания и Правительства разведывательной информацией, необходимой им для принятия решений в политической, экономической, оборонной, научнотехнической и экологической областях;

2) обеспечение условий, способствующих успешной реализации политики РФ в сфере безопасности; 
3) содействие экономическому развитию, научно-техническому прогрессу страны и военно-техническому обеспечению безопасности РФ.

Разведывательная деятельность охватывает все сферы общественной жизни и способствует реализации основных функций государства.

По своему содержанию разведывательная деятельность включает:

- добывание и обработку информации о затрагивающих жизненно важные интересы РФ реальных и потенциальных возможностях, действиях, планах и намерениях иностранных государств, организаций и лиц;

- оказание содействия в реализации мер, осуществляемых государством в интересах обеспечения безопасности РФ.

Добываемая разведывательными органами информация имеет исключительное значение для иностранных государств - участников экономического, военно-политического и идеологического противоборства и охраняется ими от утечки. Кроме того, принятие политическим руководством важнейших решений и обеспечение соответствующих условий реализации государственной политики неразрывно связаны с сохранением в тайне их содержания и характера планируемых действий. Поэтому организация и функционирование органов внешней разведки носят тайный (конспиративный) характер.

Учитывая, что разведывательная деятельность является эффективной только при условии строгого соблюдения конспирации, органы внешней разведки наделены правами зашифровки своего кадрового состава, ведомственной принадлежности организаций, помещений и транспортных средств, создания необходимых структур прикрытия. Специфика ЗГС органами внешней разведки проявляется и в использовании специальных средств, особый характер которых определяется условиями этой деятельности ${ }^{1}$.

${ }^{1}$ Как уже отмечалось, МИД России защищает государственный суверенитет с помощью дипломатических и международно-правовых средств. 
Разведывательная деятельность осуществляется под общим руководством Президента РФ как самостоятельными, так и входящими в структуру других органов исполнительной власти органами внешней разведки.

Статья 11 Федерального закона «О внешней разведке» устанавливает разграничение полномочий федеральных органов исполнительной власти, входящих в состав сил обеспечения безопасности РФ.

Так, разведывательная деятельность в политической, экономической, военно-стратегической, научно-технической и экологической сферах, в сфере шифрованной, засекреченной и иных видов специальной связи с использованием радиоэлектронных средств и методов за пределами РФ, а также в сфере обеспечения безопасности учреждений и граждан РФ, находящихся за пределами территории РФ, осуществляется Службой внешней разведки (СВР России). На орган внешней разведки Министерства обороны (ГРУ Генштаба) законом возложено ведение разведывательной деятельности в военной, военно-политической, военно-технической, военноэкономической и экологической сферах.

Разведывательная деятельность органов федеральной службы безопасности осуществляется в соответствии с Федеральным законом «О федеральной службе безопасности».

В системе конституционно-правовой защиты государственного суверенитета выделяется ряд субъектов, которые непосредственно специализируются на правоисполнительной и правоохранительной деятельности. К ним относятся ФСБ и МВД России.

Федеральная служба безопасности РФ (ФСБ России) является федеральным органом исполнительной власти, осуществляющим государственное управление в области обеспечения безопасности РФ, борьбы с терроризмом, защиты и охраны Государственной границы РФ, охраны внутренних морских вод, территориального моря, исключительной 
экономической зоны, континентального шельфа РФ и их природных ресурсов, обеспечивающим информационную безопасность РФ, а также координирующим контрразведывательную деятельность федеральных органов исполнительной власти, имеющих право на ее осуществление ${ }^{1}$.

Основными задачами ФСБ России в сфере ЗГС являются:

информирование Президента, Председателя Правительства, а также по их поручениям - федеральных органов государственной власти и органов государственной власти субъектов РФ об угрозах государственному суверенитету, безопасности и территориальной целостности РФ;

организация выявления, предупреждения и пресечения разведывательной и иной деятельности спецслужб и организаций иностранных государств, отдельных лиц, направленной на нанесение ущерба безопасности и суверенитету РФ;

организация выявления, предупреждения, пресечения и раскрытия преступлений, относящихся к подследственности органов безопасности;

организация во взаимодействии с федеральными органами государственной власти борьбы с организованной преступностью, коррупцией, незаконной миграцией, противодействия экстремистской деятельности, в том числе деятельности незаконных вооруженных формирований, преступных сообществ и групп, отдельных лиц и общественных объединений, ставящих своей целью организацию вооруженного мятежа, насильственное изменение конституционного строя РФ, насильственный захват или насильственное удержание власти;

организация и осуществление борьбы с терроризмом и обеспечение борьбы с диверсионной деятельностью;

осуществление в пределах своих полномочий разведывательной деятельности;

1 Положение о Федеральной службе безопасности Российской Федерации (утверждено Указом Президента РФ от 11 августа 2003 г. № 960). 
организация мер в области защиты и охраны государственной границы; обеспечение в пределах своих полномочий защиты сведений, составляющих государственную тайну, и противодействия иностранным техническим разведкам;

формирование и реализация в пределах полномочий государственной и научно-технической политики в области обеспечения информационной безопасности;

организация содействия федеральным органам государственной власти и органам государственной власти субъектов РФ в реализации мер, осуществляемых в интересах обеспечения безопасности РФ, повышения ее экономического, научно-технического и оборонного потенциала.

Конституционно-правовой статус ФСБ России как субъекта ЗГС характеризуется тем, что ее можно рассматривать в качестве:

- органа исполнительной власти;

- правоохранительного органа;

- спецслужбы.

ФСБ России как орган исполнительной власти осуществляет управление органами безопасности и организует их деятельность. Для выполнения своих задач ФСБ России осуществляет нормативно-правовое регулирование, участвует в разработке и реализации государственных программ, в международно-правовом оформлении и договорном закреплении государственной границы и разграничения морских пространств. ФСБ России осуществляет контроль: за соблюдением физическими и юридическими лицами режима государственной границы, пограничного режима, режима в пунктах пропуска через государственную границу и федерального законодательства о внутренних морских водах, территориальном море, об исключительной экономической зоне и о континентальном шельфе РФ; за обеспечением сохранности сведений, составляющих государственную тайну, в федеральных органах 
государственной власти, органах государственной власти субъектов РФ, органах местного самоуправления и воинских формированиях; за обеспечением защиты государственной тайны на предприятиях, в учреждениях и организациях; осуществляет меры, связанные с допуском граждан к сведениям, составляющим государственную тайну, а также с допуском предприятий, учреждений и организаций к проведению работ, связанных с использованием сведений, составляющих государственную тайну, с созданием средств защиты информации и с осуществлением мероприятий и (или) оказанием услуг по защите государственной тайны. Органы безопасности осуществляют в пределах своих полномочий меры по обеспечению режимов чрезвычайного и военного положения, участвуют в решении вопросов приема в гражданство РФ и выхода из него, выезда граждан РФ за пределы РФ и въезда иностранных граждан и лиц без гражданства в РФ, выезда их за ее пределы, оформления им разрешения на временное проживание и вида на жительство в РФ, предоставления им политического убежища в РФ, а также пребывания их на российской территории.

ФСБ России как правоохранительный орган организует оперативнорозыскную деятельность по выявлению, предупреждению, пресечению и раскрытию преступлений, борьба с которыми отнесена к ведению органов безопасности; организует деятельность по борьбе с терроризмом; ведет предварительное следствие по делам о преступлениях, относящихся к подследственности органов безопасности; обеспечивает участие пограничных органов в охране дипломатических представительств и консульских учреждений РФ в иностранных государствах; участвует в обеспечении безопасности проводимых на территории РФ общественнополитических, религиозных и иных массовых мероприятий; обеспечивает содержание под стражей задержанных, подозреваемых и обвиняемых; обеспечивает производство по делам об административных 
правонарушениях, отнесенных к ведению органов безопасности.

ФСБ России как спецслужба организует контрразведывательную и разведывательную деятельность, осуществляет агентурное и техническое проникновение в спецслужбы и организации иностранных государств, противодействие иностранным техническим разведкам, определяет порядок использования негласных методов и средств при реализации контрразведывательных и разведывательных мероприятий, устанавливает отношения сотрудничества на конфиденциальной основе.

Выступая в роли субъекта конституционно-правовой защиты государственного суверенитета, органы безопасности выявляют угрозы государственному суверенитету, осуществляют противодействие деструктивным механизмам ослабления и подрыва государственного суверенитета, охраняют и защищают государственную границу, внутренние морские воды, территориальное море, исключительную экономическую зону и континентальный шельф РФ, с помощью специальных методов сковывают и парализуют деятельность внутригосударственных и зарубежных антигосударственных сил.

Осуществляя охрану и защиту Государственной границы РФ, органы безопасности тесно взаимодействуют с таможенными органами, которые дислоцируются в пунктах пропуска через Государственную границу.

В соответствии с Федеральным законом от 27 ноября 2010 г. № 31-Ф3 «О таможенном регулировании в Российской Федерации» и Положением о Федеральной таможенной службе (утверждено Постановлением Правительства РФ от 16 сентября 2013 г. № 809) таможенные органы выполняют следующие функции:

- проводят таможенный контроль;

- содействуют развитию внешней торговли РФ, внешнеэкономических связей субъектов РФ, ускорению товарооборота;

- взимают таможенные пошлины, налоги, антидемпинговые, 
специальные и компенсационные пошлины, таможенные сборы, контролируют правильность исчисления и своевременность уплаты указанных пошлин, налогов и сборов, принимают меры по их принудительному взысканию;

- обеспечивают соблюдение порядка перемещения товаров и транспортных средств;

- контролируют соблюдение порядка осуществления международных автомобильных перевозок;

- обеспечивают соблюдение запретов и ограничений в отношении товаров, ввозимых в РФ и вывозимых из РФ;

- осуществляют в пределах компетенции контроль за валютными операциями и внешнеторговыми бартерными сделками;

- оказывают противодействие незаконному обороту наркотических средств, психотропных веществ, оружия и боеприпасов, культурных ценностей, перемещаемых через Государственную границу РФ;

- выявляют, предупреждают и пресекают преступления и административные правонарушения, отнесенные к компетенции таможенных органов, осуществляют дознание по уголовным делам об этих преступлениях, осуществляют административное производство по делам о нарушениях таможенных правил;

- содействуют развитию экспортного и транзитного потенциала РФ, защищают с использованием средств таможенного регулирования интересы отечественных товаропроизводителей;

- оказывают содействие в борьбе с международным терроризмом;

- обеспечивают меры по противодействию легализации доходов, полученных преступным путем, и финансированию терроризма при осуществлении контроля за перемещением через таможенную границу валюты, ценных бумаг и валютных ценностей, дорожных чеков.

Функции национального центра по оценке угроз, возникающих в 
результате легализации (отмывания) доходов, полученных преступным путем, финансирования терроризма и распространения оружия массового уничтожения, выработки государственной политики и правового регулирования в этой сфере реализует Федеральная служба по финансовому мониторингу (Росфинмониторинг).

В соответствии с Положением о Федеральной службе по финансовому мониторингу (утверждено Указом Президента РФ от 13 июня 2012 г. № 808) Росфинмониторинг осуществляет следующие основные полномочия:

осуществляет контроль за выполнением юридическими и физическими лицами законодательства о противодействии легализации (отмыванию) доходов, полученных преступным путем, и финансированию терроризма, а также привлечение к ответственности за нарушение законодательства в этой cфepe;

проводит мероприятия по предупреждению нарушений законодательства о противодействии легализации (отмыванию) доходов, полученных преступным путем, и финансированию терроризма;

осуществляет контроль за операциями (сделками) с денежными средствами или иным имуществом;

принимает предупредительные, ограничительные и профилактические меры;

координирует деятельность федеральных органов исполнительной власти по вопросам своей компетенции.

Осуществляя полномочия по ЗГС, Росфинмониторинг предоставляет в Генеральную прокуратуру и Минюст России информацию о контрагентах российских некоммерческих организаций, выполняющих функцию иностранного агента, о поступлении и расходовании ими денежных средств в политических целях, о контрагентах иностранных и международных неправительственных организаций, признанных нежелательными на территории РФ, а также о фактах отказа в проведении операций с денежными 
средствами и иным имуществом таких организаций. Росфинмониторинг наделен правами принимать решения о нежелательности пребывания (проживания) иностранного гражданина или лица без гражданства в РФ, а также издавать постановления о приостановлении операций с денежными средствами или иным имуществом.

Возможности Росфинмониторинга в сфере ЗГС позволяют вскрывать источники, каналы и способы финансирования террористической, экстремистской и иной антигосударственной деятельности, силы, средства, формы и методы отмывания денежных средств, имеющих незаконное происхождение и предназначенных для финансирования антиконституционной деятельности, каналы иностранного финансирования некоммерческих организаций и общественно-политических деятелей, транзакции в целях ослабления и подрыва государственного суверенитета.

Важные задачи, связанные с ЗГС, возложены на МВД России.

В соответствии с Федеральным законом от 7 февраля 2011 г. № 3-Ф3 «О полиции» и Указом Президента РФ от 5 апреля 2016 г. № 156 «О совершенствовании государственного управления в сфере контроля за оборотом наркотических средств, психотропных веществ и их прекурсоров и в сфере миграции» МВД России является федеральным органом исполнительной власти, осуществляющим функции по выработке и реализации государственной политики и нормативно-правовому регулированию в сфере внутренних дел, в сфере контроля за оборотом наркотических средств, психотропных веществ и их прекурсоров, в сфере миграции, а также правоприменительные функции по федеральному государственному контролю (надзору) в указанных сферах.

МВД России:

осуществляет оперативно-розыскную деятельность по выявлению, предупреждению, пресечению, раскрытию и расследованию: преступлений, относящихся к подследственности органов внутренних дел; тяжких и особо 
тяжких преступлений, совершенных организованными группами, преступными сообществами, носящих транснациональный или межрегиональный характер, либо преступлений, вызывающих большой общественный резонанс;

принимает меры, направленные на выявление, предупреждение и пресечение экстремистской деятельности;

принимает меры по пресечению противоправной предвыборной агитации, осуществляет охрану бюллетеней для голосования на выборах и референдумах, оказывает иное содействие избирательным комиссиям в ходе подготовки и проведения выборов и референдумов;

осуществляет мероприятия по предупреждению и пресечению массовых беспорядков и иных действий, нарушающих права и свободы граждан, работу транспорта, средств связи;

обеспечивает участие органов внутренних дел и Федеральной службы войск национальной гвардии в мероприятиях по противодействию терроризму, в обеспечении правового режима контртеррористической операции, в защите потенциальных объектов террористических посягательств и мест массового пребывания граждан;

осуществляет контроль за обеспечением безопасности объектов топливно-энергетического комплекса;

осуществляет контроль за соблюдением иностранными гражданами и лицами без гражданства порядка временного или постоянного проживания, временного пребывания в РФ, въезда в РФ, выезда из РФ и транзитного проезда через территорию РФ;

организует содержание, охрану и конвоирование задержанных, арестованных или заключенных под стражу лиц;

организует участие органов внутренних дел в осуществлении контроля (надзора) за соблюдением лицами, освобожденными из мест лишения свободы, установленных для них судом запретов и ограничений, а также в 
осуществлении контроля за поведением осужденных, которым назначено наказание, не связанное с лишением свободы, или наказание в виде лишения свободы условно;

оказывает содействие учреждениям уголовно-исполнительной системы в розыске и задержании лиц, совершивших побег из-под стражи, лиц, уклоняющихся от отбывания уголовного наказания;

осуществляет государственную защиту участников уголовного судопроизводства, судей, прокуроров, следователей, должностных лиц правоохранительных и контролирующих органов, a также других защищаемых лиц;

участвует в обеспечении режима военного положения и режима чрезвычайного положения;

обеспечивает по решению Президента участие сотрудников органов внутренних дел в деятельности по поддержанию или восстановлению международного мира и безопасности.

В соответствии с Указом Президента РФ от 5 апреля 2016 г. № $156 « \mathrm{O}$ совершенствовании государственного управления в сфере контроля за оборотом наркотических средств, психотропных веществ и их прекурсоров и в сфере миграции» МВД России переданы функции упраздненной ФМС России по государственному контролю (надзору), выработке и реализации государственной политики и оказанию государственных услуг в сфере миграции.

Основными функциями МВД России в сфере миграции стали: выработка и реализация государственной политики в сфере миграции; нормативно-правовое регулирование в сфере миграции; производство по делам о гражданстве РФ, оформление и выдача документов, удостоверяющих личность гражданина РФ; осуществление регистрационного учета граждан РФ по месту пребывания и по месту жительства в пределах РФ; 
осуществление миграционного учета иностранных граждан и лиц без гражданства в РФ;

оформление и выдача иностранным гражданам и лицам без гражданства документов для въезда в РФ, проживания и временного пребывания в РФ;

осуществление федерального государственного контроля (надзора) в сфере миграции;

осуществление контроля и надзора в сфере внешней трудовой миграции, привлечения иностранных работников в РФ и трудоустройства граждан РФ за пределами РФ;

разработка и реализация во взаимодействии с иными государственными органами мер по предупреждению и пресечению незаконной миграции;

исполнение законодательства по вопросам беженцев и вынужденных переселенцев, участие в предоставлении политического убежища иностранным гражданам и лицам без гражданства.

В целях осуществления возложенных функций и решения вытекающих из них задач, связанных с ЗГС, МВД России принимает решения:

1) о продлении либо сокращении срока временного пребывания иностранных граждан или лиц без гражданства в РФ;

2) о выдаче иностранным гражданам или лицам без гражданства разрешений на временное проживание в РФ или вида на жительство, а также об аннулировании указанных документов;

3) о депортации иностранных граждан и лиц без гражданства, а также осуществляет меры по их депортации и административному выдворению за пределы РФ;

4) о нежелательности пребывания (проживания) иностранных граждан и лиц без гражданства в РФ, а также об установлении запрета на въезд в РФ иностранных граждан и лиц без гражданства; 
5) о выдаче, приостановлении срока действия или аннулировании разрешений на привлечение и использование иностранных работников, выдаче и аннулировании разрешений на работу иностранным гражданам или лицам без гражданства, патентов для осуществления иностранными гражданами или лицами без гражданства трудовой деятельности;

6) об аннулировании виз иностранным гражданам и лицам без гражданства.

Вопросы регулирования гражданства и статуса иностранцев имеют непосредственное отношение к ЗГС. Состояние контроля за приобретением национального гражданства, проживанием и перемещением иностранцев по территории государства, соблюдением миграционного законодательства определяют обороноспособность государства, защищенность государственных и общественных институтов от иностранных лоббистских и коррупционных проявлений, стабильность межнациональных и межконфессиональных отношений.

Особым элементом правового статуса МВД России как субъекта ЗГС выступает выработка и реализация государственной политики, нормативное правовое регулирование в сфере контроля за оборотом наркотических средств, психотропных веществ и их прекурсоров, а также федеральный государственный контроль (надзор) в указанной сфере ${ }^{1}$.

Необходимость государственного регулирования отношений, связанных с оборотом и потреблением наркотических средств и психотропных веществ, противодействием их незаконному обороту, обусловлена устойчивым сокращением численности трудоспособного населения РФ из-за расширения масштабов незаконного распространения наркотиков.

1 Указ Президента РФ от 5 апреля 2016 г. № 156 «О совершенствовании государственного управления в сфере контроля за оборотом наркотических средств, психотропных веществ и их прекурсоров и в сфере миграции» // СЗ РФ. 2016. № 15. Ст. 2071. 
Как отмечается в Стратегии государственной антинаркотической политики Российской Федерации до 2020 года, утвержденной Указом Президента РФ от 9 июня 2010 г. № 690, наркотизация населения «представляет серьезную угрозу безопасности государства, экономике страны и здоровья ее населения» ${ }^{1}$.

Учитывая актуальность наркоугрозы, МВД России специально уполномочено:

обеспечивать нормативно-правовое регулирование, контроль и надзор за оборотом наркотических средств, психотропных веществ и их прекурсоров, противодействие их незаконному обороту;

выявлять, предупреждать и пресекать преступления и административные правонарушения в сфере оборота наркотических средств, психотропных веществ и их прекурсоров;

координировать деятельность органов исполнительной власти и органов местного самоуправления в сфере оборота наркотических средств, психотропных веществ и их прекурсоров; в области противодействия их незаконному обороту; в области реабилитации и ресоциализации наркоманов;

осуществлять контроль деятельности юридических лиц и предпринимателей в сфере оборота наркотических средств и психотропных веществ (в случае нарушений законодательства предъявлять в суд требования о прекращении деятельности или ликвидации соответствующих юридических лиц);

осуществлять в пределах компетенции противодействие легализации доходов, полученных в результате совершения наркопреступлений.

Противодействие незаконному обороту наркотических средств, психотропных веществ и их прекурсоров в рамках ЗГС способствует:

\footnotetext{
${ }^{1}$ Рос. газ. 2010. 15 июня.
} 
созданию системы защиты территории РФ от нелегального ввоза наркотиков из-за рубежа; разрушению инфраструктуры нелегального производства, транспортировки и распространения наркотиков, наркодилерских сетей внутри страны; пресечению коррупционных связей, способствующих незаконному обороту наркотиков, на территории РФ, а также преступных связей с международным наркобизнесом; сокращению масштабов незаконного потребления наркотиков.

Совершенствование государственного управления в сфере внутренних дел, противодействия терроризму и иным проявлениям экстремизма вызвало необходимость создания нового субъекта ЗГС - Федеральной службы войск национальной гвардии РФ.

В соответствии с Указом Президента РФ от 5 апреля 2016 г. № 157 «Вопросы Федеральной службы войск национальной гвардии Российской Федерации» Федеральная служба войск национальной гвардии РФ образована как федеральный орган исполнительной власти, осуществляющий функции по выработке и реализации государственной политики и нормативно-правовому регулированию в сфере деятельности войск национальной гвардии, в сфере оборота оружия, в сфере частной охранной деятельности и в сфере вневедомственной охраны.

На созданный государственный орган возложено решение следующих основных задач:

- участие совместно с органами внутренних дел в охране общественного порядка, обеспечении общественной безопасности и режима чрезвычайного положения;

- участие в борьбе с терроризмом и в обеспечении правового режима контртеррористической операции;

- участие в борьбе с экстремизмом;

- участие в проведении мероприятий территориальной обороны, а также в совместных действиях с Вооруженными Силами, другими войсками, 
воинскими формированиями и органами по обеспечению обороны РФ;

- охрана важных государственных объектов и специальных грузов, объектов на коммуникациях;

- оказание содействия пограничным органам ФСБ России в проведении мероприятий по защите государственной границы, обеспечение временного ограничения или воспрещения доступа граждан на отдельные участки местности или объекты вблизи государственной границы во время проведения пограничных поисков и операций, при отражении вооруженных вторжений на территорию РФ или при воспрепятствовании незаконным массовым пересечениям государственной границы;

- осуществление федерального государственного контроля (надзора) в области оборота оружия, боеприпасов, взрывчатых веществ, лицензионнонадзорной деятельности в отношении предприятий и организаций, где они обращаются, структур частной детективной и охранной деятельности, а также осуществление вневедомственной охраны.

Вопросы ЗГС, полноты реализации внутренних и внешних функций государства остро встают в условиях чрезвычайных ситуаций природного и техногенного характера. От того, насколько своевременно и квалифицированно государство сумеет обеспечить ликвидацию чрезвычайных ситуаций, спасение и эвакуацию своих граждан, устойчивость и безопасность функционирования объектов жизнеобеспечения населения, транспорта, топливно-энергетического комплекса, коммуникаций и связи, восстановление поврежденных объектов инфраструктуры и снабжение населения зависит отношение населения к представителям органов власти и управления и оценка их деятельности. Головным субъектом ЗГС в области гражданской обороны, защиты населения и территорий от чрезвычайных ситуаций, обеспечения пожарной безопасности и безопасности людей на водных объектах является Министерство Российской Федерации по делам гражданской обороны, чрезвычайным ситуациям и ликвидации 


\section{последствий стихийных бедствий (МЧС России).}

МЧС России организует ${ }^{1}$ :

работу по предупреждению и ликвидации чрезвычайных ситуаций межрегионального и федерального характера, спасению людей при этих чрезвычайных ситуациях;

предупреждение и тушение пожаров на объектах, критически важных для безопасности РФ, других особо важных пожароопасных объектах, а также при проведении мероприятий федерального уровня с массовым сосредоточением людей;

предупреждение и тушение пожаров в закрытых административнотерриториальных образованиях;

планирование и применение спасательных воинских формирований для выполнения отдельных задач в области обороны, подготовку спасательных воинских формирований к совместным с Вооруженными Силами действиям в целях обороны РФ;

работу по участию МЧС России в разработке Плана применения Вооруженных Сил, Мобилизационного плана Вооруженных Сил и Плана оперативного оборудования территории РФ в целях обороны;

работу по участию МЧС России в разработке мобилизационного плана экономики РФ в части задач, возложенных на МЧС России.

МЧС руководит созданием и поддержанием в состоянии постоянной готовности технических систем управления гражданской обороны и систем оповещения населения об опасностях, возникающих при ведении военных действий, контролирует создание и деятельность этих систем.

В период введения режима контртеррористической операции силы и средства МЧС России привлекаются органами безопасности для решения

${ }^{1}$ Положение о Министерстве РФ по делам гражданской обороны, чрезвычайным ситуациям и ликвидации последствий стихийных бедствий (утверждено Указом Президента РФ от 11 июля 2004 г. № 868). 
задач по выявлению, предупреждению и пресечению террористической деятельности.

Как субъект ЗГС МЧС России принимает непосредственное участие в реализации внешних функций государства. Для решения гуманитарных задач за пределами РФ (международные операции, доставка гуманитарной помощи, эвакуация граждан из иностранных государств, гуманитарное разминирование и др.) создан российский национальный корпус чрезвычайного гуманитарного реагирования.

Важнейшую роль в ЗГС играет социально-экономическая сфера, на базе которой обеспечивается формирование доходов государства. Без наличия материально-экономической основы и необходимых ресурсов невозможна никакая полноценная ЗГС: реализация государственных целевых программ, инфраструктурных проектов, финансирование деятельности специализированных государственных органов, закупки вооружений и специальных средств, модернизация промышленного оборудования и боевой техники и др.

Только государство обладает достаточными средствами, позволяющими решать долгосрочные общенациональные задачи. Значительная часть этих средств поступает за счет сбора налогов благодаря Федеральной налоговой службе (ФНС России).

ФНС России осуществляет контроль и надзор за соблюдением законодательства о налогах и сборах, за правильностью исчисления, полнотой и своевременностью внесения налогов и сборов; ведет учет всех налогоплательщиков. ФНC России осуществляет государственную регистрацию и проверки деятельности юридических лиц, индивидуальных предпринимателей и фермерских хозяйств; аккредитует филиалы и представительства иностранных юридических лиц (за исключением иностранных кредитных организаций); представляет интересы РФ в делах о банкротстве и в процедурах банкротства по обязательным платежам и 
денежным обязательствам ${ }^{1}$.

С целью реализации своих полномочий ФНС России наделена правом применять меры ограничительного, предупредительного и профилактического характера, a также санкции за нарушение законодательства о налогах и сборах.

Особое место среди субъектов конституционно-правовой защиты государственного суверенитета занимает прокуратура РФ, которая представляет собой единую федеральную централизованную систему органов, осуществляющих от имени РФ надзор за соблюдением Конституции и исполнением законов, действующих на территории РФ.

Согласно ст. 21 Закона РФ от 17 января 1992 г. № 2202-1 «О прокуратуре Российской Федерации» в предмет прокурорского надзора входят:

- соблюдение Конституции РФ и исполнение законов, действующих на территории РФ, федеральными органами исполнительной власти, Следственным комитетом РФ, представительными (законодательными) и исполнительными органами государственной власти субъектов РФ, органами местного самоуправления, органами военного управления, органами контроля, их должностными лицами, субъектами осуществления общественного контроля за обеспечением прав человека в местах принудительного содержания, a также органами управления и руководителями коммерческих и некоммерческих организацийㄹ;

- соответствие законам правовых актов, издаваемых поднадзорными органами и должностными лицами.

Конституционно-правовая защита государственного суверенитета базируется на правомочиях прокуроров вносить в законодательные органы и

${ }^{1}$ Постановление Правительства РФ от 30 сентября 2004 г. № 506 «Об утверждении Положения о Федеральной налоговой службе».

${ }_{2}^{2}$ В перечень поднадзорных субъектов не входят Президент, Федеральное Собрание РФ и судебные органы власти. 
в субъекты права законодательной инициативы предложения об изменении, дополнении, об отмене или о принятии законов и иных нормативных правовых актов; проводить антикоррупционную экспертизу нормативных правовых актов федеральных органов исполнительной власти, органов государственной власти субъектов РФ, иных государственных органов и организаций, органов местного самоуправления, их должностных лиц; вносить акты прокурорского реагирования (протесты, представления, предостережения). При необходимости оспаривания незаконных положений конституций и уставов субъектов РФ Генеральный прокурор обращается с запросом в Конституционный Суд РФ.

В случае возникновения угроз государственному суверенитету, исходящих от зарубежных субъектов антигосударственной деятельности, Генеральный прокурор или его заместители по согласованию с МИД России принимают решение о признании нежелательной на территории РФ деятельности иностранной или международной неправительственной организации.

Прокуратура осуществляет надзорную деятельность в любых условиях функционирования государства. При введении чрезвычайного положения на территориях нескольких субъектов РФ Генеральным прокурором может быть создана межрегиональная прокуратура.

Министерство юстиции в соответствии Положением о Министерстве юстиции Российской Федерации (утверждено Указом Президента РФ от 13 октября 2004 г. № 1313) осуществляет функции по выработке и реализации государственной политики и нормативно-правовому регулированию в сфере территориального устройства РФ, разграничения полномочий по предметам совместного ведения между федеральными органами государственной власти, органами государственной власти субъектов РФ и органами местного самоуправления, а также правоприменительные функции и функции по контролю в сфере регистрации некоммерческих организаций, включая 
отделения международных организаций и иностранных некоммерческих неправительственных организаций, политических партий, иных общественных объединений и религиозных организаций.

Анализ правомочий Минюста России как субъекта конституционноправовой защиты государственного суверенитета свидетельствует о том, что его компетенция может быть использована в интересах:

законодательного и иного правового обеспечения различных направлений защчтыь государственного суверенитета в пределах компетенции (внесение Президенту и в Правительство проектов федеральных конституционных законов, федеральных законов, актов Президента и Правительства; разработка и представление в Правительство предложений о приоритетных направлениях законопроектной деятельности Правительства, а также проектов планов законопроектной деятельности Правительства; правовая экспертиза проектов законодательных и иных нормативных правовых актов, вносимых федеральными органами исполнительной власти на рассмотрение Президента и Правительства; антикоррупционная экспертиза проектов федеральных нормативных правовых актов, правовых актов государственных органов и организаций, затрагивающих права, свободы и обязанности человека и гражданина, устанавливающих правовой статус организаций или имеющих межведомственный характер, нормативных правовых актов субъектов РФ, уставов муниципальных образований);

обеспечения приоритета федеральной Конституцуии (правовая экспертиза нормативных правовых актов субъектов РФ на предмет их соответствия Конституции и федеральным законам; государственный учет нормативных правовых актов субъектов РФ; организация государственной регистрации уставов муниципальных образований) ${ }^{1}$;

\footnotetext{
1 Минюст России обладает правом направлять федеральным органам исполнительной власти и иным органам представления об отмене или изменении
} 
гармонизацуии конституцуионно-правовых отношений между федеральным цеентром, региональньми органами власти и органами местного самоуправления (мониторинг эффективности законодательного разграничения полномочий по предметам совместного ведения между федеральными органами государственной власти, органами государственной власти субъектов РФ и органами местного самоуправления и подготовка предложений по его совершенствованию; обобщение практики наделения органов местного самоуправления государственными полномочиями и делегирования органам местного самоуправления отдельных государственных полномочий);

обеспечения реализацฺии прав и свобод человека на всей территории государства и за ее пределами (обеспечение деятельности Уполномоченного РФ при Европейском Суде по правам человека; координация деятельности федеральных органов исполнительной власти по взаимодействию РФ с Европейским комитетом по предупреждению пыток или унижающего достоинство обращения или наказания; государственная регистрация нормативных правовых актов федеральных органов исполнительной власти, затрагивающих права, свободы и обязанности человека и гражданина, устанавливающих правовой статус организаций или имеющих межведомственный характер);

защчитьл нащуиональной юрисдикции государства (государственная регистрация соглашений об осуществлении международных и внешнеэкономических связей субъектов РФ, заключенных органами государственной власти субъектов РФ; согласование предложений о заключении, прекращении, приостановлении действия или временного

принятых ими нормативных правовых актов, противоречащих Конституции и законодательству РФ. В случае выявления несоответствия действующего нормативного правового акта либо акта, содержащего правовые нормы и не прошедшего государственную регистрацию, Конституции и законодательству РФ Минюст представляет в Правительство предложение об отмене или о приостановлении действия такого акта вместе с обоснованием и проектом соответствующего распоряжения Правительства РФ. 
применения международных договоров РФ; мониторинг правоприменения в РФ в целях выполнения решений Конституционного Суда РФ и постановлений Европейского Суда по правам человека, в связи с которыми необходимо принятие (издание), изменение или признание утратившими силу (отмена) законодательных и иных нормативных правовых актов РФ; дача заключений о соответствии положений международных договоров РФ законодательству РФ и их юридической силе в РФ, а также по иным вопросам, связанным с вступлением в силу и выполнением таких договоров);

правоприменительной деятельности в рамках содействия реализаџии отдельных направлений защчиты государственного суверенитета (принятие решений о государственной регистрации некоммерческих организаций (НКО), в том числе отделений международных организаций и иностранных некоммерческих неправительственных организаций (ИННО), общественных объединений, политических партий, торгово-промышленных палат, религиозных организаций, иных юридических лиц, а также о регистрации представительств иностранных религиозных организаций, внесении сведений о филиалах и представительствах международных организаций, ИННО в реестр филиалов и представительств международных организаций и ИННО; федеральный государственный надзор за деятельностью НКО, в том числе общественных объединений, политических партий, религиозных организаций и структурных подразделений международных организаций и ИННО$^{1}$; ведение федерального списка экстремистских материалов, ведение перечня общественных объединений и религиозных организаций, иных НКО, в отношении которых судом принято вступившее в законную силу решение о ликвидации или запрете деятельности, и перечня общественных объединений и религиозных организаций, деятельность которых приостановлена в связи с

${ }^{1}$ Так, Министерство юстиции РФ ежегодно отчитывается перед Государственной Думой о деятельности НКО, выполняющих функции иностранного агента, об участии их в политической деятельности на территории РФ, о поступлении и расходовании денежных средств и о результатах контроля за их деятельностью. 
осуществлением ими экстремизма; принятие в пределах своей компетенции решений о нежелательности пребывания на территории РФ иностранных граждан и лиц без гражданства).

Специфическое положение в системе субъектов ЗГС занимают подведомственные Министерству юстиции ФСИН России и органы исполнения наказаний.

ФСИН России является федеральным органом исполнительной власти, осуществляющим правоприменительные и контрольно-надзорные функции в сфере исполнения уголовных наказаний в отношении осужденных, функции по содержанию лиц, подозреваемых либо обвиняемых в совершении преступлений, и подсудимых, находящихся под стражей, их охране и конвоированию, а также функции по контролю за поведением условно осужденных и осужденных, которым судом предоставлена отсрочка отбывания наказания, и по контролю за нахождением лиц, подозреваемых либо обвиняемых в совершении преступлений, в местах исполнения меры пресечения в виде домашнего ареста и за соблюдением ими наложенных судом запретов и (или) ограничений ${ }^{1}$.

ФСИН России обеспечивает:

правопорядок и законность в учреждениях, исполняющих наказания, и следственных изоляторах;

безопасность объектов уголовно-исполнительной системы (УИС), а также органов Минюста России;

установленный порядок исполнения наказаний и содержания под стражей, исполнение режимных требований в учреждениях УИС, и следственных изоляторах, надзор за осужденными и лицами, содержащимися под стражей;

исполнение международно-правовых обязательств РФ по передаче

${ }^{1}$ Положение о Федеральной службе исполнения наказаний (утверждено Указом Президента РФ от 13 октября 2004 г. № 1314). 
осужденных в государства их гражданства и по экстрадиции;

подготовку УИС к действиям при чрезвычайных обстоятельствах, ликвидацию их последствий на подведомственных объектах;

подготовку материалов о нежелательности пребывания (проживания) в РФ иностранных граждан и лиц без гражданства, освобождаемых из мест лишения свободы;

федеральный государственный надзор в области промышленной безопасности в отношении опасных производственных объектов УИС;

функции государственного заказчика государственного оборонного заказа;

мобилизационную подготовку и мобилизацию, проведение мероприятий гражданской обороны, повышение устойчивости работы ФСИН России, ее территориальных органов, учреждений, исполняющих наказания, и следственных изоляторов в условиях военного времени и при возникновении чрезвычайных ситуаций в мирное время.

В соответствии со статьей 16 Федерального конституционного закона «О чрезвычайном положении» силы и средства органов УИС могут привлекаться для обеспечения режимных мер и временных ограничений при введении режима чрезвычайного положения.

Правовое регулирование порядка отбывания наказания, режимные ограничения правосубъектности осужденных и следственно-арестованных, закрепление статуса специализированных органов УИС тесно связаны с конституционно-правовой защитой государственного суверенитета ${ }^{1}$. Неизбежность ответственности за противоправную антиконституционную деятельность, комплекс лишений материального и личного характера, которым подвергаются участники деструктивной деятельности,

1 Закон РФ от 21 июля 1993 г. (в ред. от 20 апреля 2015 г.) № 5473-1 «Об учреждениях и органах, исполняющих уголовные наказания в виде лишения свободы»; Уголовно-исполнительный кодекс Российской Федерации от 8 января 1997 г. (в ред. от 28 ноября 2015 г.) № 1-ФКЗ. 
направленной на ослабление или подрыв государственного суверенитета, устойчивость функционирования исправительных учреждений, обеспечивающих исполнение судебных приговоров в мирное и военное время, являются гарантиями предупреждения и пресечения посягательств на государственный суверенитет.

Головными субъектами ЗГС в идеологической сфере являются Министерство культуры и Министерство образования и науки.

Министерство культуры в соответствии с Постановлением Правительства РФ от 20 июля 2011 г. № 590 «О Министерстве культуры Российской Федерации» наделено следующими полномочиями в сфере ЗГС ${ }^{1}$ :

- реализует государственную культурную политику, исполняет законодательство о культуре;

- участвует в осуществлении внешней политики в области культурного сотрудничества;

- осуществляет государственный контроль и надзор: за сохранением, использованием, популяризацией и государственной охраной объектов культурного наследия; за состоянием объектов культурного наследия федерального значения; за вывозом из РФ и ввозом на ее территорию культурных ценностей; за соблюдением требований законодательства в сфере защиты детей от информации, причиняющей вред их здоровью и (или) развитию, к обороту информационной продукции на любых носителях, а также информационной продукции, распространяемой посредством зрелищных мероприятий.

Реализуя данные правомочия, Министерство культуры призвано обеспечивать всестороннее культурное развитие РФ и гармонизацию общественных отношений как основу экономического процветания, государственного суверенитета и цивилизационной самобытности нашей

${ }^{1}$ Постановление Правительства РФ от 20 июля 2011 г. № 590 «О Министерстве культуры Российской Федерации» // СЗ РФ. 2011. № 31. Ст. 4758. 
страны.

Министерство образования и науки (Минобрнауки России) формирует и проводит государственную политику в сфере образования, научной, научно-технической и инновационной деятельности, воспитания, поддержки и защиты молодежи.

Анализ Положения о Министерстве образования и науки РФ (утверждено Постановлением Правительства РФ от 3 июня 2013 г. № 466) позволяет выделить ряд полномочий данного государственного органа, имеющих непосредственное отношение к ЗГС.

Минобрнауки России: принимает государственные образовательные стандарты; ведет мониторинг системы образования; осуществляет координацию фундаментальных научных исследований, проводимых за счет средств федерального бюджета; выдает иностранным и российским заявителям разрешения на проведение морских научных исследований во внутренних водах и территориальном море РФ, ее исключительной экономической зоне и на ее континентальном шельфе; координирует деятельность по профилактике безнадзорности и правонарушений несовершеннолетних; создает условия для обеспечения здорового образа жизни, нравственного и патриотического воспитания молодежи, реализации профессиональных возможностей молодежи.

Как представляется, культурные учреждения и образовательные организации являются базовыми субъектами ЗГС. Их основной функцией должна быть реализация государственно ориентированной культурнообразовательной политики, направленной на формирование здоровых и всесторонне развитых граждан, воспитанных в духе нравственности и патриотизма, распространение и защита российских традиций и духовных ценностей как внутри нашей многонациональной страны, так и за ее пределами.

В соответствии с Конституцией Российской Федерации часть 
полномочий по ЗГС находится в совместном ведении РФ и ее субъектов. К их числу относятся: обеспечение соответствия конституций и законов республик, уставов и иных нормативных правовых актов субъектов РФ Конституции и федеральным законам; защита прав и свобод человека и гражданина; защита прав национальных меньшинств; режим пограничных зон, предупреждение чрезвычайных ситуаций и др. На основании данных конституционных положений органы государственной власти субъектов РФ принимают участие в ЗГС.

Компетенция региональных органов государственной власти в сфере ЗГС складывается из нескольких групп полномочий:

полномочий по законодательному и иному правовому обеспечению различных направлений ЗГС;

полномочий по установлению системы органов государственной власти субъекта РФ, формированию и досрочному прекращению деятельности региональных органов государственной власти;

полномочий по обеспечению реализации прав и свобод человека и гражданина;

полномочий по содействию реализации отдельных направлений ЗГС; полномочий в сфере конституционного контроля.

В рамках реализации полномочий по законодательному и иному правовому обеспечению различных направлений защиты государственного суверенитета законодательные органы государственной власти субъектов РФ принимают конституцию (устав) субъекта РФ и поправки к ней (нему); осуществляют законодательное регулирование по предметам ведения субъекта РФ и предметам совместного ведения РФ и субъектов РФ в пределах полномочий субъекта РФ (в том числе по вопросам бюджета субъекта РФ, взимания региональных налогов и сборов, заключения и расторжения договоров субъекта РФ, административно-территориального 
устройства субъекта и другим вопросам) ${ }^{1}$. Органы законодательной власти субъектов РФ обладают правом законодательной инициативы в Федеральном Собрании, реализация которой может быть направлена на совершенствование отношений в сфере ЗГС.

Полномочия по установлению системы органов государственной власти субъекта Российской Федеращчии, формированию и досрочному прекращению деятельности региональных органов государственной власти включают: установление порядка проведения выборов в законодательный орган государственной власти субъекта РФ; порядка выборов высшего должностного лица субъекта РФ либо порядка избрания высшего должностного лица субъекта РФ депутатами законодательного органа государственной власти субъекта РФ и порядка отзыва высшего должностного лица субъекта РФ. Данная группа полномочий позволяет обеспечивать устойчивое функционирование и воспроизводство органов государственной власти, предотвращает возможность антиконституционного присвоения властных полномочий.

Органы государственной власти субъекта РФ принимают участие в обеспечении реализаџии прав и свобод человека и гражданина. Конституцией (уставом), законом субъекта РФ в целях обеспечения дополнительных гарантий государственной защиты прав, свобод и законных интересов человека и гражданина может учреждаться должность уполномоченного по правам человека в субъекте РФ.

Значительный объем полномочий органы государственной власти субъектов РФ осуществляют путем содействия реализациии отдельных направлений защиты государственного суверенитета ${ }^{2}$.

${ }^{1}$ Статья 5 Федерального закона от 6 октября 1999 г. (в ред. от 30 декабря 2015 г.) № 184-Ф3 «Об общих принципах организации законодательных (представительных) и исполнительных органов государственной власти субъектов Российской Федерации».

2 Статьи 21, 26.3 Федерального закона от 6 октября 1999 г. (в ред. от 30 декабря 2015 г.) № 184-Ф3 «Об общих принципах организации законодательных 
К этой группе полномочий относятся:

осуществление мер по противодействию терроризму и экстремизму, борьбе с преступностью;

предупреждение чрезвычайных ситуаций межмуниципального и регионального характера, стихийных бедствий, эпидемий и ликвидация их последствий;

организация общего, среднего специального и дополнительного образования в государственных организациях субъектов РФ, осуществление региональных и межмуниципальных программ патриотического воспитания детей и молодежи;

осуществление мер по защите прав национальных меньшинств; социальной и культурной адаптации мигрантов; профилактике межнациональных (межэтнических) конфликтов и обеспечению межнационального и межконфессионального согласия;

создание мобилизационных органов в зависимости от объема мобилизационных заданий или задач по переводу экономики субъекта РФ на работу в условиях военного времени;

координация и контроль за проведением органами местного самоуправления и организациями мероприятий по мобилизационной подготовке и др. полномочия.

Региональные субъекты конституционно-правовой защиты государственного суверенитета обладают некоторыми полномочиями в сфере конституционного контроля.

Так, органы законодательной и исполнительной власти субъекта РФ вправе обратиться в Конституционный Суд РФ с запросом о соответствии Конституции федеральных законов, нормативных правовых актов Президента, Совета Федерации, Государственной Думы, Правительства РФ,

(представительных) и исполнительных органов государственной власти субъектов Российской Федерации». 
конституций республик, уставов, а также законов и иных нормативных правовых актов субъектов РФ.

Высший исполнительный орган государственной власти субъекта РФ вправе предложить органам местного самоуправления, выборному или иному должностному лицу местного самоуправления привести в соответствие с законодательством РФ изданные ими правовые акты, если они противоречат Конституции, федеральным законам и иным нормативным правовым актам РФ, конституции (уставу), законам и иным нормативным правовым актам субъекта РФ, а также вправе обратиться в суд.

В соответствии со ст. 27 Федерального конституционного закона от 31 декабря 1996 г. № 1-ФКЗ «О судебной системе Российской Федерации» субъектами РФ могут создаваться конституционные (уставные) суды.

Согласно указанному Закону к компетенции конституционного (уставного) суда субъекта РФ отнесены полномочия:

- по рассмотрению вопросов соответствия законов субъекта РФ, нормативных правовых актов органов государственной власти субъекта РФ, органов местного самоуправления субъекта РФ конституции (уставу) субъекта РФ;

- по толкованию конституции (устава) субъекта РФ.

Впоследствии установленные федеральным законодателем полномочия региональных судебных органов конституционного контроля являлись предметом проверки Конституционного Суда РФ. В Определении от 6 марта 2003 г. № 103-О по запросам Государственного Собрания Республики Башкортостан и Государственного Совета Республики Татарстан о проверке конституционности части 1 статьи 27 Федерального конституционного закона «О судебной системе Российской Федерации» Конституционный Суд пришел к выводу о возможности закрепления в конституциях (уставах) субъектов РФ дополнительных полномочий конституционных (уставных) судов, не вторгающихся в компетенцию федеральных судов, и 
соответствующих компетенции субъекта РФ.

Проведенный анализ субъектного состава механизмов конституционноправовой защиты государственного суверенитета показал, что каждый специализированный государственный орган, задействованный в решении задач ЗГС, уникален. Специфика субъектов конституционно-правовой защиты государственного суверенитета определяется их местом и ролью в механизме государства, интенсивностью и глубиной воздействия на деструктивные антигосударственные силы и негативные процессы формирования и организации государственной власти, разнообразными субординационными и координационными связями.

Для того, чтобы выяснить специфику и особенности отношений между субъектами, дать характеристику потенциала их воздействия на механизмы ослабления и подрыва государственного суверенитета, а также конкретные угрозы государственному суверенитету, обратимся к вопросам организации взаимодействия и конкретным формам решения совместных задач в сфере ЗГС $\mathrm{C}^{1}$.

Организация взаимодействия субъектов конституционно-правовой защиты государственного суверенитета базируется на объективно существующих совместных задачах ЗГС, в качестве которых можно выделить:

профилактику, выявление и нейтрализацию угроз государственному суверенитету, предотвращение и устранение с помощью конституционноправовых средств негативных явлений в области формирования и организации государственной власти;

формирование и совершенствование правовых механизмов противодействия деструктивной деятельности антигосударственных сил,

1 Под взаимодействием субъектов конституционно-правовой защиты государственного суверенитета понимается урегулированная правовыми нормами согласованная деятельность самостоятельных в организационном отношении субъектов, направленная на решение совместных задач конституционно-правовой защиты государственного суверенитета. 
направленной на ослабление и подрыв государственного суверенитета;

подготовку предложений и сопровождение принятия политикоправовых решений высшими органами государственной власти по вопросам ЗГС;

содействие в беспрепятственной реализации внутренней и внешней политики государства во всех сферах общественной жизни.

Осуществляя в пределах своей компетенции решение данных задач, субъекты конституционно-правовой защиты государственного суверенитета могут взаимодействовать в различных формах:

1. В форме участия в правотворческой деятельности в сфере ЗГС (правотворческие инициативы, правовые экспертизы, согласование проектов правовых актов и др.)

2. В форме проведения межведомственных совещаний, создания оперативных штабов, межведомственных комиссий и совместных рабочих групп для обмена информацией и выработки согласованных решений по вопросам ЗГС ${ }^{1}$.

3. В форме совместного использования сил и средств при решении конкретных практических задач ЗГС (отражение вооруженной агрессии, противодействие «цветным» революциям, «гуманитарным» интервенциям, совместные разведывательные и контрразведывательные операции и др.).

4. В форме подготовки и проведения совместных научноорганизационных (научно-практические конференции, семинары, «круглые» столы, форумы и др.) и информационно-пропагандистских мероприятий по тематике ЗГС.

5. В форме согласованного проведения оперативно-разыскных мероприятий и следственных действий (совместное расследование резонансных государственных преступлений и др.)

1 Так, для координации деятельности органов, обеспечивающих чрезвычайного положения, могут создаваться объединенные оперативные штабы. 
6. В форме государственной защиты конституционных прав и свобод граждан и организаций, общественных объединений и обеспечения гарантий их деятельности (президентский, судебный и парламентский контроль, прокурорский надзор и др.)

Рассматривая формы взаимодействия субъектов ЗГС, необходимо обратить внимание на специфику их отношений друг с другом и уникальную интенсивность воздействия на сферу ЗГС. Так, субъекты общей компетенции определяют задачи, полномочия, объем финансирования, силы и средства субъектов специальной компетенции. Возможности федеральных органов государственной власти обеспечивать реализацию функций государства в различных сферах общественной жизни существенно шире, чем у органов государственной власти субъектов РФ. Наконец, в силу особенностей своей компетенции одни субъекты (в том числе находящиеся на одном уровне иерархии в механизме государства) могут оказывать непосредственное воздействие на необходимые отношения в сфере ЗГС, а другие - лишь опосредованное.

Для того чтобы объединять уникальные правомочия, людские, информационные и материальные ресурсы различных субъектов, координировать и контролировать их деятельность, вносить своевременные коррективы в механизмы правотворчества, правореализации и государственного принуждения, в любых условиях решать масштабные общегосударственные задачи путем использования комплекса правовых средств и методов государство задействует правовые режимы.

Изучение юридической литературы, посвященной проблематике различных правовых режимов, позволяет применить сущностные характеристики понятия «правовой режим»к общественным отношениям в сфере ЗГС и ввести понятие «правовой режим защиты государственного 
суверенитета» ${ }^{1}$.

Как представляется, правовой режим ЗГС имеет следующие характерные признаки:

1. Вводится государством для защиты и укрепления государственной власти и обеспечивается принудительной силой государственного механизма.

2. Регулируется правовыми нормами различных отраслей права, определяющими характер правоотношений в ходе противоборства субъектов ЗГС и антигосударственных сил.

3. Включает комплекс методов дозволения, обязанностей, запретов и мер ответственности.

4. Ц Целевое назначение данного правового режима состоит в создании благоприятных условий для деятельности субъектов ЗГС и ограничений, препятствующих деструктивной деятельности антигосударственных сил, направленной на ослабление и подрыв государственного суверенитета.

Отталкиваясь от используемой в работе теоретической базы, определим правовой режим ЗГС как установленный государством специфический порядок правового регулирования общественных отношений, направленный на создание ограничительных условий, затрудняющих деструктивную деятельность антигосударственных сил, а также благоприятных условий для обеспечения верховенства и независимости государственной власти, полноты иммунитетов государства,

${ }^{1}$ Алешин В. В. Правовые основы применения режима чрезвычайного положения и режима контртеррористической операции // Современное право. 2006. № 4. С. 31-37; Cтепенко $B . \quad E$. Режим функционирования Государственной границы Российской Федерации как организационно-правовая основа защиты общественных отношений в пограничной сфере // Таможенное дело. 2006. № 4; Громов М. А. Чрезвычайные правовые режимы в системе административно-правовых режимов // Российский следователь. 2008. № 1. С. 36-38; Померлян А. Н. Чрезвычайный правовой режим: проблема интерпретации и правового регулирования // Юридический мир. 2008. № 8 (140). С. 28-30; Папрылин E. C. Понятие и сущность особых правовых режимов // История государства и права. М.: Юрист. 2008. № 16. С. 13-16; Лермонтова Н. В. Понятие и признаки административноправового режима // Административное и муниципальное право. 2009. № 3 (15). С. 72-75; Матузов Н. И., Малько А. В. Правовые режимы: Вопросы теории и практики // Правоведение. 1996. №1. С.16-29 и др. 
беспрепятственной реализации государственно-властных полномочий во всех сферах общественной жизни.

Правовой режим ЗГС является комплексным общегосударственным режимом. Он обеспечивает ЗГС в различных областях общественных отношений, связанных с:

- охраной государственной границы;

- таможенным контролем;

- контролем за въездом, передвижением по территории государства, проживанием и выездом иностранных граждан и лиц без гражданства;

- защитой государственной тайны;

- охраной важных и специальных государственных объектов, объектов на коммуникациях;

- формированием и функционированием органов государственной власти и управления;

- организацией и функционированием закрытых административнотерриториальных образований;

- оборотом определённых предметов, технических средств, веществ и информации, а также функционирования предприятий и организаций в интересах ЗГС;

- обеспечением чрезвычайного положения, военного положения и проведением контртеррористических операций ${ }^{1}$.

Не все области общественных отношений, несмотря на их значимость для ЗГС, требуют постоянного внимания государства и специфической жесткости правового регулирования, предполагающей введение допустимого уровня активности субъектов, ограничительных режимных мер, запретов и наказаний, и являются составными частями правовых режимов. В связи с этим в демократических государствах в формате самостоятельных правовых

${ }^{1}$ Приложение 6. 
режимов традиционно не рассматривается регулирование статуса личности, порядка проведения массовых мероприятий, деятельности общественных организаций, политических партий, СМИ и др. ${ }^{1}$

Вместе с тем в структуре правового режима ЗГС можно выделить ряд самостоятельных правовых режимов, специфика правового регулирования которых не вызывает сомнений:

пограничного контроля;

таможенного контроля;

контроля за въездом, передвижением по территории государства, проживанием и выездом иностранных граждан и лиц без гражданства;

безопасного функционирования важных государственных объектов, объектов транспорта, топливно-энергетического комплекса, критически важных и опасных производственных объектов;

безопасного формирования и функционирования органов государственной власти и управления;

защиты государственной тайны;

закрытых административно-территориальных образований (ЗАТО);

лицензионно-разрешительной системы в сфере ЗГС;

исключительных правовых режимов (чрезвычайного положения, военного положения и контртеррористической операции).

Часть этих режимов функционирует на постоянной основе (пограничного и таможенного контроля, контроля за въездом, передвижением по территории государства, проживанием и выездом иностранных граждан и лиц без гражданства, безопасного функционирования важных государственных объектов, объектов транспорта, топливно-энергетического комплекса, критически важных и опасных

${ }^{1}$ В данной работе политические партии, общественные организации, СМИ, органы местного самоуправления, выборы и правовое положение личности исследуются в качестве правовых институтов конституционных механизмов ЗГС. 
производственных объектов, защиты государственной тайны), другая часть носит временный характер (чрезвычайного положения, военного положения и контртеррористической операции).

Режим пограничного контроля устанавливается в целях недопущения противоправного изменения прохождения Государственной границы, обеспечения соблюдения физическими и юридическими лицами режима Государственной границы, пограничного режима и режима в пунктах пропуска через Государственную границу. Данный режим включает правила содержания Государственной границы; пересечения Государственной границы; перемещения через Государственную границу грузов, товаров и животных; пропуска через Государственную границу лиц, транспортных средств, грузов, товаров и животных; ведения на Государственной границе либо вблизи нее на территории РФ хозяйственной, промысловой и иной деятельности; разрешения с иностранными государствами инцидентов, связанных с нарушением этих правил. В пределах приграничной территории указанный режим обеспечивается пограничными органами, в воздушном пространстве и подводной среде - Вооруженными Силами.

На основании закона РФ от 1 апреля 1993 г. № 4730-1 «О Государственной границе Российской Федерации» пограничными органами устанавливается разрешительный порядок въезда, пребывания и передвижения лиц и транспортных средств на Государственной границе и в пограничной зоне, ведения хозяйственной, промысловой и иной деятельности, проведения массовых общественно-политических, культурных и иных мероприятий. Не подлежат пропуску через Государственную границу иностранные граждане и лица без гражданства, которым не разрешен въезд в РФ, а также лица, в отношении которых принято решение о запрещении выезда из РФ.

Перечисленные режимные ограничения способствуют вскрытию устремлений иностранных спецслужб и организаций к Государственной 
границе РФ, выявлению на каналах въезда - выезда лиц, представляющих угрозу государственному суверенитету, использующих чужие или поддельные документы, контрразведывательному обеспечению пребывания иностранных граждан и лиц без гражданства на территории РФ.

Режим таможенного контроля устанавливается в целях защиты суверенных интересов государства при осуществлении внешней торговли товарами, а также создания условий для развития внешнеэкономической и внешнеторговой деятельности. Данный режим обеспечивается совокупностью средств и методов таможенного регулирования, а также запретов и ограничений при ввозе товаров в РФ и вывозе товаров из РФ.

Таможенный контроль проводится таможенными органами в пунктах пропуска через Государственную границу в формах и порядке, которые установлены Таможенным кодексом Таможенного союза.

В соответствии со статьей 110 Таможенного кодекса формами таможенного контроля являются:

проверка документов и сведений;

устный опрос;

получение объяснений;

таможенное наблюдение;

таможенный осмотр;

таможенный досмотр;

личный таможенный досмотр;

проверка маркировки товаров специальными марками, наличия на них идентификационных знаков;

таможенный осмотр помещений и территорий;

учет товаров, находящихся под таможенным контролем;

проверка системы учета товаров и отчетности;

таможенная проверка.

Согласно статье 161 Федерального закона от 27 ноября 2010 г. № 311 - 
Ф3 «О таможенном регулировании в Российской Федерации» при проведении таможенного контроля таможенные органы исходят из принципа выборочности и ограничиваются только теми формами, которые достаточны для обеспечения соблюдения таможенного законодательства.

Возможности режима таможенного контроля позволяют субъектам ЗГС выявлять, предупреждать и пресекать противоправную деятельность криминальных структур, иностранных спецслужб и связанных с ними организаций, а также отдельных лиц в сфере внешнеэкономической и внешнеторговой деятельности.

Режим контроля за въездом, передвижением по территории государства, проживанием и выездом иностранных граждан и лиц без гражданства связан с регламентацией порядка оформления и выдачи документов для въезда в РФ и выезда из РФ, порядка пропуска через Государственную границу РФ, правил поведения иностранных граждан и лиц без гражданства на территории РФ. Правовую основу режима составляют Федеральные законы от 15 августа 1996 г. (в ред. от 30 декабря 2015 г.) № 114-Ф3 «О порядке выезда из Российской Федерации и въезда в Российскую Федерацию», от 25 июля 2002 г. (в ред. от 30 декабря 2015 г.) № 115-Ф3 «О правовом положении иностранных граждан в Российской Федерации», от 18 июля 2006 г. (в ред. от 28 ноября 2015 г.) № 109-Ф3 «О миграционном учете иностранных граждан и лиц без гражданства в Российской Федерации» и др. нормативные акты.

Миграционное законодательство РФ содержит ряд правовых механизмов, регламентирующих миграционные отношения в интересах ЗГС. Указанные механизмы представлены:

- юридическими нормами, ограничивающими въезд в РФ отдельных категорий иностранных граждан и лиц без гражданства (имеющих неснятую или непогашенную судимость за совершение умышленных преступлений; подвергавшихся выдворению (депортации); переданных иностранному 
государству в порядке реадмиссии в период предыдущего пребывания в России; участвующих в деятельности иностранных или международных неправительственных организаций, признанных нежелательными на территории РФ; иностранцев, в отношении которых принято решение о нежелательности пребывания (проживания) в РФ и др.; установление Правительством РФ квот на выдачу иностранным гражданам приглашений на въезд в РФ в целях осуществления трудовой деятельности; установление органами МВД России запрета на въезд в РФ отдельных иностранных граждан и лиц без гражданства);

- юридическими нормами, определяющими правосубъектность (ограничения отдельных прав) временно пребывающих в РФ иностранных граждан и лиц без гражданства (установление Правительством РФ квот на выдачу иностранным гражданам разрешений на временное проживание в РФ; отказ в выдаче либо аннулирование разрешения на временное проживание; сокращение Правительством РФ срока временного пребывания; принятие решения о нежелательности пребывания иностранного гражданина в РФ);

- юридическими нормами, определяющими правосубъектность (ограничения отдельных прав) постоянно проживающих в РФ иностранных граждан (отказ в выдаче либо аннулирование вида на жительство; принятие решения о нежелательности проживания иностранного гражданина в РФ);

- юридическими нормами, ограничивающими передвижение иностранных граждан и лиц без гражданства в пределах РФ (разрешительный порядок посещения отдельных территорий, организаций и объектов, перечень которых утвержден Правительством РФ);

- юридическими нормами, регулирующими трудовую деятельность иностранных работников в РФ (ограничения на допуск иностранных граждан к деятельности и замещению должностей в соответствии с федеральным законом; установление Правительством РФ квот на выдачу иностранным гражданам разрешений на работу; установление Правительством РФ 
допустимой доли иностранных работников в различных отраслях экономики; отказ в выдаче и аннулирование разрешения на работу);

- юридическими нормами, регулирующими выезд из РФ иностранных граждан и лиц без гражданства (ограничения на выезд иностранцев из РФ до принятия решения по уголовному делу, до вступления в законную силу приговора суда; до отбытия (исполнения) наказания или до освобождения от наказания; до исполнения обязательств; выдворение (депортация) иностранного гражданина за пределы РФ; передача иностранного гражданина в соответствии с международным договором о реадмиссии; установление срока выезда из РФ при принятии Правительством решения о сокращении срока временного пребывания иностранных граждан).

Правовые ограничения на въезд, пребывание (проживание), трудовую деятельность или транзитный проезд через территорию РФ установлены в отношении: лиц, выступающих за насильственное изменение основ конституционного строя РФ; представляющих угрозу безопасности РФ; пособников террористической (экстремистской) деятельности; лиц, подвергавшихся выдворению (депортации) за пределы РФ; имеющих неснятую или непогашенную судимость за совершение умышленных преступлений в РФ; переданных иностранному государству в порядке реадмиссии в период предыдущего пребывания в России; иностранцев, в отношении которых принято решение о нежелательности пребывания (проживания) в РФ; неоднократно привлекавшихся к административной ответственности в РФ за нарушение режима пребывания (проживания) иностранных граждан в РФ; совершивших административное правонарушение, связанное с незаконным оборотом наркотических средств или психотропных веществ и их прекурсоров; лиц, представивших поддельные или подложные документы либо сообщивших о себе заведомо ложные сведения.

Данные режимные ограничения позволяют: своевременно выявлять и 
предупреждать въезд в РФ лиц, въезд которым закрыт по причине их принадлежности к спецслужбам и организациям иностранных государств, чья деятельность может нанести ущерб государственному суверенитету РФ, либо к международным террористическим организациям и преступным сообществам; контролировать передвижение иностранных граждан и лиц без гражданства по территории РФ; сокращать сроки временного пребывания и прекращать проживание в РФ отдельных категорий иностранных граждан и лиц без гражданства; пресекать попытки выезда из страны лиц, находящихся под следствием и судом, уклоняющихся от уплаты налогов и исполнения иных обязательств, наложенных в судебном порядке.

В системе элементов правового режима ЗГС важное место занимает режим безопасного функционирования важных государственных объектов, объектов транспорта, топливно-энергетического комплекса, критически важных и опасных производственных объектов.

Bсе эти объекты представляют собой предприятия, организации или учреждения, осуществляющие свою деятельность для нужд государства и общества; они имеют особое или исключительное значение для государства и характеризуются закрытым порядком деятельности и безопасного функционирования. Особое или исключительное значение данных объектов состоит в том, что нарушение или прекращение их функционирования приведет к подрыву обороноспособности и безопасности государства, потере управления экономикой, существенному снижению безопасности жизнедеятельности населения.

Правовую основу режима составляют Федеральные законы от 9 февраля 2007 г. № 16-ФЗ «О транспортной безопасности», от 10 января 2003 г. № 17-Ф3 «О железнодорожном транспорте в Российской Федерации», от 8 ноября 2007 г. № 261-Ф3 «О морских портах в Российской Федерации и о внесении изменений в отдельные законодательные акты Российской Федерации», от 21 июля 2011 г. № 256-Ф3 «О безопасности объектов 
топливно-энергетического комплекса», от 21 июля 1997 г. № 116-Ф3 «О промышленной безопасности опасных производственных объектов» и др.

Режимные мероприятия на данных объектах предполагают: оборудование подъездов к периметру или контрольно-пропускным пунктам заградительными сооружениями; оборудование ограждения периметра объекта; организацию физической защиты объекта с использованием специальных средств; организацию пропускного режима; организацию охраны объекта (территории) с использованием технических средств и групп быстрого реагирования; обеспечение инженерно-технической укрепленности зданий, строений и сооружений; организацию внутриобъектового режима; подготовку персонала к действиям в условиях угрозы и осуществления диверсионно-террористической деятельности и др.

В соответствии с Указом Президента РФ от 5 апреля 2016 г. № 157 «Вопросы Федеральной службы войск национальной гвардии Российской Федерации» охрана важных государственных объектов и специальных грузов осуществляется Федеральной службой войск национальной гвардии РФ.

Некоторые законодательные акты устанавливают особые требования к отдельным категориям объектов. Так, в целях устойчивого и безопасного функционирования транспортного комплекса, предотвращения актов незаконного вмешательства в соответствии с Федеральным законом «О транспортной безопасности» на объектах транспорта реализуется режим транспортной безопасности. Элементы данного правового режима включают: нормативное правовое регулирование в области обеспечения транспортной безопасности;

определение угроз совершения актов незаконного вмешательства и их предупреждение;

оценку уязвимости и категорирование объектов транспортной инфраструктуры и транспортных средств;

разработку и реализацию требований и мер по обеспечению 
транспортной безопасности;

подготовку и аттестацию персонала обеспечения транспортной безопасности;

сертификацию технических средств обеспечения транспортной безопасности;

федеральный государственный контроль (надзор) в области обеспечения транспортной безопасности и др. мероприятия.

Согласно Федеральному закону «О безопасности объектов топливноэнергетического комплекса» режим безопасности объектов топливноэнергетического комплекса (ТЭК) охватывает: правовое регулирование в области антитеррористической защищенности объектов ТЭК; предупреждение угроз совершения актов незаконного вмешательства; категорирование объектов ТЭК; разработку и реализацию требований обеспечения безопасности объектов ТЭК; создание системы физической защиты объектов ТЭК; подготовку специалистов в сфере обеспечения безопасности объектов ТЭК; осуществление государственного контроля (надзора) за обеспечением безопасности объектов ТЭК.

В соответствии с Федеральным законом «О промышленной безопасности опасных производственных объектов» опасные производственные объекты регистрируются в государственном реестре. К деятельности опасных производственных объектов (технологическим процессам, порядку хранения опасных веществ, работникам опасных производств, обеспечению безопасности) применяются условия, запреты, ограничения и другие обязательные требования.

В рамках ЗГС возможности правового режима безопасного функционирования важных государственных объектов, объектов транспорта, ТЭК, критически важных и опасных производственных объектов используются в интересах предотвращения нарушения или прекращения деятельности указанных объектов, своевременного выявления актов 
незаконного вмешательства, задержания потенциально опасных лиц, предупреждения чрезвычайных ситуаций.

В системе конституционно-правовой защиты государственного суверенитета стратегическое значение имеет режим безопасного формирования и функционирования органов государственной власти и управления.

Целевое назначение этого режима предполагает обеспечение легитимности формирования органов государственной власти и управления, противодействие криминализации и коррупционной пораженности государственного механизма, недопущение прихода к власти и формирования «лобби» ставленников иностранных государств и финансируемых ими организаций, обеспечение гарантий беспрепятственного осуществления властных полномочий законными органами власти в условиях антиконституционных посягательств антигосударственных сил.

Правовую основу режима составляют федеральные законы от 12 июня 2002 г. № 67-Ф3 «Об основных гарантиях избирательных прав и права на участие в референдуме граждан Российской Федерации», от 10 января 2003 г. № 19-Ф3 «О выборах Президента Российской Федерации», от 22 февраля 2014 г.№ 20-Ф3 «О выборах депутатов Государственной Думы Федерального Собрания Российской Федерации», от 6 октября 1999 г. «Об общих принципах организации законодательных (представительных) и исполнительных органов государственной власти субъектов Российской Федерации», от 19 июня 2004 г. № 54-Ф3 «О собраниях, митингах, демонстрациях, шествиях и пикетированиях», от 25 июля 2002 г. № 114-Ф3 «О противодействии экстремистской деятельности» и др.

Возможности этого режима позволяют субъектам ЗГС: вырабатывать и реализовывать меры по противодействию деятельности организаций и отдельных лиц, ставящих своей целью подрыв или насильственное изменение конституционного строя, свержение законных органов 
государственной власти; противодействовать иностранному финансированию политической деятельности и выборов; обеспечивать безопасность массовых общественно-политических мероприятий; обеспечивать охрану политических деятелей в случае возникновения угроз для их жизни и здоровья.

В любом государстве на постоянной основе действует режим защиты государственной тайны, который представляет собой совокупность правовых норм, основанных на них требований и мер, устанавливающих и обеспечивающих определённый порядок деятельности государственных органов, их должностных лиц, предприятий, учреждений и организаций, а также поведения граждан в целях обеспечения сохранности сведений, составляющих государственную тайну.

Отношения, связанные с отнесением сведений к государственной тайне, их засекречиванием, рассекречиванием и защитой, регулируются Законом РФ от 21 июля 1993 г. (в ред. от 8 марта 2015 г.) № 5485-1 «О государственной тайне».

Правовой режим защиты государственной тайны (далее - ЗГТ) включает комплекс требований и мер по обеспечению сохранности сведений, составляющих государственную тайну, к которым относятся:

создание и организация деятельности структурных подразделений по ЗГТ;

допуск должностных лиц и граждан к государственной тайне; соблюдение работниками соответствующих ограничений и запретов; засекречивание сведений, составляющих государственную тайну; обеспечение режима секретности; организация выезда секретоносителей за границу; оборудование и эксплуатация режимных помещений; особый порядок обращения с носителями сведений, составляющих государственную тайну; 
защита секретной информации, обрабатываемой с использованием средств вычислительной техники;

организация и осуществление противодействия иностранным техническим разведкам;

организация и ведение секретного делопроизводства;

проведение служебных расследований по фактам нарушения режима секретности.

В число субъектов защиты сведений, составляющих государственную тайну, входят:

- межведомственная комиссия по ЗГТ, координирующая деятельность органов государственной власти в интересах разработки и выполнения государственных программ, нормативных и методических документов в сфере $3 Г Т$;

- компетентные федеральные органы исполнительной власти (ФСБ России, Министерство обороны, СВР России, Федеральная служба по техническому и экспортному контролю (ФСТЭК России);

- органы государственной власти, предприятия, учреждения и организации и их структурные подразделения по ЗГТ.

Значительными полномочиями в сфере ЗГТ наделены органы федеральной службы безопасности. Их правовое положение позволяет:

участвовать в разработке и реализации мер по ЗГТ;

осуществлять межведомственный контроль за сохранностью сведений, составляющих государственную тайну;

осуществлять лицензирование деятельности предприятий, учреждений и организаций по проведению работ, связанных с использованием сведений, составляющих государственную тайну, созданием средств защиты информации, а также с осуществлением мероприятий и (или) оказанием услуг по ЗГТ;

выдавать разрешения на открытие и ликвидацию подразделений по 
ЗГТ;

согласовывать перечни должностей секретоносителей;

приостанавливать либо аннулировать лицензии в случае нарушения предприятиями, учреждениями и организациями режимных требований;

контролировать допуск граждан к государственной тайне.

Специфика правового режима ЗГТ заключается в его экстерриториальном характере. Требования ЗГТ обязательны для исполнения как на территории РФ, так и за ее пределами. Дополнительной мерой обеспечения сохранности сведений, составляющих государственную тайну, является контроль за выездом секретоносителей за границу и возможность ограничения прав граждан и должностных лиц на выезд за рубеж.

Уникальным симбиозом режима ЗГТ и режима безопасного функционирования важных государственных объектов, объектов транспорта, ТЭК, критически важных и опасных производственных объектов выступает режим закрытого административно-территориального образования (3АТО). Эта особенность целевого назначения правового режима закреплена в Законе РФ от 14 июля 1992 г. (в ред. от 13 июля 2015 г.) № 3297-1«О закрытом административно-территориальном образовании».

Согласно статье 1 данного Закона ЗАТО «создаются в целях обеспечения безопасного функционирования находящихся на их территории организаций, осуществляющих разработку, изготовление, хранение и утилизацию оружия массового поражения, переработку радиоактивных и других представляющих повышенную опасность материалов, военных и иных объектов, для которых в целях обеспечения обороны страны и безопасности государства устанавливается особый режим безопасного функционирования и охраны государственной тайны, включающий специальные условия проживания граждан».

Решение об установлении особого режима безопасного функционирования организаций и (или) объектов в конкретном ЗАТО 
принимается Правительством РФ.

Особый режим безопасного функционирования организаций и (или) объектов в ЗАТО включает:

установление контролируемых и (или) запретных зон по границе и (или) в пределах указанного образования;

ограничения на въезд и (или) постоянное проживание граждан на его территории, включая установление перечня оснований для отказа во въезде или в постоянном проживании;

ограничения на полеты летательных аппаратов над его территорией;

ограничения на право ведения хозяйственной и предпринимательской деятельности, владения, пользования и распоряжения природными ресурсами, недвижимым имуществом, вытекающие из ограничений на въезд и (или) постоянное проживание;

ограничения на создание и деятельность на его территории организаций, учредителями которых являются иностранные граждане, лица без гражданства, иностранные некоммерческие неправительственные организации, отделения иностранных некоммерческих неправительственных организаций, организации с иностранными инвестициями;

организацию разработки и осуществление мер по предупреждению терроризма, предотвращению техногенных катастроф, обеспечению пожарной безопасности и охране общественного порядка.

На территории ЗАТО не допускаются создание и деятельность организаций, учредителями которых являются иностранные граждане, лица без гражданства и иностранные организации, иностранные некоммерческие неправительственные организации, отделения иностранных некоммерческих неправительственных организаций, а также деятельность международных организаций (объединений).

Правовой режим ЗАТО позволяет решать задачи обеспечения обороны и безопасности государства, создавать максимально благоприятные условия 
для контрразведывательной деятельности, предупреждения преступлений, чрезвычайных ситуаций и техногенных катастроф.

Эффективным инструментом правовой защиты государства, общества и граждан выступает лицензионно-разрешительная система в сфере защиты государственного суверенитета.

Данный правовой режим устанавливает и обеспечивает особый порядок обращения определённых предметов, технических средств, веществ и информации, а также функционирования предприятий и организаций в сфере $3 Г$ С.

Правовую основу режима составляют Закон РФ от 21 июля 1993 г. № 5485-1 «О государственной тайне», Федеральные законы от 13 декабря 1996 г. № 150-Ф3 «Об оружии», от 8 января 1998 г. «О наркотических средствах и психотропных веществах», от 21 ноября 1995 г. № 170-Ф3 «Об использовании атомной энергии», от 9 января 1996 г. № 3-Ф3 «О радиационной безопасности населения» и др. нормативно-правовые акты.

Лицензионно-разрешительная надзорная деятельность обладает следующими особенностями:

1. Носит государственно-властный характер.

2. Осуществляется уполномоченными органами исполнительной власти (органами внутренних дел, органами безопасности и др.)

3. Связана с лицензионно-разрешительными правоотношениями и возможностью применения мер принуждения при нарушении установленных требований и ограничений.

Целевое назначение данного режима заключается в том, чтобы предотвратить утрату и хищение предметов, веществ, технических средств, на которые распространяется особый режим обращения (например, оружия, боеприпасов, взрывчатых и ядовитых веществ, наркотических средств, радиоактивных материалов), а также предотвратить нарушения при осуществлении отдельных видов деятельности (частная детективная и 
охранная деятельность, работа со сведениями, составляющими государственную тайну и др.).

Правоотношения, возникающие в ходе реализации лицензионноразрешительной надзорной деятельности в сфере ЗГС, регулируются государством как на постоянной основе, так и при возникновении чрезвычайных обстоятельств и введении исключительных (особых) правовых режимов (режимы чрезвычайного положения (ЧП), военного положения (ВП), а также режим контртеррористической операции (КТО)).

Так, при введении режимов ЧП, ВП и КТО ограничивается или запрещается продажа оружия, боеприпасов, взрывчатых и ядовитых веществ, а также устанавливается особый режим оборота лекарственных препаратов, содержащих наркотические средства, психотропные и сильнодействующие вещества, спиртные напитки ${ }^{1}$. В условиях ЧП и ВП допускается временное изъятие у граждан и организаций оружия и боеприпасов, ядовитых веществ. В соответствии со статьей 12 Федерального конституционного закона «О чрезвычайном положении» и статьей 11 Федерального закона «О противодействии терроризму» приостанавливается деятельность опасных производств и организаций, в которых используются взрывчатые, радиоактивные, а также химически и биологически опасные вещества.

При введении режима КТО может ограничиваться или приостанавливаться частная детективная и охранная деятельность ${ }^{2}$.

Исключительные (особые) правовые режимы вводятся в целях ЗГС от наиболее опасных внутригосударственных и внешних угроз.

Данные правовые режимы ориентированы на ЗГС в условиях наступления исключительных обстоятельств. Такие правовые режимы в правовой литературе рассматриваются двояко: с одной стороны, как

${ }^{1}$ Статья 7 Федерального конституционного закона «О военном положении», статья 12 Федерального конституционного закона «О чрезвычайном положении», статья 11 Федерального закона «О противодействии терроризму».

2 Часть 3 статьи 11 Федерального закона «О противодействии терроризму». 
совокупность мероприятий временного характера; с другой стороны, как специальные правовые меры, которые принимаются в чрезвычайных обстоятельствах ${ }^{1}$.

Для исключительных (особых) правовых режимов характерны следующие признаки:

особый порядок введения в действие;

формирование особой системы государственного управления;

издание специальных нормативных правовых актов;

возникновение особых правоотношений.

Правом введения режимов ЧП и ВП обладает только Президент РФ с утверждением соответствующего указа в Совете Федерации и с уведомлением сопредельных государств и международных организаций (ООН и Совета Европы).

Главным организационно-правовым элементом исключительных режимов является система управления. Как отмечают исследователи, в условиях ЧП «выделяют несколько организационных форм создания такой системы:

1) существующие органы исполнительной власти сохраняются, но ставятся в прямое подчинение Президенту;

2) существующие органы исполнительной власти сохраняются, но ставятся в прямое подчинение органу, назначенному Президентом;

3) для координации работ по ликвидации обстоятельств, вызвавших введение ЧП, создаются специальные временные органы;

4) при ненадлежащем осуществлении своих функций органами власти и управления образуются специальные временные органы» ${ }^{2}$.

Режим ВП обеспечивается органами государственной власти и

\footnotetext{
${ }^{1}$ Рушайло В.Б. Административно-правовой режим особого положения: понятие и сущность // Современное право. 2004. № 1.

2 Алешин B.B. Правовые основы применения режима чрезвычайного положения и режима контртеррористической операции // Современное право. 2006. № 4.
} 
органами военного управления. При введении ВП указом Президента РФ могут определяться федеральные органы исполнительной власти, которыми он руководит по вопросам обеспечения обороны и безопасности государства, режима ВП. Решением Президента в условиях ВП могут перераспределяться полномочия федеральных органов исполнительной власти.

Органы особого управления территории, на которой введено ЧП, вправе издавать специальные нормативные правовые акты - приказы и распоряжения по вопросам обеспечения режима ЧП. Органы государственной власти и военного управления, обеспечивающие режим ВП, издают предписания и распоряжения.

Возникновение особых правоотношений в период действия исключительных (особых) правовых режимов связано с ограничением прав и свобод человека и гражданина, ужесточением всех видов юридической ответственности граждан и должностных лиц, изменением порядка функционирования и полномочий органов государственного управления.

Законодательство РФ четко разграничивает ЧП и ВП. Основания введения ЧП могут быть классифицированы на две группы:

а) обстоятельства политического характера: попытки насильственного изменения конституционного строя РФ, захвата или присвоения власти, вооруженный мятеж, массовые беспорядки, террористические акты, блокирование или захват особо важных объектов или отдельных местностей, подготовка и деятельность незаконных вооруженных формирований, межнациональные, межконфессиональные и региональные конфликты, сопровождающиеся насильственными действиями, создающие непосредственную угрозу жизни и безопасности граждан, нормальной деятельности органов государственной власти и органов местного самоуправления;

б) обстоятельства природного и техногенного характера: чрезвычайные ситуации природного и техногенного характера, 
чрезвычайные экологические ситуации, в том числе эпидемии и эпизоотии, возникшие в результате аварий, опасных природных явлений, катастроф, стихийных и иных бедствий, повлекшие (могущие повлечь) человеческие жертвы, нанесение ущерба здоровью людей и окружающей природной среде, значительные материальные потери и нарушение условий жизнедеятельности населения и требующие проведения масштабных аварийно-спасательных и других неотложных работ.

Основанием для введения ВП является агрессия или непосредственная угроза агрессии против РФ.

Содержание режимов ЧП и ВП определяется перечнем и характером применяемых чрезвычайных мер и режимных ограничений. Суверенные государства вправе самостоятельно решать, какие чрезвычайные меры, адекватные сложившейся ситуации, необходимо предпринять в условиях ЧП или ВП для ЗГС. Вместе с тем применяемые меры должны соответствовать международным обязательствам и не вызывать какую-либо дискриминацию отдельных лиц и групп населения.

Режимные меры, главным образом, связаны с ограничениями свободы слова и передвижения, массовых мероприятий, финансово-экономической и трудовой деятельности, дополнительными основаниями для проверки документов, личного досмотра, досмотра вещей и транспортных средств, расширением оснований для проникновения в жилые помещения, усилением охраны важных государственных объектов и т. д. Указанные ограничения предоставляют дополнительные полномочия органам, обеспечивающим исключительные (особые) правовые режимы, что позволяет им эффективнее использовать свои силы и средства, а также возможности других государственных органов и негосударственных организаций в интересах ЗГС $\mathrm{C}^{1}$.

1 Обеспечение режима ЧП осуществляется органами внутренних дел, уголовноисполнительной системы, органами безопасности, войсками национальной гвардии, а 
На территории, где введено ВП, применяется перечень более «острых» чрезвычайных мер (запрет или ограничение выезда граждан за пределы территории государства, введение цензуры, дополнительные меры по усилению режима секретности, прекращение деятельности иностранных и международных организаций, направленных на подрыв обороны и безопасности государства), отдельные из которых могут применяться только в случае агрессии (интернирование иностранных граждан).

На территории, где введен исключительный правовой режим, референдумы и выборы в органы государственной власти и органы местного самоуправления не проводятся. Вместе с тем законодатель предусмотрел ряд конституционных гарантий недопущения узурпации власти и незаконного осуществления властных полномочий. Так, в период действия ЧП и ВП не допускается изменение Конституции РФ и выборного законодательства. При введении исключительных правовых режимов на всей территории России не может быть распущена Государственная Дума. Данные конституционноправовые положения направлены на предупреждение возможных попыток насильственного захвата или удержания государственной власти, насильственного изменения конституционного строя.

Oсобое место в системе ЗГС занимает правовой режим контртеррористической операции (КТО). В соответствии со статьей 11 Федерального закона от 6 марта 2006 г. № 35-Ф3 «О противодействии терроризму» он вводится в целях пресечения и раскрытия террористического акта; минимизации его последствий; защиты жизненно важных интересов личности, общества и государства.

Режим КТО вводится Директором ФСБ России либо по его указанию другими должностными лицами ФСБ России (руководителями

также органами ГО и ЧС. Для обеспечения режима ВП используются органы государственной власти и органы военного управления. По решению Президента к обеспечению исключительных правовых режимов могут дополнительно привлекаться Вооруженные Силы, другие войска и воинские формирования. 
территориальных органов безопасности).

На территории (объектах), в пределах которой (на которых) введен правовой режим КТО, допускается применение следующих мер и временных ограничений:

- проверка документов, удостоверяющих личность;

- удаление физических лиц, а также отбуксировка транспортных средств с отдельных участков местности и объектов;

- ограничение движения транспортных средств и пешеходов на улицах, дорогах, отдельных участках местности и объектах;

- досмотр физических лиц, вещей и транспортных средств при проходе (проезде) на территорию, где введен режим КТО, и при выходе (выезде) с указанной территории;

- усиление охраны общественного порядка и объектов;

- контроль телефонных переговоров и иной информации, передаваемой по каналам телекоммуникационных систем, поиск на каналах электрической связи в почтовых отправлениях в целях выявления информации об обстоятельствах совершения террористического акта, о лицах, его подготовивших и совершивших, и в целях предупреждения других террористических актов;

- приостановление оказания услуг связи юридическим и физическим лицам или ограничение использования сетей и средств связи;

- приостановление деятельности опасных производств и организаций, в которых используются взрывчатые, радиоактивные, химически и биологически опасные вещества и др. меры.

На отдельных участках территории (объектах), в пределах которой (на которых) введен режим КТО, может устанавливаться как весь комплекс мер и временных ограничений, так и отдельные из них.

Обеспечение режима КТО осуществляется силами и средствами 
органов безопасности, а также создаваемой группировки сил и средств ${ }^{1}$.

Правовой режим КТО в системе ЗГС является эффективным инструментом борьбы с незаконными вооруженными формированиями, вооруженным мятежом, террористической деятельностью.

Элементы комплексного режима ЗГС тесно взаимосвязаны ${ }^{2}$. Так, в условиях введения режима ЧП въезд иностранных граждан на соответствующую территорию осуществляется по специальному разрешению, а Президентом РФ может быть изменен порядок допуска должностных лиц и граждан к государственной тайне. В свою очередь, правовой режим защиты государственной тайны определяет ограничения на выезд секретоносителей за границу и является основанием для установления особого режима безопасного функционирования организаций и объектов в 3ATO.

Завершая рассмотрение общегосударственной системы конституционно-правовой защиты государственного суверенитета, отметим, что, несмотря на применение различных методов и правовых средств регулирования общественных отношений базовым стержнем, важнейшим элементом содержания правового режима ЗГС в любом государстве, независимо от формы правления, государственного устройства и политического режима, выступают режимные меры.

В зависимости от целей использования и специфики возникающих при этом правоотношений, субъекты конституционно-правовой защиты государственного суверенитета применяют в своей деятельности комплекс различных мер:

- пресекательные меры, направленные на принудительное прекращение

${ }^{1}$ В состав группировки сил и средств могут включаться подразделения, части и соединения Вооруженных Сил, подразделения ФСБ России, МВД России, Федеральной службы войск национальной гвардии, Минюста России, МЧС России и других органов исполнительной власти.

2 Приложение 6. 
противоправных действий (бездействия), создающих угрозу государственному суверенитету;

- меры по локализации и устранению возникших и существующих угроз государственному суверенитету;

- меры юридической ответственности, направленные на привлечение правонарушителей к ответственности за совершение действий (бездействия), создающих угрозу государственному суверенитету.

В ряде случаев зарубежные или внутригосударственные деструктивные силы (международные организации, иностранные государства или оппозиционные движения) предпринимают попытки ограничить юрисдикцию государства или ущемить его монополию на легитимное применение режимных и принудительных мер при наличии законных оснований (в частности, для противодействия насильственному сепаратизму, террористическим или экстремистским проявлениям $)^{1}$. При согласии политических лидеров на подобное ограничение государственных прерогатив санкционированное ими лимитирование государственновластных полномочий по использованию законных правовых мер и средств ЗГС является одним из показателей ослабления или подрыва государственного суверенитета.

Конституционно-правовая защита государственного суверенитета базируется на гибком применении всего арсенала правовых мер, средств и методов, на четком функционировании правовых режимов, которые составляют основу полновластия и независимости государства, реальности и прочности его государственного суверенитета.

\footnotetext{
${ }^{1}$ Подобная ситуация была характерна для «евромайдана» в Украине.
} 


\section{2. Конституционно-правовая защита государственного} суверенитета Российской Федерации в социально-экономической сфере

Организация и функционирование правового режима ЗГС методологически могут быть рассмотрены с помощью консолидации однородных общественных отношений, направленных на обеспечение верховенства и независимости государственной власти, беспрепятственную реализацию государственно-властных полномочий, противодействие деструктивной деятельности антигосударственных сил по ослаблению и подрыву государственного суверенитета, в рамках трех основных сфер:

- социально-экономической;

- политической;

- идеологической.

Конституционно-правовое регулирование ЗГС в социальноэкономической сфере имеет принципиальное значение для функционирования и развития любого государства.

Во-первых, социально-экономическая сфера определяет потенциал реализации государственных функций во всех без исключения сферах общественной жизни. Состояние экономики и социальной системы непосредственно влияет на характер и перспективы развития государства и общественных институтов.

Во-вторых, никакая ЗГС невозможна без поддержки населения, готового защищать действующую государственную власть. Эта поддержка во многом базируется на удовлетворенности граждан реализацией своих социально-экономических прав и социальной защищенности.

В-третьих, полноценная ЗГС базируется на законодательно гарантированной материально-технической основе и необходимых ресурсах.

Целью ЗГС в социально-экономической сфере выступает развитие экономики, при котором создаются условия для высокого качества жизни населения, повышения благосостояния граждан, социально-экономической 
стабильности общества, сохранения территориальной целостности и обороноспособности государства, успешного противостояния внутренних и внешних угроз государственному суверенитету.

Применительно к ЗГС в совокупности рассматривается именно социально-экономическая сфера, поскольку социально-экономические интересы и связанные с ними права человека и гражданина имеют фундаментальное значение для населения любого государства. Органичная взаимосвязь социальной и экономической составляющих выражается не только в конституционно-правовом регулировании и защите социальноэкономических прав граждан РФ, но и в выделении самостоятельного направления развития страны, государственной политики, а также уполномоченных органов по ее реализации ${ }^{1}$. Кроме того, социальные секторы экономики обеспечиваются всей совокупностью государственных ресурсов в сфере производства, распределения, обмена и потребления. Для того, чтобы искусственно не разделять социальное и экономическое целеполагание в структуре конституционно-правового регулирования ЗГС, автор будет в комплексе рассматривать социально-экономическую сферу.

Законодательная основа ЗГС РФ в социально-экономической сфере представлена:

- Конституцией РФ (статьями 4, 7, 8, 9, 11, 15, 34-43, 45-52, 55-58, 67, $71-75,104,106,114,125,126,132)$;

- постановлениями Конституционного Суда РФ (от 17 декабря 1996 г. № 20-П, от 16 декабря 1997 г. № 20-П, от 9 января 1998 г. № 1-П, от 11 марта 1998 г. № 8-П, от 15 июля 1999 г. № 11-П, от 7 июня 2000 г. № 10-П, от 27

1 Федеральный закон от 28 июня 2014 г. № 172-Ф3 «О стратегическом планировании в Российской Федерации», Постановление Правительства РФ от 8 августа 2015 г. № 823 «Об утверждении Правил разработки, корректировки, осуществления мониторинга и контроля реализации стратегии социально-экономического развития Российской Федерации», Распоряжение Правительства РФ от 17 ноября 2008 г. № 1662-р «Об утверждении Концепции долгосрочного социально-экономического развития Российской Федерации на период до 2020 года», Прогноз долгосрочного социальноэкономического развития Российской Федерации на период до 2030 года и др. 
апреля 2001 г. № 7-П, от 1 апреля 2003 г. № 4-П, от 11 ноября 2003 г. № 16-П, от 17 июня 2004 г. № 12-П, от 15 декабря 2006 г. № 10-П, от 2 июня 2011 г. № 11-П, от 6 ноября 2013 г. № 23-П, от 14 января 2016 г. № 1-П и др.) ${ }^{1}$;

- федеральными конституционными законами (от 17 декабря 1997 г. (с изм. от 23 мая 2015 г.) № 2-ФКЗ «О Правительстве Российской Федерации», от 30 мая 2001 г. № 3-ФКЗ «О чрезвычайном положении», от 30 января 2002 г. № 1-ФКЗ «О военном положении» и др.));

- федеральными законами (данный блок представлен федеральными законами от 29 декабря 1994 г. № 79-Ф3 «О государственном материальном резерве», от 30 ноября 1995 г. (в ред. от 2 мая 2015 г.) № 187-ФЗ «О континентальном шельфе Российской Федерации», от 26 февраля 1997 г. № 31-Ф3 «О мобилизационной подготовке и мобилизации в Российской Федерации», от 19 июля 1998 г. № 114-Ф3 «О военно-техническом сотрудничестве Российской Федерации с иностранными государствами», от 31 июля 1998 г. (в ред. от 13 июля 2015 г.) № 155-ФЗ «О внутренних морских водах, территориальном море и прилежащей зоне Российской Федерации», от 17 декабря 1998 г. (в ред. от 14 октября 2014 г.) № 191-ФЗ «Об исключительной экономической зоне Российской Федерации», от 9 июля 1999 г. № 160-Ф3 «Об иностранных инвестициях в Российской Федерации», от 18 июля 1999 г. № 183-ФЗ «Об экспортном контроле», от 8 декабря 2003 г. № 164-Ф3 «Об основах государственного регулирования внешнеторговой деятельности», от 8 декабря 2003 г. № 165-Ф3 «О специальных защитных, антидемпинговых и компенсационных мерах при импорте товаров», от 10 декабря 2003 г. № 173-Ф3 «О валютном регулировании и валютном контроле», от 30 декабря 2006 г. № 281-Ф3 «О специальных экономических

1 Решения Конституционного Суда РФ рассматриваются в работе в качестве неотъемлемого элемента конституционно-правовой основы ЗГС, поскольку в отличие от обычных актов применения норм права, к которым относятся решения судов общей юрисдикции и арбитражных судов, решения органов конституционной юстиции являются не только интерпретационными актами правотворчества, но и источниками права особого рода. 
мерах», от 29 апреля 2008 г. № 57-Ф3 «О порядке осуществления иностранных инвестиций в хозяйственные общества, имеющие стратегическое значение для обеспечения обороны страны и безопасности государства», от 29 декабря 2012 г. № 275-Ф3 «О государственном оборонном заказе» и др.);

- законами РФ (от 21 февраля 1992 г. «О недрах», от 12 февраля 1993 г. № 4468-1 «О пенсионном обеспечении лиц, проходивших военную службу, службу в органах внутренних дел, государственной противопожарной службе, органах по контролю за оборотом наркотических средств и психотропных веществ, учреждениях и органах уголовно-исполнительной системы, и их семей» и др.);

- законами субъектов РФ в сфере здравоохранения, занятости населения, жилищной политике и др. (законодательство субъектов РФ принимается в установленной сфере полномочий региональных органов государственной власти. Разграничение предметов ведения и полномочий позволяет субъектам РФ решать вопросы эффективного использования трудовых ресурсов, развивать торговлю, сферу услуг, экономическую и социальную инфраструктуру, повышать качество предоставления образовательных, медицинских и культурных услуг. При этом сохраняется единое политическое, социально-экономическое и культурное пространство, обеспечивающее беспрепятственное перемещение товаров, трудовых ресурсов, оказание услуг, реализацию единых стандартов в области образования, здравоохранения и культуры);

- подзаконными правовыми актами (фрагмент подзаконного конституционно-правового регулирования включает указы Президента Российской Федерации от 29 апреля 1996 г. № 608 «О Государственной стратегии экономической безопасности Российской Федерации (Основных положениях)», от 15 марта 1999 г. № 350 «Об утверждении Положения о Службе специальных объектов при Президенте Российской Федерации», от 
10 сентября 2005 г. № 1062 «Об утверждении Положения о порядке осуществления военно-технического сотрудничества Российской Федерации с иностранными государствами», от 30 января 2010 г. № 120 «Об утверждении Доктрины продовольственной безопасности Российской Федерации», постановления Правительства Российской Федерации от 15 декабря 2007 г. № 877 «Об утверждении перечня товаров, являющихся существенно важными для внутреннего рынка Российской Федерации, в отношении которых в исключительных случаях могут быть установлены временные ограничения или запреты экспорта», от 15 апреля 2014 г. № 327 «Об утверждении государственной программы Российской Федерации «Управление федеральным имуществом», от 29 сентября 2015 г. № 1031 «Об утверждении Правил принятия решения о предоставлении права пользования участками недр, расположенными в Черном и Азовском морях, в пределах которых РФ осуществляет суверенитет, суверенные права или юрисдикцию в связи с принятием в Российскую Федерацию Республики Крым и образованием в составе Российской Федерации новых субъектов Республики Крым и г. Севастополя и др.).

Представленный нормативный комплекс конституционно-правовой защиты государственного суверенитета в социально-экономической сфере призван обеспечивать регулирование рыночной экономики, единство правового и экономического пространства РФ, соблюдение конституционных прав и рост благосостояния граждан, защиту экономических интересов государства внутри страны и за ее пределами, решение национально-значимых задач социально-экономического развития государства.

Концентрация государственных усилий по ЗГС в социальноэкономической сфере осуществляется в рамках следующих основных направлений:

- конституционно-правовое регулирование социально-экономических 
прав граждан в контексте ЗГС;

- конституционно-правовое регулирование экономической свободы (рыночной экономики) в государстве;

- конституционно-правовое обеспечение экономической основы государственного суверенитета;

- конституционно-правовое регулирование обеспечения продовольственной безопасности;

- конституционно-правовое регулирование мобилизационной подготовки, мобилизации и государственного оборонного заказа;

- конституционно-правовое регулирование военно-технического сотрудничества с иностранными государствами;

- конституционно-правовое регулирование российских и иностранных инвестиций в контексте ЗГС;

- конституционно-правовое регулирование аудиторской деятельности и государственного (муниципального) финансового контроля в контексте ЗГС;

- конституционно-правовое регулирование применения специальных экономических, специальных защитных, антидемпинговых и компенсационных мер в интересах ЗГС.

Конституционно-правовое регулирование сочиально-экономических прав граждан в контексте ЗГС охватывает несколько фрагментов:

- конституционно-правовое регулирование программ поддержки занятости населения и сокращения бедности;

- конституционно-правовая защита семьи, материнства, отцовства и детства;

- конституционно-правовое регулирование пенсионного и социального обеспечения пожилых и нетрудоспособных граждан;

- конституционно-правовое регулирование охраны здоровья и оказания 
медицинской помощи населению ${ }^{1}$.

Конституционно-правовое регулирование социально-экономических прав граждан базируется на принципе социального государства, который закреплен в ст. 7 Конституции РФ. Социальное государство является одной из основ конституционного строя России и предполагает проведение политики, направленной на создание условий, обеспечивающих достойную жизнь и свободное развитие человека. Как отмечается в юридической литературе, «главная задача социальной политики - обеспечить каждого гражданина комплексом социальных благ, удовлетворяющих его необходимые биологические, материальные, социальные, духовные потребности» ${ }^{2}$.

Конституционно-правовое содержание социального государства заключается в том, что оно стремится к «социальной справедливости» определенному выравниванию социального статуса людей за счет перераспределения государственных доходов, сокращения уровня бедности и имущественной дифференциации населения, создания адекватной социальной инфраструктуры. При этом имманентная проблема развития социально-экономической сферы состоит в поиске оптимального баланса между эффективным выполнением государством своей социальной функции, обеспечивающим достойный уровень жизни граждан, качественное удовлетворение основных социальных потребностей, и снижением социального бремени государства в условиях нестабильной экономической ситуации. Нахождение некоего компромиссного решения, отвечающего и

1 Конституционное право на образование относится к категории социальноэкономических прав. Вместе с тем с учетом ключевого значения образовательной политики для патриотического воспитания, формирования ценностей, гражданской и национальной идентичности, приобщения населения к культуре конституционно-правовое регулирование образования рассмотрено автором в параграфе 3.4 «Конституционноправовая защита государственного суверенитета РФ в идеологической сфере».

2 Чиркин B.E. О некоторых правовых критериях социального государства / Россия как социальное государство: конституционная модель и реальность. М., 2007. С. 64-65; Хабриева Т.Я. Российская конституционная модель социального государства / Конституция, закон и социальная сфера общества: материалы науч - практ. конф. М., 2009. C. 6-9. 
публичным интересам государства (сокращение финансовых расходов), и частной заинтересованности граждан (получение качественных услуг в полном объеме, гарантированном Конституцией), усложняется не только зачастую антагонистической направленностью этих интересов, но и трудностями, связанными с неготовностью общества к кардинальным преобразованиям в данной сфере ${ }^{1}$.

Конституционная характеристика социального государства складывается из совокупности положений:

1) целевая ориентация государственной социальной политики направлена на обеспечение достойной жизни и свободного развития человека. Содержание понятия «достойная жизнь» вытекает из статьи 25 Всеобщей декларации прав человека и означает такой жизненный уровень, включая пищу, одежду, медицинский уход и необходимое социальное обслуживание, который необходим для поддержания здоровья человека и его семьи. Под свободным развитием человека понимается основанная на всеобщем равенстве возможность своими силами занять определенное место в обществе: получить образование, профессию, иметь возможность получать достойный заработок, соответствующий выполняемой работе, возможность содержать семью, вести культурную жизнь и другие аспекты. Другими словами, конституционно-правовое регулирование социально-экономических прав граждан в социальном государстве ориентировано на обеспечение достойного уровня и качества жизни населения, свободного развития граждан, показателями которого является валовой внутренний продукт на душу населения, уровень безработицы и дифференциации доходов, обеспеченность материальными благами и услугами, состояние окружающей среды и др.

2) основные направления государственной социальной политики

1 Волкова Н.С. Государственное управление социальной сферой: состояние и модернизация // Журнал российского права. 2013. № 7. 
охватывают:

- охрану труда и здоровья людей;

- установление гарантированного минимального размера оплаты труда;

- обеспечение государственной поддержки семьи, материнства, отцовства и детства, инвалидов и пожилых граждан;

- развитие системы социальных служб;

- установление государственных пенсий, пособий;

- иные гарантии социальной защиты;

Как отмечают Е.И. Козлова и О.Е. Кутафин, система государственных гарантий социально-экономических прав человека и гражданина предполагает:

законодательное закрепление таких условий экономической деятельности, при которых человек реально обладает всеми конституционно признанными правами и свободами;

создание правовых, политических, материальных, организационных условий для реализации личной инициативы человека в экономической cфepe;

осуществление контроля за соблюдением законодательства, обеспечивающего социально-экономические права и свободы;

эффективную защиту социально-экономических прав и свобод человека в предусмотренных законом формах, в том числу судебную защиту ${ }^{1}$.

3) реализация государственной социальной политики зависит от финансово-экономических и ресурсных возможностей государства. Государство, находящееся в нестабильной экономической и политической обстановке, не может обеспечить и гарантировать принцип социальной государственности.

\footnotetext{
${ }^{1}$ Козлова Е.И., Кутафин О.Е. Конституционное право России. М.: Юристъ, 2001.
} 
Закрепление в Конституции принципа социального государства является перспективной программной установкой, к достижению которой должно стремиться наше государство.

В контексте ЗГС важнейшую роль играет конституциионно-правовое регулирование программ поддержки занятости населения и сокрашіения бедности.

Состояние рынка труда выступает ключевым внутренним фактором экономического суверенитета государства. Автор разделяет мнение Л.И. Алонкиной о том, что «неэффективная занятость трудоспособного населения негативно сказывается на экономических процессах и усиливает демографический кризис» ${ }^{1}$. Существующий в Российской Федерации низкий уровень рождаемости (вследствие малых доходов семей, отсутствия нормальных жилищных условий, тяжелых условий труда значительной части работающих женщин, высокого числа абортов и др.) недостаточен для расширенного воспроизводства населения, что ведет к демографическому старению. Приток трудовых мигрантов, особенно с низким уровнем квалификации, усиливает рыночную конкуренцию и сдерживает рост заработной платы работников из числа коренного населения, а растущая численность нелегальных мигрантов (их семей) увеличивает нагрузку на социальную инфраструктуру.

В соответствии с Концепцией долгосрочного социальноэкономического развития Российской Федерации на период до 2020 года, утвержденной распоряжением Правительства РФ от 17 ноября 2008 г. № 1662-р, целью современной государственной политики в области рынка труда является «создание правовых, экономических и институциональных условий, обеспечивающих развитие гибкого эффективно функционирующего

1 Алонкина Л.И. Государственное регулирование рынка труда в контексте обеспечения экономической безопасности России. Автореф. дис. ...д-ра экон. наук. М.: Академия управления МВД России, 2008. 
рынка труда, позволяющего преодолеть структурное несоответствие спроса и предложения на рабочую силу, сократить долю нелегальной занятости, повысить мотивацию к труду и трудовую мобильность». Достижение этой цели предполагается осуществить посредством решения следующих задач:

1. Повышение гибкости рынка труда и стимулирование сокращения нелегальной занятости.

2. Улучшение качества рабочей силы и развитие ее профессиональной мобильности на основе реформирования системы профессионального образования, системы профессиональной подготовки и переподготовки кадров с учетом государственных приоритетов развития экономики.

3. Развитие институтов рынка труда, рост занятости и эффективности использования труда.

4. Создание условий труда, позволяющих сохранить трудоспособность работающего населения на всем протяжении профессиональной карьеры.

5. Создание условий для привлечения квалифицированной иностранной рабочей силы с учетом перспективных потребностей экономики в трудовых ресурсах и на основе принципа приоритетного использования национальных кадров.

Эффективным механизмом регулирования рынка труда является государственная поддержка малого бизнеса с помощью грамотной налоговой политики, работающих механизмов реструктуризации задолженностей, льготных кредитов.

Улучшение социального климата в обществе невозможно без снижения бедности и уменьшения дифференциации населения по уровню доходов.

В Концепции долгосрочного социально-экономического развития Российской Федерации на период до 2020 года запланирован комплекс мероприятий по борьбе с бедностью и улучшению благосостояния населения. Разработанные Правительством меры направлены на: 
повышение минимального размера оплаты труда и оплаты труда работников бюджетных организаций, что позволит снизить бедность среди работающего населения;

повышение среднего размера трудовой пенсии по старости до уровня, обеспечивающего минимальный потребительский бюджет;

повышение эффективности социальной поддержки отдельных групп населения, в том числе путем усиления адресности региональных программ государственной социальной помощи, совершенствования процедур проверки нуждаемости граждан, внедрения современных социальных технологий оказания помощи, в том числе системы социальных контрактов;

повышение ориентации налоговой системы на проблемы выравнивания уровня доходов путем расширения использования налоговых вычетов, введения налога на недвижимость, зависящего от ее рыночной стоимости, что позволит более справедливо распределять нагрузку между группами населения с разным уровнем доходов ${ }^{1}$.

Одним из приоритетных направлений долгосрочной политики социальной поддержки населения является конституцуионно-правовое регулирование защуить семьи, материнства, отщуовства и детства.

В статье 38 Конституции закреплена норма о государственной защите семьи, материнства и детства.

Реализация данного конституционного положения охватывает:

- развитие системы предоставления пособий в связи с рождением и воспитанием детей;

- усиление дополнительных мер государственной поддержки семей, имеющих детей (включая расширение образовательных услуг для детей и масштабов строительства доступного жилья для семей с детьми);

${ }^{1}$ Следует констатировать, что разработчики Концепции оставили без внимания такой важнейший инструмент выравнивания уровня доходов, как введение прогрессивной шкалы налогообложения. 
- создание механизмов оказания дополнительной поддержки неполным семьям с детьми и многодетным семьям с низкими доходами, семьям, принимающим на воспитание детей, оставшихся без попечения родителей;

- развитие программ социального сопровождения и помощи семье в воспитании малолетних детей путем развития детских дошкольных учреждений, профилактики семейного неблагополучия;

- укрепление системы профилактики беспризорности и безнадзорности, консолидация действий федеральных, региональных и местных социальных институтов, направленных на решение этой проблемы;

- повышение эффективности и доступности сети социальных служб, деятельность которых связана с профилактикой семейного неблагополучия и предоставлением социальной и психологической поддержки детям из семей, находящихся в социально опасном положении, и дезадаптированным детям;

- совершенствование порядка и процедуры усыновления детей, приема детей в замещающие семьи ${ }^{1}$;

- создание системы реабилитации детей - инвалидов, обеспечивающей комплексное психолого-педагогическое и медико-социальное сопровождение индивидуального развития ребенка с ограниченными возможностями здоровья.

Принципиально важным для ЗГС является укрепление демографического потенциала и института семьи. Не случайно в Концепции демографической политики на период до 2025 года, утвержденной Указом Президента РФ от 9 октября 2007 г. № 1351, акцентируется внимание на сокращении материнской и младенческой смертности, а также повышении уровня рождаемости.

${ }^{1}$ В целях упорядочения процедуры усыновления российских детей и принятия ответных мер в отношении недружественных действий иностранных государств, иностранных организаций и должностных лиц иностранных государств в РФ был принят Федеральный закон от 28 декабря 2012 г. № 272-Ф3 «О мерах воздействия на лиц, причастных к нарушениям основополагающих прав и свобод человека, прав и свобод граждан Российской Федерации» (т.н. «Закон Димы Яковлева»). 
Решение задач по сокращению уровня материнской и младенческой смертности, укреплению репродуктивного здоровья населения, здоровья детей и подростков включает в себя:

повышение доступности и качества оказания бесплатной медицинской помощи женщинам в период беременности и родов, их новорожденным детям за счет развития семейно ориентированных перинатальных технологий, снижающих риск неблагоприятного исхода беременности и родов, укрепления материально-технического и кадрового обеспечения службы материнства и детства, развития высокотехнологичной медицинской помощи женщинам в период беременности и родов и новорожденным детям;

обеспечение доступности и повышение качества медицинской помощи по восстановлению репродуктивного здоровья, в том числе вспомогательных репродуктивных технологий, снижение доли рабочих мест с тяжелыми, вредными и опасными условиями труда;

проведение профилактических мероприятий в целях раннего выявления нарушений состояния здоровья детей и подростков, обеспечение доступности первичной медико-санитарной, специализированной медицинской помощи детям, совершенствование системы оказания реабилитационной помощи детям и подросткам, восстановительной медицины, усиление профилактической работы по предупреждению алкоголизма, наркомании, табакокурения, нежелательной беременности;

развитие системы оказания медицинской помощи детям и подросткам в образовательных организациях, организация качественного горячего питания в образовательных организациях, в том числе бесплатного питания для детей из малообеспеченных семей, обязательность занятий физической культурой во всех типах образовательных организаций.

Закрепленные в Концепции демографической политики пути решения задачи по повышению уровня рождаемости направлены на:

усиление государственной поддержки семей, имеющих детей, включая 
поддержку семьи в воспитании детей (пересмотр и индексация пособий в связи с рождением и воспитанием детей, предоставление материнского капитала, изменение размеров налоговых вычетов в зависимости от дохода семьи и количества детей);

создание условий для повышения доступности жилья для семей с детьми (развитие ипотечного кредитования, реализация региональных программ обеспечения жильем молодых семей, первоочередное предоставление жилья детям, оставшимся без попечения родителей, в семьях опекунов (попечителей), в приемных семьях);

реализацию комплекса мер по содействию занятости женщин, имеющих малолетних детей (в том числе организация дополнительного профессионального образования, частичная занятость и др.) $)^{1}$.

Материальные гарантии поддержки семьи, материнства, отцовства и детства предусмотрены в федеральном законодательстве и касаются различных пособий, денежных выплат по беременности, родам, воспитанию детей, многодетности, потере кормильца, материнского капитала, адресной помощи при оплате жилищно-коммунальных услуг в зависимости от состава и материального положения семьи и др. На федеральном и региональном уровнях создана специализированная система защиты прав детей (институт уполномоченных по правам ребенка) ${ }^{2}$.

Основополагающим направлением деятельности государства в социально-экономической сфере является конституцчионно-правовое регулирование пенсионного $u$ сочуильного обеспечения пожильх $u$ нетрудоспособных граждан.

Данные фрагменты государственной социальной политики нельзя рассматривать узко - только как выплату различных пособий

1 Указ Президента РФ от 9 октября 2007 г. № 1351 «Об утверждении Концепции демографической политики Российской Федерации на период до 2025 года».

2 Федеральный закон от 24 июля 1998 г. № 124-Ф3 «Об основных гарантиях прав ребенка в Российской Федерации», Указ Президента РФ от 1 сентября 2009 г. № 986 «Об Уполномоченном при Президенте Российской Федерации по правам ребенка». 
компенсирующего и стимулирующего характера установленным категориям граждан. Сюда относится весь комплекс социально-бытовых, социальномедицинских, психолого-педагогических, социально-правовых и др. услуг, а также государственная социальная помощь (социальные пособия, субсидии, доплаты и др. $)^{1}$.

Центральным институтом системы социального обеспечения является пенсионное обеспечение. Пенсионные расходы составляют существенную часть социальных расходов государства. Пенсионное обеспечение должно поддерживать материальную обеспеченность и удовлетворять основные жизненные потребности граждан. Качество пенсионного обеспечения непосредственно влияет на продолжительность жизни пожилых граждан. От состояния пенсионного обеспечения зависит уровень социальной напряженности в обществе и отношение населения к органам государственной власти.

Блок конституцчионно-правового регулирования пенсионного обеспечения представлен федеральными законами от 7 мая 1998 г. № 75-Ф3 «О негосударственных пенсионных фондах», от 15 декабря 2001 г. № 166-Ф3 «О государственном пенсионном обеспечении в Российской Федерации», от 15 декабря 2001 г. № 167-Ф3 «Об обязательном пенсионном страховании в Российской Федерации», от 17 декабря 2001 г. № 173-Ф3 «О трудовых пенсиях в Российской Федерации», от 28 декабря 2013 г. № 400-Ф3 «О страховых пенсиях» и др.

Базовым законом для большинства пенсионеров в РФ является Федеральный закон «О государственном пенсионном обеспечении в Российской Федерации». Этот закон определяет категории граждан, имеющих право на пенсию по государственному пенсионному обеспечению,

${ }^{1}$ См. федеральные законы от 12 января 1995 г. № 5-Ф3 «О ветеранах», от 24 ноября 1995 г. № 181-Ф3 «О социальной защите инвалидов в Российской Федерации», от 16 июля 1999 г. № 165-Ф3 «Об основах обязательного социального страхования», от 17 июля 1999 г. № 178-Ф3 «О государственной социальной помощи», от 28 декабря 2013 г. № 442-Ф3 «Об основах социального обслуживания граждан в Российской Федерации». 
и несколько видов пенсий ${ }^{1}$.

Одной из особенностей Федерального закона «О государственном пенсионном обеспечении в Российской Федерации» является распространение его юридической силы и государственной защиты на иностранных граждан, проходивших военную службу в Вооруженных Силах, других войсках, воинских формированиях и органах, и членов их семей. Кроме того, в соответствии с законом и договорами РФ о социальном обеспечении с другими государствами регулируются вопросы пенсионного обеспечения российских граждан и членов их семей, выехавших на постоянное жительство за границу.

В Федеральных законах «Об обязательном пенсионном страховании в Российской Федерации» и «О страховых пенсиях» учтена социальная значимость трудовой и иной общественно-полезной деятельности граждан для их пенсионного обеспечения.

Как указано в Постановлении Конституционного Суда РФ от 14 января 2016 г. № 1-П, «исходя из социальной ценности в правовом государстве трудовой и иной общественно полезной деятельности, осуществляемой в различных организационных формах, федеральный законодатель отнес к основаниям пенсионного обеспечения прохождение военной и (или) приравненной к ней службы установленной законом продолжительности и, учитывая особую значимость военной службы и службы в органах внутренних дел, непосредственно связанной с обеспечением обороны страны и безопасности государства, общественного порядка, законности, прав и свобод граждан и осуществляемой в публичных интересах, предусмотрел специальные правила пенсионного обеспечения соответствующих категорий государственных служащих, включая виды пенсий, их размеры, условия

${ }^{1}$ В законе предусмотрены следующие виды пенсий: пенсия за выслугу лет, пенсия по старости, пенсия по инвалидности, пенсия по случаю потери кормильца, социальная пенсия. 
назначения и выплаты».

Из правовых позиций Конституционного Суда РФ, сформулированных в постановлениях от 2 июня 2011 г. № 11-П и от 6 ноября 2013 г. № 23-П, следует, что общий порядок выплаты пенсий, предусмотренный Законом РФ «О пенсионном обеспечении лиц, проходивших военную службу, службу в органах внутренних дел, государственной противопожарной службе, органах по контролю за оборотом наркотических средств и психотропных веществ, учреждениях и органах уголовно-исполнительной системы, и их семей», «основан на принципе ведомственной ответственности за организацию пенсионного обеспечения лиц, на которых распространяется его действие, в зависимости от последнего места их службы, а также обязательности своевременного и полного перечисления необходимых для этого денежных средств, что требует установления контролируемого государством механизма расходования бюджетных средств, учитывающего специфику регулирования пенсионного обеспечения соответствующих категорий граждан».

Другие аспекты признания государством социальной значимости трудовой деятельности граждан связаны с возможностью досрочного назначения пенсии и установления ее повышенного размера. Так, страховая пенсия по старости назначается досрочно, если гражданин работал на производствах с вредными или тяжелыми условиями труда, выполнял работы с повышенной интенсивностью, являлся работником плавательного или летного состава, пожарной охраны, аварийно-спасательных формирований. Списки соответствующих работ, производств, профессий, должностей, специальностей и учреждений (организаций), с учетом которых назначается страховая пенсия, утверждаются Правительством РФ $\Phi^{1}$. Инвалидность и потеря кормильца вследствие военной травмы (наступившая вследствие

${ }^{1}$ Постановление Правительства РФ от 16 июля 2014 г. № 665 «О списках работ, производств, профессий, должностей, специальностей и учреждений (организаций), с учетом которых досрочно назначается страховая пенсия по старости, и правилах исчисления периодов работы (деятельности), дающей право на досрочное пенсионное обеспечение». 
ранения, контузии, увечья или заболевания, полученных при защите Родины, в том числе в связи с пребыванием на фронте, прохождением военной службы на территориях других государств, где велись боевые действия, или при исполнении иных обязанностей военной службы) влекут установление повышенных размеров пенсии. Повышенное пенсионное обеспечение устанавливается участникам Великой Отечественной войны и гражданам, награжденным знаком «Жителю блокадного Ленинграда».

Острой проблемой российского рынка труда является расширение теневой сферы трудовых отношений и снижение уровня государственных социальных гарантий. В условиях отсутствия адекватного страхования от безработицы граждане зачастую соглашаются на временную занятость и неофициальные схемы оплаты труда. По экспертным оценкам, в неформальные трудовые отношения в той или иной мере вовлечено от 30 до 50\% работающего населения РФ. Следует отметить, что распространение неформальных трудовых отношений не только существенно сокращает финансовые поступления во внебюджетные фонды, но и лишает неформально занятых сотрудников социальных гарантий и денежных компенсаций в случае потери дохода.

Заметное место в структуре конституцчионно-правового регулирования сочиального обеспечения занимают нормативные правовые акты субъектов РФ ${ }^{1}$. Социальное обслуживание осуществляется на основе государственных

${ }^{1}$ См. Закон Алтайского края от 3 декабря 2004 г. № 61-3С «О мерах социальной поддержки отдельных категорий ветеранов», Закон Республики Башкортостан от 17 декабря 2004 г. № 130-3 «О социальной поддержке инвалидов в Республике Башкортостан», Закон Республики Ингушетия от 14 сентября 2007 г. № 31-Р3 «О мерах социальной поддержки детей-сирот и детей, оставшихся без попечения родителей», Закон Республики Ингушетия от 31 декабря 2004 г. № 40-Р3 «О мерах социальной поддержки малоимущих слоев населения», Закон Республики Крым от 17 декабря 2014 г. № 39ЗРК/2014 «О социальной поддержке многодетных семей в Республике Крым», Закон г. Севастополя от 26 декабря 2014 г. № 98-3С «О социальной поддержке многодетных семей в г. Севастополе», Закон г. Севастополя от 26 декабря 2014 г. № 95-ЗС «Об установлении доплат к пособиям по безработице отдельным категориям граждан, признанных в установленном порядке безработными и проживающих на территории города федерального значения Севастополя», Закон Рязанской области от 12 января 2007 г. № 11О3 «О дополнительных мерах социальной поддержки беременных женщин» и др. 
стандартов, которые устанавливаются в порядке, определяемом органами государственной власти субъектов РФ. Как справедливо отмечают исследователи, «следует отметить некоторую уязвимость такого порядка, связанную с неравномерностью социально-экономического уровня развития субъектов РФ и, соответственно, разбалансированностью подходов к социальному обслуживанию в разных субъектах РФ. Очевидно, что государственная политика в сфере защиты наиболее уязвимых категорий граждан, нетрудоспособного и малоимущего населения должна быть нацелена на выравнивание прослеживающихся региональных различий в финансировании данной сферы и развитии социальной инфраструктуры» 1 .

Провозглашенные в Конституции Российской Федерации цели политики Российской Федерации как социального государства предопределяют обязанность государства заботиться о благополучии своих граждан, их социальной защищенности, и если в силу возраста, состояния здоровья, по другим не зависящим от него причинам человек трудиться не может и не имеет дохода для обеспечения прожиточного минимума себе и своей семье, он вправе рассчитывать на получение соответствующей помощи, материальной поддержки со стороны государства и общества.

Социальное обеспечение осуществляется с помощью денежных выплат (пенсий, социальных пособий и др.), предоставления гражданам натуральных видов содержания, социальных услуг за счет обязательного социального страхования, бюджетных ассигнований и иных источников.

Согласно Федеральному закону от 28 декабря 2013 г. № 442-Ф3 «Об основах социального обслуживания граждан в Российской Федерации» социальные услуги предоставляются их получателям в форме социального

1 Волкова Н.С. Государственное управление социальной сферой: состояние и модернизация // Журнал российского права. 2013. № 7. В.Д. Зорькин справедливо выделяет тревожную тенденцию передачи части обязательств социальной защиты на уровень субъектов РФ. Дефицит региональных бюджетов ведет к приостановлению социальных выплат и ликвидации части льгот (например, ветеранам боевых действий, ветеранам войны и труда). См. Зорькин В.Д. Право против хаоса. М.: Редакция «Российской газеты», 2016. С. 65. 
обслуживания на дому, в полустационарной форме или в стационарной форме. Гражданам могут предоставляться следующие виды социальных услуг ${ }^{1}$ :

социально-бытовые (направлены на поддержание жизнедеятельности в быту);

социально-медицинские (направлены на поддержание и сохранение здоровья путем организации ухода, оказания содействия в проведении оздоровительных мероприятий, систематического наблюдения);

- социально-психологические (предусматривают оказание помощи в коррекции психологического состояния для адаптации в социальной среде);

- социально-педагогические (направлены на профилактику отклонений в поведении и развитии личности, организацию досуга, оказание помощи в воспитании детей);

- социально-трудовые (направлены на оказание помощи в трудоустройстве и трудовой адаптации);

- социально-правовые (помощь в получении юридических услуг);

- услуги в целях повышения коммуникативного потенциала;

- срочные социальные услуги.

Социальное обеспечение позволяет восстановить статус члена общества при наступлении юридически значимых социальных рисков (болезнь, инвалидность, возраст и др.).

Правовые и организационные основы оказания государством социальной помощи малоимущим семьям, малоимущим одиноко проживающим гражданам и иным категориям лиц (участники Великой Отечественной войны, инвалиды войны, дети-инвалиды и др.), установлены Федеральным законом от 17 июля 1999 г. (в ред. от 28 ноября 2015 г.) № 178Ф3 «О государственной социальной помощи». Государственная социальная

${ }^{1}$ Постановление Правительства РФ от 24 ноября 2014 г. № 1236 «Об утверждении Примерного перечня социальных услуг по видам социальных услуг». 
помощь включает предоставление малоимущим гражданам социальных пособий, социальных доплат и пенсий, субсидий, социальных услуг и жизненно необходимых товаров.

Государственная социальная помощь оказывается в целях: поддержания уровня жизни малоимущих граждан, среднедушевой доход

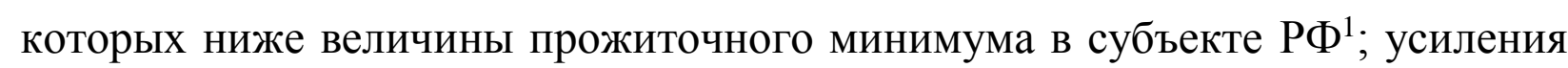
адресности социальной поддержки нуждающихся граждан; создания необходимых условий для обеспечения всеобщей доступности и общественно приемлемого качества социальных услуг; снижения уровня социального неравенства; повышения доходов населения.

Контроль за оказанием гражданам государственной социальной помощи производится Федеральной службой по труду и занятости Министерства труда и социальной защиты РФ, а также Федеральной службой по надзору в сфере здравоохранения Минздрава России.

В соответствии с Федеральным законом от 24 ноября 1995 г. (в ред. от 29 декабря 2015 г.) № 181-Ф3 «О социальной защите инвалидов в Российской Федерации» особая социальная защита государства распространяется на инвалидов.

Инвалиды и семьи с детьми-инвалидами, нуждающиеся в улучшении жилищных условий, обеспечиваются жильем. Им предоставляются меры социальной поддержке по оплате коммунальных услуг.

Инвалидам предоставляются гарантии трудовой занятости путем установления в организациях независимо от организационно-правовых форм и форм собственности квоты для приема на работу инвалидов и минимального количества специальных рабочих мест для инвалидов, резервирования рабочих мест по профессиям, подходящим для инвалидов, обучения инвалидов новым профессиям и др.

\footnotetext{
${ }^{1}$ Федеральный закон от 24 октября 1997 г. № 134-Ф3 «О прожиточном минимуме в Российской Федерации».
} 
Государство гарантирует инвалидам проведение реабилитационных мероприятий, получение технических средств и услуг, предусмотренных федеральным перечнем, за счет средств федерального бюджета. Оказание квалифицированной медицинской помощи инвалидам осуществляется в рамках программы государственных гарантий оказания гражданам РФ бесплатной медицинской помощи.

Реализация важнейших государственных функций, прогрессивное развитие общества невозможны без доступного и качественного здравоохранения, гарантий оказания гражданам квалифицированной медицинской помощи.

He случайно в системе конституционно-правовой защиты государственного суверенитета одно из видных мест занимает конституционно-правовое регулирование охрань здоровья и оказания медищиской помощи населению. Основополагающим актом в рассматриваемой сфере является Федеральный закон от 21 ноября 2011 г. № 323-Ф3 «Об основах охраны здоровья граждан в Российской Федерации». Организационно-правовые основы оказания гражданам медицинской помощи в рамках системы обязательного медицинского страхования определены Федеральным законом от 29 ноября 2010 г. № 326-Ф3 «Об обязательном медицинском страховании в Российской Федерации».

B разделе IV Стратегии национальной безопасности Российской Федерации закреплено, что «цели государственной политики в сфере охраны здоровья граждан заключаются в профилактике заболеваний, предотвращении роста заболеваний, представляющих опасность для окружающих, повышении доступности для населения медицинской помощи, повышении эффективности и качества медицинских услуг, снижении уровня инвалидности, разработке и внедрении новых медицинских технологий и 
лекарственных средств» ${ }^{1}$.

Государство обеспечивает гражданам охрану здоровья независимо от пола, расы, возраста, национальности, языка, наличия заболеваний, состояний, происхождения, имущественного и должностного положения, места жительства, отношения к религии, убеждений, принадлежности к общественным объединениям и других обстоятельств. Государство гарантирует гражданам защиту от любых форм дискриминации, обусловленной наличием у них каких-либо заболеваний.

Федеральным законом «Об основах охраны здоровья граждан в Российской Федерации» установлены приоритеты охраны здоровья детей и профилактических мер.

Дети независимо от их семейного и социального благополучия подлежат особой охране, включая заботу об их здоровье и надлежащую правовую защиту в сфере охраны здоровья, и имеют преимущественные права при оказании медицинской помощи.

Профилактическая система охраны здоровья населения, в первую очередь, включает пропаганду здорового образа жизни и повышение ответственности работодателя за здоровье своих работников ${ }^{2}$. Важным элементом охраны здоровья является разработка и реализация программ по профилактике алкоголизма, табакокурения и других факторов риска³

В целях укрепления здоровья населения, профилактики заболеваний, вызванных неполноценным и несбалансированным питанием в Российской Федерации, осуществляется государственная политика в области здорового питания населения.

1 Стратегия национальной безопасности Российской Федерации (утверждена Указом Президента РФ от 31 декабря 2015 г. № 683).

2 Декларированная в качестве одного из приоритетов государственной политики в сфере охраны здоровья профилактика заболеваний должна быть подкреплена законодательно - путем введения обязательного ежегодного диспансерного обследования всех работников.

3 Федеральный закон от 23 февраля 2013 г. № 15-Ф3 «Об охране здоровья граждан от воздействия окружающего табачного дыма и последствий потребления табака». 
Решению задачи укрепления здоровья населения в значительной степени способствует внедрение комплексных оздоровительных и реабилитационных программ после перенесенных заболеваний и травм.

Обязательным компонентом конституционно-правового регулирования охраны здоровья выступает обеспечение безопасной для жизнедеятельности человека окружающей среды и санитарно-эпидемиологического благополучия населения.

В последние годы государством сделаны существенные инвестиции в здравоохранение. Однако заметное отставание уровня развития российского здравоохранения от уровня ведущих стран Запада продолжает сохраняться.

Государственные расходы на здравоохранение на протяжении многих лет составляли около 3 \% ВВП. Согласно экспертным оценкам, в 2016 г. в связи с дефицитом бюджета государственные ассигнования на здравоохранение по сравнению с 2014 г. сократятся на 15\% в реальном выражении. Население все чаще будет вынуждено отказываться от медицинской помощи, прибегая к самолечению.

Основной целью государственной политики в области здравоохранения на период до 2020 года является формирование системы, обеспечивающей доступность медицинской помощи и повышение эффективности медицинских услуг, объемы, виды и качество которых должны соответствовать уровню заболеваемости и потребностям населения, передовым достижениям медицинской науки ${ }^{1}$.

Реализация заявленных конституционных целей развития системы здравоохранения предполагает решение следующих основных задач.

\footnotetext{
Концепция долгосрочного социально-экономического развития Российской Федерации на период до 2020 года (утверждена распоряжением Правительства РФ от 17 ноября 2008 г. № 1662-р).
} 
1. Обеспечение государственных гарантий оказания гражданам бесплатной медицинской помощи в полном объеме ${ }^{1}$.

2. Модернизация системы обязательного медицинского страхования ${ }^{2}$.

3. Повышение эффективности системы организации медицинской помощи, в т.ч.:

- развитие системы оказания первичной медико-санитарной помощи и повышение роли профилактического лечения;

- совершенствование службы скорой медицинской и санитарноавиационной помощи;

- обеспечение преемственности в оказании медицинской помощи, включая реабилитационные методы и санитарно-курортное лечение;

- повышение доступности медицинской помощи в сельской местности;

- развитие системы медико-социальной помощи пожилому населению на дому;

- укрепление материально-технической базы медицинских организаций и др.

4. Улучшение лекарственного обеспечения граждан. Вопросы охраны здоровья, оказания медицинской помощи невозможно решать без активного развития современной российской медицинской и фармацевтической промышленности, обеспечения полного цикла производства на территории РФ стратегически необходимых лекарственных средств и медицинских

1 Эффективному решению этой задачи мог бы способствовать запрет оказания платных медицинских услуг в муниципальных учреждениях здравоохранения. В настоящее время коммерческая деятельность муниципальных медицинских учреждений приводит к навязыванию бюджетными учреждениями платных медицинских услуг гражданам, способствует коррупции среди медицинского персонала (происходит вымогательство денег под предлогом отсутствия бесплатных лекарств и медицинских изделий). Кроме того, происходит дифференциация оказания населению медицинской помощи в зависимости от уровня доходов граждан.

2 Речь идет о введении страховых взносов на обязательное медицинское страхование по единому тарифу для всех работодателей, установлении единых требований к размеру взносов субъектов РФ на обязательное медицинское страхование неработающего населения, формировании конкурентной модели обязательного медицинского страхования. 
изделий, государственного регулирования цен на лекарственные средства и медицинские изделия первой необходимости ${ }^{1}$.

5. Развитие медицинской науки и инноваций в сфере здравоохранения, повышение квалификации медицинских работников и создание системы повышения мотивации к качественному труду².

6. Информатизация системы здравоохранения.

Последовательное и комплексное решение перечисленных приоритетных задач в случае смены вектора оптимизации здравоохранения с экономии средств на развитие отрасли позволит увеличить продолжительность жизни населения, сократить уровень смертности, укрепить здоровье граждан и будет способствовать улучшению демографической ситуации в стране.

Самостоятельным фрагментом конституционно-правовой защиты государственного суверенитета в социально-экономической сфере выступает регулирование рыночных отношений. В качестве основы конституционного строя РФ закреплен принцип экономической свободы (рыночной экономики) в государстве. Важнейшие элементы конституциионно-правового регулирования экономической свободы сформулированы в статье 8 Конституции РФ:

1) единство экономического пространства и свободное перемещение товаров, услуг и финансовых средств. Это означает, что на территории РФ не

${ }^{1}$ В настоящее время, по оценкам специалистов, в России сохраняется критически высокий уровень зависимости от импорта медицинской техники. Так, в сегменте лучевой диагностики монополистами выступают Philips, Siemens, Toshiba и GE, в сегменте расходных материалов для ангиографии /коронографии доминируют Terumo, Abbott, Medtronic, Boston Scientific. Сервисное обслуживание медицинского оборудования также осуществляют зарубежные компании. См. Мазин П.В. Здравоохранение как структурный фактор суверенитета и «мягкой силы» / Проблема суверенности современной России. Материалы Всерос. научн. - общ. конф. М.: Центр научной политической мысли и идеологии, 2014. С. 345-350.

2 Предусмотренные статьей 100 Федерального закона «Об основах охраны здоровья граждан в Российской Федерации» сертификаты медицинских работников имеют крайне узкую специализацию по Номенклатуре специальностей и являются весьма дорогостоящими документами. Как представляется, существующая система сертификации вместо повышения качества оказания медицинских услуг на практике привела к появлению узких специалистов с ограниченным уровнем оказания медицинской помощи. 
допускается установление каких-либо границ или иных препятствий для свободного перемещения товаров, услуг и финансовых средств. В соответствии со статьей 74 Конституции РФ ограничения перемещения товаров и услуг могут вводиться в соответствии с федеральным законом, если это необходимо для обеспечения безопасности, защиты жизни и здоровья людей, охраны природы и культурных ценностей ${ }^{1}$.

Как отмечается в Постановлении Конституционного Суда РФ от 15 декабря 2006 г. № 10-П, «гарантиями единства экономического пространства (часть 1 статьи 8 Конституции) являются установление (в рамках предметов ведения Российской Федерации) правовых основ единого рынка, осуществление финансового и бюджетного регулирования, а также запрет на установление каких-либо препятствий для свободного перемещения товаров, услуг и финансовых средств. Данные конституционные начала, имеющие своим предназначением экономическое обеспечение государственного единства и государственной целостности Российской Федерации, предполагают осуществление такого законодательного регулирования экономических отношений, которое способствовало бы достижению указанной конституционной цели, не умаляя при этом финансовой самостоятельности субъектов Российской Федерации вне пределов ведения Российской Федерации и полномочий Российской Федерации по предметам совместного ведения Российской Федерации и субъектов Российской Федерации»;

2) поддержка и защита конкуренции, создание условий эффективного функционирования товарных рынков. Поддержка и защита конкуренции обеспечиваются предоставлением субъектам предпринимательской деятельности равных прав и возможностей в сфере гражданского оборота, а также ограничением монополистической деятельности и недобросовестной

1 Такие ограничения могут вводиться в случае, например, чрезвычайного экологического бедствия. 
конкуренции на рынке ${ }^{1}$. В соответствии с Федеральным законом от 26 июля 2006 г. № 135-Ф3 «О защите конкуренции» запрещаются действия субъектов, доминирующих на рынке (соглашения между субъектами, доминирующими на рынке), и действия со стороны органов государственной власти (в том числе принятие актов), которые ограничивают самостоятельность хозяйствующих субъектов, создают дискриминирующие или благоприятствующие условия деятельности отдельных хозяйствующих субъектов, если такие акты или действия имеют или могут иметь своим результатом ограничение конкуренции и (или) ущемление интересов других хозяйствующих субъектов или граждан;

3) свобода экономической деятельности означает преимущественное применение законодателем диспозитивного метода в регулировании хозяйственной деятельности предпринимателей. Государство, его органы не вправе произвольно вмешиваться в предпринимательскую деятельность, устанавливать какие-либо планы, директивы и т. п. Регулирование предпринимательской деятельности осуществляется двумя основными способами: во-первых, с помощью гражданского законодательства, закрепляющего юридические формы экономических отношений, и, вовторых, с помощью финансового законодательства, устанавливающего налоги на доходы от предпринимательской деятельности и иные объекты налогообложения;

4) многообразие и равная защита форм собственности. В Конституции РФ устанавливается равенство всех форм собственности, что означает их равный правовой режим и равное содержание права собственности независимо от ее формы. Не допускается установления каких-либо ограничений или благоприятствований для той или иной формы

${ }^{1} \mathrm{C} 1$ января 2015 г. на территориях государств - членов ЕАЭС действует Протокол об общих принципах и правилах конкуренции (приложение № 19 к Договору о Евразийском экономическом союзе (Астана, 29 мая 2014 г.)) 
собственности. Равная защита всех форм собственности выражается в их одинаковой защите нормами гражданского, уголовного, административного права.

Статья 9 Конституции особо выделяет землю и другие природные ресурсы как объекты права собственности. Устанавливается, что данные объекты могут находиться на праве собственности во всех ее формах. Вместе с тем норма части 1 статьи 9 подразумевает возможность ограничений правового режима собственности на землю и природные объекты: во-первых, земля и другие природные ресурсы используются и охраняются в РФ как основа жизни и деятельности народов, проживающих на соответствующей территории. Во-вторых, в соответствии со статьей 36 Конституции собственность на землю и другие природные ресурсы ограничена необходимостью воздерживаться от нанесения ущерба окружающей среде.

Стратегически важным элементом комплексного правового режима ЗГС является конституцฺионно-правовое обеспечение экономической основы государственного суверенитета. Данный нормативный комплекс включает в себя:

- установление правового режима использования природных и сырьевых ресурсов;

- установление правового режима использования воздушного пространства и космической деятельности под юрисдикцией РФ;

- конституционно-правовое регулирование суверенных прав и юрисдикции государства во внутренних морских водах, территориальном море, прилежащей зоне, в исключительной экономической зоне и на континентальном шельфе;

- конституционно-правовое регулирование налогообложения;

- конституционно-правовое регулирование национальной платежной системы;

- конституционно-правовое регулирование внешнеторговой 
деятельности;

- конституционно-правовое регулирование распоряжения и управления государственным имуществом РФ;

- конституционно-правовое регулирование юрисдикционных иммунитетов и имущества иностранного государства в РФ.

Базовым компонентом экономической основы государственного суверенитета выступает установление правового режима использования природных и cырьевых ресурсов. Конституционность правовых положений законодательства ряда субъектов РФ о том, что земля, недра, леса, растительный и животный мир, водные и другие природные ресурсы являются собственностью субъектов РФ, а вопросы владения, пользования и распоряжения землей, недрами и водами регулируются региональным законодательством, неоднократно являлась предметом оценки Конституционного Суда РФ.

В Постановлении от 9 января 1998 г. «О проверке конституционности Лесного кодекса Российской Федерации» указано, что лесной фонд ввиду его важной многофункциональной роли и значимости для общества в целом представляет собой публичное достояние многонационального народа России и как таковой является федеральной собственностью особого рода. Использование, охрана, защита и воспроизводство лесов должны осуществляться таким образом, чтобы была возможность обеспечить учет и согласование интересов РФ и ее субъектов.

Эта же правовая позиция была выражена в Постановлении Конституционного Суда от 7 июня 2000 г. № 10-П «По делу о проверке конституционности отдельных положений Конституции Республики Алтай и Федерального закона «Об общих принципах организации законодательных (представительных) и исполнительных органов государственной власти субъектов Российской Федерации» и Определении от 27 июня 2000 г. № 92-О «По запросу группы депутатов Государственной Думы о проверке 
соответствия Конституции Российской Федерации отдельных положений конституций Республики Адыгея, Республики Башкортостан, Республики Ингушетия, Республики Коми, Республики Северная Осетия - Алания и Республики Татарстан».

В Постановлении от 7 июня 2000 г. № 10-П Конституционный Суд подтвердил силу своего Постановления от 9 января 1998 г. по делу о проверке конституционности Лесного кодекса Российской Федерации и распространил положения о публичной значимости лесного фонда и его использовании в общегосударственных интересах на другие природные ресурсы $^{1}$.

Конституционный Суд пришел к выводу о том, что субъект РФ не вправе объявить своим достоянием (собственностью) природные ресурсы на своей территории и осуществлять такое регулирование отношений собственности на природные ресурсы, которое ограничивает их использование в интересах всех народов РФ, поскольку этим нарушается суверенитет РФ.

По мнению Конституционного Суда, положение части 1 статьи 16 Конституции Республики Алтай, согласно которому земля, недра, леса, растительный и животный мир, водные и другие природные ресурсы являются достоянием (собственностью) Республики Алтай, как допускающее признание за Республикой Алтай права собственности на все природные ресурсы, находящиеся на ее территории, ограничивает суверенитет РФ и нарушает установленное Конституцией РФ разграничение предметов ведения и полномочий между органами государственной власти РФ и органами государственной власти ее субъектов и потому не соответствует Конституции РФ, ее статьям 4 (части 1 и 2), 9, 15 (часть 1), 36, 72 (пункты

\footnotetext{
${ }^{1}$ Как отмечалось в Постановлении Конституционного Суда РФ от 7 июня 2000 г. № 10-П, сходные специальные правовые режимы установлены в отношении других природных ресурсов Законом РФ от 21 февраля 1992 г. «О недрах» и Федеральным законом от 24 апреля 1995 г. «О животном мире».
} 
«в», «г» части 1) и 76 (части 2 и 5). Вместе с тем с РФ и ее субъектов не снимается вытекающая из статьи 9 Конституции РФ во взаимосвязи с ее статьями 71 и 72 обязанность по охране и обеспечению использования земли и других природных ресурсов как основы жизни и деятельности народов, проживающих на соответствующих территориях.

В Определении от 27 июня 2000 г. № 92-О Конституционный Суд вновь рассмотрел правовые положения ряда республик (Адыгея, Башкортостан, Ингушетия, Коми, Северная Осетия - Алания и Татарстан), регулирующие отношения собственности на природные ресурсы, находящиеся на их территории. Судьи Конституционного Суда пришли к выводу о том, что в обращении группы депутатов Государственной Думы оспариваются нормативные положения, ранее уже признанные не соответствующими Конституции РФ, и своим решением подтвердил, что оспариваемые нормы не могут иметь юридической силы.

Значимым фрагментом правового режима использования природных и сырьевых ресурсов является конституционно-правовое регулирование отношений в области изучения, разведки, добычи, производства, использования и обращения драгоценных металлов и камней.

Вопросы владения, пользования и распоряжения участками недр, содержащими драгоценные металлы и драгоценные камни, находятся в совместном ведении РФ и субъектов РФ. Разграничение между РФ и субъектами РФ собственности на указанные объекты осуществляется в соответствии с Конституцией, Законом РФ «О недрах», Федеральным законом «О драгоценных металлах и драгоценных камнях».

РФ обладает суверенными правами и осуществляет юрисдикцию на участках недр континентального шельфа, содержащих драгоценные металлы и драгоценные камни.

Запасы драгоценных металлов и камней имеют важнейшее значение для ЗГС и обеспечения независимости государства. С учетом этого 
приоритетами государственной политики являются стимулирование добычи и производства драгоценных металлов и камней, а также их рациональное использование в интересах социально-экономического развития РФ и субъектов РФ. Конституционно-правовое регулирование изучения, разведки, добычи, производства, использования и обращения драгоценных металлов и камней осуществляется посредством:

лицензирования пользования участками недр, содержащими драгоценные металлы и драгоценные камни;

преимущественного права приобретения добываемых драгоценных металлов и драгоценных камней для Государственного фонда драгоценных металлов и драгоценных камней РФ, формирования золотого запаса РФ и государственных фондов драгоценных металлов и драгоценных камней субъектов РФ;

установления требований к учету, хранению, перевозке драгоценных металлов и драгоценных камней и отчетности о них, а также к порядку осуществления операций с драгоценными металлами и драгоценными камнями;

нормативно-правовой регламентации действий организаций и индивидуальных предпринимателей, осуществляющих операции с драгоценными камнями и драгоценными металлами на внутреннем и внешнем рынках; специального учета указанных организаций и индивидуальных предпринимателей;

государственного контроля (надзора) за геологическим изучением и разведкой месторождений драгоценных металлов и камней, добычей драгоценных металлов и камней (за исключением сортировки, первичной классификации и первичной оценки драгоценных камней), осуществляемого в соответствии с законодательством о недрах;

государственного контроля (надзора) за производством, использованием и обращением драгоценных металлов, а также за добычей (в 
части сортировки, первичной классификации и первичной оценки драгоценных камней), использованием и обращением драгоценных камней;

определения Президентом РФ особенностей порядка ввоза и вывоза из РФ в государства, не входящие в ЕАЭС, драгоценных металлов и драгоценных камней;

установления порядка сортировки, первичной классификации и первичной оценки драгоценных камней;

особого порядка таможенного контроля за ввозом в РФ и вывозом из РФ драгоценных металлов и драгоценных камней, а также изделий из них;

организации подтверждения соответствия драгоценных металлов, драгоценных камней и продукции из них;

установления перечня организаций, проводящих аффинаж драгоценных металлов.

В РФ установлена государственная монополия на опробование и клеймение государственным пробирным клеймом ювелирных и других изделий из драгоценных металлов, а также государственная монополия на регулирование экспорта необработанных алмазов.

В области геологического изучения и разведки месторождений драгоценных металлов и камней, их добычи функционирует государственная разрешительная система. Федеральным органом управления государственным фондом недр, его территориальными подразделениями совместно с органами исполнительной власти субъектов РФ осуществляется лицензирование пользования участками недр в целях разведки месторождений драгоценных металлов и драгоценных камней, а также добычи драгоценных металлов и камней. Лицензирование операций банков и иных кредитных организаций с драгоценными металлами и драгоценными камнями возложено на Центральный банк РФ.

Лицензионная деятельность в данной сфере дополняется государственным контролем (надзором) за производством, использованием и 
обращением драгоценных металлов, а также за добычей (в части сортировки, первичной классификации и первичной оценки драгоценных камней), использованием и обращением драгоценных камней. В Федеральном законе закреплены два вида государственного контроля (надзора):

1) федеральный государственный пробирный надзор (осуществляется путем проверок юридических лиц и индивидуальных предпринимателей, а также принятия мер по устранению выявленных нарушений);

2) государственный контроль при ввозе в РФ из государств, не входящих в ЕАЭС, и вывозе из РФ в государства, не входящие в ЕАЭС, драгоценных металлов, камней и сырьевых товаров, содержащих драгоценные металлы.

Специфическим объектом конституционно-правового регулирования в контексте ЗГС являются золотовалютные резервы, относящиеся к казне РФ. Золотовалютные резервы РФ состоят из двух частей:

1) Государственный фонд драгоценных металлов и драгоценных камней, находящийся в управлении Министерства финансов РФ;

2) золотовалютный резерв Банка России.

Двухэлементная система управления предопределяет и специфическое правовое регулирование золотовалютных резервов: нормативное регулирование Минфина России (в отношении Государственного фонда драгоценных металлов и драгоценных камней) и нормативное регулирование Центрального банка (в отношении резервов Банка России) ${ }^{1}$.

Государственный фонд драгоценных металлов и камней РФ включает в себя совокупность драгоценных металлов (золота, серебра, платины и металлов платиновой группы), драгоценных камней (природных алмазов, изумрудов, рубинов, сапфиров и александритов, природного жемчуга в

1 Поветкина Н.A. Проблемы правовой квалификации золотовалютных резервов (запасов) Российской Федерации и их роль в обеспечении финансовой устойчивости государства // Законодательство и экономика. 2016. № 2. 
сыром и обработанном виде), а также их лома и отходов. В соответствии со статьями 7 и 8 Федерального закона от 26 марта 1998 г. № 41-Ф3 «О драгоценных металлах и драгоценных камнях» структура Государственного фонда драгоценных металлов и драгоценных камней представлена:

- Алмазным фондом РФ;

- Золотым запасом РФ;

- иными ценностями.

Алмазный фонд РФ состоит из уникальных самородков драгоценных металлов и уникальных драгоценных камней, имеющих историческое и художественное значение, а также уникальных ювелирных изделий из драгоценных металлов и драгоценных камней. Алмазный фонд неделим, является федеральной собственностью и не подлежим отчуждению в любой форме и иному обременению, в том числе сдаче в аренду. Ценности Алмазного фонда могут быть использованы исключительно в целях экспонирования или научного изучения.

Золотой запас РФ состоит из аффинированного золота в слитках, находящегося в федеральной собственности ${ }^{1}$. Данная часть золотовалютных резервов РФ предназначена для осуществления суверенной финансовой политики государства и удовлетворения экстренных потребностей РФ при чрезвычайных ситуациях.

Драгоценные металлы и камни из Государственного фонда драгоценных металлов и драгоценных камней используются в соответствии с ежегодными планами Правительства РФ с указанием конкретных целей отпуска драгоценных металлов и драгоценных камней. Расходование золота для проведения операций на внешнем и внутреннем рынках, а также отпуск из Государственного фонда драгоценных металлов и драгоценных камней

1 В аффинированном золоте на 1 тысячу массовых долей сплава драгоценного металла приходится не менее 995 массовых долей химически чистого драгоценного металла. 
иных драгоценных металлов и камней сверх установленных ежегодных объемов и для целей, не предусмотренных планами Правительства, осуществляется только по решению Президента РФ.

Другая часть золотого запаса, хранящаяся в Центральном банке РФ, учитывается на его счетах. Решение о расходовании этой части золотовалютных резервов принимает Центральный банк по согласованию с Правительством РФ. Отчет о состоянии золотовалютных резервов Председатель Центрального банка представляет в Государственную Думу.

Сведения о запасах платины, металлов платиновой группы, природных алмазов в Государственном фонде драгоценных металлов и драгоценных камней РФ, Центральном банке РФ составляют государственную тайну.

Органы государственной власти субъектов РФ по согласованию с Правительством РФ могут формировать и использовать государственные фонды драгоценных металлов и камней субъектов РФ$\Phi^{1}$. Отчет о состоянии этих фондов ежегодно представляется в Правительство органами исполнительной власти субъектов РФ.

Золотовалютные резервы являются инструментом поддержания финансовой стабильности и суверенитета государства, гарантом выполнения государством своих обязательств. Чем выше величина золотовалютных резервов, тем большим доверием иностранных инвесторов и кредиторов пользуется государство ${ }^{2}$.

В статье 24 Федерального закона «О драгоценных металлах и драгоценных камнях» закреплены особенности государственного регулирования международной и внешнеэкономической деятельности РФ в

1 Постановление Правительства РФ от 15 мая 1999 г. № 537 «О порядке согласования вопроса о создании государственного фонда драгоценных металлов и драгоценных камней субъекта Российской Федерации».

2 Ольшаныци А.И. Золотовалютные резервы Российской Федерации: структура и управление // Российский внешнеэкономический вестник. 2006. № 12; Фетисов $Г$. Золотовалютные резервы России: объем, структура, управление // Вопросы экономики. 2005 . № 1; Поветкина Н.А. Проблемы правовой квалификации золотовалютных резервов (запасов) Российской Федерации и их роль в обеспечении финансовой устойчивости государства // Законодательство и экономика. 2016. № 2. 
области добычи, производства, использования и обращения драгоценных металлов и камней:

во-первых, возможность заключения субъектами РФ с субъектами либо административно-территориальными образованиями иностранных государств и иностранными юридическими лицами соглашений в области добычи, производства, использования и обращения указанных ценностей; во-вторых, представление проектов международных договоров РФ и соглашений (договоров) субъектов РФ с субъектами либо административнотерриториальными образованиями иностранных государств и иностранными юридическими лицами соглашений в области добычи, производства, использования и обращения драгоценных металлов и камней в Правительство РФ для прохождения обязательной экономико-правовой экспертизы;

в-третьих, обязательная ратификация международных договоров в области добычи, производства и использования драгоценных металлов и драгоценных камней;

в-четвертых, вступление в силу соглашений (договоров) субъектов РФ с субъектами либо административно-территориальными образованиями иностранных государств и иностранными юридическими лицами в области добычи, производства, использования и обращения драгоценных металлов и камней после их государственной регистрации в порядке, определяемом Правительством.

В связи с принятием в РФ Республики Крым и образованием в составе России новых субъектов - Республики Крым и города федерального значения Севастополя возникла необходимость юридической защиты суверенных прав в сфере пользования недрами и распространения юрисдикции государства на воссоединившиеся части территории РФ. Отношения в сфере недропользования на территориях Республики Крым и города федерального значения Севастополя, а также пользования участков недр, расположенных в 
Черном и Азовском морях, были урегулированы Федеральным законом от 29 июня 2015 г. № 161-Ф3 «Об особенностях правового регулирования отношений в сфере пользования недрами в связи с принятием в Российскую Федерацию Республики Крым и образованием в составе Российской Федерации новых субъектов - Республики Крым и города федерального значения Севастополя», а также Постановлением Правительства РФ от 29 сентября 2015 г. № 1031 «Об утверждении Правил принятия решения о предоставлении права пользования участками недр, расположенными в Черном и Азовском морях, в пределах которых РФ осуществляет суверенитет, суверенные права или юрисдикцию в связи с принятием в Российскую Федерацию Республики Крым и образованием в составе Российской Федерации новых субъектов - Республики Крым и г. Севастополя».

В данных нормативных актах предусмотрено:

- использование участков недр, расположенных в Черном и Азовском морях, в соответствии с российским законодательством;

- возможность отказа Правительством РФ на основании заключений Министерства обороны и ФСБ России в предоставлении права пользования участками недр, расположенными в Черном и Азовском морях, в случае возникновения угрозы обороне и безопасности государства Правительством может быть принято решение об отказе;

- предоставление права пользования участками недр, расположенными на территориях Республики Крым и города федерального значения Севастополя, государственным унитарным предприятиям и государственным учреждениям, созданным решениями органов государственной власти Республики Крым и города федерального значения Севастополя для целей пользования недрами, без проведения торгов (конкурсов, аукционов).

Рассмотренные особенности конституционно-правового регулирования разработки месторождений полезных ископаемых и пользования недрами в 
других целях в границах участков недр, расположенных на территории Республики Крым и города федерального значения Севастополя, направлены на защиту экономической основы государственного суверенитета, дальнейшую интеграцию в состав РФ и восстановление единства правового пространства на всей территории страны.

Прерогативой государства выступает установление правового режима использования воздушного пространства. Конституционно-правовое регулирование использования воздушного пространства и деятельности в области авиации в контексте ЗГС направлено на обеспечение потребностей граждан и экономики в воздушных перевозках, авиационных работах, а также на обеспечение обороны и безопасности государства, охраны интересов государства, безопасности полетов воздушных судов, авиационной и экологической безопасности.

РФ обладает полным и исключительным суверенитетом в отношении воздушного пространства РФ над территорией государства, в том числе над внутренними водами и территориальным морем.

Законодательное регулирование использования воздушного пространства предполагает установление государством общих правил осуществления такой деятельности, организацию и проведение государственного контроля (надзора), а также установление ответственности за нарушения правил использования воздушного пространства.

Юридические пределы действия законодательного регулирования охватывают:

отношения в области авиации на территории России;

отношения, возникающие в связи с нахождением воздушных судов РФ за пределами территории РФ (если иное не предусмотрено законами страны пребывания или международным договором РФ);

отношения, возникающие в связи с выполнением полетов воздушных судов иностранных государств в воздушном пространстве РФ. 
На прибывающие в РФ, убывающие из РФ и следующие транзитом с посадкой на территории РФ воздушные суда, их экипажи и пассажиров, а также на имущество, багаж, грузы и почту, ввозимые в РФ и вывозимые из РФ, распространяется действие паспортных, таможенных и иных правил, установленных законодательством РФ.

Планирование и координирование использования воздушного пространства осуществляются в соответствии с государственными приоритетами, установленными статьей 13 Воздушного кодекса Российской Федерации от 19 марта 1997 г. № 60-Ф3.

Государственные приоритеты в использовании воздушного пространства означают, что при возникновении потребности в использовании воздушного пространства одновременно двумя и более пользователями воздушного пространства право на его использование предоставляется пользователям в следующей последовательности:

1) отражение воздушного нападения, предотвращение и прекращение нарушений Государственной границы РФ или вооруженного вторжения на территорию РФ;

2) оказание помощи при чрезвычайных ситуациях природного и техногенного характера;

3) запуск, посадка, поиск и эвакуация космических аппаратов и их экипажей;

4) предотвращение и прекращение нарушений федеральных правил использования воздушного пространства;

5) выполнение полетов воздушных судов, в том числе в интересах обороноспособности и безопасности государства, или иная деятельность по использованию воздушного пространства, осуществляемые в соответствии с решениями Правительства РФ или в порядке, установленном Правительством; 
6) выполнение полетов воздушных судов или иная деятельность по использованию воздушного пространства, осуществляемые в соответствии со специальными договорами;

7) выполнение полетов воздушных судов государственной авиации при внезапных проверках боевой готовности, а также при перебазировании частей и подразделений государственной авиации;

8) осуществление регулярных воздушных перевозок пассажиров и багажа;

9) выполнение полетов воздушных судов государственной авиации;

10) выполнение полетов воздушных судов экспериментальной авиации;

11) осуществление регулярных воздушных перевозок грузов и почты;

12) осуществление нерегулярных воздушных перевозок, выполнение авиационных работ;

13) проведение учебных, спортивных, демонстрационных и иных мероприятий;

14) выполнение полетов воздушных судов или иная деятельность по использованию воздушного пространства, осуществляемые в целях удовлетворения потребностей граждан.

Предполагаемые для выполнения полетов воздушные гражданские суда подлежат государственной регистрации и учету в Государственном реестре. Воздушные суда, зарегистрированные или учтенные в РФ, приобретают национальную принадлежность РФ.

В соответствии со структурой и классификацией воздушного пространства федеральными правилами использования воздушного пространства устанавливается разрешительный или уведомительный порядок использования воздушного пространства ${ }^{1}$.

1 Федеральные правила использования воздушного пространства РФ утверждены Постановлением Правительства РФ от 11 марта 2010 г. № 138. 
ЗГС РФ от недружественных действий иностранного государства, его государственных органов и должностных лиц может быть реализована в виде запрета использования воздушного пространства РФ или отдельных его районов $^{1}$. Соответствующие запреты или ограничения использования воздушного пространства устанавливаются Правительством.

Государственный контроль (надзор) в области использования воздушного пространства осуществляется уполномоченным органом в области использования воздушного пространства при осуществлении федерального государственного транспортного надзора.

Деятельность авиационных предприятий и индивидуальных предпринимателей, в том числе иностранных авиапредприятий, международных эксплуатационных агентств и иностранных индивидуальных предпринимателей (соблюдение российского законодательства, международных договоров, требований сертификатов и лицензий) контролирует уполномоченный орган в области гражданской авиации.

Правовой режим космической деятельности под юрисдикиией Российской Федеращии установлен законом РФ от 20 августа 1993 г. № 5663$1 \ll \mathrm{O}$ космической деятельности».

Как отмечается в преамбуле к Закону, «в Российской Федерации исследование и использование космического пространства, в том числе луны и других небесных тел, являются важнейшими приоритетами государственных интересов».

В статье 3 Закона РФ «О космической деятельности» закреплены цели космической деятельности, к которым отнесены:

- содействие экономическому развитию государства, повышению благосостояния населения РФ путем рационального и эффективного

\footnotetext{
${ }^{1}$ Статья 3 Федерального закона «О специальных экономических мерах».
} 
использования космической техники, космических материалов и космических технологий, а также расширения масштабов их использования;

- укрепление и развитие научно-технического и интеллектуального потенциала космической индустрии и ее инфраструктуры;

- содействие укреплению обороны и обеспечению безопасности РФ;

- дальнейшее совершенствование и накопление научных знаний о земле, космическом пространстве и небесных телах;

- развитие и расширение международного сотрудничества в интересах дальнейшей интеграции РФ в систему мировых хозяйственных связей и обеспечению международной безопасности.

Космическая деятельность находится в ведении РФ. Общее руководство космической деятельностью осуществляет Президент РФ. Глава государства: рассматривает и утверждает основные положения государственной политики в области космической деятельности; устанавливает особо важным космическим проектам и программам статус президентских; решает наиболее важные вопросы государственной политики в области космоса. Непосредственная реализация государственной политики в данной сфере осуществляется Правительством РФ и уполномоченным органом по космической деятельности (Государственная корпорация «Роскосмос»).

Элементами правового регулирования космической деятельности выступают лицензирование и обязательная сертификация космической техники (создаваемой в научных и социально-экономических целях). Финансирование космической деятельности осуществляется из федерального бюджета в порядке ГОЗ. В целях привлечения инвестиций законом предусмотрена поощрительная норма о возможности предоставления государственных гарантий и льгот организациям и гражданам, участвующим в осуществлении космических проектов. 
Космические объекты РФ подлежат регистрации и должны иметь маркировку, удостоверяющую их принадлежность РФ. РФ сохраняет юрисдикцию и контроль над зарегистрированными в ней космическими объектами и над любым экипажем зарегистрированного в ней пилотируемого космического объекта во время нахождения этих объектов на Земле, на любом этапе полета в космос или пребывания в космосе, на небесных телах, а также после возвращения на Землю за пределами юрисдикции какого-либо государства.

В целях ЗГС РФ Законом «О космической деятельности» предусмотрены условия пролета космических объектов иностранных государств через воздушное пространство РФ: одноразовость (запуск объекта на орбиту вокруг Земли или в космическое пространство, возвращение на Землю); отсутствие вреда интересам РФ, обороноспособности и безопасности государства; заблаговременное уведомление Роскосмоса о времени, месте, траектории и иных условиях пролета.

Исходя из принципа уважения суверенитета иностранных государств, Роскосмос и Министерство обороны информируют о запуске и посадке космических объектов РФ заинтересованные иностранные государства и международные организации. В случаях запуска, посадки или прекращения существования космических объектов РФ за ее пределами соответствующие службы РФ осуществляют свои функции по согласованию с компетентными органами заинтересованных иностранных государств.

Часть 2 статьи 28 Закона РФ «О космической деятельности» закрепляет приоритет национального законодательства в регулировании космической деятельности с участием организаций и граждан РФ перед законодательством иностранного государства (если иное не предусмотрено международными договорами РФ).

Традиционным фрагментом регулирования ЗГС является конституциионно-правовое регулирование суверенных прав и юрисдикции 
государства во внутренних морских водах, территориальном море, прилежащуей зоне, в исключительной экономической зоне и на континентальном щельфе.

Глава 2 Федерального закона от 31 июля 1998 г. № 155-Ф3 «О внутренних морских водах, территориальном море и прилежащей зоне Российской Федерации» определяет особенности правового режима морских портов, внутренних морских вод и территориального моря.

Правовой режим морских портов в РФ является единым для всех портов на территории РФ. Морские порты объявляются открытыми для захода иностранных судов решением Правительства. Все иностранные суда, кроме военных кораблей и других государственных судов, эксплуатируемых в некоммерческих целях, независимо от их предназначения и форм собственности могут заходить в морские порты, открытые для захода иностранных судов. Иностранные военные корабли и другие государственные суда, эксплуатируемые в некоммерческих целях, могут заходить в морские порты по предварительному разрешению, запрашиваемому по дипломатическим каналам, если иной порядок не предусмотрен международными договорами РФ. В отношении иностранных судов, иностранных военных кораблей и других государственных судов государств, в которых имеются специальные ограничения захода в их морские порты в отношении аналогичных судов, военных кораблей и других государственных судов РФ, Правительством могут устанавливаться ответные ограничения ${ }^{1}$.

В контексте ЗГС большого внимания заслуживают правовые аспекты регулирования стратегически важных для РФ транспортных коммуникаций, одной из которых является акватория Северного морского пути.

${ }^{1}$ Порядок прохода иностранных судов, иностранных военных кораблей и других государственных судов через территориальное море, установления запретных для плавания районов рассмотрен в параграфе 3.3 настоящей главы. 
Американское экспертное сообщество при поддержке официальных лиц выдвигает идею максимальной «интернационализации» правового режима Северного морского пути, под которой понимается получение США возможности для свободного использования этого транспортного коридора ${ }^{1}$. Для России важно сохранить за собой суверенное право на регулирование порядка использования Северного морского пути. В этих целях в 2012 г. был принят Федеральный закон от 28 июля 2012 г. № 132-Ф3 «О внесении изменений в отдельные законодательные акты Российской Федерации в части государственного регулирования торгового мореплавания в акватории Северного морского пути».

Согласно Федеральному закону плавание в акватории Северного морского пути, исторически сложившейся национальной транспортной коммуникации РФ, осуществляется в соответствии с общепризнанными принципами и нормами международного права, международными договорами РФ, федеральными законами и издаваемыми в соответствии с ними иными нормативными правовыми актами. Под акваторией Северного морского пути понимается водное пространство, прилегающее к северному побережью Российской Федерации, охватывающее внутренние морские воды, территориальное море, прилежащую зону и исключительную экономическую зону Российской Федерации и ограниченное с востока линией разграничения морских пространств с США и параллелью мыса Дежнева в Беринговом проливе, с запада меридианом мыса Желания до архипелага Новая земля, восточной береговой линией архипелага Новая Земля и западными границами проливов Маточкин Шар, Карские Ворота, Югорский Шар.

1 Гуреев С.А., Буник И.В. О необходимости подтверждения и правового закрепления исключительных прав России в Арктике / Морская деятельность Российской Федерации: состояние и проблемы законодательного обеспечения (мат-лы «круглого стола»). Инф. бюллетень № 1 Временной комиссии по национальной морской политике. M., 2005. C. 164. 
Судну под любым флагом гарантируется безопасность движения, ледокольное и лоцманское сопровождение, помощь в чрезвычайной ситуации, право пользования береговой инфраструктурой.

Приказом Министерства транспорта Российской Федерации от 17 января 2013 г. № 7 утверждены Правила плавания в акватории Северного морского пути. По ним введен разрешительный порядок плавания судов в акватории Северного морского пути. Организация плавания судов в акватории Северного морского пути возложена на администрацию Северного морского пути.

Принятие данного законодательного акта позволило защитить суверенные экономические интересы и укрепить безопасность РФ в Арктическом регионе.

Особенностью правового режима внутренних морских вод и территориального моря являются запретные для плавания (временно опасные для плавания) районы, которые устанавливаются для обеспечения безопасности судоходства, охраны государственных интересов РФ и охраны окружающей среды. В этих районах полностью запрещаются или временно ограничиваются плавание, постановка на якорь, добыча морских млекопитающих, осуществление рыболовства придонными орудиями вылова, подводные или дноуглубительные работы, отбор образцов грунта, подводные взрывы, плавание с вытравленной якорь-цепью, пролет, зависание и посадка (приводнение) летательных аппаратов и другая деятельность. В запретных для плавания районах плавание всех судов, военных кораблей, других государственных судов и всех иных плавучих средств запрещается.

Допуск спасательных судов и средств иностранных государств во внутренние морские воды и в территориальное море и их участие в поисковоспасательных и судоподъемных операциях в целях поиска и спасения людей, спасения и буксировки аварийных судов, подъема затонувших судов и грузов 
производятся в соответствии с российским законодательством и международными договорами.

Создание, эксплуатация, использование искусственных островов, установок, сооружений, проведение буровых работ, прокладка подводных кабелей, трубопроводов во внутренних морских водах и в территориальном море осуществляются с соблюдением требований водного законодательства в порядке, установленном Правительством РФ¹.

Эксплуатация, использование искусственных островов, установок, сооружений, подводных трубопроводов, проведение буровых работ при геологическом изучении, разведке и добыче углеводородного сырья, а также при транспортировке и хранении нефти и нефтепродуктов во внутренних морских водах и в территориальном море допускаются только при наличии плана предупреждения и ликвидации разливов нефти и нефтепродуктов и положительного заключения государственной экологической экспертизы.

Правовой режим внутренних морских вод и территориального моря также включает проведение морских научных исследований, в разрешении на проведение которых может быть отказано, если морские исследования создают помехи деятельности РФ во внутренних морских водах и в территориальном море, создают или могут создать угрозу обороне и безопасности РФ.

В контексте ЗГС важное значение имеет часть 2 статьи 28 Федерального закона «О внутренних морских водах, территориальном море и прилежащей зоне Российской Федерации», в соответствии с которой российские и иностранные заявители обязаны обеспечивать участие в морских научных исследованиях представителей РФ, в том числе их

${ }^{1}$ Постановление Правительства РФ от 19 января 2000 г. № 44 «Об утверждении Порядка создания, эксплуатации и использования искусственных островов, сооружений и установок во внутренних морских водах и в территориальном море Российской Федерации»; Постановление Правительства РФ от 26 января 2000 г. № 68 «Об утверждении Порядка прокладки подводных кабелей и трубопроводов во внутренних морских водах и в территориальном море Российской Федерации». 
размещение и полное обеспечение на борту исследовательских судов, летательных аппаратов, на установках и сооружениях, в местах дислокации экспедиции на берегу наравне с собственным командным (руководящим) составом, а также обеспечивать указанным представителям РФ доступ ко всем данным и образцам, полученным в ходе морских научных исследований, и передавать им данные, с которых можно сделать копии, и образцы, которые могут быть разделены без ущерба для их научной ценности. Все данные, полученные в результате морских научных исследований, после их обработки и анализа должны быть переданы в государственные фонды данных РФ.

В целях защиты морской среды и природных ресурсов внутренних морских вод и территориального моря законодателем введен запрет на захоронение отходов и других материалов (за исключением захоронения грунта при проведении дноуглубительных работ), а также сброс загрязняющих веществ во внутренних морских водах и в территориальном Mope.

К территориальному морю прилегает морской пояс прилежащей зоны, где РФ осуществляет контроль, необходимый для:

- предотвращения нарушений таможенных, фискальных, иммиграционных или санитарных правил, действующих на территории РФ;

- задержания виновных, включая преследование по горячим следам, остановку, осмотр и задержание всех иностранных судов - нарушителей (за исключением военных кораблей и государственных судов, эксплуатируемых в некоммерческих целях);

- наказания за нарушение указанных правил, совершенное на территории РФ.

Федеральный закон от 17 декабря 1998 г. № 191-Ф3 «Об исключительной экономической зоне Российской Федерации» определяет суверенные права РФ в ее исключительной экономической зоне и порядок их 
осуществления.

РФ в исключительной экономической зоне осуществляет:

1) суверенные права в целях разведки, разработки и сохранения водных биоресурсов и неживых ресурсов и управления такими ресурсами, а также в отношении других видов деятельности по экономической разведке и разработке исключительной экономической зоны;

2) суверенные права в целях разведки морского дна и его недр и разработки минеральных и других неживых ресурсов, а также разработки водных биоресурсов, относящихся к «сидячим видам» морского дна и его недр;

3) исключительное право разрешать и регулировать буровые работы на морском дне и в его недрах для любых целей ${ }^{1}$;

4) исключительное право сооружать, а также разрешать и регулировать создание, эксплуатацию и использование искусственных островов, установок и сооружений ${ }^{2}$.

5) юрисдикцию в отношении:

- искусственных островов, установок и сооружений, в том числе в отношении таможенных, фискальных, санитарных и иммиграционных законов и правил, а также правил безопасности;

- морских научных исследований ${ }^{3}$;

- защиты и сохранения морской среды от загрязнения из всех источников;

- прокладки и эксплуатации подводных кабелей и трубопроводов РФ룰

1 Буровые работы осуществляются в соответствии с Федеральным законом «О континентальном шельфе».

2 Создание, эксплуатация и использование искусственных островов, установок и сооружений в исключительной экономической зоне осуществляются в соответствии с Федеральным законом «О континентальном шельфе Российской Федерации».

3 Постановление Правительства РФ от 30 июля 2004 г. № 391 «Об утверждении Правил проведения морских научных исследований во внутренних морских водах, в территориальном море, в исключительной экономической зоне и на континентальном шельфе Российской Федерации». 
6) другие права, предусмотренные международными договорами РФ.

РФ осуществляет свои суверенные права и юрисдикцию в исключительной экономической зоне, руководствуясь экономическими, торговыми, научными и иными государственными интересами.

По аналогии с Федеральным законом «О внутренних морских водах, территориальном море и прилежащей зоне Российской Федерации» правовой режим исключительной экономической зоны предусматривает требование об обязательном участии уполномоченных представителей РФ в проводимых исследованиях водных биоресурсов, обеспечении доступа ко всем данным и образцам, передаче всех данных и образцов, окончательных результатов исследований в государственные научные учреждения РФ.

Исследования водных биоресурсов и морские научные исследования должны носить исключительно мирный характер и не создавать угрозу обороне страны и безопасности государства ${ }^{2}$.

Все виды хозяйственной и иной деятельности в исключительной экономической зоне могут осуществляться только при наличии положительного заключения государственной экологической экспертизы.

Правительство РФ в целях сохранения и восстановления популяций морских млекопитающих и в других необходимых случаях может устанавливать режимы ограничения или регулирования рыболовства морских млекопитающих в исключительной экономической зоне, вплоть до запрещения рыболовства отдельных видов морских млекопитающих.

В контексте ЗГС представляет интерес статья 37 Федерального закона «Об исключительной экономической зоне Российской Федерации», на основании которой федеральные органы исполнительной власти, капитаны

1 Прокладка подводных кабелей и трубопроводов РФ, а также прокладка подводных кабелей и трубопроводов иностранных государств в исключительной экономической зоне осуществляются в соответствии с Федеральным законом «О континентальном шельфе Российской Федерации».

2 Речь идет о недопустимости осуществления разведывательной деятельности, направленной на нанесение ущерба суверенитету и безопасности РФ. 
судов и командиры военных кораблей, летательных аппаратов РФ, ответственные лица на искусственных островах, установках, сооружениях и береговых постах обязаны оказывать содействие органам охраны и информировать об обнаружении военных кораблей, судов, установок и сооружений, нарушающих суверенные права и юрисдикцию РФ в исключительной экономической зоне.

Статус континентального шельфа, суверенные права и юрисдикция РФ на континентальном шельфе определяются Федеральным законом от 30 ноября 1995 г. № 187-Ф3 «О континентальном шельфе Российской Федерации».

Континентальный шельф РФ включает в себя морское дно и недра подводных районов, находящиеся за пределами территориального моря РФ на всем протяжении естественного продолжения ее сухопутной территории до внешней границы подводной окраины материка.

РФ на континентальном шельфе осуществляет:

1) суверенные права в целях разведки континентального шельфа и разработки его минеральных ресурсов и водных биоресурсов ${ }^{1}$;

2) исключительное право разрешать и регулировать буровые работы на континентальном шельфе для любых целей;

3) исключительное право сооружать, а также разрешать и регулировать создание, эксплуатацию и использование искусственных островов, установок и сооружений;

4) юрисдикцию в отношении:

- искусственных островов, установок и сооружений, в том числе юрисдикцию в отношении таможенных, фискальных, санитарных и иммиграционных правил, а также правил безопасности;

${ }^{1}$ Суверенный (исключительный) характер этих прав состоит в том, что если РФ не производит разведку континентального шельфа или не разрабатывает его минеральные ресурсы или водные биоресурсы, никто не может делать это без согласия РФ. 
- морских научных исследований;

- защиты и сохранения морской среды в связи с разведкой континентального шельфа, разработкой его минеральных ресурсов и водных биоресурсов, захоронением отходов и других материалов;

- прокладки и эксплуатации подводных кабелей и трубопроводов РФ.

Участки континентального шельфа, к которым относятся участки недр континентального шельфа, могут предоставляться для:

регионального геологического изучения;

геологического изучения;

геологического изучения, разведки и добычи минеральных ресурсов; осуществления иных видов пользования недрами.

Правовой режим континентального шельфа определяет особенности рыболовства иностранных судов на континентальном шельфе. Иностранные суда обязаны:

представлять в уполномоченные государственные органы ежесуточную информацию о каждом заходе в район разрешенного рыболовства и выходе из него с обязательным прохождением точек контроля при заходе и выходе;

ежедневно информировать органы охраны о местонахождении судов при осуществлении рыболовства или при приемке уловов водных биоресурсов с других судов;

осуществлять рыболовство только в присутствии должностного лица органов охраны и под его контролем;

обеспечивать бесплатно доставку должностных лиц охраны к месту осуществления рыболовства и обратно и использование средств радиосвязи, а также нести все расходы на содержание, размещение и полное обеспечение должностных лиц органов охраны с момента их прибытия на судно и до момента схода с судна наравне с командным (руководящим) составом судна;

представлять в уполномоченный государственный орган ежесуточную, ежедекадную и ежемесячную информацию о результатах рыболовства. 
В целях обеспечения обороны страны и безопасности государства на континентальном шельфе могут создаваться и использоваться искусственные острова, установки и сооружения.

Иностранные заявители обязаны обеспечивать присутствие на искусственных островах, установках, сооружениях представителей РФ, выдавших разрешения на создание искусственных островов, установок и сооружений, включая размещение и полное обеспечение наравне с собственным командным (руководящим) составом, а также обеспечивать доступ указанным представителям во все помещения и на все объекты искусственных островов, установок и сооружений. Работы иностранных заявителей по созданию искусственных островов, установок и сооружений могут начинаться только в присутствии и под контролем представителей РФ.

Федеральный закон «О континентальном шельфе Российской Федерации» содержит требование об обязательном участии уполномоченных представителей РФ в проводимых исследованиях водных биоресурсов, обеспечении доступа ко всем данным и образцам, передаче всех данных и образцов, окончательных результатов исследований в государственные научные учреждения РФ.

В целях охраны континентального шельфа, его минеральных ресурсов и водных биоресурсов, защиты экономических и иных законных интересов РФ законодателем закреплен обширный перечень правомочий должностных лиц органов охраны и норм, обязывающих оказывать содействие органам охраны и информировать об обнаружении военных кораблей, судов, установок и сооружений, нарушающих суверенные права и юрисдикцию РФ на континентальном шельфе.

Споры между РФ и иностранными государствами по поводу реализации их прав и обязанностей во внутренних морских водах, территориальном море, прилежащей зоне, в исключительной экономической зоне и на континентальном шельфе разрешаются мирными средствами в 
соответствии с международными договорами РФ и нормами международного права.

Рассмотрев конституционно-правовое регулирование суверенных прав и юрисдикции государства во внутренних морских водах, территориальном море, исключительной экономической зоне и на континентальном шельфе, выступающих неотъемлемым компонентом экономической основы государственного суверенитета, перейдем к регулированию налогообложения - другой ключевой составляющей экономического суверенитета любого государства. Основным источником государственных доходов является налогообложение, которое составляет экономическую базу решения государством социально-экономических, военно-политических, идеологических и других задач.

Как указано в Постановлении Конституционного Суда РФ от 17 декабря 1996 г. № 20-П, «налог - необходимое условие существования государства, поэтому обязанность платить налоги, закрепленная в статье 57 Конституции Российской Федерации, распространяется на всех налогоплательщиков в качестве безусловного требования государства. Взыскание налога представляет собой законное изъятие части имущества, вытекающее из конституционной публично-правовой обязанности. ... С публично-правовым характером налога и государственной казны и с фискальным суверенитетом государства связаны законодательная форма учреждения налога, обязательность и принудительность его изъятия, односторонний характер налоговых обязательств».

Конституцчионно-правовое регулирование налогообложения в контексте защиты государственного суверенитета направлено на обеспечение стабильности налоговой системы, недопущение увеличения налоговой нагрузки на экономику, повышение привлекательности российской юрисдикции для инвесторов, а также дальнейшее повышение эффективности налогового администрирования. 
При этом налоговая политика РФ должна отвечать современным глобальным вызовам и угрозам государственному суверенитету, среди которых антироссийские санкции, попытки дезинтеграции экономических связей РФ с государствами СНГ, низкая конкурентоспособность национальной экономики.

Система налоговых мер, предусмотренная Основными направлениями налоговой политики на 2016 г. и на плановый период 2017-2018 гг. и реализуемая в контексте защиты экономической основы суверенитета, включает:

- предоставление налоговых льгот для вновь создаваемых предприятий промышленности - «гринфилдов» (ограничения для субъектов РФ и местных органов власти по увеличению ставок региональных и местных налогов, ограничения на повышение федеральной составляющей налога на прибыль организаций);

- меры налогового стимулирования инвестиций для резидентов территорий опережающего социально-экономического развития (преференции по налогу на добавленную стоимость, налогу на прибыль организаций и налогу на добычу полезных ископаемых);

- меры налогового стимулирования развития малого предпринимательства через специальные налоговые режимы (расширение перечня видов деятельности, в отношении которых применяется патентная система налогообложения; предоставление права субъектам РФ снижать ставки налогов в зависимости от категорий налогоплательщиков и видов предпринимательской деятельности $\left.{ }^{1}\right)$;

- меры по совершенствованию налогообложения физических лиц (с 2015 г. введен налог на имущество физических лиц, целью которого является

1 Так, субъектам РФ предоставлено право устанавливать для впервые зарегистрированных индивидуальных предпринимателей, перешедших на упрощенную систему налогообложения и патентную систему налогообложения и осуществляющих деятельность в производственной, социальной и научной сферах, «налоговые каникулы» в виде налоговой ставки в размере 0\%, которые будут действовать в 2015 - 2018 годах. 
переход к более справедливому налогообложению исходя из кадастровой стоимости имущества, как наиболее приближенной к рыночной стоимости этого имущества; для обеспечения равенства налогообложения и защиты социально-незащищенных категорий граждан на федеральном уровне предложены налоговые вычеты в отношении объектов жилого назначения, налоговые льготы отдельным категориям налогоплательщиков ${ }^{1}$; предусмотрены единые сроки уплаты физическими лицами транспортного, земельного налогов и налога на имущество физических лиц);

- меры по совершенствованию налогового администрирования (в законодательство о налогах и сборах введен институт налогового мониторинга, который должен позволить повысить прогнозируемость налоговых платежей, сократить затраты на проведение налоговых проверок, обеспечить повышение правовой культуры налогоплательщиков; урегулированы положения, связанные с использованием личного кабинета налогоплательщика; расширен электронный документооборот между участниками налоговых правоотношений и др.);

- меры по борьбе с размыванием налоговой базы и выводом прибыли из-под налогообложения (устранение двойного «неналогообложения»; раскрытие информации; автоматический обмен информацией по финансовым операциям с иностранными юрисдикциями: в 2018 г. запланировано присоединение РФ к многостороннему соглашению по автоматическому обмену финансовой информацией, предусмотренному Единым стандартом отчетности Организации экономического сотрудничества и развития (ОСЭР) для налоговых целей; внедрение механизма налогообложения прибыли контролируемых иностранных компаний (глава 3.4 Налогового кодекса

\footnotetext{
${ }^{1}$ Учитывая общий вектор государственной политики, направленный на сокращение и отмену налоговых льгот (освобождение от налогообложения, изъятия из налоговой базы и объекта налогообложения), необходимо обязательно принимать во внимание социальный эффект отмены тех или иных налоговых льгот. Так, единовременная отмена налоговых льгот, имеющих важное социальное и государственное значение (например, льготы для пенсионеров и инвалидов), приводила к социальной напряженности в обществе.
} 
Российской Федерации) ${ }^{1}$; совершенствование правил налогообложения при трансфертном ценообразовании $)^{2}$.

В разделе 10 Основных направлений налоговой политики на 2016 г. и на плановый период 2017-2018 гг. указано, что наряду с необходимостью создания комфортных условий администрирования для добросовестных налогоплательщиков важной задачей государства остается работа по ужесточению мер противодействия созданию и использованию недобросовестными налогоплательщиками схем уклонения от уплаты налогов и незаконного возмещения налогов из бюджета. Одной из мер борьбы с агрессивным налоговым планированием является закрепление на законодательном уровне механизмов, ограничивающих использование налогоплательщиками т.н. «фирм-однодневок», а также налоговых схем с использованием оффшорных компаний. Такие изменения не затронут добросовестных налогоплательщиков и при этом будут способствовать созданию нормальных условий ведения бизнеса.

Значимым элементом обеспечения экономической основы государственного суверенитета РФ является конституциионно-правовое регулирование национальной платежной системьл. Необходимость совершенствования правовой регламентации национальной платежной системы в контексте защиты государственного суверенитета возникла 21 марта 2014 г., когда международные платежные системы Visa и Mastercard прекратили проводить операции для клиентов банков «Россия», «Собинбанк», «Инвесткапиталбанк», СМП Банк, «Финсервис» по требованию Минфина США. После этого оплатить товары и услуги не

${ }^{1} \mathrm{O}$ механизме налогообложения прибыли контролируемых иностранных компаний подробнее см. подраздел данной главы «конституционно-правовое регулирование возврата российского капитала и сокращения его неконтролируемого вывоза за рубеж».

2 РФ активно участвует в реализации Плана действий по борьбе с размыванием налоговой базы и выводом прибыли из-под налогообложения (OECD Action Plan on Base Erosion and Profit Shifting - План BEPS), который был одобрен главами государств и правительств «Группы двадцати» в сентябре 2013 г. под председательством России в Большой двадцатке. 
смогли более миллиона клиентов попавших под санкции США банков.

В связи с произошедшими событиями был принят Федеральный закон от 5 мая 2014 г. № 112-Ф3 «О внесении изменений в Федеральный закон «О национальной платежной системе» и отдельные законодательные акты Российской Федерации». Данный законодательный акт в определенной степени позволил повысить самостоятельность национальных платежных инструментов и гарантировать бесперебойность функционирования услуг платежной инфраструктуры участникам национальной платежной системы и их клиентам.

Федеральным законом от 5 мая 2014 г. № 112-Ф3 в Федеральный закон от 27 июня 2011 г. № 161-Ф3 «О национальной платежной системе» были введены гарантии устойчивого функционирования национальных платежных инструментов и защиты информации о переводах денежных средств от неконтролируемой передачи иностранным государствам.

В соответствии с частью 11 статьи 16 Федерального закона «О национальной платежной системе» при осуществлении перевода денежных средств в рамках платежной системы операторами по переводу денежных средств, находящимися на территории РФ, должны привлекаться операторы услуг платежной инфраструктуры, которые соответствуют требованиям федерального закона, находятся и осуществляют все функции на российской территории (кроме трансграничного перевода денежных средств).

Операторы услуг платежной инфраструктуры не вправе передавать информацию по любому переводу денежных средств, осуществляемому в рамках платежной системы на территории РФ, на территорию иностранного государства или предоставлять доступ к такой информации с территории иностранного государства ${ }^{1}$. Операторы услуг платежной инфраструктуры не вправе в одностороннем порядке приостанавливать (прекращать) оказание

1 Исключением является трансграничный перевод денежных средств, а также использование электронных средств платежа без согласия клиентов. 
услуг платежной инфраструктуры участникам платежной системы и их клиентам.

В статье 22 Федерального закона «О национальной платежной системе» законодатель ввел критерии национально значимой платежной системы:

РФ, Банк России, российские граждане прямо или косвенно установили контроль в отношении оператора платежной системы и операторов услуг платежной системы, за исключением расчетного центра платежной системы ${ }^{1}$;

используемые операторами услуг платежной инфраструктуры информационные технологии соответствуют устанавливаемым Банком России по согласованию с Правительством требованиям ${ }^{2}$. Указанные требования должны включать использование в установленной доле программных средств, разработчиками которых являются российские организации, требования к лицензионным соглашениям, требования к материальным носителям платежных карт, включая их интегральные микросхемы, а также к обеспечению защиты информации.

Платежная система Банка России, платежная система, в рамках которой осуществляются переводы денежных средств по сделкам на организованных торгах, национальная система платежных карт признаны национально значимыми платежными системами.

Федеральным законом от 5 мая 2014 г. № 112-Ф3 в Федеральный закон «О национальной платежной системе» введена глава 4.1 «Национальная система платежных карт». Целью организации национальной системы платежных карт (далее - НСПК) является обеспечение бесперебойности,

${ }^{1}$ Порядок определения указанного контроля, а также составления и представления Банку России информации об установлении контроля регулируется Банком России.

2 Указание Банка России от 25 июля 2014 г. № 3342-У «О требованиях к информационным технологиям, используемым операторами услуг платежной инфраструктуры, для целей признания платежной системы национально значимой платежной системой». 
эффективности и доступности оказания услуг по переводу денежных средств.

В рамках НСПК осуществляются переводы денежных средств с использованием платежных карт и иных средств электронного платежа (национальные платежные инструменты), а также оказываются услуги платежной инфраструктуры по осуществляемым на территории РФ переводам денежных средств с использованием международных платежных карт.

В целях повышения самостоятельности национальных платежных инструментов и устойчивости функционирования услуг платежной инфраструктуры законодателем установлены правомочия Банка России по применению мер принуждения за приостановление (прекращение) оказания услуг платежной инфраструктуры.

В случае неоднократного невыполнения в течение одного года предписаний с требованием об устранении нарушения, влияющего на бесперебойность функционирования платежной системы, Банк России исключает оператора платежной системы из реестра операторов платежных систем.

Согласно статье 82.4 Федерального закона «О Центральном банке Российской Федерации (Банке России)» в случае приостановления (прекращения) в одностороннем порядке оказания услуг платежной инфраструктуры участнику (участникам) платежной системы и его (их) клиентам Банк России взыскивает штраф:

1) с оператора платежной системы, не являющейся национально значимой платежной системой, - в размере до 10\% от обеспечительного взноса за каждый день приостановления (прекращения) оказания услуг платежной инфраструктуры;

2) с оператора национально значимой платежной системы - в размере до 10 млн рублей за каждый день приостановления (прекращения) оказания услуг платежной инфраструктуры. 
Оператор платежной системы, не являющийся национально значимой платежной системой, вносит на специальный счет в Банке России обеспечительный взнос в размере суммы переводов денежных средств, осуществленных на территории РФ. Средства, учитываемые на специальном счете обеспечительного взноса, используются Банком России для уплаты штрафа. Наложение на операторов платежных систем штрафных санкций дополняется привлечением поднадзорных организаций и их должностных лиц к административной ответственности.

Предусмотренная Федеральным законом «О национальной платежной системе» возможность ограничения платежных услуг зарубежных операционных центров наряду с принудительным исключением из реестра операторов платежных систем, административной и материальной ответственностью операторов платежных систем образует систему достаточных конституционно-правовых гарантий бесперебойного и эффективного функционирования национально значимых платежных систем в РФ.

Составной частью экономической политики РФ является ее торговая политика. Конституцุионно-правовое регулирование торговой политики Российской Федеращии осуществляется базовым Федеральным законом от 8 декабря 2003 г. № 164-Ф3 «Об основах государственного регулирования внешнеторговой деятельности».

В соответствии с конституционным принципом разграничения предметов ведения и полномочий в РФ в Федеральном законе «Об основах государственного регулирования внешнеторговой деятельности» определены полномочия Российской Федерации и субъектов Российской Федерации в области внешнеторговой деятельности.

К полномочиям федеральных органов государственной власти в области внешнеторговой деятельности отнесены:

формирование концепции и стратегии развития внешнеторговых связей 
и основных принципов торговой политики РФ;

защита экономического суверенитета и экономических интересов РФ и российских лиц;

государственное регулирование внешнеторговой деятельности;

установление обязательных на всей территории РФ требований и критериев безопасности для жизни и здоровья граждан, имущества физических и юридических лиц, государственного или муниципального имущества, окружающей среды, жизни или здоровья животных и растений при ввозе в РФ товаров и правил контроля за ними;

определение порядка вывоза из РФ и ввоза в РФ делящихся (расщепляющихся) ядерных веществ, отравляющих, взрывчатых, ядовитых веществ, опасных отходов, сильнодействующих, наркотических средств, психотропных веществ и их прекурсоров, биологически и генетически активных материалов, а также иных товаров, которые могут оказать неблагоприятное воздействие на жизнь и здоровье граждан, жизнь или здоровье животных и растений, окружающую среду;

определение особенностей ввоза в РФ из стран, не входящих в ЕАЭС, и вывоза из РФ в страны, не входящие в ЕАЭС, драгоценных металлов и драгоценных камней;

координация международного сотрудничества РФ в области космической деятельности и контроль за разработкой и реализацией международных космических проектов РФ;

установление показателей статистической отчетности внешнеторговой деятельности, обязательных на всей территории РФ;

заключение международных договоров РФ в области внешнеэкономических связей;

учреждение и ликвидация торговых представительств РФ в иностранных государствах;

участие в деятельности международных экономических организаций и 
реализации решений, принятых этими организациями;

определение порядка вывоза из РФ товаров, составной частью которых является информация, составляющая государственную тайну;

информационное обеспечение внешнеторговой деятельности на территории РФ;

создание страховых и залоговых фондов в области внешнеторговой деятельности.

Органы государственной власти субъектов РФ наделены следующими полномочиями в области внешнеторговой деятельности:

- проведение переговоров и заключение соглашений об осуществлении внешнеэкономических связей с субъектами иностранных федеративных государств, административно-территориальными образованиями иностранных государств, а также с согласия Правительства РФ с органами государственной власти иностранных государств;

- содержание своих представителей при торговых представительствах РФ в иностранных государствах за счет средств бюджетов субъектов РФ по согласованию с уполномоченным федеральным органом исполнительной власти и МИД России;

- открытие представительства в иностранных государствах в целях реализации соглашений об осуществлении внешнеэкономических связей;

- осуществление формирования и реализации региональных программ внешнеторговой деятельности;

- информационное обеспечение внешнеторговой деятельности на территории субъекта РФ;

- создание страховых и залоговых фондов в области внешнеторговой деятельности на территории субъекта РФ.

Перечисленные полномочия федеральных органов государственной власти и органов государственной власти субъектов РФ в области внешнеторговой деятельности носят закрытый характер и могут быть 
дополнены только федеральным законом.

В статье 13 Федерального закона «Об основах государственного регулирования внешнеторговой деятельности» выделены полномочия субъектов государственного регулирования внешнеторговой деятельности, выступающего неотъемлемой частью ЗГС.

В рамках осуществления своих полномочий по ЗГС Президент РФ: определяет основные направления торговой политики РФ;

определяет особенности ввоза в РФ из стран, не входящих в ЕАЭС, и вывоза из стран, не входящих в ЕАЭС, драгоценных металлов и камней;

устанавливает запреты и ограничения внешней торговли товарами, услугами и интеллектуальной собственностью;

осуществляет иные полномочия.

В целях ЗГС Правительство:

обеспечивает проведение в РФ единой торговой политики и осуществляет меры по ее реализации;

применяет специальные защитные меры, антидемпинговые меры и компенсационные меры при осуществлении внешней торговли товарами, а также иные меры по защите экономических интересов РФ;

устанавливает ставки таможенных пошлин, если иное не предусмотрено международными договорами государств - членов Таможенного союза;

вводит количественные ограничения экспорта и импорта товаров и определяет порядок их применения;

устанавливает разрешительный порядок экспорта и (или) импорта отдельных видов товаров, которые могут оказать неблагоприятное воздействие на безопасность государства, жизнь или здоровье граждан, имущество физических или юридических лиц, государственное или муниципальное имущество, окружающую среду, жизнь или здоровье животных и растений, а также определяет перечень отдельных видов 
товаров, в отношении которых применяется такой порядок;

принимает в пределах своей компетенции решения о проведении переговоров и подписании международных договоров РФ;

принимает решения о введении в качестве ответных мер в отношении иностранных государств ограничений внешней торговли товарами, услугами и интеллектуальной собственностью;

устанавливает порядок вывоза из РФ товаров, составной частью которых является информация, составляющая государственную тайну;

осуществляет иные полномочия.

Как уже отмечалось, государственное регулирование внешнеторговой деятельности и реализация торговой политики РФ осуществляются с использованием методов таможенно-тарифного регулирования, нетарифного регулирования, запретов и ограничений внешней торговли товарами, услугами и интеллектуальной собственностью, мер экономического и административного характера, способствующих развитию внешнеторговой деятельности ${ }^{1}$.

Таможенно-тарифное регулирование предназначено для регулирования внешней торговли товарами, в том числе для защиты внутреннего рынка РФ и стимулирования прогрессивных структурных изменений в экономике ${ }^{2}$ Оно осуществляется с помощью ввозных и вывозных таможенных пошлин. Таможенно-тарифное регулирование возложено на Федеральную таможенную службу (ФТС России). Данный государственный орган выдает свидетельства и разрешения на право деятельности в определенных сферах таможенного дела, определяет порядок и непосредственно осуществляет таможенное оформление и контроль.

1 Уполномоченным органом в сфере государственного регулирования внешнеторговой деятельности, за исключением вопросов таможенного тарифного регулирования, является Минпромторг России.

2 Указом Президента РФ от 30 января 2010 г. № 120 «Об утверждении Доктрины продовольственной безопасности Российской Федерации» предусмотрено оперативное применение мер таможенно-тарифного регулирования для рационализации соотношения экспорта и импорта сельскохозяйственной и рыбной продукции, сырья и продовольствия. 
Специфика таможенно-тарифного регулирования, направленная на защиту экономического суверенитета и экономической безопасности государства, была отмечена в Определении Конституционного Суда РФ от 8 июня 2000 г. «Об отказе в принятии к рассмотрению жалобы ООО «Твин Холдинг Интернешнл» на нарушение конституционных прав и свобод применением положений ст. 31 и 126 Таможенного кодекса Российской Федерации». В Постановлении от 14 мая 1999 года «По делу о проверке конституционности положений части первой статьи 131 и части первой статьи 380 Таможенного кодекса Российской Федерации» Конституционный Суд РФ сформулировал правовую позицию о суверенных интересах и взаимности таможенного регулирования во внешнеторговых отношениях с иностранными государствами (союзами иностранных государств). В соответствии с данным решением Конституционного Суда было подтверждено, что интересы защиты экономической основы суверенитета требуют признания принципа единства и взаимности, согласно которому государство не может ставить себя в невыгодные с точки зрения таможенных режимов правовые условия по сравнению с другими странами.

Значимую роль в ЗГС и обеспечении его экономической основы играют полномочия ФТС России по борьбе с правонарушениями в области таможенного дела и полномочия по взиманию таможенных пошлин и сборов ${ }^{1}$. Наряду с налогами и доходами от управления государственным имуществом таможенные платежи являются одним из основных видов доходов федерального бюджета.

Нетарифное регулирование внешней торговли включает:

- количественные ограничения импорта и экспорта товаров;

- введение квот;

- лицензирование в сфере внешней торговли товарами;

1 О месте и роли ФТС России в системе субъектов конституционно-правовой защиты государственного суверенитета см. параграф 3.1 данной главы. 
- предоставление исключительного права на экспорт и (или) импорт отдельных видов товаров;

- специальные защитные, антидемпинговые и компенсационные меры.

В соответствии с международными договорами Правительство РФ может устанавливать:

временные ограничения или запреты экспорта товаров для предотвращения либо уменьшения критического недостатка на внутреннем рынке продовольственных или иных товаров, которые являются существенно важными для внутреннего рынка РФ$\Phi^{1}$;

ограничения импорта сельскохозяйственных товаров или водных биологических ресурсов, ввозимых в РФ в любом виде.

Введение количественных ограничений как метод ЗГС в социальноэкономической сфере носит исключительный, временный (устанавливается не более чем на 6 месяцев) и неизбирательный характер (ограничения применяются вне зависимости от страны происхождения товара). В случае применения количественных ограничений импорта и экспорта товаров начинает действовать режим лицензирования в сфере внешней торговли.

При принятии решения о введении квоты Правительство определяет метод распределения квоты и устанавливает порядок проведения конкурса или аукциона. Распределение квоты основывается на равноправии участников внешнеторговой деятельности и их недискриминации по признакам формы собственности, места регистрации или положения на рынке.

Правовой режим лицензирования в сфере внешней торговли товарами устанавливается в случаях:

a) введения временных количественных ограничений экспорта или

1 Перечень товаров, являющихся существенно важными для внутреннего рынка РФ, в отношении которых в исключительных случаях могут быть установлены временные ограничения или запреты экспорта, утвержден Постановлением Правительства РФ от 15 декабря 2007 г. № 877. 
импорта отдельных видов товаров;

б) реализации разрешительного порядка экспорта и (или) импорта отдельных видов товаров, которые могут оказать неблагоприятное воздействие на безопасность государства, жизнь или здоровье граждан, имущество физических или юридических лиц, государственное или муниципальное имущество, окружающую среду, жизнь или здоровье животных и растений;

в) предоставления исключительного права на экспорт и (или) импорт отдельных видов товаров;

г) выполнения РФ международных обязательств.

Лицензии на экспорт и (или) импорт отдельных видов товаров (за исключением лицензий на экспорт и импорт природного газа в сжиженном состоянии, которые выдает Минэнерго России) выдаются Минпромторгом России ${ }^{1}$.

Право на осуществление внешнеторговой деятельности может ограничиваться путем предоставления исключительного права на экспорт и (или) импорт отдельных видов товаров решением Комиссии Таможенного Союза, а в случаях, предусмотренных международными договорами, Правительством РФ.

В соответствии с международными договорами, решениями Комиссии в целях ЗГС могут вводиться специальные защитные, антидемпинговые и компенсационные меры при импорте товаров ${ }^{2}$.

По решению Президента внешняя торговля может быть ограничена в связи с участием РФ в международных санкциях в соответствии с Уставом ООН. Принимая такое решение, руководство РФ исходит из приоритета суверенных национальных интересов РФ.

${ }^{1}$ Постановление Правительства РФ от 9 июня 2005 г. № 364 «Об утверждении Положения о лицензировании в сфере внешней торговли товарами».

2 Конституционно-правовое регулирование применения указанных мер в интересах ЗГС подробно рассмотрено в самостоятельном разделе данной главы. 
В целях защиты внешнего финансового положения и поддержания равновесия платежного баланса РФ Правительство по представлению Центрального банка РФ может ввести ряд мер ограничения внешней торговли товарами, услугами и интеллектуальной собственностью. Данные меры касаются количественных ограничений, предоставления товарам иностранного государства (групп иностранных государств) или иностранным исполнителям услуг иного режима регулирования, взимания платежей в связи с импортом и экспортом. Указанные меры вводятся для решения задач:

- остановки серьезного сокращения валютных резервов РФ или предотвращения подобной угрозы;

- достижения разумного темпа увеличения валютных резервов РФ.

Эффективным методом ЗГС в области внешнеторговой деятельности может служить введение ответных мер.

Правительство принимает решение о введении ответных мер в случае, если иностранное государство:

не выполняет принятые им по международным договорам обязательства в отношении РФ;

предпринимает меры, которые нарушают экономические интересы РФ, субъектов РФ, муниципальных образований или российских лиц либо политические интересы РФ, в том числе меры, которые необоснованно закрывают российским лицам доступ на рынок иностранного государства или иным образом необоснованно дискриминируют российских лиц;

не предоставляет российским лицам адекватную и эффективную защиту их законных интересов в этом государстве (например, защиту от антиконкурентной деятельности других лиц);

не предпринимает разумных действий для борьбы с противоправной деятельностью физических или юридических лиц этого государства на территории РФ.

Предложения о введении ответных мер представляются в 
Правительство Минпромторгом России после согласования с Министерством иностранных дел.

Проведенный анализ конституционно-правовых механизмов ЗГС в области внешней торговли, государственных методов регулирования и реализации торговой политики свидетельствует о разнонаправленности и взаимосвязи доминирующих векторов регулирования правоотношений в охраняемой государством сфере.

С одной стороны, конституционно-правовое регулирование внешнеторговой деятельности ориентировано на развитие внешнеторговых отношений с иностранными государствами и стимулирование прогрессивных структурных изменений в национальной экономике. С другой стороны, предусмотренный законодателем комплекс запретов и ограничений внешней торговли товарами, услугами и интеллектуальной собственностью направлен на противодействие антиконкурентной деятельности и попыток ослабления и подрыва государственного суверенитета извне с помощью экономических, административных и иных методов.

Четко прослеживается и другая закономерность. Создание благоприятных условий для российских товаров, услуг и интеллектуальной собственности на зарубежных рынках, недискриминационное отношение к российским экспортерам ведут к предоставлению иностранным партнерам РФ соответствующих режимов благоприятствования и преференций на основе взаимности. И напротив: ущемление российских производителей, использование механизмов недобросовестной конкуренции, установление необоснованных экономических и торговых барьеров влечет применение РФ защитных мер, ответных запретов и ограничений.

Одной из экономических основ государственного суверенитета выступает государственное имущество. Конституичионно-правовое регулирование распоряжения и управления государственным имуществом является суверенной прерогативой государства, поскольку позволяет органам 
власти сосредотачивать и использовать ресурсы для решения важнейших национальных задач, обеспечивать устойчивое развитие экономики, гарантировать надежную оборону и безопасность государства, защиту экономических интересов и имущественных прав.

Как отмечается в Постановлении Правительства РФ от 15 апреля 2014 г. № 327 «Об утверждении государственной программы Российской Федерации «Управление федеральным имуществом», «государственная политика по управлению федеральным имуществом направлена на достижение следующих целей:

создание условий для эффективного управления федеральным имуществом, необходимым для выполнения государственных функций органами государственной власти РФ, и отчуждения федерального имущества, востребованного в коммерческом обороте;

совершенствование системы государственного материального резерва, повышение ее роли в позитивных процессах, происходящих в экономике и политике РФ и направленных на укрепление экономической независимости и национальной безопасности государства».

Достижение указанных целей призвано обеспечить:

оптимизацию состава и структуры федерального имущества в интересах обеспечения устойчивых предпосылок для экономического роста, a также формирование экономической основы деятельности РФ и ее субъектов;

повышение эффективности управления федеральным имуществом, включая развитие конкурентоспособности и инвестиционной привлекательности компаний с государственным участием, повышение уровня их корпоративного управления и информационной прозрачности;

замещение прямого участия государства в экономике мерами отраслевого и иного регулирования, создание условий для привлечения инвестиций, стимулирования развития фондового рынка, a также 
модернизации и технологического развития экономики.

В соответствии с Постановлением Правительства РФ от 5 июня 2008 г. № 432 «О Федеральном агентстве по управлению государственным имуществом» функции по управлению федеральным имуществом, функции по организации продажи приватизируемого федерального имущества, реализации арестованного, конфискованного, движимого бесхозного, изъятого и иного имущества, обращенного в собственность государства, функции по оказанию государственных услуг и правоприменительные функции в сфере имущественных и земельных отношений возложены на Федеральное агентство по управлению государственным имуществом (Росимущество).

Данный государственный орган осуществляет функции в области приватизации и полномочия собственника, в том числе права акционера и участника общества с ограниченной ответственностью, в сфере управления имуществом РФ.

Для защиты имущественных и иных прав и законных интересов РФ Росимущество:

выступает от имени РФ при государственной регистрации права собственности РФ на недвижимое имущество, составляющее государственную казну РФ, и сделок с ним, а также права собственности РФ на земельные участки, которое возникает в соответствии с федеральными законами;

осуществляет контроль за управлением, распоряжением, использованием по назначению и сохранностью земельных участков, находящихся в федеральной собственности, иного федерального имущества, закрепленного в хозяйственном ведении или оперативном управлении федеральных государственных унитарных предприятий и федеральных государственных учреждений, а также переданного иным лицам, и при выявлении нарушений принимает необходимые меры по их устранению и 
привлечению виновных лиц к ответственности ${ }^{1}$;

организует и проводит проверки эффективного использования и обеспечения сохранности федерального имущества, закрепленного за федеральными государственными унитарными предприятиями, федеральными казенными предприятияи и федеральными государственными учреждениями;

обращается в суды с исками и в правоохранительные органы с заявлениями от имени РФ в защиту имущественных и иных прав и законных интересов РФ по вопросам приватизации, управления и распоряжения федеральным имуществом, а также признания движимого имущества бесхозяйным.

Уникальным фрагментом имущества казны РФ является государственный материальный резерв, в состав которого входят запасы материальных ценностей для мобилизационных нужд РФ (в том числе мобилизационный резерв), запасы стратегических материалов и товаров, запасы материальных ценностей для обеспечения неотложных работ при ликвидации последствий чрезвычайных ситуаций.

В соответствии со статьей 3 Федерального закона от 29 декабря 1994 г. № 79-Ф3 «О государственном материальном резерве» государственный резерв предназначен для:

обеспечения мобилизационных нужд РФ;

обеспечения неотложных работ при ликвидации последствий чрезвычайных ситуаций;

\footnotetext{
${ }^{1}$ Согласно статье 5 Федерального закона от 5 апреля 2013 г. № 41-Ф3 «О Счетной палате Российской Федерации» задача определения эффективности и соответствия нормативным правовым актам РФ порядка формирования, управления и распоряжения федеральной собственностью возложена на Счетную палату РФ. В соответствии со статьей 9 Федерального закона от 7 февраля 2011 г. № 6-Ф3 «Об общих принципах организации и деятельности контрольно-счетных органов субъектов Российской Федерации и муниципальных образований» контроль за соблюдением установленного порядка управления и распоряжения имуществом, находящимся в собственности субъекта РФ, осуществляет контрольно-счетный орган субъекта РФ. Подробнее о полномочиях Счетной палаты и контрольно-счетных органов см. самостоятельный раздел данной главы.
} 
оказания государственной поддержки различным отраслям экономики, организациям, субъектам РФ в целях стабилизации экономики при временных нарушениях снабжения важнейшими видами сырьевых и топливно-энергетических ресурсов, продовольствия в случае возникновения диспропорций между спросом и предложением на внутреннем рынке;

оказания гуманитарной помощи;

оказания регулирующего воздействия на рынок (товарные интервенции).

Порядок управления государственным резервом определяется Правительством РФ. Формирование, хранение и обслуживание запасов государственного резерва обеспечивается федеральным органом исполнительной власти, осуществляющим управление государственным резервом (Росрезерв), его территориальными органами и подведомственными организациями.

Законодателем установлены особые характеристики данного вида государственного имущества.

1. Ограничения (обременения) имущуества и вещуных прав. Государственный резерв не подлежит приватизации. Запасы материальных ценностей в составе государственного резерва не могут быть использованы в качестве предмета залога.

2. Обязательное постоянное пополнение запасов материальных цุенностей. В составе государственного резерва образуется неснижаемый запас материальных ценностей.

3. Дополнительные обязанности поставщчиков. Поставщики, занимающие доминирующее положение на товарном рынке, а также предприятия, в объеме производства которых государственный оборонный заказ превышает 70\%, не вправе отказаться от заключения государственных контрактов на поставку материальных ценностей в государственный резерв. 
4. Повыщенная имущуественная ответственность по операциям с материальныли цеенностями. За недопоставку, неполную закладку материальных ценностей в государственный резерв поставщик (ответственный хранитель) уплачивает штраф в размере 50\% стоимости недопоставленных, незаложенных материальных ценностей. За поставку, закладку в государственный резерв материальных ценностей, непригодных для длительного хранения, некомплектных или не соответствующих по своему качеству или ассортименту условиям государственного контракта поставщик (ответственный хранитель) уплачивает штраф в размере 20\% стоимости забракованных (не соответствующих условиям государственного контракта) материальных ценностей. Аналогичный штраф уплачивается ответственным хранителем в случае нарушения правил и условий хранения материальных ценностей, несвоевременного освежения запасов и замены материальных ценностей государственного резерва.

5. Особый правовой режим защчиты сведений об этом виде государственного имущуества. Сведения о нормах накопления, о поставке, выпуске, закладке, об освежении, дислокации и фактических запасах государственного резерва являются государственной тайной.

Конституционно-правовое регулирование распоряжения и управления государственным имуществом РФ находится в тесной связи с конституцุионно-правовым регулированием юрисдикциионных иммунитетов и имущуества иностранного государства в Российской Федераџии.

Развитие внешнеэкономической деятельности, упразднение государственной монополии на внешнюю торговлю, привлечение иностранного капитала в РФ стали причиной того, что РФ заключила ряд двусторонних международных соглашений о взаимной защите и поощрении капиталовложений. Положения многочисленных двусторонних международных соглашений содержат условия о разрешении споров по поводу осуществления иностранных инвестиций в международном 
коммерческом арбитраже, что означает отказ государства от абсолютного иммунитета применительно к частноправовым отношениям.

Федеральный закон от 3 ноября 2015 г. № 297-Ф3 «О юрисдикционных иммунитетах иностранного государства и имущества иностранного государства в Российской Федерации» законодательно закрепил концепцию функционального (ограниченного) иммунитета иностранного государства и его собственности с учетом реалий международного экономического сотрудничества и потребности защиты интересов физических и юридических лиц, выступающих в качестве контрагентов во взаимоотношениях с иностранным государством ${ }^{1}$. Целью данного закона является создание правовой основы участия иностранного государства в международных частноправовых отношениях в качестве субъекта международного частного права.

Согласно Федеральному закону «О юрисдикционных иммунитетах иностранного государства и имущества иностранного государства в Российской Федерации» иностранное государство пользуется в РФ юрисдикционным иммунитетом, за изъятиями, к которым относятся:

- отказ от судебного иммунитета;

- отказ от иммунитета в отношении мер по обеспечению иска;

- отказ в отношении исполнения решения суда.

Действие закона не затрагивает привилегии и иммунитеты дипломатических представительств, консульских учреждений, специальных миссий иностранного государства, представительств при международных организациях или делегаций в органах международных организаций либо на международных конференциях. Закон не распространяется на привилегии и иммунитеты глав государств, правительств или министров иностранных дел.

K имуществу, используемому только в целях осуществления

1 Веселкова Е.Е. Концепция проекта Федерального закона «О юрисдикционном иммунитете иностранного государства и его собственности» // Адвокат. 2015. № 10. 
суверенной власти государства, отнесены воздушные суда и космические объекты, принадлежащие иностранному государству или эксплуатируемые им, а также военные корабли и другие эксплуатируемые в некоммерческих целях государственные суда.

Иммунитетом в отношении мер по обеспечению иска и иммунитетом в отношении исполнения решения суда пользуется имущество иностранного государства, используемое или предназначенное для осуществления суверенных властных полномочий:

- имущество (в том числе денежные средства на банковском счете), используемое или предназначенное для осуществления функций дипломатических представительств иностранного государства или его консульских учреждений, специальных миссий, представительств при международных организациях, делегаций иностранного государства в органах международных организаций либо на международных конференциях;

- военное имущество или имущество, используемое либо предназначенное для использования в военных целях или в миротворческих операциях, признаваемых РФ$\Phi^{1}$;

- культурные ценности или архивы, не выставленные на продажу либо не предназначенные для продажи;

- имущество, являющееся частью экспозиций выставок, представляющее научный, культурный или исторический интерес и не выставленное на продажу либо не предназначенное для продажи;

- имущество центрального банка или иного органа банковского надзора иностранного государства.

Юрисдикционные иммунитеты иностранного государства и его

1 Важной особенностью ст. 16 Федерального закона «О юрисдикционных иммунитетах иностранного государства и имущества иностранного государства в Российской Федерации» является законодательное закрепление режима непризнания Российской Федерацией т.н. «гуманитарных интервенций» (непризнание «миротворческих операций», проводимых без санкции СБ ООН). 
имущества могут быть ограничены на основе принципа взаимности. Заключения по вопросу предоставления юрисдикционных иммунитетов РФ и ее имуществу в иностранном государстве дает МИД России.

Конституционно-правовое регулирование юрисдикционных иммунитетов и имущества иностранного государства обеспечивает единый подход к упорядочению общественных отношений в частноправовой сфере с участием иностранного государства, способствует защите экономических интересов государства и его собственности.

Ключевым элементом ЗГС выступает конституц̧ионно-правовое регулирование обеспечения продовольственной безопасности Российской Федерациии.

Как отмечается в Указе Президента РФ от 30 января 2010 г. № 120 «Об утверждении Доктрины продовольственной безопасности Российской Федерации», «продовольственная безопасность является фактором сохранения государственности и суверенитета, важнейшей составляющей демографической политики».

Стратегической целью продовольственной безопасности является обеспечение населения страны безопасной сельскохозяйственной продукцией, рыбной продукцией и продовольствием. Гарантией ее достижения является стабильность внутреннего производства, а также наличие необходимых резервов и запасов.

Современные угрозы продовольственной безопасности РФ обусловлены деградацией материально-технической базы сельскохозяйственного производства, недостаточным развитием инфраструктуры внутреннего рынка, инновационной и инвестиционной активности в сфере производства сельскохозяйственной и рыбной продукции, сырья и продовольствия, сокращением национальных генетических ресурсов животных и растений, уменьшением площадей сельскохозяйственных угодий, снижением плодородия почв, значительной 
зависимостью от импортных поставок продуктов питания и контрабандой отдельных видов сырья и пищевых продуктов, запрет на ввоз которых связан с введением иностранными государствами экономических санкций в отношении РФ. Проводимая Правительством политика импортозамещения способствовала увеличению в 2015 г. объемов производства агропромышленного комплекса на 2,9 \%. Вместе с тем недостаточная обеспеченность кормами в животноводстве, зависимость от импорта семенного и генетического материала, ветеринарных препаратов, а также от современных технических средств формируют риски снижения объемов производства в сельском хозяйстве и ухудшения уровня обеспечения продовольственной безопасности в ближайшие годы.

В соответствии с Доктриной продовольственной безопасности Российской Федерации (раздел I) основными задачами обеспечения продовольственной безопасности являются:

своевременное прогнозирование, выявление и предотвращение внутренних и внешних угроз продовольственной безопасности, минимизация их негативных последствий за счет постоянной готовности системы обеспечения граждан пищевыми продуктами, формирования стратегических запасов пищевых продуктов;

устойчивое развитие отечественного производства продовольствия и сырья, достаточное для обеспечения продовольственной независимости страны;

достижение и поддержание физической и экономической доступности для каждого гражданина страны безопасных пищевых продуктов в объемах и ассортименте, которые соответствуют установленным рациональным нормам потребления пищевых продуктов, необходимых для активного и здорового образа жизни;

обеспечение безопасности пищевых продуктов.

К числу ключевых мер государственного регулирования в области 
обеспечения продовольственной безопасности Доктриной продовольственной безопасности Российской Федерации отнесены: контроль соответствия требованиям безопасности пищевых продуктов сельскохозяйственной, рыбной продукции и продовольствия на всех стадиях их производства, хранения, транспортировки, переработки и реализации; определение норм накопления сырья и продовольствия в составе государственного материального резерва; регулирование рынка сельскохозяйственной и рыбной продукции, сырья и продовольствия в части повышения оперативности и устранения ценовых диспропорций на рынках сельскохозяйственной и рыбной продукции и материально-технических ресурсов; таможенно-тарифное регулирование для целей рационализации соотношения экспорта и импорта сельскохозяйственной и рыбной продукции, сырья и продовольствия; введение защитных мер при растущем импорте сельскохозяйственной и рыбной продукции, сырья и продовольствия, а также в случаях демпинга и применения в зарубежных странах субсидий при их экспорте ${ }^{1}$.

Важнейшее место в системе конституционно-правовой защиты государственного суверенитета занимает правовая регламентация действий государства по защите своего суверенитета и населения в условиях открытого вооруженного вторжения иностранного государства (союза государств), составной частью которой выступает конституциионно-правовое регулирование мобилизационной подготовки, мобилизацчии и государственного оборонного заказа.

Конституционно-правовое регулирование мобилизационной подготовки и мобилизации в РФ осуществляется в соответствии с Федеральным законом от 26 февраля 1997 г. № 31-Ф3 «О мобилизационной

1 Применение защитных и антидемпинговых мер направлено на преодоление искусственных конкурентных преимуществ зарубежной продукции, формируемых за счет различных мер государственной поддержки производства пищевых продуктов в зарубежных странах. 
подготовке и мобилизации в Российской Федерации».

Под мобилизационной подготовкой понимается комплекс мероприятий, проводимых в мирное время, по заблаговременной подготовке экономики РФ, экономики субъектов РФ и экономики муниципальных образований, подготовке органов государственной власти, органов местного самоуправления и организаций, подготовке Вооруженных Сил, других войск, воинских формирований, органов и создаваемых на военное время специальных формирований к обеспечению защиты государства от вооруженного нападения и удовлетворению потребностей государства и нужд населения в военное время. Мобилизация подразумевает комплекс мероприятий по переводу экономики РФ, экономики субъектов РФ и экономики муниципальных образований, переводу органов государственной власти, органов местного самоуправления и организаций на работу в условиях военного времени, переводу Вооруженных Сил, других войск, воинских формирований, органов и специальных формирований на организацию и состав военного времени.

Согласно части 3 статьи 2 Федерального закона «О мобилизационной подготовке и мобилизации в Российской Федерации» в содержание мобилизационной подготовки и мобилизации входят:

нормативное правовое регулирование в области мобилизационной подготовки и мобилизации;

определение условий работы и подготовка органов государственной власти, органов местного самоуправления и организаций к работе в период мобилизации и в военное время;

проведение мероприятий по переводу органов государственной власти, органов местного самоуправления и организаций на работу в условиях военного времени;

подготовка Вооруженных Сил, других войск, воинских формирований, органов и специальных формирований к мобилизации; 
проведение мобилизации Вооруженных Сил, других войск, воинских формирований, органов и специальных формирований;

разработка мобилизационных планов экономики РФ, экономики субъектов РФ и экономики муниципальных образований, мобилизационных планов Вооруженных Сил, других войск, воинских формирований, органов и специальных формирований;

подготовка экономики РФ, экономики субъектов РФ и экономики муниципальных образований, подготовка организаций к работе в период мобилизации и в военное время;

проведение мероприятий по переводу экономики РФ, экономики субъектов РФ и экономики муниципальных образований, переводу организаций на работу в условиях военного времени;

оценка состояния мобилизационной готовности РФ;

создание, развитие и сохранение мобилизационных мощностей и объектов для производства продукции, необходимой для удовлетворения потребностей государства, Вооруженных Сил, других войск, воинских формирований, органов и специальных формирований и нужд населения в военное время;

создание и подготовка специальных формирований, предназначенных при объявлении мобилизации для передачи в Вооруженные Силы или использования в их интересах, а также в интересах экономики РФ;

подготовка техники, предназначенной при объявлении мобилизации для поставки в Вооруженные Силы, другие войска, воинские формирования, органы и специальные формирования или использования в их интересах;

создание в составе государственного материального резерва запасов материальных ценностей (в том числе запаса мобилизационного резерва и неснижаемого запаса государственного материального резерва), предназначенных для мобилизационных нужд РФ;

подготовка и организация нормированного снабжения населения 
продовольственными и непродовольственными товарами, его медицинского обслуживания и обеспечения средствами связи и транспортными средствами в период мобилизации и в военное время;

создание запасных пунктов управления органов государственной власти, органов местного самоуправления и организаций и подготовка указанных пунктов управления к работе в условиях военного времени;

подготовка СМИ к работе в период мобилизации и в военное время; организация воинского учета;

создание и переподготовка квалифицированного запаса Вооруженных Сил, запаса СВР и ФСБ России;

подготовка граждан по военно-учетным специальностям для комплектования Вооруженных Сил, других войск, воинских формирований, органов и специальных формирований в период мобилизации и в военное время;

бронирование на период мобилизации и на военное время граждан, пребывающих в запасе Вооруженных Сил, федеральных органов исполнительной власти, и работающих в органах государственной власти, органах местного самоуправления и организациях;

проведение учений и тренировок по мобилизационному развертыванию и выполнению мобилизационных планов и др.

Согласно Указу Президента РФ от 15 марта 1999 г. № 350 «Об утверждении Положения о Службе специальных объектов при Президенте Российской Федерации» федеральным органом обеспечения мобилизационной подготовки органов государственной власти РФ является Служба специальных объектов при Президенте РФ.

Особенностью конституционно-правового регулирования мобилизационной подготовки и мобилизации в целях ЗГС является наличие императивных норм, определяющих обязанности органов государственной власти, муниципальных органов, организаций и граждан при объявлении 
мобилизации.

Так, органы государственной власти и органы местного самоуправления обязаны: разрабатывать мобилизационные планы и проводить мероприятия по их выполнению; оказывать содействие военным комиссариатам в организации своевременного оповещения и явки граждан, предоставлять здания, сооружения, коммуникации, земельные участки; организовывать бронирование граждан на период мобилизации и на военное время; предоставлять транспортные средства для обеспечения Вооруженных Сил, других войск, воинских формирований, органов и специальных формирований (военно-транспортная обязанность) и др.

Организации обязаны проводить мероприятия по переводу производства на работу в условиях военного времени, оказывать содействие военным комиссариатам, предоставлять здания, сооружения, коммуникации, земельные участки, транспортные и другие материальные средства в соответствии с планами мобилизации. Организации обязаны заключать договоры (контракты) о выполнении мобилизационных заданий (заказов) в целях обороны страны и безопасности государства, если с учетом мобилизационного развертывания их возможности позволяют выполнить эти задания (заказы) $)^{1}$.

На граждан возлагаются обязанности: выполнять требования мобилизационных предписаний, повесток и распоряжений военных комиссариатов; предоставлять в военное время здания, сооружения, транспортные средства и другое имущество, находящееся в их собственности, с возмещением государством понесенных ими убытков; участвовать в выполнении работ в целях обеспечения обороны страны и безопасности государства и др.

Должностные лица органов государственной власти, органов местного

${ }^{1}$ Порядок возмещения убытков, понесенных организациями в связи с выполнением мобилизационных заданий (заказов), определяется Правительством РФ. 
самоуправления и организаций несут персональную ответственность за исполнение возложенных на них обязанностей в области мобилизационной подготовки и мобилизации.

Основы конституционно-правового регулирования отношений, связанных с формированием, размещением, выполнением государственного оборонного заказа и государственного контроля (надзора) в сфере государственного оборонного заказа, установлены Федеральным законом от 29 декабря 2012 г. № 275-Ф3 «О государственном оборонном заказе», федеральными законами в области обороны и безопасности, законодательством о контрактной системе в сфере закупок товаров, работ, услуг для обеспечения государственных и муниципальных нужд, а также принимаемыми в соответствии с ними иными нормативными правовыми актами.

Под государственным оборонным заказом (далее - ГОЗ) понимаются установленные нормативным правовым актом Правительства РФ задания на поставки товаров, выполнение работ, оказание услуг для федеральных нужд в целях обеспечения обороны и безопасности РФ, а также поставки продукции в области военно-технического сотрудничества РФ с иностранными государствами в соответствии с международными обязательствами РФ.

В состав ГОЗ включаются:

- научно-исследовательские и опытно-конструкторские работы по созданию, модернизации вооружения, военной и специальной техники, а также утилизации и уничтожению выводимых из эксплуатации вооружения, военной и специальной техники;

- научно-исследовательские и опытно-конструкторские работы по развитию исследовательской, проектно-конструкторской и производственнотехнологической базы организаций в целях обеспечения выполнения ГОЗ, а также повышения мобилизационной подготовки экономики РФ; 
- поставки вооружения, военной и специальной техники, а также сырья, материалов и комплектующих изделий;

- поставки военного имущества, продовольственных и непродовольственных товаров;

- ремонт, модернизация вооружения, военной и специальной техники, их сервисное обслуживание, а также утилизация выводимых из эксплуатации вооружения, военной и специальной техники;

- работы по уничтожению химического оружия;

- работы по строительству, реконструкции, техническому перевооружению объектов, предназначенных для нужд обеспечения обороны и безопасности РФ, в том числе для утилизации выводимых из эксплуатации вооружения, военной и специальной техники;

- работы по мобилизационной подготовке экономики РФ;

- поставки продукции в области военно-технического сотрудничества РФ с иностранными государствами;

- поставки продукции для накопления материальных ценностей государственного материального резерва;

- иные поставки продукции в целях обеспечения обороны и безопасности РФ.

Для выполнения ГОЗ устанавливаются квоты обязательных поставок (государственное бронирование) важнейших видов материально-технических ресурсов государственному заказчику, головному исполнителю, исполнителю организациями-поставщиками, организациями-изготовителями независимо от их организационно-правовых форм.

ГО3, мероприятия по его выполнению и сроки размещения утверждаются Правительством РФ.

Правительство в целях обеспечения и стимулирования выполнения ГОЗ вправе:

определять примерные условия государственных контрактов и 
контрактов;

устанавливать сроки размещения заданий ГО3;

устанавливать предельный уровень прибыли при расчете цены на продукцию по ГОЗ;

предусматривать головным исполнителям, исполнителям бюджетные ассигнования на осуществление бюджетных инвестиций;

устанавливать при утверждении ГОЗ размер авансовых платежей по государственному контракту;

предоставлять государственные гарантии Российской Федерации по кредитам, привлекаемым головными исполнителями, исполнителями для осуществления деятельности в целях обеспечения выполнения ГОЗ;

предоставлять головным исполнителям, исполнителям субсидии на возмещение части затрат на уплату процентов по кредитам, полученным в российских кредитных организациях;

предоставлять головным исполнителям, исполнителям субсидии в целях предупреждения несостоятельности (банкротства).

Расчеты по ГОЗ осуществляются в рамках правового режима отдельного счета, открытого головному исполнителю (исполнителю) в уполномоченном банке.

Уполномоченный банк должен соответствовать ряду законодательных критериев: должен быть создан в соответствии с законодательством РФ; должен иметь собственные средства (капитал) по состоянию на первое число отчетного месяца в размере не менее 100 млрд. рублей; должен находиться под контролем РФ или Банка России ${ }^{1}$; должен иметь лицензию на проведение

\footnotetext{
${ }^{1}$ В соответствии со ст. 8.1 Федерального закона от 29 декабря 2012 г. № 275-Ф3 «О государственном оборонном заказе» под контролем РФ или Банка России понимается возможность РФ или Банка России прямо или косвенно (через юридическое лицо или через несколько юридических лиц) определять решения, принимаемые банком посредством распоряжения более чем $50 \%$ общего числа голосов, приходящихся на голосующие акции (доли), составляющие уставный капитал банка, назначать (избирать) единоличный исполнительный орган и (или) более 50\% состава наблюдательного совета (совета директоров) банка.
} 
работ, связанных с использованием сведений, составляющих государственную тайну.

Правовой режим отдельного счета предусматривает:

- списание денежных средств только при указании в распоряжении идентификатора государственного контракта (уникального номера, присваиваемого конкретному государственному контракту);

- списание денежных средств только на отдельный счет (за исключением уплаты налогов и сборов, таможенных платежей, страховых взносов в Пенсионный фонд РФ, Фонд социального страхования РФ, совершения иных разрешенных операций и расходов);

- запрет совершения ряда операций (предоставление ссуд, займов, кредитов; приобретение иностранной валюты; покупка ценных бумаг; предоставление гарантий обеспечения исполнения обязательств; списание денежных средств на иные счета, открытые в кредитных организациях и др.).

Росфинмониторинг анализирует информацию о банковских операциях и расчетах уполномоченного банка, и в случае возникновения рисков неисполнения государственного контракта сообщает об этом государственному заказчику.

Федеральный закон «О государственном оборонном заказе» устанавливает особенности государственного контроля (надзора) в сфере ГО3, в том числе: порядок проведения проверок соблюдения государственными заказчиками, головными исполнителями, исполнителями, федеральными органами исполнительной власти, организациями законодательства в сфере ГОЗ; порядок возбуждения и рассмотрения дел о нарушении законодательства в сфере ГОЗ; порядок обжалования решений и предписаний контролирующего органа.

В рамках укрепления военно-политических позиций, обеспечения экономических интересов и ЗГС Российской Федерации за рубежом обязательному изучению должно подвергаться конституцчионно-правовое 
регулирование военно-технического сотрудничества с иностранныли государствами.

Суверенитет РФ в сфере военно-технического сотрудничества (далее ВТС) обеспечивается:

- регламентированием ВТС в соответствии с военно-политическими и экономическими интересами РФ;

- исключительными полномочиями федеральных органов государственной власти в сфере ВТС;

- введением разрешительного порядка экспорта и импорта продукции военного назначения;

- проведением единой государственной политики в области формирования внешнеторговых цен на продукцию военного назначения;

- обеспечением бюджетного финансирования экспорта и импорта продукции военного назначения, осуществляемых во исполнение международных обязательств РФ.

Одним из основных принципов государственной политики при осуществлении ВТС РФ с иностранными государствами является государственная монополия в сфере ВТС. Монополия государства в сфере ВТС включает следующие элементы:

лицензирование разработки, производства продукции военного назначения, определение порядка ввоза и вывоза, продажи и закупки продукции военного назначения, разрешительный порядок деятельности в cфepe BTC;

систему экспортного контроля при осуществлении внешнеторговой деятельности в отношении продукции военного назначения в целях обеспечения обороны, безопасности и экономической стабильности РФ, защиты ее внутреннего рынка, сохранения и упрочения ее политических и стратегических позиций, соблюдения международных обязательств по сокращению и ликвидации вооружения, а также по нераспространению 
оружия массового поражения ${ }^{1}$;

определение порядка предоставления российским организациям права на осуществление внешнеторговой деятельности в отношении продукции военного назначения;

лицензирование ввоза и вывоза продукции военного назначения;

недопущение в РФ монополии одного субъекта ВТС;

недопущение участия в ВТС российских организаций, не получивших права на осуществление внешнеторговой деятельности в отношении продукции военного назначения;

недопущение конкуренции на внешнем рынке нескольких российских субъектов ВТС посредством разделения сфер их деятельности;

таможенное регулирование ввоза и вывоза продукции военного назначения, в том числе экспортно-импортных операций в области ВТС;

недопущение передачи иностранным заказчикам результатов интеллектуальной деятельности без определения условий их использования и (или) обеспечения их правовой охраны;

координация федеральными органами государственной власти деятельности в сфере ВТС и осуществление государственного контроля за этой деятельностью².

Государственный контроль осуществляется за:

- соответствием деятельности уполномоченных государственных органов и субъектов ВТС законодательству РФ, целям и принципам государственной политики в сфере ВТС;

- эффективностью системы государственного регулирования и использования бюджетных средств в сфере ВТС;

1 В настоящее время отчетливо прослеживается тенденция продвижения Европейским союзом Международного договора о торговле оружием, с помощью которого предпринимается попытка распространить нормы экспортного контроля ЕС на страны - участницы соглашения и ограничить передачу вооружений неугодных Западу государствам.

2 Статья 5 Федерального закона от 19 июля 1998 г. № 114-Ф3 «О военнотехническом сотрудничестве Российской Федерации с иностранными государствами». 
- эффективностью использования федеральной собственности субъектами ВТС;

- ценообразованием на экспортируемую продукцию военного назначения с учетом экономических интересов РФ, поступлением, движением и использованием доходов, получаемых от экспорта продукции военного назначения;

- соблюдением международных обязательств РФ в сфере ВТС;

- исполнением нормативных правовых актов в сфере ВТС;

- обеспечением охраны и защиты прав РФ на результаты интеллектуальной деятельности в ходе ВТС.

ВТС может быть связано не только с развитием военного производства, научно-технической базы, укреплением стратегических позиций государства, наращиванием его экспортного потенциала, но и нести в себе угрозы жизни и здоровью военнослужащих и технических специалистов, осуществляющих военно-техническое сопровождение поставок продукции военного назначения, наносить ущерб безопасности и внешнеполитическим интересам PФ.

Так, в современных условиях крупномасштабной террористической угрозой становится расширение инфраструктуры нелегального производства, ремонта, модернизации, транспортировки и контрабандного распространения оружия и боеприпасов в зоны вооруженных конфликтов ${ }^{1}$. Эту деятельность стремятся финансировать и контролировать организованные преступные формирования и международные террористические организации.

Заметную угрозу представляют посягательства на жизнь и здоровье, попытки захвата в заложники военно-технического персонала РФ, командируемого в регионы повышенной террористической активности (Афганистан, Алжир, Пакистан, Сирия, Ирак, Египет, Ливия, Йемен и др.).

\footnotetext{
1 Зарубежное военное обозрение. 2015. № 12. С. 116.
} 
Особые опасения вызывают намерения экстремистских объединений и террористических организаций получить новейшие средства вооружения, доступ к оружию массового поражения, его компонентам и технологиям производства.

Для снижения уязвимости ВТС и предотвращения террористических угроз необходима реализация комплекса мер:

- определение основных террористических угроз, устремлений организованных преступных групп и незаконных вооруженных формирований, иностранных разведорганов, вскрытие каналов связи, финансирования и ресурсного обеспечения, поставки средств вооружения террористическим ячейкам и международным террористическим организациям, поиск лагерей подготовки боевиков, лабораторий по производству взрывчатых веществ и др. ${ }^{1}$;

- обеспечение безопасности переговорного процесса, защиты военной и технической информации в сфере ВТС, в том числе при организации визитов иностранных делегаций в рамках программ международного сотрудничества и технологического обмена, проведения международных выставок вооружения и военной техники, совместных учений ${ }^{2}$;

- проверка иностранных контрагентов-заказчиков (анализ аффилированных и учредительских связей; деятельности государственных и негосударственных организаций, направленной на получение доступа к технологиям создания оружия, инфраструктуры для его испытания и хранения, технологиям двойного назначения; изучение финансовых

\footnotetext{
${ }^{1}$ В соответствии с Приложением к Указу Президента РФ от 10 сентября 2005 г. № 1062 «Перечень федеральных органов исполнительной власти по координации и контролю в области военно-технического сотрудничества Российской Федерации с иностранными государствами, а также по решению других задач государственного регулирования в этой области» обеспечение данных мер возложено на СВР и ФСБ России.

2 Производители и разработчики получают в Межведомственной комиссии по защите государственной тайне экспертные заключения о возможности поставок иностранным государствам продукции военного назначения, составляющей государственную тайну. Планы мероприятий по защите государственной тайны при работе с иностранными делегациями в РФ и за рубежом согласуются с ФСБ России.
} 
показателей и др.) и сопровождение подготовки и подписания контрактов ${ }^{1}$; - оценка уязвимости каналов поставки вооружений и объектов инфраструктуры в ходе военно-технического сопровождения;

- обеспечение безопасности каналов поставки вооружений и комплектующих, транзита грузов;

- обеспечение безопасности объектов инфраструктуры в районах дислокации конечных потребителей и заказчиков военной продукции;

- обеспечение безопасности в районах непосредственного боевого применения вооружений.

Значимой задачей является недопущение передачи военных технологий и технологий двойного назначения в обход международных договоренностей ${ }^{2}$. В этой связи осуществляется контроль за передачей закрытой информации и военных технологий иностранным государствам, а также за порядком выдачи экспортных лицензий на поставки за рубеж обычных вооружений, технологий двойного назначения. В рамках этой работы принимаются меры по недопущению реэкспорта или передачи третьим странам продукции военного назначения, поставленной иностранным заказчикам, без согласия РФ.

В отношении товаров, работ, услуг, результатов интеллектуальной деятельности, которые могут быть использованы при создании оружия массового поражения, средств его доставки, иных видов вооружения и

${ }^{1}$ В соответствии с пп. «н» п. 12 Положения о порядке осуществления военнотехнического сотрудничества Российской Федерации с иностранными государствами (утверждено Указом Президента РФ от 10 сентября 2005 г. № 1062) организации, осуществляющие внешнеэкономическую деятельность в отношении продукции военного назначения, обязаны информировать Федеральную службу по военно-техническому сотрудничеству, Министерство обороны, СВР и ФСБ России о любых контактах с иностранными юридическими и физическими лицами по вопросам производства и поставки продукции военного назначения.

${ }^{2}$ В соответствии с ч.3 ст. 6 Федерального закона от 19 июля 1998 г. № 114-Ф3 «О военно-техническом сотрудничестве Российской Федерации с иностранными государствами» Президент РФ запрещает или ограничивает вывоз продукции военного назначения в отдельные государства в целях обеспечения выполнения решений СБ ООН о мерах по поддержанию или восстановлению международного мира и безопасности, а также в целях защиты национальных интересов РФ. 
военной техники либо при подготовке и совершении террористических актов, осуществляется экспортный контроль ${ }^{1}$.

В соответствии с Постановлением Правительства РФ от 30 декабря 2008 г. № 1079 «О совершенствовании государственного регулирования внешнеэкономической деятельности в отношении отдельных видов товаров и технологий в целях обеспечения национальной безопасности» внешнеэкономические операции с контролируемыми товарами и технологиями, предусматривающие их вывоз из РФ либо передачу иностранным лицам на территории РФ, осуществляются на основании разовых или генеральных лицензий, выдаваемых Федеральной службой по техническому и экспортному контролю.

Контроль за соблюдением внешнеполитических интересов РФ в области ВТС обеспечивается МИД России.

Данный комплекс мер обеспечения безопасности ВТС способствует поддержанию и развитию военных связей РФ, укрепляет защищенность персонала участников ВТC, содействует реализации единой внешнеполитической и торгово-экономической линии РФ.

Экономический рост, развитие конкурентоспособности и инвестиционной привлекательности российской экономики, модернизация производства невозможны без формирования правовой базы, регламентирующей привлечение российских и иностранных инвестиций ${ }^{2}$.

Конституцчионно-правовое регулирование российских и иностранных

${ }^{1}$ Статья 1 Федерального закона от 18 июля 1999 г. № 183-Ф3 «Об экспортном контроле».

2 Существующая динамика и структура инвестиций формируют угрозу модернизации и технологическому развитию российской экономики. Так, в последние годы наблюдается постоянное снижение инвестиций в основной капитал (в 2014 г. - на $2,7 \%$, в 2015 - на 5,5\%). В 2015 г. объем инвестиций составил 11,5 трлн. рублей (менее $20 \%$ ВВП). Структура инвестиций отражает зависимость инвестиционных процессов от внешних заимствований, усиление стагнационных тенденций в российской экономике, недостаточную стратегическую проработку вопросов территориального и отраслевого развития страны. Не отвечают задачам социально-экономического развития, обеспечения обороноспособности и безопасности государства инвестиции в модернизацию транспортной инфраструктуры. 
инвестищий в контексте защуиты государственного суверенитета включает несколько приоритетных направлений:

- конституционно-правовое регулирование возврата российского капитала и сокращения его неконтролируемого вывоза за рубеж;

- конституционно-правовое регулирование защиты российских организаций от поставок морально устаревших и материалоемких, энергоемких и ненаукоемких технологий, оборудования, конструкций и материалов в ходе инвестирования в капитальные вложения;

- конституционно-правовое регулирование иностранных инвестиций в хозяйственные общества, имеющие стратегическое значение для обеспечения обороны страны и безопасности государства.

Проблема неконтролируемого вывода капитала за рубеж и невозвращения из-за границы средств в иностранной валюте приобрела в настоящее время острый характер. Право собственности на большую часть российских негосударственных корпораций и их активов (до 80\%) регистрируется в оффшорных зонах, где осуществляется основная часть операций с их оборотом ${ }^{1}$. Целый ряд государств (территорий-оффшоров) уклоняется от обмена информацией с РФ для целей налогообложения ${ }^{2}$. По данным Минэкономразвития, только в 2015 г. чистый вывоз частного капитала из РФ оценивался в 57 млрд. долларов. Это свидетельствует о сохраняющихся масштабах уклонения от налогообложения и теневого перемещения прибыли в низконалоговые юрисдикции.

Для репатриации российского капитала и деоффшоризации национальной экономики законодателем введено налогообложение прибыли контролируемых иностранных компаний и организаций, имеющих

${ }^{1}$ Современный мир и геополитика / Отв. ред. М.А. Неймарк. М.: Канон РООИ «Реабилитация», 2015. С. 89.

2 Перечень государств (территорий), не обеспечивающих обмена информацией для целей налогообложения с РФ, утверждается ФНС России. В целях борьбы с оффшоризацией российской экономики целесообразно законодательно запретить перевод активов в государства и территории-оффшоры, с которыми не заключены соглашения об обмене налоговой информацией. 
контролируемые иностранные компании.

В целях борьбы с использованием низконалоговых юрисдикций (офшоров) для получения необоснованных преференций и налоговой выгоды, а также совершенствования налогообложения иностранных организаций был принят Федеральный закон от 24 ноября 2014 г. № 376-Ф3 «О внесении изменений в части первую и вторую Налогового кодекса Российской Федерации (в части налогообложения прибыли контролируемых иностранных компаний и доходов иностранных организаций)». В Налоговый кодекс были введены понятия «контролируемые иностранные компании», «контролирующие лица», «налоговые резиденты Российской Федерации».

Контролируемой иностранной компанией признается иностранная организация, удовлетворяющая одновременно всем следующим условиям:

- организация не признается налоговым резидентом РФ;

- ее контролирующими лицами являются юридические или физические лица, признаваемые налоговыми резидентами РФ;

- это иностранная структура без образования юридического лица ${ }^{1}$, контролирующими лицами которой являются организации и (или) физические лица, признаваемые налоговыми резидентами РФ.

Контролирующим лицом организации признается:

а) физическое или юридическое лицо, доля участия которого в организации более $25 \%$;

б) физическое или юридическое лицо (совместно с супругами и несовершеннолетними детьми), доля участия которого в организации более 10\%, если доля участия всех лиц - налоговых резидентов РФ в этой организации более $50 \%$;

в) лицо, осуществляющее контроль над такой организацией в своих

\footnotetext{
${ }^{1}$ Например, траст.
} 
интересах или в интересах своего супруга и несовершеннолетних детей ${ }^{1}$.

Лицо, являющееся налоговым резидентом РФ, вправе самостоятельно признать себя контролирующим лицом.

Если иностранная компания признается контролируемой, ее прибыль включается в состав дохода контролирующего лица в соответствующей доле владения. Порядок учета прибыли контролируемой иностранной компании зависит от того, заключен ли договор об избежании двойного налогообложения с государством, в котором находится контролируемая иностранная компания, и подлежит ли ее финансовая отчетность обязательном аудиту.

Новеллой Федерального закона от 24 ноября 2014 г. № 376-ФЗ является предусмотренная ст. 246.2 НК РФ возможность признания иностранной компании налоговым резидентом РФ. Признание налоговым резидентом РФ осуществляется в отношении иностранных компаний в соответствии с международным договором, а также в отношении иностранных компаний, местом фактического управления которыми является РФ. В этом случае весь доход этой иностранной компании подлежит налогообложению по правилам, установленным для российских организаций с уплатой налогов в бюджет РФ.

Налогоплательщики, признаваемые налоговыми резидентами РФ, уведомляют налоговый орган о своем участии в иностранных организациях, а также контролируемых иностранных компаниях, контролирующими лицами которых они являются.

Федеральным законом установлены штрафы за неуведомление (предоставление недостоверных данных) о контролируемых иностранных компаниях, об участии в иностранных организациях, а также за неуплату (неполную уплату) сумм налога в результате невключения в налоговую базу

${ }^{1}$ Под контролем понимается оказание или возможность оказывать определяющее влияние на решения, принимаемые контролируемой иностранной компанией, относительно распределения прибыли. 
доли прибыли контролируемой иностранной организации.

Кроме того, в целях повышения эффективности налогового контроля в рамках противодействия уклонению от налогообложения в РФ с помощью оффшорных компаний:

- ратифицирована Конвенция о взаимной административной помощи по налоговым делам. Положения данной Конвенции обеспечивают возможность обмена налоговой информации, включая проведение одновременных налоговых проверок со странами - участницами Конвенции, а также помощь по взиманию налогов на их территориях;

- утверждено Типовое межправительственное соглашение об обмене налоговой информацией. На основе данного Типового соглашения возможно заключение соответствующих двусторонних межправительственных соглашений с оффшорными и низконалоговыми юрисдикциями в целях противодействия использованию незаконных схем минимизации налогообложения.

Данные нормы направлены на обеспечение прозрачности ведения бизнеса, создание действенного механизма пресечения использования низконалоговых юрисдикций с целью создания необоснованных преференций и получения необоснованной налоговой выгоды.

Вместе с тем на практике сохраняется ряд острых проблем, связанных с деятельностью контролируемых компаний.

Во-первых, если компании не заявляют о своей аффилированности, установить ее весьма затруднительно. Возможным решением данной проблемы могло бы служить введение обязательной и официально публикуемой ежегодной отчетности о структуре группы и участниках компании (акционеры, вкладчики, выгодоприобретатели). Нарушение порядка предоставления такой информации в налоговые органы (сокрытие или предоставление недостоверной информации) должно наказываться адекватными санкциями. 
Во-вторых, вызывает озабоченность преднамеренно убыточная деятельность российских компаний, входящих в иностранные группы. Западные владельцы группы, как правило, рассматривают российские связанные компании как непрофильные, временные проекты и в связи с этим осуществляют на российской территории сомнительные финансовые операции и расходы. В силу этих причин контроль за убыточными предприятиями с иностранной собственностью, не приносящими налогов в бюджет, должен быть заметно усилен. На наш взгляд, целесообразно внести изменения в Налоговый кодекс Российской Федерации, в которых следует обязать контролируемые иностранные компании, организации, имеющие контролируемые иностранные компании, а также российские организации, учредителями которых являются иностранные компании, ежегодно представлять в налоговые органы сведения о структуре доходов и расходов, а также подробные данные об убыточных сделках и финансовых операциях. По результатам анализа представленной информации налоговые органы могли бы принимать решения о проверках конкретных операций и сделок, запрашивать соответствующие документы в рамках камеральных проверок.

Реализация предложенных мер позволила бы сократить количество сомнительных сделок и финансовых операций, а также снизить давление иностранных учредителей на российские дочерние компании.

Необходимо упомянуть и другой аспект проблемы «оффшоризации» экономики и утечки капиталов из России - низкую привлекательность российской юрисдикции, связанную с высокими инвестиционными рисками, недостатком квалифицированных юристов на рынке международных коммерческих услуг и уязвимостью российской судебной системы.

Обострившееся экономическое соперничество между государствами породило новый инструмент недобросовестной конкуренции аффилированность международного коммерческого арбитража и национальных судов государства, в котором этот арбитраж расположен. В 
связи с этим прослеживается двойственная тенденция:

С одной стороны, высшие политические и деловые круги ведущих государств наряду с другими методами конкурентной борьбы стремятся использовать органы судебной власти для реализации своих политических интересов и необоснованного распространения собственной юрисдикции на другие страны, иностранные организации и граждан ${ }^{1}$.

С другой стороны, учитывая уязвимость российской судебной системы ключевые представители отечественного бизнессообщества стремятся выводить заключаемые сделки на зарубежные арбитражные площадки и передавать споры в компетенцию международного арбитража.

Не случайно многие российские компании базируются в иностранных юрисдикциях: в оффшорах или тесно связанными с ними низконалоговыми юрисдикциями зарегистрировано от 70 до 90\% всех крупных отечественных компаний. Представители российского бизнеса стремятся искусственно привнести в отношения иностранный элемент и подчинить их иностранному праву. Так, в настоящее время популярен выбор в пользу английского права. Особенно часто по английскому праву совершаются сделки в области внешнеторговой поставки, сделки слияний и поглощений компаний, соглашения акционеров. Такое положение дел вызвано императивностью российского акционерного законодательства. Английское право, напротив, является гибким и диспозитивным, позволяет реализовать практически любые корпоративные запросы².

В.Д. Зорькин для решения этой и взаимосвязанной с ней других проблем справедливо предлагает наращивать привлекательность правовой системы России для международного арбитража, осваивать международный рынок коммерческих услуг, готовить специалистов, способных

Данная проблематика обсуждалась в рамках Второго Международного юридического форума в Санкт-Петербурге (май 2012 г.).

2 Зорькин В.Д. Право в условиях глобальных перемен. М.: Норма, 2013. С. 241, 242. 
конкурировать на этом рынке с зарубежными юристами, обеспечивать консультативную поддержку отечественным предпринимателям ${ }^{1}$.

Стратегическим инструментом предотвращения бесконтрольного вывоза капитала за рубеж является валютное регулирование и контроль.

Валютное регулирование - часть государственной валютной политики, направленной на установление порядка проведения операций с валютными ценностями, обеспечение устойчивости валюты РФ и стабильности внутреннего валютного рынка РФ. Валютный контроль предполагает проверку соблюдения правил реализации единой государственной валютной политики.

В ходе валютного регулирования и контроля первостепенное значение имеет решение проблемы предотвращения утечки капиталов за границу и их репатриации в РФ. Вывоз капитала, как правило, сопряжен с уклонением от уплаты налогов, нарушением требований валютного и иного законодательства, отмыванием денежных средств, коррупцией.

Как отмечают специалисты, «незаконно вывезенный из России капитал сформировался в основном за счет невозвращения: валютной выручки от экспортных операций под предлогом форс-мажорных и иных обстоятельств; авансовых платежей по импортным контрактам, не обеспеченным поставками товаров; валютных средств, необоснованно перечисленных на счета иностранных фирм в счет оплаты фиктивных услуг, прежде всего маркетинговых и консалтинговых; средств, образовавшихся путем искусственного завышения экспортных цен и осуществления неэквивалентных бартерных сделок; а также вследствие вывоза частными лицами наличной валюты и средств с использованием страховых технологий» ${ }^{2}$.

1 Зорькин В.Д. Указ. соч. С. 131.

${ }^{2}$ Колядинский М.А. Валютный контроль и экономическая безопасность Российской Федерации // Законодательство. 2002. № 4. Помимо перечисленных притворных 
В соответствии со статьей 5 Федерального закона от 10 декабря 2003 г. № 173-Ф3 «О валютном регулировании и валютном контроле» органами валютного регулирования в Российской Федерации являются Центральный банк РФ и Правительство РФ. Центральный банк устанавливает единый формы учета и отчетности по валютным операциям, порядок и сроки их представления, а также готовит и опубликовывает статистическую информацию по валютным операциям.

В целях предотвращения существенного сокращения золотовалютных резервов, резких колебаний курса валюты, а также для поддержания устойчивости платежного баланса РФ в Законе установлены некоторые ограничения в отношении валютных операций: запрет валютных операций между резидентами (кроме операций, предусмотренных пунктом 9 части 1 статьи 1, частями 2-4 статьи 9, частью 6 статьи 12 и частью 3 статьи 14 Федерального закона «О валютном регулировании и валютном контроле»); открытие нерезидентами на территории РФ банковских счетов (вкладов) только в уполномоченных банках; осуществление валютных операций между нерезидентами на территории РФ в валюте РФ через банковские счета (банковские вклады), открытые на российской территории; купля-продажи иностранной валюты и чеков в РФ только через уполномоченные банки.

7 мая 2013 г. был принят Федеральный закон «О запрете отдельным категориям лиц открывать и иметь счета (вклады), хранить наличные денежные средства и ценности в иностранных банках, расположенных за пределами территории Российской Федерации, владеть и (или) пользоваться иностранными финансовыми инструментами». Данный закон направлен на укрепление государственного суверенитета и повышение эффективности противодействия коррупции путем установления запрета лицам, принимающим по долгу службы решения, затрагивающие вопросы вывоза капитала относится уплата завышенных процентов по иностранным кредитам. 
государственного суверенитета и безопасности РФ, открывать и иметь счета (вклады), хранить наличные денежные средства и ценности в иностранных банках, расположенных за пределами территории РФ, владеть или пользоваться иностранными финансовыми инструментами. К указанной категории отнесены лица, замещающие государственные должности РФ, должности федеральной государственной службы, назначение на которые и освобождение от которых осуществляются Президентом, Правительством РФ, должности заместителей руководителей федеральных органов исполнительной власти, глав городских округов, глав муниципальных районов и ряд других должностей. Кроме того, установлен порядок осуществления проверки соблюдения указанными лицами данного запрета и меры ответственности за его нарушение. Вместе с тем установленные законом ограничения никак не затрагивают финансовой основы коррупционной деятельности - возможности беспрепятственно выводить денежные средства за пределы территории РФ и вкладывать их в недвижимое имущество за рубежом.

Переводы резидентами средств на свои счета (во вклады), открытые в банках за пределами территории РФ, со своих счетов (вкладов) в уполномоченных банках осуществляются при предъявлении уполномоченному банку уведомления налогового органа по месту учета резидента об открытии счета (вклада) с отметкой о принятии указанного уведомления.

Резиденты, за исключением физических лиц - резидентов, дипломатических представительств, консульских учреждений РФ и иных официальных представительств РФ, находящихся за пределами территории РФ, а также постоянных представительств РФ при межгосударственных или межправительственных организациях, представляют налоговым органам по месту своего учета отчеты о движении средств по счетам (вкладам) в банках за пределами территории РФ с подтверждающими банковскими 
документами. Порядок отчетности о движении средств физических лиц резидентов по счетам (вкладам) в зарубежных банках устанавливается Правительством по согласованию с Центральным банком РФ.

Глава 3 Федерального закона «О валютном регулировании и валютном контроле» регулирует правоотношения, связанные с репатриацией резидентами иностранной валюты и валюты РФ.

При осуществлении внешнеторговой деятельности резиденты, если иное не предусмотрено законом, обязаны в сроки, предусмотренные внешнеторговыми договорами (контрактами), обеспечить:

- получение от нерезидентов на свои банковские счета в уполномоченных банках иностранной валюты или валюты РФ, причитающейся в соответствии $\mathrm{c}$ условиями указанных договоров (контрактов) за переданные нерезидентам товары, выполненные для них работы, оказанные им услуги, переданные им информацию и результаты интеллектуальной деятельности, в том числе исключительные права на них;

- возврат в РФ денежных средств, уплаченных нерезидентам за неввезенные в РФ (неполученные на территории РФ) товары, невыполненные работы, неоказанные услуги, непереданные информацию и результаты интеллектуальной деятельности, в том числе исключительные права на них.

В целях обеспечения учета и отчетности по валютным операциям, осуществления валютного контроля Центральный банк может устанавливать единые правила оформления паспорта сделки при осуществлении валютных операций между резидентами и нерезидентами.

Оформленные паспорта сделок передаются уполномоченными банками для осуществления валютного контроля.

Рассмотренные нормы о репатриации резидентами иностранной валюты и валюты РФ в определенной степени позволяют государству контролировать вывоз валютных ценностей и гарантировать возвращение в страну национального капитала. Вместе с тем автор разделяет точку зрения 
М.А. Колядинского, что «основным средством предотвращения вывоза капиталов за рубеж является все же создание социально-экономических и политических условий для того, чтобы заинтересовать в инвестировании в экономику прежде всего отечественных производителей» ${ }^{1}$.

Важную роль в предотвращении массового и бесконтрольного вывоза капитала, повышении прозрачности экономической деятельности физических и юридических лиц играет валютный контроль. В РФ валютный контроль осуществляется Правительством, органами и агентами валютного контроля. Органами валютного контроля являются Центральный банк РФ, ФТС и ФНС России ${ }^{2}$ Агентами валютного контроля выступают уполномоченные банки, профессиональные участники рынка ценных бумаг, а также государственная корпорация «Банк развития и внешнеэкономической деятельности (Внешэкономбанк)».

Контроль за осуществлением валютных операций кредитными организациями осуществляет Центральный банк РФ.

Контроль за осуществлением валютных операций резидентами и нерезидентами, не являющимися кредитными организациями, осуществляют в пределах своей компетенции федеральные органы исполнительной власти, являющиеся органами валютного контроля, и агенты валютного контроля.

Органы и агенты валютного контроля в пределах своей компетенции наделены правом:

проводить проверки соблюдения резидентами и нерезидентами актов валютного законодательства и актов органов валютного регулирования;

проводить проверки полноты и достоверности учета и отчетности по валютным операциям резидентов и нерезидентов;

запрашивать и получать документы и информацию, которые связаны с

${ }_{2}^{1}$ Колядинский М.А. Указ. соч.

2 Распоряжение Правительства РФ от 2 июня 2016 г. № 1095-р «Об уполномоченных органах Российской стороны, осуществляющих валютный контроль в целях реализации Договора о Евразийском экономическом союзе от 29 мая 2014 г.» 
проведением валютных операций, открытием и ведением счетов.

Органы валютного контроля и их должностные лица выдают предписания об устранении выявленных нарушений актов валютного законодательства РФ и актов органов валютного регулирования, а также применяют меры ответственности.

Имеющийся объем правомочий в целом позволяет органам и агентам валютного контроля следить за полнотой и своевременностью поступления в бюджет валютной выручки, обоснованностью платежей в иностранной валюте, законностью внешнеторговых сделок и операций неторгового характера. В то же время регулирование финансово-кредитной и внешнеэкономической деятельности имеет резервы (развитие взаимодействия органов и агентов валютного контроля, формирование правовой базы международного сотрудничества и др.).

Совершенствование конституционно-правовой регламентации валютного контроля позволит более эффективно решать задачи регулирования финансовых потоков и расчетных отношений, противодействия коррупции и оффшоризации экономики, обеспечения финансовых условий для активизации инвестиционной деятельности, формирования и реализации адресных инвестиционных программ.

Самостоятельным направлением ЗГС является конституциионноправовое регулирование защциты российских организаций от поставок морально устаревиих и материалоемких, энергоемких и ненаукоемких технологий, оборудования, конструкциий и материалов.

От модернизации производства, замены устаревшего оборудования высокотехнологичным зависит экономический рост не только отдельных предприятий и организаций, но и целых отраслей народного хозяйства страны.

В соответствии с пунктом 2 статьи 11 Федерального закона от 25 февраля 1999 г. № 39-Ф3 «Об инвестиционной деятельности в Российской 
Федерации, осуществляемой в форме капитальных вложений» не допускаются инвестиции в основной капитал, связанные с поставками морально устаревших и материалоемких, энергоемких и ненаукоемких технологий, оборудования, конструкций и материалов. Данная норма детализирована Постановлением Правительства РФ от 15 апреля 2014 г. № 316 «Об утверждении государственной программы Российской Федерации «Экономическое развитие и инновационная экономика», в котором установлен запрет на приобретение физически изношенных и морально устаревших машин и оборудования ${ }^{1}$.

Своевременные реконструкция, техническое перевооружение и повышение энергоэффективности производства являются обязательными условиями модернизации экономики и осуществления инвестиционной деятельности на современном этапе социально-экономического развития РФ.

Как уже отмечалось, продолжающееся санкционное воздействие США и ЕС на ключевые сектора российской экономики, попытки сковывания экономической самостоятельности РФ, снижение поступлений иностранных инвестиций, ухудшение качества активов, отток капитала за рубеж актуализируют вопрос места и роли иностранных инвестиций в экономике России.

Правовое регулирование иностранных инвестиций в экономике РФ осуществляется Федеральным законом от 9 июля 1999 г. № 160-Ф3 «Об иностранных инвестициях в Российской Федерации».

В контексте ЗГС регулирование иностранных инвестиций имеет два аспекта. С одной стороны, государство должно способствовать формированию в стране предсказуемого и прозрачного делового климата для иностранных инвесторов. С другой стороны, государство обязано не

1 Аналогичные запреты и ограничения на приобретение изношенных, морально устаревших, низкотехнологичных материалов, оборудования, технологий, продукции следует закрепить в технических регламентах. Подобная мера могла бы стимулировать обновление основных фондов и производственной базы. 
допустить реализацию угроз обороноспособности страны и безопасности государства, ослабления и подрыва своего суверенитета ${ }^{1}$.

В целях привлечения и эффективного использования иностранных материальных и финансовых ресурсов, передовой техники и технологий иностранным инвесторам предоставляются гарантии использования различных форм осуществления инвестиций на территории РФ, гарантии компенсации при национализации и реквизиции имущества, гарантии на приобретение российских ценных бумаг, гарантии участия в приватизации государственного и муниципального имущества, льготы по уплате таможенных платежей и другие изъятия стимулирующего характера.

Иностранный инвестор обязан соблюдать антимонопольное законодательство РФ и не допускать недобросовестной конкуренции и ограничительной деловой практики, в том числе путем создания на территории РФ коммерческой организации с иностранными инвестициями или филиала иностранного юридического лица для производства какого-либо пользующегося повышенным спросом товара, а затем самоликвидации в целях продвижения на рынок аналогичного товара иностранного происхождения, а также посредством злонамеренного соглашения о ценах или о распределении рынков сбыта товара либо об участии в торгах (аукционах, конкурсах).

Общий правовой режим иностранных инвестиций предполагает государственную регистрацию коммерческих организаций с иностранными

${ }^{1}$ В 1990-е гг. возможности стабилизации российской экономики, устойчивость валютного курса, восстановление финансового рынка, обеспечение населения продовольствием оказались в зависимости от привлечения кредитных ресурсов международных финансовых организаций (МВФ и Всемирного банка) и иностранных государств, что повлекло ослабление государственного суверенитета РФ. В тот период МВФ фактически утверждал федеральный бюджет, а Всемирный банк контролировал процессы приватизации и отраслевую политику. Иностранные фирмы приобретали и в последующем банкротили стратегические российские предприятия в целях вытеснения отечественной продукции с внешнего и внутреннего рынка. Репатриация российского криминального капитала под видом иностранных инвестиций позволила представителям организованных преступных сообществ установить контроль над рядом крупных бюджетообразующих предприятий и рентабельных производств. 
инвестициями, аккредитацию филиалов и представительств иностранных юридических лиц, меры ограничительного характера и контроль за деятельностью иностранных инвесторов.

Создание и ликвидация коммерческой организации с иностранными инвестициями осуществляется в порядке, предусмотренном гражданским законодательством РФ. Юридические лица, являющиеся коммерческими организациями с иностранными инвестициями, подлежат государственной регистрации. Российская коммерческая организация получает статус коммерческой организации с иностранными инвестициями со дня вхождения в состав ее участников иностранного инвестора.

Иностранное юридическое лицо, деятельность которого имеет коммерческий характер, приобретает право осуществлять деятельность на территории РФ через аккредитованный филиал или представительство. Подтверждением факта аккредитации филиала, представительства иностранного юридического лица (за исключением кредитных организаций) является документ о внесении записи в реестр, выданный ФНС России.

В аккредитации филиала или представительства может быть отказано, если:

в представленных документах содержится недостоверная информация;

цели создания, открытия филиала, представительства иностранного юридического лица противоречат Конституции, международным договорам РФ, законодательству РФ;

цели создания, открытия филиала, представительства иностранного юридического лица создают угрозу суверенитету, политической независимости, территориальной неприкосновенности, национальным интересам РФ.

Грубое нарушение филиалом или представительством иностранного юридического лица Конституции, международных договоров и законодательства РФ служит основанием прекращения аккредитации 
филиала или представительства ${ }^{1}$.

Элементом правового режима иностранных инвестиций в РФ выступают запреты и ограничения на осуществление иностранных инвестиций в определенных сферах экономики.

Ограничение допуска иностранных инвесторов в стратегические отрасли экономики не является особенностью российской конституционноправовой системы защиты государственного суверенитета. Так, в соответствии с Законом Японии об иностранной валюте и международной торговле 1949 г. процедура допуска иностранных инвесторов в экономику распространяется на иностранные инвестиции, которые потенциально угрожают национальной безопасности, затрагивают существующий публичный порядок, препятствуют обеспечению безопасности населения или имеют существенное негативное влияние на эффективное управление экономикой Японии.

В Исландии иностранным инвесторам запрещены инвестиции в рыболовство и энергетику, в Мексике - в нефтяную отрасль, в США - в авиационные компании; в Чили действуют ограничения иностранных инвестиций в морской транспорт и атомную энергетику, в Аргентине - в финансовый сектор и сферу телекоммуникаций, в Бразилии - в финансовый сектор, железнодорожный транспорт и горное дело. В соответствии с законами ФРГ «О внешнеэкономической деятельности» и «О защите данных, передаваемых с помощью спутников» иностранные инвесторы не могут совершать сделки и инвестировать в предприятия оборонно-промышленного комплекса, в разработку криптографических систем и систем космической разведки.

1 В качестве грубого нарушения Конституции, международных договоров и законодательства РФ можно рассматривать участие руководителей и (или) сотрудников филиала (представительства) иностранного юридического лица в преступной деятельности на российской территории и за ее пределами, финансовую, ресурсную, информационную и иную поддержку такой деятельности, нарушение международных обязательств РФ, заключение притворных гражданско-правовых сделок и др. 
В Китае отрасли национальной экономики классифицируются в зависимости от степени их открытости для иностранного капитала на четыре основные категории: поощряемые, лимитированные для инвестиций отрасли, запрещенные отрасли и разрешенные отрасли. Правительство КНР публикует перечни отраслей экономики, отнесенных к этим категориям. В соответствии с Законом Республики Казахстан 2003 г. «О государственном мониторинге собственности в отраслях экономики, имеющих стратегическое значение» объектами государственного мониторинга и регулирования являются инвестиции в такие стратегические отрасли экономики, как: добыча и переработка топливно-энергетических полезных ископаемых, машиностроение, химическая промышленность, транспорт и связь, производство и распределение электроэнергии, а также отрасли военнопромышленного комплекса. Правительством Казахстана сформированы закрытые перечни стратегических объектов имущества, в отношении которых предусмотрен разрешительный порядок сделок и преимущественное право перехода права собственности к государству ${ }^{1}$.

Выделение стратегических отраслей экономики и установление ограничений допуска иностранных инвесторов вызвано их значением для устойчивого экономического развития и безопасности государства. Приватизация государственных активов в стратегических отраслях экономики может приводить к существенным рискам и угрозам (снижение качества, сокращение доступа граждан к услугам, замедление экономического роста, подрыв обороноспособности, ограничение суверенитета государства).

В Российской Федерации меры ограничительного характера для иностранных инвесторов могут быть установлены федеральными законами в целях защиты основ конституционного строя, нравственности, здоровья, прав

1 Дораев М.Г. Допуск иностранных инвесторов в стратегические отрасли экономики (правовые основы). М.: Инфотропик Медиа, 2013. 
и законных интересов других лиц, обеспечения обороны страны и безопасности государства.

Можно выделить три специальных правовых режима ограничений в отношении иностранных инвестиций в РФ:

1) отраслевые ограничения в отношении секторов экономики, хозяйственных обществ и видов деятельности, имеющих стратегическое значение для обороны и безопасности государства;

2) территориальные ограничения в отношении создания и деятельности организаций с иностранными инвестициями;

3) адресные ограничения в отношении иностранных граждан, причастных к нарушениям основополагающих прав и свобод российских граждан, и должностных лиц иностранных организаций, деятельность которых признана нежелательной на территории РФ.

Правовой режим отраслевых ограничений в части привлечения иностранных инвестиций определен в Федеральном законе от 29 апреля 2008 г. № 57-Ф3 «О порядке осуществления иностранных инвестиций в хозяйственные общества, имеющие стратегическое значение для обеспечения обороны страны и безопасности государства».

В соответствии с законом сделки, которые совершаются иностранными государствами, международными организациями или находящимися под их контролем организациями и в результате которых приобретается право прямо или косвенно распоряжаться более чем 25 \% общего количества голосов, приходящихся на голосующие акции (доли в уставном капитале) российского хозяйственного общества, или иная возможность блокировать решения органов управления такого общества, требуют предварительного согласования ${ }^{1}$. Данное требование также распространяется на все сделки, в

${ }^{1}$ Предварительное согласование осуществляется в соответствии с Федеральным законом «О порядке осуществления иностранных инвестиций в хозяйственные общества, имеющие стратегическое значение для обеспечения обороны страны и безопасности государства» за исключением сделок, в которых участвуют международные финансовые 
результате которых иностранный инвестор приобретает контроль над хозяйственным обществом, имеющим стратегическое значение для обеспечения обороны страны и безопасности государства. Решение о предварительном согласовании сделки принимается Правительственной комиссией по контролю за осуществлением иностранных инвестиций в $Р \Phi^{1}$.

Законодателем определены признаки нахождения хозяйственного общества под контролем иностранного инвестора; виды сделок, требующих предварительного согласования; указан перечень видов деятельности, имеющих стратегическое значение для обеспечения обороны страны и безопасности государства. Так, стратегически важной признана деятельность в атомной, космической и авиационной отраслях, а также в сферах производства и оборота вооружения, военной и специальной техники, в области геологического изучения недр, разведки и добычи полезных ископаемых на участках недр федерального значения, разработки и производства шифровальных средств и др.

Рассматривая особенности конституционно-правового регулирования иностранных инвестиций в хозяйственные общества, имеющие стратегическое значение для обеспечения обороны страны и безопасности государства, необходимо обратить внимание на специфику правового режима иностранных инвестиций в указанные хозяйственные общества.

Во-первых, законом определен особый порядок проверки хозяйственных обществ, имеющих стратегическое значение.

Во-вторых, для получения предварительного согласования сделки или согласования установления контроля иностранного инвестора в ряде случаев

организации, созданные в соответствии с международными договорами, участником которых является РФ, или международные финансовые организации, с которыми РФ заключила международные договоры.

${ }_{1}$ Правила осуществления предварительного согласования сделок и согласования установления контроля иностранных инвесторов или группы лиц, в которую входит иностранный инвестор, над хозяйственными обществами, имеющими стратегическое значение для обеспечения обороны страны и безопасности государства, утверждены Постановлением Правительства РФ от 17 октября 2009 г. № 838. 
на заявителя возлагается выполнение комплекса обязательств в сфере обороны и безопасности государства.

В-третьих, законом предусмотрены различные виды неблагоприятных правовых последствий при нарушения требований совершения сделок, иных действий над хозяйственными обществами, имеющими стратегическое значение.

На основании части 6 статьи 13 Федерального закона «О порядке осуществления иностранных инвестиций в хозяйственные общества, имеющие стратегическое значение для обеспечения обороны страны и безопасности государства» в целях определения факта установления контроля иностранного инвестора над хозяйственным обществом, имеющим стратегическое значение, а также факта наличия между иностранным инвестором, иностранными инвесторами и третьими лицами соглашения, направленного на установление контроля над хозяйственным обществом, имеющим стратегическое значение, оперативные подразделения органов федеральной службы безопасности вправе проводить оперативно-розыскные мероприятия. Результаты оперативно-розыскной деятельности органов федеральной службы безопасности могут использоваться в доказывании по судебным искам.

После определения факта установления контроля иностранного инвестора над хозяйственным обществом, имеющим стратегическое значение, Федеральная антимонопольная служба (ФАС) направляет в Министерство обороны и ФСБ России запросы о предоставлении сведений о возникновении угрозы обороне страны, безопасности государства или об отсутствии такой угрозы в результате совершения соответствующей сделки либо установления контроля над указанным хозяйственным обществом. После этого проводится комплекс проверочных мероприятий, который предусматривает проверку:

- наличия у хозяйственного общества необходимых лицензий (наличие 
лицензии на проведение работ с использованием сведений, составляющих государственную тайну; наличие лицензии на осуществление внешнеэкономических операций с контролируемыми товарами и технологиями; наличие лицензии на осуществление телевизионного вещания, радиовещания и др.);

- наличия у хозяйственного общества необходимых прав (право на осуществление внешнеэкономической деятельности в отношении продукции военного назначения; исключительные права на результаты интеллектуальной деятельности в области критических технологий, имеющих важное значение для обороны страны и безопасности государства; право на геологическое изучение недр и (или) разведку и добычу полезных ископаемых на участках недр федерального значения и др.);

- нахождения хозяйственного общества в реестре субъектов естественных монополий;

- др. юридически значимых фактов и признаков.

После поступления запроса от ФАС Министерство обороны и ФСБ России направляют в ФАС заключения о возникновении угрозы обороне страны, безопасности государства или об отсутствии такой угрозы в результате совершения соответствующей сделки либо в результате установления контроля иностранного инвестора.

В случае, если хозяйственное общество имеет лицензию на проведение работ с использованием сведений, составляющих государственную тайну, ФАС направляет в межведомственную комиссию по защите государственной тайны запрос о предоставлении сведений о наличии международного договора РФ, на основании которого иностранные физические лица могут быть допущены к государственной тайне. Ходатайство заявителя, заключения Министерства обороны и ФСБ России, собранные в результате проверки материалы передаются в Правительственную комиссию по контролю за осуществлением иностранных инвестиций в РФ. 
Правительственная комиссия принимает одно из следующих решений:

о предварительном согласовании сделки или о согласовании установления контроля;

о предварительном согласовании сделки или о согласовании установления контроля при обеспечении выполнения заявителем определенных обязательств;

об отказе в предварительном согласовании сделки или о согласовании установления контроля ${ }^{1}$.

Правительственная комиссия может возложить на заявителя одно или несколько обязательств ${ }^{2}$ :

- формирование органов управления хозяйственного общества, имеющего стратегическое значение, из числа лиц, которые могут быть допущены к сведениям, составляющим государственную тайну, и выполнение таким хозяйственным обществом мероприятий по защите государственной тайны, в том числе в случае необходимости оформление допуска заявителя либо должностных лиц или работников заявителя к сведениям, составляющим государственную тайну;

- продолжение осуществления таким хозяйственным обществом поставок продукции (работ, услуг) по государственному оборонному заказу;

- продолжение выполнения таким хозяйственным обществом работ по поддержанию мобилизационных мощностей;

- осуществление таким хозяйственным обществом деятельности по оказанию услуг по ценам (тарифам), установленным в соответствии с

\footnotetext{
${ }^{1}$ Аналогичный порядок привлечения компетентных государственных органов для проверочных мероприятий, согласования сделок и согласования установления контроля иностранного инвестора над предприятием, имеющим стратегическое значение для обороны и безопасности, существует и за рубежом. Так, в США действует Комиссия по иностранным инвестициям, которая может запретить приобретение акций американской компании любым иностранным инвесторам в связи с угрозой национальной безопасности США. В Германии для проведения проверок иностранных инвесторов и согласования сделок привлекается Федеральная разведывательная служба (BND). ${ }_{2}$ Обязательства, установленные федеральными законами или иными нормативными правовыми актами, возлагаются на заявителя в безусловном порядке.
} 
законодательством РФ о естественных монополиях;

- выполнение представленного заявителем бизнес-плана такого хозяйственного общества;

- незамедлительное принятие таким хозяйственным обществом определенных законодательством мер в условиях введения военного положения, чрезвычайного положения на территории РФ либо в ее отдельных местностях, где расположено такое хозяйственное общество ${ }^{1}$;

- сохранение таким хозяйственным обществом среднесписочной численности работников в течение срока, определенного решением о предварительном согласовании сделки или о согласовании установления контроля;

- переработка на территории РФ полезных ископаемых, добываемых хозяйственным обществом, имеющим стратегическое значение и осуществляющим пользование участком недр федерального значения;

- переработка на территории РФ водных биологических ресурсов, добываемых (вылавливаемых) хозяйственным обществом, имеющим стратегическое значение.

Между заявителем и ФАС подписывается соглашение, в котором перечисляются обязательства заявителя, условия их выполнения и ответственность заявителя за нарушение обязательств. Проверка выполнения заявителем обязательств осуществляется ФАС. Полный или частичный отказ заявителя от принятия обязательств в сфере обороны и безопасности государства, определенных Правительственной комиссией, влечет за собой

1 В случае введения правового режима ВП вводится особый режим работы транспорта, коммуникаций, связи, объектов энергетики, объектов повышенной опасности, в организациях реализуются дополнительные меры по усилению режима секретности, выполняются задания в целях обороны и безопасности, эвакуируются объекты хозяйственного назначения. В условиях ЧП могут предусматриваться: изменение режима работы и мобилизация ресурсов организаций любых организационно-правовых форм и форм собственности; переориентация организаций на производство необходимой в условиях чрезвычайного положения продукции; ограничения на осуществление отдельных видов финансово-экономической деятельности, перемещение товаров, услуг и финансовых средств; приостановление деятельности опасных производств и организаций; эвакуация материальных ценностей в безопасные районы и др. 
отказ в предварительном согласовании сделки или согласовании установления контроля.

Сделки, подлежащие предварительному согласованию и совершенные с нарушением требований Федерального закона «О порядке осуществления иностранных инвестиций в хозяйственные общества, имеющие стратегическое значение для обеспечения обороны страны и безопасности государства», признаются ничтожными.

Режим территориальных ограничений в отношении создания и деятельности организаций с иностранными инвестициями предусмотрен на территориях РФ с особым правовым статусом. К их числу отнесены закрытые административно территориальные образования и территории с регламентированным посещением для иностранных граждан ${ }^{1}$.

Специальный режим адресных ограничений в отношении инвестиций иностранных граждан, причастных к нарушениям основополагающих прав и свобод российских граждан, и должностных лиц иностранных организаций, деятельность которых признана нежелательной на территории Российской Федерации, может вводиться в соответствии с федеральными законами от 28 декабря 2012 г. № 272-Ф3 «О мерах воздействия на лиц, причастных к нарушениям основополагающих прав и свобод человека, прав и свобод граждан Российской Федерации» (т.н. «Закон Димы Яковлева») и от 23 мая 2015 г. № 129-Ф3 «О внесении изменений в отдельные законодательные акты Российской Федерации»².

Данные законодательные акты в качестве мер воздействия на

1 Закон РФ от 14 июля 1992 г. № 3297-1 «О закрытом административнотерриториальном образовании», Постановление Правительства РФ от 4 июля 1992 г. (с изм. от 4 июля 2014 г.) № 470 «Об утверждении Перечня территорий Российской Федерации с регламентированным посещением для иностранных граждан»

2 Федеральным законом от 23 мая 2015 г. № 129-Ф3 «О внесении изменений в отдельные законодательные акты Российской Федерации» введен институт нежелательности на территории РФ деятельности иностранных и международных неправительственных организаций. Решение о признании нежелательной на территории РФ деятельности указанной организации принимается Генеральным прокурором РФ или его заместителями по согласованию с МИД России. 
указанные субъекты права предусматривают запрет на любые сделки с их собственностью и инвестициями, отказ в проведении операций с денежными средствами и иным имуществом, а также другие ограничения.

Основным субъектом реализации государственной политики и ЗГС в области иностранных инвестиций выступает Правительство РФ.

В соответствии со статьей 23 Федерального закона «Об иностранных инвестициях в Российской Федерации» Правительство РФ:

определяет целесообразность введения запретов и ограничений осуществления иностранных инвестиций на территории РФ, разрабатывает законопроекты о перечнях указанных запретов и ограничений;

определяет меры по контролю за деятельностью иностранных инвесторов в Р $\Phi^{1}$;

утверждает перечень приоритетных инвестиционных проектов;

разрабатывает и обеспечивает реализацию федеральных программ привлечения иностранных инвестиций;

привлекает инвестиционные кредиты международных финансовых организаций и иностранных государств на финансирование Бюджета развития РФ и инвестиционных проектов федерального значения;

осуществляет взаимодействие с субъектами РФ по вопросам международного инвестиционного сотрудничества;

осуществляет контроль за подготовкой и заключением инвестиционных соглашений с иностранными инвесторами о реализации ими крупномасштабных инвестиционных проектов ${ }^{2}$;

1 Так, Правительство РФ осуществляет контроль за исполнением иностранным инвестором и коммерческой организацией с иностранными инвестициями взятых ими обязательств по реализации приоритетных инвестиционных проектов. В случае невыполнения указанных обязательств они лишаются льгот в отношении взимания федеральных налогов и взносов, а сумма неуплаченных денежных средств подлежит возврату.

${ }_{2}$ В соответствии с частью 10 статьи 14 Федерального закона от 5 апреля 2013 г. № 41-Ф3 «О Счетной палате Российской Федерации» аудит государственных и международных инвестиционных проектов в целях оценки обоснованности объемов и сроков осуществления капитальных вложений (инвестиций), а также оценки результатов 
осуществляет контроль за подготовкой и заключением международных договоров РФ о поощрении и взаимной защите инвестиций.

Таким образом, проведенное изучение особенностей правового регулирования иностранных инвестиций в экономике РФ свидетельствует о том, что национальная инвестиционная политика имеет два четких вектора:

- «стимулирующий» (ориентация на привлечение иностранных инвестиций, закрепление различных государственных гарантий и льгот);

- «рестрикционный» (ограничительные режимные меры отраслевого и адресного характера в интересах обороны и безопасности государства).

Как представляется, сбалансированная государственная политика в инвестиционной сфере должна быть направлена, с одной стороны, на повышение привлекательности российской юрисдикции, конкурентоспособности национальной экономики, надежное регулирование капитала и ликвидности, снижение инвестиционных рисков, с другой стороны, - должна обеспечивать защиту общественных интересов, поддерживать должный уровень обороноспособности и безопасности государства.

Учитывая важность для государства и представителей бизнеса регулярного получения достоверной информации о происходящих в экономике процессах, состоянии финансово-хозяйственной деятельности и бухгалтерской отчетности бюджетообразующих предприятий и стратегических организаций, выявления и пресечения экономических преступлений значимым фрагментом правовой защиты государственного суверенитета в социально-экономической сфере выступает конституциионноправовое регулирование аудиторской деятельности и государственного (муниципального) финансового контроля в контексте защчитьл государственного суверенитета.

действий и эффективности вложений федеральных и иных ресурсов проводится Счетной палатой РФ. 
Аудит является важнейшим элементом инфраструктуры финансовой системы РФ. По состоянию на 1 января 2016 г. в сфере аудиторской деятельности задействовано 4,4 тыс. аудиторских организаций и 21,5 тыс. аудиторов, в том числе 0,7 тыс. индивидуальных аудиторов. Более 90\% аудиторских организаций относятся к субъектам малого и среднего предпринимательства. В 2015 г. аудиторские организации и индивидуальные аудиторы оказали услуг на общую сумму 56,1 млрд. руб.

В соответствии со статьей 1 Федерального закона от 30 декабря 2008 г. № 307-Ф3 «Об аудиторской деятельности» под аудиторской деятельностью понимается деятельность аудиторских организаций и индивидуальных аудиторов по проведению аудита (независимой проверки бухгалтерской отчетности аудируемого лица в целях выражения мнения о достоверности такой отчетности) и оказанию сопутствующих аудиту услуг.

Аудиторская деятельность осуществляется в соответствии с международными стандартами аудита, которые являются обязательными для аудиторских организаций, аудиторов, саморегулируемых организаций аудиторов (далее - СРО) и их работников, а также со стандартами аудиторской деятельности СРО аудиторов ${ }^{2}$. На территории РФ применяются Федеральные правила (стандарты) аудиторской деятельности (утверждены Постановлением Правительства РФ от 23 сентября 2002 г. № 696) и поэтапно вводятся в действие международные стандарты аудита, принимаемые Международной федерацией бухгалтеров.

${ }^{1}$ Раздел 2 Проекта Концепции дальнейшего развития аудиторской деятельности в Российской Федерации, разработанной в целях исполнения поручения Президента РФ от 19 декабря 2015 г. № Пр-2629 (одобрен Советом по аудиторской деятельности 23 июня 2016 г.). URL: http/minfin.ru/common/upload/library/2016/06/main/proj_concep_ot230616.pdf (дата обращения: 14 июля 2016 г.)

Аудиторские организации, аудиторы в РФ объединены в СРО, которые присоединились к Международной федерации бухгалтеров. Вместе с тем следует констатировать номинальное участие СРО в Международной федерации бухгалтеров. Так, российское аудиторское сообщество практически не принимает участие в работе по совершенствованию системы международных стандартов в сфере аудиторской деятельности. Невысоким остается уровень сотрудничества с профессиональными институтами аудиторов стран ЕАЭС и СНГ (пункт 8 раздела 3 Проекта Концепции дальнейшего развития аудиторской деятельности в Российской Федерации. 
Для защиты государственных и общественных интересов, обеспечения достоверности бухгалтерской отчетности организаций законодатель предусмотрел правовой инструмент обязательного аудита.

Обязательный аудит проводится в случаях:

- если организация имеет организационно-правовую форму акционерного общества;

- если ценные бумаги допущены к организованным торгам;

- если организация является кредитной организацией, бюро кредитных историй, организацией, являющейся профессиональным участником рынка ценных бумаг, страховой организацией, клиринговой организацией, обществом взаимного страхования, организатором торговли, негосударственным пенсионным или иным фондом, акционерным инвестиционным фондом, управляющей компанией акционерного инвестиционного фонда, паевого инвестиционного фонда или негосударственного пенсионного фонда (за исключением государственных внебюджетных фондов);

- если объем выручки от продажи продукции (продажи товаров, выполнения работ, оказания услуг) организации (за исключением органов государственной власти, органов местного самоуправления, государственных и муниципальных учреждений, государственных и муниципальных унитарных предприятий, сельскохозяйственных кооперативов, союзов этих кооперативов) за предшествовавший отчетному год превышает 400 миллионов рублей или сумма активов бухгалтерского баланса по состоянию на конец предшествовавшего отчетному года превышает 60 миллионов рублей;

- если организация (за исключением органа государственной власти, органа местного самоуправления, государственного внебюджетного фонда, а также государственного и муниципального учреждения) представляет и (или) публикует сводную (консолидированную) бухгалтерскую отчетность: 
- в иных случаях, установленных федеральными законами ${ }^{1}$.

Как вытекает из Постановления Конституционного Суда РФ от 1 апреля 2003 г. № 4-П «По делу о проверке конституционности положения пункта 2 статьи 7 Федерального закона «Об аудиторской деятельности» в связи с жалобой гражданки И.В. Выставкиной», необходимость обязательного аудита обусловлена спецификой организационно-правовой формы, высокорисковым характером деятельности (функций) проверяемых лиц и большим объемом отреализации продукции (значительной суммой активов бухгалтерского баланса) на конец отчетного года, т.е. такими обстоятельствами, которые - в целях защиты прав и законных интересов других лиц и обеспечения экономической безопасности Российской Федерации - требуют установления повышенных гарантий достоверности финансовой (бухгалтерской) отчетности проверяемых лиц.

В Постановлении Конституционного Суда от 1 апреля 2003 г. № 4-П отмечается, что проведение обязательного аудита ориентировано на защиту публичных интересов и имеет публично-правовой характер. Осуществляющая обязательную аудиторскую проверку аудиторская организация действует официально в качестве независимой контрольноревизионной инстанции по уполномочию государства. В основе обязательного аудита лежит публичный интерес, поскольку государство заинтересовано в минимизации рисков и функционировании крупнейших налогоплательщиков. Кроме того, независимая проверка бухгалтерской (финансовой) отчетности и соблюдения организациями законодательства позволяет государственным органам принимать необходимые экономические и налоговые решения. Без аудиторского заключения пользователи финансовой (бухгалтерской) отчетности, в том числе налоговые органы, не

${ }^{1}$ Например, см. Федеральный закон от 24 ноября 2014 г. № 376-Ф3 «О внесении изменений в части первую и вторую Налогового кодекса Российской Федерации (в части налогообложения прибыли контролируемых иностранных компаний и доходов иностранных организаций)». 
могут считать ее достоверной.

Государственное регулирование аудиторской деятельности складывается из:

выработки государственной политики в сфере аудиторской деятельности;

принятия нормативных правовых актов, регулирующих аудиторскую деятельность;

ведения государственного реестра саморегулируемых организаций аудиторов, а также контрольного экземпляра реестра аудиторов и аудиторских организаций;

анализа состояния рынка аудиторских услуг в РФ.

Повышенные требования к профессиональному статусу аудитора предполагают аттестацию на право осуществления аудиторской деятельности. Порядок проведения квалификационного экзамена, а также порядок определения его результата устанавливается уполномоченным федеральным органом - Минфином России.

Квалификационный аттестат аудитора аннулируется в случаях:

- получения аттестата с использованием подложных документов либо несоответствия претендента требованиям закона;

- вступления в законную силу приговора суда, предусматривающего наказание в виде лишения права заниматься аудиторской деятельностью в течение определенного срока;

- несоблюдения аудитором правил независимости и разглашения аудиторской тайны;

- систематического нарушения аудитором требований закона или стандартов аудиторской деятельности;

- подписания аудитором аудиторского заключения, признанного заведомо ложным;

- неучастия аудитора в осуществлении аудиторской деятельности в 
течение трех последовательных лет (за исключением ряда лиц, предусмотренных законом);

- несоблюдения без уважительной причины аудитором требования о прохождении обучения по программам повышения квалификации;

- уклонения аудитором от прохождения внешнего контроля качества работы.

Аннулирование квалификационного аттестата аудитора и признание аудиторского заключения заведомо ложным являются основанием для прекращения членства в СРО аудиторов.

В целях контроля соблюдения аудиторской организацией, аудитором требований закона, стандартов аудиторской деятельности, правил независимости аудиторов и аудиторских организаций в Федеральном законе «Об аудиторской деятельности» закреплена процедура внешнего контроля качества работы аудиторских организаций, аудиторов.

Внешний контроль качества работы аудиторских организаций, проверяющих общественно-значимые субъекты, осуществляет Федеральное казначейство. При этом СРО аудиторов осуществляет внешний контроль качества работы всех своих членов. Принципы осуществления внешнего контроля качества работы аудиторских организаций, индивидуальных аудиторов и требования к организации указанного контроля устанавливаются Минфином России. Кроме того, Минфин определяет порядок назначения и осуществления проверки аудиторской организации Федеральным казначейством, перечень типовых вопросов программы указанной проверки, а также порядок оформления ее результатов.

В отношении аудиторской организации, допустившей нарушение требований закона, стандартов аудиторской деятельности, правил независимости аудиторов и аудиторских организаций, кодекса профессиональной этики аудиторов, Федеральное казначейство может применить следующие меры воздействия: 
а) вынести предписание об устранении выявленных по результатам внешней проверки качества работы аудиторской организации нарушений со сроками устранения таких нарушений;

б) вынести письменное предупреждение о недопустимости нарушения требований закона, стандартов аудиторской деятельности, правил независимости аудиторов и аудиторских организаций, кодекса профессиональной этики аудиторов;

в) направить СРО аудиторов, членом которой является аудиторская организация, обязательное для исполнения предписание о приостановлении членства аудиторской организации в СРО аудиторов до устранения выявленных нарушений (но не более 180 дней со дня приостановления членства);

г) направить СРО аудиторов, членом которой является аудиторская организация, обязательное для исполнения предписание об исключении сведений об аудиторской организации из реестра аудиторов и аудиторских организаций ${ }^{1}$.

Для осуществления функций внешнего контроля аудиторской деятельности представители уполномоченного федерального органа вправе присутствовать на собраниях (заседаниях) и иных мероприятиях органов управления и специализированных органов СРО аудиторов, а также запрашивать у СРО аудиторов необходимую информацию и документацию.

Значимым элементом государственного контроля аудиторской деятельности выступает государственный контроль (надзор) Минфина России за деятельностью СРО аудиторов в форме плановых и внеплановых

1 В соответствии с Федеральным законом «Об аудиторской деятельности» основаниями для исключения сведений об аудиторской организации из реестра аудиторов и аудиторских организаций являются: осуществление предпринимательской деятельности помимо аудита; нарушение правил независимости аудиторских организаций; составление документов не на русском языке; нарушение установленных сроков хранения документов, полученных или составленных в ходе оказания аудиторских услуг, на территории РФ, в том числе неразмещение баз данных информации на территории России; нарушение установленных сроков хранения документов, полученных или составленных при оказании прочих, связанных с аудиторской деятельностью услуг. 
проверок соблюдения СРО аудиторов требований законодательства.

В случае выявления нарушений СРО аудиторов требования Федерального закона «Об аудиторской деятельности» и принятых в соответствии с ним нормативных правовых актов Минфин России по результатам проверки может применить следующие меры воздействия:

вынести предписание об устранении СРО выявленных по результатам проверки нарушений со сроками устранения таких нарушений;

вынести письменное предупреждение о недопустимости нарушения требований закона и нормативных правовых актов;

вынести решение об исключении сведений о некоммерческой организации из государственного реестра СРО аудиторов;

обратиться в арбитражный суд с заявлением об исключении сведений о некоммерческой организации из государственного реестра СРО аудиторов.

В проекте Концепции дальнейшего развития аудиторской деятельности в Российской Федерации на период до 2022 г. (одобрен Советом по аудиторской деятельности 23 июня 2016 г.) предложен ряд мер по совершенствованию механизмов ответственности аудиторских организаций и аудиторов, в том числе:

- унификация подходов к квалификации нарушений;

- обеспечение применения эффективных и соразмерных мер ответственности за недобросовестный аудит, оказание некачественных либо незаконных аудиторских услуг;

- повышение значимости репутационных факторов при оценке работы аудиторских организаций и аудиторов;

- совершенствование практики функционирования института признания аудиторских заключений заведомо ложными в судебном порядке;

- введение административной ответственности аудиторских организаций, аудиторов за грубые нарушения законодательства РФ об аудиторской деятельности; 
- совершенствование механизма уголовной ответственности за преступления в сфере аудиторской деятельности.

Создание условий для добросовестного поведения на рынке аудиторских услуг и активное противодействие недобросовестным аудиторским организациям, аудиторам позволят укрепить доверие к аудиторскому рынку, повысить престиж аудиторской профессии, а также будут способствовать обеспечению справедливой конкуренции на рынке аудиторских услуг, его стабильному функционированию и развитию1.

Острой проблемой ЗГС является аудиторская проверка важнейших кредитных организаций (Банка России), предприятий (федеральных государственных унитарных предприятий, государственных корпораций и др.) и целых стратегических сфер деятельности т.н. «большой четверкой» аудиторских компаний: PricewaterhouseCoopers (CША), Ernst\&Young (Великобритания), KPMG (Нидерланды), Deloitte (США). Российские представители международных сетей аудиторских фирм «большой четверки» представляют собой зависимые (аффилированные) компании от вышестоящей головной организации, которая является в свою очередь зависимой по вертикали от своей головной компании. Несмотря на то, что аудиторские организации зарегистрированы по российскому законодательству с местонахождением в Российской Федерации, зачастую ключевой управленческий персонал в них представлен иностранными специалистами из крупных международных компаний. Нередко даже внутренний контроль осуществляют иностранные менеджеры, для чего письменная информация (отчет по результатам проведения аудита) готовится сразу на двух языках - английском и русском.

По некоторым оценкам, транснациональные сети аудиторских

${ }^{1}$ Раздел 5.5. Проекта Концепции дальнейшего развития аудиторской деятельности в Российской Федерации (одобрен Советом по аудиторской деятельности 23 июня 2016 г.). URL: http/minfin.ru/common/upload/library/2016/06/main/proj_concep_ot230616.pdf (дата обращения: 14 июля 2016 г.) 
компаний «большой четверки» контролируют 75\% мирового рынка консалтинга и аудита. Зарубежные аудиторские организации владеют немалой долей и в российском аудиторском бизнесе через цепочку аффилированных структур ${ }^{1}$.

В условиях санкционного давления США и Западной Европы, целенаправленного разрушения интеграционных связей России с ЕС, СНГ, ЕАЭС, ОДКБ, попыток недопущения диверсификации российской экономики и развития ее стратегически важных отраслей иностранные аудиторские структуры являются обычным инструментом реализации стратегических установок своего руководства, а также интересов зарубежных групп влияния и транснациональных корпораций. Политическое руководство ведущих стран Запада не заинтересовано в модернизации российской экономики, становлении в России независимых национальных экономических институтов, проводящих успешную инновационную, денежно-кредитную, финансовую политику, самостоятельно распоряжающихся трудовыми и сырьевыми ресурсами. Поэтому необходимо повышать конкурентоспособность национальных структур аудита, продвигать российские аудиторские бренды на Евразийское экономическое пространство и платформы других интеграционных объединений Российской Федерации, формировать единый рынок аудиторских услуг на территории ЕАЭС и СНГ².

1 Бульга Р.П. Интеллектуальный капитал бизнеса: методологические проблемы бухгалтерского учета и аудита. М.: Бухгалтерский учет, 2005; Гизятова A.ШI. Ключевые факторы и приоритетные направления развития аудиторской деятельности на интернациональном пространстве Евроазиатского экономического союза // Международный бухгалтерский учет. 2014. № 36.

2 Как отмечается в разделе 5.6 Проекта Концепции дальнейшего развития аудиторской деятельности в Российской Федерации (одобрен Советом по аудиторской деятельности 23 июня 2016 г.), «основное взаимодействие должно вестись в рамках «Группы Двадцати»»,, Совета по финансовой стабильности, ЕАЭС, Международного форума независимых регуляторов аудиторской деятельности, Межправительственной рабочей группы экспертов по международным стандартам бухгалтерского учета ЮНКТАД, Международной федерации бухгалтеров, Координационного совета по бухгалтерскому учету при Исполкоме СНГ. В среднесрочной перспективе предстоит завершение разработки и принятие соглашения об аудиторской деятельности на территории ЕАЭС, приведение законодательства РФ в соответствие с этим соглашением, 
Важнейшим инструментом решения задач государственной социальноэкономической политики является бюджет. В целях недопущения нецелевого и неэффективного использования бюджетных средств, оценки эффективности формирования, управления и распоряжения федеральными и иными ресурсами в интересах обеспечения безопасности и социальноэкономического развития государства, предотвращения бюджетного ущерба, борьбы с коррупцией РФ осуществляет государственный (муниципальный) финансовый контроль в сфере бюджетных правоотношений.

Правовые основы государственного (муниципального) финансового контроля в РФ составляют Бюджетный кодекс Российской Федерации от 31 июля 1998 г. (в ред. от 23 июня 2016 г.) № 145-ФЗ, Федеральный закон от 5 апреля 2013 г. (в ред. от 27 октября 2015 г.) № 41-Ф3 «О Счетной палате Российской Федерации», Федеральный закон от 7 февраля 2011 г. (в ред. от 4 марта 2014 г.) № 6-Ф3 «Об общих принципах организации и деятельности контрольно-счетных органов субъектов Российской Федерации и муниципальных образований» и др.

Согласно статье 265 Бюджетного кодекса Российской Федерации государственный (муниципальный) финансовый контроль осуществляется в целях обеспечения соблюдения бюджетного законодательства Российской Федерации и иных нормативных правовых актов, регулирующих бюджетные правоотношения.

Государственный $\quad$ (муниципальный) $\quad$ финансовый $\quad$ контроль подразделяется на внешний и внутренний, предварительный и последующий.

Внешний государственный (муниципальный) финансовый контроль в сфере бюджетных правоотношений является контрольной деятельностью Счетной палаты РФ, контрольно-счетных органов субъектов РФ и

взаимное устранение государствами-членами ЕАЭС барьеров и ограничений доступа на http/minfin.ru/common/upload/library/2016/06/main/proj_concep_ot230616.pdf обращения: 14 июля 2016 г.) 
муниципальных образований.

Внутренний государственный (муниципальный) финансовый контроль возложен на органы государственного (муниципального) финансового контроля, являющиеся органами (должностными лицами) исполнительной власти субъектов РФ, местных администраций, Федерального казначейства (финансовые органы субъектов РФ или муниципальных образований).

Предварительный контроль нацелен на предупреждение и пресечение бюджетных нарушений в процессе исполнения бюджетов бюджетной системы РФ.

Последующий контроль осуществляется по результатам исполнения бюджетов бюджетной системы РФ в целях установления законности их исполнения, достоверности учета и отчетности.

Отношения, возникающие в процессе осуществления внешнего государственного контроля (аудита) порядка формирования, управления и распоряжения средствами федерального бюджета, бюджетов государственных внебюджетных фондов, федеральной собственностью (далее - федеральные ресурсы), иными ресурсами, обеспечивающими безопасность и социально-экономическое развитие РФ, регулируются Федеральным законом «О Счетной палате Российской Федерации».

Счетная палата РФ является постоянно действующим высшим органом внешнего государственного аудита (контроля), подотчетным Федеральному Собранию.

В качестве задач Счетной палаты РФ в статье 5 Федерального закона «О Счетной палате Российской Федерации» закреплены:

- организация и осуществление контроля за целевым и эффективным использованием средств федерального бюджета, бюджетов государственных внебюджетных фондов;

- аудит реализуемости и результативности достижения стратегических целей социально-экономического развития РФ; 
- определение эффективности и соответствия нормативным правовым актам РФ порядка формирования, управления и распоряжения федеральными и иными ресурсами в пределах компетенции Счетной палаты, в том числе для целей стратегического развития в РФ;

- анализ выявленных недостатков и нарушений в процессе формирования, управления и распоряжения федеральными и иными ресурсами в пределах компетенции Счетной палаты, выработка предложений по их устранению, а также по совершенствованию бюджетного процесса в целом в пределах компетенции;

- оценка эффективности предоставления налоговых и иных льгот и преимуществ, бюджетных кредитов за счет средств федерального бюджета, а также оценка законности предоставления государственных гарантий и поручительств или обеспечения исполнения обязательств другими способами по сделкам, совершаемым юридическими лицами и индивидуальными предпринимателями за счет федеральных и иных ресурсов, в пределах компетенции;

- определение достоверности бюджетной отчетности главных администраторов средств федерального бюджета и бюджетов государственных внебюджетных фондов РФ и годового отчета об исполнении федерального бюджета, бюджетов государственных внебюджетных фондов РФ;

- контроль за законностью и своевременностью движения средств федерального бюджета и средств государственных внебюджетных фондов в Центральном банке РФ, уполномоченных банках и иных кредитных организациях РФ;

- обеспечение в пределах компетенции мер по противодействию коррупции.

Основными видами деятельности Счетной палаты РФ являются контрольная и экспертно-аналитическая деятельность. Данные виды 
деятельности осуществляются в форме предварительного аудита, оперативного анализа и контроля и последующего аудита (контроля).

Предварительный аудит формирования федерального бюджета и бюджетов государственных внебюджетных фондов РФ проводится в целях установления их соответствия законодательству РФ, а также определения обоснованности показателей проектов бюджетов. В рамках предварительного аудита Счетная палата осуществляет проверку и анализ обоснованности показателей проектов федерального бюджета и бюджетов государственных внебюджетных фондов РФ, наличия и состояния нормативной методической базы их формирования, оценку проектов указанных бюджетов, их соответствия посланиям Президента РФ и иных программных документов, оценку качества прогнозирования доходов федерального бюджета и бюджетов государственных внебюджетных фондов РФ, использования бюджетных средств, инвестиционной и долговой политики ${ }^{1}$, а также эффективности межбюджетных отношений. Счетная палата готовит заключения на проекты федеральных законов о федеральном бюджете и бюджетах государственных внебюджетных фондов РФ и направляет их палатам Федерального Собрания.

В рамках оперативного анализа и контроля исполнения федерального бюджета Счетная палата исследует полноту и своевременность поступлений доходов федерального бюджета, кассовое исполнение федерального бюджета в сравнении с утвержденными показателями федерального закона о федеральном бюджете, выявляет отклонения и нарушения, вносит предложения по их устранению. Оперативный доклад о ходе исполнения

${ }^{1}$ Согласно статье 21 Федерального закона от 5 апреля 2013 г. № 41-Ф3 «О Счетной палате Российской Федерации» Счетная палата осуществляет внешний государственный аудит (контроль) состояния государственного внутреннего и внешнего долга РФ, долга иностранных государств и (или) иностранных юридических лиц перед Российской Федерацией, бюджетных кредитов, предоставленных из федерального бюджета. Кроме того, в целях оценки обоснованности объемов и сроков осуществления капитальных вложений (инвестиций), а также оценки результатов действий и эффективности вложений федеральных и иных ресурсов Счетная палата РФ проводит аудит государственных и международных инвестиционных проектов. 
федерального бюджета ежеквартально предоставляется в Федеральное Собрание.

Счетная палата осуществляет последующий контроль в ходе проверки исполнения федеральных законов о федеральном бюджете и бюджетах государственных внебюджетных фондов РФ за отчетный финансовый год в целях определения соответствия фактических показателей исполнения бюджетов законодательно утвержденным показателям, полноты и своевременности исполнения показателей бюджета, в ходе внешней проверки годовых отчетов об исполнении федерального бюджета и бюджетов государственных внебюджетных фондов РФ, бюджетной отчетности главных администраторов средств федерального бюджета в целях установления законности исполнения бюджетов, достоверности учета и отчетности, эффективности использования средств бюджетов, а также в ходе проведения тематических проверок.

Результаты проведенных контрольных и экспертно-аналитических мероприятий направляются палатам Федерального Собрания, руководителям соответствующих федеральных органов исполнительной власти, иных государственных органов, органов местного самоуправления, организаций и учреждений. Об ущербе, причиненном государству, и о выявленных нарушениях нормативных правовых актов Счетная палата информирует палаты Федерального Собрания, а при наличии данных, указывающих на признаки составов преступлений, передает соответствующие материалы в правоохранительные органы.

Единая система внешнего финансового контроля органично дополняется региональным компонентом, представленным контрольносчетными органами субъектов РФ и муниципальных образований, статус которых закреплен Федеральным законом от 7 февраля 2011 г. № 6-Ф3 «Об общих принципах организации и деятельности контрольно-счетных органов субъектов Российской Федерации и муниципальных образований». 
Бюджетные полномочия Счетной палаты РФ и контрольно-счетных органов субъектов РФ и муниципальных образований закреплены в статье 157 Бюджетного кодекса Российской Федерации.

Анализ правового положения высшего и региональных органов внешнего государственного аудита (контроля) свидетельствует о ряде их общих признаков:

- формируются представительными органами;

- являются постоянно действующими органами внешнего финансового контроля;

- подотчетны представительным органам;

- обладают организационной и функциональной независимостью и осуществляют свою деятельность самостоятельно;

- схожи по составу;

- схожи по основным видам деятельности (контрольная и экспертноаналитическая деятельность).

Вместе с тем Счетная палата РФ как высший орган финансового контроля:

оказывает контрольно-счетным органам организационную, правовую, информационную, методическую и иную помощь;

организует проведение совместных контрольных и экспертноаналитических мероприятий;

по обращению контрольно-счетных органов субъектов РФ или законодательных органов государственной власти субъектов РФ осуществляет анализ деятельности контрольно-счетных органов субъектов РФ и дает рекомендации по повышению эффективности их работы.

Среди общегосударственных приоритетов работы Счетной палаты, связанных с ЗГС в социально-экономической сфере, следует выделить:

- обеспечение гарантий защищенности средств федерального бюджета, государственной собственности и иных общенациональных ресурсов от 
нецелевого и неэффективного использования ${ }^{1}$;

- повышение эффективности бюджетных расходов и инвестиций в социальной сфере, сфере науки и технологий;

- комплексный аудит закрытых статей бюджета на национальную оборону и безопасность, правоохранительную деятельность;

- аудит государственных закупок с целью снижения злоупотреблений в данной сфере и повышения прозрачности процесса закупок;

- контроль реализации проектов общегосударственного значения;

- разработка предложений по совершенствованию законодательства в целях противодействия коррупции, преднамеренному и фиктивному банкротству, оффшоризации экономики и иным экономическим правонарушениям.

Как отмечается в Стратегии деятельности Счетной палаты Российской Федерации на 2013 - 2019 года (утверждена Счетной палатой Российской Федерации 11 февраля 2014 г.), «от эффективности и качества деятельности Счетной палаты в значительной степени зависит решение поставленных государством задач социально-экономического развития Российской Федерации, обеспечения устойчивого роста благосостояния российских граждан, национальной безопасности, динамичного развития и модернизации экономики, укрепления позиций России в мировом сообществе и повышения ее конкурентоспособности».

Анализируя и контролируя формирование и исполнение бюджета, оценивая порядок управления и распоряжения федеральными и иными ресурсами, проверяя законность, эффективность и результативность деятельности государственных органов по использованию бюджетных средств Счетная палата способствует социально-экономическому развитию

1 В контексте ЗГС большую актуальность представляют вопросы контроля за размещением и использованием средств суверенных фондов (Резервного фонда и Фонда национального благосостояния), а также эффективности инвестирования средств Фонда национального благосостояния в экономику РФ. 
РФ, влияет на функциональность государственного управления и содействует реализации конституционных принципов подотчетности государственной власти обществу. В этом заключается ее роль как субъекта конституционно-правовой защиты государственного суверенитета в социально-экономической сфере.

Важнейшим органом внутреннего государственного финансового контроля является Федеральное казначейство.

Федеральное казначейство осуществляет:

прогнозирование и кассовое планирование средств федерального бюджета;

распределение доходов от уплаты федеральных налогов и сборов между бюджетами бюджетной системы РФ;

кассовое обслуживание исполнения бюджетов бюджетной системы РФ; предварительный и текущий контроль за ведением операций со средствами федерального бюджета главными распорядителями, распорядителями и получателями средств федерального бюджета;

составление и представление в Минфин России оперативной информации и отчетности об исполнении федерального бюджета, отчетности об исполнении консолидированного бюджета РФ;

полномочия по контролю и надзору в финансово-бюджетной сфере;

внешний контроль качества работы аудиторских организаций;

анализ исполнения бюджетных полномочий органов государственного (муниципального) финансового контроля;

анализ проведения главными администраторами средств федерального бюджета внутреннего финансового контроля и внутреннего финансового аудита, а также направление главным администраторам бюджетных средств рекомендаций по организации внутреннего финансового контроля и внутреннего финансового аудита;

контроль за соблюдением органами государственного 
(муниципального) финансового контроля Федерального закона «О контрактной системе в сфере закупок товаров, работ, услуг для обеспечения государственных и муниципальных нужд»;

контроль за своевременностью и полнотой устранения объектами контроля нарушений законодательства РФ и (или) возмещения причиненного государству ущерба.

Вопросы бюджетных полномочий субъектов РФ (в том числе самостоятельного кассового обслуживания исполнения региональных бюджетов) являлись предметом проверки Конституционного Суда РФ. Из правовой позиции, сформулированной Конституционным Судом в Постановлении от 17 июня 2004 г. № 12-П по делу о проверке конституционности положений статей 155, 156 и 283 Бюджетного кодекса Российской Федерации, следует, что федеральный законодатель при осуществлении финансового регулирования ориентируется на реализацию целей государственной экономической политики, имея в виду как конституционно обусловленные особенности федеративного устройства Российской Федерации, так и задачи реформирования финансовой системы на данном этапе социально-экономического развития государства. В условиях федеративного государства, в котором бюджеты соответствующих уровней, будучи самостоятельными, составляют единую бюджетную систему, особое значение приобретают вопросы координации деятельности органов публичной власти, вовлеченных в бюджетный процесс, и взаимодействия между ними. Проведение в РФ единой финансовой, кредитной и денежной политики, которые обеспечиваются Правительством РФ и осуществляются на основе установленных федеральными органами государственной власти единых федеральных стандартов финансовой деятельности, в то же время не исключает совместного участия федеральных органов исполнительной власти и органов исполнительной власти субъектов РФ в отдельных процедурах бюджетного процесса, в том числе на стадии 
исполнения бюджета субъекта РФ.

По мнению Конституционного Суда РФ, необходимость обеспечения действенного и стабильного механизма защиты бюджетных прав субъектов РФ и их равноправия во взаимоотношениях с федеральными органами государственной власти обусловливает определение единого порядка кассового обслуживания исполнения бюджетов, основ взаимодействия Федерального казначейства и органов исполнительной власти субъектов РФ в процессе кассового обслуживания исполнения бюджетов субъектов РФ, а также форм и мер ответственности Федерального казначейства за ненадлежащее исполнение возложенных на него функций.

Роль Федерального казначейства как субъекта ЗГС в социальноэкономической сфере также состоит в обеспечении содействия эффективному управлению финансовыми ресурсами государства, казначейском сопровождении государственных контрактов и соглашений, обеспечении устойчивости казначейской системы и бюджетных платежей.

ЗГС от внешних угроз в экономической сфере предполагает обеспечение равноправной интеграции нашей страны в мирохозяйственные связи, недопущение критической зависимости России от иностранных государств (их союзов) во внешнеэкономической деятельности, торговых операциях и других статегически важных вопросах экономического сотрудничества. Данное обстоятельство актуализирует необходимость изучения конституциионо-правового регулирования применения специальных экономических, специильных защчитных, антидемпинговых $и$ компенсационных мер в интересах ЗГС.

Конституционно-правовое регулирование применения соответствующих экономических мер осуществляется в рамках двух субинститутов:

субинститута специальных экономических мер в отношении иностранных государств, иностранных организаций и граждан, а также лиц 
без гражданства для защиты интересов РФ, обеспечения безопасности РФ, а также защиты прав и свобод граждан;

субинститута специальных защитных, антидемпинговых и компенсационных мер в целях защиты экономических интересов российских производителей товаров в связи с возросшим импортом, демпинговым или субсидируемым иностранным импортом на таможенную территорию РФ.

Субинститут специальных экономических мер введен Федеральным законом от 30 декабря 2006 г. № 281-Ф3 «О специальных экономических мерах». Основаниями применения специальных экономических мер является возникновение совокупности обстоятельств, требующих безотлагательной реакции на международно-противоправное деяние либо недружественное действие иностранного государства или его органов и должностных лиц, представляющие угрозу интересам и безопасности РФ и (или) нарушающие права и свободы ее граждан, а также принятие соответствующих резолюций СБ $\mathrm{OOH}^{1}$. Как мы видим, основания для применения данных мер связаны с возникновением внешних угроз государственному суверенитету. Целями применения специальных экономических мер являются обеспечение интересов и безопасности РФ и (или) устранение или минимизация угрозы нарушений прав и свобод ее граждан.

Специальные экономические меры носят временный характер (срок их применения устанавливается Президентом РФ) и применяются независимо от других мер ЗГС.

Примерный перечень данных мер закреплен в статье 3 Федерального закона «О специальных экономических мерах»:

1 Так, в случае с актом агрессии Вооруженных сил Турецкой Республики в отношении российского бомбардировщика СУ-24, сбитого над территорией Сирии в ноябре 2015 г., руководством РФ с учетом особенностей политической ситуации не объявлялась мобилизация и не вводился режим военного положения. Вместе с тем в качестве реакции на агрессивные действия иностранного государства - члена НАТО для ЗГС были использованы специальные экономические меры. 
1) приостановление реализации всех или части программ в области экономической, технической помощи, а также программ в области военнотехнического сотрудничества ${ }^{1}$;

2) запрещение финансовых операций или установление ограничений на их осуществление;

3) запрещение внешнеэкономических операций или установление ограничений на их осуществление ${ }^{2}$;

4) прекращение или приостановление действия международных торговых договоров и иных международных договоров РФ в области внешнеэкономических связей;

5) изменение вывозных и (или) ввозных таможенных пошлин;

6) запрещение или ограничение захода в порты РФ судов и использования воздушного пространства РФ или отдельных его районов;

7) установление ограничений на осуществление туристской деятельности;

8) запрещение или отказ от участия в международных научных и научно-технических программах и проектах, научных и научно-технических программах и проектах иностранного государства.

Предложения о введении специальных экономических мер вносятся Президенту РФ, который и принимает решение об их применении. Законодателем установлен перечень субъектов, имеющих право вносить предложения о применении этих мер. К ним относятся Совет Безопасности, Совет Федерации и Государственная Дума, а также Правительство РФ³ основании решения Президента Правительство устанавливает перечень

${ }^{1}$ Ограничение программ двустороннего военно-технического сотрудничества как специальная мера ЗГС активно использовалось Китаем для ответа на недружественные действия США по поставкам вооружений Тайваню в 2010 и 2015 гг.

${ }^{2}$ Аналогичные специальные меры применяются и за рубежом для ЗГС. Так, в 2012 г. в связи с конфликтом из-за разграничения территориального моря в Южно-Китайском море КНР вводила ограничения на импорт фруктов и овощей из Филиппин.

${ }^{3}$ Отмена специальных экономических мер осуществляется в аналогичном порядке: управомоченные субъекты обращаются к Президенту РФ с предложениями об отмене указанных мер, который и принимает соответствующее решение. 
конкретных действий и ограничительных мер в отношении недружественных иностранных государств, их органов и должностных лиц.

В связи с агрессией Вооруженных Сил Турецкой Республики против российского бомбардировщика СУ-24, сбитого над территорией Сирии 24 ноября 2015 г., Указом Президента РФ от 28 ноября 2015 г. № 583 «О мерах по обеспечению национальной безопасности Российской Федерации и защите граждан Российской Федерации от преступных и иных противоправных действий и о применении специальных экономических мер в отношении Турецкой Республики» с 1 января 2016 г. было приостановлено действие Соглашения между Правительством Российской Федерации и Правительством Турецкой Республики об условиях взаимных поездок граждан Российской Федерации и граждан Турецкой Республики от 12 мая 2010 г. По поручению Президента Правительством РФ была приостановлена деятельность Смешанной межправительственной Российско-Турецкой комиссии по торгово-экономическому сотрудничеству, приостановлен переговорный процесс с турецкой стороной по проекту Соглашения между Правительством Российской Федерации и Правительством Турецкой Республики о торговле услугами и инвестициях, проекту Среднесрочной программы торгово-экономического, научно-технического и культурного сотрудничества между Правительством Российской Федерации и Правительством Турецкой Республики на 2016-2019 гг., а также по созданию Российско-турецкого совместного фонда по финансированию инвестиционных проектов.

В связи с приостановлением с 1 января 2016 г. действия Договора о зоне свободной торговли в отношении Украины Президентом РФ введены меры по обеспечению экономической безопасности и национальных интересов РФ при осуществлении международных транзитных перевозок 
грузов с территории Украины на территорию Республики Казахстан через территорию РФ$\Phi^{1}$.

В отличие от специальных экономических мер субинститут специальных защитных, антидемпинговых и компенсационных мер имеет более узкое целевое назначение и направлен на защиту экономических интересов национальных товаропроизводителей ${ }^{2}$ Кроме того, перед введением специальных защитных, антидемпинговых и компенсационных мер допускается введение предварительных мер в отношении недобросовестных экспортеров.

Основанием введения специальных защитных, антидемпинговых и компенсационных мер является совокупность условий для защиты внутреннего рынка: резкий рост импорта, демпингового импорта или субсидируемого импорта; нанесение таким импортом серьезного ущерба (угрозы) отрасли экономики (для специальных защитных мер) или материального ущерба (угрозы материального ущерба) национальным производителям или замедления создания отрасли экономики (для антидемпинговых и компенсационных мер); причинно-следственная связь между импортом и ущербом экономике.

Меры защиты внутреннего рынка предназначены для противодействия несправедливой конкуренции со стороны импортируемых товаров или возросшего импорта. Зарубежная практика применения подобных мер

1 Указом Президента РФ от 1 января 2016 г. № 1 «О мерах по обеспечению экономической безопасности и национальных интересов Российской Федерации при осуществлении международных транзитных перевозок грузов с территории Украины на территорию Республики Казахстан через территорию Российской Федерации» предусмотрено осуществление международных транзитных перевозок с территории Украины в Казахстан только с территории Республики Белоруссия при условии применения к грузовым помещениям транспортных средств и железнодорожного подвижного состава средств идентификации (пломб), в том числе функционирующих на основе технологии глобальной навигационной спутниковой системы ГЛОНАСС, а также при наличии у водителей транспортных средств учетных талонов.

2 Указом Президента РФ от 30 января 2010 г. № 120 «Об утверждении Доктрины продовольственной безопасности Российской Федерации» предусмотрено использование специальных защитных, антидемпинговых и компенсационных мер при растущем импорте сельскохозяйственной и рыбной продукции, сырья и продовольствия, а также в случаях демпинга и применения в зарубежных странах субсидий при их импорте. 
сложилась давно. Впервые антидемпинговые меры были применены Канадой в 1904 г. против импорта стали из США. Вскоре антидемпинговые законы были изданы в Новой Зеландии (1905), Австралии (1906), а затем получили широкое распространение в большинстве государств мира. В 1947 г. в целях выработки общих принципов применения мер защиты внутреннего рынка было подписано Генеральное соглашение по тарифам и торговле (ГАТТ). После образования в 1995 г. Всемирной торговой организации (ВТО) для членов ВТО были введены обязательные правила применения мер защиты внутреннего рынка и способы разрешения торговых споров.

Защитные меры вводятся общегосударственными (Глава государства, Правительство) или отраслевыми органами государственного управления (министерства и ведомства). Так, Глава государства обладает правом введения защитных мер в Республике Беларусь, Туркменистане ${ }^{1}$. В другой группе стран меры защиты внутреннего рынка применяются по решению Правительства (Австралия, Кыргызстан, Россия, Турция и др.). Во многих государствах защитные, антидемпинговые и компенсационные меры вводятся уполномоченными министерствами и ведомствами (Министерство финансов - в Индии и Индонезии, Министерство торговли - в США, и Колумбии, Комитет по специальным защитным мерам в Таиланде). В Украине защитные меры вводятся решением Межведомственной комиссии по международной торговле Украины.

В настоящее время практика применения мер защиты внутреннего рынка распространена в большинстве государств мира, что отражается на условиях доступа российских производителей на внешние рынки, влияет на

${ }^{1}$ См. Указ Президента Республики Беларусь от 12 октября 2009 г. № 498 «О специальной пошлине на ввозимые на таможенную территорию Республики Беларусь сетки стеклянные (стеклосетки)», Указ Президента Республики Беларусь от 29 октября 2007 г. № 543 «О введении специальной пошлины на преформы, происходящие из Украины и ввозимые на таможенную территорию Республики Беларусь». Помимо Главы государства меры по защите внутреннего рынка Белоруссии могут устанавливаться Правительством. См., например, Постановление Совета Министров Республики Беларусь от 18 августа 2008 г. № 1178 «О введении антидемпинговой пошлины на карамель, происходящую из Украины и ввозимую на территорию Республики Беларусь». 
их конкурентоспособность и требует адекватного реагирования со стороны России ${ }^{1}$.

По состоянию на 1 мая 2016 г., по данным Минэкономразвития РФ, 25 стран (Австралия, Азербайджан, Аргентина, Беларусь, Бразилия, Вьетнам, Индия, Индонезия, Иран, Казахстан, Китай, Лаос, Малайзия, Марокко, Мексика, Молдова, Нигерия, США, Таиланд, Туркменистан, Турция, Узбекистан, Украина, Филиппины, Шри-Ланка), а также ЕС применяют защитные меры в отношении российских товаров ${ }^{2}$. Применительно к отечественной экспортной продукции проводятся 7 антидемпинговых, 9 специальных защитных и 1 компенсационное расследование ${ }^{3}$.

В рамках санкционной политики ЕС, США, Японии, Украины, Швейцарии, Норвегии, Австралии, Новой Зеландии, Исландии, Лихтенштейна, Черногории и Албании указанные страны ввели запрет на ввоз товаров, происходящих из Крыма и г. Севастополя.

Российская сторона в целях защиты внутреннего рынка эффективно применяла защитные меры в машиностроении, металлургии, химической промышленности, пищевой промышленности, сельском хозяйстве.

Защитные меры являются выгодным инструментом регулирования внешней торговли в РФ. В частности, в связи с беспошлинным режимом свободной торговли в отношении товаров, происходящих из СНГ, защитные меры остаются для российских производителей надежным средством защиты внутреннего рынка.

К числу актуальных тенденций международной и российской внешнеторговой практики следует отнести широкое применение антидемпинговых мер, что обусловлено следующими факторами:

${ }^{1}$ После вступления РФ 22 августа 2012 г. в ВТО и ратификации международных соглашений по ВТО некоторые ограничительные меры в отношении российского экспорта были отменены.

2 Наибольшее число защитных мер в отношении РФ применяется к продукции отечественной металлургической, трубной и химической отраслей.

${ }^{3}$ www.ved.gov.ru/rus_export 
- стремлением придать протекционистским мерам избирательный и целенаправленный характер;

- созданием системы многосторонних международных обязательств в области применения традиционных торговых ограничений в рамках ГАТТ и общей либерализацией международной торговли;

- усилением монополизации многих товарных рынков, создавшей предпосылки для применения демпинговой практики наиболее мощными компаниями ${ }^{1}$.

Как показывает практика, противодействовать поставкам из одной или нескольких стран (что предусмотрено антидемпинговыми мерами) технически проще, чем с импортом из всех государств в целом. К тому же членство РФ в ВТО дает право нашей стране обращаться в суд ВТО на расследование правомочности применения антидемпинговых мер к российскому экспорту и вводить ответные защитные меры.

К числу преимуществ антидемпинговых мер также относятся: более низкая степень ущерба национальным производителям, которую необходимо доказать для введения антидемпинговых мер и достаточно высокий средний уровень вводимых антидемпинговых пошлин ${ }^{2}$.

В РФ условия и процедура применения защитных мер регулируются Федеральным законом от 8 декабря 2003 г. № 165-Ф3 «О специальных защитных, антидемпинговых и компенсационных мерах при импорте товаров».

Правовой основой применения данных мер на территории Таможенного союза выступает решение Коллегии Евразийской экономической комиссии от 7 марта 2012 г. № 1 «О некоторых вопросах применения специальных защитных, антидемпинговых и компенсационных

${ }^{1}$ Исаченко T.M. Практика применения специальных защитных, антидемпинговых и компенсационных мер в торговой политике ЕС // Вестник Томского университета. 2010. № 33. C. 1 13-114.

Для введения специальных защитных мер ущерб отрасли экономики должен быть серьезным, а для применения антидемпинговых мер достаточно материального ущерба. 
мер на единой таможенной территории Таможенного союза», а также Договор о Евразийском экономическом союзе (Астана, 29 мая 2014 г.). Таможенный союз может применять специальные защитные, антидемпинговые или компенсационные меры как единое межгосударственное объединение или от имени государства-члена. В последнем случае применение меры ограничивается только этим государством.

Введению специальных защитных, антидемпинговых и компенсационных мер предшествует квазисудебная процедура расследование, проводимое уполномоченным органом исполнительной власти ${ }^{1}$. Уполномоченный орган по результатам расследования представляет в Правительство РФ доклад с предложениями о целесообразности введения, применения, пересмотра или отмены указанных мер. Правительство принимает соответствующее решение.

В соответствии со статьей 6 Федерального закона «О специальных защитных, антидемпинговых и компенсационных мерах при импорте товаров» специальные защитные меры могут применяться к товару, если по результатам расследования установлено, что импорт данного товара на таможенную территорию Российской Федерации осуществляется в таких количествах и на таких условиях, что это причиняет серьезный ущерб отрасли российской экономики или создает угрозу причинения серьезного ущерба отрасли российской экономики². В целях установления серьезного

${ }^{1}$ В соответствии с Постановлением Правительства РФ от 5 июня 2008 г. № 438 «О Министерстве промышленности и торговли Российской Федерации» Минпромторг России проводит расследования, предшествующие введению специальных защитных, антидемпинговых или компенсационных мер при импорте товаров. Решением Коллегии Евразийской экономической комиссии от 7 марта 2012 г. № 1 межгосударственным органом, ответственным за проведение расследований, предшествующих введению специальных защитных, антидемпинговых и компенсационных мер на единой таможенной территории Таможенного союза, определен Департамент защиты внутреннего рынка Евразийской экономической комиссии.

2 Специальные защитные меры применяются путем введения импортной квоты, специальной пошлины или предварительной специальной пошлины. К примеру, импортные квоты устанавливались постановлениями Правительства РФ от 5 декабря 2005 г. № 732 «Об импорте говядины, свинины и мяса домашней птицы в $2006-2009$ годах», 
ущерба отрасли экономики или угрозы его причинения уполномоченный орган, проводящий расследование, оценивает объективные факторы, которые оказывают воздействие на экономическое положение отрасли в том числе:

- темпы и объем прироста импорта товара в абсолютных и относительных показателях к общему объему производства или потребления в государстве конкурирующего товара;

- уровень цен на импортный товар по сравнению с ценой конкурирующего товара, производимого в государстве;

- изменение объема продажи конкурирующего товара на внутреннем рынке;

- изменение объема производства конкурирующего товара, производительности, загрузки производственных мощностей, размеров прибыли и убытков, а также уровня занятости в отраслях экономики государства;

- долю импортного товара в общем объеме продажи на рынке данного товара и конкурирующего товара.

В условиях критического положения в отрасли экономики государства, если задержка с применением специальной защитной меры причинила бы серьезный ущерб отрасли экономики, который трудно будет устранить впоследствии, Правительством РФ вводится предварительная специальная пошлина ${ }^{1}$.

Специальные защитные меры применяются по решению Правительства в размере и в течение срока, которые необходимы для устранения серьезного ущерба отрасли российской экономики или угрозы причинения серьезного ущерба отрасли российской экономики и для облегчения процесса адаптации

от 28 января 2006 г. № 50 «О мерах по защите российских производителей ламп накаливания». Специальная пошлина вводилась Постановлением Правительства РФ от 12 февраля 2011 г. № 68 «О специальной защитной мере в отношении крепежных изделий».

${ }^{1}$ Впервые предварительная специальная пошлина была введена Постановлением Правительства РФ от 17 июля 1998 г. № 783 «О временных мерах по защите российского свекольного комплекса» с 1 августа по 31 декабря 1998 г. на сахар-сырец и белый сахар. 
отрасли российской экономики к меняющимся экономическим условиям ${ }^{1}$. Срок действия специальной защитной меры не должен превышать 4 года, за исключением случая продления действия такой меры. Общий срок действия специальной защитной меры, включая срок действия предварительной специальной пошлины и срок продления, не должен превышать 8 лет.

В рамках ВТО специальные защитные меры рассматриваются в качестве чрезвычайных мер (статья ХІХ ГАТТ 1994 г.).

Антидемпинговая мера может быть применена к товару, если по результатам расследования установлено, что импорт такого товара на таможенную территорию РФ причиняет материальный ущерб отрасли российской экономики, создает угрозу причинения материального ущерба отрасли экономики или существенно замедляет создание отрасли экономики ${ }^{2}$. Ущерб отрасли российской экономики вследствие демпингового импорта устанавливается на основе результатов анализа объема демпингового импорта, воздействия демпингового импорта на цены аналогичного товара на рынке РФ и воздействия такого импорта на российских производителей аналогичного товара.

При анализе объема демпингового импорта уполномоченный орган, проводящий расследование, определяет, произошло ли существенное увеличение демпингового импорта данного товара.

При анализе воздействия демпингового импорта на цены аналогичного товара на рынке РФ устанавливаются следующие факторы:

были ли цены товара, являющегося предметом демпингового импорта, существенно ниже цен аналогичного товара на рынке РФ;

${ }^{1}$ Как уже отмечалось, в отличие от антидемпинговых и компенсационных мер, которые применяются в отношении импорта из отдельных стран, специальные защитные меры вводятся для защиты от импорта товара независимо от страны его происхождения.

Украин Так, антидемпинговые меры применялись в отношении происходящих из Украины некоторых видов стальных труб, машиностроительного крепежа, никельсодержащего плоского проката. Проводились антидемпинговые расследования в отношении металлопроката с полимерным покрытием, происходящего из КНР, Республики Корея, Бельгии, Финляндии, Казахстана, а также в отношении полиамидных технических нитей из Украины. 
привел ли демпинговый импорт к существенному снижению цен аналогичного товара на рынке РФ;

препятствовал ли существенно демпинговый импорт росту цен аналогичного товара на рынке РФ, который имел бы место в случае отсутствия демпингового импорта.

Анализ воздействия демпингового импорта на отрасль российской экономики заключается в оценке экономических факторов, имеющих отношение к состоянию отрасли российской экономики, в том числе:

степени восстановления экономического положения отрасли российской экономики после воздействия на нее имевших место ранее демпингового импорта или субсидируемого импорта;

происшедшего или возможного в будущем сокращения производства, продажи товара, доли его на рынке РФ, прибыли, производительности труда, доходов от привлеченных инвестиций или использования производственных мощностей;

факторов, влияющих на цены товара на рынке РФ;

размера демпинговой маржи;

происшедшего или возможного в будущем негативного воздействия на движение денежных потоков, запасы товара, уровень занятости, заработную плату, темпы роста производства товара, возможность привлечения инвестиций.

При установлении угрозы причинения материального ущерба отрасли российской экономики вследствие демпингового импорта учитываются следующие факторы:

темпы роста демпингового импорта, свидетельствующие о реальной возможности дальнейшего увеличения такого импорта;

наличие у экспортера достаточных экспортных возможностей или очевидная неотвратимость их увеличения, которые свидетельствуют о реальной возможности увеличения демпингового импорта данного товара, с 
учетом возможности других экспортных рынков принять дополнительный экспорт данного товара;

уровень цен товара, являющегося предметом демпингового импорта, если такой уровень цен может привести к снижению или сдерживанию цены аналогичного товара на рынке РФ и дальнейшему росту спроса на товар, являющийся предметом демпингового импорта;

запасы у экспортера товара, являющегося предметом демпингового импорта.

Если информация, полученная до завершения расследования, свидетельствует о наличии демпингового импорта и обусловленного этим ущерба отрасли российской экономики, Правительством на основании доклада Минпромторга России принимается решение о введении предварительной антидемпинговой пошлины.

Расследование может быть приостановлено или прекращено при получении от экспортера письменных обязательств о пересмотре установленных им цен данного товара или прекращении экспорта данного товара на таможенную территорию РФ по ценам ниже нормальной стоимости данного товара (при наличии аффилированных лиц экспортера в РФ - о поддержке этих обязательств экспортера его аффилированными лицами) ${ }^{1}$.

Согласно части 3 статьи 15 Федерального закона «О специальных защитных, антидемпинговых и компенсационных мерах при импорте товаров» решение об одобрении ценовых обязательств не принимается Правительством РФ в случае, если орган, проводящий расследование, приходит к заключению о неприемлемости одобрения таких обязательств в связи с большим числом реальных или потенциальных экспортеров товара или по причинам, связанным с интересами государственной политики.

1 Как мы видим, законодателем особо оговаривается т.н. «скрытый демпинг», осуществляемый аффилированными лицами. 
При нарушении или отзыве экспортерами ценовых обязательств Правительство вводит предварительную или окончательную антидемпинговую пошлину. Срок действия антидемпинговой меры не должен превышать 5 лет со дня начала применения такой меры или со дня завершения повторного расследования, которое проводилось в связи с изменившимися обстоятельствами и одновременно касалось анализа демпингового импорта и связанного с ним ущерба отрасли российской экономики или в связи с истечением срока действия антидемпинговой меры.

В рамках ВТО применение антидемпинговых мер допускается, если демпинг причиняет или угрожает причинить материальный ущерб промышленности, созданной на территории члена ВТО, или материально сдерживает создание отечественной промышленности ${ }^{1}$.

В отношении государств или их союзов, осуществляющих субсидирование своих экспортеров для проникновения на внешние рынки, используется инструмент компенсационных мер. Компенсационная мера может быть применена к импортированному товару, при производстве, экспорте или транспортировке которого использовалась специфическая субсидия иностранного государства (союза иностранных государств), если по результатам расследования установлено, что импорт такого товара на таможенную территорию РФ причиняет материальный ущерб отрасли российской экономики или существенно замедляет создание отрасли российской экономики. При анализе воздействия субсидируемого импорта на отрасль экономики государства оцениваются те же экономические факторы, что и при демпинговом импорте.

До завершения расследования Правительством РФ может вводиться предварительная компенсационная пошлина.

\footnotetext{
${ }^{1}$ Статья VI ГАТT 1994 г.
} 
Как и в случае с демпинговым импортом, расследование может быть приостановлено или прекращено при принятии иностранным государством (союзом иностранных государств) или экспортером письменных ценовых обязательств или обязательств по отмене или устранению последствий субсидирования.

Срок действия компенсационной меры не должен превышать 5 лет со дня начала применения такой меры или со дня завершения повторного расследования.

Для целей применения антидемпинговых и компенсационных расследований важную роль играет наличие «рыночного статуса» государства, против товаров которого ведется расследование ${ }^{1}$. Наличие такого статуса означает, что расчет себестоимости импортируемой продукции в стране его происхождения будет проводиться на основе данных, предоставленных непосредственно производителем или экспортером товара, против которого проводится расследование. При нерыночном сценарии орган, проводящий расследование, основывает свои расчеты на данных третьей рыночной страны, имеющей схожие общеэкономические показатели и показатели отрасли, производящей товар, против которого ведется расследование («суррогатный подход»). Возможно использование данных, предоставленных национальной компанией - заявителем, по чьей инициативе было начато расследование. И в том, и в другом случае данные по себестоимости будут искажаться в пользу заявителя и в ущерб интересам производителей страны с нерыночной экономикой ${ }^{2}$.

${ }^{1}$ До 1 июля 1998 г. к странам с нерыночной экономикой относились Азербайджан, Албания, Армения, Белоруссия, Вьетнам, Грузия, Казахстан, КНР, Кыргызстан, Молдова, Монголия, Россия, КНДР, Таджикистан, Турция, Узбекистан и Украина. В мае 2002 г. в ходе саммита «Россия-ЕС» была достигнута договоренность о предоставлении РФ рыночного статуса для целей антидемпинговых процедур.

2 Меры защиты внутреннего рынка. Материалы Департамента координации, развития и регулирования внешнеэкономической деятельности Минэкономразвития России. URL: www.ved.gov.ru/rus_export 
Поэтому суверенное государство заинтересовано в устранении дискриминационного подхода $\mathrm{\kappa}$ национальным производителям на зарубежных рынках, проводит работу по пересмотру действующих антидемпинговых, компенсационных и специальных защитных мер и либерализации торговых барьеров.

В рамках ВТО применение компенсационных мер в соответствии со ст.10 Соглашения ВТО по субсидиям и компенсационным мерам 1994 г. допускается только в отношении последствий конкретной субсидии на внутреннем рынке импортирующего члена ВТО.

Интеграция российской экономики в мировую торговую систему, открытие российских рынков для иностранных товаров, противодействие несправедливой иностранной конкуренции повышает актуальность ЗГС в социально-экономической сфере.

Рассмотренная система мер ЗГС в социально-экономической сфере успешно применяется в различных секторах экономики, позволяет разрабатывать и осуществлять сбалансированную внешнеэкономическую политику на основе удовлетворения потребностей внутреннего рынка и защиты отечественных производителей с использованием принятых в международной практике защитных мер. 


\section{3. Конституционно-правовая защита государственного суверенитета Российской Федерации в политической сфере}

В рамках системной организации общества, включающей в себя взаимосвязанную совокупность социальной, экономической, идеологической, правовой, культурной и некоторых других систем, политическая сфера общественной жизни занимает специфическое место.

Политическая сфера характеризует отношения между классами, нациями и другими социальными группами по поводу завоевания, удержания и использования государственной власти ${ }^{1}$.

Понятийно-категориальный аппарат теории ЗГС отличается от общепринятых в обществознании, политологии и теории государства определений.

Так, в традиционном понимании завоевание государственной власти предполагает конституционный (путем выборов или назначения) либо неконституционный (насильственный захват власти, вооруженный мятеж) приход к власти. Конституционно-правовая защита государственного суверенитета основана исключительно на конституционных способах прихода к власти и запрещает другие варианты завоевания государственной власти, которые выступают предметом уголовно-правового регулирования (блокирование работы органов государственной власти и управления, угрозы физической расправы, убийство либо принудительная изоляция представителей власти, вооруженные выступления против законных органов власти и др.).

Государство признает правомерным только такой приход к власти,

${ }^{1}$ Государственная власть - форма политической власти, которая имеет классовый характер, располагает монопольным правом издавать общеобязательные веления (законы) и опирается на специальный аппарат принуждения. Понятие «политическая власть» шире понятия «государственная власть», т.к. политическая власть осуществляется не только государством, но и партиями, общественными организациями и некоторыми другими элементами политической системы. 
который основан на законе и установленных им процедурах. В соответствии с частью 4 статьи 3 Конституции РФ «захват власти или присвоение властных полномочий преследуются по федеральному закону». Часть 5 статьи 13 Конституции запрещает создание и деятельность общественных объединений, цели или действия которых направлены на насильственное изменение основ конституционного строя и нарушение целостности РФ, подрыв безопасности государства, создание вооруженных формирований.

Удержание государственной власти означает недопущение функционирования конституционной системы государственной власти, незаконное исполнение властных полномочий и воспрепятствование в реализации полномочий законным органам власти, т.е. удержание власти лицами с истекшим сроком полномочий либо лицами, незаконно захватившими государственную власть. В таком ракурсе удержание государственной власти является уголовно наказуемым деянием. В контексте конституционно-правовой защиты государственного суверенитета под удержанием государственной власти понимается легитимная деятельность представителей конституционных органов власти по осуществлению своих законных полномочий, контролю принятия и исполнения своих государственно-властных решений в условиях антиконституционных посягательств антигосударственных сил.

Использование государственной власти связано с осуществлением органом государственной власти или должностным лицом государственных функций либо реализацией властных полномочий по предмету ведения в пределах компетенции. Конституционно-правовая защита государственного суверенитета основана на принципах законности, недопустимости деятельности государственных органов и их должностных лиц вне их компетенции, в условиях отсутствия административных процедур и контроля, a также недопустимости использования возможностей и полномочий институтов государственной власти в противоправных целях. 
Вопросы законности использования полномочий государственной власти приобретают особую актуальность в антидемократических режимах (диктаторских, фашистских, авторитарных государствах) при попытках задействования карательных государственных органов (спецслужб, полиции, Вооруженных сил) и проправительственных экстремистских негосударственных организаций для уничтожения и запугивания лидеров политической оппозиции внутри страны и за ее пределами ${ }^{1}$.

Конституционно-правовой смысл использования государственной власти также не допускает осуществления политической деятельности и воздействия на нее со стороны иностранных государств, организаций и международных структур. Данные ограничения реализованы в избирательных процедурах на выборах, в прерогативе государства признавать деятельность отдельных иностранных организаций нежелательной на своей территории, в особом контроле за деятельностью иностранных (международных) неправительственных организаций, а также некоммерческих организаций, выполняющих функцию иностранных агентов.

Политическая сфера обладает верховенством над другими сферами жизни общества, поскольку она регулирует распределение социальных благ и вырабатывает властные решения, являющиеся обязательными для всех членов данного общества.

Политическая сфера тесно связана с социально-классовой структурой общества. В функционировании политических институтов выражается политика правящих социальных групп, заинтересованных в сохранении и укреплении своей власти в обществе. В свою очередь, именно политические институты призваны удовлетворять базовые потребности членов общества в безопасности, стабильности, интеграции и порядке.

${ }^{1}$ Примерами могут служить уничтожение политических противников в условиях Третьего Рейха, режима Пиночета в Чили, теракты в отношении Патриса Лумумбы, Фиделя Кастро и др. 
Политическая сфера характеризуется высоким уровнем самостоятельности и активности в связи с наличием особого механизма управления и принуждения, возможности и права распоряжаться ресурсами всего общества.

Содержание деятельности государства по ЗГС в политической сфере вытекает из характера угроз и структуры политической организации общества (ее элементов и объектов защиты государственного суверенитета) ${ }^{1}$.

Как отмечают исследователи, элементы политической организации общества выделяются на основе двух главных критериев: организационного и политического ${ }^{2}$.

Организационный критерий означает внутреннюю упорядоченность и оформленность элемента (наличие специфических задач, функций, иерархия, автономность), а политический критерий предполагает политический характер деятельности элемента, которая раскрывается в нескольких аспектах:

a) способность выражать политические интересы определенной социальной группы;

б) способность участвовать в политической жизни, т.е. иметь непосредственное или опосредованное отношение к завоеванию, удержанию или использованию государственной власти;

в) способность следовать в своей деятельности определенной политической программе и руководствоваться политическими нормами.

В зависимости от политического критерия все элементы политической

\footnotetext{
${ }^{1}$ Характеристика основных угроз государственному суверенитету дана в параграфе 1.4., а объекты ЗГС рассмотрены в параграфе 1.5.

${ }_{2}^{2}$ Существуют различные точки зрения в отношении количества критериев отбора элементов политической организации. Так, Ф.М. Бурлацкий и В.Е. Чиркин предлагали семь таких критериев, В.Н. Жуков, С.А. Комаров и М.Н. Марченко - три. Несмотря на многообразие мнений, все авторы признают наличие организационного и политического критериев.
} 
организации общества можно классифицировать на три группы ${ }^{1}$ :

1. собственно политические организации (государство, органы местного самоуправления, политические партии, отдельные общественные объединения), возникающие и действующие в силу политических причин и непосредственно связанные с политикой;

2. косвенно-политические организации (профсоюзы, финансовопромышленные объединения, религиозные организации), возникающие и действующие в силу социальных, экономических, идеологических и иных причин и косвенно связанные с политикой;

3. нейтральные организации (творческие объединения и т.п.), возникающие и действующие в силу индивидуальных интересов той или иной социальной группы и являющиеся объектом воздействия со стороны политических организаций.

В формате конституционно-правовой защиты государственного суверенитета приоритетное внимание уделяется не всем элементам политической организации общества. В современных условиях государство избегает вмешательства в деятельность институтов гражданского общества, творчество, религиозные отношения и частную жизнь. С помощью конституционно-правовых средств защищаются, главным образом, институты, имеющие непосредственное отношение к политической деятельности (собственно политические организации), a также основополагающие конституционные права и свободы граждан.

Конституционно-правовое регулирование ЗГС РФ в политической сфере осуществляется взаимосвязанной совокупностью конституционных положений, а также правовых норм законодательных и подзаконных актов, регламентирующих отношения по поводу завоевания, удержания и

1 Разветвленность структуры политической организации современного общества обусловило появление политических теорий «плюралистической демократии», суть которых сводится к «диффузии» (распылению) политической власти между многочисленными политическими партиями и общественными организациями. 
использования государственной власти.

Законодательная основа ЗГС РФ в политической сфере представлена ${ }^{1}$ :

- Конституцией РФ (статьи 1-6, 10-15, 29-33, 38, 40, 44, 55-64, 67, 87-89, $102-104,106,114,125,126,132)$;

- постановлениями Конституционного Суда РФ (от 13 марта 1992 г. № П-РЗ-І, от 31 июля 1995 г. № 10-П, от 16 октября 1997 г. №14-П, от 7 июня 2000 г. № 10-П, от 4 апреля 2002 г. № 8-П, от 30 октября 2003 г. № 15-П, от 15 декабря 2004 г. № 18-П, от 1 февраля 2005 г. № 1-П, от 16 июля 2007 г. № 11-П, от 22 июня 2010 г. № 14-П, от 27 июня 2013 г. № 15-П, от 10 октября 2013 г. № 20-П, от 19 марта 2014 г. № 6-П, от 8 апреля 2014 г. № 10-П, от 26 июня 2014 г. № 19-П, от 1 декабря 2015 г. № 30-П и др.);

- федеральными конституционными законами от 21 июля 1994 г. (с изм. от 8 июня 2015 г.) № 1-ФКЗ «О Конституционном Суде Российской Федерации», от 31 декабря 1996 г. (с изм. от 5 февраля 2014 г.) № 1-ФКЗ «О судебной системе Российской Федерации», от 26 февраля 1997 г. (с изм. от 23 мая 2015 г.) № 1-ФКЗ «Об Уполномоченном по правам человека в Российской Федерации», от 17 декабря 1997 г. (с изм. от 23 мая 2015 г.) № 2ФКЗ «О Правительстве Российской Федерации», от 23 июня 1999 г. (с изм. от 8 марта 2015 г.) № 1-ФКЗ «О военных судах Российской Федерации», от 30 мая 2001 г. (с изм. от 12 марта 2014 г.) № 3-ФК3 «О чрезвычайном положении», от 17 декабря 2001 г. (с изм. от 31 октября 2005 г.) № 6-ФКЗ «О порядке принятия в Российскую Федерацию и образования в ее составе нового субъекта Российской Федерации», от 30 января 2002 г. (с изм. от 12 марта 2014 г.) № 1-ФКЗ «О военном положении», от 28 июня 2004 г. (с изм. от 6 апреля 2015 г.) № 5-ФКЗ «О референдуме Российской Федерации», от 7 февраля 2011 г. (с изм. от 21 июля 2014 г.) № 1-ФКЗ «О судах общей юрисдикции в Российской Федерации», от 5 февраля 2014 г. (с изм. от 4

\footnotetext{
${ }^{1}$ Перечень приведенных законодательных актов не является исчерпывающим.
} 
ноября 2014 г.) № 3-ФКЗ «О Верховном Суде Российской Федерации» и др.; - федеральными законами от 19 мая 1995 г. (в ред. от 8 марта 2015 г.) № 82-Ф3 «Об общественных объединениях», от 30 ноября 1995 г. (в ред. от 2 мая 2015 г.) № 187-Ф3 «О континентальном шельфе Российской Федерации», от 12 января 1996 г. (в ред. от 31 января 2016 г.) № 7-Ф3 «О некоммерческих организациях», от 15 августа 1996 г. (в ред. от 28 ноября 2015 г.) № 114-Ф3 «О порядке выезда из Российской Федерации и въезда в Российскую Федерацию», от 31 июля 1998 г. (в ред. от 13 июля 2015 г.) № 155-ФЗ «О внутренних морских водах, территориальном море и прилежащей зоне Российской Федерации», от 17 декабря 1998 г. (в ред. от 14 октября 2014 г.) № 191-Ф3 «Об исключительной экономической зоне Российской Федерации», от 6 октября 1999 г. (в ред. от 28 ноября 2015 г.) «Об общих принципах организации законодательных (представительных) и исполнительных органов государственной власти субъектов Российской Федерации», от 11 июля 2001 г. (в ред. от 23 мая 2015 г.) № 95-Ф3 «О политических партиях», от 31 мая 2002 г. (в ред. от 31 декабря 2014 г.) № 62Ф3 «О гражданстве Российской Федерации», от 12 июня 2002 г. (в ред. от 3 ноября 2015 г.) № 67-Ф3 «Об основных гарантиях избирательных прав и права на участие в референдуме граждан Российской Федерации», от 25 июля 2002 г. (в ред. от 23 ноября 2015 г.) № 114-Ф3 «О противодействии экстремистской деятельности», от 25 июля 2002 г. (в ред. от 28 ноября 2015 г.) № 115-Ф3 «О правовом положении иностранных граждан в Российской Федерации», от 6 октября 2003 г. (в ред. от 28 ноября 2015 г.) № 131-Ф3 «Об общих принципах организации местного самоуправления в Российской Федерации», от 19 июня 2004 г. (в ред. от 2 мая 2015 г.) № 54-Ф3 «О собраниях, митингах, демонстрациях, шествиях и пикетированиях», от 6 марта 2006 г. (в ред. от 31 декабря 2014 г.) № 35-Ф3 «О противодействии терроризму» и др.;

- законами РФ от 27 декабря 1991 г. (в ред. от 13 июля 2015 г.) № 2124- 
1 «О средствах массовой информации», от 1 апреля 1993 г. (в ред. от 31 декабря 2014 г.) «О Государственной границе Российской Федерации», от 21 июля 1993 г. (в ред. от 8 марта 2015 г.) № 5485-1 «О государственной тайне» и др. законодательными актами.

Подзаконная правовая основа детализирует и развивает положения Конституции, федеральных конституционных и федеральных законов, законов РФ в сфере ЗГС.

Специфика конституционно-правовой защиты государственного суверенитета в политической сфере состоит в том, что суверенитет государства обеспечивается с помощью защиты не только государства, но и других собственно политических институтов, непосредственно связанных с государством (партии, общественные объединения, органы местного самоуправления и др.). Другая особенность заключается в высоком регулятивном потенциале политической сферы, который включает нормативное регулирование, правоприменение и юрисдикционную деятельность, направленные на обеспечение верховенства и независимости государственной власти, беспрепятственную реализацию государственновластных полномочий в наиболее важных сферах общественной жизни, противодействие деструктивной деятельности антигосударственных сил по ослаблению и подрыву государственного суверенитета. Наконец, в политической сфере возможно использование любых легальных методов и институтов ЗГС, в том числе и военных.

Зная ключевые элементы политической организации общества, недостатки правового регулирования, правореализации и юрисдикционной деятельности в процессе формирования и функционирования государственной власти, которые используются антигосударственными силами для ослабления и подрыва государственного суверенитета, субъекты ЗГС концентрируют свои усилия на основных направлениях ЗГС в политической сфере. Конституционно-правовая защита этих приоритетов 
позволяет государству выделять стратегические цели и первоочередные задачи юридической деятельности государства по обеспечению верховенства и независимости государственной власти, беспрепятственной реализации властных полномочий, противодействию деструктивной деятельности антигосударственных сил, рационально использовать имеющиеся силы и средства.

Основные направления конституционно-правовой защиты государственного суверенитета в политической сфере охватывают:

- конституционно-правовую защиту государства и его механизма;

- конституционно-правовое регулирование статуса личности;

- конституционно-правовое регулирование деятельности общественных объединений и некоммерческих организаций ${ }^{1}$;

- конституционно-правовое регулирование деятельности политических партий;

- конституционно-правовое регулирование деятельности СМИ;

- конституционно-правовую защиту местного самоуправления.

Выделенные направления комплексно охватывают важнейшие институты конституционно-правовой защиты государственного суверенитета.

Ключевым элементом ЗГС является государство и его механизм. Конституционно-правовая защита государства и его институтов гарантирует функционирование и развитие остальных элементов политической организации общества. Напротив, деградация государства и его структурного механизма с неизбежностью приводит к дестабилизации общественнополитической обстановки, снижению функциональности и регрессу других политических институтов общества.

Особое значение конституционно-правовой защиты государства и его

${ }^{1}$ Конституционно-правовое регулирование деятельности религиозных организаций в контексте ЗГС рассматривается в параграфе 3.4. 
механизма определяется ведущей ролью государства в политической сфере общественной жизни:

1. государство является единственной политической организацией, в масштабе всей страны выступающей от имени всего населения, официально выражающей его волю и его интересы; остальные политические институты представляют интересы отдельных социальных групп общества;

2. государство является единственной политической организацией, обладающей всей полнотой власти на территории всей страны; остальные политические институты могут лишь в той или иной степени участвовать в осуществлении политической власти или влиять на нее;

3. государство является единственной политической организацией, которая определяет юридический статус всех иных элементов политической системы общества и издает общеобязательные веления (законы); остальные политические институты принимают акты и решения, распространяющиеся только на своих членов;

4. государство является единственной политической организацией, обладающей особым аппаратом управления и принуждения (армия, тюрьмы, полиция, разведка, контрразведка); только государство обладает монополией на принуждение членов общества к выполнению своих предписаний;

5. в ведении государства находится основная часть всей системы образовательных учреждений страны, позволяющая государству играть ведущую роль в идеологической сфере общества.

Только государство объединяет всех членов общества независимо от их социального положения, материального достатка, профессии, возраста, национальной принадлежности, вероисповедания. И только государство способно решать наиболее сложные общественные проблемы, поскольку располагает для этого необходимыми людскими, материальными, финансовыми и иными ресурсами. С учетом этого вокруг государства объединяются все остальные политические институты общества. 
Конституционно-правовая защита механизма государства реализуется в рамках правового режима безопасного формирования и функционирования органов государственной власти и управления, который включает:

- принципы формирования и функционирования органов государственной власти (распространение суверенитета РФ на всю ее территорию, территориальная целостность РФ, верховенство Конституции и федеральных законов на всей территории, единство системы государственной власти, периодичность воспроизводства органов народного представительства, разделение власти, разграничение предметов ведения и полномочий и др.)

- требования к кандидатам на выборные должности; к кандидатам на государственные должности, должности гражданской, военной и правоохранительной службы ${ }^{1}$;

- порядок государственной охраны должностных лиц и объектов (в том числе должностных лиц иностранных государств в период их пребывания на территории РФ);

- возможность обжалования решений, действий (бездействия) органов государственной власти, иных органов, организаций и должностных лиц, наделенных государственными полномочиями;

- ответственность органов государственной власти и должностных лиц за действия (бездействие), представляющие угрозу государственному суверенитету (отрешение Президента РФ от должности, досрочное прекращение полномочий законодательного органа государственной власти субъекта РФ и высшего должностного лица субъекта РФ).

В условиях чрезвычайной обстановки (попытки захвата и присвоения власти, вооруженный мятеж, активизация незаконных вооруженных

1 Более подробно ограничения прав граждан и требования к кандидатам на замещение соответствующих должностей, связанные с формированием выборных и назначаемых органов власти, рассматриваются в рамках такого направления ЗГС в политической сфере, как конституционно-правовое регулирование статуса личности. 
формирований, инспирирование межнациональных и межконфессиональных конфликтов, другие действия, создающие угрозу нормальной деятельности органов государственной власти и управления) конституционно-правовая защита механизма государства осуществляется с использованием исключительных правовых режимов.

Конституционно-правовая защита российского государства и его механизма базируется на принципах формирования и функционирования органов государственной власти, важнейшими из которых являются: распространение суверенитета на всю территорию государства, территориальная целостность и верховенство Конституции Российской Федерации и федеральных законов на всей территории.

Государственный суверенитет закреплен в Конституции РФ в качестве одной из основ конституционного строя (часть 1 статьи 4).

В соответствии со статьей 1 Закона РФ от 1 апреля 1993 г. № 4730-1 «О Государственной границе Российской Федерации» пространственный предел действия государственного суверенитета РФ определяется пределами государственной территории (суши, вод, недр и воздушного пространства).

Территория РФ включает в себя территории субъектов, внутренние воды и территориальное море, воздушное пространство над ними (статья 67 Конституции Российской Федерации).

Согласно статье 1 Федерального закона от 31 июля 1998 г. № 155-Ф3 «О внутренних морских водах, территориальном море и прилежащей зоне Российской Федерации» в качестве внутренних морских вод Российской Федерации понимаются воды, расположенные в сторону берега от исходных линий, от которых отмеряется ширина территориального моря Российской Федерации. В статье 2 Федерального закона «О внутренних морских водах, территориальном море и прилежащей зоне Российской Федерации» дано определение территориального моря РФ, под которым понимается примыкающий к сухопутной территории или внутренним морским водам 
морской пояс шириной 12 морских миль, отмеряемых от исходных линий. Внешняя граница территориального моря является Государственной границей РФ.

На территориальное море, воздушное пространство над ним, а также на дно территориального моря и его недра распространяется суверенитет РФ с признанием права мирного прохода иностранных судов через территориальное море.

Как указано в статье 11 Федерального закона «О внутренних морских водах, территориальном море и прилежащей зоне Российской Федерации», проход через территориальное море иностранного судна, иностранного военного корабля или другого государственного судна считается нарушающим мир, добрый порядок или безопасность РФ, если в территориальном море указанное судно осуществляет любой из следующих видов деятельности:

- угрозу силой или ее применение против суверенитета, территориальной целостности или независимости РФ или каким-либо другим образом в нарушение принципов международного права;

- любые маневры или учения с оружием любого вида;

- любой акт, направленный на сбор информации в ущерб обороне или безопасности РФ;

- любой акт пропаганды, имеющий целью посягательство на оборону или безопасность РФ;

- подъем в воздух, посадку или принятие на борт любого летательного аппарата;

- подъем в воздух, посадку или принятие на борт любого военного устройства;

- погрузку или выгрузку любого товара или валюты, посадку или высадку любого лица вопреки пограничным, таможенным, налоговым (фискальным), санитарным, иммиграционным, ветеринарным, 
фитосанитарным, навигационным и другим правилам, установленным законами и иными нормативными правовыми актами РФ;

- любой акт преднамеренного и серьезного загрязнения окружающей среды;

- любую деятельность в области рыболовства;

- проведение исследовательской или гидрографической деятельности;

- любой акт, направленный на создание помех функционированию любых систем связи либо любых других сооружений и установок РФ;

- любую другую деятельность, не имеющую прямого отношения к проходу через территориальное море.

В интересах обеспечения безопасности РФ, а также в целях проведения учений с оружием любого вида Министерство обороны или ФСБ России могут временно приостановить в определенных районах территориального моря осуществление права мирного прохода через территориальное море для иностранных судов, иностранных военных кораблей и других государственных судов.

В соответствии со статьей 67 Конституции Российской Федерации РФ обладает суверенными правами и осуществляет юрисдикцию на континентальном шельфе и в исключительной экономической зоне РФ 1 .

Континентальный шельф РФ включает в себя морское дно и недра подводных районов, находящиеся за пределами территориального моря РФ, на всем протяжении естественного продолжения ее сухопутной территории до внешней границы подводной окраины материка².

Исключительная экономическая зона РФ рассматривается как морской район, находящийся за пределами территориального моря РФ и прилегающий к нему, с особым правовым режимом, установленным

${ }^{1}$ Содержание суверенных прав и юрисдикции РФ на континентальном шельфе и в исключительной экономической зоне рассматриваются в параграфе 3.2. данной монографии.

континентальном 1 Фельфе Российской Федерации». 
Федеральным законом «Об исключительной экономической зоне Российской Федерации», международными договорами РФ и нормами международного права ${ }^{1}$.

Делимитация континентального шельфа и исключительной экономической зоны РФ осуществляются на основании международных договоров РФ или норм международного права.

РФ при установлении и изменении своей Государственной границы, регулировании отношений с иностранными государствами руководствуется принципами обеспечения безопасности РФ и международной безопасности; взаимовыгодного всестороннего сотрудничества с иностранными государствами; взаимного уважения суверенитета, территориальной целостности государств и нерушимости государственных границ; мирного разрешения пограничных вопросов.

Вопросы территории в контексте ЗГС могут быть связаны с противодействием сепаратизму и восстановлением правопорядка в государстве.

Для защиты территориальной целостности и конституционной законности важнейшее значение имеют решения Конституционного Суда РФ по вопросам восстановления законности и правопорядка на территории Чеченской Республики (Постановление от 31 июля 1995 г. № 10-П) и преодоления конфедеративного характера взаимоотношений с отдельными субъектами РФ (Постановление от 13 марта 1992 г., Постановление от 7 июня 2000 г. № 10-П и Определение от 27 июня 2000 г. N 92-О).

В Постановлении Конституционного Суда РФ от 31 июля 1995 г. № 10П рассматривалась конституционность использования Вооруженных Сил при разрешении внутренних конфликтов и мер государственного принуждения для обеспечения территориальной целостности РФ. Оспариваемые по делу

1 Статья 1 Федерального закона от 17 декабря 1998 г. № 191-Ф3 «Об исключительной экономической зоне Российской Федерации». 
правовые акты Президента и Правительства РФ регламентировали меры обеспечения государственной безопасности и территориальной целостности РФ, разоружения незаконных вооруженных формирований на территории Чеченской Республики.

Конституционный Суд пришел к выводу, что государственная целостность является одной из основ конституционного строя РФ (статьи 4 (часть 3), 5 (часть 3), 8, 65, 67 (часть 1), 71 (пункт «б») Конституции РФ)) и выступает важным условием равного правового статуса всех граждан независимо от места их проживания, одной из гарантий их конституционных прав и свобод. Односторонние действия по изменению статуса субъекта РФ и его выходу из состава РФ не предусматриваются Конституцией РФ. Статус субъекта РФ может быть изменен только по взаимному согласию РФ и ее субъекта путем принятия федерального конституционного закона.

Конституционным Судом была подтверждена конституционность полномочий Президента принимать меры по ЗГС РФ, ее независимости, безопасности и территориальной целостности, а также возлагать на Правительство решение задач во исполнение указов Президента.

По мнению Конституционного Суда, обеспечение государственной целостности и конституционного порядка в экстраординарных ситуациях может осуществляться и другими способами, помимо введения чрезвычайного или военного положения.

Оспариваемые акты Президента РФ были признаны принятыми в пределах конституционных полномочий Президента и соответствующими Конституции.

Укреплению государственного суверенитета и конституционной законности способствовало Постановление Конституционного Суда РФ от 13 марта 1992 г. по делу о проверке конституционности Декларации о государственном суверенитете Татарской ССР от 30 августа 1990 г., Закона Татарской ССР от 18 апреля 1991 г. «Об изменениях и дополнениях 
Конституции (Основного Закона) Татарской ССР», Закона Татарской ССР от 29 ноября 1991 г. «О референдуме Татарской ССР», постановления Верховного Совета Республики Татарстан от 21 февраля 1992 г. «О проведении референдума Республики Татарстан по вопросу о государственном статусе Республики Татарстан», в котором была сформулирована важнейшая правовая позиция о неконституционности государственного суверенитета субъекта Федерации ${ }^{1}$.

В Постановлении от 7 июня 2000 г. № 10-П по делу о проверке конституционности отдельных положений Конституции Республики Алтай и Федерального закона «Об общих принципах организации законодательных (представительных) органов государственной власти субъектов Российской Федерации» и Определении от 27 июня 2000 г. № 92-О по запросу группы депутатов Государственной Думы о проверке соответствия Конституции Российской Федерации отдельных положений конституций Республики Адыгея, Республики Башкортостан, Республики Ингушетия, Республики Коми, Республики Северная Осетия - Алания и Республики Татарстан доктринальные позиции Конституционного Суда о государственном суверенитете получили развитие.

В интерпретации Конституционным Судом смысла статей 3, 4, 5, 67 и 79 Конституции РФ суверенитет предполагает верховенство, независимость и самостоятельность государственной власти, полноту законодательной, исполнительной и судебной власти государства на его территории и независимость в международном общении, представляет собой необходимый качественный признак РФ как государства, характеризующий еe

1 Положения Декларации о государственном суверенитете Татарской ССР от 30 августа 1990 г., которыми устанавливался новый статус Республики вне состава РФ и верховенство республиканских законов над федеральными, Конституционный Суд РФ признал неконституционными. Суд также признал противоречащими Конституции РФ ряд положений Закона Татарской ССР от 29 ноября 1991 г. «О референдуме Татарской ССР» и формулировку вопроса референдума, в которой был закреплен новый государственный статус республики как суверенного государства, субъекта международного права, строящего свои отношения с РФ и другими республиками на основе равноправных договоров. 
конституционно-правовой статус.

Конституция РФ не допускает какого-либо иного носителя суверенитета и источника власти, помимо многонационального народа России, и, следовательно, не предполагает какого-либо иного государственного суверенитета, помимо суверенитета РФ. Суверенитет РФ не допускает суверенитета субъектов РФ.

Содержащееся в Конституции Российской Федерации решение вопроса о суверенитете предопределяет характер федеративного устройства, исторически обусловленного тем, что субъекты РФ не обладают суверенитетом, который изначально принадлежит РФ в целом. Признание Конституцией РФ суверенитета только за РФ воплощено также в конституционных принципах государственной целостности и единства системы государственной власти (статья 5, часть 3), верховенства Конституции и федеральных законов, которые имеют прямое действие и применяются на сей территории РФ, включающей в себя территории ее субъектов (статья 4, часть 2; статья 15 , часть 1 , и статья 67 , часть 1 ).

Исходя из этих конституционных принципов все правовые акты, принимаемые в РФ, в том числе конституции республик, не должны противоречить Конституции РФ. Законы же и другие правовые акты, действовавшие на территории РФ до вступления в силу Конституции РФ, подлежат применению лишь в части, ей не противоречащей ${ }^{1}$.

Приоритет положений Конституции РФ имеет место при определении как статуса субъектов РФ, так и предметов ведения и полномочий органов государственной власти РФ и органов государственной власти ее субъектов.

Были признаны неконституционными, утратившими силу и не подлежащими применению оспариваемые положения:

1 Именно поэтому положения Федеративного договора от 31 марта 1992 г., предусматривавшие суверенитет республик и позволявшие тем самым обосновывать ограничения суверенитета РФ, ее конституционно-правового статуса и полномочий, что нашло отражение в конституциях ряда республик, в настоящее время не действуют и не подлежат применению как противоречащие Конституции РФ. 
- о республиканском суверенитете и народе республики как единственном источнике власти и носителе суверенитета;

- о договорном характере статуса республики как субъекта в составе РФ, международной правосубъектности республик, их правомочиях быть самостоятельным участником межгосударственных отношений и заключать договоры международно-правового характера ${ }^{1}$;

- о верховенстве республиканского законодательства на всей территории республики, ограничении применения и возможности приостановки действия федеральных нормативных правовых актов, введении процедур разрешения коллизий, не предусмотренных Конституцией РФ и федеральными законами.

Важной составляющей конституционно-правовой защиты государственного суверенитета являются правовые позиции Конституционного Суда по вопросам единства государственной власти и разграничению предметов ведения и полномочий.

В Постановлении Конституционного Суда РФ от 7 июня 2000 г. № 10П среди других положений Конституции Республики Алтай оспаривалась статья 154, согласно которой городской и районный суды Республики Алтай образовывались и действовали в соответствии с федеральным законом и законом Республики Алтай.

При этом судоустройство и установление системы федеральных органов судебной власти, порядка их организации и деятельности относится к ведению РФ и определяется исключительно Конституцией РФ (пункт «о» статьи 71, пункт «г» статьи 71, часть 3 статьи 118) и федеральными

${ }^{1}$ По мнению Конституционного Суда, этим не затрагивается право республик в соответствии со статьями 72 (пункт «о» части 1) и 76 (часть 2) Конституции РФ осуществлять международные и внешнеэкономические связи, при условии, что такие связи не вторгаются в полномочия и прерогативы РФ как суверенного государства, предусмотренные статьей 71 (пункты «К», «Л», «М», «н»), и что их координация определяется федеральным законом и принимаемыми на его основе законами и иными нормативными актами субъектов РФ. 
конституционными законами.

В Постановлении Конституционного Суда РФ от 1 февраля 1996 г. по делу о проверке конституционности ряда положений Устава - Основного Закона Читинской области указано, что Конституция РФ устанавливает единую судебную систему. Данная правовая позиция подтверждена в Определении Конституционного Суда от 12 марта 1998 г. № 32-О по запросу высших должностных лиц ряда субъектов РФ о проверке конституционности некоторых положений Федерального конституционного закона «О судебной системе Российской Федерации».

Согласно статье 4 Федерального конституционного закона «О судебной системе Российской Федерации» районные суды и приравненные к ним городские суды относятся к федеральным судам, которые создаются и действуют на основе федерального регулирования. Исходя из этого Конституционный Суд пришел к выводу, что положение статьи 154 Конституции Республики Алтай о том, что в Республике Алтай указанные суды создаются и действуют в том числе в соответствии с законом Республики Алтай, нарушает принцип верховенства Конституции РФ и федеральных законов на всей территории РФ и является вторжением в полномочия РФ по предметам ее ведения, т.е. не согласуется со статьями 4 (часть 2), 71 (пункты «г» и «о») и 76 (часть 1) Конституции РФ.

Данные правовые позиции Конституционного Суда способствовали укреплению федерализма, единых принципов организации системы государственной власти, четкому разграничению полномочий РФ и ее субъектов.

Конституционно-правовая защита российского государства и его механизма предполагает особый порядок обеспечения безопасности и защиты государственных должностных лиц в целях безопасного и беспрепятственного осуществления государственной власти в РФ и исполнения международных обязательств РФ. 
В соответствии с Федеральным законом от 27 мая 1996 г. № 57-Ф3 «О государственной охране» к объектам государственной охраны отнесены Президент РФ, лица, замещающие государственные должности РФ (Председатель Правительства, Председатель Совета Федерации, Председатель Государственной Думы, Председатель Конституционного Суда, Председатель Верховного Суда, Генеральный прокурор, Председатель Следственного комитета РФ), федеральные государственные служащие и иные лица, а также главы иностранных государств и правительств и иные лица иностранных государств во время пребывания на территории РФ.

Государственную охрану должностных лиц осуществляют органы государственной охраны, которые для решения своих задач привлекают органы федеральной службы безопасности, органы внутренних дел и Федеральную службу войск национальной гвардии, органы внешней разведки, Вооруженные Силы и иные государственные органы.

В целях обеспечения безопасности органов власти, защиты прав и свобод человека и гражданина, обеспечения законности, правопорядка, надежного функционирования объектов жизнеобеспечения, транспортной и социальной инфраструктуры, связи, предупреждения массовых беспорядков законодательством подробно урегулирован порядок обеспечения условий проведения публичных мероприятий (собраний, митингов, демонстраций, шествий и пикетирований), установлены требования к организаторам и участникам публичных мероприятий.

На основании части 2 статьи 5 Федерального закона от 19 июня 2004 г. № 54-Ф3 «О собраниях, митингах, демонстрациях, шествиях и пикетированиях» организатором публичного мероприятия не могут быть:

а) лицо, признанное судом недееспособным либо ограниченно дееспособным, а также лицо, содержащееся в местах лишения свободы по приговору суда;

б) лицо, имеющее неснятую или непогашенную судимость за 
совершение умышленного преступления против основ конституционного строя и безопасности государства или преступления против общественной безопасности и общественного порядка либо два и более раза привлекавшееся к административной ответственности за административные правонарушения, предусмотренные статьями 5.38, 19.3, 20.1 - 20.3, 20.18, 20.29 КоАП РФ, в течение срока, когда лицо считается подвергнутым административному наказанию;

в) политическая партия, другое общественное объединение и религиозное объединение, их региональные отделения и иные структурные подразделения, деятельность которых приостановлена или запрещена либо которые ликвидированы в установленном законом порядке.

В целях недопущения использования публичных мероприятий в качестве инструмента дестабилизации обстановки, дезорганизации нормального функционирования органов государственной власти, попыток неконституционного прихода к власти («цветных революций») и насильственного изменения конституционного строя участники публичных мероприятий не вправе:

- скрывать свое лицо, в том числе использовать маски, средства маскировки, иные предметы, специально предназначенные для затруднения установления личности;

- иметь при себе оружие, боеприпасы, колющие и режущие предметы, другие предметы в качестве оружия, взрывные устройства, взрывчатые, ядовитые, отравляющие, едко пахнущие, легковоспламеняющиеся вещества, огнеопасные и пиротехнические изделия, предметы (химические материалы), которые могут быть использованы для изготовления пиротехнических изделий или дымов, горючие материалы и вещества, иные вещества, предметы и изделия, в том числе самодельного изготовления, использование которых может привести к задымлению, воспламенению, иметь при себе и (или) распивать алкогольную продукцию; 
- находиться в месте проведения публичного мероприятия в состоянии опьянения.

В соответствии с частью 2 статьи 8 Федерального закона «О собраниях, митингах, демонстрациях, шествиях и пикетированиях» определены места, в которых проведение публичных мероприятий запрещено:

- территории, непосредственно прилегающие к опасным производственным объектам;

- путепроводы, железнодорожные магистрали и полосы отвода железных дорог, нефте -, газо- и продуктопроводов, высоковольтных ЛЭП;

- территории, непосредственно прилегающие к резиденциям Президента РФ, к зданиям судов, к территориям и зданиям учреждений, исполняющих наказание в виде лишения свободы;

- пограничные зоны (при отсутствии специального разрешения пограничных органов).

Законодателем регламентирован порядок приостановления и прекращения публичных мероприятий, в том числе при создании реальной угрозы жизни и здоровью граждан, имуществу, совершении участниками публичных мероприятий противоправных действий и неисполнении организаторами мероприятия своих обязанностей.

Конституционно-правовая защита механизма государства неразрывно связана с возможностью обжалования решений, действий (бездействия) органов государственной власти, иных органов, организаций и должностных лиц, наделенных государственными полномочиями.

Обжалование решений, действий (бездействия) органов государственной власти, иных органов, организаций и должностных лиц, наделенных государственными полномочиями, возможно в формате административных процедур или в судебном порядке.

Административный порядок обжалования регулируется Федеральным законом от 2 мая 2006 г. № 59-Ф3 «О порядке рассмотрения обращений 
граждан Российской Федерации». В законе закреплено свободное и добровольное право граждан обращаться лично, а также направлять индивидуальные и коллективные обращения в государственные органы, органы местного самоуправления и их должностным лицам, в государственные и муниципальные учреждения и иные организации, на которые возложено осуществление публично значимых функций, и их должностным лицам. Реализация гражданами права на обращение (предложение, заявление или жалобу) не должна нарушать права и свободы других лиц.

Обжалование решений и действий государственных органов, организаций и должностных лиц, наделенных публичными полномочиями, имеет непосредственное отношение к ЗГС, поскольку эффективная ЗГС возможна лишь при полноценной реализации (восстановлении) конституционных прав граждан, защите их законных интересов, совершенствовании работы государственного аппарата и при активном сотрудничестве субъектов ЗГС с общественными институтами.

В Федеральном законе «О порядке рассмотрения обращений граждан Российской Федерации» предусмотрены гарантии безопасности гражданина в связи с его обращением. Так, запрещается преследование гражданина в связи с его обращением в государственный орган, орган местного самоуправления или к должностному лицу с критикой деятельности указанных органов или должностного лица либо в целях восстановления или защиты своих прав, свобод и законных интересов либо прав, свобод и законных интересов других лиц. При рассмотрении обращения не допускается разглашение сведений, содержащихся в обращении, а также сведений, касающихся частной жизни гражданина, без его согласия. Запрещается направлять жалобу на рассмотрение в государственный орган, орган местного самоуправления или должностному лицу, решение или действие (бездействие) которых обжалуются. 
Государственные органы, органы местного самоуправления и должностные лица осуществляют в пределах своей компетенции контроль за соблюдением порядка рассмотрения обращений и принимают меры по своевременному выявлению и устранению причин нарушения прав, свобод и законных интересов граждан.

Административный порядок обжалования может являться как альтернативным способом разрешения споров, так и являться обязательной процедурой досудебного порядка разрешения споров.

Судебный порядок оспаривания решений, действий (бездействия) органов государственной власти, органов местного самоуправления, иных органов, организаций, наделенных отдельными государственными или иными публичными полномочиями, должностных лиц, государственных и муниципальных служащих регулируется главой 22 Кодекса административного судопроизводства РФ от 8 марта 2005 г. № 21-Ф3.

Гражданин, организация, иные лица могут обратиться в суд с требованиями об оспаривании решений, действий (бездействия) органов государственной власти, органов местного самоуправления, иных органов, организаций, наделенных отдельными государственными или иными публичными полномочиями, должностных лиц, государственных и муниципальных служащих, если полагают, что нарушены или оспорены их права, свободы и законные интересы, созданы препятствия к осуществлению их прав, свобод и реализации законных интересов или на них незаконно возложены какие-либо обязанности.

С заявлениями в суд в защиту прав, свобод и законных интересов иных лиц о признании незаконными решений, действий (бездействия) органа, организации, лица, наделенных государственными или иными публичными полномочиями, могут также обратиться органы государственной власти, Уполномоченный по правам человека в РФ, Уполномоченный по правам человека в субъекте РФ, иные органы, организации и лица, а также прокурор. 
В случае признания решения, действия (бездействия) незаконными орган, организация, лицо, наделенные государственными или иными публичными полномочиями и принявшие оспоренное решение или совершившие оспоренное действие (бездействие), обязаны устранить допущенные нарушения или препятствия к осуществлению прав, свобод и реализации законных интересов истца либо прав, свобод и законных интересов лиц, в интересах которых было подано соответствующее заявление, и восстановить данные права, свободы и законные интересы указанным судом способом в установленный им срок, а также сообщить об этом в суд, гражданину, в организацию, иному лицу, в отношении которых допущены нарушения или созданы препятствия.

По решению суда гражданину могут быть возмещены убытки и компенсирован моральный вред, причиненные незаконным действием (бездействием) государственного органа, органа местного самоуправления или должностного лица.

Принципиальное значение в системе конституционно-правовой защиты государственного суверенитета в политической сфере имеют вопросы ответственности органов государственной власти и должностных лиц за действия (бездействие), представляющие угрозу государственному суверенитету.

Учитывая высокий статус Президента РФ, его роль и место в механизме государства, объем принадлежащих Главе государства властных полномочий, вопросы его юридической ответственности (основание, порядок привлечения, уполномоченные субъекты) подробно закреплены на конституционном уровне. Статья 93 Конституции РФ регулирует процедуру досрочного прекращения полномочий Президентом РФ в связи с отрешением его от должности. Правовым основанием для отрешения от должности является совершение Президентом государственной измены или иного тяжкого преступления. 
Инициатива выдвижения обвинения Президенту должна исходить не менее чем от $1 / 3$ депутатов Государственной Думы при наличии заключения образованной Государственной Думой специальной комиссии. Выдвинутое Государственной Думой обвинение должно быть подтверждено заключением Верховного Суда РФ о наличии в действиях Президента РФ признаков состава государственной измены или иного тяжкого преступления.

Конституционный Суд РФ по запросу Совета Федерации дает заключение о соблюдении установленного порядка выдвижения обвинения Президента РФ в государственной измене или совершении иного тяжкого преступления.

Решение об отрешении Президента от должности принимает Совет Федерации на основании представленных материалов не позднее чем в 3 месячный срок с момента выдвижения Государственной Думой обвинения. Если 3-месячный срок не соблюден, обвинение считается отклоненным.

Вопросы конституционно-правовой ответственности органов государственной власти субъектов РФ рассматривались в Постановлении Конституционного Суда РФ от 4 апреля 2002 г. № 8-П по делу о проверке конституционности отдельных положений Федерального закона «Об общих принципах организации законодательных (представительных) и исполнительных органов государственной власти субъектов Российской Федерации» в связи с запросами Государственного Собрания (Ил Тумэн) Республики Саха (Якутия) и Совета Республики Государственного Совета Хасэ Республики Адыгея.

В данном деле оспаривались введенные Федеральным законом «Об общих принципах организации законодательных (представительных) и исполнительных органов государственной власти субъектов Российской Федерации» меры федерального воздействия, применяемые на основе соответствующих судебных решений в случае их неисполнения:

- досрочное прекращение полномочий (роспуск) законодательного 
(представительного) органа государственной власти субъекта РФ, осуществляемое федеральным законом;

- вынесение Президентом РФ предупреждения законодательному (представительному) органу государственной власти и высшему должностному лицу субъекта РФ;

- временное отстранение высшего должностного лица субъекта РФ от исполнения обязанностей и отрешение его от должности; отставка высшего исполнительного органа государственной власти субъекта РФ в случае отрешения возглавляющего его лица от должности Президентом РФ.

Оспариваемые положения Федерального закона «Об общих принципах организации законодательных (представительных) и исполнительных органов государственной власти субъектов Российской Федерации» направлены на обеспечение исполнения решений федеральных судов, вынесенных в связи с принятием органами государственной власти субъектов РФ нормативных актов, противоречащих Конституции РФ и федеральным законам. По мнению Конституционного Суда, неподчинение органа государственной власти субъекта РФ решению Федерации, выраженному в судебном решении, обязывающем отменить принятый им нормативный акт, противоречащий Конституции РФ и федеральным законам, представляет собой непризнание верховенства Конституции РФ и, по существу, означает присвоение органом государственной власти субъекта РФ не принадлежащих ему властных полномочий и суверенных прав РФ (статья 3, часть 4; статья 4 Конституции). По смыслу конституционных положений такие действия органа государственной власти субъекта РФ ведут к утрате им своей легитимности, и поэтому досрочное прекращение его полномочий в предусмотренном Федеральным законом порядке согласуется с целями защиты Конституции РФ.

Возможность досрочного прекращения (роспуска) законодательного (представительного) органа государственной власти субъекта РФ была 
признана конституционной, поскольку процедура реализации данной меры федерального воздействия, завершающаяся принятием федерального закона, включает в качестве обязательных элементов решение суда о признании нормативного правового акта субъекта РФ не соответствующим Конституции РФ и федеральным законам, а также решение суда, которым подтверждается уклонение от исполнения первоначального судебного акта и признается необходимость федерального воздействия в целях его исполнения. При этом применение данной меры федерального воздействия обусловлено обязательностью подтверждения в судебном порядке наступления конституционно значимых тяжких последствий, вызванных неправомерным нормативным актом и его несвоевременным устранением из правовой системы РФ.

Принятие федерального закона о роспуске законодательного (представительного) органа государственной власти субъекта РФ служит повышению степени защиты от произвольного, несоразмерного и нецелесообразного использования федерального воздействия.

Допустимость отрешения, т.е. досрочного освобождения, от должности высших должностных лиц субъектов РФ в связи с их незаконными действиями и решениями неоднократно была предметом рассмотрения Конституционного Суда РФ. В Постановлении от 18 января 1996 г. по делу о проверке конституционности ряда положений Устава (Основного Закона) Алтайского края Конституционный Суд установил, что нормы, закрепляющие досрочное освобождение от должности главы администрации Алтайского края за неправомерные действия в качестве института конституционной ответственности, не противоречат Конституции РФ при условии, что неправомерность этих действий подтверждается вступившим в силу решением суда. Данная правовая позиция была подтверждена в Определении Конституционного Суда от 14 января 1999 г. № 37-О по запросу администрации Калининградской области о проверке 
конституционности отдельных положений Устава (Основного Закона) Калининградской области.

Как установил Конституционный Суд, досрочное прекращение полномочий (отрешение от должности) высшего должностного лица субъекта РФ предполагает следующие обязательные элементы: признание судом акта, изданного высшим должностным лицом субъекта РФ, противоречащим Конституции РФ и федеральным законам; подтверждение в судебном порядке неисполнения решения суда при условии, что высшее должностное лицо субъекта РФ не обратилось в суд для разрешения спора; вынесение Президентом РФ предупреждения в адрес этого лица в связи с непринятием им мер по отмене приостановленного указом Президента РФ соответствующего нормативного акта. Данная мера федерального воздействия не может быть реализована без судебного подтверждения наступивших конституционно значимых тяжких последствий (неправомерный нормативный акт повлек массовые и грубые нарушения прав и свобод человека и гражданина, угрозу единству, территориальной целостности, национальной безопасности, обороноспособности, единству правового и экономического пространства РФ).

По мнению Конституционного Суда, вынесение Президентом РФ предупреждения в адрес законодательного (представительного) органа государственной власти субъекта РФ следует рассматривать как профилактическую меру, которая призвана побудить органы государственной власти субъектов РФ к добровольному исполнению решения суда, способствовать выполнению ими конституционных обязанностей и одновременно создает дополнительную гарантию для субъекта РФ в процедуре применения федерального воздействия. Такое предупреждение способствует как своевременному исключению применения нормативных правовых актов, признанных противоречащими федеральному законодательству, так и инициированию субъектом РФ рассмотрения дела 
Конституционным Судом РФ в процедурах проверки нормативных правовых актов или спора о компетенции.

Сформулированная в 2002 г. правовая позиция Конституционного Суда о досрочном прекращении полномочий высшего должностного лица субъекта РФ должна рассматриваться в нормативном единстве с принятыми позже пунктами 3.1 и 3.2 статьи 29.1 Федерального закона «Об общих принципах организации законодательных (представительных) и исполнительных органов государственной власти субъектов Российской Федерации». Законодателем было закреплено право Президента РФ отрешить от должности высшее должностное лицо субъекта РФ в связи с выражением ему недоверия законодательным (представительным) органом государственной власти субъекта РФ, с утратой доверия Президента, за ненадлежащее исполнение своих обязанностей (в том числе по осуществлению переданных полномочий РФ). В соответствии с пунктом 3.2 статьи 29.1 комментируемого Федерального закона Президент получил право отрешить от должности высшее должностное лицо субъекта РФ в случае неисполнения им решения Конституционного Суда РФ, принятого в отношении нормативного правового акта высшего должностного лица субъекта РФ, если указанное решение не исполнено в течение 1 месяца со дня его вступления в силу или в иной указанный в решении срок.

Как представляется, возможность применения Президентом РФ перечисленных мер федерального воздействия является серьезным правовым инструментом реализации Главой государства своих функций по защите суверенитета и Конституции РФ.

Отрешение от должности является юридическим фактом, препятствующим выдвижению кандидатом на выборные должности в органы государственной власти и местного самоуправления.

Так, гражданин РФ, замещавший должность Президента РФ и досрочно прекративший исполнение полномочий Президента в случае отставки, 
стойкой неспособности по состоянию здоровья осуществлять принадлежащие ему полномочия или отрешения от должности, не может быть выдвинут кандидатом на выборах, назначенных в связи с указанными обстоятельствами.

Гражданин РФ, замещавший должность высшего должностного лица субъекта РФ (руководителя высшего исполнительного органа государственной власти субъекта РФ) и отрешенный от этой должности Президентом РФ, в течение двух лет, исчисляемых со дня вступления в силу указа Президента РФ об отрешении его от должности и до дня назначения выборов высшего должностного лица субъекта РФ (руководителя высшего исполнительного органа государственной власти субъекта РФ), не может быть выдвинут кандидатом на указанную должность ни в одном субъекте РФ.

Гражданин РФ, замещавший должность главы муниципального образования и ушедший с указанной должности в отставку по собственному желанию, в том числе в связи с избранием его депутатом либо на иную выборную должность, замещение которой несовместимо со статусом главы муниципального образования, либо отрешенный от должности главы муниципального образования высшим должностным лицом субъекта РФ (руководителем высшего исполнительного органа государственной власти субъекта РФ), не может быть выдвинут кандидатом на выборах, назначенных в связи с указанными обстоятельствами.

В целях ЗГС могут быть реализованы антикриминальные правовые механизмы в виде временного отстранения должностного лица от замещения должности (исполнения должностных обязанностей).

Пункт 4 ст. 29.1 Федерального закона «Об общих принципах организации законодательных (представительных) и исполнительных органов государственной власти субъектов Российской Федерации» содержит норму о том, что Президент РФ в порядке, установленном 
уголовно-процессуальным законодательством, вправе по представлению Генерального прокурора РФ временно отстранить высшее должностное лицо субъекта РФ от исполнения обязанностей в случае предъявления ему обвинения в совершении тяжкого или особо тяжкого преступления. В Постановлении от 4 апреля 2002 г. № 8-П Конституционный Суд выразил правовую позицию, в силу которой данная обеспечительно-исполнительная мера служит правовым средством обеспечения объективности уголовного преследования, а также защиты прав потерпевших от преступлений и злоупотреблений властью. Временное отстранение от должности Президентом РФ связано со статусом высших должностных лиц исполнительной власти субъектов РФ, которые в силу принципов единства системы государственной власти находятся в отношениях субординации непосредственно с Президентом. Принятие соответствующего решения именно Президентом РФ создает гарантию от возможного злоупотребления служебным положением со стороны высшего должностного лица субъекта PФ.

В контексте конституционной ответственности особый публичноправовой характер имеют вопросы отзыва выборных лиц.

Конституционно-правовые требования к институту отзыва высшего должностного лица субъекта РФ закреплены в Постановлении Конституционного Суда от 7 июня 2000 г. № 10-П. По мнению Конституционного Суда, институт отзыва отражает конституционную ответственность высшего должностного лица перед избравшим его народом. При этом отзыв не должен использоваться для дестабилизации выборных институтов власти и самой демократии. В силу закрепленных Конституцией РФ принципов демократического правового государства, в том числе принципов идеологического и политического многообразия, многопартийности (статья 13, части 1-3), а также поскольку избираемое высшее должностное лицо субъекта РФ не связано императивным мандатом, 
основанием для отзыва может служить лишь его неправомерная деятельность. Сама процедура отзыва должна обеспечивать лицу возможность дать избирателям объяснения по поводу обстоятельств, выдвигаемых в качестве основания для отзыва, а избирателям - проводить агитацию как за, так и против отзыва, а также гарантировать всеобщее, равное, прямое участие избирателей в тайном голосовании по отзыву.

Вопросы конституционно-правовой защиты механизма государства находятся в неразрывной связи с правовым статусом личности, поскольку именно население государства непосредственно участвует в обеспечении и реализации функций государства, решении всех задач ЗГС в любых сферах общественной жизни.

Конституционно-правовое регулирование статуса личности в контексте ЗГС в политической сфере осуществляется путем предоставления гражданства РФ, правового упорядочения вопросов въезда в РФ и выезда из РФ иностранных граждан и лиц без гражданства, пребывания и проживания их на территории РФ, реализации иностранными гражданами и апатридами политических прав, допуска к государственной тайне.

Реализация государственных предписаний, связанных с правовым положением личности, обеспечивается следующими основными правовыми режимами:

- контроля за въездом, передвижением по территории государства, проживанием и выездом иностранных граждан и лиц без гражданства;

- безопасного формирования и функционирования органов государственной власти и управления;

- пенитенциарного режима;

- защиты государственной тайны;

- режимами чрезвычайного и военного положения.

Важнейшим конституционно-правовым институтом, непосредственно связанным с комплексом прав и юридических обязанностей лица и 
государства, выступает гражданство. Осуществляя конституционно-правовое регулирование статуса личности в контексте ЗГС, государство определяет корпус своих граждан и наделяет их полным объемом прав.

Институт гражданства выполняет двоякую социально-юридическую функцию. С одной стороны, гражданство выступает как средство и способ защиты прав индивида, с другой, как институт защиты прав и интересов государства ${ }^{1}$.

Элементами института гражданства выступают нормы права, содержащиеся в Конституции РФ, международных договорах, Федеральном законе «О гражданстве Российской Федерации», а также принимаемых в соответствии с ними другими нормативными правовыми актами РФ.

Конституция РФ устанавливает основные принципы гражданства, основы правового статуса иностранных граждан и лиц без гражданства в РФ, конституционные права и обязанности граждан России. Регулирование общественных отношений, связанных с гражданством в РФ, отнесено статьей 71 Конституции к исключительному ведению РФ².

В ряде международных правовых актов о гражданстве содержатся положения, позволяющие осуществлять конституционно-правовое регулирование правоотношений, связанных с гражданством, с учетом интересов обеспечения национальной безопасности РФ. Так, в Конвенции о сокращении безгражданства, принятой 30 августа 1961 г., предусмотрено, что «договаривающееся государство предоставляет свое гражданство лицу, рожденному на его территории, которое иначе не имело бы гражданства. Договаривающееся государство может поставить предоставление своего гражданства по ходатайству в зависимость от одного или нескольких условий: ... с) заинтересованное лицо не было осуждено за совершение

${ }_{1}^{1}$ См.: Кутафин О.Е. Российское гражданство. М.: Юрист, 2003. С. 7, 79.

2 Регулирование вопросов гражданства является важным суверенным полномочием государства. Поэтому существование гражданства республик в составе РФ противоречит пункту «в» статьи 71 Конституции, нарушает единство правового пространства и равноправие субъектов РФ. См. подробней: Кутафин О.Е. Указ. соч. С. 183, 186, 191. 
правонарушения против государственной безопасности и не приговорено к тюремному заключению на срок пять лет или более по уголовному обвинению».

Международным пактом о гражданских и политических правах, принятом Генеральной Ассамблеей ООН 16 декабря 1966 г., установлено, что каждому, кто законно находится на территории какого-либо государства, принадлежит в пределах этой территории право на свободное передвижение и свобода выбора места жительства. Каждый человек имеет право покидать любую страну. Никто не может быть произвольно лишен права на въезд в свою собственную страну. Эти права могут быть ограничены в исключительных случаях, которые предусмотрены законом и применяются для охраны государственной безопасности, общественного порядка, здоровья или нравственности населения или других прав и свобод.

Непосредственное отношение к обороноспособности и безопасности государства имеет Европейская конвенция о гражданстве от 7 ноября 1997 г., регламентирующая вопросы воинской обязанности и альтернативной гражданской службы в случаях множественного гражданства.

На уровне национального законодательства Российской Федерации основополагающим нормативным правовым актом, позволяющим осуществлять детальное правовое регулирование отношений гражданства в целях ЗГС, является Федеральный закон от 31 мая 2002 г. № 62-Ф3 «О гражданстве Российской Федерации».

Глава 2 данного Закона определяет основания и порядок приобретения российского гражданства. Поскольку гражданство выступает важным элементом правового статуса лица, порождает обязанность государства гарантировать права и свободы своих граждан, осуществлять их защиту как внутри страны, так и за рубежом, Закон устанавливает ряд правовых 
ограничений в контексте ЗГС ${ }^{1}$. Так, в соответствии со статьей 16 Закона отклоняются заявления о приеме в гражданство РФ и о восстановлении в гражданстве РФ, поданные лицами, которые: а) выступают за насильственное изменение основ конституционного строя РФ или иными действиями создают угрозу безопасности РФ; б) участвуют либо участвовали в международных, межнациональных, межтерриториальных или иных вооруженных конфликтах, либо в совершении в ходе таких конфликтов действий, направленных против российского контингента миротворческих сил или направленных против Вооруженных Сил РФ, либо в совершении террористических актов, осуществлении экстремистской деятельности или в подготовке совершения таких актов, в осуществлении такой деятельности за пределами РФ в отношении граждан РФ, представительств РФ в иностранных государствах и международных организациях, представительств субъектов РФ и их сотрудников; в) участвуют либо участвовали в совершении или в подготовке к совершению противоправных действий, содержащих хотя бы один из признаков экстремистской деятельности, либо иных действий, создающих угрозу безопасности РФ или граждан РФ; г) имеют ограничения на въезд в РФ в связи с тем, что они подвергались административному выдворению за пределы РФ, депортации или передавались иностранному государству в соответствии с международными договорами РФ о реадмиссии, либо в связи с принятием решения о нежелательности пребывания (проживания) в РФ; д) использовали подложные документы или сообщили заведомо ложные сведения; е) состоят на военной службе, на службе в органах безопасности или в правоохранительных органах иностранного государства, если иное не предусмотрено международным договором РФ; ж) имеют неснятую или непогашенную судимость за совершение умышленных преступлений на

1 Данные ограничения соответствуют Европейской конвенции о гражданстве от 7 ноября 1997 г. 
территории РФ или за ее пределами, признаваемых таковыми в соответствии с федеральным законом; 3) преследуются в уголовном порядке компетентными органами РФ или компетентными органами иностранных государств за преступления, признаваемые таковыми в соответствии с федеральным законом (до вынесения приговора суда или принятия решения по делу); и) осуждены и отбывают наказание в виде лишения свободы за действия, преследуемые в соответствии с федеральным законом.

Помимо ограничений, связанных с приобретением российского гражданства, установленных в целях ЗГС, Закон предусматривает и поощрительные нормы. Так, согласно части 3 статьи 13 Закона и пункту 12 части 2 Положения о порядке рассмотрения вопросов гражданства РФ прием в гражданство может осуществляться на основании особых заслуг перед РФ. Особыми заслугами перед РФ являются выдающиеся достижения в области науки, техники, производства, культуры, спорта, значительный вклад в развитие экономики, обеспечение обороны и безопасности РФ и другие заслуги, способствовавшие повышению международного престижа России. Решение о предоставлении российского гражданства лицу, имеющему особые заслуги перед государством, принимается Президентом РФ. Лица, имеющие особые заслуги перед РФ, могут приниматься в гражданство без соблюдения условий общего порядка приема в гражданство ${ }^{1}$

Важное значение для конституционно-правового регулирования института гражданства в контексте ЗГС РФ имеет прекращение гражданства.

Часть 3 статьи 6 Конституции РФ указывает, что гражданин РФ не может быть лишен своего гражданства. Аналогичное положение содержится и в пункте 4 статьи 5 Закона.

Гражданство РФ может быть прекращено на основании добровольного волеизъявления гражданина о выходе из гражданства или о выборе иного

${ }^{1}$ Правовой режим приема в российское гражданство за особые заслуги перед РФ подразумевается в статье 23 Федерального закона «О внешней разведке». 
гражданства при изменении Государственной границы РФ. Выход из гражданства не допускается, если гражданин имеет не выполненное перед РФ обязательство, установленное федеральным законом; привлечен компетентными органами РФ в качестве обвиняемого по уголовному делу либо в отношении его имеется вступивший в законную силу и подлежащий исполнению обвинительный приговор суда; не имеет иного гражданства и гарантий его приобретения.

Прекращение российского гражданства возможно и по инициативе государства. Решение о приобретении или прекращении гражданства РФ подлежит отмене, если будет установлено, что данное решение принималось на основании представленных заявителем подложных документов или заведомо ложных сведений. Факт использования подложных документов или сообщения заведомо ложных сведений устанавливается судом.

Обладание российским гражданством имеет для лица ряд важных правовых последствий, непосредственно связанных с целями ЗГС. Только гражданин РФ, согласно части 2 статьи 6 Конституции, обладает на ее территории всеми правами и свободами и несет все предусмотренные ею обязанности.

В соответствии со статьей 14 Федерального закона «О правовом положении иностранных граждан в Российской Федерации» иностранные граждане не имеют права находиться на государственной или муниципальной службе, быть членами экипажей военных кораблей РФ, заниматься иной деятельностью и замещать иные должности, допуск иностранных граждан к которым ограничен федеральным законом ${ }^{1}$.

Отсутствие гражданства РФ не позволяет лицу быть принятым на работу на объекты и в организации, деятельность которых связана с обеспечением безопасности России. Перечень таких объектов и организаций

1 Об особенностях правосубъектности иностранных граждан см.: Авакьян С.A. Гражданство Российской Федерации. М., 1994. С. 5-12. 
утверждается Правительством.

Кадровый состав правоохранительных органов и органов безопасности формируется из числа российских граждан. Статьей 7 Федерального закона «О Федеральной службе безопасности», статьей 17 Федерального закона «О внешней разведке», статьей 18 Федерального закона «О государственной охране», статьей 40.1 Федерального Закона «О прокуратуре Российской Федерации», статьей 25 Федерального закона «О полиции» предусмотрено, что на службу в органы федеральной службы безопасности, органы внешней разведки, органы государственной охраны, в органы прокуратуры, на службу в полицию принимаются только граждане РФ.

Существенное влияние на правовой статус лица оказывает наличие двойного гражданства.

Под двойным гражданством понимается приобретение лицом с ведения государства, гражданином которого оно является, второго гражданства. Получение двойного гражданства должно быть предусмотрено международным договором РФ или федеральным законом. Получение гражданства другого государства иным путем не признается РФ: гражданин РФ, имеющий также иное гражданство, рассматривается только как российский гражданин ${ }^{1}$. Данное положение закреплено частью 1 статьи 6 Федерального закона «О гражданстве Российской Федерации» и соответствует статьям 7, 14 и 15 Европейской конвенции о гражданстве.

Приобретение иностранными гражданами российского гражданства допускается при условии их отказа от прежнего гражданства (отказ не требуется, если это предусмотрено международным договором или федеральным законом, а также в силу его невозможности по независящим от лица причинам. Если отказ от имеющегося гражданства связан с

1 Проблема «незаконного» двойного гражданства в контексте ЗГС приобрела особую актуальность в связи с назначением на должность заместителя Секретаря Совета безопасности РФ Березовского Б.А., имевшего помимо российского гражданства гражданство Израиля. 
приобретением российского гражданства, дается обязательство в течение 1 года со дня приобретения гражданства РФ представить документ о выходе из иного гражданства. Если иное гражданство прекращается вследствие приобретения гражданства РФ, дается обязательство представить соответствующий документ в течение 3 месяцев со дня приобретения российского гражданства.

Однако правовое регулирование приобретения российского гражданства иностранными гражданами не всегда отличалось четкостью и последовательностью. В частности, с момента вступления в силу Закона РФ от 17 июня 1993 г. № 5206-1 «О внесении изменений и дополнений в закон РСФСР «О гражданстве РСФСР» до 1 июля 2002 г. в России легально существовала практика приобретения российского гражданства иностранными гражданами без отказа от имеющегося гражданства.

Признание Россией двойного гражданства породило ряд проблем, связанных с $3 Г \mathrm{C}^{1}$.

Примером может служить статья 21 Закона РФ «О государственной тайне» и пункт 3 Положения о порядке допуска лиц, имеющих двойное гражданство, лиц без гражданства, а также лиц из числа иностранных граждан, эмигрантов и реэмигрантов к государственной тайне, утвержденного Постановлением Правительства РФ от 22 августа 1998 г. (с изм. от 27 мая 2008 г.) № $1003^{2}$. Так, лица, имеющие двойное гражданство, приобретенное в соответствии с законом, получают допуск лишь к сведениям, составляющим государственную тайну с грифом «секретно», а лица без гражданства могут быть допущены к государственной тайне только

${ }^{1}$ Ряд ведущих государствоведов (В.С. Шевцов, О.Е. Кутафин) подвергли двойное гражданство обоснованной критике. Так, В.С. Шевцов считает двойное гражданство нарушением государственного суверенитета, поскольку тем самым подрывается осуществление полной юрисдикции суверенной государственной власти над своими гражданами. О.Е. Кутафин отмечает, что интерес к приобретению двойного гражданства проявляют представители криминалитета, готовые в случае угрозы своим материальным и нематериальным благам выехать на постоянное место жительства за границу.

${ }^{2}$ См.: СЗ РФ. 1998. N 35. Ст. 4407. 
на основании решения Правительства. При этом к сведениям особой важности и совершенно секретным сведениям лица без гражданства, как правило, не допускаются.

Согласно статье 22 Закона «О государственной тайне» основанием для отказа должностному лицу или гражданину в допуске к государственной тайне являются: а) постоянное проживание его самого и (или) его близких родственников за границей и (или) оформление указанными лицами документов для выезда на постоянное жительство в другие государства; б) выявление в результате проверочных мероприятий действий оформляемого лица, создающих угрозу безопасности РФ; в) уклонение его от проверочных мероприятий и (или) сообщение им заведомо ложных анкетных данных. Понятно, что по этим основаниям ни одно лицо, имеющее двойное гражданство, не может, да и не должно быть уравнено в правах с лицами, имеющими только российское гражданство ${ }^{1}$.

Правовое регулирование статуса личности в контексте ЗГС в значительной степени основано на режиме контроля за въездом, передвижением по территории государства, проживанием и выездом иностранных граждан и лиц без гражданства.

Правовые ограничения на въезд, пребывание (проживание), трудовую деятельность или транзитный проезд через территорию РФ установлены в отношении: лиц, выступающих за насильственное изменение основ конституционного строя РФ; представляющих угрозу безопасности РФ; пособников террористической (экстремистской) деятельности; лиц, подвергавшихся выдворению (депортации) за пределы РФ; имеющих неснятую или непогашенную судимость за совершение умышленных преступлений в РФ; переданных иностранному государству в порядке реадмиссии в период предыдущего пребывания в России; иностранцев, в

1 Свинарев B.B. К вопросу о правовом регулировании статуса лиц с двойным гражданством // Право и политика. 2001. № 2. 
отношении которых принято решение о нежелательности пребывания (проживания) в РФ; неоднократно привлекавшихся к административной ответственности в РФ за нарушение режима пребывания (проживания) иностранных граждан в РФ; совершивших административное правонарушение, связанное с незаконным оборотом наркотических средств или психотропных веществ и их прекурсоров; лиц, представивших поддельные или подложные документы либо сообщивших о себе заведомо ложные сведения.

В целях ЗГС иностранные граждане ограничиваются в передвижении по территории государства. В соответствии с пунктом 1 статьи 11 Федерального закона «О правовом положении иностранных граждан в Российской Федерации» Правительством утвержден перечень территорий, организаций и объектов, для въезда на которые иностранным гражданам требуется специальное разрешение ${ }^{1}$. К числу таких территорий, организаций и объектов отнесены:

1. Территории закрытых административно-территориальных образований.

2. Территории с регламентированным посещением для иностранных граждан ${ }^{2}$.

3. Территории, на которых введено чрезвычайное или военное положение.

4. Территории, на которых в случае опасности распространения инфекционных и массовых неинфекционных заболеваний и отравлений людей введены особые условия и режим пребывания.

${ }^{1}$ Постановление Правительства РФ от 11 октября 2002 г. (с изм. от 14 июля 2006 г.) № 754 «Об утверждении перечня территорий, организаций и объектов, для въезда на которые иностранным гражданам требуется специальное разрешение».

${ }^{2}$ В соответствии с Постановлением Правительства РФ от 4 июля 1992 г. № 470 «Об утверждении Перечня территорий РФ с регламентированным посещением для иностранных граждан» въезд иностранных граждан на территории с регламентированным посещением согласовывается принимающими организациями с органами федеральной службы безопасности. 
5. Территории закрытых военных городков.

6. Территории (объекты), в пределах которых (на которых) введен правовой режим контртеррористической операции.

7. Зоны экологического бедствия.

8. Пограничная зона.

9. Объекты и организации Вооруженных Сил, других войск и воинских формирований.

10. Объекты, на которых размещаются органы государственной власти и иные органы и организации, осуществляющие работы, связанные с использованием сведений, составляющих государственную тайну.

11. Другие территории, организации и объекты, для посещения которых российским гражданам требуется специальное разрешение.

Федеральным законом «О порядке выезда из Российской Федерации и въезда в Российскую Федерацию» регулируется выезд из РФ иностранных граждан и лиц без гражданства (устанавливаются ограничения на выезд иностранцев из РФ до принятия решения по уголовному делу, до вступления в законную силу приговора суда; до отбытия (исполнения) наказания или до освобождения от наказания; до исполнения обязательств; предусматриваются основания выдворения (депортации) иностранного гражданина за пределы РФ; передачи иностранного гражданина в соответствии с международным договором о реадмиссии ${ }^{1}$, устанавливается срок выезда из РФ при принятии Правительством РФ решения о сокращении срока временного пребывания иностранных граждан).

В случае выявления предусмотренных законом обстоятельств субъектами ЗГС принимается решение о нежелательности пребывания (проживания) иностранного гражданина или лица без гражданства в РФ, а

1 Особенности производства по делам о помещении иностранного гражданина, подлежащего депортации или реадмиссии, в специальное учреждение или о продлении срока пребывания иностранного гражданина, подлежащего депортации или реадмиссии, в специальном учреждении, закреплены в главе 28 Кодекса административного судопроизводства РФ от 8 марта 2015 г. № 21-Ф3. 
также устанавливается запрет на въезд в РФ отдельных иностранных граждан и лиц без гражданства ${ }^{1}$.

В целях безопасного формирования и функционирования органов государственной власти и управления законодателем установлена специальная правосубъектность должностных лиц, замещающих выборные и назначаемые должности.

Важное значение для ЗГС в сфере избирательного права имеет конституционно-правовое регулирование отношений, связанных с наличием иностранного гражданства либо вида на жительство на территории иностранного государства.

В соответствии с пунктом 3.1 статьи 4 Федерального закона от 12 июня 2002 г. № 67-Ф3 «Об основных гарантиях избирательных прав и права на участие в референдуме граждан Российской Федерации» не имеют права быть избранными граждане РФ, имеющие гражданство иностранного государства либо вид на жительство или иной документ, подтверждающий право на постоянное проживание гражданина РФ на территории иностранного государства.

Аналогичные ограничения для кандидатов закреплены в пункте 5.1 статьи 3 Федерального закона от 10 января 2003 г. № 19-Ф3 «О выборах Президента Российской Федерации» и статье 5 Федерального закона от 18 мая 2005 г. № 51-Ф3 «О выборах депутатов Государственной Думы Федерального Собрания Российской Федерации».

Данное требование к кандидатам, баллотирующимся на выборах в органы государственной власти, было введено законодателем в целях ограничения иностранного влияния на политические процессы, проходящие в РФ, а также укрепления политико-правовой связи избираемых народных

${ }^{1}$ Постановление Правительства РФ от 7 апреля 2003 г. (в ред. от 14 декабря 2009 г.) № 199 «Об утверждении Положения о принятии решения о нежелательности пребывания (проживания) иностранного гражданина или лица без гражданства в Российской Федерации и перечня федеральных органов исполнительной власти, уполномоченных принимать решение о нежелательности пребывания (проживания) иностранного гражданина или лица без гражданства в Российской Федерации». 
представителей с российским государством.

Конституционность и обоснованность приведенных законодательных положений была подтверждена решениями Конституционного Суда РФ.

В Определении от 4 декабря 2007 г. № 797-О-О «Об отказе в принятии к рассмотрению жалобы гражданина Кара-Мурзы Владимира Владимировича на нарушение его конституционных прав положением пункта 3.1 статьи 4 Федерального закона «Об основных гарантиях избирательных прав и права на участие в референдуме граждан Российской Федерации» Конституционный Суд РФ обосновал правомерность ограничения пассивного избирательного права в связи с наличием гражданства иностранного государства.

По мнению Конституционного Суда, «поскольку гражданин Российской Федерации, имеющий гражданство иностранного государства, находится в политико-правовой связи одновременно с Российской Федерацией и с соответствующим иностранным государством, перед которым он также несет конституционные и иные, вытекающие из законов данного иностранного государства, обязанности, значение для него гражданства Российской Федерации как политико-юридического выражения ценности связи с Отечеством объективно снижается. Волеизъявление такого лица - в случае избрания его - может обусловливаться не только требованиями конституционного правопорядка Российской Федерации и интересами ее народа, но и требованиями, вытекающими из принадлежности к иностранному государству.

Между тем формально-юридическая либо фактическая подчиненность депутата законодательного (представительного) органа суверенной воле не только народа Российской Федерации, но и народа иностранного государства не согласуется с конституционными принципами независимости депутатского мандата и государственного суверенитета и ставит под сомнение верховенство Конституции Российской Федерации» ${ }^{1}$.

${ }^{1}$ Определение Конституционного Суда РФ от 4 декабря 2007 г. № 797-О-О «Об отказе в принятии к рассмотрению жалобы гражданина Кара-Мурзы Владимира 
Буквальное толкование пункта 3.1 статьи 4 Федерального закона от 12 июня 2002 г. № 67-Ф3 «Об основных гарантиях избирательных прав и права на участие в референдуме граждан Российской Федерации» позволяет сделать вывод о наличии двух самостоятельных оснований ограничения пассивного избирательного права российских граждан:

- наличие гражданства иностранного государства;

- наличие вида на жительство или иного документа, подтверждающего право на постоянное проживание гражданина РФ.

Согласно ст. 3 Федерального закона от 31 мая 2002 г. № 62-Ф3 «О гражданстве Российской Федерации» вид на жительство рассматривается законодателем как документ, удостоверяющий личность лица без гражданства, выданный в подтверждение разрешения на постоянное проживание на территории РФ лицу без гражданства или иностранному гражданину и подтверждающий их право на свободный выезд из РФ и возвращение в РФ.

На основании международных договоров РФ и в порядке, установленном законом, иностранные граждане, постоянно проживающие на территории соответствующего муниципального образования, имеют право избирать и быть избранными в органы местного самоуправления, участвовать в иных избирательных действиях на указанных выборах, а также участвовать в местном референдуме на тех же условиях, что и российские граждане.

Таким образом, наличие вида на жительство или иного документа, подтверждающего право на постоянное проживание гражданина на территории иностранного государства, обладает двойственной правовой природой. С одной стороны, оно позволяет иностранным гражданам, постоянно проживающим на территории соответствующего муниципального образования, реализовать свои избирательные права на муниципальных

Владимировича на нарушение его конституционных прав положением пункта 3.1 статьи 4 Федерального закона «Об основных гарантиях избирательных прав и права на участие в референдуме граждан Российской Федерации» // Рос. газ. 2007. 26 декабря. 
выборах и референдумах, проходящих в РФ. С другой стороны, оно ограничивает пассивное избирательное право граждан РФ, располагающих подобными документами.

Пропорциональность, допустимость и правомерность установления государствами ряда ограничений пассивного избирательного права граждан подтверждается практикой Совета Европы и ЕСПЧ.

Вместе с тем в настоящее время европейскими международными организациями предпринимаются активные усилия по предоставлению иностранным гражданам и лицам с множественным гражданством полного объема политических прав, адекватного правосубъектности граждан государств.

Важное значение для развития правовых принципов, касающихся множественного гражданства, имело Постановление Европейского Суда по правам человека от 18 ноября 2008 г. по делу «Танасэ и Киртоакэ против Молдовы», а также Постановление Большой Палаты Европейского Суда по правам человека от 27 апреля 2010 г. по делу «Танасэ против Молдовы».

Европейский Суд по правам человека установил, что запрет на двойное гражданство для депутатов парламента Молдовы нарушает статью 3 Протокола № 1 Европейской Конвенции, гарантирующей право на свободные выборы. Положения, препятствующие избранным депутатам, имеющим множественное гражданство, занимать места в парламенте, были признаны несоразмерными.

Под влиянием европейского опыта Конституционный Суд РФ 22 июня 2010 г. принял Постановление по жалобе А.М. Малицкого, в котором поставлены под сомнения прежние правовые позиции Конституционного Суда по вопросам ограничения прав российских граждан на участие в выборах в связи с наличием иностранного гражданства либо вида на жительство на территории иностранного государства ${ }^{1}$.

\footnotetext{
${ }^{1}$ Постановление Конституционного Суда РФ от 22 июня 2010 г. № 14-П «По делу о проверке конституционности подпункта «а» пункта 1 и подпункта «а» пункта 8 статьи 29 Федерального закона «Об основных гарантиях избирательных прав и права на участие в
} 
Постановлением Конституционного Суда по делу А.М. Малицкого законодательные ограничения в отношении правового статуса организаторов выборов - членов территориальных избирательных комиссий в части требований к отсутствию вида на жительство иностранного государства были сняты. По мнению Конституционного Суда, наличие у организаторов выборов вида на жительство на территории иностранного государства не дает повода усомниться в зависимости членов избирательных комиссий от влияния заинтересованных зарубежных сил. Тем самым, как считает Конституционный Суд, был снят и вопрос о недоверии к избранной такими организаторами выборов представительной власти.

В 2014 г. были приняты изменения в законодательстве о гражданстве, в соответствии с которыми для граждан РФ введена обязанность уведомлять миграционные органы о наличии гражданства (подданства) иностранного государства либо вида на жительство или иного действительного документа, подтверждающего право на его постоянное проживание в иностранном государстве. Данные изменения были закреплены Федеральным законом от 4 июня 2014 г. № 142-Ф3 «О внесении изменений в статьи 6 и 30 Федерального закона «О гражданстве Российской Федерации» и отдельные законодательные акты Российской Федерации». Согласно его правовым положениям за неисполнение обязанности предусмотрена уголовная ответственность (ст. 330.2 УК РФ), а за нарушение установленного порядка подачи уведомления - административное наказание (ст. 19.8.3 КоАП РФ).

Проведенный анализ конституционно-правовой доктрины свидетельствует о наличии проблем в регулировании правового статуса лиц, обладающих иностранным гражданством или видом на жительство на территории другого государства, констатирует различие подходов европейских и российских органов конституционной юстиции к правотворчеству и правореализации при решении вопросов гражданства, установлении критериев избираемости.

референдуме граждан Российской Федерации» в связи с жалобой гражданина А.М. Малицкого // Рос. газ. 2010. 7 июля. 
Режим безопасного формирования и функционирования органов государственной власти и управления помимо требований к отсутствию иностранного гражданства охватывает и требования к отсутствию судимости у кандидатов на выборные и иные должности, связанные с осуществлением государственных полномочий.

Согласно части 3 статьи 32 Конституции Российской Федерации не обладают активным и пассивным избирательным правом граждане, признанные судом недееспособными или содержащиеся в местах лишения свободы по приговору суда.

В соответствии с пунктом 3.2 статьи 4 Федерального закона «Об основных гарантиях избирательных прав и права на участие в референдуме граждан Российской Федерации»:

«Не имеют права быть избранными граждане Российской Федерации:

а) осужденные к лишению свободы за совершение тяжких и (или) особо тяжких преступлений и имеющие на день голосования неснятую и непогашенную судимость за указанные преступления;

а.1) осужденные к лишению свободы за совершение тяжких преступлений, судимость которых снята или погашена, - до истечения десяти лет со дня снятия или погашения судимости;

а.2) осужденные к лишению свободы за совершение особо тяжких преступлений, судимость которых снята или погашена, - до истечения пятнадцати лет со дня снятия или погашения судимости;

б) осужденные за совершение преступлений экстремистской направленности, предусмотренных Уголовным кодексом РФ, и имеющие на день голосования на выборах неснятую и непогашенную судимость за указанные преступления, если на таких лиц не распространяется действие подпунктов «а.1» и «а.2» пункта 3.2 ;

в) подвергнутые административному наказанию за пропаганду и публичное демонстрирование нацистской или сходной экстремистской 
атрибутики и символики, за производство и распространение экстремистских материалов, если голосование на выборах состоится до окончания срока, в течение которого лицо считается подвергнутым административному наказанию;

г) в отношении которых вступившим в силу решением суда установлен факт призывов к экстремистской деятельности, обоснования или оправдания экстремизма, если указанные нарушения либо действия совершены до дня голосования на выборах в течение срока полномочий органа государственной власти или органа местного самоуправления, в которые назначены выборы, либо должностного лица, для избрания которого назначены выборы».

Законодателем закреплены гарантии защиты пассивного избирательного права граждан, связанные с истечением срока правовых ограничений и действием уголовного закона.

Если срок действия ограничений пассивного избирательного права, предусмотренных подпунктами «а.1» и «а.2» истекает в период избирательной кампании до дня голосования на выборах, гражданин, пассивное избирательное право которого было ограничено, вправе быть выдвинутым кандидатом на этих выборах.

Если деяние, за совершение которого был осужден гражданин, в соответствии с новым уголовным законом не признается тяжким или особо тяжким преступлением, действие ограничений пассивного избирательного права, предусмотренных подпунктами «а», «а.1» и «а.2», прекращается со дня вступления в силу этого уголовного закона. Если тяжкое преступление, за совершение которого был осужден гражданин, в соответствии с новым уголовным законом признается особо тяжким или если особо тяжкое преступление, за совершение которого был осужден гражданин, в соответствии с новым уголовным законом признается тяжким, ограничения пассивного избирательного права, предусмотренные подпунктами «а.1» и «а.2», действуют до истечения десяти лет со дня снятия или погашения 
судимости.

Согласно пункту 1 статьи 4 Закона Российской Федерации «О статусе судей в Российской Федерации», пункту 2 статьи 40.1 Закона Российской Федерации «О прокуратуре Российской Федерации», подпункту 2 и 3 части 1 статьи 29 Федерального закона «О полиции», подпункту 4 пункта 5 статьи 18 Федерального закона «О государственной охране», пункту «в» части 3 статьи 16 Федерального закона «О Федеральной службе безопасности», пункту 2 части 4 статьи 16 Федерального закона «О Следственном комитете Российской Федерации», гражданин, имеющий судимость (в том числе снятую и погашенную), а также в отношении которого уголовное преследование прекращено за истечением срока давности, в связи с примирением сторон, вследствие акта об амнистии или в связи с деятельным раскаянием, не может поступить на службу или на работу в органы прокуратуры, полиции, органы государственной охраны, федеральной службы безопасности, следственные органы, не может быть назначен на должность судьи.

Данные ограничения введены законодателем в целях защиты институтов публичной власти от криминализации.

Процессы криминализации органов власти и управления требуют адекватного реагирования со стороны государства и институтов гражданского общества, реализации последовательной антикриминальной политики.

Как представляется, основные направления противодействия криминализации органов публичной власти в РФ необходимо выстраивать с учетом существующих международно-правовых стандартов.

Пропорциональность, допустимость и правомерность установления государствами ряда ограничений пассивного избирательного права граждан неоднократно рассматривалась в прецедентной практике Европейского Суда по правам человека. 
Статья 25 Международного пакта о гражданских и политических правах допускает введение обоснованных ограничений права и возможности каждого гражданина быть избранным на выборах. Как отмечается в постановлениях Европейского Суда по правам человека по делам «МатьеМоэн и Клерфейт против Бельгии», «Дойл против Соединенного Королевства», право лица выдвигать свою кандидатуру на выборах не носит абсолютного характера ${ }^{1}$. Поскольку статья 3 Протокола № 1 к Конвенции о защите прав человека и основных свобод, признавая это право, не конкретизирует его и тем более не дает ему юридического определения, появляются возможности для введения так называемых имплицитных или подразумеваемых ограничений (постановление по делу «Матье-Моэн (Mathieu-Mohin) и Клерфейт (Clerfayt) против Бельгии»); государства свободны в рамках своего конституционного строя устанавливать статус парламентариев, включая критерии избираемости (постановление по делу «Гитонас (Gitonas) и другие против Греции», «Подколзина против Латвии», «Дойл против Соединенного Королевства»). Эти критерии различаются в зависимости от исторических и политических особенностей каждого государства.

Либерализация пенитенциарной политики в государствах Европейского Союза привела к изменению правовых позиций органов конституционной юстиции по вопросу защиты избирательных прав осужденных лиц. Так, 6 октября 2005 г. Большая палата Европейского Суда по правам человека вынесла окончательное решение по делу «Херст против Соединенного Королевства» (Hirst v. United Kingdom) (жалоба № 74025/01)².

1 Решение Европейского Суда по правам человека от 2 марта 1987 г. по делу «Матье-Моэн (Mathieu-Mohin) и Клерфейт (Clerfayt) против Бельгии» // Европейский Суд по правам человека. Избранные решения: в 2 т. М.: Норма, 2000; Решение Европейского Суда по правам человека от 6 февраля 2007 г. по делу «Дойл (Doyle) против Соединенного Королевства» // Бюллетень Европейского Суда по правам человека. Российское издание. 2007. № 8 .

2 Постановление Европейского Суда по правам человека от 6 октября 2005 г. по делу «Херст против Соединенного Королевства» (Hirst v. United Kingdom) (жалоба № 
Заявитель, Джон Херст, приговоренный к пожизненному лишению свободы за убийство, обжаловал положения ст. 3 Акта о народном представительстве 1983 г. о запрете принимать участие в голосовании на выборах в Парламент или местные органы власти. Европейский Суд признал несоответствие ст.3 Акта о народном представительстве Протоколу № 1 Конвенции о защите прав человека. По мнению Суда, запрет на участие заключенных в выборах не должен распространяться на всех осужденных, кроме того, данное ограничение должно применяться в зависимости от срока назначенного наказания и тяжести правонарушения. Европейский Суд предоставил Великобритании право самостоятельно избрать способ обеспечения избирательных прав заключенных ${ }^{1}$.

Сформулированная Европейским судом правовая позиция по делу «Херст против Соединенного Королевства» (Hirst v. United Kingdom) о том, что автоматическое и недифференцированное лишение избирательных прав группы лиц независимо от срока наказания, характера или тяжести совершенного правонарушения и личных обстоятельств несовместимо со ст. 3 Протокола № 1 к Конвенции была позднее подтверждена в Постановлении от 8 апреля 2010 г. по делу «Фродль (Frodl) против Австрии» и Постановлении от 22 мая 2012 г. по делу «Скоппола (Scoppola) против Италии», Постановлении от 4 июля 2013 г. по делу «Анчугов (Anchugov) и Гладков (Gladkov) против России».

В Постановлении от 8 апреля 2010 г. по делу «Фродль против Австрии» Европейский Суд напомнил, что «лишение избирательных прав может быть предусмотрено только для преступников, отбывающих длительные сроки лишения свободы; между фактами, положенными в основу

74025/01) // Бюллетень Европейского Суда по правам человека. Российское издание. 2006. № 4.

1 В государствах, где заключенные имеют право голоса (Албания, Босния и Герцеговина, Кипр, Хорватия, Чехия, Дания, Финляндия, бывшая югославская республика Македония, Исландия, Литва, Португалия, Словения, Испания, Швеция, Швейцария и Украина), они реализуют свое избирательное право путем голосования по почте, по доверенности и другими предусмотренными законом способами. 
осуждения, и санкцией в виде лишения избирательных прав должна быть прямая связь; и такая мера должна предпочтительно применяться не в силу действия закона, а по решению судьи по результатам судебного разбирательства» ${ }^{1}$.

В Судебном решении от 22 мая 2012 г. по делу «Скоппола против Италии» Европейский Суд указал, что «меры ограничения избирательных прав заключенных неодинаковы в различных национальных правовых системах. Государства-участники могут отнести пропорциональность меры ограничения избирательных прав заключенных на усмотрение судов или включить в законодательство положения, определяющие обстоятельства, при которых применяется такая мера»²

Серьезные политико-правовые последствия для России имело Постановление Европейского суда по правам человека от 4 июля 2013 г. по делу «Анчугов (Anchugov) и Гладков (Gladkov) против России». В деле «Анчугов и Гладков против России» Страсбургский суд со ссылкой на правовую позицию по делу «Херст против Соединенного Королевства» признал, что часть 3 статьи 32 Конституции Российской Федерации нарушает ст. 3 Протокола № 1 к Европейской Конвенции, гарантирующую право на свободные выборы. В ответ на аргументы властей Российской Федерации, что данное дело отличается от дела «Херст против Соединенного Королевства», поскольку в России запрет заключенным на участие в выборах установлен Конституцией Российской Федерации, принятой всенародным голосованием, а не «обычным законом», Европейский Суд указал, что Конвенция распространяется на любые нормы и меры, относящиеся к

${ }^{1}$ Постановление Европейского Суда по правам человека от 8 апреля 2010 г. по делу «Фродль против Австрии» (Frodl v. Austria) (жалоба №20201/04) // Информационный бюллетень по прецедентной практике Европейского Суда по правам человека. 2010, № 129.

2 Постановление Европейского Суда по правам человека от 22 мая 2012 г. по делу «Скоппола против Италии» (Scoppola v. Italy) (жалоба № 74025/01) // Бюллетень Европейского Суда по правам человека. Российское издание. 2012, № 11. 
юрисдикции национальных властей, которые реализуются именно через Конституцию.

Страсбургский суд постановил, что власти не представили доказательств того, что в ходе широких общественных обсуждений проекта Конституции РФ рассматривался вопрос о пропорциональности оспариваемого ограничения общественным интересам. Оспаривая позицию российской стороны о том, что изменение ст. 32 Конституции РФ представляет собой сложную процедуру (невозможность пересмотра Федеральным Собранием, необходимость поддержки предложения о пересмотре $3 / 5$ голосов от общего числа членов Совета Федерации и депутатов Государственной Думы, созыв Конституционного Собрания) Европейский суд по правам человека указал, что способ исправления выявленного нарушения остается на усмотрение государства-ответчика, находясь при этом под надзором Комитета министров Совета Европы ${ }^{1}$. И государство вполне может прибегнуть с этой целью к тому или иному политическому процессу или истолковать Конституцию соответствующим образом.

10 октября 2013 г. позиция Европейского Суда по проблеме ограничения избирательного права в связи с наличием судимости была учтена Конституционным Судом РФ при вынесении решения по делу «О проверке конституционности подпункта «а» пункта 3.2 статьи 4 Федерального закона «Об основных гарантиях избирательных прав и права на участие в референдуме граждан Российской Федерации», части первой статьи 10 и части 6 статьи 86 УК РФ в связи с жалобами граждан Г.Б.Егорова, А.Л.Казакова, И.Ю.Кравцова, А.В. Куприянова, А.С. Латыпова

\footnotetext{
1 Состав, порядок формирования и деятельности Конституционного Собрания должен быть урегулирован Федеральным конституционным законом «О Конституционном Собрании Российской Федерации», который до настоящего времени не принят.
} 
и В.Ю. Синькова» ${ }^{1}$.

Постановление Конституционного Суда РФ от 10 октября 2013 г. № 20П подтвердило конституционность ограничения пассивного избирательного права для граждан, осужденных за тяжкие и особо тяжкие преступления: «ограничение пассивного избирательного права введено федеральным законодателем в качестве особого конституционно-правового дисквалифицирующего препятствия для занятия выборных публичных должностей, сопряженного с повышенными репутационными требованиями к носителям публичной (политической) власти, что обусловлено их прямым участием в принятии правовых актов (нормативных и индивидуальных) и ответственностью, с которой связано осуществление ими своих полномочий» ${ }^{2}$.

В тоже время бессрочное и недифференцированное ограничение пассивного избирательного права в отношении граждан РФ, осужденных к лишению свободы за совершение тяжких и (или) особо тяжких преступлений, не являющееся уголовным наказанием, признано Конституционным Судом не соответствующим статьям 3 (части 2 и 3), 15 (часть 4), 17 (часть 3), 19 (части 1 и 2), 32 (части 1, 2 и 3) и 55 (части 2 и 3) Конституции Российской Федерации ${ }^{3}$. Как постановил Конституционный Суд, в приговоре должен указываться срок конституционно-правового дисквалифицирующего препятствия для занятия осужденными лицами выборных публичных должностей после отбытия ими наказания.

По мнению Конституционного Суда, сроки вводимых федеральным законом ограничений пассивного избирательного права, по общему правилу, должны устанавливаться соответственно дифференциации сроков судимости,

${ }^{1}$ Постановление Конституционного Суда РФ от 10 октября 2013 г. № 20-П // Рос. газ. 2013. 23 октября. В Постановлении от 19 апреля 2016 г. № 12-П Конституционный Суд признал частично невозможным исполнение Постановления ЕСПЧ от 4 июля 2013 г. по делу «Анчугов и Гладков против России».

2 Рос. газ. 2013. 23 октября.

${ }^{3}$ Рос. газ. 2013. 23 октября. 
предусмотренной УК РФ. В исключительных случаях за отдельные тяжкие и особо тяжкие преступления, исходя из повышенной степени их общественной опасности, федеральным законом могут вводиться ограничения пассивного избирательного права и на более продолжительные сроки с соблюдением конституционных критериев соразмерности и необходимости ${ }^{1}$.

Конституционный Суд также обязал федерального законодателя установить процессуальные гарантии восстановления пассивного избирательного права граждан, судимость которых снята или погашена, в случае принятия нового уголовного закона, в соответствии с которым совершенное ими деяние более не признается тяжким или особо тяжким преступлением².

Имплементация международных стандартов в российское законодательство актуализирует значимость судебной практики назначения уголовных наказаний в виде лишения права занимать выборные должности. Модернизация материальных и процессуальных норм в соответствии с международными стандартами требует от организаторов выборов единообразной практики уточнения степени тяжести преступлений с учетом периода действия разных редакций уголовного закона.

В системе конституционно-правового регулирования статуса личности в интересах ЗГС существенное значение имеет пенитенциарный режим и административный надзор за лицами, освобожденными из мест лишения свободы.

Исправительные учреждения являются элементом карательного механизма реализации государственной политики. Путем привлечения

1 Данная позиция Конституционного Суда РФ была учтена законодателем в Федеральном законе от 21 февраля 2014 г. № 19-Ф3 «О внесении изменений в отдельные законодательные акты Российской Федерации».

2 Процессуальные гарантии восстановления пассивного избирательного права граждан были закреплены в Федеральном законе от 21 февраля 2014 г. № 19-Ф3 «О внесении изменений в отдельные законодательные акты Российской Федерации». 
правонарушителей к юридической ответственности государство реализует свое монопольное право на применение силы и принудительно обеспечивает государственный суверенитет. Справедливая штрафная политика и неизбежность привлечения к юридической ответственности в определенной степени стабилизируют общественно-политическую обстановку в стране, влияют на доверие граждан к органам власти и карательному механизму.

В целях предупреждения совершения лицами, освобожденными из мест лишения свободы, преступлений, а также для защиты государственных и общественных интересов за данной категорией граждан по решению суда может быть установлен административный надзор.

Административный надзор в обязательном порядке применяется к совершеннолетним лицам, освобождаемым или освобожденным из мест лишения свободы, если они имеют непогашенную или неснятую судимость за совершение преступления при опасном или особо опасном рецидиве преступлений либо за совершение преступления против половой неприкосновенности и половой свободы несовершеннолетнего.

Согласно части 1, пункту 1 части 3 статьи 3 Федерального закона от 6 апреля 2011 г. № 64-Ф3 «Об административном надзоре за лицами, освобожденными из мест лишения свободы» за совершеннолетними лицами, освобождаемыми или освобожденными из мест лишения свободы, имеющими непогашенную или неснятую судимость за совершение тяжкого или особо тяжкого преступления либо при рецидиве преступлений или умышленном преступлении в отношении несовершеннолетнего, административный надзор устанавливается судом при условии их признания в период отбывания наказания в местах лишения свободы злостными нарушителями установленного порядка отбывания наказания. Если эти лица в период отбывания наказания злостными нарушителями не признавались, административный надзор может быть применен при совершении ими после освобождения из мест лишения свободы в течение одного года двух и более 
административных правонарушений против порядка управления и (или) административных правонарушений, посягающих на общественный порядок и общественную безопасность и (или) на здоровье населения и общественную нравственность.

Административный надзор может быть установлен в отношении лиц, совершивших преступление в несовершеннолетнем возрасте и достигших восемнадцати лет к моменту или после освобождения из мест лишения свободы.

Применение административного надзора к иностранным гражданам и апатридам возможно при условии их законного проживания (пребывания) на территории РФ.

Федеральный закон «Об административном надзоре за лицами, освобожденными из мест лишения свободы» содержит исчерпывающий перечень административных ограничений, которые могут быть применены к поднадзорному лицу. К ним относятся: запрещение пребывания в определенных местах; запрещение посещения мест проведения массовых и иных мероприятий и участия в указанных мероприятиях; запрещение пребывания вне жилого или иного помещения, являющегося местом жительства либо пребывания поднадзорного лица, в определенное время суток; запрещение выезда за установленные судом пределы территории; обязательная явка от 1 до 4 раз в месяц в органы внутренних дел по месту жительства или пребывания для регистрации.

Применение данных ограничений в контексте ЗГС направлено на предотвращение преступлений против государства и общества и обеспечение социально-политической стабильности в стране и отдельных регионах.

В целях безопасного формирования и функционирования органов государственной власти и управления законодателем установлены антикоррупционные стандарты, нацеленные на выявление, предупреждение, пресечение, раскрытие и расследование коррупционных правонарушений со 
стороны должностных лиц, принимающих властные решения в сфере ЗГС и обеспечения безопасности государства.

Антикоррупционные стандарты, определяющие требования к назначению (избранию) на соответствующую должность, и требования к осуществлению определенной властной деятельности (исполнительнораспорядительной, депутатской, судопроизводству, гражданской, военной, муниципальной службе, службе в органах прокуратуры и полиции, закреплены в статье 12.1 Федерального закона «О противодействии коррупции.

В соответствии с указанной статьей лица, замещающие государственные должности РФ, государственные должности субъектов РФ, муниципальные должности не вправе:

- заниматься предпринимательской или другой оплачиваемой деятельностью, кроме преподавательской, научной и иной творческой деятельности ${ }^{1}$;

- состоять членом органа управления хозяйственного общества или иной коммерческой организации;

- входить в состав органов управления, попечительских или наблюдательных советов, иных органов иностранных некоммерческих неправительственных организаций и действующих на территории РФ их структурных подразделений, если иное не предусмотрено международным договором РФ или законодательством РФ;

- получать в связи с осуществлением соответствующих полномочий не предусмотренные законодательством РФ вознаграждения (ссуды, денежное и иное вознаграждение, услуги, оплату развлечений, отдыха, транспортных расходов) от физических и юридических лиц;

${ }^{1}$ При этом преподавательская, научная и иная творческая деятельность не может финансироваться исключительно за счет средств иностранных государств, международных и иностранных организаций, иностранных граждан и лиц без гражданства, если иное не предусмотрено международным договором или законодательством РФ. 
- выезжать в связи с осуществлением соответствующих полномочий за пределы территории РФ за счет средств физических и юридических лиц, за исключением служебных командировок, осуществляемых в соответствии с законодательством РФ, международными договорами РФ или договоренностями на взаимной основе федеральных органов государственной власти, органов государственной власти субъектов РФ с государственными органами иностранных государств, международными и иностранными организациями;

- использовать в целях, не связанных с осуществлением соответствующих полномочий, средства материально-технического, финансового и информационного обеспечения, предназначенные для служебной деятельности;

- разглашать или использовать в целях, не связанных с осуществлением соответствующих полномочий, сведения, отнесенные к информации ограниченного доступа, или служебную информацию, ставшие ему известными в связи с осуществлением соответствующих полномочий;

- открывать и иметь счета (вклады), хранить наличные денежные средства и ценности в иностранных банках, расположенных за пределами территории РФ, владеть и (или) пользоваться иностранными финансовыми инструментами.

В случае возможного конфликта интересов в результате владения доходными ценными бумагами, акциями (долями участия в уставных капиталах организаций) должностное лицо-владелец обязано передать принадлежащие ему указанные ценные бумаги, акции (доли участия в уставных капиталах организаций) в доверительное управление ${ }^{1}$.

1 Под конфликтом интересов понимается ситуация, при которой личная заинтересованность должностного лица влияет или может повлиять на объективное исполнение им должностных обязанностей и при которой возникает или может возникнуть противоречие между личной заинтересованностью данного лица и законными интересами граждан, организаций, общества, государства, субъекта РФ, муниципального образования, способное привести к причинению вреда этим законным интересам. 
Аналогичные требования к назначению (избранию) на соответствующую должность, и требования к осуществлению публичной властной деятельности установлены в статье 6 Федерального закона «О статусе члена Совета Федерации и статусе депутата Государственной Думы Федерального Собрания Российской Федерации», статье 11 Федерального конституционного закона «О Правительстве Российской Федерации», статьях 12 и 18 Федерального закона «Об общих принципах организации законодательных (представительных) и исполнительных органов государственной власти субъектов Российской Федерации», статье 40 Федерального закона «Об общих принципах организации местного самоуправления в Российской Федерации», статье 16 Федерального закона «О государственной гражданской службе Российской Федерации», статье 13 Федерального закона «О муниципальной службе в Российской Федерации», статье 40.2 Закона Российской Федерации «О прокуратуре Российской Федерации», статье 3 Закона Российской Федерации «О статусе судей в Российской Федерации», статье 17 Федерального закона «О Следственном комитете Российской Федерации», статье 29 Федерального закона «О полиции», статье 10 Федерального закона «О статусе военнослужащих», статье 51 Федерального закона «О воинской обязанности и военной службе».

Антикоррупционные стандарты сформулированы в российском законодательстве и как правопрекращающий юридический факт, выступающий основанием для досрочного прекращения полномочий члена Совета Федерации, депутата Государственной Думы, высшего должностного лица субъекта РФ, депутатских полномочий, прекращения полномочий судьи, расторжения служебного контракта, трудового договора с муниципальным служащим, увольнения с гражданской и военной службы ${ }^{1}$.

\footnotetext{
1 Так, невыполнение должностным лицом обязанности предоставлять сведения о доходах, расходах, имуществе и обязательствах имущественного характера; предоставление заведомо недостоверных или неполных сведений; наличие счетов (вкладов) в иностранных банках за пределами территории РФ, владение или пользование
} 
В структуре комплексного общегосударственного правового режима ЗГС выделяются чрезвычайные правовые режимы, введение которых существенно меняет правовое положение личности ${ }^{1}$.

Как уже отмечалось, содержание режимов ЧП, ВП и КТО определяется перечнем и характером применяемых чрезвычайных мер и режимных ограничений. Суверенные государства самостоятельно решают, какие чрезвычайные меры, адекватные сложившейся ситуации, необходимо предпринять в особых условиях ${ }^{2}$.

Одним из эффективных инструментов ЗГС, предусмотренных международным правом, выступает интернирование иностранных граждан. Интернирование предполагает временное ограничение прав и свобод граждан государства противника и его союзников.

Интернирование может применяться к широкой категории иностранных граждан, которые, по мнению государства, представляют угрозу безопасности государства и выезд которым на территорию другого государства воюющей стороной не разрешен. К таким категориям могут относиться, например, специалисты, работавшие на режимных объектах; военнослужащие, обучавшиеся на период войны в военных учебных заведениях; члены экипажей воздушных и морских судов; различные специалисты в области оборонного комплекса и др ${ }^{3}$. Кроме того, интернирование может применяться в качестве ответной меры на действия другой воюющей стороны.

На интернированных лиц распространяется специальный правовой режим, который предполагает запрет покидать обычное или установленное

иностранными финансовыми инструментами влекут освобождение от замещаемой (занимаемой должности), увольнение с гражданской, военной и муниципальной службы.

${ }^{1}$ Приложение 6.

2 Ограничения прав граждан и режимные меры в условиях введения ЧП, ВП и КТО рассмотрены в параграфе 3.1.

Лица, наделенные дипломатическим иммунитетом, в случае вооруженного конфликта беспрепятственно покидают государство. Алешин B.B. Интернирование и вооруженный конфликт // Международное публичное и частное право. 2006. № 3. 
для проживания место жительства, наличие распорядка дня, ограничения в личном имуществе и денежных средствах ${ }^{1}$. K собственности иностранных граждан могут быть применены различные ограничения, не предусмотренные действующим законодательством. В.В. Алешин справедливо предлагает урегулировать данные вопросы в самостоятельном Федеральном законе «О собственности интернированных иностранных граждан в Российской Федерации»².

Режим интернирования действует только в период вооруженного конфликта, поэтому интернированные лица освобождаются после завершения военных действий.

В соответствии с международными обязательствами удерживающее государство должно соблюдать права человека, пресекать любые незаконные действия в отношении иностранных граждан и контролировать уполномоченные государственные органы, занимающиеся учетом и работой с иностранцами.

Как уже отмечалось, интернирование иностранных граждан может применяться лишь в условиях вооруженного конфликта. В мирное время важным элементом ЗГС в политической сфере является субинститут контрсанкций, применяемых в отношении граждан иностранных государств, проводящих враждебную политику в отношении РФ, российских организаций и граждан. Так, в ответ на необоснованные визовые ограничения и арест активов граждан РФ в ряде иностранных государств по мотиву их причастности к нарушениям прав человека в РФ был принят Федеральный закон от 28 декабря 2012 г. № 272-Ф3 «О мерах воздействия на лиц, причастных к нарушениям основополагающих прав и свобод человека, прав и свобод граждан Российской Федерации» (т.н. «Закон Димы

\footnotetext{
${ }^{1}$ Алешин В.В. Правовое положение интернированных лиц и их собственности // Московский журнал международного права. 2000. № 2.

2 Алешин B.B. Интернирование и вооруженный конфликт // Международное публичное и частное право. 2006. № 3.
} 
Яковлева»).

Законодателем был определен круг субъектов, причастных к нарушениям прав человека в РФ. В него вошли граждане США и других иностранных государств:

- причастные к нарушениям основополагающих прав и свобод человека;

- совершившие преступления в отношении граждан РФ, находящихся за рубежом, или причастные к их совершению;

- наделенные государственными полномочиями и способствовавшие своими действиями (бездействием) освобождению от ответственности лиц, совершивших преступления в отношении граждан РФ или причастных к их совершению;

- причастные к похищению и незаконному лишению свободы граждан РФ;

- вынесшие необоснованные и несправедливые приговоры в отношении граждан РФ;

- осуществляющие необоснованное юридическое преследование граждан РФ;

- принявшие необоснованные решения, нарушившие права и законные интересы граждан и организаций РФ.

В качестве мер воздействия в отношении указанных субъектов права предусмотрены: запрет на въезд в РФ; арест финансовых и иных активов; приостановление полномочий (членства) в советах директоров или иных органах управления организаций, зарегистрированных на российской территории; запрет на любые сделки с собственностью и инвестициями; приостановление деятельности подконтрольных юридических лиц; приостановление деятельности некоммерческой организации, еe структурного подразделения, которые участвуют в политической деятельности на территории РФ; отказ в проведении операций с денежными 
средствами и иным имуществом с участием иностранных или международных неправительственных организаций, деятельность которых признана нежелательной на территории РФ.

Специфика данного законодательного акта заключается в его экстерриториальном характере действия и закреплении положений, устанавливающих для органов правоприменения широкие пределы усмотрения в интересах ЗГС.

Важную роль в функционировании политической системы играет взаимодействие государства и негосударственных структур - общественных объединений и некоммерческих организаций.

Конституционно-правовое регулирование деятельности общественных объединений и некоммерческих организаций в контексте ЗГС реализуется, главным образом, в рамках соответствующего правового режима контроля за их деятельностью.

Раздел IV Стратегии национальной безопасности Российской Федерации (утверждена Указом Президента РФ от 31 декабря 2015 г. № 683) в числе основных угроз государственной и общественной безопасности РФ называет разведывательную и иную деятельность спецслужб и организаций иностранных государств, наносящую ущерб национальным интересам, а также деятельность иностранных и международных неправительственных организаций, направленную на нарушение единства и территориальной целостности РФ, дестабилизацию внутриполитической и социальной ситуации в стране, включая инспирирование «цветных революций».

Не случайно в системе конституционно-правового регулирования ЗГС в политической сфере выделяется институт организаций с особым правовым статусом - некоммерческих организаций (далее - НКО), выполняющих функцию иностранного агента, иностранных некоммерческих неправительственных организаций (далее - ИННО), а также иностранных или международных неправительственных организаций, признанных 
нежелательными на территории РФ.

В целях обеспечения публичности и прозрачности финансирования российских НКО, участвующих в политической деятельности, в том числе в интересах своих зарубежных доноров, система конституционно-правовой защиты государственного суверенитета в политической сфере была дополнена правовым институтом НКО, выполняющих функции иностранного агента.

В соответствии с Федеральным законом от 20 июля 2012 г. № 121-Ф3 «О внесении изменений в отдельные законодательные акты Российской Федерации в части регулирования деятельности некоммерческих организаций, выполняющих функции иностранного агента» в качестве НКО, выполняющей функции иностранного агента, рассматривается российская НКО, которая получает денежные средства и иное имущество от иностранных государств, их государственных органов, международных и иностранных организаций, иностранных граждан, лиц без гражданства либо уполномоченных ими лиц и (или) от российских юридических лиц, получающих денежные средства и иное имущество от указанных источников (далее - иностранные источники), и которая участвует, в том числе в интересах иностранных источников, в политической деятельности, осуществляемой на территории РФ.

В Федеральном законе от 2 июня 2016 г. № 179-Ф3 «О внесении изменений в статью 8 Федерального закона «Об общественных объединениях» и статью 2 Федерального закона «О некоммерческих организациях» уточнено понятие участия НКО в политической деятельности, осуществляемой на территории РФ. НКО признается участвующей в политической деятельности на территории РФ, если независимо от целей и задач, указанных в ее учредительных документах, она осуществляет деятельность в сфере государственного строительства, защиты основ конституционного строя РФ, федеративного устройства РФ, защиты 
суверенитета и обеспечения территориальной целостности РФ, обеспечения законности, правопорядка, государственной и общественной безопасности, обороны страны, внешней политики, социально-экономического и национального развития РФ, развития политической системы, деятельности государственных органов, органов местного самоуправления, законодательного регулирования прав и свобод человека и гражданина в целях оказания влияния на выработку и реализацию государственной политики, формирование государственных органов, органов местного самоуправления, на их решения и действия ${ }^{1}$.

Приведенное нормативное определение содержит следующие существенные характеристики признания участия НКО в политической деятельности:

1. Деятельность осуществляется в определенных законодателем cфepax.

2. Целями деятельности являются оказание влияния на выработку и реализацию государственной политики, формирование государственных органов, органов местного самоуправления, на их решения и действия.

3. Государством оценивается фактическая, a не юридически закрепленная в учредительных документах деятельность НКО.

Законодателем дан закрытый перечень форм политической деятельности:

- участие в организации и проведении публичных мероприятий в форме собраний, митингов, демонстраций, шествий или пикетирований либо в различных сочетаниях этих форм, организации и проведении публичных дебатов, дискуссий, выступлений;

1 К политической деятельности не относится деятельность в области науки, культуры, искусства, здравоохранения, профилактики и охраны здоровья граждан, социального обслуживания, социальной поддержки и защиты граждан, защиты материнства и детства, социальной поддержки инвалидов, пропаганды здорового образа жизни, физической культуры и спорта, защиты растительного и животного мира, благотворительная деятельность. 
- участие в деятельности, направленной на получение определенного результата на выборах, референдуме, в наблюдении за проведением выборов, референдума, формировании избирательных комиссий, комиссий референдума, в деятельности политических партий;

- публичные обращения к государственным органам, органам местного самоуправления, их должностным лицам, а также иные действия, оказывающие влияние на деятельность этих органов, в том числе направленные на принятие, изменение, отмену законов или иных нормативных правовых актов;

- распространение, в том числе с использованием современных информационных технологий, мнений о принимаемых государственными органами решениях и проводимой ими политике;

- формирование общественно-политических взглядов и убеждений, в том числе путем проведения опросов общественного мнения и обнародования их результатов или проведения иных социологических исследований;

- вовлечение граждан, в том числе несовершеннолетних, в указанную деятельность;

- финансирование указанной деятельности.

По мнению Конституционного Суда РФ, сформулированному в Постановлении от 8 апреля 2014 г. № 10-П, «получение иностранного финансирования российскими некоммерческими организациями само по себе не ставит под сомнение их лояльность по отношению к государству. Однако политическая деятельность таких некоммерческих организаций со всей очевидностью затрагивает публично-правовые интересы, а также права и свободы конкретных граждан, так как связана с воздействием на принимаемые государством решения». При этом Конституционный Суд подчеркнул, что законодательная конструкция НКО, выполняющей функции иностранного агента, не предполагает негативной оценки такой организации 
со стороны государства, не рассчитана на формирование отрицательного отношения к осуществляемой ею политической деятельности и тем самым не может восприниматься как проявление недоверия или желания дискредитировать такую НКО и (или) цели ее деятельности ${ }^{1}$.

Специфика правосубъектности $\mathrm{HKO}$, выполняющих функции иностранного агента, включает:

- создание реестра НКО, выполняющих функции иностранного агента; заявительный порядок включения в данный реестр при осуществлении некоммерческой организацией политической деятельности, в том числе за счет денежных средств и иного имущества, поступающего из иностранных источников;

- ведение НКО раздельного учета доходов (расходов), полученных (произведенных) в рамках поступлений от иностранных источников, и доходов (расходов), полученных (произведенных) в рамках иных поступлений;

- регулярное представление НКО, выполняющей функции иностранного агента, в уполномоченный орган отчета о своей деятельности, документов о расходовании денежных средств и об использовании иного имущества;

- возможность проведения внеплановой проверки НКО, выполняющей функции иностранного агента, в том числе при поступлении в уполномоченный орган обращений и заявлений граждан, юридических лиц, сообщений средств массовой информации о фактах, свидетельствующих о наличии признаков экстремизма;

- обязательный аудит годовой бухгалтерской отчетности НКО,

${ }^{1}$ Постановление Конституционного Суда РФ от 8 апреля 2014 г. № 10-П «По делу о проверке конституционности пункта 6 статьи 2 и пункта 7 статьи 32 Федерального закона «О некоммерческих организациях», части 6 статьи 29 Федерального закона «Об общественных объединениях» и части 1 статьи 19.34 КоАП в связи с жалобами Уполномоченного по правам человека в Российской Федерации, фонда «Костромской центр поддержки общественных инициатив», граждан Л.Г. Кузьминой, С.М. Смиренского и В.П. Юкечева». 
выполняющей функции иностранного агента, а также годовой бухгалтерской отчетности структурного подразделения иностранной некоммерческой неправительственной организации;

- необходимость указания при издании и (или) распространении материалов, в том числе в средствах массовой информации и с использованием сети Интернет, на то, что данные материалы изданы (распространены) НКО, выполняющей функции иностранного агента.

В соответствии с частью 6 статьи 29 Федерального закона от 19 мая 1995 г.№ 82-Ф3 «Об общественных объединениях» общественное объединение, намеревающееся после государственной регистрации получать денежные средства и иное имущество от иностранных источников и участвовать в политической деятельности на территории РФ, обязано до начала участия в политической деятельности подать в регистрирующий орган заявление о включении его в реестр НКО, выполняющих функции иностранного агента и предоставить соответствующие сведения.

Росфинмониторинг анализирует информацию об операциях общественных объединений и НКО и при наличии оснований, свидетельствующих о неполноте и (или) недостоверности указанной информации либо о том, что общественное объединение не исполняет или не в полной мере исполняет требования российского законодательства, сообщает об этом регистрирующему органу.

В случае выявления НКО, выполняющей функции иностранного агента, уклонившейся от подачи заявления о включении ее в реестр организаций, выполняющих функции иностранного агента, уполномоченный орган в сфере юстиции включает такую организацию в указанный реестр. С момента включения данной структуры в реестр на нее в полном объеме распространяются права, обязанности и ответственность, предусмотренные законодательством.

Введение в систему конституционно-правовой защиты 
государственного суверенитета института НКО, выполняющих функцию иностранного агента, позволило наладить правовой контроль за работой общественных структур, осуществляющих политическую деятельность на территории РФ и финансируемых из иностранных источников ${ }^{1}$.

В связи с активным участием негосударственных организаций в реализации различных механизмов ослабления и подрыва государственного суверенитета (в первую очередь, тайной политической, информационной, материально-технической и финансовой поддержки антигосударственных сил и сценариев «цветных революций») большое внимание законодателя уделено конституционно-правовому регулированию деятельности иностранных некоммерческих неправительственных организаций (ИННО).

Согласно Федеральному закону от 12 января 1996 г. № 7-Ф3 «О некоммерческих организациях» особенности правового положения ИННО заключаются:

- в уведомлении уполномоченного органа в сфере юстиции о создании на территории России филиала или представительства с приложением соответствующих документов;

- включении сведений о филиале или представительстве в реестр филиалов и представительств международных организаций и ИННО и уведомлении уполномоченного органа об изменении данных сведений; возможности отказа во внесении в реестр сведений о филиале или представительстве ИННО;

- в государственной регистрации отделения ИННО и возможности отказа в ней;

${ }^{1}$ В результате предпринятых прокурорами мер в ходе осуществления надзора за исполнением законов о НКО, выполняющих функции иностранного агента, 38 организаций включены в реестр НКО, выполняющих функции иностранного агента (по состоянию на 20.03.2015 г.). Наибольшая их часть финансируется США (более 20 организаций). Активное участие в финансовой поддержке подобных организаций принимает Великобритания (12) и Норвегия (8). Некоторые НКО финансируются сразу из нескольких иностранных источников. См. Экстремизм: стратегия противодействия и прокурорский надзор: монография / П.В. Агапов, С.В. Борисов и др. М.: Акад. Ген. прокуратуры РФ, 2015. С. 115-116. 
- в ограничениях на участие отдельных категорий должностных лиц в деятельности ИННО;

- в особом государственном контроле за финансированием ИННО;

- в возможности запрета осуществления на территории РФ заявленной ИННО программы или ее части;

- в возможности запрета структурному подразделению ИННО направления денежных средств и иного имущества определенным получателям.

ИННО в течение 3 месяцев со дня принятия решения о создании на территории РФ филиала или представительства уведомляет об этом уполномоченный орган. Сведения об организации включаются в реестр филиалов и представительств международных организаций и ИННО.

В контексте ЗГС заслуживают внимания следующие основания для отказа ИННО во внесении в реестр сведений о филиале или представительстве:

- в представленных документах содержится недостоверная информация;

- цели и задачи создания филиала или представительства ИННО противоречат Конституции или законодательству РФ;

- цели и задачи создания филиала или представительства ИННО создают угрозу суверенитету, политической независимости, территориальной неприкосновенности и национальным интересам РФ;

- ранее внесенные в реестр филиал или представительство ИННО были исключены из реестра в связи с грубым нарушением Конституции и законодательства РФ.

Внесение в реестр сведений о соответствующем структурном подразделении ИННО является юридическим фактом, определяющим возникновение правоспособности филиала или представительства ИННО.

Действующее законодательство не ограничивает права иностранных 
граждан и апатридов, законно находящихся на территории РФ, выступать учредителями (участниками, членами) НКО.

Специальные ограничения права быть учредителем (участником, членом) НКО установлены в отношении некоторых категорий граждан и организаций:

- иностранный гражданин или лицо без гражданства, в отношении которых принято решение о нежелательности их пребывания (проживания) в РФ;

- лицо, включенное в соответствии с Федеральным законом «О противодействии легализации (отмыванию) денежных средств, полученных преступным путем, и финансированию терроризма» в перечень организаций и физических лиц, в отношении которых имеются сведения об их причастности к экстремистской деятельности или терроризму;

- общественное объединение или религиозная организация, деятельность которых приостановлена в соответствии с Федеральным законом «О противодействии экстремистской деятельности»;

- лицо, в отношении которого вступившим в законную силу решением суда установлено, что в его действиях содержатся признаки экстремистской деятельности;

- лицо, которое не соответствует предъявляемым к учредителям (участникам, членам) требованиям федеральных законов, определяющих правовое положение некоммерческих организаций отдельных видов;

- лицо, которое ранее являлось руководителем или входило в состав руководящего органа общественного или религиозного объединения либо иной организации, в отношении которых по основаниям, предусмотренным Федеральным законом «О противодействии экстремистской деятельности» либо Федеральным законом «О противодействии терроризму», судом принято вступившее в законную силу решение о ликвидации или запрете деятельности (в течение 10 лет со дня вступления в силу соответствующего 
решения суда).

Элементом правового статуса отделений ИННО является их обязательная государственная регистрация.

Как уже отмечалось, законодательство предусматривает несколько оснований отказа в государственной регистрации отделения ИННО:

а) основания, связанные с несоответствием статуса учредителей, участников и членов организации требованиям законодательства;

б) основания, связанные с нарушением порядка создания и деятельности организации:

- противоречие целей создания отделения организации Конституции и законодательству РФ;

- взаимосвязь целей создания отделения организации и угроз суверенитету, политической независимости, территориальной неприкосновенности и национальным интересам Российской Федерации;

- ликвидация ранее зарегистрированного отделения организации в связи с грубым нарушением Конституции и законодательства РФ.

Статья 30.1 Федерального закона «О некоммерческих организациях» устанавливает ограничения на участие отдельных категорий граждан, осуществляющих властные полномочия, в деятельности ИННО. В состав органов управления, попечительских и наблюдательных советов, иных органов ИННО и действующих на территории РФ их структурных подразделений не могут входить лица, замещающие государственные или муниципальные должности, а также должности государственной или муниципальной службы, если иное не предусмотрено международным договором или законодательством РФ. Указанные лица не вправе заниматься оплачиваемой деятельностью, финансируемой исключительно за счет средств иностранных государств, международных и иностранных организаций, иностранных граждан и лиц без гражданства, если иное не предусмотрено международным договором или законодательством РФ. 
Перечисленные правовые положения направлены на обеспечение гарантий независимости и предотвращение подкупа депутатов, выборных должностных лиц, государственных и муниципальных чиновников, а также на недопущение попыток лоббирования и иного вмешательства иностранных государств, международных и иностранных организаций, иностранных граждан и апатридов в законную деятельность органов власти и управления РФ.

Государство осуществляет особый контроль за финансированием ИННО. В соответствии с пунктами 3-4 статьи 32 Федерального закона «О некоммерческих организациях» НКО обязана представлять в уполномоченный орган в сфере юстиции документы, содержащие отчет о своей деятельности, о персональном составе руководящих органов, а также документы о расходовании денежных средств и об использовании иного имущества, в том числе полученных от международных и иностранных организаций, иностранных граждан и лиц без гражданства. Структурное подразделение ИННО обязано информировать уполномоченный орган об объеме получаемых данным подразделением денежных средств и иного имущества, их предполагаемом распределении, о целях их расходования или использования и об их фактическом расходовании или использовании, о предполагаемых для осуществления на территории РФ программах, а также о расходовании предоставленных физическим и юридическим лицам указанных денежных средств и об использовании предоставленного им иного имущества.

Структурное подразделение ИННО ежегодно представляет в уполномоченный орган аудиторское заключение, полученное от российской аудиторской организации (российского индивидуального аудитора).

НКО, выполняющие функции иностранного агента, представляют в уполномоченный орган документы, содержащие отчет о своей деятельности, о персональном составе руководящих органов, один раз в полгода, 
документы о целях расходования денежных средств и использования иного имущества, в том числе полученных от иностранных источников, ежеквартально, аудиторское заключение - ежегодно.

В случае несоответствия характера деятельности и расходов филиала или представительства ИННО заявленным целям такое структурное подразделение по решению уполномоченного органа может быть исключено из реестра филиалов и представительств международных организаций и ИННО.

Эффективной мерой борьбы с попытками оказания из-за рубежа конспиративного целенаправленного информационно-пропагандистского, финансового, политического и силового воздействия на политический процесс в РФ в ущерб суверенитету нашего государства может служить предусмотренная пунктом 12 статьи 32 Федерального закона «О некоммерческих организациях» возможность запрета осуществления на территории РФ программ ИННО, создающих угрозу суверенитету, политической независимости и территориальной неприкосновенности РФ. Уполномоченный орган в сфере юстиции направляет структурному подразделению ИННО мотивированное решение о запрете заявленной для осуществления на территории РФ программы или ее части. Структурное подразделение ИННО, получившее указанное решение, обязано прекратить деятельность, связанную с осуществлением данной программы в указанной в решении части. Невыполнение решения влечет за собой исключение соответствующего филиала или представительства ИННО из реестра, ликвидацию отделения ИННО.

В целях защиты основ конституционного строя, нравственности, здоровья, прав и законных интересов других лиц, обеспечения обороны страны и безопасности государства уполномоченный орган вправе вынести структурному подразделению ИННО мотивированное решение о запрете направления денежных средств и иного имущества определенным 
получателям.

Федеральным законом от 23 мая 2015 г. № 129-Ф3 «О внесении изменений в отдельные законодательные акты Российской Федерации» в систему конституционно-правовой защиты государственного суверенитета введен институт нежелательности на территории РФ деятельности иностранных и международных неправительственных организаций.

Федеральным законом предусмотрено, что деятельность иностранной или международной неправительственной организации, представляющая угрозу основам конституционного строя РФ, обороноспособности страны или безопасности государства, может быть признана нежелательной на территории РФ.

Признание нежелательной деятельности иностранной или международной неправительственной организации влечет за собой:

- запрет на создание (открытие) на территории РФ структурных подразделений иностранной или международной неправительственной организации и прекращение деятельности ранее созданных (открытых) на территории РФ таких структурных подразделений;

- отказ кредитных организаций и некредитных финансовых учреждений в проведении операций с денежными средствами и иным имуществом, одной из сторон которых является организация, признанная нежелательной в РФ;

- запрет на распространение информационных материалов, издаваемых или распространяемых организацией, в том числе через СМИ или с использованием сети «Интернет», а также производство или хранение таких материалов в целях распространения;

- запрет на осуществление на территории РФ программ (проектов) организаций, деятельность которых признана нежелательной в РФ.

Решение о признании нежелательной на территории РФ деятельности указанной организации принимается Генеральным прокурором или его 
заместителями по согласованию с МИД России ${ }^{1}$. Федеральным законом установлена уголовная и административная ответственность за осуществление деятельности на территории РФ иностранной или международной неправительственной организации, в отношении которой принято решение о нежелательности её деятельности на территории РФ.

Специфической организационно-правовой формой общественных объединений (видом общественной организации) являются политические партии ${ }^{2}$.

Конституционно-правовое регулирование деятельности политических партий в контексте ЗГС охватывает вопросы создания, государственной регистрации, приостановления деятельности и ликвидации политических партий (их региональных отделений).

Согласно статье 9 Федерального закона от 11 июля 2001 г. № 95-Ф3 «О политических партиях» государство запрещает создание и деятельность политических партий, цели или действия которых направлены на осуществление экстремистской деятельности.

Руководящие и иные органы политической партии, ее региональные отделения и иные структурные подразделения должны находиться на территории РФ. Не допускается создание и деятельность в РФ политических партий иностранных государств и структурных подразделений таких партий.

В целях недопущения сращивания партийного и государственного аппаратов законодатель запретил создание политических партий и их

${ }^{1}$ По состоянию на 1 августа 2016 г. распоряжениями Минюста России от 29 июля 2015 г. № 1076-p, от 1 декабря 2015 г. № 1777-р, от 1 декабря 2015 г. № 1778-р, от 7 декабря 2015 г. № 1821-р, от 17 марта 2016 г. № 393-р в Перечень иностранных и международных неправительственных организаций, деятельность которых признана нежелательной на территории РФ, включены Национальный фонд в поддержку демократии (The National Endowment for Democracy), Институт Открытое Общество Фонд Содействия (OSI Assistance Foundation), Фонд Открытое общество (Open Society Foundation, «Американо-российский фонд по экономическому и правовому развитию» (U.S. Russia Foundation for Economic Advancement and the Rule of Law), Национальный Демократический Институт Международных отношений (National Democratic Institute for International Affairs).

${ }^{2}$ Статья 3 Федерального закона «О политических партиях». 
структурных подразделений в органах государственной власти, органах местного самоуправления, в Вооруженных Силах, в правоохранительных и иных государственных органах, в государственных организациях.

Не допускается создание политических партий по признакам профессиональной, расовой, национальной или религиозной принадлежности.

В Постановлении от 15 декабря 2004 года № 18-П «По делу о проверке конституционности пункта 3 статьи 9 Федерального закона «О политических партиях» в связи с запросом Коптевского районного суда города Москвы, жалобами общероссийской общественной политической организации «Православная партия России» и граждан И.В. Артемова и Д.А. Савина» ${ }^{1}$ Конституционный Суд РФ подтвердил законность ограничения создания политических партий по признакам национальной и религиозной принадлежности.

Конституционный Суд отметил, что на современном этапе российское общество, в том числе политические партии и религиозные объединения, еще не приобрело прочный опыт демократического существования. В этих условиях создание партий по религиозному признаку открыло бы путь к политизации религии и религиозных объединений, политическому фундаментализму и клерикализации партий. Создание партий по национальному признаку могло бы привести к преобладанию в выборных органах власти представителей партий, отражающих интересы больших этнических групп в ущерб интересам малых этнических групп, и тем самым к нарушению установленного Конституцией принципа правового равенства независимо от национальной принадлежности.

\footnotetext{
${ }^{1}$ Постановление Конституционного Суда РФ от 15 декабря 2004 г. № 18-П "По делу о проверке конституционности пункта 3 статьи 9 Федерального закона "О политических партиях" в связи с запросом Коптевского районного суда города Москвы, жалобами общероссийской общественной политической организации "Православная партия России" и граждан И.В. Артемова и Д.А. Савина"// Рос. газ. 2004. 24 декабря.
} 
По мнению Конституционного Суда, политические партии в России надконфессиональны и внеконффессиональны. В многонациональной и многоконфессиональной России - вследствие особенностей функционирования ведущих вероучений, их влияния на социальную жизнь, в том числе использования в политической идеологии, - такие понятия, как «христианский», «православный», «мусульманский», «русский», «татарский» и т. п., ассоциируются в общественном сознании скорее с конкретными конфессиями и отдельными нациями, чем с системой ценностей российского народа в целом. Поэтому Конституционный Суд высказался против использования соответствующих слов в наименованиях политических партий.

Предметом рассмотрения Конституционного Суда по жалобам Балтийской республиканской партии и Российской коммунистической рабочей партии являлся численный состав и территориальный масштаб деятельности политических партий.

В своем Постановлении от 1 февраля 2005 г. № 1-П по жалобе Балтийской республиканской партии Конституционный Суд указал, что «создание региональных и местных политических партий могло бы привести - принимая во внимание сложносоставной характер Российской Федерации к образованию множества региональных партийных систем, что чревато превращением формирующейся партийной системы в фактор ослабления развивающейся российской демократии, народовластия, федерализма, единства страны и тем самым - ослабления конституционных гарантий прав и свобод на всей территории Российской Федерации» ${ }^{1}$.

Конституционный Суд подтвердил, что законодательное

${ }^{1}$ Постановление Конституционного Суда РФ от 1 февраля 2005 г. № 1-П "По делу о проверке конституционности абзацев второго и третьего пункта 2 статьи 3 и пункта 6 статьи 47 Федерального закона "О политических партиях" в связи с жалобой общественно-политической организации "Балтийская республиканская партия" // С3 РФ. 2005. N 6. Ст. 491. 
регулирование, в соответствии с которым статус политической партии могут получить только общенациональные (общероссийские) общественные объединения, не только направлено на формирование в стране реальной многопартийности, на правовую институционализацию партий в качестве важного фактора становления гражданского общества и стимулирование образования крупных общенациональных партий, но и необходимо в целях защиты конституционных ценностей, прежде всего - обеспечения единства страны.

Численный состав и территориальный масштаб деятельности политических партий должен быть достаточным, чтобы они были способны выполнять свои уставные задачи в качестве общероссийских политических партий. Для формирования и выражения политической воли народа партия должна обладать значительной поддержкой в обществе. Численность партии должна устанавливаться с учетом невозможности раздробления депутатского корпуса на множество мелких групп, чтобы обеспечить нормальное функционирование парламента, стабильность законодательной власти и конституционного строя в целом.

В Постановлении от 16 июля 2007 г. № 11-П по жалобе Российской коммунистической рабочей партии Конституционный Суд отметил, что федеральный законодатель вправе устанавливать требования к численному составу политических партий, исходя из конкретно-исторических условий развития РФ; данные требования обусловлены решаемыми в законодательном порядке задачами в сфере развития политической системы и обеспечения ее адекватности принципам конституционного строя Российской Федерации и не влекут отмену или умаление конституционного права граждан на объединение в политические партии или его несоразмерное ограничение.

Государство регистрирует политические партии и их региональные отделения. Решение о государственной регистрации принимается 
Министерством юстиции и его территориальными органами.

В целях ЗГС политической партии может быть отказано в регистрации, если:

a) положения устава партии противоречат Конституции РФ и федеральным законам;

б) наименования и символика партии не соответствуют требованиям закона (оскорбляют расовые, национальные или религиозные чувства; оскорбляют или порочат государственную символику; используют символику запрещенных на территории РФ организаций; используют наименования ликвидированных экстремистских партий и др.);

в) не представлены необходимые для государственной регистрации документы или нарушены сроки их представления;

г) содержащиеся в документах на государственную регистрацию сведения недостоверны.

Для недопущения иностранного вмешательства в политическую деятельность и избирательный процесс иностранные граждане и лица без гражданства лишены права быть членами политической партии. В отношении определенных категорий граждан РФ (лиц, замещающих государственные должности, военнослужащих, сотрудников спецслужб и правоохранительных органов) могут устанавливаться ограничение права на вступление в политическую партию либо обязанность приостановления членства в партии.

Государственный контроль за деятельностью политических партий предполагает:

- возложение на политические партии обязанностей соблюдать Конституцию, законодательство и устав партии; заблаговременно извещать избирательные комиссии о выдвижении своих кандидатов (списков кандидатов) в депутаты и на иные выборные должности; представлять в органы юстиции сведения о продолжении своей деятельности, о количестве 
зарегистрированных кандидатов (списков кандидатов) в депутаты и на иные выборные должности;

- контроль за соблюдением политическими партиями, их региональными отделениями и иными структурными подразделениями законодательства РФ, а также за соответствием деятельности партии и ее структурных подразделений уставным положениям, целям и задачам;

- контроль за финансовой деятельностью политической партии и ее структурных подразделений.

Обязанности политической партии коррелируют правам уполномоченных государственных органов (органов юстиции) по контролю за деятельностью политических партий.

Уполномоченные органы вправе:

знакомиться с документами политических партий и их региональных отделений, подтверждающими наличие региональных отделений, число членов партии и число членов каждого регионального отделения партии;

направлять своих представителей для участия в проводимых политической партией, еe региональными отделениями и иными структурными подразделениями открытых мероприятиях (в том числе в съездах, конференциях или общих собраниях) по принятию устава и программы, внесению в них изменений и дополнений, выборам руководящих и контрольно-ревизионных органов политической партии, выдвижению кандидатов в депутаты и на иные выборные должности, реорганизации и ликвидации политической партии и ее региональных отделений;

выносить политической партии, ее региональному отделению или иному зарегистрированному структурному подразделению письменное предупреждение в случае осуществления ими деятельности, противоречащей положениям, целям и задачам, предусмотренным уставом политической партии;

вносить в суд заявление о приостановлении деятельности или 
ликвидации политической партии, ее регионального отделения или иного зарегистрированного структурного подразделения.

Принципиальное значение для ЗГС имеют вопросы приостановления деятельности и ликвидации политических партий. При наличии предусмотренных законом оснований Верховный Суд РФ принимает решение о ликвидации политической партии.

Партия может быть ликвидирована по решению Верховного Суда в случае:

а) невыполнения требований закона, связанных с недопустимостью создания и деятельности структурных подразделений политических партий в органах государственной власти, органах местного самоуправления (за исключением деятельности в законодательных органах государственной власти и представительных органах муниципальных образований), в Вооруженных Силах, в правоохранительных и иных государственных органах, в государственных и негосударственных организациях, а также вмешательства политических партий в учебный процесс образовательных учреждений;

б) неустранения в установленный решением суда срок нарушений, послуживших основанием для приостановления деятельности политической партии;

в) неучастия политической партии в выборах;

г) несоответствия количества региональных отделений в субъектах РФ;

д) отсутствия необходимого числа членов политической партии;

е) неоднократного непредставления политической партией в установленный срок в федеральный уполномоченный орган обновленных сведений, необходимых для внесения изменений в единый государственный реестр юридических лиц, за исключением сведений о полученных 
лицензиях ${ }^{1}$.

В Федеральном законе «О политических партиях» также закреплены основания, при которых политическая партия и ее региональное отделение не могут быть ликвидированы. Политическая партия, представленная в Государственной Думе, не может быть ликвидирована по основаниям отсутствия необходимого числа членов политической партии и отсутствия региональных отделений более чем в половине субъектов РФ, в течение пяти лет со дня голосования на соответствующих выборах. Не допускается ликвидация политической партии по решению Верховного Суда со дня официального опубликования решения о назначении (проведении) выборов депутатов Государственной Думы Федерального Собрания РФ, выборов Президента РФ до дня официального опубликования результатов указанных выборов, за исключением случаев осуществления партией экстремистской деятельности. Региональное отделение политической партии не может быть ликвидировано по решению суда со дня официального опубликования решения о назначении (проведении) выборов в органы государственной власти соответствующего субъекта РФ до дня официального опубликования результатов указанных выборов, за исключением случаев осуществления региональным отделением партии экстремистской деятельности.

Осуществляя конституционно-правовое регулирование деятельности политических партий в контексте ЗГС, законодатель особое внимание уделяет контролю за финансовой деятельностью политических партий, их региональных отделений и иных структурных подразделений.

Контроль за источниками и размерами имущества, получаемого

1 В соответствии с частью 2 статьи 263 Кодекса административного судопроизводства РФ от 8 марта 2015 г. № 21-Ф3 по делам о приостановлении деятельности или ликвидации политической партии, ее регионального отделения или иного структурного подразделения суд на основании соответствующего заявления может применить меры предварительной защиты по исковому заявлению в виде: приостановления деятельности соответствующих организаций; приостановления выпуска и (или) реализации печатного издания партии либо распространения материалов; наложения ареста на имущество; запрещения совершения определенных действий. 
политическими партиями, их региональными отделениями и иными структурными подразделениями в виде вступительных и членских взносов, пожертвований граждан и юридических лиц, а также за источниками денежных средств и иного имущества политических партий, их региональных отделений и иных структурных подразделений, полученных в результате совершения сделок, осуществляют ЦИК России и соответствующие избирательные комиссии субъектов РФ.

He допускаются пожертвования политической партии и ee региональным отделениям от: иностранных государств и иностранных юридических лиц; иностранных граждан; лиц без гражданства; российских граждан, не достигших 18 лет; российских юридических лиц с иностранным участием, если доля (вклад) иностранного участия в их уставном (складочном) капитале превышает 30 \% на день внесения пожертвования; международных организаций и международных общественных движений; органов государственной власти, иных государственных органов, органов местного самоуправления; государственных и муниципальных учреждений (унитарных предприятий); юридических лиц, в уставном (складочном) капитале которых доля (вклад) РФ, субъектов РФ и (или) муниципальных образований превышает 30\% на день внесения пожертвования; организаций, учрежденных государственными органами и (или) органами местного самоуправления; организаций, учрежденных юридическими лицами с иностранным, государственным или муниципальным участием, превышающем 30\%; организаций, в уставном капитале которых доля (вклад) юридических лиц с иностранным, государственным или муниципальным участием, превышающем $30 \%$, превышает $30 \%$ на день внесения пожертвования; воинских частей, военных организаций, правоохранительных органов; благотворительных организаций и религиозных объединений, учрежденных ими организаций; анонимных жертвователей; юридических лиц, зарегистрированных менее чем за один год до дня внесения 
пожертвования, а также от некоммерческих организаций, выполняющих функции иностранного агента; некоммерческих организаций, получавших в течение года, предшествующего дню внесения пожертвования политической партии, ее региональным отделениям, денежные средства либо иное имущество от перечисленных выше субъектов.

Аналогичные запреты установлены федеральным законодательством о выборах в части финансирования избирательных кампаний кандидатов, зарегистрированных кандидатов и избирательных объединений.

Помимо ограничений на внесение пожертвований с указанными в законе субъектами не допускается заключение сделок.

Законодательное перечисление перечня субъектов, которым запрещено вносить пожертвования политическим партиям, их региональным отделениям, вносить добровольные пожертвования в избирательные фонды, связано с противодействием попыткам иностранного финансирования политической деятельности и выборов в ущерб государственному суверенитету РФ, а также недопущением нецелевого использования бюджетных средств в избирательном процессе.

Ограничения в отношении НКО не применяются, если полученные денежные средства либо иное имущество возвращены перечислившим (передавшим) их иностранным государствам, органам, организациям или физическим лицам (в случае невозможности возврата - перечислены в доход федерального бюджета) до дня внесения пожертвования политической партии, ее региональным отделениям.

Политическая партия, еe региональные отделения и иные зарегистрированные структурные подразделения ведут учет поступления и расходования средств, ежеквартально представляют соответствующие сведения для проверки в ЦИК России или избирательную комиссию субъекта РФ, на территории которого они зарегистрированы. Политическая партия ежегодно представляет в ЦИК России сводный финансовый отчет. ЦИК 
России проверяет указанный сводный финансовый отчет партии. Результаты проверки размещаются в сети Интернет и передаются для опубликования в общероссийских периодических печатных изданиях.

Проверка бухгалтерской отчетности политической партии, eе региональных отделений и иных структурных подразделений осуществляется налоговыми органами. Если в отчетный период политическая партия получала государственное финансирование либо общая сумма пожертвований политической партии составила шестьдесят и более миллионов рублей либо общая сумма партийных расходов превысила шестьдесят миллионов рублей годовая бухгалтерская отчетность и сводный финансовый отчет политической партии подлежат обязательному аудиту.

Перечисленные правовые меры (учет средств, финансовые отчеты, сводный финансовый отчет, проверка и опубликование сведений о поступлении и расходовании средств, проверка сводного финансового отчета, обязательный аудит) позволили усилить контроль за денежными средствами и имуществом политических партий, минимизировать возможности иностранного влияния на политическую деятельность и криминального финансирования выборов в органы государственной власти и местного самоуправления.

Серьезные ограничения правосубъектности политических партий вводятся в условиях ЧП и ВП.

На территории, где введены чрезвычайные режимы (ЧП или ВП) приостанавливается деятельность политических партий и других общественных объединений, препятствующих устранению обстоятельств для введения указанных режимов, ведущих пропаганду и (или) агитацию, а также иную деятельность, подрывающую оборону и безопасность государства. С учетом вводимых для ЗГС ограничений запрещается или ограничивается проведение собраний, митингов, демонстраций, шествий и пикетирования, а также иных массовых мероприятий. Партии приостанавливают участие в 
референдумном и избирательном процессе, поскольку в условиях чрезвычайных режимов референдумы и выборы в органы государственной власти и местного самоуправления не проводятся.

Важным элементом механизма ЗГС в политической сфере выступает конституционно-правовое регулирование деятельности СМИ.

Свобода выражения мнений и свобода массовой информации являются одной из основ развития современного общества и демократического государства. Вместе с тем осуществление поиска, получения, производства и распространения массовой информации, учреждение СМИ может быть сопряжено с определенными ограничениями, которые предусмотрены законом и необходимы в демократическом обществе.

Конституционно-правовое регулирование деятельности СМИ в контексте ЗГС призвано обеспечивать баланс между свободами мысли и слова, массовой информации, с одной стороны, и иными правами и свободами человека и гражданина, а также охраняемыми Конституцией ценностями - с другой.

Статья 29 Конституции РФ устанавливает запрет на пропаганду и агитацию, возбуждающие социальную, расовую, национальную или религиозную ненависть и вражду, а также на пропаганду социального, расового, национального, религиозного или языкового превосходства.

Статьей 4 Закона РФ «О средствах массовой информации» определена недопустимость злоупотребления свободой массовой информации. В РФ не допускается использование СМИ в целях совершения преступлений, для разглашения сведений, составляющих государственную или иную охраняемую законом тайну, для распространения материалов, содержащих публичные призывы к осуществлению террористической деятельности, или публично оправдывающих терроризм, других экстремистских материалов. Запрещается распространение информации об общественном объединении или иной организации, включенных в опубликованный перечень 
общественных и религиозных объединений, иных организаций, в отношении которых судом принято вступившее в законную силу решение о ликвидации или запрете деятельности по основаниям, предусмотренным Федеральным законом «О противодействии экстремистской деятельности», без указания на то, что соответствующее общественное объединение или иная организация ликвидированы или их деятельность запрещена.

В Законе РФ «О средствах массовой информации» установлен запрет распространения в СМИ и информационно-телекоммуникационных сетях сведений, содержащих инструкции по самодельному изготовлению взрывчатых веществ и взрывных устройств.

Особое внимание уделено регламентации получения, производства и распространения информации в ходе проведения контртеррористических операций (КТО). Порядок сбора информации журналистами на территории (объекте) проведения КТО определяется руководителем КТО. При освещении КТО запрещается распространение в СМИ сведений о специальных средствах, технических приемах и тактике проведения такой операции, если их распространение может препятствовать проведению КТО или поставить под угрозу жизнь и здоровье людей. Сведения о сотрудниках специальных подразделений, лицах, оказывающих содействие в проведении КТО, выявлении, предупреждении, пресечении и раскрытии террористического акта, и о членах семей указанных лиц составляют государственную тайну.

Злоупотребление свободой массовой информации влечет вынесение уполномоченными органами и должностными лицами письменных предупреждений учредителю, редакции (главному редактору), а также прекращение судом деятельности СМИ (статья 16 Закона РФ «О средствах массовой информации», статьи 8 и 11 Федерального закона «О противодействии экстремистской деятельности»).

За нарушение требований Закона РФ «О средствах массовой 
информации» предупреждение вправе выносить регистрирующий орган, а за нарушение требований Федерального закона «О противодействии экстремистской деятельности» - не только регистрирующий орган, но и федеральный орган исполнительной власти в сфере печати, телерадиовещания и средств массовых коммуникаций, Генеральный прокурор РФ или подчиненный ему соответствующий прокурор.

Действующее законодательство содержит ряд ограничений, связанных с учреждением и регистрацией СМИ.

Учредителем СМИ не может выступать: гражданин, не достигший 18летнего возраста, либо отбывающий наказание в местах лишения свободы по приговору суда, либо душевнобольной, признанный судом недееспособным; объединение граждан, предприятие, учреждение, организация, деятельность которых запрещена по закону; гражданин другого государства или лицо без гражданства, не проживающее постоянно в РФ.

Иностранное государство, международная организация, а также находящаяся под их контролем организация, иностранное юридическое лицо, российское юридическое лицо с иностранным участием, иностранный гражданин, лицо без гражданства, гражданин РФ, имеющий гражданство другого государства, в совокупности или каждый в отдельности, не вправе выступать учредителем СМИ, являться редакцией СМИ, организацией, осуществляющей вещание.

Иностранное государство, международная организация, а также находящаяся под их контролем организация, иностранное юридическое лицо, российское юридическое лицо, доля иностранного участия в уставном капитале которого составляет более 20 \%, иностранный гражданин, лицо без гражданства, гражданин РФ, имеющий гражданство другого государства, не вправе осуществлять владение, управление либо контроль прямо или косвенно в отношении более $20 \%$ долей (акций) в уставном капитале участника (члена, акционера), учредителя СМИ, редакции СМИ, вещателя. 
Закон запрещает перечисленным субъектам устанавливать любые формы контроля над учредителем СМИ, редакцией СМИ, организацией, осуществляющей вещание, над участниками (членами, акционерами) учредителя СМИ, в результате которого указанные субъекты приобретают возможность прямо или косвенно владеть, управлять таким учредителем, такой редакцией, такой организацией, их контролировать, а также фактически определять принимаемые ими решения.

Любые сделки, которые приводят к нарушению ограничений, связанных с учреждением СМИ, признаются ничтожными.

В случае получения редакцией СМИ, вещателем или издателем денежных средств от иностранного государства, международной (иностранной) организации, российской некоммерческой организации, выполняющей функции иностранного агента, иностранного гражданина, лица без гражданства, а также от российской организации, участниками и (или) учредителями которой являются указанные лица, редакция СМИ, вещатель или издатель обязаны один раз в квартал предоставить информацию о получении денежных средств от указанных лиц путем направления уведомления в федеральный орган исполнительной власти, осуществляющий функции по контролю и надзору в сфере СМИ, массовых коммуникаций, информационных технологий и связи.

Перечисленные правовые ограничения на иностранное участие в СМИ, установление любых форм зарубежного управления либо контроля над учредителями, редакцией СМИ и вещателем преследуют конституционнозначимые цели. Иностранное влияние на информационную политику может способствовать формированию выгодного для зарубежных государств общественного мнения внутри страны по важным внутри- и внешнеполитическим вопросам, провоцировать недовольство населения, массовые беспорядки, стихийные и организованные выступления против 
законных властей ${ }^{1}$. В угрожаемый период и военное время иностранные позиции влияния в СМИ могут использоваться для инициирования панических и пораженческих настроений, деморализации войск и населения.

Значимым элементом конституционно-правового регулирования деятельности СМИ в контексте ЗГС является государственная регистрация СМИ и возможность отказа в ней.

Государственная регистрация СМИ порождает возникновение прав и обязанностей учредителя и редакции СМИ².

В регистрации СМИ может быть отказано:

- если заявление подано от имени гражданина, объединения граждан, предприятия, учреждения, организации, не обладающих правом учреждения СМИ;

- если указанные в заявлении сведения не соответствуют действительности;

- если регистрирующим органом ранее зарегистрировано СМИ с теми же названием и формой распространения массовой информации;

- если наименование (название), примерная тематика и (или) специализация СМИ представляют злоупотребление свободой массовой информации (предназначены для совершения преступлений, разглашения государственной или иной охраняемой законом тайны, для распространения материалов с публичными призывами к осуществлению террористической деятельности или публично оправдывающих терроризм, других экстремистских материалов).

Особенностью правового положения организаций, осуществляющих телевизионное вещание и радиовещание, является лицензирование их деятельности.

1 Эффективные возможности внешнего информационного воздействия на различные целевые аудитории (прежде всего, на молодежь) были продемонстрированы в ходе «арабской весны» и «евромайдана».

2 Исключение составляют перечисленные в статье 12 Закона РФ «О средствах массовой информации» случаи освобождения СМИ от государственной регистрации. 
Вещатель несет ответственность за соответствие распространяемых телеканала, радиоканала требованиям законодательства РФ.

В предоставлении или переоформлении лицензии может быть отказано: при несоответствии требованиям Федерального закона от 4 мая 2011 г. № 99-Ф3 «О лицензировании отдельных видов деятельности»; в случае несоответствия заявителя ограничениям, связанным с учреждением СМИ, организации, осуществляющей вещание, а также владением, управлением либо иностранным контролем участника (члена, акционера), учредителя СМИ, редакции СМИ, вещателя.

Специфический блок правового регулирования посвящен участию СМИ в избирательном (референдумном) процессе. Отдельного внимания с позиций ЗГС заслуживает стадия информирования избирателей и предвыборной агитации.

В связи с необходимостью адекватного противодействия «грязной» предвыборной агитации, проводимой под предлогом информирования граждан, законодатель разделяет понятия «информирование избирателей» и «предвыборная агитация» ${ }^{1}$. Отграничение информирования избирателей от предвыборной агитации направлено на обеспечение формирования свободного волеизъявления граждан и гласности выборов и отвечает требованиям статей 3 (часть 3), 29 (части 1, 3, 4 и 5), 32 (части 1, 2 и 3) Конституции РФ, поскольку только когда реально гарантированы право на объективную информацию и свобода выражения мнений, выборы могут считаться свободными ${ }^{2}$. Применительно к СМИ свободу выражения мнений

\footnotetext{
${ }^{1}$ Понятия «информирование избирателей» и «предвыборная агитация» различаются по субъектам и содержанию. Информирование избирателей осуществляют органы государственной власти, органы местного самоуправления, избирательные комиссии, организации, осуществляющие выпуск средств массовой информации, юридические и физические лица. Политические партии, кандидаты, доверенные лица субъектами информирования не являются. При этом, в отличие от агитационных материалов, информационные материалы должны быть объективными и достоверными.

2 См. Постановление Конституционного Суда РФ от 30 октября 2003 г. № 15-П по делу о проверке конституционности отдельных положений Федерального закона «Об основных гарантиях избирательных прав и права на участие в референдуме граждан
} 
нельзя отождествлять со свободой предвыборной агитации, к которой не предъявляются требования объективности.

Федеральные законы и законы субъектов РФ о выборах, как правило, содержат разделы (главы), регламентирующие порядок и условия ведения предвыборной агитации.

Деятельность кандидатов, избирательных объединений, СМИ в ходе предвыборной агитации должна осуществляться в установленных законодательством пределах. Во-первых, закон закрепляет сроки предвыборной агитации. Во-вторых, закон определяет субъекты агитационной деятельности. В-третьих, закон устанавливает равные условия доступа кандидатов, избирательных объединений к средствам массовой информации ${ }^{1}$.

Предвыборные программы кандидатов, политических партий, иные агитационные материалы (в том числе размещаемые в сети «Интернет»), выступления кандидатов и их доверенных лиц, представителей политических партий, граждан на публичных мероприятиях, в СМИ не должны содержать призывы к совершению экстремистской деятельности, а также обосновывать или оправдывать экстремизм.

Как мы видим, конституционно-правовая регламентация предвыборной агитации в контексте ЗГС направлена на предотвращение фактов злоупотребления свободой массовой информации, предупреждение и пресечение экстремистской деятельности кандидатов, политических партий и общественных объединений, недопустимость распространения избирательных технологий манипулятивного воздействия на общественное

Российской Федерации» в связи с запросом группы депутатов Государственной Думы и жалобами граждан С.А. Бунтмана, К.А. Катаняна и К.С. Рожкова // СЗ РФ. 2003. № 44. Ст. 4358.

${ }^{1}$ В отношении споров о нарушении равенства участников избирательного процесса при осуществлении предвыборной агитации и освещении СМИ их деятельности см. Решение Верховного Суда РФ от 3 июля 2008 г. по делу № ГКПИ08-1472; Решение Верховного Суда РФ от 16 июля 2008 г. по делу № ГКПИ08-1403. 
сознание.

Действующим законодательством предусмотрена возможность привлечения к ответственности организации телерадиовещания, редакции периодического печатного издания, их должностных лиц в случае нарушения порядка проведения предвыборной агитации и распространения экстремистских материалов (пункт 8 статьи 56 Федерального закона от 12 июня 2002 г. № 67-Ф3, статьи 8 и 11 Федерального закона «О противодействии экстремистской деятельности»).

В статье 54 Федерального закона «Об основных гарантиях избирательных прав и права на участие в референдуме граждан Российской Федерации» закреплены условия выпуска и распространения агитационных материалов (плакатов, листовок, календарей, аудио- и видеопродукции). Все агитационные материалы должны изготавливаться на территории РФ и содержать сведения об изготовителе, заказчике, информацию о тираже и дате выпуска, указание об оплате их изготовления из средств соответствующего избирательного фонда. Экземпляры печатных агитационных материалов или их копии, экземпляры аудиовизуальных материалов, фотографии и другие материалы до начала их распространения должны предоставляться в соответствующую избирательную комиссию вместе со сведениями о месте нахождения (адресе места жительства) организации (лица), изготовившей и заказавшей (изготовившего и заказавшего) эти материалы. Запрещается изготовление агитационных материалов без предварительной оплаты за счет средств соответствующего избирательного фонда.

В соответствии с пунктом 9 статьи 56 Федерального закона «Об основных гарантиях избирательных прав и права на участие в референдуме граждан Российской Федерации» правоохранительные органы обязаны принимать меры по предотвращению изготовления подложных и незаконных предвыборных печатных, аудиовизуальных, иных агитационных материалов, их изъятию, а также устанавливать изготовителей указанных материалов и 
источник их оплаты, а также незамедлительно информировать соответствующую избирательную комиссию о выявленных фактах и принятых мерах.

На основании части 2 статьи 28 Закона Российской Федерации «О средствах массовой информации» изъятие, а равно уничтожение тиража или его части допускается не иначе как по вступившему в силу решению суда. Судебный порядок изъятия, уничтожения тиража (его части) служит гарантией обеспечения законности агитационной деятельности, а также защиты прав СМИ в условиях гласности и свободы выборов.

В контексте ЗГС особое значение имеет процедура прекращения и приостановления деятельности СМИ.

Деятельность СМИ может быть прекращена или приостановлена только по решению учредителя либо судом по иску регистрирующего органа.

Основанием для прекращения судом деятельности СМИ являются неоднократные в течение 12 месяцев злоупотребления редакцией свободой массовой информации, по поводу которых регистрирующим органом делались письменные предупреждения учредителю и (или) редакции (главному редактору), а равно неисполнение постановления суда о приостановлении деятельности СМИ. Деятельность СМИ может быть также прекращена в порядке и по основаниям, предусмотренным Федеральным законом «О противодействии экстремистской деятельности».

Прекращение деятельности СМИ влечет недействительность свидетельства о его регистрации и устава редакции.

Приостановление деятельности СМИ является исключительной мерой по обеспечению иска, а также обеспечения заявления регистрирующего органа по основаниям нарушения ограничений, связанных с учреждением СМИ, организации, осуществляющей вещание, нарушением законодательства о выборах и референдумах, а также владением, управлением либо иностранным контролем участника (члена, акционера) 
учредителя СМИ, редакции СМИ, вещателя.

Конституционно-правовое регулирование деятельности СМИ в контексте ЗГС в качестве обязательного элемента предполагает установление правил распространения зарубежной информации, аккредитации и пребывания корреспондентов иностранных СМИ на территории РФ.

Гражданам РФ гарантируется беспрепятственный доступ к сообщениям и материалам зарубежных СМИ. При этом согласно статье 54 Закона РФ «О средствах массовой информации» для распространения продукции зарубежного периодического печатного издания, т.е. не зарегистрированного в РФ и имеющего место постоянного пребывания учредителя или редакции вне ее пределов, а равно финансируемого иностранными государствами, юридическими лицами или гражданами, необходимо получить разрешение уполномоченного федерального органа исполнительной власти, если порядок распространения не установлен межгосударственным договором РФ.

Открытие представительств (корреспондентских пунктов) зарубежных СМИ осуществляется с разрешения МИД России. Аккредитация иностранных корреспондентов проводится МИД России. В соответствии с пунктом 21 Правил аккредитации и пребывания корреспондентов иностранных СМИ на территории Российской Федерации, утвержденных Постановлением Правительства Российской Федерации от 13 сентября 1994 г. (с изм. от 7 июня 2002 г.) № 1055, не могут быть аккредитованы в качестве корреспондентов сотрудники иностранных дипломатических представительств и консульских учреждений, аппаратов военных атташе, зарегистрированных в России представительств авиакомпаний, банков, торгово-промышленных и посреднических фирм, а также лица, являющиеся сотрудниками российских СМИ.

Въезд в РФ корреспондентов из числа иностранных граждан осуществляется при наличии въездной визы, выданной иностранным журналистам на условиях взаимности при наличии согласия МИД России на 
их аккредитацию.

МИД России может прекратить аккредитацию предложенных руководством иностранного СМИ лиц, если имеет место нарушение ими законодательства РФ, а также на основании статей 19 и 20 Международного пакта о гражданских и политических правах (в целях охраны государственной безопасности, общественного порядка, здоровья или нравственности населения). Правительством могут быть установлены ответные ограничения в отношении корреспондентов СМИ тех государств, в которых имеются специальные ограничения для осуществления профессиональной деятельности российских журналистов.

В условиях исключительных правовых режимов вводится особый порядок деятельности СМИ. Несмотря на общий запрет цензуры, предусмотренный статьей 29 Конституции Российской Федерации, положения ее статей 56 и 87 допускают возможность ограничения свободы массовой информации в качестве временной меры в условиях ЧП или ВП. В этих случаях цензура может вводиться и осуществляться в порядке, установленном федеральными конституционными законами «О чрезвычайном положении» и «О военном положении».

При введении ЧП на всей территории РФ в соответствии со статьей 12 Федерального конституционного закона «О чрезвычайном положении» может быть введен особый порядок аккредитации корреспондентов иностранных СМИ на территории РФ. При введении ЧП в отдельных местностях РФ в соответствии со статьей 18 Федерального конституционного закона «О чрезвычайном положении» комендант территории, на которой введено ЧП, устанавливает особый порядок аккредитации корреспондентов иностранных СМИ на данной территории и порядок их работы.

Особый фрагмент конституционно-правовой регламентации касается реализации публичных функций, имеющих государственное значение, в деятельности органов местного самоуправления (далее - MCУ). В 
соответствии со статьей 12 Конституции РФ МСУ не входит в систему органов государственной власти. Вместе с тем, учитывая непосредственное отношение к публичной власти и политической жизни общества, неразрывные взаимосвязи местных органов власти с государственным механизмом $^{1}$, конституционно-правовое регулирование МСУ предлагается рассматривать в качестве составной части конституционно-правовой защиты государственного суверенитета в политической сфере.

Как отмечается в Постановлении Конституционного Суда РФ от 1 декабря 2015 г. № 30-П, «местное самоуправление выступает обязательной на всей территории Российской Федерации формой публичнотерриториальной самоорганизации населения, обеспечивающей участие граждан в самостоятельном и под свою ответственность решении населением непосредственно и через представительство в выборных и других органах местного самоуправления вопросов местного значения, и одновременно является неотъемлемой частью единого механизма управления делами федеративного государства» ${ }^{2}$.

Конституционно-правовое регулирование МСУ в контексте ЗГС охватывает, в первую очередь, правовое решение вопросов формирования, подотчетности и подконтрольности органов МСУ, а также досрочного прекращения полномочий (роспуска) представительного органа МСУ, отрешения от должности главы муниципального образования или главы местной администрации, удаления главы муниципального образования в

1 Выборные должностные лица МСУ являются обязательными участниками процедуры выдвижения кандидатов на должность высшего должностного лица субъекта РФ, а представительные органы муниципальных образований - субъектами права законодательной инициативы в законодательном (представительном) органе государственной власти субъекта РФ. Для органов государственной власти субъекта РФ, в свою очередь, одним из основных принципов деятельности является оказание содействия развитию МСУ на территории субъекта РФ.

2 Постановление Конституционного Суда РФ от 1 декабря 2015 г. № 30-П «По делу о проверке конституционности частей 4, 5 и 5.1 статьи 35 , частей 2 и 3.1 статьи 36 Федерального закона «Об общих принципах организации местного самоуправления в Российской Федерации» и части 1.1 статьи 3 Закона Иркутской области «Об отдельных вопросах формирования органов местного самоуправления муниципальных образований Иркутской области» в связи с запросом группы депутатов Государственной Думы». 
отставку.

Порядок формирования, полномочия, срок полномочий, подотчетность и подконтрольность органов МСУ, а также иные вопросы организации и деятельности указанных органов определяются уставом муниципального образования в соответствии с законом субъекта РФ.

Предусмотренные законодательством модели формирования органов МСУ стали предметом рассмотрения Конституционного Суда РФ по делу о проверке конституционности частей 4, 5 и 5.1 статьи 35, частей 2 и 3.1 статьи 36 Федерального закона «Об общих принципах организации местного самоуправления в Российской Федерации» и части 1.1 статьи 3 Закона Иркутской области «Об отдельных вопросах формирования органов местного самоуправления муниципальных образований Иркутской области» в связи с запросом группы депутатов Государственной Думы».

Конституционный Суд подчеркнул следующее.

Определение порядка формирования представительного органа муниципального района, городского округа с внутригородским делением, а также порядка избрания главы муниципального образования должно осуществляться в соответствии с законом субъекта РФ и уставом муниципального образования. Что касается представительного органа поселения, городского округа, внутригородского района, внутригородского муниципального образования города федерального значения, то состав данного органа в силу прямого предписания части 2 статьи 35 Федерального закона «Об общих принципах организации местного самоуправления в Российской Федерации» формируется из депутатов, избираемых на муниципальных выборах.

В силу правовой позиции Конституционного Суда РФ, выраженной в Определении от 5 марта 2009 г. № 375-О-О, федеральный законодатель вправе установить в отношении определенной категории муниципальных образований (наукоград, приграничная территория, закрытое 
административно-территориальное образование) конкретный способ наделения полномочиями главы муниципального образования и его место в структуре органов МСУ в целях создания условий для эффективного взаимодействия органов МСУ с органами государственной власти, а также достижения баланса государственных (региональных) и местных интересов при организации и осуществлении публичной власти в пределах соответствующих границ.

Конституционно-правовое регулирование ЗГС в деятельности представительных органов и выборных должностных лиц ОМСУ предполагает определение мер конституционно-правовой ответственности в отношении этих органов и лиц.

В статье 73 Федерального закона «Об общих принципах организации местного самоуправления в Российской Федерации» предусмотрены основания и процедура досрочного прекращения полномочий представительного органа муниципального образования в связи с привлечением представительного органа к конституционно-правовой ответственности ${ }^{1}$.

В случае, если судом установлено, что представительным органом муниципального образования принят нормативный правовой акт, противоречащий Конституции РФ, федеральным конституционным законам, федеральным законам, конституции (уставу), законам субъекта РФ, уставу муниципального образования, а представительный орган муниципального образования в течение трех месяцев со дня вступления в силу решения суда либо в течение иного предусмотренного решением суда срока не принял в пределах своих полномочий мер по исполнению решения суда, в том числе не отменил соответствующий нормативный правовой акт, высшее

Другие основания прекращения полномочий представительного органа муниципального образования предусмотрены в части 16 статьи 35 Федерального закона «Об общих принципах организации местного самоуправления в Российской Федерации». 
должностное лицо субъекта РФ в течение одного месяца после вступления в силу решения суда, установившего факт неисполнения данного решения, вносит в законодательный (представительный) орган государственной власти субъекта РФ проект закона субъекта РФ о роспуске представительного органа муниципального образования.

Если судом установлено, что избранный в правомочном составе представительный орган муниципального образования в течение трех месяцев подряд не проводил правомочного заседания, высшее должностное лицо субъекта РФ в течение трех месяцев со дня вступления в силу решения суда, установившего данный факт, вносит в законодательный (представительный) орган государственной власти субъекта РФ проект закона субъекта РФ о роспуске представительного органа муниципального образования.

Аналогичная процедура применяется в отношении факта непроведения вновь избранным представительным органом муниципального образования правомочного заседания в течение трех месяцев подряд.

Правовыми характеристиками роспуска представительного органа муниципального образования как меры конституционной ответственности перед государством являются:

- судебный порядок установления противоречия нормативного правового акта представительного органа муниципального образования Конституции, федеральному законодательству, конституции и законам субъекта РФ, уставу муниципального образования; судебный порядок подтверждения неисполнения решения о приведении в соответствие (отмене) данного нормативного акта;

- судебный порядок установления факта непроведения представительным органом муниципального образования правомочного заседания;

- законодательное оформление досрочного прекращения полномочий 
представительного органа муниципального образования с внесением проекта соответствующего закона высшим должностным лицом субъекта РФ;

- возможность судебного обжалования закона субъекта РФ о роспуске представительного органа муниципального образования.

В контексте ЗГС вопросы ответственности должностных лиц МСУ также увязаны с досрочным прекращением их полномочий.

Полномочия главы муниципального образования (наряду с другими основаниями) прекращаются досрочно в случае: отрешения от должности; удаления в отставку; вступления в отношении его в законную силу обвинительного приговора суда; выезда за пределы РФ на постоянное место жительства; прекращения гражданства РФ, прекращения гражданства иностранного государства - участника международного договора РФ, в соответствии с которым иностранный гражданин имеет право быть избранным в органы МСУ, приобретения им гражданства иностранного государства либо получения им вида на жительство или иного документа, подтверждающего право на постоянное проживание на территории иностранного государства, не являющегося участником международного договора, в соответствии с которым гражданин РФ, имеющий гражданство иностранного государства, имеет право быть избранным в органы МСУ; отзыва избирателями.

В статье 74 Федерального закона «Об общих принципах организации местного самоуправления в Российской Федерации» закреплена процедура отрешения главы муниципального образования и главы местной администрации от должности.

Основаниями отрешения от должности являются:

1) издание должностным лицом МСУ нормативного правового акта, противоречащего Конституции РФ, федеральным конституционным законам, федеральным законам, конституции (уставу), законам субъекта РФ, уставу муниципального образования, если такие противоречия установлены 
соответствующим судом, а это должностное лицо в течение двух месяцев со дня вступления в силу решения суда либо в течение иного предусмотренного решением суда срока не приняло в пределах своих полномочий мер по исполнению решения суда;

2) совершение должностным лицом МСУ действий, в том числе издания им правового акта, не носящего нормативного характера, влекущих нарушение прав и свобод человека и гражданина, угрозу единству и территориальной целостности РФ, национальной безопасности РФ и ее обороноспособности, единству правового и экономического пространства РФ, нецелевое расходование субвенций из федерального бюджета или бюджета субъекта РФ, если это установлено соответствующим судом, а указанное должностное лицо не приняло в пределах своих полномочий мер по исполнению решения суда.

Правовой акт об отрешении от должности главы муниципального образования или главы местной администрации издается высшим должностным лицом субъекта РФ и может быть обжалован в судебном порядке.

Особый правовой режим досрочного прекращения полномочий установлен в отношении специальных субъектов - главы муниципального района и главы городского округа. Согласно п. 6.1 статьи 36 Федерального закона «Об общих принципах организации местного самоуправления в Российской Федерации» полномочия главы муниципального района, главы городского округа прекращаются досрочно в связи с утратой доверия Президента РФ в случаях:

1) несоблюдения главой муниципального района, главой городского округа, их супругами и несовершеннолетними детьми запрета, установленного Федеральным законом «О запрете отдельным категориям лиц открывать и иметь счета (вклады), хранить наличные денежные средства и ценности в иностранных банках, расположенных за пределами территории 
Российской Федерации, владеть и (или) пользоваться иностранными финансовыми инструментами»;

2) установления в отношении избранных на муниципальных выборах главы муниципального района, главы городского округа факта открытия или наличия счетов (вкладов), хранения наличных денежных средств и ценностей в иностранных банках, расположенных за пределами территории РФ, владения и (или) пользования иностранными финансовыми инструментами в период, когда указанные лица были зарегистрированы в качестве кандидатов на выборах соответственно главы муниципального района, главы городского округа.

Статья 74.1 Федерального закона «Об общих принципах организации местного самоуправления в Российской Федерации» устанавливает правовой режим удаления главы муниципального образования в отставку. Основаниями реализации данного режима выступают:

- решения, действия (бездействие) главы муниципального образования, повлекшие просроченную задолженность муниципального образования по исполнению своих долговых и бюджетных обязательств, превышающую $30 \%$ собственных доходов бюджета муниципального образования в отчетном финансовом году, и (или) просроченную задолженность по исполнению бюджетных обязательств, превышающую 40\% бюджетных ассигнований в отчетном финансовом году, при условии выполнения бюджетных обязательств в отношении бюджета указанного муниципального образования;

- решения, действия (бездействие) главы муниципального образования, повлекшие установленные судом нецелевое расходование бюджетных средств либо нарушение Конституции РФ, федерального закона, иных нормативных правовых актов при осуществлении переданных государственных полномочий за счет предоставления субвенций местному бюджету; 
- неисполнение в течение трех и более месяцев обязанностей по решению вопросов местного значения, осуществлению полномочий, предусмотренных федеральными законами, уставом муниципального образования, и (или) обязанностей по осуществлению органами МСУ отдельных государственных полномочий, переданных органам МСУ федеральными законами и законами субъекта РФ;

- неудовлетворительная оценка деятельности главы муниципального образования представительным органом муниципального образования по результатам его ежегодного отчета перед представительным органом муниципального образования, данная два раза подряд;

- несоблюдение ограничений и запретов и неисполнение обязанностей, предусмотренных Федеральным законом «О противодействии коррупции» и другими федеральными законами;

- допущение главой муниципального образования, местной администрацией, иными органами и должностными лицами МСУ муниципального образования и подведомственными организациями массового нарушения государственных гарантий равенства прав и свобод человека и гражданина в зависимости от расы, национальности, языка, отношения к религии и других обстоятельств, ограничения прав и дискриминации по признакам расовой, национальной, языковой или религиозной принадлежности, если это повлекло нарушение межнационального и межконфессионального согласия и способствовало возникновению межнациональных (межэтнических) межконфессиональных конфликтов.

Решение об удалении главы муниципального образования в отставку принимается представительным органом муниципального образования по инициативе депутатов представительного органа муниципального образования или по инициативе высшего должностного лица субъекта РФ.

При досрочном прекращении полномочий выборных органов МСУ и 
выборных должностных лиц MCУ, как неоднократно указывал Конституционный Суд (постановления от 16 октября 1997 г. № 14-П и от 10 июня 1998 г. № 17-П; определения от 14 января 2000 г. № 2-О, от 17 июля 2007 г. № 561-О-О, от 4 октября 2011 г. № 1264-О-О, от 2 ноября 2011 г. № 1464-О-О и от 17 ноября 2011 г. № 1489-О-О), должны быть гарантированы возможность судебной проверки соответствующего решения по заявлению выборных лиц, которых оно затрагивает, а также проведение досрочных выборов в установленные сроки.

Между тем, как отмечается в Постановлении Конституционного Суда от 26 июня 2014 г. № 19-П, части 3 и 10 статьи 40 Федерального закона «Об общих принципах организации местного самоуправления в Российской Федерации» допускали проведение досрочных выборов главы муниципального образования до разрешения судом вопроса о законности состоявшегося удаления в отставку и не гарантировали возможность реального восстановления его прав в случае признания судом соответствующего решения представительного органа МСУ незаконным. В связи с этим в правоприменительной практике возникали ситуации, при которых должность выборного должностного лица МСУ (главы муниципального образования) замещалась одновременно лицом, вновь избранным на эту должность на досрочных выборах после удаления главы муниципального образования в отставку, и лицом, восстановленным в должности главы муниципального образования в связи с признанием судом решения об удалении его в отставку незаконным ${ }^{1}$.

Оценивая институт удаления главы муниципального образования в отставку, в Постановлении от 27 июня 2013 г. № 15-П Конституционный Суд пришел к следующему выводу: как мера ответственности перед представительным органом, а в конечном счете - и перед населением

\footnotetext{
${ }^{1}$ Постановление Конституционного Суда РФ от 26 июня 2014 г. № 19-П.
} 
процедура досрочного прекращения полномочий главы муниципального образования в порядке удаления в отставку не является отступлением от Конституции РФ, поскольку она предполагает, в частности, возможность судебной проверки по заявлению удаленного в отставку главы муниципального образования законности соответствующего решения представительного органа муниципального образования, а также проведение досрочных выборов главы муниципального образования в установленные федеральным законом сроки, при том что удаленный в отставку глава муниципального образования вправе баллотироваться на этих выборах в качестве кандидата (определения от 4 октября 2011 г. № 1264-О-О, от 2 ноября 2011 г. № 1464-О-О и от 17 ноября 2011 г. № 1489-О-О).

C учетом изложенной правовой позиции Конституционный Суд постановил внести в правовое регулирование отношений, связанных с удалением главы муниципального образования в отставку и проведением досрочных выборов главы муниципального образования, изменения о недопустимости назначения досрочных выборов до разрешения судом соответствующего дела, а также обеспечении максимально возможного сокращения сроков судебного обжалования такого решения и незамедлительном рассмотрении судом дела о проверке его законности.

Конституционно-правовое регулирование МСУ в контексте ЗГС может включать элементы федеральной интервенции.

Так, на основании пункта 1 части 1 статьи 75 Федерального закона «Об общих принципах организации местного самоуправления в Российской Федерации» в связи со стихийными бедствиями, катастрофами, иными чрезвычайными ситуациями (при отсутствии или невозможности формирования местной администрации или представительного органа муниципального образования) высшим должностным лицом субъекта РФ может быть принято решение о временном осуществлении исполнительными органами государственной власти субъекта РФ соответствующих 
полномочий органов МСУ. В порядке и случаях, установленных федеральными конституционными и федеральными законами, отдельные полномочия органов МСУ могут временно осуществляться федеральными органами государственной власти ${ }^{1}$.

Полномочия органов МСУ могут выступать как самостоятельными объектами конституционно-правового регулирования, так и являться элементами реализации комплексного правового режима $3 \mathrm{C}^{2}$.

Реализуя свою компетенцию, органы МСУ во взаимодействии с органами военного управления обеспечивают исполнение законодательства в области обороны: организуют и осуществляют мероприятия по территориальной обороне, проводят мероприятия по мобилизационной подготовке муниципальных предприятий и учреждений.

Органы МСУ участвуют в профилактике терроризма и экстремизма, а также в минимизации и ликвидации последствий террористических и экстремистских проявлений.

Органы МСУ принимают активное участие в реализации различных правовых режимов, направленных на ЗГС.

При реализации режима пограничного контроля органы МСУ наделены некоторыми полномочиями в сфере защиты Государственной границы. Так, в соответствии со статьей 37 Закона Российской Федерации от 1 апреля 1993 г. № 4730-1 «О Государственной границе Российской Федерации» органы МСУ предоставляют земельные участки для нужд защиты Государственной границы и осуществляют на них муниципальный земельный контроль; создают условия для участия граждан на добровольных началах в защите

${ }^{1}$ Пункт 3 статьи 25 Федерального конституционного закона от 30 мая 2001 г. № 3ФКЗ «О чрезвычайном положении».

2 Закрепленные законом полномочия органов МСУ реализуются далеко не в полном объеме. На сегодняшний день органы МСУ находятся в тяжелом финансовом положении. В своем большинстве муниципалитеты не в состоянии выполнять возложенные на них функции. Доля самодостаточных (обходящихся без дотаций и субсидий) местных бюджетов не превышает 3-5\% от их общего числа. Между тем за счет за счет местных бюджетов должно обеспечиваться финансирование до $80 \%$ расходов на социальные нужды и переданных государством полномочий. 
Государственной границы в пределах приграничной территории; оказывают помощь пограничным органам, Вооруженным Силам, государственным органам, исполняют их законные предписания, предоставляют необходимую для их деятельности информацию. Уставами муниципальных образований, расположенных на приграничной территории, могут быть предусмотрены должностные лица местного самоуправления по пограничным вопросам.

Органы МСУ участвуют в осуществлении режима защиты государственной тайны: обеспечивают защиту переданных им органами государственной власти, предприятиями, учреждениями и организациями сведений, составляющих государственную тайну, а также сведений, засекречиваемых ими; обеспечивают защиту государственной тайны на муниципальных предприятиях и учреждениях; обеспечивают в пределах своей компетенции проведение проверочных мероприятий в отношении граждан, допускаемых к государственной тайне; реализуют предусмотренные законодательством меры по ограничению прав граждан и предоставлению льгот лицам, имеющим либо имевшим доступ к сведениям, составляющим государственную тайну.

В формате реализации режима закрытого административнотерриториального образования (ЗАТО) органы МСУ:

- координируют деятельность организаций и объектов, подразделений охраны, полиции, гражданской обороны и других служб при угрозе возникновения чрезвычайной ситуации;

- могут устанавливать особенности безопасной работы и проживания граждан в 3АTO;

- участвуют совместно с руководителями организаций и объектов, по роду деятельности которых созданы ЗАТО, и органами федеральной службы безопасности в определении пропускного режима в ЗАТО, за исключением режимных территорий организаций и объектов, находящихся в границах внутренних контролируемых и (или) запретных зон; 
- по согласованию с органами федеральной службы безопасности имеют право давать разрешение на въезд граждан в ЗАТО и выезд из него, за исключением режимных территорий организаций и объектов, находящихся в границах внутренних контролируемых и (или) запретных зон;

- осуществляют контроль за санитарно-эпидемиологическим, радиационным и экологическим состоянием территорий ЗАТО, за исключением режимных территорий организаций и объектов, находящихся в границах внутренних контролируемых и (или) запретных зон;

- вносят предложения в соответствующие органы государственного и военного управления о проведении инспекционных проверок по соблюдению особого режима и обеспечению достаточных мер для защиты населения ЗАТО от воздействия радиоактивных и других материалов, представляющих повышенную опасность ${ }^{1}$.

При введении чрезвычайных правовых режимов органы МСУ переходят на особые условия деятельности.

В целях обеспечения политической стабильности и непрерывного функционирования органов государственной власти и органов МСУ в чрезвычайной обстановке на территории, на которой введено ЧП или ВП, референдумы и выборы в органы государственной власти и органы МСУ не проводятся ${ }^{2}$.

Указом Президента РФ на период действия ЧП полномочия органов МСУ могут полностью или частично приостанавливаться. При введении особого управления территорией, на которой введено ЧП, функции органов МСУ возлагаются на федеральный орган управления. В случае противоречия правовых актов органов МСУ указу Президента РФ о введении ЧП, действие муниципальных правовых актов приостанавливается.

1 Пункт 2 статьи 4 Закона РФ от 14 июля 1992 г. № 3297-1 «О закрытом административно-территориальном образовании».

${ }^{2}$ Пункт 4 статьи 7 Федерального конституционного закона от 30 января 2002 г. № 1-ФКЗ «О военном положении», статья 14 Федерального конституционного закона от 30 мая 2001 г. № 3-ФКЗ «О чрезвычайном положении». 
Проведенное исследование основных элементов системы конституционно-правовой защиты государственного суверенитета РФ в политической сфере позволяет выделить ряд ее особенностей:

- для политической сферы характерен высокий регулятивный потенциал, который включает нормативное регулирование, правоприменение и юрисдикционную деятельность;

- базовым элементом ЗГС в политической сфере является государство и его механизм. Конституционно-правовая защита государства и его институтов гарантирует развитие остальных элементов политической организации общества;

- с помощью конституционно-правовых средств защищается не только государство, но и другие собственно политические институты, непосредственно связанные с государством (партии, общественные объединения, органы местного самоуправления и др.);

- в политической сфере применяется максимально возможный арсенал любых легальных методов и институтов ЗГС, в том числе и военных.

Конституционно-правовое регулирование ЗГС в политической сфере имеет пределы, которые устанавливаются в ходе конституционного контроля. Благодаря практике конституционного судопроизводства обеспечиваются независимость российской правовой системы и верховенство национальной юрисдикции, создаются гарантии деятельности оппозиции, соблюдения прав и свобод граждан, защиты политической независимости и территориальной целостности государства, непрерывности формирования и функционирования органов власти и местного самоуправления. 


\section{4. Конституционно-правовая защита государственного суверенитета Российской Федерации в идеологической сфере}

Рассмотрение вопросов конституционно-правовой защиты государственного суверенитета в идеологической сфере предполагает анализ терминологической системы, выявление свойств и компонентов идеологии, характера связей идеологии с государством, обоснования основных направлений конституционно-правовой защиты государственного суверенитета в рассматриваемой сфере.

Ключевым понятием, на котором строится изучение конституционноправовой защиты государственного суверенитета в идеологической сфере, является идеология. Идеология рассматривается в работе как система политических, правовых, нравственных, религиозных, эстетических и философских идей, теорий и взглядов, выражающих интересы различных социальных групп общества, в которых осознаются и оцениваются отношения между людьми и формируется образ идеального состояния общественной жизни. Идеология является духовно-культурной основой существования любого общества. Общество не может жить без духовных ориентиров и основанных на них экономических, политических и социальных приоритетах. Отсутствие программ перспективного развития государства, объединяющих граждан ценностей ведут к ослаблению суверенитета, деградации государственных институтов и разрыву взаимосвязей между населением и органами власти.

Значение идеологии как духовно-теоретического и нравственного фундамента общественного развития актуализирует внимание государства к идеологической сфере и ее защите.

Идеологическая сфера общественной жизни характеризуется следующими особенностями:

- отражает ценности, интересы и цели государства (путем выработки идеологии государство формирует национальные социально-значимые 
приоритеты общественного развития, управляет сознанием и поведением населения страны, мобилизует население на осуществление национальных проектов);

- связана с осуществлением государственной власти (формирование и реализация государственной политики строятся с опорой на суверенную идеологию, обосновывающую необходимость изменения или сохранения существующего конституционного строя ${ }^{1}$; идеология является инструментом государственной власти и политических действий: формы и методы осуществления идеологической политики государства определяются и гарантируются высшими органами власти в целях сплочения людей, близких по своим политическим ориентирам, и повышения их политического участия в модернизации государства) $)^{2}$;

- содержание и тенденции развития идеологических процессов определяются материальными условиями жизни общества ${ }^{3}$;

- обладает динамизмом и влиянием на развитие общества (сплачивающие людей общие ценности со временем изменяются; в связи с этим идеология может способствовать развитию общества (носить прогрессивный характер) или препятствовать ему (реакционная идеология));

- государство стремится контролировать и защищать идеологическую сферу (любое суверенное государство сохраняет и развивает ценности своей

1 Как отмечает В.Э. Багдасарян, «вопрос о суверенности государственной идеологии предполагает, что эта идеология не должна противоречить исторически выработанной соответствующим сообществом системе ценностей». См. Багдасарян В.Э. Государственная идеология как фактор национального суверенитета / Государственная идеология и современная Россия. Мат-лы Всерос. науч.-обществ. конф. (Москва, 28 марта 2014 г.) М.: Наука и политика, 2014. С. 39.

2 Поздняков А.И. Основной вектор борьбы политических идеологий в современной России / Государственная идеология и современная Россия. Мат-лы Всерос. науч.обществ. конф. (Москва, 28 марта 2014 г.) М.: Наука и политика, 2014. С. 133.

${ }^{3}$ В исследованиях Г. Хофстеде, Р. Инглхарта содержится вывод о наличии корреляции между динамикой основополагающих ценностей и количественными показателями социально-экономического развития общества. 
этнокультурной, исторической и цивилизационной идентичности, пытается упорядочивать деятельность субъектов идеологических процессов) ${ }^{1}$.

Ключевым институтом защиты идеологии всегда выступало и продолжает выступать государство, стремящееся осуществлять самостоятельную идеологическую политику.

Особенностью ЗГС в идеологической сфере является большая гибкость правового регулирования, обусловленная ключевым местом субъектов идеологических процессов в системе институтов гражданского общества, а также широким диапазоном прав и свобод указанных субъектов (религиозных объединений, образовательных организаций, национальнокультурных автономий и др.), что в значительно меньшей степени предполагает введение ограничительных мер, запретов и наказаний. В связи с этим конституционно-правовое регулирование деятельности субъектов идеологических процессов, форм и методов взаимодействия государства с ними, как правило, не рассматривается в формате самостоятельных правовых режимов.

В отечественной литературе нередко возникают споры о разграничении понятий «государственная» и «национальная» идеология. При этом многие исследователи отрицают возможность формирования в РФ государственной идеологии, ссылаясь на буквальное толкование статьи 13 Конституции РФ: «Никакая идеология не может устанавливаться в качестве государственной или обязательной» ${ }^{2}$.

1 В разделе IV Стратегии национальной безопасности Российской Федерации (утверждена Указом Президента РФ от 31 декабря 2015 г. № 683) обеспечение культурного суверенитета связано с принятием мер по защите российского общества от внешней идейно-ценностной экспансии и деструктивного информационнопсихологического воздействия, осуществлением контроля в информационной сфере и недопущением распространения продукции экстремистского содержания, пропаганды насилия, религиозной и межнациональной нетерпимости.

2 Существует и значительное число сторонников развития национальной (государственной) идеологии как условия суверенности государства. См. Козырев Г.И. Деидеологизация - угроза национальному суверенитету / Проблема суверенности современной России. Материалы Всерос. научн. - общ. конф. М.: Центр научной политической мысли и идеологии, 2014. С. 339-344; Матюхин А.В. Идеологичность 
Вместе с тем Конституция не запрещает разрабатывать и иметь идеологическую доктрину (концепцию) национальной идеи, развивать национальное самосознание ${ }^{1}$.

В любом государственно организованном обществе именно государство выражает и защищает на системной основе базовые ценности, имеющие значение для самосознания всего народа. Нет никакой другой политической силы, способной выступать от имени всего общества, выражать интересы большинства граждан, формулировать цели и программы исторического развития. Заинтересованное в укреплении своего конституционного строя, экономической модернизации, духовном возрождении нации и сохранении цивилизационной самобытности государство выражает и защищает фундаментальные интересы и ценности народа, способствует развитию общества, а не препятствует ему.

Государство не может и не должно отказываться от участия в формировании общественного сознания своих граждан. Иначе это сознание будет формироваться другими институтами и без каких-либо гарантий, что в интересах российского общества. В частности, в Стратегии национальной безопасности Российской Федерации (утверждена Указом Президента РФ от 31 декабря 2015 г. № 683) отмечается опасность размывания традиционных российских духовно-нравственных ценностей и ослабления единства многонационального народа РФ путем внешней культурной и информационной экспансии (включая распространение низкокачественной продукции массовой культуры), пропаганды вседозволенности и насилия, расовой, национальной и религиозной нетерпимости, а также снижения роли русского языка в мире, качества его преподавания, попыток фальсификации

суверенного развития России // Там же. С. 563-570; Чикаева Т.А. Национальная идеология - важнейший фактор суверенности России // Там же. С. 608.

1 Автор поддерживает точку зрения А.Бастрыкина о необходимости создания «концепции идеологической политики государства. Базовым ее элементом могла бы стать национальная идея, которая по-настоящему сплотила бы единый многонациональный российский народ». См. Бастрыкин A. Пора поставить действенный заслон информационной войне! // Коммерсант Власть. 2016. 18 апреля. 
российской и мировой истории, противоправных посягательств на объекты культуры ${ }^{1}$.

Заслуживает поддержки позиция Н.Н. Сухотского и И.А. Гущи о том, что «создание государственной идеологии - важная задача для любого государства как для консолидации нации, так и для определения курса национальной внутренней и внешней политики»².

Руководствуясь изложенной аргументацией, автор не отделяет друг от друга понятия «государственная» и «национальная» идеология.

Важнейшие компоненты концепции идеологической политики регламентированы конституционным законодательством и находятся под юридической защитой государства. Правовые нормы, с одной стороны, закрепляют подлежащие защите духовно-нравственные и социальнокультурные ценности, значимые для всего народа; с другой стороны, устанавливают приоритеты общественного развития и перспективы государственного строительства.

Конституционно-правовая основа ЗГС в идеологической сфере представлена:

- Конституцией РФ (статьи 1, 2, 4, 13, 14, 15, 19, 26, 28, 29, 43, 44, 49, $53-55,68,69,71-74,84,104,114,125,126,132)$;

- постановлениями Конституционного Суда РФ (от 20 июля 1999 г. № 12-П, от 3 марта 2004 г. № 5-П, от 16 ноября 2004 г. № 16-П, от 15 декабря 2004 года № 18-П и др.);

1 В статьях 12 и 87 Федерального закона «Об образовании в Российской Федерации» упоминаются «принятые в обществе духовно-нравственные и социокультурные ценности». В разделе IV Стратегии национальной безопасности Российской Федерации к традиционным российским духовно-нравственным ценностям отнесены: приоритет духовного над материальным, защита человеческой жизни, прав и свобод человека, семья, созидательный труд, служение Отечеству, нормы морали и нравственности, гуманизм, милосердие, справедливость, взаимопомощь, коллективизм, историческое единство народов России, преемственность истории нашей Родины. 2009. C. 16.

Сухотский Н.Н., Гуща И.А. Основы идеологии белорусского государства. Минск, 
- федеральными конституционными законами (от 21 июля 1994 г. (с изм. от 8 июня 2015 г.) № 1-ФКЗ «О Конституционном Суде Российской Федерации», от 17 декабря 1997 г. (с изм. от 23 мая 2015 г.) № 2-ФК3 «О Правительстве Российской Федерации», от 30 мая 2001 г. (с изм. от 12 марта 2014 г.) № 3-ФКЗ «О чрезвычайном положении», от 30 января 2002 г. (с изм. от 12 марта 2014 г.) № 1-ФКЗ «О военном положении» и др.);

- федеральными законами (данный блок представлен федеральными законами от 17 июня 1996 г. № 74-Ф3 «О национально-культурной автономии», от 26 сентября 1997 г. № 125-Ф3 «О свободе совести и о религиозных объединениях», от 15 апреля 1998 г. № 64-Ф3 «О культурных ценностях, перемещенных в Союз ССР в результате Второй мировой войны и находящихся на территории Российской Федерации», от 24 мая 1999 г. № 99Ф3 «О государственной политике Российской Федерации в отношении соотечественников за рубежом», от 6 октября 1999 г. № 184-Ф3 «Об общих принципах организации законодательных (представительных) и исполнительных органов государственной власти субъектов Российской Федерации», от 1 июня 2005 г. № 53-Ф3 «О государственном языке Российской Федерации», от 29 декабря 2012 г. № 273-Ф3 «Об образовании в Российской Федерации» и др.);

- законами РФ (от 25 октября 1991 г. № 1807-1 «О языках народов Российской Федерации», от 9 октября 1992 г. № 3612-1 «Основы законодательства Российской Федерации о культуре», от 15 апреля 1993 г. № 4804-1 «О вывозе и ввозе культурных ценностей» и др.);

- подзаконными правовыми актами (указы Президента РФ от 6 сентября 2008 г. № 1315 «О некоторых вопросах государственного управления в области международного сотрудничества», от 19 декабря 2012 г. № 1666 «О Стратегии государственной национальной политики Российской Федерации на период до 2025 года», от 24 декабря 2014 г. № 808 «Об утверждении Основ государственной культурной политики», от 31 
декабря 2015 г. № 683 «Об утверждении Стратегии национальной безопасности Российской Федерации» и др.).

Данный нормативный комплекс регулирует различные виды юридической деятельности государства в идеологической сфере.

Сгруппированные по задачам и объектам конституционно-правовой защиты приоритетные виды правотворческой, правоприменительной и правоохранительной деятельности государства, обеспечивающие формирование и реализацию общенациональных идей, ценностей и взглядов по организации и управлению общественной жизни, можно назвать основными направлениями конституционно-правовой защиты государственного суверенитета в идеологической сфере.

Основные направления конституционно-правовой защиты государственного суверенитета в идеологической сфере охватывают:

- конституционно-правовое регулирование гражданских и культурных прав и свобод личности;

- конституционно-правовую защиту государственного языка РФ;

- конституционно-правовую защиту культурного наследия народов РФ и национального культурного достояния, конституционно-правовое регулирование реституционных процессов;

- конституционно-правовое регулирование образовательной деятельности, развития системы образования и гражданско-патриотического воспитания;

- конституционно-правовое регулирование противодействия фальсификации исторических фактов и событий, направленной на принижение международного престижа РФ, инспирирование националистических и иных экстремистских проявлений;

- конституционно-правовую защиту традиционных религиозных ценностей и противодействие религиозному экстремизму; 
- конституционно-правовое регулирование адаптации и интеграции мигрантов.

Ядром конституционно-правовой защиты государственного суверенитета в идеологической сфере является конституциионно-правовое регулирование гражданских и культурных прав и свобод личности в контексте защуиты государственного суверенитета.

Применительно к идеологической сфере наибольший интерес представляет регулирование и защита гражданских (личных) прав и свобод, таких как:

- свобода мысли и слова (ч.1 ст. 29 Конституции РФ);

- свобода совести и вероисповедования (ст. 28 Конституции РФ);

- право на пользование родным языком, на свободный выбор языка общения, воспитания, обучения и творчества (ч.2 ст. 26 Конституции РФ).

Закрепленные в Конституции личные права и свободы составляют единый нормативный комплекс с положениями статьей 13 и 14 Основ конституционного строя РФ.

Согласно ст. 13 Конституции РФ в России признается идеологическое многообразие. Никакая идеология не может устанавливаться в качестве государственной или обязательной.

Конституционные положения о невозможности установления общеобязательной государственной идеологии в ст. 14 дополняются нормой о светском характере российского государства. Данная характеристика означает, что религиозные объединения в РФ отделены от государства, государственное образование отделено от церкви и никакая религия не может устанавливаться в качестве государственной или обязательной.

К группе культурных прав личности, гарантированных Конституцией, относятся:

- право на образование (ч.1 ст.43 Конституции РФ); 
- право на участие в культурной жизни и пользование учреждениями культуры, на доступ к культурным ценностям (ч.2 ст. 44 Конституции РФ);

- право на свободу литературного, художественного, научного, технического и других видов творчества, преподавания (ч. 1 ст. 44 Конституции РФ).

Перечисленным культурным правам коррелирует установленная ч. 3 ст.44 Конституции обязанность каждого заботиться о сохранении исторического и культурного наследия, беречь памятники истории и культуры.

В качестве элемента механизма конституционно-правовой защиты государственного суверенитета в идеологической сфере необходимо рассматривать конституционно-правовые гарантии.

В целях общедоступности культурной деятельности, культурных ценностей и благ государство обязано:

поощрять деятельность граждан по приобщению детей к творчеству и культурному развитию, самообразованию;

создавать условия для эстетического воспитания и художественного образования, сохранения бесплатности для населения основных услуг общедоступных библиотек;

способствовать развитию благотворительности и спонсорства в области культуры;

содействовать доступу к культурным ценностям и благам наименее защищенных слоев и групп населения;

обеспечивать доступность культурных ценностей и благ инвалидов.

Органы государственной власти и управления, органы местного самоуправления не вмешиваются в творческую деятельность граждан и их объединений, государственных и негосударственных организаций культуры, за исключением случаев, когда такая деятельность ведет к пропаганде войны, насилия и жестокости, расовой, национальной, религиозной, классовой и 
иной исключительности и нетерпимости, порнографии. Запрет какой-либо творческой (культурной) деятельности устанавливается судом в случае нарушения законодательства РФ.

В соответствии с ч. 2 ст. 19 Конституции РФ государство гарантирует равенство прав и свобод человека и гражданина независимо от пола, расы, национальности, языка, происхождения, имущественного и должностного положения, места жительства, отношения к религии, убеждений, принадлежности к общественным объединениям, a также других обстоятельств. Запрещаются любые формы ограничения прав граждан по признакам социальной, расовой, национальной, языковой или религиозной принадлежности.

Защищаемые права и свободы могут быть реализованы как самостоятельно (право на личную культурную самобытность, свобода творчества), так и с участием государства и других заинтересованных субъектов права (право на образование, право на участие в культурной жизни, право создавать творческие союзы и иные культурные объединения и др.).

Важнейшим направлением конституционно-правовой регламентации в контексте ЗГС в идеологической сфере выступает конституциионно-правовое регулирование защчиты государственного языка Российской Федерации.

В соответствии с Конституцией государственным языком РФ на всей ее территории является русский язык. Русский язык является средством национальной идентичности и культурной самобытности, способствует взаимопониманию, укреплению межнациональных связей народов РФ в едином многонациональном государстве ${ }^{1}$.

1 См. также Янкова Н.А. Языковой фактор в укреплении государственного суверенитета Российской Федерации/ Проблема суверенности современной России. Материалы Всерос. научн. - общ. конф. М.: Центр научной политической мысли и идеологии, 2014. С. 472-476. 
Раздел IV Стратегии национальной безопасности Российской Федерации акцентирует внимание на том, что «особое значение для укрепления национальной безопасности в области культуры имеет проведение государственной политики по реализации функции русского языка как государственного языка Российской Федерации, средства обеспечения государственной целостности страны и межнационального общения народов Российской Федерации, основы развития интеграционных процессов на постсоветском пространстве и средства удовлетворения языковых и культурных потребностей соотечественников за рубежом».

В соответствии с частью 5 статьи 1 Федерального закона от 1 июня 2005 г. № 53-Ф3 «О государственном языке Российской Федерации» защита и поддержка русского языка как государственного языка РФ способствуют приумножению и взаимообогащению духовной культуры народов РФ.

Конституционный статус русского языка как государственного языка РФ предусматривает обязательность использования русского языка в определенных законодательством сферах общественной жизни, его защиту и поддержку, а также обеспечение права граждан РФ на пользование государственным языком РФ ${ }^{1}$.

В статье 3 Федерального закона «О государственном языке Российской Федерации» определены сферы использования государственного языка РФ. Русский язык подлежит обязательному использованию:

- в деятельности федеральных органов государственной власти, органов государственной власти субъектов РФ, иных государственных органов, органов местного самоуправления, организаций всех форм собственности, в том числе в деятельности по ведению делопроизводства;

- в наименованиях федеральных органов государственной власти, органов государственной власти субъектов РФ, иных государственных

${ }^{1}$ Подробнее см. Ляменко Н.В. Русский язык как государственный язык Российской Федерации: конституционно-правовой анализ. Автореф. дис. ...канд. юрид наук. М., 2004. 
органов, органов местного самоуправления, организаций всех форм собственности;

- при подготовке и проведении выборов и референдумов;

- в судопроизводстве;

- при официальном опубликовании международных договоров РФ, а также законов и иных нормативных правовых актов;

- во взаимоотношениях федеральных органов государственной власти, органов государственной власти субъектов РФ, иных государственных органов, органов местного самоуправления, организаций всех форм собственности и граждан РФ, иностранных граждан, лиц без гражданства, общественных объединений;

- при написании наименований географических объектов, нанесении надписей на дорожные знаки;

- при оформлении документов, удостоверяющих личность гражданина РФ, изготовлении бланков свидетельств о государственной регистрации актов гражданского состояния, документов об образовании и о квалификации, а также других документов, оформление которых в соответствии с законом осуществляется на государственном языке РФ;

- в продукции СМИ ${ }^{1}$;

- при публичных исполнениях произведений литературы, искусства, народного творчества посредством проведения театрально-зрелищных, культурно-просветительных, зрелищно-развлекательных мероприятий;

- в иных определенных федеральными законами сферах.

Обязательность использования государственного языка РФ не должна трактоваться как отрицание или умаление права на пользование

${ }^{1}$ Несмотря на проводимую работу в российском обществе растет беспокойство по поводу качества использования русского языка в электронных и печатных средствах массовой информации. В информационном пространстве страны практически не представлены образовательные передачи по русскому языку, формированию культуры чтения. 
государственными языками республик, находящихся в составе РФ, и языками народов РФ $\Phi^{1}$.

В целях защиты и поддержки государственного языка РФ федеральные органы государственной власти в пределах своей компетенции:

а) обеспечивают функционирование государственного языка РФ на всей территории РФ;

б) разрабатывают и принимают федеральные законы и иные нормативные правовые акты РФ, разрабатывают и реализуют направленные на защиту и поддержку государственного языка РФ соответствующие федеральные целевые программы;

в) принимают меры, направленные на обеспечение права российских граждан на пользование государственным языком РФ;

г) принимают меры по совершенствованию системы образования и системы подготовки специалистов в области русского языка и преподавателей русского языка ка иностранного языка, а также осуществляют подготовку научно-педагогических кадров для образовательных организаций с обучением на русском языке за пределами РФ;

д) содействуют изучению русского языка за пределами РФ²;

е) осуществляют государственную поддержку издания словарей и грамматик русского языка;

${ }^{1}$ Как отмечается в Стратегии государственной национальной политики Российской Федерации на период до 2025 года (утверждена Указом Президента РФ от 19 декабря 2012 г. № 1666), культурное и языковое многообразие народов России защищено государством. В РФ используются 277 языков и диалектов, в государственной системе образования используются 89 языков, из них 30 - в качестве языка обучения, 59 - в качестве предмета изучения.

${ }^{2}$ Как отмечается в Постановлении Совета Федерации от 25 февраля 2015 г. № 51 СФ «О сохранении и развитии русского языка, повышении его роли в области международных культурных и гуманитарных связей», «в настоящее время сужается область применения русского языка в странах ближнего и дальнего зарубежья, практически не переводятся на государственные языки государств - участников Содружества Независимых Государств и европейские языки произведения художественной литературы, в том числе для детей и подростков. Ощущается нехватка квалифицированных кадров преподавателей русского языка, владеющих современными методиками преподавания, отсутствуют соответствующие учебники и утвержденные программы обучения русскому языку как второму языку» // СЗ РФ. 2015. № 9. Ст. 1217. 
ж) осуществляют контроль за соблюдением законодательства о государственном языке РФ, в том числе за использованием слов и выражений, не соответствующих нормам современного русского литературного языка, путем организации проведения независимой экспертизы;

з) принимают иные меры по защите и поддержке государственного языка РФ.

Обеспечение права граждан РФ на пользование государственным языком РФ предусматривает:

- получение образования на русском языке в государственных и муниципальных образовательных учреждениях;

- получение информации на русском языке в федеральных органах государственной власти, органах государственной власти субъектов РФ, иных государственных органах, органах местного самоуправления, организациях всех форм собственности;

- получение информации на русском языке через общероссийские, региональные и муниципальные СМИ.

Важную роль в конституционно-правовой защите государственного языка РФ сыграло Постановление Конституционного Суда от 16 ноября 2004 г. № 16-П¹. Предметом рассмотрения по данному делу являлись нормативные положения, касающиеся статуса государственных языков в РФ:

положения пункта 2 статьи 10 Закона Республики Татарстан «О языках народов Республики Татарстан» и пункта 2 статьи 6 Закона Республики Татарстан «Об образовании», согласно которым татарский и русский языки

${ }^{1}$ Постановление Конституционного Суда РФ от 16 ноября 2004 г. № 16-П «По делу о проверке конституционности положений пункта 2 статьи 10 Закона Республики Татарстан «О языках народов Республики Татарстан», части 2 статьи 9 Закона Республики Татарстан «О государственных языках Республики Татарстан и других языках в Республике Татарстан», пункта 2 статьи 6 Закона Республики Татарстан «Об образовании» и пункта 6 статьи 3 Закона РФ «О языках народов Российской Федерации» в связи с жалобой гражданина С.И. Хапугина и запросами Государственного Совета Республики Татарстан и Верховного Суда Республики Татарстан» // Рос. газ. 2004. 23 ноября. 
как государственные языки Республики Татарстан в общеобразовательных учреждениях и учреждениях начального и среднего профессионального образования изучаются в равных объемах;

положения пункта 6 статьи 3 Закона Российской Федерации «О языках народов Российской Федерации» о строении алфавита государственных языков республик на графической основе кириллицы и о возможности установления иных графических основ алфавитов государственных языков республик федеральными законами ${ }^{1}$.

По мнению Конституционного Суда Российской Федерации, введение законами Республики Татарстан изучения татарского языка как государственного в общеобразовательных учреждениях Республики само по себе не нарушило конституционных прав на свободный выбор языка воспитания и обучения (часть 2 статьи 26 Конституции Российской Федерации) и право на образование (статья 43 Конституции Российской Федерации). Однако регулирование статуса татарского языка как государственного языка Республики Татарстан, его защита и развитие, изучение (преподавание) как обязательной учебной дисциплины должны осуществляться без ущерба для функционирования и изучения русского языка как государственного языка РФ в соответствии с общефедеральными государственными стандартами с учетом того, что в отличие от русского языка татарский язык не является официальным языком на территориях других субъектов РФ. В противном случае создавалась бы возможность нарушения гарантированных Конституцией РФ принципов равенства прав и свобод человека и гражданина и несения гражданами РФ равных обязанностей на всей ее территории, в том числе применительно к

${ }^{1}$ В тот период органами государственной власти Республики Татарстан был принят Закон Республики Татарстан от 15 сентября 1999 г. «О восстановлении татарского алфавита на основе латинской графики», предусматривающий, что в Республике Татарстан восстанавливается татарский алфавит на основе латинской графики и что до 1 сентября 2011 г. действуют одновременно два алфавита - на основе латинской графики и кириллицы. 
реализации права на образование и языковых прав и свобод (часть 2 статьи 6, часть 2 статьи 19, статьи 43 и 68 Конституции).

Как следует из правовой позиции Конституционного Суда, изучение татарского языка как государственного языка Республики Татарстан не может осуществляться в ущерб федеральному компоненту федерального базисного учебного плана и примерных учебных планов для общеобразовательных учреждений РФ и препятствовать реализации прав учащихся на углубленное изучение иных предметов учебного плана, включая русский язык, дисциплин по выбору и т.п. При этом учебные планы и программы должны быть составлены так, чтобы для учащихся, для которых татарский язык не является родным и которые не имели возможности изучать его как учебную дисциплину в необходимом объеме, не создавались препятствия к прохождению итоговой аттестации и выдаче документа о получении основного общего образования, а также к реализации права на получение образования более высокого уровня.

Рассматривая вопрос о правомочии республик устанавливать свои государственные языки и выбирать графическую основу алфавита, Конституционный Суд РФ указал, что установление основ государственной языковой политики и содействие развитию государственных языков республик относится к ведению РФ (пункты «б» и «е» статьи 71 Конституции). Установив единую графическую основу алфавитов государственного языка РФ и государственных языков республик, федеральный законодатель прежде всего констатировал и легитимировал исторически сложившиеся в РФ реалии - существование и развитие языков народов России, получивших статус государственного языка, на графической основе кириллицы. Такое законодательное решение обеспечивает гармонизацию и сбалансированное функционирование общефедерального языка и государственных языков республик, направлено на достижение их оптимального взаимодействия в рамках общего языкового пространства. 
Данная позиция Конституционного Суда РФ о разграничении полномочий РФ и республик в языковой сфере позволила укрепить федеративное единство и общегосударственное языковое пространство нашего многонационального государства.

Конституционно-правовая защита государственного языка РФ (обязательность использования в установленных сферах, меры государственной поддержки) поддерживается и другими конституционными гарантиями. Так, в соответствии с частью 2 статьи 29 Конституции РФ запрещается пропаганда языкового превосходства.

Принятие федеральных законов и иных нормативных правовых актов РФ, законов и иных нормативных правовых актов субъектов РФ, направленных на ограничение использования русского языка как государственного языка РФ, а также иные действия и нарушения, препятствующие осуществлению права граждан на пользование государственным языком РФ, влекут за собой ответственность, установленную законодательством РФ.

Значимым направлением обеспечения государственного суверенитета РФ в идеологической сфере выступает конституц̧ионно-правовая защчита культурного наследия народов Российской Федераџчии и наџионального культурного достояния.

В Законе РФ от 9 октября 1992 г. № 3612-1 «Основы законодательства Российской Федерации о культуре» отмечается неразрывная связь создания и сохранения культурных ценностей, приобщения к ним всех граждан с социально-экономическим прогрессом, развитием демократии, укреплением целостности и суверенитета РФ.

В качестве культурного наследия народов РФ понимаются материальные и духовные ценности, созданные в прошлом, а также памятники и историко-культурные территории и объекты, значимые для сохранения и развития самобытности РФ и всех ее народов, их вклада в 
мировую цивилизацию. Культурным достоянием признается совокупность культурных ценностей, а также организации, учреждения, предприятия культуры, которые имеют общенациональное (общероссийское) значение и в силу этого безраздельно принадлежат РФ и ее субъектам без права их передачи иным государствам и союзам государств.

В статье 5 «Основ законодательства Российской Федерации о культуре» закреплен суверенитет РФ в области культуры, который проявляется в прерогативе РФ самостоятельно реализовывать на своей территории соглашения и иные акты, регулирующие отношения РФ в области культуры с другими государствами, объединениями государств, а также международными организациями.

Политика в области сохранения, создания и распространения культурных ценностей коренных национальностей не должна наносить ущерб культурам других народов и иных этнических общностей, проживающих на данных территориях.

Частью культурного достояния является национальный библиотечноинформационный фонд документов РФ, комплектуемый на основании обязательного экземпляра ${ }^{1}$. Предметы библиотечного, музейного, архивного, кино-, фото- и иных аналогичных фондов, находящиеся в оперативном управлении государственных учреждений культуры, относятся к особо ценному движимому имуществу государственных учреждений культуры.

Целостность российской культуры обеспечивается законодательным регулированием федеральной государственной культурной политики и реализацией федеральных государственных программ сохранения и развития культуры.

В соответствии с Указом Президента РФ от 24 декабря 2014 г. № 808 в России были утверждены Основы государственной культурной политики,

\footnotetext{
${ }^{1}$ Федеральный закон от 29 декабря 1994 г. № 77-Ф3 «Об обязательном экземпляре документов».
} 
которые определяют цели и стратегические задачи государственной культурной политики, ключевые принципы ее реализации в нашей стране ${ }^{1}$.

Государственная культурная политика призвана обеспечивать приоритетное культурное и гуманитарное развитие как основу экономического процветания, государственного суверенитета и цивилизационной самобытности страны ${ }^{2}$. Как отмечается в документе, «на протяжении всей отечественной истории именно культура сохраняла, накапливала и передавала новым поколениям духовный опыт нации, обеспечивала единство многонационального народа России, воспитывала чувства патриотизма и национальной гордости, укрепляла авторитет страны на международной арене» ${ }^{3}$.

В Основах государственной культурной политики впервые в постсоветской истории культура признана национальным приоритетом, важнейшим фактором роста качества жизни и гармонизации общественных отношений, гарантом сохранения единого культурного пространства и территориальной целостности России.

Общими целями государственной культурной политики провозглашены:

- формирование гармонично развитой личности;

- укрепление единства российского общества;

- укрепление гражданской идентичности;

- создание условий для воспитания граждан и реализации каждым человеком его творческого потенциала;

- сохранение исторического и культурного наследия и его использование для воспитания и образования;

\footnotetext{
${ }^{1}$ СЗ РФ. 2014. № 52 (ч.1). Ст. 7753.

${ }^{2}$ На расширенном заседании президиума Совета по культуре и искусству 3 февраля 2014 г. Президент РФ В.В. Путин отметил: «если нет культуры, то непонятно вообще, что такое суверенитет, и непонятно тогда, за что бороться». URL: www.kremlin.ru/events/president/news/20138/videos

${ }^{3}$ СЗ РФ. 2014. № 52 (ч.1). Ст. 7753.
} 
- передача от поколения к поколению традиционных для российской цивилизации ценностей и норм, традиций, обычаев и образцов поведения;

- обеспечение доступа граждан к знаниям, информации, культурным ценностям и благам ${ }^{1}$.

Признание руководством РФ значимости культурного суверенитета привело к выработке специальных (стратегических) целей государственной культурной политики, в числе которых раздел IV Стратегии национальной безопасности Российской Федерации выделяет:

1. сохранение и приумножение традиционных российских духовнонравственных ценностей как основы российского общества, воспитания детей и молодежи в духе гражданственности;

2. сохранение и развитие общероссийской идентичности народов Российской Федерации, единого культурного пространства страны;

3. повышение роли России в мировом гуманитарном и культурном пространстве.

По мнению разработчиков приведенных документов стратегического планирования, результатами реализации государственной политики защиты суверенитета в идеологической сфере должны стать:

повышение интеллектуального потенциала российского общества;

гармонизация социально-экономического развития регионов России (в первую очередь, малых городов и сельских поселений);

увеличение числа граждан, прежде всего молодежи, стремящихся жить и работать на Родине, считающих Россию наиболее благоприятным местом проживания, раскрытия творческих и созидательных способностей ${ }^{2}$.

${ }^{1}$ На региональном уровне под лозунгом «оптимизации расходов» местные органы власти упраздняют немногие оставшиеся в сельской местности культурные учреждения. Сеть библиотек и культурно-досуговых учреждений резко сократилась.

2 Проблема «утечки мозгов» имеет прямое отношение к ослаблению и подрыву государственного суверенитета. По оценкам экспертов, выезд только одного специалиста за рубеж, по приблизительным подсчетам, наносит России ущерб в 200-250 тысяч долларов. Современный мир и геополитика / Отв. ред. М.А. Неймарк. М.: Канон плюс, 2015. C. 167. 
Чтобы достигнуть таких результатов, требуется длительная работа по развитию эффективной социальной инфраструктуры, повышению качества жизни народа, воспитанию гражданственности, патриотизма, поддержке талантливой молодежи, формированию гордости за цивилизационную и культурную самобытность своей страны.

Как отмечается в Стратегии государственной национальной политики Российской Федерации на период до 2025 года (утверждена Указом Президента РФ от 19 декабря 2012 г. № 1666), «современное Российское государство объединяет основанный на сохранении и развитии русской культуры и языка, историко-культурного наследия всех народов России единый культурный (цивилизационный) код, который характеризуется особым стремлением к правде и справедливости, уважением самобытных традиций населяющих Россию народов и способностью интегрировать их лучшие достижения в единую российскую культуру».

Сохранение историко-культурного наследия и национального культурного достояния необходимо рассматривать как фактор формирования духовной общности народов России, национального самосознания и укрепления российской государственности.

Составляющими конституционно-правовой защиты культурного наследия народов Российской Федерации и национального культурного достояния являются правовое регулирование реституционных процессов $и$ защчита объектов нацчионального культурного наследия и достояния от незаконного вывоза.

В целях защиты культурных ценностей от расхищения, предотвращения их неправомерной передачи и незаконного вывоза за пределы РФ, частичной компенсации ущерба, причиненного культурному достоянию РФ в результате разграбления и уничтожения ее культурных ценностей Германией и ее военными союзниками в период Второй мировой войны, обеспечения интересов РФ при урегулировании с иностранными 
государствами спорных вопросов, касающихся перемещенных культурных ценностей, был принят Федеральный закон от 15 апреля 1998 г. № 64-Ф3 «О культурных ценностях, перемещенных в Союз ССР в результате Второй мировой войны и находящихся на территории Российской Федерации».

Как следует из статей 3 и 6 Федерального закона «О культурных ценностях, перемещенных в Союз ССР в результате Второй мировой войны и находящихся на территории Российской Федерации», объектом регулирования являются культурные ценности, которые в осуществление компенсаторной реституции, определяемой как вид материальной международно-правовой ответственности государства-агрессора, применяемой в случаях, если осуществление ответственности данного государства в форме обычной реституции невозможно, были перемещены в СССР с территорий Германии и ее бывших военных союзников - Болгарии, Венгрии, Италии, Румынии и Финляндии в соответствии с приказами военного командования Советской Армии, Советской военной администрации в Германии, распоряжениями других компетентных органов СССР и только в тот период, в течение которого указанные органы обладали полномочиями по осуществлению компенсаторной реституции. Перемещение культурных ценностей в СССР с территорий Германии и ее бывших военных союзников в порядке компенсаторной реституции обусловлено принципом международно-правовой ответственности государства - агрессора за развязывание и ведение агрессивной войны и основывалось на нормах международно-правовых актов, устанавливающих репарации и реституции в отношении неприятельских государств. В силу этих норм бывшие неприятельские государства - Германия, Болгария, Венгрия, Италия, Румыния, Финляндия утратили право собственности на те принадлежавшие им культурные ценности, которые были правомерно изъяты и перемещены с их территории на территорию СССР в осуществление его права на компенсаторную реституцию, а СССР, в свою очередь, получил 
право владения, пользования и распоряжения ими. $\mathrm{K}$ России как правопреемнику СССР перешли соответствующие права на такие культурные ценности, находящиеся на ее территории.

Нормативные положения Федерального закона «О культурных ценностях, перемещенных в Союз ССР в результате Второй мировой войны и находящихся на территории Российской Федерации» о признании перемещенных культурных ценностей достоянием РФ и федеральной собственностью, о гарантиях права собственности бывших союзных республик, оккупированных во время Второй мировой войны, о процедуре возврата иностранным государствам перемещенных культурных ценностей являлись предметом рассмотрения Конституционного Суда РФ.

В Постановлении от 20 июля 1999 г. № 12-П по делу о проверке конституционности Федерального закона «О культурных ценностях, перемещенных в Союз ССР в результате Второй мировой войны и находящихся на территории Российской Федерации» Конституционный Суд пришел к выводу, что нормы статей 3, 5 и 6 Закона, объявляющие перемещенные культурные ценности достоянием Российской Федерации и федеральной собственностью, в части, относящейся к перемещенным культурным ценностям, являвшимся собственностью бывших неприятельских государств, соответствуют Конституции РФ. Статья 7 Федерального закона о гарантиях права собственности Республики Беларусь, Латвийской Республики, Литовской Республики, Республики Молдова, Украины и Эстонской Республики на перемещенные культурные ценности также была признана соответствующей Конституции.

Рассматривая процедуру возврата иностранным государствам перемещенных культурных ценностей, Конституционный Суд признал неконституционными положения пунктов 2 и 3 статьи 18 Федерального закона в той мере, в которой они предполагали принятие специального федерального закона о передаче перемещенной культурной ценности, не 
имеющей уникального характера, особо важного культурно-исторического значения.

Законодателем определен полномочный федеральный орган по сохранению культурных ценностей - Минкультуры Российской Федерации, на который возложены функции:

- учета и ведения базы данных всех перемещенных культурных ценностей, опубликования сведений о них;

- ведения реестра культурных ценностей, предназначенных для обмена;

- контроля за сохранностью перемещенных культурных ценностей;

- рассмотрения претензий иностранных государств и ходатайств иностранных граждан;

- подготовки решений по вопросам, касающимся прав собственности на перемещенные культурные ценности;

- распределения перемещенных культурных ценностей между учреждениями культуры в целях обращения этих ценностей на возмещение ущерба, понесенного этими учреждениями культуры в результате разграбления и уничтожения их имущества войсками бывших неприятельских государств;

- определения категорий перемещенных культурных ценностей, не подлежащих передаче иностранным государствам, международным организациям и (или) вывозу из Российской Федерации, а также режима их хранения;

- контроля за соблюдением правил внешнеэкономической деятельности, касающихся перемещенных культурных ценностей;

- подготовки совместно с МИД России или по согласованию с ним предложений Правительству РФ о проведении переговоров о перемещенных культурных ценностях.

В контексте ЗГС конституционно-правовое регулирование реституционных процессов способствует выявлению и возврату в 
собственность РФ ее культурных ценностей; сохранности перемещенных культурных ценностей; защите культурных ценностей и объектов национального достояния от их незаконного вывоза из РФ; формированию правовых условий для компенсации ущерба культурному достоянию РФ в период Второй мировой войны и урегулированию спорных вопросов с иностранными государствами.

Одним из приоритетов государственной политики ЗГС в идеологической сфере выступает конституциионно-правовое регулирование образовательной деятельности, развития системьл образования и гражданско-патриотического воспитания.

Акцент на качественном образовании и гражданско-патриотическом воспитании позволяет государству содействовать всестороннему развитию своих граждан, расширять их познавательные и оценочные возможности, внедрять в массовое и групповое сознание устоявшиеся в обществе духовнонравственные и социокультурные ценности.

В целях ЗГС федеральные органы государственной власти формируют единое образовательное пространство: разрабатывают и проводят единую государственную политику в сфере образования; разрабатывают, утверждают и реализуют государственные программы РФ и федеральные целевые программы в сфере образования; утверждают федеральные государственные образовательные стандарты; осуществляют лицензирование образовательной деятельности.

В соответствии со статьей 6 Федерального закона от 29 декабря 2012 г. № 273- Ф3 «Об образовании в Российской Федерации» лицензированию, государственной аккредитации и государственному контролю подлежит образовательная деятельность:

- организаций, осуществляющих образовательную деятельность по образовательным программам высшего образования; 
- федеральных государственных профессиональных образовательных организаций, реализующих образовательные программы среднего профессионального образования в сферах обороны, производства продукции по оборонному заказу, внутренних дел, безопасности, ядерной энергетики, транспорта и связи, наукоемкого производства по специальностям, перечень которых утверждается Правительством РФ;

- российских образовательных организаций, расположенных за пределами территории РФ, образовательных организаций, созданных в соответствии с международными договорами РФ, а также осуществляющих образовательную деятельность дипломатических представительств и консульских учреждений РФ, представительств РФ при международных (межгосударственных, межправительственных) организациях;

- иностранных образовательных организаций, осуществляющих образовательную деятельность по месту нахождения филиала на территории РФ.

Согласно статье 12 Федерального закона «Об образовании в Российской Федерации» содержание образования определяется образовательными программами, которые должны обеспечивать развитие способностей каждого человека, формирование и развитие его личности в соответствии с принятыми в семье и обществе духовно-нравственными и социокультурными ценностями.

При реализации имеющих государственную аккредитацию образовательных программ начального общего, основного общего и среднего общего образования образовательные организации используют учебники из федерального перечня.

К суверенным полномочиям государства отнесены:

- вопросы создания и деятельности образовательных организаций федеральных государственных органов, осуществляющих подготовку кадров 
в интересах обороны и безопасности государства, обеспечения законности и правопорядка;

- вопросы создания, приостановления и прекращения деятельности структурных образовательных подразделений заграничных учреждений МИД России.

Образовательные организации, реализующие образовательные программы высшего образования в области обороны и безопасности государства, обеспечения законности и правопорядка, могут создаваться только РФ.

Реализация образовательных программ, предусматривающих ознакомление обучающихся со сведениями, составляющими государственную тайну, и (или) использование в учебных целях секретных образцов вооружения, военной и специальной техники, их комплектующих изделий, специальных материалов и веществ, допускается при условиях соблюдения требований законодательства о защите государственной тайны.

Ключевой составляющей ЗГС в идеологической сфере выступает конституционно-правовое регулирование гражданско-патриотического воспитания.

Гражданско-патриотическое воспитание как направление ЗГС является важным элементом системы образования многих зарубежных стран.

Во Франции в рамках школьной программы с 2015 г. преподается курс «морального и гражданского воспитания», цель которого состоит в формировании у учащихся «гражданской совести» и укреплении «единой нации». Национальные ценности прививаются с помощью исторических примеров, изучения национального гимна, герба и флага. После террористической атаки на издание «Шарли Эбдо» в январе 2015 г. Министерством образования и науки Франции была принята специальная программа «Большая мобилизация образования в поддержку ценностей Республики». Программа предусматривает усиление работы образовательных 
учреждений по формированию национальной идентичности и пропаганде светских ценностей с целью укрепления единства общества ${ }^{1}$.

В США в силу децентрализации образовательной системы функция гражданско-патриотического воспитания реализуется косвенным образом. В частности, учащиеся государственных общеобразовательных школ ежедневно отдают честь национальному флагу и повторяют клятву верности стране. В большинстве университетов США введен учебный курс American Polity («Американская политическая система»). В ходе изучения этого курса студенты знакомятся с организацией политической власти в США в контексте воспитания лояльности к ней²

С 2002 г. в Великобритании в качестве обязательного преподается предмет «Гражданство». В ноябре 2014 г. Министерство образования Великобритании выпустило директиву «Продвижение фундаментальных британских ценностей как часть системы воспитания в школах» ${ }^{3}$. Согласно указанному документу, школам рекомендовано продвигать знания о британской законодательной системе, институте выборов, формировать уважение к правительственным органам и общественным организациям Великобритании. Помимо включения данных аспектов преподавания в образовательный процесс школы должны стимулировать самостоятельную активность учеников в продвижении британских ценностей ${ }^{4}$.

Таким образом, многие государства в рамках реализации образовательной политики воспитывают гражданское самосознание обучающихся в школах и вузах и защищают свой суверенитет.

1 Доклад ЦОППиК. Решение актуальных задач внутренней политики механизмами образования: зарубежный опыт и предложения для России // Поиск. Альтернативы. Выбор. 2016. № 1. С. 213.

${ }^{2}$ Там же. С. 205.

3 Promoting fundamental British values as part of SMSC in schools Departmental advice for maintained schools. https // www.gov.uk/government/uploads/system/uploads/attachment_data/file/380595/SMSC_Guidanc e_Maintained_Schools.pdf (дата обращения: 27 ноября 2015 г.)

4 Доклад ЦОППиК. Решение актуальных задач внутренней политики механизмами образования: зарубежный опыт и предложения для России // Поиск. Альтернативы. Выбор. 2016. № 1. С. 206. 
К числу задач государственной политики РФ в сфере образования, гражданско-патриотического воспитания подрастающего поколения

Стратегия государственной национальной политики Российской Федерации на период до 2025 года относит ${ }^{1}$ :

формирование у детей и молодежи общероссийского гражданского самосознания, чувства патриотизма, гражданской ответственности, гордости за историю нашей страны;

воспитание культуры межнационального общения, основанной на толерантности, уважении чести и национального достоинства граждан, духовных и нравственных ценностей народов России ${ }^{2}$.

Решать поставленные задачи предполагается путем:

разработки учебных программ по изучению многовекового опыта взаимодействия народов России посредством ознакомления с историческими документами о знаковых событиях, раскрывающих истоки общероссийского единства и солидарности;

совершенствования системы обучения в общеобразовательных учреждениях в целях сохранения и развития культур и языков народов России наряду с воспитанием уважения к общероссийской истории и культуре, мировым культурным ценностям;

введения в программы общеобразовательных учреждений образовательных курсов, включающих в себя сведения о культурных ценностях и национальных традициях народов России;

${ }^{1}$ Стратегия государственной национальной политики Российской Федерации на период до 2025 года (утверждена Указом Президента РФ от 19 декабря 2012 г. № 1666).

2 В настоящее время сферу межнационального общения в России трудно назвать благополучной. Большой резонанс получили межнациональные конфликты в г. Кондопоге Республики Карелия в 2006 г., в г. Ростове-на-Дону в 2010 г., в районе Бирюлево г. Москвы в 2013 г., в г. Пугачеве Саратовской области в 2013 г., в г. Твери в 2013 г., в гг. Ставрополь и Минеральные Воды в 2013, 2014 и 2015 гг. и др. По данным Генеральной прокуратуры РФ, в 2015 г. было зафиксировано 1503 проявления этноконфессиональной напряженности, в результате которых из-за национальной и религиозной вражды пострадали 222 человека, из них 30 убиты и 192 ранены. Наиболее проблемными субъектами РФ по числу локальных конфликтов стали Ставропольский край (155), Республика Татарстан (137) и г. Санкт-Петербург (130). 
использования в системе образования двуязычия и многоязычия как эффективного пути сохранения и развития этнокультурного и языкового многообразия российского общества;

создания в образовательных учреждениях структур студенческого самоуправления на интернациональной основе;

совершенствования учебной литературы и программ обучения в целях более эффективного формирования у подрастающего поколения общероссийского гражданского самосознания, воспитания культуры межнационального общения;

поддержки общественных инициатив, направленных на патриотическое воспитание граждан $Р \Phi^{1}$.

Как мы видим, на высшем государственном уровне подчеркивается, что главным элементом государственной идеологии остается патриотизм: любовь к Родине, осознание своей принадлежности к единому многонациональному российскому народу, готовность защищать честь Отечества и готовность жертвовать собой во имя спасения своего народа и государства.

По мнению Н.Н. Сухотского и И.А. Гущи, «именно патриотизм граждан дает гарантию благополучия государства, так как нацеливает народ на единение, консолидацию личностных и государственных интересов. ... Формирование патриотически настроенных людей означает формирование такого типа человека, который будет в своем поведении руководствоваться гражданскими обязанностями, долгом, будет нести ответственность за свои поступки как перед собой, так и перед обществом и государством» ${ }^{2}$.

Автор поддерживает точку зрения А.И. Конурова о том, что «суверенное государство должно проводить независимую образовательную

${ }^{1}$ В 2015 г. всероссийский масштаб приобрели общественные патриотические акции «Вахта памяти». «Георгиевская ленточка», «Бессмертный полк», «Народная победа» и др. 2009. C. 63.

Сухотский Н.Н., Гущза И.А. Основы идеологии белорусского государства. Минск, 
политику и способствовать формированию мировоззрения своих граждан. В свою очередь, сами граждане, получившие высококачественное образование и воспитанные в духе патриотизма и преданности своей стране, готовые отстаивать ее интересы, в том числе и с оружием в руках, являются дополнительным фактором, усиливающим государственный суверенитет» ${ }^{1}$.

Вместе с тем, следует констатировать, что на протяжении длительного времени с помощью СМИ, литературы, кинопродукции, либерально ориентированных образовательных учреждений в общественном сознании российских граждан формировалось мнение, что только США и страны Западной Европы соответствуют высоким принципам совершенного политического порядка, а англо-саксонская идеология и культура должны быть моральным ориентиром каждого прогрессивного человека. Концепция «тотальной свободы личности», «превосходства американского образа жизни» возводила в ранг самых передовых принятые в США нравственные нормы, сложившийся национальный характер, культурные традиции.

В качестве важнейшего инструмента создания необходимых ценностных установок и стереотипов поведения рассматривалась система образования. Для формирования необходимых качеств личности (космополитизм, западничество, размывание национальной самоидентификации и забвение своей истории), как правило, задействовались два основных канала: оплачиваемые иностранными государствами и негосударственными организациями зарубежные стажировки и подготовка в иностранных обучающих центрах (филиалах иностранных образовательных организаций), действующих на территории РФ.

В соответствии с подразделом а 2 раздела 5 Закона «О демократии в России» 2002 г. (Russian Democracy Act of 2002) Президент США получил

${ }^{1}$ Конуров А.И. Государственный суверенитет в условиях глобализации. Дис. ... докт. полит. наук. М., 2012. С. 6. 
право «вводить гражданские образовательные программы, связанные с представлениями о демократии, социальной политике, законности, значении независимых СМИ, в том числе учреждать т.н. Американские центры и общественно-политические школы в российских университетах, а также поощрять общение россиян с представителями американских университетов посредством Интернет-коммуникаций через обучающие центры, расположенные в российских университетах» ${ }^{1}$. Данные программы должны были поддерживать «развитие в Российской Федерации гражданского общества при сохранении за США соответствующих регулирующих и контролирующих функций» ${ }^{2}$.

Для укрепления системы ценностей, периодической корректировки линии поведения, поддержки и контроля принятия решений в интересах иностранных государств и подконтрольных им негосударственных организаций вводилась практика регулярных встреч иностранных дипломатов, политиков и иных функционеров с представляющими интерес российскими гражданами.

Выдержки из Закона «О демократии в России» свидетельствуют о попытках США организационно и юридически оформить систему регулирования и контроля над идеологической и политической сферами жизни российского общества.

Последствия такого «регулирования и контроля» проявляются в потере зависимыми странами политического суверенитета, периферийности их экономики, уменьшению численности населения, снижению обороноспособности, засилью чуждой местным традициям массовой англосаксонской культуры. А.А. Горелов справедливо выделяет основные признаки неоколонии: «отсутствие науки и высоких технологий; низкая

\footnotetext{
1 Электронный pecypc URL: http:// www.access.gpo.gov/nara/publaw/107publ.html (дата обращения 06.03.2016)

2 Подраздел D 1 Раздела 3 Закона «О демократии в России».
} 
продолжительность и качество жизни населения; ориентированное на подготовку узких и недалеких специалистов образование; примитивный уровень медицины; выкачивание сырьевых и интеллектуальных ресурсов; желание эмигрировать и др.» ${ }^{1}$.

Агрессивная внешняя политика США и Евросоюза в отношении России, беспрецедентное санкционное давление, манипулятивная антироссийская риторика «объективных» западных СМИ, правозащитных институтов и неправительственных организаций позволили избавиться от этих иллюзий. У руководства российского государства появилось четкое осознание значимости государственно ориентированной культурной политики, поддержки образования, развития науки и искусства, патриотического воспитания населения. В условиях обострения антигосударственной деятельности пришло понимание, что только вмешательство государства может остановить засилье массовой культуры, пропаганду вседозволенности и насилия, расовой, национальной и религиозной нетерпимости, деградацию семейных ценностей, противоправные посягательства на объекты культуры, попытки пересмотра взглядов на историю России, ее роль и место в мировой истории.

Как показали события на Украине, переписывание истории собственного государства, переоценка причин и итогов Второй мировой войны могут стать эффективным инструментом оболванивания населения, подрыва традиций, духовных ценностей и нравственных принципов народа.

В качестве примера можно привести законы «О правовом статусе и чествовании памяти участников борьбы за независимость Украины в XX веке», «Об осуждении коммунистического и национал-социалистического (нацистского) тоталитарных режимов на Украине и запрете пропаганды их

${ }^{1}$ Горелов А.А. Глобальный неоколониализм и значение государственной идеологии / Государственная идеология и современная Россия. Мат-лы Всерос. науч.-обществ. конф. (Москва, 28 марта 2014 г.) М.: Наука и политика, 2014. С. 172-173. 
символики», «О доступе к архивам репрессивных органов коммунистического тоталитарного режима 1917-1991 годов», «Об увековечивании победы над нацизмом во Второй мировой войне 1939-1945 ГГ.».

Рассматривая период 1917-1991 годов как период борьбы за независимость Украины и объявляя «коммунистический тоталитарный режим» этого периода «преступным» и «проводившим политику государственного террора», украинские власти пытаются стереть из памяти миллионов украинцев страницы подлинной истории Украины XX века, ее развития в составе Советского Союза ${ }^{1}$.

Данными законами были фактически уравнены фашистские агрессоры и борцы за освобождение страны от фашизма. В качестве национальных героев признаны пособники нацистов в лице ОУН/УПА². Отменено понятие «Великая Отечественная Война».

Современное искажение истории Второй мировой войны, оправдание германского нацизма и его сравнение с другими режимами и идеологиями имеют практическую цель - переложить на современную Россию ответственность как за мнимые и реальные ошибки и просчеты советского руководства, так и за действия других государств и политиков в предвоенный, военный и послевоенный периоды, столкнуть страны, являющиеся наследниками героической истории государств антигитлеровской коалиции, в исторически бессмысленном и с моральной точки зрения кощунственном споре о так называемом национальном вкладе в общую победу. Все это представляет прямую угрозу не только национальной

\footnotetext{
1 Желание забыть историю своего народа навязывается в системе с установками на презрение к старшим поколениям, советскому государству и органам власти.

2 O правовых аспектах противодействия реабилитации нацизма см. Экстремизм: стратегия противодействия и прокурорский надзор: монография / П.В. Агапов, С.В. Борисов и др. М.: Акад. Ген. прокуратуры РФ, 2015. С. 163-173.
} 
безопасности РФ, но и европейскому сотрудничеству и международной стабильности ${ }^{1}$.

Манипулирование общественным мнением, дезориентация населения, разрыв социально-психологических и культурных связей с русским народом осуществляются под предлогом борьбы с якобы тоталитарным советским прошлым. При этом принудительно введены антидемократичные методы ликвидации неугодных партий, общественных организаций и движений, проводятся люстрации. Фактически установлена цензура.

На территории Украины приостановлено вещание российских телеканалов, заблокированы русскоязычные версии официальных сайтов государственных органов Украины в сети «Интернет», на российских журналистов оказывается психологическое и физическое давление, хакерским атакам подвергаются веб-сайты российских СМИ, освещающие ситуацию на Украине 2 .

Фальсификация истории СССР и Украины, тенденциозная интерпретация событий «евромайдана», манипулирование массовым сознанием граждан в угоду политическим интересам правящего на Украине политического режима и его зарубежных покровителей наглядно демонстрируют возможность форсированного инспирирования националистических проявлений и попыток удержания власти путем лавирования между ориентированными на Запад и неонацистскими политическими силами.

${ }^{1}$ Постановление Совета Федерации Федерального Собрания РФ от 20 мая 2015 г. № 186-СФ «Об итогах парламентских слушаний «Политико-правовые аспекты противодействия реабилитации нацизма, героизации нацистских преступников и их пособников: сравнительный анализ и уроки на будущее» // С3 РФ. 2015. № 21. Ст. 3001.

2 По мнению ряда авторов, именно насильственная «украинизация», непродуманная языковая политика, «языковой сепаратизм» во многом способствовали гражданской войне и развалу Украины. См. Янкова Н.А. Языковой фактор в укреплении государственного суверенитета Российской Федерации/ Проблема суверенности современной России. Материалы Всерос. научн. - общ. конф. М.: Центр научной политической мысли и идеологии, 2014. С. 474. 
Поддержка США и Европейским союзом антиконституционного государственного переворота на Украине привела к глубокому расколу в украинском обществе и возникновению вооруженного конфликта. Укрепление крайне правой националистической идеологии, целенаправленное формирование у украинского населения образа врага в лице России, неприкрытая ставка на силовое решение внутригосударственных противоречий, глубокий социально-экономический кризис превратили Украину в долгосрочный очаг нестабильности в Европе и непосредственно у границ России ${ }^{1}$.

Общественная опасность повторения подобных деструктивных процессов в России диктует необходимость конституционно-правового регулирования противодействия фальсификации исторических фактов и событий, направленной на принижение международного престижа Российской Федерации, инспирирование националистических и иных экстремистских проявлений.

Попытки фальсификации истории (т.е. сознательного искажения исторических событий в определенных целях) являются частью антигосударственной пропаганды. Применительно к нашей стране эти попытки, как правило, призваны способствовать обоснованию материальных или территориальных претензий к Российской Федерации под видом компенсации за якобы нанесенный когда-то «ущерб».

Историческое наследие формирует национальную и гражданскую идентичность населения страны, во многом определяет систему ценностей и политическое будущее государств. По мнению Е.Е. Вяземского, «историческая версия обеспечивает возможность преемственности в развитии государства, стимулирует гражданскую солидарность, укрепляет легитимность самого государства, помогает обосновывать его достоинства и

\footnotetext{
${ }^{1}$ Стратегия национальной безопасности Российской Федерации (раздел II).
} 
отличительную привлекательность для внешнего мира» ${ }^{1}$. Искажение истории, инспирируемое и поддерживаемое антигосударственными силами, способно подорвать гражданское согласие, территориальную целостность, разжечь межнациональную и межконфессиональную рознь, нанести ущерб межгосударственным отношениям и международному имиджу государства.

Не случайно «проблема исторической точности является одновременно и проблемой укрепления суверенитета государства»².

Как отмечают специалисты, общей задачей распространения искаженных трактовок событий Новейшей истории можно считать ослабление влияния России в мире за счет внедрения в общественное сознание таких «версий» исторических событий, которые призваны формировать негативный образ России, провоцировать рост русофобских настроений в мире ${ }^{3}$.

Приоритетным направлением фальсификаций истории России является обоснование и выдвижение материальных и территориальных претензий к РФ на основе существенного искажения истории Второй мировой войны, ее подлинных причин и итогов. Особого внимания заслуживают обвинения в адрес нашей страны в «совиновности» с нацистской Германией в развязывании Второй мировой войны, умаление роли СССР в достижении победы над государствами фашистского блока. Актуальными темами в этом контексте являются вопросы компенсации за «советскую оккупацию» стран Балтии, статуса и принадлежности Курильских островов ${ }^{4}$.

Большую опасность представляют фальсификации истории национальных отношений в нашей стране, имеющие целью ослабление

${ }^{1}$ Вяземский E.E. Проблема фальсификации истории России и общее историческое образование: теоретические и практические аспекты // Проблемы современного образования. 2012. № 1. С. 39.

2 Подберезкин А.И. Политические аспекты фальсификации истории России // www.mgimo.ru/files /118847/podberezkin _falsifikacia__istorii.pdf (дата обращения 03.05.2016)

${ }_{3}^{3}$ Вяземский Е.Е. Указ. соч. С. 39.

${ }^{4}$ Вяземский E.E. Указ. соч. С. 38. 
территориальной целостности России путем искажения истории вхождения в состав Российского государства ряда народов и территорий. Тенденциозные интерпретации взаимоотношений народов России направлены на провоцирование сепаратистских настроений на этнонациональной основе в национально-государственных и полиэтнических субъектах РФ (Республика Дагестан, Чеченская Республика, Республика Ингушетия, Республика Северная Осетия - Алания, Карачаево-Черкесская Республика, КабардиноБалкарская Республика, Республика Татарстан, Республика Крым).

Системная деятельность в формате конституционно-правового регулирования противодействия фальсификации исторических фактов и событий была развернута в соответствии с Указом Президента РФ от 15 мая 2009 г. № 549. Данным правовым актом Главы государства была учреждена Комиссия при Президенте по противодействию попыткам фальсификации истории в ущерб интересам России и определены основные направления государственной политики по противодействию попыткам фальсификации истории:

a) обобщение и анализ информации о фальсификации исторических фактов и событий, направленной на умаление международного престижа РФ, и подготовка соответствующих докладов Президенту;

б) выработка стратегии противодействия попыткам фальсификации исторических фактов и событий, предпринимаемым в целях нанесения ущерба интересам России;

в) подготовка предложений Президенту по осуществлению мер, направленных на противодействие попыткам фальсификации исторических фактов и событий, наносящих ущерб интересам России;

г) рассмотрение предложений и координация деятельности федеральных органов государственной власти, органов государственной власти субъектов РФ и организаций по вопросам противодействия попыткам фальсификации исторических фактов и событий в ущерб интересам России; 
д) выработка рекомендаций по адекватному реагированию на попытки фальсификации исторических фактов и событий в ущерб интересам России и по нейтрализации их возможных негативных последствий.

Несмотря на прекращение деятельности в феврале 2012 г., Комиссия сыграла значимую роль в консолидации экспертного сообщества, политических и общественных деятелей, начавших масштабную работу по выявлению и устранению исторических фактов (их умышленных искажений), негативно влияющих на гражданскую солидарность и политический престиж России. Как представляется, с учетом резкого усиления информационно-пропагандистских кампаний антироссийской направленности с начала введения санкций в 2014 г. данный орган мог бы возобновить свою деятельность.

Важнейшую роль в ЗГС играет конституционно-правовая защчита сложивиихся в государстве традиционных религиозных иченностей $и$ противодействие религиозному экстремизму.

Несмотря на провозглашенный в Конституции светский характер российского государства, религиозные ценности и духовно-нравственные принципы всегда были неразрывно связаны с национальной идеологией. Не случайно в преамбуле к Федеральному закону от 26 сентября 1997 г. № 125 Ф3 «О свободе совести и о религиозных объединениях» признается «особая роль православия в истории России, в становлении и развитии ее духовности и культуры», закрепляется уважение к «христианству, исламу, буддизму, иудаизму и другим религиям, составляющим неотъемлемую часть исторического наследия народов России».

Идеология, построенная на традиционных религиозных ценностях, выражает духовные идеалы народа, способствует внутреннему совершенствованию граждан, приобщению к культуре, обеспечивает рост нравственного и творческого потенциала. 
Государство оказывает финансовую, материальную и иную помощь религиозным организациям в реставрации, содержании и охране памятников истории и культуры, а также в преподавании общеобразовательных дисциплин в образовательных учреждениях религиозных организаций. Государство поддерживает благотворительную деятельность религиозных организаций, реализацию ими общественно значимых культурнопросветительских программ и мероприятий.

Согласно Конституции в РФ никакая религия не может устанавливаться в качестве государственной или обязательной. Конституционный принцип отделения религиозных объединений от государства означает, что государство:

не вмешивается в определение гражданином своего отношения к религии и религиозной принадлежности, в воспитание детей в соответствии со своими убеждениями и с учетом права ребенка на свободу совести и свободу вероисповедания;

не возлагает на религиозные объединения выполнение функций органов государственной власти, других государственных органов, государственных учреждений и органов местного самоуправления;

обеспечивает светский характер образования в государственных и муниципальных образовательных учреждениях;

не вмешивается в деятельность религиозных объединений, если она не противоречит федеральному закону.

В свою очередь, религиозные объединения:

- создаются и осуществляют свою деятельность в соответствии со своей собственной иерархической и институционной структурой;

- не выполняют функций органов государственной власти, других государственных органов, государственных учреждений и органов местного самоуправления; 
- не участвуют в выборах в органы государственной власти и в органы местного самоуправления;

- не участвуют в деятельности политических партий и политических движений, не оказывают им материальную и иную помощь.

В формате противодействия религиозно-политическому экстремизму представляют интерес решения Конституционного Суда РФ, касающиеся статуса политических партий, принципов их организации и деятельности.

В Постановлении от 15 декабря 2004 года № 18-П «По делу о проверке конституционности пункта 3 статьи 9 Федерального закона «О политических партиях» в связи с запросом Коптевского районного суда города Москвы, жалобами общероссийской общественной политической организации «Православная партия России» и граждан И.В. Артемова и Д.А. Савина» Конституционный Суд подтвердил законность ограничения создания политических партий по признакам национальной и религиозной принадлежности ${ }^{1}$. Конституционный Суд отметил, что создание партий по религиозному признаку открыло бы путь к политизации религии и религиозных объединений, а создание партий по национальному признаку могло бы привести к преобладанию в выборных органах власти представителей больших этнических групп в ущерб интересам малых этнических групп.

В целях исключения политизации религии запрещается создание религиозных объединений в органах государственной власти, других государственных органах, государственных учреждениях и органах местного самоуправления, воинских частях, государственных и муниципальных организациях.

${ }^{1}$ Постановление Конституционного Суда РФ от 15 декабря 2004 г. N 18-П "По делу о проверке конституционности пункта 3 статьи 9 Федерального закона "О политических партиях" в связи с запросом Коптевского районного суда города Москвы, жалобами общероссийской общественной политической организации "Православная партия России" и граждан И.В. Артемова и Д.А. Савина"// Рос. газ. 2004. 24 декабря. 
Право человека и гражданина на свободу совести и свободу вероисповедания может быть ограничено в целях ЗГС и противодействия религиозному экстремизму.

Непосредственное отношение к подобной практике имеет Постановление Конституционного Суда от 28 июня 2007 г. № 8-П «По делу о проверке конституционности статьи 14.1 Федерального закона «О погребении и похоронном деле» и Положения о погребении лиц, смерть которых наступила в результате пресечения совершенного ими террористического акта, в связи с жалобой граждан К.И. Гузиева и Е.Х.Кармовой〉 ${ }^{1}$.

Согласно сформулированной в данном Постановлении правовой позиции Конституционного Суда, «интересы пресечения терроризма, его общей и специальной превенции, ликвидации последствий террористических актов, сопряженных с возможностью массовых беспорядков, столкновений различных этнических групп, эксцессов между родственниками лиц, причастных к террористическим актам, населением и правоохранительными органами, угрозой жизни и здоровью людей, могут обусловливать в определенных конкретно-исторических условиях установление особого правового регулирования погребения лиц, уголовное преследование в отношении которых в связи с участием в террористической деятельности прекращено из-за их смерти, наступившей в результате пресечения террористического акта.

Захоронение лица, принимавшего участие в террористическом акте, в непосредственной близости от могил жертв его действий, совершение обрядов захоронения и поминовения, с одной стороны, служат пропаганде

${ }^{1}$ Постановление Конституционного Суда РФ от 28 июня 2007 г. N 8-П "По делу о проверке конституционности статьи 14.1 Федерального закона "О погребении и похоронном деле" и Положения о погребении лиц, смерть которых наступила в результате пресечения совершенного ими террористического акта, в связи с жалобой граждан К.И. Гузиева и Е.Х. Кармовой" // СЗ РФ. 2007. N 27. Ст. 3346. 
идей террора, а с другой - оскорбляют чувства родственников жертв этого акта и создают предпосылки для нагнетания межнациональной и религиозной розни. Выдача родственникам для захоронения тел лиц, смерть которых наступила в результате совершенного ими террористического акта, способна создать угрозу общественному порядку, правам и законным интересам других лиц, их безопасности, в том числе привести к разжиганию ненависти, спровоцировать акты вандализма, насильственные действия, массовые беспорядки и столкновения, что может повлечь за собой новые жертвы, а места захоронений участников террористических актов могут стать местами культового поклонения отдельных экстремистски настроенных лиц, будут использоваться ими в качестве средства пропаганды идеологии терроризма и вовлечения в террористическую деятельность.

При таких обстоятельствах Конституционный Суд признал правомерность особого порядка погребения лиц, чья смерть наступила в результате пресечения террористического акта, участниками которого они являлись.

Регулируя деятельность религиозных объединений, государство устанавливает:

конституционно обоснованные ограничения на создание религиозных организаций;

специальный порядок государственной регистрации религиозных организаций и возможность отказа в регистрации;

особый порядок отчетности и государственного надзора за деятельностью религиозных организаций, получивших денежные средства или иное имущество от международных и иностранных организаций, иностранных граждан и лиц без гражданства;

возможность приостановления деятельности религиозного объединения, ликвидации религиозной организации и запрета на 
деятельность религиозного объединения в случае нарушения ими законодательства.

В соответствии с пунктом 3 статьи 9 Федерального закона «О свободе совести и о религиозных объединениях» законодателем введен запрет быть учредителем (участником, членом) религиозной организации:

иностранному гражданину или лицу без гражданства, в отношении которых принято решение о нежелательности их пребывания (проживания) в $\mathrm{P} \Phi$

лицу, включенному в Перечень организаций и физических лиц, в отношении которых имеются сведения об их причастности к экстремистской деятельности или терроризмуㅜㅜ

религиозной организации, деятельность которой приостановлена в соответствии с Федеральным законом «О противодействии экстремистской деятельности»;

лицу, в отношении которого вступившим в законную силу решением суда установлено, что в его действиях содержатся признаки экстремистской деятельности.

Частью 4 статьи 9 Федерального закона «О свободе совести и о религиозных объединениях» закреплено специальное ограничение правосубъектности бывших руководителей и лидеров общественных или религиозных объединений, других организаций, признанных террористическими или экстремистскими. Так, лицо, которое ранее являлось руководителем или входило в состав руководящего органа общественного или религиозного объединения либо иной организации, в отношении которых по основаниям, предусмотренным Федеральным законом «О

${ }^{1}$ Постановление Правительства РФ от 6 августа 2015 г. № 804 «Об утверждении Правил определения перечня организаций и физических лиц, в отношении которых имеются сведения об их причастности к экстремистской деятельности или терроризму, и доведения этого перечня до сведения организаций, осуществляющих операции с денежными средствами или иным имуществом, и индивидуальных предпринимателей» // Рос. газ. 2015. 17 августа. 
противодействии экстремистской деятельности» либо Федеральным законом «О противодействии терроризму», судом принято решение о ликвидации или запрете деятельности, не может создавать религиозную организацию в течение десяти лет со дня вступления в законную силу соответствующего решения суда ${ }^{1}$.

Религиозные организации в РФ подлежат государственной регистрации. Регистрирующий орган вправе провести государственную религиоведческую экспертизу предоставленных для регистрации документов.

Религиозной организации может быть отказано в государственной регистрации, если:

- цели и деятельность религиозной организации противоречат Конституции и законодательству РФ;

- создаваемая организация не признана в качестве религиозной;

- устав и другие представленные документы не соответствуют требованиям законодательства РФ или содержащиеся в них сведения не достоверны;

- в едином государственном реестре юридических лиц ранее зарегистрирована организация с тем же названием;

- учредитель (учредители) неправомочен.

Серьезную угрозу государственному суверенитету представляет деятельность ряда протестантских (пятидесятники, неопятидесятники,

\footnotetext{
${ }^{1}$ Решение Верховного Суда РФ от 10 апреля 2008 г. «О признании международного религиозного объединения «Нурджулар» экстремистским и запрете его деятельности на территории Российской Федерации; Решение Верховного Суда РФ от 7 мая 2009 г. № ГКПИ 09-525 «О признании международного религиозного объединения «Таблиги Джамаат» экстремистским и запрете его деятельности на территории Российской Федерации; Решение Верховного Суда РФ от 15 сентября 2010 г. № ГКПИ 10-848 «О признании международного религиозного объединения «Ат-Такфир Валь-Хиджра экстремистским и запрете его деятельности на территории Российской Федерации»; Решение Верховного Суда РФ от 17 ноября 2014 г. № АКПИ 14-1292 с «О признании украинских организаций «Правый сектор», «Украинская националистическая ассамблея Украинская народная самооборона» (УНА-УНСО), «Украинская повстанческая армия» (УПА), «Тризуб им. Степана Бандеры», «Братство» экстремистскими и запрете их деятельности на территории Российской Федерации».
} 
баптисты, адвентисты) приходов, а также адептов некоторых религиозных движений (саентологи, мормоны, «Свидетели Иеговы»). Речь идет о нескольких тысячах структур, объединяющих свыше 2 млн. последователей и функционирующих в роли филиалов зарубежных религиозных центров.

Наиболее массовыми и агрессивными религиозными организациями, действующими на территории РФ, являются «Свидетели Иеговы», саентологи и мормоны ${ }^{1}$. Их деятельность контролируется из США, а руководство связано с американскими спецслужбами. Основные руководящие должности в данных структурах занимают иностранные граждане. Из-за рубежа в адрес российских отделений перечисленных структур поступают агитационные издания антироссийской направленности, формирующие негативное отношение к политической системе РФ и органам государственной власти. В программных документах некоторых протестантских структур закреплены задачи по изменению конституционных основ российской суверенной государственности. Так, теоретической основой деятельности движения «Новое поколение» является концепция «Новый мировой порядок», призывающая к формированию единого протестантского пространства под эгидой США. Одним из способов достижения поставленной цели названо проведение массовых протестных акций. Для обеспечения своей деятельности и легализации финансовой помощи из-за рубежа, получение которой было затруднено после введения в действие Федерального закона от 20 июля 2012 г. № 121-Ф3 «О внесении изменений в отдельные законодательные акты Российской Федерации в части регулирования деятельности некоммерческих организаций, выполняющих функции иностранного агента», прозападные религиозные структуры используют благотворительные фонды, позволяющие скрывать источники поступления средств.

\footnotetext{
${ }^{1}$ Общая численность достигает 400 тысяч человек, а ежегодный доход - свыше 200 млн долларов США.
} 
В целях предупреждения иностранного вмешательства в вопросы вероисповедания, развития духовности и культуры, нейтрализации попыток распространения влияния зарубежных деструктивных религиозных культов и сект, повышения прозрачности финансирования религиозной деятельности в РФ предусмотрен особый порядок отчетности религиозных организаций, получивших денежные средства и иное имущество от международных и иностранных организаций, иностранных граждан, лиц без гражданства.

Религиозные организации, получившие денежные средства и иное имущество из иностранных источников, ведут раздельный учет доходов (расходов), полученных (произведенных) в рамках поступлений из этих источников, и доходов (расходов), полученных (произведенных) в рамках иных поступлений. Религиозные организации, получившие в течение одного года денежные средства и иное имущество из иностранных источников, обязаны предоставить в регистрирующий орган отчет о своей деятельности, персональном составе руководящих органов, целях расходования денежных средств и использования иного имущества, об их фактическом расходовании (использовании). Аналогичный отчет размещается в сети «Интернет» или предоставляется СМИ для опубликования.

Регистрирующий орган вправе проводить проверки финансовохозяйственной деятельности религиозных организаций, получающих иностранное финансирование.

Необходимость усиленного государственного надзора за религиозными объединениями, действующими на грани закона, а также контроля за финансированием религиозной деятельности в РФ активно оспаривается правозащитниками и зарубежными общественными организациями при любых попытках задействования государством легального правового инструментария в целях приостановления и пресечения деятельности деструктивных религиозных культов и сект. 
Так, правящие круги США используют сектантский фактор в качестве инструмента политического вмешательства во внутренние дела РФ. В качестве примеров преследования в России религиозных меньшинств в ежегодных докладах Комиссии США по религиозной свободе в странах мира приводятся мероприятия по противодействию органов власти противоправной деятельности ряда сект, имеющих мощную поддержку в США («Свидетели Иеговы», «Церковь Саентологии», неопятидесятники, мормоны). Даже факт пресечения преступной деятельности секты сатанистов в Республике Мордовия был тенденциозно отмечен в докладе Госдепартамента США о религиозной свободе в странах мира за 2009 г. как случай нарушения свободы вероисповедания.

Секты выиграли ряд процессов против России в Европейском Суде по правам человека. Так, в 2007 г. «Саентологическая церковь Москвы», которой ГУ МЮ РФ по г. Москве было отказано в перерегистрации, выиграла судебный процесс ${ }^{1}$ В июне 2010 г. Европейский суд по правам человека признал незаконным решение Головинского районного суда г. Москвы о запрете деятельности московской общины «Свидетелей Иеговы»².

Грамотная информационно-пропагандистская деятельность сект, квалифицированная правовая защита, активная поддержка российских правозащитников, спекулирование свободой вероисповедания позволяет их руководству и адептам создавать положительный имидж «жертв системы» и дискредитировать своих оппонентов.

Указанные обстоятельства свидетельствуют о целесообразности дальнейшего совершенствования правоохранительной практики уполномоченных органов (органов юстиции, прокуратуры и др.) и производства по делам о приостановлении деятельности религиозного

\footnotetext{
${ }^{1}$ Саентологи отсудили у Москвы 25 тысяч евро // URL: BBC Russian com. Дата обращения 5 апреля 2007 г.

2 Свидетели Иеговы одержали новую победу в Европейском суде // URL: http:// europeancourt.ru /2010/06/10/876 Дата обращения 22 декабря 2014 г.
} 
объединения, ликвидации религиозной организации и запрете деятельности религиозного объединения в случае нарушения ими законодательства.

В соответствии с действующим законодательством религиозные организации могут быть ликвидированы по решению суда в случае неоднократных или грубых нарушений норм Конституции РФ, федеральных законов либо в случае систематического осуществления религиозной организацией деятельности, противоречащей уставным целям.

Основаниями для ликвидации религиозной организации и запрета на деятельность религиозной организации или религиозной группы в судебном порядке являются:

- нарушение общественной безопасности и общественного порядка;

-осуществление экстремистской деятельности;

- принуждение к разрушению семьи;

- посягательство на личность, права и свободы граждан;

- нанесение ущерба нравственности, здоровью граждан;

- склонение к самоубийству или к отказу по религиозным мотивам от оказания медицинской помощи лицам, находящимся в опасном для жизни и здоровья состоянии;

- воспрепятствование получению обязательного образования;

- принуждение членов и последователей религиозного объединения и иных лиц к отчуждению принадлежащего им имущества в пользу религиозного объединения;

- воспрепятствование угрозой причинения вреда жизни, здоровью, имуществу, другими противоправными действиями выходу гражданина из религиозного объединения;

- побуждение граждан к отказу от исполнения установленных законом гражданских обязанностей и совершению иных противоправных действий;

- неоднократное непредставление в регистрирующий орган в установленный срок отчетности при получении денежных средств и иного 
имущества от международных и иностранных организаций, иностранных граждан и лиц без гражданства.

Представление о ликвидации религиозной организации либо о запрете деятельности религиозного объединения (религиозной организации или религиозной группы) может быть внесено в суд органами прокуратуры, органами юстиции, а также органами местного самоуправления.

Деятельность религиозного объединения может быть приостановлена, религиозная организация может быть ликвидирована, а деятельность религиозного объединения, не являющегося религиозной организацией, может быть запрещена на основании Федерального закона «О противодействии экстремистской деятельности».

Проведенный анализ конституционно-правового регулирования деятельности религиозных объединений, регламентации права на свободу совести и свободу вероисповедания свидетельствует о наличии достаточных гарантий беспрепятственного осуществления свободы вероисповедания законопослушными верующими и религиозными деятелями, а также разнообразных правовых механизмов привлечения религиозных объединений и их членов, нарушающих законодательство РФ, к ответственности.

Защита традиционных религиозных ценностей, сохранение духовных ориентиров народа и противодействие религиозному экстремизму осложняется в связи с постоянным увеличением потока мигрантов, прибывающих в РФ.

Создание замкнутых этнических анклавов, рост националистических и экстремистских настроений в этнических общинах, землячествах и диаспорах, инспирирование массовых беспорядков на почве межэтнических и межконфессиональных конфликтов с местным населением обусловливают необходимость конституциионо-правового регулирования адаптаџฺии и интеграции мигрантов. 
Эффективность реализации государственной политики РФ в данной сфере требует скоординированного и системного подхода со стороны органов государственной власти на всех уровнях (федеральном, региональном и муниципальном). Вопросы адаптации и интеграции мигрантов носят комплексный характер и затрагивают различные аспекты жизни мигранта. Создание условий для социальной и культурной адаптации и интеграции мигрантов является одним из приоритетных направлений государственной национальной политики Российской Федерации ${ }^{1}$

Как справедливо отмечает Л.В. Андриченко, «иммигранты должны учить язык принимающей страны, знать и принимать ценности данной страны, соответствовать ожиданиям и требованиям к ним со стороны граждан принимающей страны. Они должны быть готовы и способны вступать в отношения с людьми и организациями, которые обеспечивают для них доступ к важным сферам жизни - к рынку рабочей силы, системе образования, гражданским и социальным правам, услугам по здоровью. Все это направлено на то, чтобы иммигранты имели возможность и были способны строить и развивать новые социальные отношения» ${ }^{2}$.

Вопросы адаптации и интеграции мигрантов являются производными государственной миграционной и национальной политики. На российскую интеграционную модель наиболее заметное влияние оказывают следующие факторы:

во-первых, многонациональность (полиэтничность) принимающего общества ${ }^{3}$;

во-вторых, наличие значительных иммигрантских диапор;

1 Подпункт «г» пункта 20 Стратегии государственной национальной политики Российской Федерации на период до 2025 года (утверждена Указом Президента РФ от 19 декабря 2012 г. № 1666).

2 Андриченко Л.В. Правовые механизмы социальной и культурной адаптации и интеграции мигрантов в Российской Федерации // Журнал российского права. 2015. № 10.

3 РФ является одним из крупнейших многонациональных государств мира. По данным Всероссийской переписи населения 2020 г., на ее территории проживают представители 193 национальностей. 
в-третьих, различная степень привлекательности субъектов РФ для мигрантов;

в-четвертых, существенные этнокультурные различия между коренным населением и прибывающими мигрантами;

в-пятых, распространенность отрицательных стереотипов в отношении некоторых народов и негативный опыт конфликтов принимающего населения и мигрантов.

Исследователи справедливо указывают, что интеграция мигрантов длительный и сложный процесс, требующий от мигрантов и граждан принимающих стран взаимного уважения и желания приспосабливаться друг к другу ${ }^{1}$.

Положительный вклад в решение проблем профилактики этнонационального экстремизма и раннего предупреждения межнациональных конфликтов в субъектах РФ внесло установление ответственности должностных лиц государственных и муниципальных органов за состояние межнациональных отношений на соответствующих территориях.

Наиболее важным элементом в процессе адаптации мигрантов является изучение ими русского языка, культуры, традиций, основ законодательства и истории принимающего общества. Соответствующие нормы нашли закрепление в статье 15.1 Федерального закона от 25 июля 2002 г. № 115-Ф3 «О правовом положении иностранных граждан в Российской Федерации».

С 1 января 2015 г. для иностранных граждан при получении разрешительных документов введено требование о подтверждении знаний в области русского языка, истории России и основ законодательства РФ.

\footnotetext{
Злочевская A.A. Теоретико-методологические основы исследования социокультурной адаптации в иноэтнической среде // Административное и муниципальное право. 2011. № 8.
} 
Наиболее широкий спектр мер по адаптации и интеграции предусмотрен в отношении соотечественников, переселяющихся в РФ. В соответствии со статьей 11.1 Федерального закона от 24 мая 1999 г. № 99-Ф3 «О государственной политике в отношении соотечественников за рубежом» соотечественники имеют право на приобретение гражданства РФ в упрощенном порядке. Им оказывается содействие в социальной, культурной и психологической адаптации в местах их нового проживания, проводится мониторинг программ переселения ${ }^{1}$.

Вместе с тем полномочия в области адаптации и интеграции мигрантов не закреплены ни за одним федеральным органом исполнительной власти. Миграционные органы реализуют лишь отдельные направления интеграционной политики (взаимодействие с национальными, религиозными и общественными организациями, создание системы обучения мигрантов русскому языку).

Четкое разграничение компетенции между органами власти различных территориальных уровней по вопросам интеграции мигрантов также отсутствует.

В статьях 21, 26.3 Федерального закона от 6 октября 1999 г. № 184-Ф3 «Об общих принципах организации законодательных (представительных) и исполнительных органов государственной власти субъектов Российской Федерации», статьях 14-16 Федерального закона от 6 октября 2003 г. № 131Ф3 «Об общих принципах организации местного самоуправления в Российской Федерации» установлены общие полномочия органов государственной власти субъектов РФ и органов местного самоуправления поселений, городских округов и муниципальных районов по социальной и культурной адаптации мигрантов.

${ }^{1}$ Государственная программа по оказанию содействия добровольному переселению в Российскую Федерацию соотечественников, проживающих за рубежом (утверждена Указом Президента РФ от 22 июня 2006 г. № 637). 
Отсутствие базовых системных подходов к обеспечению адаптации и интеграции мигрантов на федеральном уровне не способствует развитию региональной и муниципальной политики адаптации и интеграции мигрантов.

Важно отметить, что в реализации интеграционных программ помимо государственных органов самое активное участие должны принимать общественные институты (культурные учреждения, национальные общественные объединения мигрантов, национально-культурные автономии, СМИ, хозяйствующие субъекты, работодатели).

В соответствии со Стратегией государственной национальной политики Российской Федерации на период до 2025 года формирование системы социальной и культурной адаптации и интеграции мигрантов предполагает укрепление роли национальных общественных объединений и национально-культурных автономий (далее - НКА).

В статье 1 Федерального закона от 17 июня 1996 г. № 74-Ф3 «О национально-культурной автономии» НКА рассматривается как форма национально-культурного самоопределения, представляющая собой объединение граждан РФ, относящих себя к определенной этнической общности, находящейся в ситуации национального меньшинства на соответствующей территории, на основе их добровольной самоорганизации в целях самостоятельного решения вопросов сохранения самобытности, развития языка, образования, национальной культуры, укрепления единства российской нации, гармонизации межэтнических отношений, содействия межрелигиозному диалогу, а также осуществления деятельности, направленной на социальную и культурную адаптацию и интеграцию мигрантов.

В целях обеспечения права на сохранение и развитие национальной культуры НКА могут: 
- создавать негосударственные учреждения национальной культуры и обеспечивать их функционирование;

- организовывать творческие союзы, коллективы профессионального и самодеятельного искусства, кружки по изучению национального культурного наследия, достижений национальной культуры;

- проводить массовые мероприятия в области национальной культуры: фестивали, конкурсы, смотры, выставки и другие мероприятия;

- содействовать организации национального краеведения, охране национальных памятников истории культуры; создавать краеведческие, этнографические и иные общественные музеи;

- учреждать организации, занимающиеся художественными народными промыслами и ремеслами;

- издавать произведения исторической, художественной, музыкальной, фольклорной, этнографической литературы на национальных (родных) и иных языках;

- создавать частные образовательные организации по подготовке работников в области национальной культуры;

- разрабатывать и представлять в соответствующие органы государственной власти, органы местного самоуправления предложения о сохранении и развитии национальной культуры;

- заключать договоры с неправительственными организациями, находящимися за пределами РФ, о культурном обмене и сотрудничестве в области сохранения национальной культуры.

Право на НКА не является правом на национально-территориальное самоопределение и не должно наносить ущерб интересам других этнических общностей.

Рассматривая вопросы учреждения и регистрации НКА, Конституционный Суд РФ в Постановлении от 3 марта 2004 г. № 5-П по делу о проверке конституционности части 3 статьи 5 Федерального закона «О 
национально-культурной автономии» в связи с жалобой граждан А.Х. Дитца и О.А. Шумахер пришел к выводу, что НКА как способ самоопределения соответствующей этнической общности в целях обеспечения ее этнокультурных прав и интересов является такой формой самоорганизации, через которую осуществляется государственная поддержка национальных меньшинств в целях сохранения их самобытности, развития языка, образования, национальной культуры. Этим обусловливается значение регистрации НКА, в результате которой соответствующая НКА приобретает права юридического лица и иные публичные права. НКА не исключает другие формы самоорганизации граждан по признаку принадлежности к той же этнической общности.

Неотъемлемым компонентом внешнеполитической идеологической сфере является развитие русской культуры, укрепление дружественных отношений с государствами, ориентированными на РФ, поддержка и защита прав соотечественников за пределами территории РФ.

Данная деятельность в той или иной степени возложена на Федеральное агентство по делам Содружества Независимых Государств, соотечественников, проживающих за рубежом, и по международному гуманитарному сотрудничеству (Россотрудничество) $)^{1}$. Россотрудничество реализует проекты, нацеленные на укрепление международных связей, сотрудничество в гуманитарной сфере и формирование позитивного имиджа РФ за рубежом.

Федеральные и региональные органы государственной власти осуществляют всестороннее сотрудничество с НКА соотечественников в иностранных государствах. Соотечественникам предоставляется возможность использовать российские центры науки и культуры в

1 Указ Президента РФ от 6 сентября 2008 г. № 1315 «О некоторых вопросах государственного управления в области международного сотрудничества» // СЗ РФ. 2008. № 37. Ст. 4181. 
иностранных государствах, получать образование в учебных и научных организациях РФ. В целях содействия соотечественникам в сохранении и развитии их культурного наследия и языка, других элементов самобытности федеральные и региональные органы государственной власти оказывают помощь культурным учреждениям и творческим коллективам соотечественников, содействуют всем видам культурного обмена между РФ и соотечественниками.

Данные мероприятия способствуют преодолению культурных барьеров, негативных стереотипов и иных препятствий на пути к развитию международного сотрудничества.

Суверенная политика РФ по защите прав соотечественников за рубежом позволяет государству применять комплекс дипломатических, правовых, социально-экономических, организационных и иных мер, в том числе ограничительного характера, в отношении иностранных государств, ущемляющих их права и законные интересы ${ }^{1}$. При этом приоритетом политики ЗГС современного российского государства выступает использование культурно-гуманитарных методов и технологий т.н. «мягкой силы».

1 Повышению уровня конституционно-правовой защиты соотечественников за рубежом могло бы способствовать введение должности Управомоченного РФ по правам соотечественников. 


\section{5. Совершенствование конституционно-правовых и иных механизмов защиты государственного суверенитета Российской Федерации}

Несмотря на достигнутые положительные результаты в осуществлении правотворческой, правоприменительной и правоохранительной деятельности по ЗГС в формате правотворчества, правореализации и государственного принуждения, далеко не все элементы национальной российской системы ЗГС действуют достаточно эффективно и адекватно масштабам и потенциалу формирующихся угроз государственному суверенитету. Кроме того, не все формы и методы ЗГС могут быть задействованы с учетом экономических возможностей государства, международной и внутриполитической обстановки, гуманитарных и правозащитных аспектов. В связи с этим существующая система ЗГС нуждается в дальнейшем совершенствовании.

Как уже отмечалось, ЗГС осуществляется не только с помощью конституционно-правовых механизмов. Значительную роль в этом процессе играют дипломатические, организационные, военные, разведывательные, материально-технические, финансовые, пропагандистские и иные усилия, во многих случаях опосредованно связанные с конституционно-правовой защитой государственного суверенитета. В связи с этим вопросы совершенствования ЗГС будут рассматриваться применительно к расширенному перечню сфер, включающему не только рассмотренные в работе сферы и основные направления конституционно-правовой защиты государственного суверенитета, но и иные самостоятельные устойчивые отношения с участием государства, возникающие в процессе ЗГС.

В современных условиях совершенствование механизмов ЗГС, как представляется, должно комплексно охватывать следующие ключевые сферы:

политическую;

экономическую;

военную; 
сферу международного сотрудничества;

информационную;

идеологическую.

В политической сфере модернизация механизмов ЗГС требует:

- укрепления авторитета и роли ООН, СБ ООН, «Группы 20», ОБСЕ, БРИКС, РИК, ШОС в глобальных и региональных делах;

- дальнейшего противодействия расширению НАТО и организационноправового блокирования продвижения военной инфраструктуры блока к Государственной границе РФ;

- сохранения российского присутствия на территории иностранных государств в соответствии с политическими интересами РФ;

- противодействия введению односторонних экстерриториальных санкций и попыток распространения юрисдикции США и ЕС на российские организации и граждан с использованием политической и псевдоправозащитной мотивации;

- использования потенциала традиционного взаимовыгодного недискриминационного сотрудничества России с Грецией, Сербией, Словакией, Чехией, Венгрией и др. европейскими странами;

- укрепления стратегических связей с Китаем, Индией, Вьетнамом, государствами Латинской Америки и Карибского бассейна;

- углубления внешнеполитической координации государств участников ОДКБ и других международных организаций с российским участием;

- развития общегосударственной законодательной базы противодействия террористическим, сепаратистским и иным экстремистским посягательствам, предупреждения межнациональных И межконфессиональных конфликтов, совершенствования миграционного законодательства и антикоррупционных стандартов и др. правовых инициатив по ЗГС; 
- прекращения практики договорных отношений с отдельными республиками в составе РФ и делегирования полномочий по предметам исключительного ведения РФ органам государственной власти субъектов РФ;

- дальнейшего укрепления национальной правоохранительной и судебной системы, органов конституционной и международной юстиции ${ }^{1}$;

- проведения общегосударственных (при координирующей роли Российской академии наук) и ведомственных (на базе ФСБ и МВД России) исследований факторов, угроз, тенденций и прогнозных сценариев, нарушающих суверенитет РФ.

Совершенствование ЗГС в экономической сфере направлено на повышение конкурентоспособности национальной экономики, защиту отечественных производителей, противодействие механизмам ослабления и подрыва государственного суверенитета с использованием экономических санкций и недобросовестной конкуренции. Данная деятельность предполагает:

- обеспечение долгосрочной сбалансированности и устойчивости бюджетной системы, ценовой стабильности;

- государственную поддержку занятости;

- устойчивое развитие отечественного производства продовольствия и сырья;

${ }^{1}$ Автор поддерживает позицию В.Д. Зорькина, что «для усиления влияния позиций России в европейском судопроизводстве необходимо изменение алгоритма взаимодействия с ЕСПЧ, в том числе более активное участие в качестве третьей стороны в делах, рассматриваемых в Страсбурге (по вопросам, которые имеют стратегическое значение для российской правовой системы и в которых потенциальное постановление ЕСПЧ может вызвать несогласие со стороны России). Необходима координация усилий с другими государствами - партнерами в целях влияния на выработку «конвенционных стандартов». Следует вырабатывать механизмы влияния России на деятельность Международного уголовного суда, Международного трибунала по бывшей Югославии. См. Зорькин В.Д. Право в условиях глобальных перемен : монография. М.: Норма, 2013. С. 292-293. 
- техническую и технологическую модернизацию промышленности и сельского хозяйства; снижение зависимости отечественного производства от импорта технологий, машин, оборудования и других ресурсов;

- защиту российских организаций от поставок морально устаревших и материалоемких, энергоемких и ненаукоемких технологий, оборудования, конструкций и материалов в ходе инвестирования в капитальные вложения;

- расширение мер государственной поддержки малого и среднего предпринимательства;

- ослабление зависимости от контролируемых США международных экономических организаций и финансовых институтов с помощью активизации участия России в организации Банка развития ШОС, деятельности Азиатского банка инфраструктурных инвестиций, Нового банка развития БРИКС, Пула валютных резервов;

- поддержку евразийской экономической интеграции (укрепление и расширение Евразийского экономического союза, Таможенного союза, дальнейшее развитие Единого экономического пространства; подписание и ратификацию соглашений о свободной торговле между ЕАЭС, его государствами - членами и заинтересованными государствами (Израиль, Сербия, Венесуэла, Куба, Индия, Иран, Египет, Сирия, Монголия, Мьянма, Южная Корея, Перу, Чили, Таиланд, Судан и др.)) и региональными организациями (АСЕАН, МЕРКОСУР);

- правовое обоснование применения механизмов предотвращения недобросовестной конкуренции, связанных с членством России в ВТО, ЕАЭС и Таможенном Союзе (устранение антидемпинговых, компенсационных и специальных защитных мер, иных экономических и торговых барьеров, введение ответных мер);

- недопущение дискриминации российских товаропроизводителей и поставщиков энергоносителей на зарубежных рынках и российских добывающих предприятий при освоении месторождений за пределами РФ; 
- повышение конкурентоспособности национальных структур аудита, продвижение российских аудиторских брендов на Евразийское экономическое пространство и платформы других интеграционных объединений РФ, формирование единого рынка аудиторских услуг на территории ЕАЭС и СНГ;

- переход в международных сделках РФ к обязательной доле расчетов в национальных валютах контрагентов;

- создание и поддержку региональных и международных экономических проектов (Северный морской путь, экономический пояс «Шелкового пути», Транссиб) ${ }^{1}$;

- совершенствование российской национальной платежной системы, ее интеграция с платежными инфраструктурами стран, имеющих тесные экономические связи с РФ;

- поддержка форсированного импортозамещения в стратегических отраслях национальной экономики и экспорта высокотехнологичных товаров;

- отказ от транзитных маршрутов поставок сырья и энергоносителей через нестабильные регионы с негативной деловой и кредитной репутацией;

- совершенствование механизмов противодействия вывозу капитала в оффшорные и низконалоговые юрисдикции ${ }^{2}$;

- повышение привлекательности российской юрисдикции (налоговое стимулирование российских компаний осуществить передачу имущества,

1 В настоящее время российское направление - далеко не главное в планах «Шелкового пути», отдающего приоритет Казахстану, Пакистану и Восточной Европе в виде южных маршрутов. КНР начала инвестирование по пакистано-казахстанскому коридору и восточно-европейскому направлению в обход России. В связи с этим требуется безотлагательная активизация переговоров на высшем уровне в отношении сопряжения Экономического пояса Шелкового пути и планов развития ЕАЭС.

${ }_{2}^{2}$ В этих целях следует ввести заблаговременное предварительное уведомление об операциях по вывозу капитала и законодательно запретить перевод активов в государства и территории-оффшоры, с которыми не заключены соглашения об обмене налоговой информацией. 
ценных бумаг, имущественных прав в национальную юрисдикцию; пополнение флота, зарегистрированного в реестрах судов РФ и др.);

- закрепление прав РФ на разведку и разработку ресурсов морского дна за пределами юрисдикции прибрежных государств.

В военной сфере основные усилия по совершенствованию механизмов ЗГС необходимо сосредоточить на противодействии «гуманитарным» интервенциям и попыткам военного вторжения, что предполагает:

- разработку и форсированное внедрение в эксплуатацию новейших систем преодоления ПРО США;

- ввод на боевое дежурство боевых железнодорожных ракетных комплексов (БЖРК);

- усиление орбитальной разведывательной группировки и компонентов системы ГЛОНАСС;

- инженерно-техническое оборудование, войсковое и оперативное прикрытие всех участков Государственной границы РФ;

- оперативное оборудование территорий и акваторий возможных театров военных действий Вооруженных Сил РФ;

- оснащение соединений и воинских частей специального назначения средствами автоматизации управления и связи, способными обеспечить передачу всех разведданных в реальном масштабе времени;

- модернизацию существующих комплексов технической разведки и развертывание новых в стратегических важных регионах СНГ и Дальнего Зарубежья;

- оснащение пограничных органов и органов безопасности, дислоцированных в приграничных регионах, беспилотными летательными аппаратами (БПЛА) с возможностями ведения геопространственной разведки;

- разработку и передачу в войска новейших систем военно-космической обороны, высокоточного оружия и средств радиоэлектронной борьбы, 
беспилотных летательных и автономных морских аппаратов, управляемых роботизированных образцов вооружения и военной техники, оружия на новых физических принципах;

- наращивание, обустройство и оснащение общевойсковой арктической группировки;

- комплексное обеспечение безопасности Калининградской области;

- формирование, обустройство и оснащение общевойсковой группировки сил мобильного развертывания на западном, южном и юговосточном стратегических направлениях (силы «антинатовского» реагирования с дислокацией в Южном, Северо-Кавказском, Крымском федеральных округах, в Республиках Беларусь, Абхазия и Южная Осетия);

- развитие портовой инфраструктуры и флота в Калининградской области, на Сахалине и Курильских островах;

- активное обновление вертолетного парка и транспортной авиации Вооруженных Сил, других войск и воинских формирований;

- строительство и ввод на боевое дежурство перспективных стратегических бомбардировщиков дальней авиации;

- государственный контроль над стратегически значимыми предприятиями и организациями военно-промышленного комплекса;

- поддержание постоянной мобилизационной готовности экономики государства;

- расширение состава и повышение боеспособности ОДКБ, создание общего оборонного пространства ОДКБ и совместное использование элементов военной инфраструктуры.

В сфере международного сотрудничества в интересах ЗГС необходимо:

- продвигать на международной арене российские инициативы по интернационализации управления сетью «Интернет» и укреплению роли Международного союза электросвязи; 
- завершить международно-правовое оформление Государственной границы РФ, предупреждать и пресекать территориальные претензии к России;

- развивать систему международных договоров РФ о поощрении и взаимной защите инвестиций, об обмене информации в налоговых целях;

- инициировать и продвигать заключение международных соглашений в сфере борьбы с незаконными валютными операциями и репатриации нелегально вывезенных капиталов;

- активизировать заключение международных договоров о признании судебных решений на основе взаимности;

- повышать эффективность функционирования международных организаций с традиционным влиянием РФ (ООН, ОБСЕ, СНГ, МПА СНГ, ШОС, ОДКБ, Парламентское Собрание Союза Беларуси и России);

- создавать и развивать альтернативные международные организации (Третейский Суд Таможенного Союза, Суд СНГ по правам человека);

- создавать условия для благоприятного развития международного сотрудничества РФ с иностранными государствами в области обеспечения национальной, региональной и международной безопасности ${ }^{1}$.

В качестве приоритетного направления целесообразно рассматривать двусторонний формат международного сотрудничества в интересах ЗГС. Необходимо использовать дифференцированные подходы к международному сотрудничеству и планировать развитие отношений в зависимости от конкретных результатов двустороннего взаимодействия. В случае

1 Примером такой работы может быть сотрудничество с международными партнерами по созданию новой системы Евроатлантической безопасности. Так, подготовленный РФ проект Договора о европейской безопасности был основан на принципах неделимости безопасности и необеспечения своей безопасности за счет безопасности других государств. Наиболее активное обсуждение проекта Договора с участием представителей США, ЕС, НАТО, СНГ и ОДКБ проходило в период с июня 2008 г. по ноябрь 2010 г. Ведущие европейские государства (Германия, Франция, Италия, Испания) признают необходимость создания новой системы безопасности. Вместе с тем, в новых геополитических условиях под давлением США страны ЕС не готовы к возобновлению конструктивных дискуссий на различных международных форумах. 
необходимости углубления сотрудничества возможно заключение договоров (соглашений) с заинтересованными зарубежными партнерами либо дополнительных протоколов к действующим договоренностям о международном сотрудничестве.

В информационной сфере для ЗГС необходимо:

- массово внедрять информационные и коммуникационные технологии в реальный сектор экономики;

- повысить информатизацию органов местного самоуправления, системы образования, здравоохранения, сферы услуг;

- осуществить ускоренный поэтапный перевод критических объектов информационной инфраструктуры на отечественную программную и элементную базу;

- создать условия для обеспечения технологического суверенитета в области информационных и коммуникационных технологий и преодоления информационного неравенства между развитыми и развивающимися странами

- формировать и развивать государственные информационные ресурсы, государственные сегменты сети «Интернет»²;

- обеспечивать накопление, сохранность, эффективное использование и безопасность важнейших отечественных информационных ресурсов на территории РФ $\Phi^{1}$;

${ }^{1}$ Подпункт «е» пункта 9 Основ государственной политики Российской Федерации в области международной информационной безопасности на период до 2020 года (утверждены Президентом РФ 24 июля 2013 г. № Пр-1753). Следует отметить, что большинство крупных иностранных компаний - производителей телекоммуникационного оборудования и программного обеспечения сотрудничают со спецслужбами своих стран, а ряд фирм выполняют их прямые заказы.

В целях защиты национального информационного пространства Министерство промышленности и информатизации КНР с 10 марта 2016 г. ввело запрет на работу электронных СМИ, полностью или частично принадлежащих иностранным резидентам. Китайские СМИ вправе сотрудничать с иностранными онлайн-СМИ только при наличии разрешения Министерства промышленности и информатизации КНР. В руководстве национальных СМИ могут работать только граждане Китая. Данный опыт представляет интерес и для РФ, столкнувшейся с беспрецедентным информационным давлением со стороны США и их союзников. Подробнее см. A. Бастрыкин. Пора поставить действенный заслон информационной войне! // Коммерсант Власть. 2016. 18 апреля. 
- развивать проектирование и внедрение конкурентоспособных отечественных средств связи, телекоммуникации, современного программного обеспечения операционных систем и систем управления базами данных ${ }^{2}$;

- противодействовать угрозам использования информационных и коммуникационных технологий для осуществления враждебных действий и актов агрессии, несанкционированного доступа к информационным ресурсам.

Совершенствование механизмов ЗГС в идеологической сфере предполагает:

- разработку и официальное утверждение системы государствообразующих идей и ценностей (национальной идеологической концепции) российского общества;

- распространение и укрепление позиций русского языка в мире, популяризацию культурных достижений народов России ${ }^{3}$;

- введение должности Управомоченного РФ по правам соотечественников в целях консолидации организаций соотечественников, более эффективной защиты ими своих прав в странах проживания,

${ }^{1}$ Примером может служить китайский опыт ЗГС в информационной сфере. Так, в соответствии с требованиями китайского законодательства серверы онлайн-СМИ могут находиться только на территории КНР.

2 Доля телекоммуникационного оборудования от американских и европейских поставщиков у российских операторов связи составляет от 95 до 99 процентов. Критичность этого обстоятельства заключается в том, что через это оборудование проходит весь объем голосовой информации, SMS-сообщений, интернет-трафика и финансовых транзакций. В сложившейся геополитической ситуации существует риск потерять контроль не только за информацией внутри страны, но и за функциями государственного управления через электронные средства коммуникации. При этом главная угроза может заключаться во внешнем деструктивном воздействии (остановка предоставления услуг по поддержке используемого программного обеспечения, отключение сетей связи на территории России за счет недекларированных возможностей зарубежного оборудования) / Постановление Совета Федерации от 26 ноября 2014 г. № 578-СФ «О развитии информационных технологий в Российской Федерации и мерах по поддержке отечественного производства средств связи».

3 Требуется внешнеполитическая поддержка усилий по приданию в государствах бывшего СССР русскому языку статуса второго государственного, что позволит избежать ущемления прав русскоязычных граждан и сохранит их национально-культурную идентичность. 
сохранения этнокультурной самобытности русской диаспоры («русского мира») и ее связей с исторической Родиной;

- активное участие в формировании интеллектуальной элиты в иностранных государствах, ориентированной на долгосрочное гуманитарное и культурное сотрудничество с Россией;

- расширение гуманитарного и культурного присутствия России в мире (развитие сети российских центров науки и культуры, гуманитарных некоммерческих организаций);

- активизацию использования потенциала традиционных конфессий и иных институтов гражданского общества для патриотического воспитания, распространения культуры межнационального общения, идей единства, исторической общности и добрососедства среди народов России;

- противодействие любым попыткам оправдания нацизма, героизации нацистских преступников и их пособников, в том числе в странах Прибалтики и на Украине; активное использование ресурсов сети «Интернет» для распространения исторической правды о Великой Отечественной войне, о роли народов СССР в разгроме гитлеровской Германии, о нацистских преступниках и их пособниках;

- проведение упреждающих информационно-пропагандистских мероприятий по нейтрализации искусственно созданного негативного образа России в мировых СМИ и формированию позитивного имиджа страны; противодействие русофобской и антисоветской пропаганде.

Таким образом, в рамках перечисленных сфер можно выделить несколько приоритетных направлений совершенствования конституционноправовых и иных механизмов ЗГС:

- Обеспечение устойчивого экономического развития и удовлетворения основных потребностей большинства населения государства.

Укрепление единства государственной власти и внутригосударственных интеграционных связей с учетом особенностей 
федеративного государственного устройства РФ.

- Формирование военно-политических, торгово-экономических, финансовых и иных союзов.

- Поддержание оборонного потенциала и системы национальной безопасности на уровне, обеспечивающем отражение любых внешних и внутренних угроз государственному суверенитету.

- Обеспечение технологического паритета и защищенности информационных ресурсов.

- Сохранение традиционных духовных ценностей, защита общественного сознания от деструктивных идей, противоречащих основам государства; консолидация общества на основе гражданственности и преданности государству.

- Повышение эффективности функционирования универсальных международных организаций и развитие модели многополярного миропорядка.

Указанные направления совершенствования конституционно-правовых и иных механизмов ЗГС в выделенных сферах не являются исчерпывающими, носят динамичный характер и могут корректироваться.

Как представляется, модернизация российской национальной системы ЗГС должна включать не только механизмы рефлексивного реагирования (пресечения и локализации) на возникающие угрозы и деструктивную деятельность антигосударственных сил по ослаблению и подрыву государственного суверенитета, но и механизмы раннего прогнозирования и предупреждения такой деятельности, наносящей ущерб государственному суверенитету. 


\section{ЗАКЛЮЧЕНИЕ}

Проведенное исследование показало, что государственный суверенитет, олицетворяя основу независимости государства и полноты его власти на своей территории, занимает в силу своей значимости центральное место в системе деструктивных антигосударственных посягательств.

Современная теория конституционного права, государственное строительство и международные отношения остро нуждаются в концептуальном и политико-правовом обосновании защиты государственного суверенитета (далее - ЗГС).

Комплексный анализ существующих подходов к пониманию государственного суверенитета позволяет выделить следующие основные положения.

1. Государственный суверенитет в конституционно-правовом смысле верховенство и независимость государственной власти внутри страны и за ее пределами, которые проявляются в способности государства самостоятельно решать любые внутри- и внешнеполитические задачи, обеспечивать реализацию своих властных полномочий в отношении всех субъектов права в пределах территориальной юрисдикции. Чем шире спектр применяемых государством полномочий по реализации своих внутренних и внешних функций, тем больше оснований вести речь о глубоком наполнении реального содержания государственного суверенитета.

2. Государственный суверенитет как категория международного права является постулатом международных отношений. Современное международное право основывается на фундаментальных принципах уважения государственного суверенитета, невмешательства во внутренние дела, суверенного равенства государств, признания нерушимости границ, неприменения силы или угрозы силой, разрешения споров мирными средствами. Такой подход обеспечивает наиболее полную реализацию 
большинством государств своих национальных интересов, возможность независимого развития внутри- и межгосударственных политических, социальных, экономических и культурных отношений.

3. Становление и развитие политико-правовой концепции государственного суверенитета определяется уровнем экономического, социального, политического и культурного развития государств и охватывало ряд этапов:

- обоснование независимости светской власти от духовной и отождествление суверенитета государства с суверенитетом его конкретного носителя;

- становление государственного суверенитета как особого свойства (характеристики) государственной власти, не связанной с конкретным носителем;

- распространение элементов суверенитета на общество (обоснование "народного суверенитета"), его взаимосвязь либо противопоставление государственному суверенитету;

- распространение суверенитета не только на общество, но и нацию (разграничение "государственного", "народного" и "национального" суверенитетов).

На современном этапе развития конституционного и международного права государственный суверенитет уже не отождествляется с абсолютной властью. Анализ международных и внутригосударственных правовых актов позволяет вычленить доктринально-нормативное понимание пределов государственного суверенитета, которое включает несколько элементов:

- Пределы государственного суверенитета устанавливаются Конституцией и законами в интересах граждан, общества и государства.

- Внутренние пределы государственного суверенитета неразрывно связаны с основополагающими правами и свободами человека. Суверенные права государства не могут использоваться для открытого подавления и 
произвольного ограничения прав и свобод человека. Государственные органы, общественные объединения и должностные лица обязаны уважать и обеспечивать реализацию основополагающих прав и свобод.

- Внешние пределы государственного суверенитета определяются международной правосубъектностью государства.

- Ограничение полноты и мощи государственной власти обеспечивается конституционными гарантиями (разделение властей; ответственность должностных лиц разных уровней; невозможность неконституционного порядка изменения или отмены Основного Закона и др.).

4. Суверенитет не зависит от формы государства и является динамичной характеристикой государства. Он может быть подорван и утрачен, что влечет за собой снижение качественных характеристик реализации функций государства в наиболее важных сферах общественной жизни или полную утрату способности государства осуществлять самостоятельное управление делами общества и государства. В силу этого государственный суверенитет нуждается в защите.

5. Учитывая выдвинутый подход к пониманию государственного суверенитета, ЗГС представляет собой постоянную активную правомерную деятельность государственных и негосударственных организаций, направленную на обеспечение верховенства и независимости государственной власти, беспрепятственную реализацию государственновластных полномочий во всех сферах общественной жизни, противодействие деструктивной деятельности антигосударственных сил по ослаблению и подрыву государственного суверенитета. Основанием ЗГС выступает деструктивная деятельность внутригосударственных и зарубежных субъектов по его ослаблению и подрыву, которая формирует реальные угрозы государственному суверенитету.

Проводимая руководством США и их союзниками политика 
глобального доминирования предполагает сохранение на максимально возможный период лидирующей роли Соединенных Штатов с помощью нанесения ущерба суверенным государствам, проводящим независимую политику, для чего в настоящее время используется ряд механизмов ослабления и подрыва их государственного суверенитета:

- экономические санкции, блокады, эмбарго и демпинг;

- "цветные революции";

- "гуманитарные" интервенции;

- тайная и открытая политическая, информационная, материальнотехническая и финансовая поддержка сепаратистских и иных антигосударственных сил;

- открытое военное вторжение.

Реализация данных деструктивных механизмов носит политикостратегический, долгосрочный характер и не зависит от императивов глав государств и правительств, текущего информационно-пропагандистского фона, экономической конъюнктуры, тактических установок спецслужб и органов внешних сношений.

6. Существует система внешних индикаторов - признаков, свидетельствующих об ослаблении и подрыве государственного суверенитета. Задача компетентных государственных структур своевременно обнаружить и зафиксировать эти признаки, выявить подготовку конкретных антигосударственных сценариев и принять ответные меры реагирования: ослабить воздействие или нейтрализовать угрозообразующие факторы, инициировать адекватные механизмы ЗГС.

Механизмы ослабления и подрыва государственного суверенитета, с одной стороны, и механизмы ЗГС, с другой, тесно взаимосвязаны и включают весь арсенал экономических, политических, дипломатических, идеологических, правовых и иных методов.

7. Существенное влияние на содержание и формы реализации 
государственного суверенитета оказывает глобализация. Рассматривая государственный суверенитет в контексте глобализации, нельзя обойти вниманием общие положительные и отрицательные последствия этого процесса для функционирования и развития суверенных государств.

В числе положительных последствий необходимо упомянуть: ускорение внедрения научно-технических достижений и современных методов государственного управления, новые экономические перспективы для хозяйствующих субъектов, возможности обеспечения более высокого уровня жизни граждан, объединение ресурсов для осуществления межгосударственных проектов.

В тоже время глобализацию как процесс всемирной универсализации нельзя оценивать только в положительном смысле. В числе негативных последствий глобализации можно вести речь:

- о закреплении экономической отсталости государств с развивающейся экономикой, вытеснении их с международных рынков;

- дискриминационном сотрудничестве с межгосударственными объединениями, международными организациями и форумами;

- соперничестве ценностных ориентиров и навязывании евроатлантических подходов к демократии, правам человека, новейшей истории;

- снижении авторитета и координирующей роли универсальных и региональных международных организаций.

8. Важнейшим последствием глобализации стало общее ослабление роли национальных государств и критический пересмотр содержания государственного суверенитета. Закономерной реакцией на уменьшение функциональности государств стало появление многочисленных теорий «ограничения государственного суверенитета», в которых обосновывается «глобальная квазигосударственность», «ограниченный или мягкий суверенитет», «гуманитарные интервенции». Данные теории объединены 
тем, что сформулированные в них идеи глобального управления маскируют создание наднациональных механизмов контроля над общемировым развитием. Научная разработка проблемы защиты государственного суверенитета требует недопущения пересмотра традиционной, общепризнанной концепции государственного суверенитета, противодействия теоретической аргументации насильственного ограничения суверенитета в обход существующих международно-правовых механизмов и процедур.

9. Государственный суверенитет неразрывно связан с правами человека и попытками ограничить полновластие государства.

Оценивая влияние основополагающих прав и свобод человека на адаптацию международной и конституционно-правовой доктрины государственного суверенитета к современным реалиям, необходимо отметить, что оно в целом носит конструктивный характер.

С другой стороны, концепция прав человека в силу своей надзаконной природы нередко выступает как субъективная оценочная категория. Если требуется идеологически оправдать какой-либо политический режим или стабилизировать общественные отношения, существующая правовая система и государственный строй объявляются единственно возможными и соответствующими правам человека. Если ставится цель общественных преобразований, смены власти, конституционный строй и правовое регулирование провозглашаются несоответствующими правам человека и несправедливыми.

Актуальная конструкция государственного суверенитета основана на уважении государством прав человека и предполагает не только гарантирование максимально возможного объема прав и свобод, реализацию разнообразных потребностей и интересов, но и ответственность граждан и взаимные обязательства государства и членов общества по отношению друг к другу. Только сильное независимое государство может обеспечить и 
защитить права человека.

10. В современных условиях потребности совершенствования механизмов ЗГС позволяют выделить несколько основных направлений ЗГС:

- Обеспечение устойчивого экономического развития и удовлетворения основных потребностей большинства населения государства.

- Формирование военно-политических, торгово-экономических, финансовых и иных союзов.

- Поддержание оборонного потенциала и системы национальной безопасности на уровне, обеспечивающем отражение любых внешних и внутренних угроз государственному суверенитету.

- Укрепление единства государственной власти и внутригосударственных интеграционных связей с учетом особенностей государственного устройства.

- Обеспечение технологического паритета и защищенности информационных ресурсов.

- Сохранение традиционных духовных ценностей, защита общественного сознания от деструктивных антигосударственных идей; консолидация общества на основе гражданственности и преданности государству.

- Повышение эффективности функционирования универсальных международных организаций и развитие модели многополярного миропорядка.

Как представляется, совершенствование конституционно-правовых и иных механизмов ЗГС в рамках предложенных направлений будет способствовать укреплению обороны и независимости страны, ее территориальной целостности, формированию благоприятных условий для социально-экономического развития РФ, укреплению региональной безопасности и сохранению устойчивости международно-правовой системы. 
11. В глобализирующемся мире гармонизация международной и национальных правовых систем, сближение правотворческой, правоприменительной и судебной практики нуждаются в обновленной концепции государственного суверенитета, предусматривающей вопросы национальной юрисдикции государств, вопросы юрисдикции наднациональных органов и международных организаций, а также перечень исчерпывающих оснований для международного вмешательства.

Выработка такой концепции возможна лишь в формате ООН с привлечением всех заинтересованных государств. Реализация согласованного подхода к определению правосубъектности государств, национальной и наднациональной юрисдикции, пределов ограничения государственного суверенитета, разработки исчерпывающих оснований для международного вмешательства во внутренние дела государств позволит избежать «двойных» стандартов в международных отношениях и оптимизировать существующие механизмы разрешения межгосударственных и внутренних конфликтов.

12. В настоящее время в России сформирована независимая национальная конституционно-правовая система, позволяющая осуществлять ЗГС внутри страны и за ее пределами, а также обеспечивать конституционные права и свободы граждан во всех сферах общественной жизни.

Комплексное конституционно-правовое регулирование стратегически важных групп общественных отношений, юридическое закрепление суверенных прав государства, поступательное развитие конституционноправовой доктрины способствовали укреплению государственного суверенитета РФ во всех сферах:

- в социально-экономической (разработка системы гарантий социальноэкономических прав граждан, ограничение деятельности монополий, обеспечение продовольственной безопасности, мобилизации и 
государственного оборонного заказа, защита единого экономического пространства, противодействие оффшоризации экономики, стимулирование репатриации капитала, легитимация специальных экономических, защитных, антидемпинговых и иных мер ЗГС);

- в политической (защита конституционных принципов формирования и функционирования органов государственной власти, территориальной целостности, верховенства Конституции, правовое обоснование несостоятельности региональных суверенитетов, регулирование статуса личности, деятельности политических партий, СМИ, местного самоуправления, подтверждение мер федерального принуждения);

- в идеологической (защита государственного языка, культурного достояния и национального культурного наследия, традиционных религиозных ценностей, контроль реституционных процессов, развитие системы образования и гражданско-патриотического воспитания, противодействие фальсификации истории, обеспечение социокультурной адаптации и интеграции мигрантов).

Системная работа федеральных и региональных органов власти, ориентированная на выработку и отстаивание общегосударственных интересов, задействование потенциала негосударственных (в том числе муниципальных) структур в публично-значимых целях, гибкое и адаптивное использование уполномоченными субъектами адекватных правовых механизмов ЗГС при наличии финансовой и ресурсной поддержки позволят повысить эффективность не только отдельных звеньев государственного механизма, но и функциональность государства в целом. 


\section{СПИСОК ИСПОЛЬЗОВАННЫХ ИСТОЧНИКОВ И ЛИТЕРАТУРЫ}

1. Конституция РФ (с учетом поправок, внесенных законами РФ о поправках к Конституции РФ от 30 декабря 2008 г., от 5 февраля 2014 г. и от 21 июля 2014 г.) // Рос. газ. 1993. 25 декабря; 2009. 21 января; СЗ РФ. 2014. № 31. Ст. 4398.

\section{Постановления и Определения Конституционного Суда РФ}

2. Постановление Конституционного Суда РФ от 13 марта 1992 г. № 3-П «По делу о проверке конституционности Декларации о государственном суверенитете Татарской ССР от 30 августа 1990 года, Закона Татарской ССР от 18 апреля 1991 года «Об изменениях и дополнениях Конституции (Основного Закона) Татарской ССР», Закона Татарской ССР от 29 ноября 1991 года «О референдуме Татарской ССР», постановления Верховного Совета Республики Татарстан от 21 февраля 1992 года «О проведении референдума Республики Татарстан по вопросу о государственном статусе Республики Татарстан» // Вестник Конституционного Суда РФ. 1993. № 1. С. 43-45.

3. Постановление Конституционного Суда РФ от 31 июля 1995 года по делу о проверке конституционности Указа Президента РФ от 30 ноября 1994 года № 2137 «О мероприятиях по восстановлению конституционной законности и правопорядка на территории Чеченской Республики», Указа Президента РФ от 9 декабря 1994 года № 2166 «О мерах по пресечению деятельности незаконных вооруженных формирований на территории Чеченской Республики и в зоне осетино-ингушского конфликта», Постановления Правительства РФ от 9 декабря 1994 года № 1360 «Об̆ обеспечении государственной безопасности и территориальной целостности Российской Федерации, законности, прав и свобод граждан, разоружения

незаконных вооруженных формирований на территории Чеченской Республики и прилегающих к ней регионов Северного Кавказа», Указа Президента РФ от 2 ноября 1993 года № 1833 «Об основных положениях военной доктрины Российской Федерации» // СЗ РФ. 1995. №33. Ст. 3424.

4. Постановление Конституционного Суда РФ от 7 июня 2000 г. № 10-П «По делу о проверке конституционности отдельных положений Конституции Республики Алтай и Федерального закона «Об общих принципах организации законодательных (представительных) и исполнительных органов государственной власти субъектов Российской Федерации» // СЗ РФ. 2000. № 25. Ст. 2728.

5. Постановление Конституционного Суда РФ от 30 ноября 2000 г. № 15-П «По делу о проверке конституционности отдельных положений Устава (Основного Закона) Курской области в редакции закона Курской области от 22 марта 1999 г. «О внесении изменений и дополнений в Устав (Основной Закон) Курской области» // СЗ РФ. 2000. № 50. Ст. 4943.

6. Постановление Конституционного Суда РФ от 4 апреля 2002 г. № 8П «По делу о проверке конституционности отдельных положений Федерального закона «Об общих принципах организации законодательных (представительных) и исполнительных органов государственной власти субъектов Российской Федерации» в связи с запросами Государственного Собрания (Ил Тумэн) Республики Саха (Якутия) и Совета Республики 
Государственного Совета - Хасэ Республики Адыгея» // Вестник Конституционного Суда РФ. 2002. № 5.

7. Постановление Конституционного Суда РФ от 19 марта 2003 г. № 3-П «По делу о проверке конституционности положений Уголовного кодекса Российской Федерации, регламентирующих правовые последствия судимости лица, неоднократности и рецидива преступлений, а также пунктов 1-8 Постановления Государственной Думы Федерального Собрания Российской Федерации от 26 мая 2000 г. «Об объявлении амнистии в связи с 55-летием Победы в Великой Отечественной Войне 1941-1945 годов» в связи с запросом Останкинского межмуниципального (районного) суда города Москвы и жалобами ряда граждан» // Рос. Газ. 2003. 2 апреля.

8. Постановление Конституционного Суда РФ от 3 марта 2004 г. № 5-П «По делу о проверке конституционности части 3 статьи 5 Федерального закона «О национально-культурной автономии» в связи с жалобой граждан А.Х. Дитца и О.А. Шумахер» // Вестник Конституционного Суда РФ. 2004. № 2.

9. Постановление Конституционного Суда РФ от 16 ноября 2004 г. № 16П «По делу о проверке конституционности положений пункта 2 статьи 10 Закона Республики Татарстан «О языках народов Республики Татарстан», части 2 статьи 9 Закона Республики Татарстан «О государственных языках Республики Татарстан и других языках в Республике Татарстан», пункта 2 статьи 6 Закона Республики Татарстан «Об образовании» и пункта 6 статьи 3 Закона Российской Федерации «О языках народов Российской Федерации» в связи с жалобой гражданина С.И. Хапугина и запросами Государственного Совета Республики Татарстан и Верховного Суда Республики Татарстан» // Рос. газ. 2004. 23 ноября.

10. Постановление Конституционного Суда РФ от 15 декабря 2004 г. № 18-П «По делу о проверке конституционности пункта 3 статьи 9 Федерального закона «О политических партиях» в связи с запросом Коптевского районного суда города Москвы, жалобами общероссийской общественной политической организации «Православная партия России» и граждан И.В. Артемова и Д.А. Савина»// Рос. газ. 2004. 24 декабря.

11. Постановление Конституционного Суда РФ от 28 июня 2007 г. № 8-П «По делу о проверке конституционности статьи 14.1 Федерального закона «О погребении и похоронном деле» и Положения о погребении лиц, смерть которых наступила в результате пресечения совершенного ими террористического акта, в связи с жалобой граждан К.И. Гузиева и Е.Х.Кармовой» // СЗ РФ. 2007. № 27. Ст. 3346.

12. Постановление Конституционного Суда РФ от 22 июня 2010 г. № 14-П «По делу о проверке конституционности подпункта «а» пункта 1 и подпункта «а» пункта 8 статьи 29 Федерального закона «Об основных гарантиях избирательных прав и права на участие в референдуме граждан Российской Федерации» в связи с жалобой гражданина А.М. Малицкого // Рос. газ. 2010. 7 июля.

13. Постановление Конституционного Суда РФ от 10 октября 2013 г. № 20 -П «По делу о проверке конституционности подпункта «а» пункта 3.2 статьи 4 Федерального закона «об основных гарантиях избирательных прав и права на участие в референдуме граждан Российской Федерации», части первой статьи 10 и части 6 статьи 86 УК РФ в связи с жалобами граждан Г.Б.Егорова, А.Л.Казакова, И.Ю.Кравцова, А.В. Куприянова, А.С. Латыпова и В.Ю. Синькова» // Рос. газ. 2013. 23 октября.

14. Постановление Конституционного Суда Российской Федерации от 6 декабря 2013 г. № 27-П «По делу о проверке конститущионности положений статьи 11 и пунктов 3 и 4 части 4 статьи 392 ГПК РФ в связи с запросом 
президиума Ленинградского окружного военного суда» // Рос. газ. 2013 . 18 декабря.

15. Постановление Конституционного Суда РФ от 19 марта 2014 г. № 6-П «По делу о проверке конституционности не вступившего в силу международного договора между Российской Федерацией и Республикой Крым и образовании в составе Российской Федерации новых субъектов» // Рос. газ. 2014. 20 марта.

16. Постановление Конституционного Суда РФ от 26 июня 2014 г. № 19-П «По делу о проверке конституционности положений части 18 статьи 35 Федерального закона «Об общих принципах организации местного самоуправления в Российской Федерации», пункта 4 статьи 10 и пункта 2 статьи 77 Федерального закона «Об основных гарантиях избирательных прав и права на участие в референдуме граждан Российской Федерации» и пункта 3 статьи 7 Закона Ивановской области «О муниципальных выборах» в связи с жалобой граждан А.В. Ерина и П.В. Лебедева»// Вестник Конституционного Суда РФ. 2014. № 5.

17. Постановление Конституционного Суда РФ от 14 июля 2015 г. № 21-П «По делу о проверке конституционности положений статьи 1 Федерального закона «О ратификации Конвенции о защите прав человека и основных свобод и Протоколов к ней», пунктов 1 и 2 статьи 32 Федерального закона «О международных договорах Российской Федерации», частей 1 и 4 статьи 11, пункта 4 части 4 статьи 392 Гражданского процессуального кодекса Российской Федерации, частей 1 и 4 статьи 13, пункта 4 части 3 статьи 311 Арбитражного процессуального кодекса Российской Федерации, частей 1 и 4 статьи 15, пункта 4 части 1 статьи 350 Кодекса административного судопроизводства Российской Федерации и пункта 2 части 4 статьи 413 Уголовно-процессуального кодекса Российской Федерации в связи с запросом группы депутатов Государственной Думы» // Рос. газ. 2015. 27 июля.

18. Постановление Конституционного Суда РФ от 1 декабря 2015 г. № 30-П «По делу о проверке конституционности частей 4, 5 и 5.1 статьи 35 , частей 2 и 3.1 статьи 36 Федерального закона «Об общих принципах организации местного самоуправления в Российской Федерации» и части 1.1 статьи 3 Закона Иркутской области «Об отдельных вопросах формирования органов местного самоуправления муниципальных образований Иркутской области» в связи с запросом группы депутатов Государственной Думы» // Рос. газ. 2015. 14 декабря.

19. Постановление Конституционного Суда РФ от 19 апреля 2016 г. № 12-П «По делу о разрешении вопроса о возможности исполнения в соответствии с Конституцией Российской Федерации постановления Европейского Суда по правам человека от 4 июля 2013 г. по делу «Анчугов и Гладков против России» в связи с запросом Министерства юстиции Российской Федерации» // Рос. газ. 2016. 5 мая.

20. Определение Конституционного Суда РФ от 27 июня 2000 г. № 92-О «По запросу группы депутатов Государственной Думы о проверке соответствия Конституции Российской Федерации отдельных положений Конституций Республики Адыгея, Республики Башкортостан, Республики Ингушетия, Республики Коми, Республики Северная Осетия - Алания и Республики Татарстан // СЗ РФ. 2000. № 29. Ст. 3117.

21. Определение Конституционного Суда РФ от 6 марта 2003 г. № 103-О «О проверке конституционности части 1 статьи 27 Федерального конституционного закона «О судебной системе Российской Федерации» // С3 РФ. 2003. № 17. Ст. 1658. 
22. Определение Конституционного Суда РФ от 4 декабря 2007 г. № 797О-О «Об отказе в принятии к рассмотрению жалобы гражданина Кара-Мурзы Владимира Владимировича на нарушение его конституционных прав положением пункта 3.1 статьи 4 Федерального закона «Об основных гарантиях избирательных прав и права на участие в референдуме граждан Российской Федерации» // Рос. газ. 2007. 26 декабря.

23. Определение Конституционного Суда РФ от 15 января 2009 г. N 187-О-О «Об отказе в принятии к рассмотрению жалоб гражданина Маркина Константина Александровича на нарушение его конституционных прав положениями статей 13 и 15 Федерального закона «О государственных пособиях гражданам, имеющим детей», статей 10 и 11 Федерального закона «О статусе военнослужащих», статьи 32 Положения о порядке прохождения военной службы и пунктов 35 и 44 Положения о назначении и выплате государственных пособий гражданам, имеющим детей». Документ не был опубликован.

24. Определение Конституционного Суда РФ от 29 сентября 2011 г. «Об отказе в принятии к рассмотрению жалобы гражданина Баукина В.А. на нарушение его конституционных прав статьей 1, частью 3 статьи 3 , частью 1 статьи 4 и частью 1 статьи 8 Федерального закона «О порядке осуществления иностранных инвестиций в хозяйственные общества, имеющие стратегическое значение для обеспечения обороны страны и безопасности государства». Документ не был опубликован.

\section{Международные акты}

25. Устав Организации Объединенных Наций (г. Сан-Франциско, 26 июня 1945 г.) / Действующее международное право. Т. 1. М.: Московский независимый институт международного права, 1996.

26. Устав Организации американских государств (г. Богота, 30 апреля 1948 г.) / Действующее международное право. Т. 2. М.: Московский независимый институт международного права, 1997.

27. Декларация о недопустимости вмешательства во внутренние дела государств, об ограждении их независимости и суверенитета (Нью-Иорк, 21 декабря г.) [URL] // http: WWw.un.org.ru/documents/decl_conv/declarations/inadmissibility_of_intervention.sht $\mathrm{ml}$ (дата обращения: 04.08.2015).

28. Декларация о принципах международного права, касающихся дружественных отношений и сотрудничества между государствами (27 октября 1970 г.). Электронный ресурс. URL://http wwW.un.org/ru/documents/declarations intlaw_principles.shtml (дата обращения 20.02.2015 г.)

29. Декларация об укреплении международной безопасности (Нью-Йорк, 16 декабря 1970 г.) / Действующее международное право. Т. 2. М.: Московский независимый институт международного права, 1997.

30. Заключительный акт СБСЕ (г. Хельсинки, 1 августа 1975 г.) / Действующее международное право. Т. 1. М.: Московский независимый институт международного права, 1996.

31. Декларация о недопустимости интервенции и вмешательства во внутренние дела государств (Нью-Иорк, 9 декабря 1981 г.) / Международное право. М.: Юрид. лит-ра, 2000. 
32. Манильская декларация о мирном разрешении международных споров (15 ноября 1982 г.) / Действующее международное право. Т. 1. М.: Московский независимый институт международного права, 1996.

33. Декларация о соблюдении принципов сотрудничества в рамках Содружества Независимых Государств (Минск, 14 февраля 1992 г.) // Информационный Вестник Совета глав государств и Совета глав правительств СНГ «Содружество». 1992. № 2.

34. Декларация о неприменении силы или угрозы силой во взаимоотношениях между государствами - участниками Содружества Независимых Государств (Киев, 20 марта 1992 г.) // Информационный Вестник Совета глав государств и Совета глав правительств СНГ «Содружество». 1992. № 4.

35. Декларация о соблюдении суверенитета, территориальной целостности и неприкосновенности границ государств-участников Содружества Независимых Государств (Москва, 15 апреля 1994) // Информационный Вестник Совета глав государств и Совета глав правительств СНГ «Содружество». 1994. № 1.

36. Меморандум о поддержании мира и стабильности в Содружестве Независимых Государств (Алматы, 10 февраля 1995 г.).

\title{
Нормативные правовые акты федеральных органов государственной власти
}

\author{
Федеральные конституционные и федеральные законь
}

37. Федеральный конституционный закон от 21 июля 1994 г. (с изм. и доп. от 8 июня 2015 г.) № 1-ФКЗ «О Конституционном Суде Российской Федерации» // Рос. газ. 1994. 23 июля.

38. Федеральный конституционный закон от 17 декабря 1997 г. (в ред. от 23 мая 2015 г.) № 2-ФКЗ «О Правительстве Российской Федерации» // Рос. газ. 1997. 23 декабря.

39. Федеральный конституционный закон от 31 декабря 1996 г. (с изм. и доп. от 5 февраля 2014 г.) № 1-ФКЗ «О судебной системе Российской Федерации» // Рос. газ. 1997. 6 января.

40. Федеральный конституционный закон от 23 июня 1999 г. (в ред. от 8 марта 2015 г.) № 1-ФКЗ «О военных судах Российской Федерации» // Рос. газ. 1999. 29 июня.

41. Федеральный конституционный закон от 30 мая 2001 г. № 3-ФК3 «О чрезвычайном положении» // Рос. газ. 2001. 2 июня.

42. Федеральный конституционный закон от 17 декабря 2001 г. (в ред. от 31 октября 2005 г.) «О порядке принятия в Российскую Федерацию и образования в ее составе нового субъекта Российской Федерации» // Рос. газ. 2001. 20 декабря.

43. Федеральный конституционный закон от 30 января 2002 г. № 1ФКЗ «О военном положении» // Рос. газ. 2002. 2 февраля.

44. Федеральный конституционный закон от 7 февраля 2011 г. (в ред. от 21 июля 2014 г.) № 1-ФКЗ «О судах общей юрисдикции в Российской Федерации» // СЗ РФ. 2011. № 7. Ст. 898. 
45. Федеральный конституционный закон от 21 марта 2014 г. № 6ФК3 «О принятии в Российскую Федерацию и образовании в составе Российской Федерации новых субъектов - Республики Крым и города федерального значения Севастополя» // Рос. газ. 2014. 24 марта.

46. Федеральный закон от 3 апреля 1995 г. № 40-Ф3 «О федеральной службе безопасности» // Рос. газ. 1995. 12 апреля.

47. Федеральный закон от 23 июня 1995 г. (с изм. от 4 июня 2014 г.) «О порядке предоставления Российской Федерацией военного и гражданского персонала для участия в деятельности по поддержанию международного мира и безопасности» // Рос. газ. 1995. 30 июня.

48. Федеральный закон от 15 июля 1995 г. (в ред. от 2 марта 2014 г.) № 101-Ф3 «О международных договорах Российской Федерации» // Рос. газ. 1995. 21 июля.

49. Федеральный закон от 30 ноября 1995 г. (в ред. от 2 мая 2015 г.) № 187-Ф3 «О континентальном шельфе Российской Федерации» // Рос. газ. 1995. 17 декабря.

50. Федеральный закон от 10 января 1996 г. (в ред. от 30 декабря 2015 г.) № 5-Ф3 «О внешней разведке»// Рос. газ. 1996. 17 января.

51. Федеральный закон от 31 мая 1996 г. № 61-Ф3 «Об обороне»// Рос. газ. 1996. 6 июня.

52. Федеральный закон от 17 июня 1996 г. (в ред. от 4 ноября 2014 г.) № 74-Ф3 «О национально-культурной автономии» // Рос. газ. 1996. 25 июня.

53. Федеральный закон от 15 августа 1996 г. (в ред. от 30 декабря 2015 г.) № 114-Ф3 «О порядке выезда из Российской Федерации и въезда в Российскую Федерацию» // СЗ РФ. 1996. № 34. Ст. 4029.

54. Воздушный кодекс Российской Федерации от 19 марта 1997 г. (в ред. от 26 апреля 2016 г.) № 60-Ф3 // СЗ РФ. 1997. № 12. Ст. 1383.

55. Федеральный закон от 21 июля 1997 г. (в ред. от 13 июля 2015 г.) № 116-Ф3 «О промышленной безопасности опасных производственных объектов» // С3 РФ. 1997. № 30. Ст. 3588.

56. Федеральный закон от 26 марта 1998 г. (в ред. от 2 мая 2015 г.) № 41-Ф3 «О драгоценных металлах и драгоценных камнях»// С3 РФ. 1998. № 13. СТ. 1463 .

57. Федеральный закон от 31 июля 1998 г. (в ред. от 13 июля 2015 г.) № 155-Ф3 «О внутренних морских водах, территориальном море и прилежащей зоне Российской Федерации» // Рос. газ. 1998. 6 августа.

58. Федеральный закон от 17 декабря 1998 г. (в ред. от 14 октября 2014 г.) № 191-Ф3 «Об исключительной экономической зоне Российской Федерации» // Рос. газ. 1998. 24 декабря.

59. Федеральный закон от 4 января 1999 г. (с изм. от 13 июля 2015 г.) № 4-Ф3 «О координации международных и внешнеэкономических связей субъектов Россииской Федерации» // Рос. газ. 1999. 16 января.

60. Федеральный закон от 9 июля 1999 г. (в ред. от 5 мая 2014 г.) № 160-Ф3 «Об иностранных инвестициях в Российской Федерации» // С3 РФ. 1999. № 28. Ст. 3493.

61. Федеральный закон от 6 октября 1999 г. (в ред. от 28 декабря 2010 г.) № 184-Ф3 «Об общих принципах организации законодательных 
(представительных) и исполнительных органов государственной власти субъектов Российской Федерации» // СЗ РФ. 1999. № 42. Ст. 5005.

62. Федеральный закон от 11 июля 2001 г. (в ред. от 5 апреля 2011 г.) № 95-Ф3 «О политических партиях» // СЗ РФ. 2001. № 29. Ст. 2950.

63. Федеральный закон от 31 мая 2002 г. № 62-Ф3 «О гражданстве Российской Федерации» // Рос. газ. 2002. 5 июня.

64. Федеральный закон от 12 июня 2002 г. (в ред. от 20 марта 2011 г.) № 67-Ф3 «Об основных гарантиях избирательных прав и права на участие в референдуме граждан Российской Федерации» // Рос. газ. 2002. 15 июня.

65. Федеральный закон от 10 июля 2002 г. (в ред. от 30 декабря 2015 г.) № 86-Ф3 «О Дентральном банке Российской Федерации (Банке России)» // Рос. газ. 2002. 13 июля.

66. Федеральный закон от 25 июля 2002 г. № 114-Ф3 «О противодействии экстремистской деятельности» // Рос. газ. 2002. 30 июля.

67. Федеральный закон от 25 июля 2002 г. (в ред. от 30 декабря 2015 г.) № 115-Ф3 «О правовом положении иностранных граждан в Российской Федерации» // Рос. газ. 2002. 31 июля.

68. Федеральный закон от 10 января 2003 г. (в ред. от 28 декабря 2010 г.) № 19-Ф3 «О выборах Президента Российской Федерации»// Рос. газ. 2003. 16 января.

69. Федеральный закон от 8 декабря 2003 г. (в ред. от 13 июля 2015 г.) № 164-Ф3 «Об основах государственного регулирования внешнеторговой деятельности» //Рос. газ. 2003. 18 декабря.

70. Федеральный закон от 8 декабря 2003 г. № 165-Ф3 «О специальных защитных, антидемпинговых и компенсационных мерах при импорте товаров» // Рос. газ. 2003. 17 декабря.

71. Федеральный закон от 18 мая 2005 г. (в ред. от 23 февраля 2011 г.) № 51-Ф3 «О выборах депутатов Государственной Думы Федерального Собрания Российской Федерации» // Рос. газ. 2005. 24 мая.

72. Федеральный закон от 6 марта 2006 г. № $\quad 35-\Phi 3 ~ « О$ противодействии терроризму» // Рос. газ. 2006. 10 марта.

73. Федеральный закон от 18 июля 2006 г. (в ред. от 28 ноября 2015 г.) № 109-Ф3 «О миграционном учете иностранных граждан и лиц без гражданства в Российской Федерации» // Рос. газ. 2006. 20 июля.

74. Федеральный закон от 26 июля 2006 г. № 135-Ф3 (в ред. от 5 октября 2015 г.) «О защите конкуренции»// С3 РФ. 2006. № 31 (ч.1). Ст. 3434.

75. Федеральный закон от 30 декабря 2006 г. № 281-Ф3 «О специальных экономических мерах» // Рос. газ. 2007. 10 января.

76. Федеральный закон от 9 февраля 2007 г. (в ред. от 13 июля 2015 г.) № 16-ФЗ «О транспортной безопасности» // С 3 РФ. 2007 . № 7. Ст. 837.

77. Федеральный закон от 29 апреля 2008 г. № 57-Ф3 «О порядке осуществления иностранных инвестиций в хозяйственные общества, имеющие стратегическое значение для обеспечения обороны страны и безопасности государства» // Рос. газ. 2008. 7 мая.

78. Федеральный закон от 25 декабря 2008 г. № 273-Ф3 «О противодействии коррупции» // Рос. газ. 2008. 30 декабря. 
79. Федеральный закон от 5 апреля 2010 г. № 54-Ф3 «О ратификации Соглашения между Российской Федерацией и Республикой Абхазия о совместных усилиях в охране государственной границы Республики Абхазии» // Рос. газ. 2010. 7 апреля.

80. Федеральный закон от 5 апреля 2010 г. № 59-Ф3 «О ратификации Соглашения между Российской Федерацией и Республикой Южная Осетия о совместных усилиях в охране государственной границы Республики Южная Осетия» // Рос. газ. 2010. 7 апреля.

81. Федеральный закон от 27 ноября 2010 г. (в ред. от 13 июля 2015 г.) № 31-Ф3 «О таможенном регулировании в Российской Федерации»// Рос. газ. 2010. 29 ноября.

82. Федеральный закон от 28 декабря 2010 г. № 390-Ф3 «О безопасности»// Рос. газ. 2010. 29 декабря.

83. Федеральный закон от 28 декабря 2010 г. № 403-Ф3 «О Следственном комитете Российской Федерации» // Рос. газ. 2010. 30 декабря.

84. Федеральный закон от 7 февраля 2011 г. № 3-Ф3 «О полиции» // С3 РФ. 2011. № 7. С т. 900.

85. Федеральный закон от 6 апреля 2011 г. (в ред. от 28 октября 2013 г.) № 64-Ф3 «Об административном надзоре за лицами, освобожденными из мест лишения свободы» // Рос. газ. 2011. 8 апреля.

86. Федеральный закон от 21 июля 2011 г. ( в ред. от 14 октября 2014 г.) № 256-Ф3 «О безопасности объектов топливно-энергетического комплекса» // СЗ РФ. 2011. № 30 (ч.1). Ст. 4604.

87. Федеральный закон от 20 июля 2012 г. № 121-Ф3 «О внесении изменений в отдельные законодательные акты Российской Федерации в части регулирования деятельности некоммерческих организаций, выполняющих функции иностранного агента» // Рос. газ. 2012. 23 июля.

88. Федеральный закон от 28 июля 2012 г. № 132-Ф3 «О внесении изменений в отдельные законодательные акты Российской Федерации в части государственного регулирования торгового мореплавания в акватории Северного морского пути» // СЗ РФ. 2012. № 31. Ст. 4321.

89. Федеральный закон от 3 декабря 2012 г. № 230-Ф3 «О контроле за соответствием расходов лиц, замещающих государственные должности, и иных лиц их доходам» // Рос. газ. 2012. 5 декабря.

90. Федеральный закон от 28 декабря 2012 г. № 272-Ф3 «О мерах воздействия на лиц, причастных к нарушениям основополагающих прав и свобод человека, прав и свобод граждан Российской Федерации» // Рос. газ. 2012. 28 декабря.

91. Федеральный закон от 7 мая 2013 г. № 79-Ф3 «О запрете отдельным категориям лиц открывать и иметь счета (вклады), хранить наличные денежные средства и ценности в иностранных банках, расположенных за пределами территории Российской Федерации, владеть и (или) пользоваться иностранными финансовыми институтами»// С3 РФ. 2013. № 19. Ст. 2306.

92. Федеральный закон от 24 ноября 2014 г. (в ред. от 15 февраля 2016 г.) № 376-Ф3 «О внесении изменений в части первую и вторую Налогового кодекса Российской Федерации (в части налогообложения прибыли контролируемых иностранных компаний и доходов иностранных организаций)» // С3 РФ. 2014. № 48. Ст. 6657. 
93. Федеральный закон от 29 июня 2015 г. № 161-Ф3 «Об особенностях правового регулирования отношений в сфере пользования недрами в связи с принятием в Российскую Федерацию Республики Крым и образованием в составе Российской Федерации новых субъектов Республики Крым и города федерального значения Севастополя» // C3 РФ. 2015. № 27. Ст. 3952.

94. Федеральный закон от 3 ноября 2015 г. № 297-Ф3 «О юрисдикционных иммунитетах иностранного государства и имущества иностранного государства в Российской Федерации»// Рос. газ. 2015. 6 ноября.

\section{Законы РФ и РСФСР, иные правовые акты РСФСР}

95. Закон РСФСР от 31 октября 1990 № 293-1«Об обеспечении экономической основы суверенитета Российской Советской Федеративной Социалистической Республики» // Ведомости СНД РСФСР и ВС РСФСР. 1990. № 22.

96. Закон РФ от 25 октября 1991 (с изм. от 12 марта 2014 г.) г. № 1807 - 1 «О языках народов Российской Федерации» // Ведомости СНД и ВС РФ. 1991. № 50. Ст. 1740.

97. Закон РФ от 17 января 1992 г. (в ред. от 7 февраля 2011 г.) № 22021 «О прокуратуре Российской Федерации» // Рос. газ. 1992. 18 февраля.

98. Закон РФ от 21 февраля 1992 г. (в ред. от 13 июля 2015 г.) № 2395-1 «О недрах» // СЗ РФ. 1995. № 10. Ст. 823.

99. Закон РФ от 26 июня 1992 г. № 3132-1 «О статусе судей в Российской Федерации» // Рос. газ. 1992. 29 июля.

100. Закон РФ от 14 июля 1992 г. (в ред. от 13 июля 2015 г.) № 3297-1 «О закрытом административно-территориальном образовании» // Рос. газ. 1992. 26 августа.

101. Закон РФ от 15 апреля 1993 г. (с изм. от 23 июля 2013 г.) № 48041 «О вывозе и ввозе культурных ценностей» // Рос. газ. 1993. 15 мая.

102. Закон РФ от 21 июля 1993 г. (в ред. от 20 апреля 2015 г.) № $5473-$ 1 «Об учреждениях и органах, исполняющих уголовные наказания в виде лишения свободы» // Ведомости СНД и ВС РФ. 1993. № 33. Ст. 1316.

103. Закон РФ от 21 июля 1993 г. (в ред. от 8 марта 2015 г.) № 5485-1 «О государственной тайне» // Рос. газ. 1993. 21 сентября.

104. Декларация о государственном суверенитете Российской Советской Федеративной Социалистической Республики от 12 июня 1990 г. // Ведомости СНД РСФСР и ВС РСФСР. 1990. № 2. Ст. 22.

\section{Постановления Государственной Думы и Совета Федераичи Федерального Собрания РФ}

105. Постановление Государственной Думы Федерального Собрания РФ от 1 апреля 2014 г. № 4056-6 ГД «О заявлении Государственной Думы Федерального Собрания Российской Федерации «О ситуации в Парламентской Ассамблее Совета Европы» // Парламентская газета. 2014. 4 10 апреля. 
106. Постановление Государственной Думы Федерального Собрания РФ от 4 апреля 2014 г. № 4075-6 ГД «О заявлении Государственной Думы Федерального Собрания Российской Федерации «О политических репрессиях на Украине» // Парламентская газета. 2014. 11-17 апреля.

107. Постановление Государственной Думы Федерального Собрания РФ от 18 апреля 2014 г. № 4160-6 ГД «О заявлении Государственной Думы Федерального Собрания Российской Федерации «Об антироссийской резолюции Парламентской Ассамблеи Совета Европы» // Парламентская газета. 2014. 25 апреля - 7 мая.

108. Постановление Совета Федерации Федерального Собрания РФ от 21 июня 1994 г. № 136-1 СФ «Об использовании Вооруженных Сил Российской Федерации для проведения операции по поддержанию мира в зоне грузино-абхазского конфликта»// Ведомости ФС РФ. 1994. №6. Ст. 262.

109. Постановление Совета Федерации Федерального Собрания РФ от 25 августа 2008 г. № 298-СФ «Об использовании дополнительных миротворческих сил Вооруженных Сил Российской Федерации для поддержания мира и безопасности в зоне грузино-абхазского конфликта»// СЗ РФ. 2008. № 35. Ст. 3996.

110. Постановление Совета Федерации Федерального Собрания РФ от 1 марта 2014 г. № 48-СФ «Об использовании Вооруженных Сил Российской Федерации на территории Украины» // СЗ РФ. 2014. 3 марта.

111. Постановление Совета Федерации Федерального Собрания РФ от 16 апреля 2014 г. № 126-СФ «О заявлении Совета Федерации Федерального Собрания Российской Федерации в связи с ограничением деятельности российских СМИ на Украине» // Парламентская газета. 2014. 18 - 24 апреля.

112. Постановление Совета Федерации Федерального Собрания РФ от 25 июня 2014 г. № 296-СФ «Об отмене Постановления Совета Федерации Федерального Собрания Российской Федерации от 1 марта 2014 г. № 48-СФ «Об использовании Вооруженных Сил Российской Федерации на территории Украины» // СЗ РФ. 2014. № 26 (ч.2). Ст. 3442.

113. Постановление Совета Федерации Федерального Собрания РФ от 26 ноября 2014 г. № 578-СФ «О развитии информационных технологий в Российской Федерации и мерах по поддержке отечественного производства средств связи» // СЗ РФ. 2014. № 48. Ст. 6738.

114. Постановление Совета Федерации Федерального Собрания РФ от 28 января 2015 г. № 16-СФ «О заявлении Совета Федерации Федерального Собрания Российской Федерации в связи с обострением ситуации на ЮгоВостоке Украины» // Парламентская газета. 2015. 30 января - 5 февраля.

115. Постановление Совета Федерации Федерального Собрания РФ от 25 февраля 2015 г. № 49-СФ «О заявлении Совета Федерации Федерального Собрания Российской Федерации о ситуации на Украине»// Парламентская газета. 2015. 27 февраля - 5 марта.

116. Постановление Совета Федерации Федерального Собрания РФ от 25 февраля 2015 г. № 51-СФ «О сохранении и развитии русского языка, повышении его роли в области международных культурных и гуманитарных связей» // СЗ РФ. 2015. № 9. Ст. 1217.

117. Постановление Совета Федерации Федерального Собрания РФ от 20 мая 2015 г. № 186-СФ «Об итогах парламентских слушаний «Политикоправовые аспекты противодействия реабилитации нацизма, героизации нацистских преступников и их пособников: сравнительный анализ и уроки на будущее // С3 РФ. 2015. № 21. Ст. 3001. 


\section{Указы Президента и Постановления Правительства РФ}

118. Указ Президента РФ от 23 ноября 1995 г. (с изм. от 15 марта 1999 г.) № 1173 «О мерах по осуществлению устойчивого функционирования объектов, обеспечивающих безопасность государства» // СЗ РФ. 1995. № 48. Ст. 4658.

119. Указ Президента РФ от 11 августа 2003 г. (в ред. от 20 января 2015 г.) № 960 «Вопросы Федеральной службы безопасности Российской Федерации» // Рос. газ. 2003. 15 августа.

120. Указ Президента РФ от 11 июля 2004 г. (в ред. от 12 марта 2015 г.) № 865 «Вопросы Министерства иностранных дел Российской Федерации» // СЗ РФ. 2004. № 28. Ст. 2880.

121. Указ Президента РФ от 11 июля 2004 г. (в ред. от 12 марта 2015 г.) № 868 «Вопросы Министерства Российской Федерации по делам гражданской обороны, чрезвычайным ситуациям и ликвидации последствий стихийных бедствий» // СЗ РФ. 2004. № 28. Ст. 2882.

122. Указ Президента РФ от 13 октября 2004 г. (в ред. от 12 сентября 2015 г.) № 1313 «Вопросы Министерства юстиции Российской Федерации» // Рос. газ. 2004. 19 октября.

123. Указ Президента РФ от 13 октября 2004 г. (в ред. от 27 ноября 2015 г.) № 1314 «Вопросы Федеральной службы исполнения наказаний» // Рос. газ. 2004. 19 октября.

124. Указ Президента РФ от 15 февраля 2006 г. (в ред. от 26 декабря 2015 г.) № 116 «О мерах по противодействию терроризму» // Рос. газ. 2006. 17 февраля.

125. Указ Президента РФ от 26 августа 2008 г. № 1260 «О признании Республики Абхазия» // Рос. газ. 2008. 29 августа.

126. Указ Президента РФ от 26 августа 2008 г. № 1261 «О признании Республики Южная Осетия» // Рос. газ. 2008. 29 августа.

127. Указ Президента РФ от 6 сентября 2008 г. № 1315 «О некоторых вопросах государственного управления в области международного сотрудничества»// СЗ РФ. 2008. № 37. Ст. 4181.

128. Указ Президента РФ от 1 марта 2011 г. (в ред. от 12 сентября 2015 г.) № 248 «Вопросы Министерства внутренних дел Российской Федерации» // Рос. газ. 2011. 2 марта.

129. Указ Президента РФ от 13 июня 2012 г. (в ред. от 20 января 2015 г.) № 808 «Вопросы Федеральной службы по финансовому мониторингу» // СЗ РФ. 2012. № 25. Ст. 3314.

130. Указ Президента РФ от 6 августа 2014 г. № 560 «О применении отдельных специальных экономических мер в целях обеспечения безопасности Российской Федерации» // Рос. газ. 2014. 7 августа.

131. Указ Президента РФ от 24 июня 2015 г. № 320 «О продлении действия отдельных специальных экономических мер в целях обеспечения безопасности Российской Федерации» // СЗ РФ. 2015. № 36. Ст. 3878.

132. Указ Президента РФ от 28 ноября 2015 г. (в ред. от 28 декабря 2015 г.) № 583 «О мерах по обеспечению национальной безопасности Российской Федерации и защите граждан Российской Федерации от преступных и иных противоправных действий и о применении специальных 
экономических мер в отношении Турецкой Республики» // Рос. газ. 2015. 29 декабря.

133. Указ Президента РФ от 16 декабря 2015 г. № $628 \ll \mathrm{O}$ приостановлении Российской Федерацией действия Договора о зоне свободной торговли в отношении Украины» // Рос. газ. 2015. 17 декабря.

134. Указ Президента РФ от 1 января 2016 г. № 1 «О мерах по обеспечению экономической безопасности и национальных интересов Российской Федерации при осуществлении международных транзитных перевозок грузов с территории Украины на территорию Республики Казахстан через территорию Российской Федерации» // Рос. газ. 2016. 20 января.

135. Указ Президента РФ от 5 апреля 2016 г. № 157 «Вопросы Федеральной службы войск национальной гвардии Российской Федерации» // СЗ РФ. 2016. № 15. Ст. 2072.

136. Постановление Правительства РФ от 4 июля 1992 г. (в ред. от 3 июля 2014 г.) № 470 «Об утверждении Перечня территорий Российской Федерации с регламентированным посещением для иностранных граждан» // Собрание актов Президента и Правительства Российской Федерации. 1992. № 2. Ст. 37.

137. Постановление Правительства РФ от 22 августа 1998 г. (с изм. от 27 мая 2008 г.) № 1003 «Об утверждении Положения о порядке допуска лиц, имеющих двойное гражданство, лиц без гражданства, а также лиц из числа иностранных граждан, эмигрантов и реэмигрантов к государственной тайне» // Рос. газ. 1998. 4 сентября.

138. Постановление Правительства РФ от 2 октября 1999 г. № $1102 « \mathrm{O}$ правилах плавания и пребывания иностранных военных кораблей и других государственных судов, эксплуатируемых в некоммерческих целях, в территориальном море, во внутренних морских водах, на военно-морских базах, в пунктах базирования военных кораблей и морских портах Российской Федерации» // СЗ РФ. 1999. № 42. Ст. 5030.

139. Постановление Правительства РФ от 11 октября 2002 г. ( с изм. от 14 июля 2006 г.) № 754 «Об утверждении перечня территорий, организаций и объектов, для въезда на которые иностранным гражданам требуется специальное разрешение» // Рос. газ. 2002. 16 октября.

140. Постановление Правительства РФ от 7 апреля 2003 г. (в ред. от 14 декабря 2009 г.) № 199 «Об утверждении Положения о принятии решения о нежелательности пребывания (проживания) иностранного гражданина или лица без гражданства в Россииской Федерации и перечня федеральных органов исполнительной власти, уполномоченных принимать решение о нежелательности пребывания (проживания) иностранных граждан или лиц без гражданства в Российской Федерации» // Рос. газ. 2003. 11 апреля.

141. Постановление Правительства РФ от 30 декабря 2008 г. № 1079 (в ред. от 23 октября 2014 г.) «О совершенствовании государственного регулирования внешнеэкономической деятельности в отношении отдельных видов товаров и технологий в целях обеспечения национальной безопасности» // С3 РФ. 2009. № 3. Ст. 386.

142. Постановление Правительства РФ от 2 октября 2009 г. № 783 (в ред. от 4 февраля 2011 г.) «О некоторых мерах по реализации Федеральных законов «О континентальном шельфе Российской Федерации» и «Об исключительной экономической зоне Российской Федерации» // СЗ РФ. 2009. № 41. Ст. 4769. 
143. Постановление Правительства РФ от 2 сентября 2010 г. № 663 (в ред. от 22 октября 2012 г.) «О дополнительных мерах по реализации Федеральных законов «О континентальном шельфе Российской Федерации», «О внутренних морских водах, территориальном море и прилежащей зоне Российской Федерации» и «Об исключительной экономической зоне Российской Федерации» // С3 РФ. 2010. № 37. Ст. 4679.

144. Постановление Правительства РФ от 20 июля 2011 г. № $590 « \mathrm{O}$ Министерстве культуры Российской Федерации»// С3 РФ. 2011. № 31. Ст. 4758.

145. Постановление Правительства РФ от 7 августа 2014 г. № $778 « \mathrm{O}$ мерах по реализации Указа Президента Российской Федерации от 6 августа 2014 г. № 560 «О применении отдельных специальных экономических мер в целях обеспечения безопасности Российской Федерации»// Рос. газ. 2014. 8 августа.

146. Постановление Правительства РФ от 13 августа 2015 г. № $842 « \mathrm{O}$ дополнении списка стран, в отношении которых вводится запрет на ввоз в Россию сельскохозяйственной продукции, сырья и продовольствия»// Рос. газ. 2015. 17 августа.

147. Постановление Правительства РФ от 15 августа 2015 г. № $845 « \mathrm{O}$ континентальном шельфе Российской Федерации в Охотском море» // Рос. газ. 2015. 28 августа.

148. Постановление Правительства РФ от 29 сентября 2015 г. № 1031 «Об утверждении Правил принятия решения о предоставлении права пользования участками недр, расположенными в Черном и Азовском морях, в пределах которых Россииская Федерация осуществляет суверенитет, суверенные права или юрисдикцию в связи с принятием в Российскую Федерацию Республики Крым и образованием в составе Российской Федерации новых субъектов - Республики Крым и г. Севастополя» // С3 РФ. 2015. № 41 (ч. II). С Т. 5653.

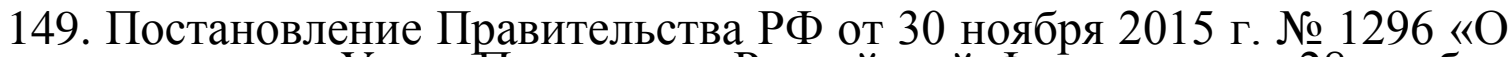
мерах по реализации Указа Президента Российской Федерации от 28 ноября 2015 г. № 583 «О мерах по обеспечению национальной безопасности Российской Федерации и защите граждан Российской Федерации от преступных и иных противоправных действий и о применении специальных экономических мер в отношении Турецкой Республики» // Рос. газ. 2015. 2-3 декабря.

\section{Документы стратегического планирования РФ}

150. Доктрина информационной безопасности Российской Федерации (утверждена Президентом Российской Федерации 9 сентября 2000 г., № Пр1895) // Рос. газ. 2000. 28 сентября.

151. Морская доктрина Российской Федерации на период до 2020 г. (утверждена Президентом РФ 27 июля 2001 г.)

152. Концепция демографической политики Российской Федерации на период до 2025 г. (утверждена Указом Президента РФ от 9 октября 2007 г. № 1351 (в ред. от 1 июля 2014 г.)) // Парламентская газета. 2007. 16 октября.

153. Основы государственной политики Российской Федерации в Арктике на период до 2020 г. и дальнейшую перспективу (утверждены Президентом РФ 18 сентября 2008 г.) // Рос. газ. 2009. 30 марта.

154. Концепция долгосрочного социально-экономического развития Российской Федерации на период до 2020 г. (утверждена распоряжением 
Правительства РФ от 17 ноября 2008 г. (с изм. от 8 августа 2009 г.) // СЗ РФ. 2008. № 47. Ст. 5489.

155. Доктрина продовольственной безопасности Российской Федерации (утверждена Указом Президента РФ от 30 января 2010 г. № 120) // Рос. газ. 2010. 3 февраля.

156. Стратегия государственной антинаркотической политики Российской Федерации до 2020 г. (утверждена Указом Президента РФ от 9 июня 2010 г. № 690) // Рос. газ. 2010. 15 июня.

157. Концепция государственной миграционной политики Российской Федерации на период до 2025 г. (утверждена Президентом РФ 13 июня 2012 г.).

158. Стратегия государственной национальной политики Российской Федерации на период до 2025 г. (утверждена Указом Президента РФ от 19 декабря 2012 г. № 1666) // СЗ РФ. 2012. № 52. Ст. 7477.

159. Стратегия развития Арктической зоны Российской Федерации и обеспечения национальной безопасности на период до 2020 г. (утверждена Президентом РФ 8 февраля 2013 г.).

160. Концепция внешней политики Российской Федерации (утверждена 12 февраля 2013 г.).

161. Основы государственной политики Российской Федерации в области международной информационной безопасности на период до 2020 г. (утверждены Президентом РФ 24 июля 2013 г., № Пр-1753).

162. Стратегия противодействия экстремизму в Российской Федерации до 2025 г. (утверждена Президентом РФ 28 ноября 2014г., Пр2753).

163. Основы государственной культурной политики (утверждены Указом Президента РФ от 24 декабря 2014 г. № 808) // С3 РФ. 2014. № 52 (ч.1). Ст. 7753.

164. Военная доктрина Российской Федерации (утверждена Президентом РФ 25 декабря 2014 г., № Пр-2976) // Рос. газ. 2014. 30 декабря.

165. Стратегия национальной безопасности Российской Федерации (утверждена Указом Президента РФ от 31 декабря 2015 г. № 683).

\section{Нормативные правовые акты министерств и ведомств РФ}

166. Приказ Министерства обороны РФ, Минтранса России и Росавиакосмоса от 31 марта 2002 г. № 136/42/51 «Об утверждении Федеральных авиационных правил полетов в воздушном пространстве Российской Федерации» // Рос. газ. 2002. 13 августа.

167. Приказ Министерства природных ресурсов РФ от 4 апреля 2002 г. № 167 «О регламенте организации работы по реализации Федеральных законов «О континентальном шельфе», «О внутренних морских водах, территориальном море и прилежащей зоне Российской Федерации», постановлений Правительства РФ от 26 января 2000 г. № 68 и от 19 января 2000 г. № 44.

168. Приказ МИД России от 27 июля 2007 г. № 12828 «Об утверждении Правил государственной регистрации и государственного учета 
международных договоров Российской Федерации» // Бюллетень нормативных актов федеральных органов исполнительной власти. 2007. № 38 .

169. Приказ Минюста России от 20 августа 2007 г. № 171 «О порядке представления и рассмотрения документов для подготовки распоряжений Министерства юстиции Российской Федерации о нежелательности пребывания (проживания) в Российской Федерации иностранных граждан и лиц без гражданства, подлежащих освобождению из мест лишения свободы» // Рос. газ. 2007. 5 сентября.

170. Приказ Федеральной службы по финансовому мониторингу от 11 января 2011 г. № 2 «Об утверждении Порядка принятия решения Федеральной службой по финансовому мониторингу о нежелательности пребывания (проживания) иностранных граждан или лиц без гражданства в Российской Федерации» // Рос. газ. 2011. 24 февраля.

171. Приказ МВД России от 10 ноября 2012 г. № 1024 «О порядке представления и рассмотрения в МВД России и его территориальных органах материалов для принятия решения о нежелательности пребывания (проживания) иностранного гражданина или лица без гражданства в Российской Федерации» // Рос. газ. 2013. 18 января.

172. Приказ ФСБ России от 13 ноября 2012 г. № 572 (в ред. от 6 февраля 2014 г.) «Об утверждении Административного регламента Федеральной службы безопасности Российской Федерации по предоставлению государственной услуги по выдаче пропусков для въезда (прохода) лиц и транспортных средств в пограничную зону, разрешений на хозяйственную, промысловую и иную деятельность, проведение массовых общественно-политических, культурных и других мероприятий, содержание и выпас скота в пограничной зоне, промысловую, исследовательскую, изыскательскую и иную деятельность в российской части вод пограничных рек, озер и иных водных объектов, где установлен пограничный режим»// Рос. газ. 2013. 3 апреля.

173. Приказ Министерства транспорта РФ от 17 января 2013 г. № 7 «Об утверждении Правил плавания в акватории Северного морского пути» // Рос. газ. 2013. 19 апреля.

\section{Нормативные правовые акты иностранных государств}

174. Australian Citizenship Act [электронный pecypc] https://www.legislation.gov.au/details/C2006C000317 (дата обращения 22.04.2016).

175. Executive Order 13660 - Blocking Property of Certain Persons Contributing to the Situation in Ukraine // Federal Register. Vol. 79. No. 46. Part I.V. March 10, 2014. URL: http://www.treasury.gov/resourcecenter/sanctions/Programs/Documents/ukraine_eo.pdf (дата обращения: 10.07.2014).

176. Executive Order 13661 - Blocking Property of Additional Persons Contributing to the Situation in Ukraine // Federal Register. Vol. 79. No. 53. Part I.V. $\quad$ March 19, 2014. URL:http://www.treasury.gov/resourcecenter/sanctions/Programs/Documents/ukra ine_eo2.pdf (дата обращения: 10.07.2014).

177. Executive Order 13662 - Blocking Property of Additional Persons Contributing to the Situation in Ukraine // Federal Register. Vol. 79. No. 56. Part I.V. March 24, 2014. URL: http://www.treasury.gov/resourcecenter/sanctions/Programs/Documents/ukraine_eo3.pdf (дата обращения: 
10.07.2014).

178. Treasury Sanctions Additional Individuals For Threatening The Territorial Integrity Of Ukraine / Sanctions Target Seven Separatists in Ukraine // U.S. Department of the Treasury. 20.06.2014. URL: http://www.treasury.gov/press-center/press-releases/Pages/j12438.aspx (дата обращения: 10.07.2014).

179. Constitutions of the countries of the world / Ed.H. Flanz. N.Y., 1995.

180. Counter-Terror and Security Act 2015[электронный pecypc] https://www.gov.uk/government/publications/factsheet-counter-terrorism-andsecurity-bill (дата обращения - 22.04.2016).

181. Конституции зарубежных государств: США, Великобритания, Франция, Германия, Италия, Испания, Греция, Япония, Канада / Сост. В.В. Маклаков. М.: Бек, 1997.

182. Конституции государств Америки / Под ред. Т.Я. Хабриевой. Т.1. Северная и Центральная Америка. М.: Институт законодательства и сравнительного правоведения при Правительстве Российской Федерации, 2006. $832 \mathrm{c}$.

183. Конституции государств Америки / Под ред. Т.Я. Хабриевой. Т.3. Южная Америка. М.: Институт законодательства и сравнительного правоведения при Правительстве Российской Федерации, 2006. 1168 с.

184. Конституции государств Азии / Под ред. Т.Я. Хабриевой. Т.3. Дальний Восток. М.: Институт законодательства и сравнительного правоведения при Правительстве Российской Федерации: Норма, 2010. 1040 c.

185. Human Rights Act of 1998. Электронный ресурс URL: http: //www.legislationonline.org/UK_Human_ Rights_Act_1998_as_of_2014_en.pdf (дата обращения 24.04.2016).

186. Russian Democracy Act of 2002. Электронный ресурc URL: http:// www.access.gpo.gov/nara/publaw/107publ.html (дата обращения 06.03.2016)

187. Sergei Magnitsky Rule of Law Accountability Act of 2012. Электронный pecypc URL: http :// www.gpo.gov/fdsys/pkg/Bills112hr4405ih.pdg (дата обращения 24.04.2016)

188. О введении санкций по отношению к Российской Федерации для обеспечения дополнительной помощи Украине, а также для других целей: Билль от 11 декабря 2014 г. № 2828. Электронный ресурс URL: https://www.congress.gov.bill/113th-congress/senate-bill/2828/text (дата обращения 20.03.2015).

\section{Судебная практика}

\section{Решения Международного Суда ООН}

189. Решение Международного Суда ООН от 9 апреля 1949 г. «Дело о проливе Корфу») // Краткое изложение решений, консультативных заключений и постановлении Международного Суда 1948 - 1991. Организация Объединенных Наций, Нью-Иорк, 1993. С. 6 - 9.

190. Решение Международного Суда ООН от 27 августа 1952 г. «Дело, касающееся прав граждан Соединенных Штатов Америки в Марокко» // Краткое изложение решений, консультативных заключений и постановлений 
Международного Суда 1948 - 1991. Организация Объединенных Наций, НьюИорк, 1993. С. $31-32$.

191. Решение Международного Суда ООН от 17 ноября 1953 г. «Дело об островах Менкье и Экрихос» // Краткое изложение решений, консультативных заключений и постановлений Международного Суда 1948 - 1991. Организация Объединенных Наций, Нью-Иорк, 1993. С. 33 - 35.

192. Решение Международного Суда ООН от 20 июня 1959 г. «Дело, касающееся суверенитета над некоторыми приграничными землями» // Краткое изложение решений, консультативных заключений и постановлений Международного Суда 1948 - 1991. Организация Объединенных Наций, НьюИорк, 1993. С. 62 - 64.

193. Решение Международного Суда ООН от 20 февраля 1969 г. «Дела о континентальном шельфе Северного моря» // Краткое изложение решений, консультативных заключений и постановлений Международного Суда 1948 1991. Организация Объединенных Наций, Нью-Йорк, 1993. С. 90 - 95.

194. Решение Международного Суда ООН от 19 декабря 1978 г. «Дело о континентальном шельфе Эгейского моря» // Краткое изложение решений, консультативных заключений и постановлений. Международного Суда 1948 1991. Организация Объединенных Наций, Нью-Йорк, 1993. С. 129 - 132.

195. Решение Международного Суда ООН от 26 ноября 1984 г. «Дело, касающееся военных и военного характера действий в Никарагуа и против Никарагуа (Никарагуа против Соединенных Штатов Америки) (юрисдикция и подсудность) // Краткое изложение решений, консультативных заключений и постановлений Международного Суда 1948 - 1991. Организация Объединенных Наций, Нью-Иорк, 1993. С. 175 - 183.

196. Решение Международного Суда ООН от 27 июня 1986 г. «Дело о военной и военизированной деятельности в Никарагуа и против Никарагуа (Никарагуа против Соединенных Штатов Америки) // Краткое изложение решений, консультативных заключений и постановлений Международного Суда 1948 - 1991. Организация Объединенных Наций, Нью-Иорк, 1993. С. 198 - 213.

197. International Court of Justice. Case «East Timor» (Portugal v. Australia). Judgment of 30 June 1995 / ICJ Reports 1995, para. 29.

198. International Court of Justice. Case concerning Avena and other Mexican nationals (Mexico v. USA). Judgment of 31 March 2004 URL: http://www.icjcij.org/docket/index.php?case=128\&code (дата обращения 11.09.2015)

199. International Court of Justice. Advisory Opinion of 22 July 2010 «Accordance with International Law of the Unilateral Declaration of Independence in Respect of Kosovo» URL: http://www.icj-cij.org/docket/files/141/ 15987.pdf (дата обращения 11.09.2015)

200. International Court of Justice. Case concerning Jurisdictional Immunities of the State (Germany v. Italy: Greece Intervening). Judgment of 3 February 2012 URL: http://www. icj-cij. org/docket/files/143/16883.pdf (дата обращения 11.09.2015)

\section{Решения Международного уголовного суда}

201. Warrant of Arrest for Omar Hassan Ahmad Al Bashir. Situation in Darfur, Sudan. No.: ICC-02/05-01/09. Date: 4 March 2009. In the case of The Prosecutor v. Omar Hassan Ahmad Al Bashir («Omar Al Bashir») // http: // www.icccpi.int/iccdocs/ doc/doc639078.pdf

202. Second Warrant of Arrest for Omar Hassan Ahmad Al Bashir. Situation in Darfur, Sudan. No.: ICC-02/05-01/09. Date: 12 July 2010. In the case of The 
Prosecutor v. Omar Hassan Ahmad Al Bashir («Omar Al Bashir») // http: // www.icccpi.int/iccdocs/ doc/doc907140.pdf

203. Warrant of Arrest for Muammar Mohammed Abu Minyar Gaddafi. Situation in the Libyan Arab Jamahiriya. No.: ICC-01/11. Date: 27 June 2011// http: // www.icc-cpi.int/iccdocs/ doc/doc1099321.pdf

204. Decision Pirsuant to Article 87 (7) of the Rome Statute on the Failure by the Republic of Malawi to Comply with the Cooperation Requests Issued by the Court with Respect to the Arrest and Surrender of Omar Hassan Ahmad Al Bashir. Situation in Darfur, Sudan. No.: ICC-02/05-01/09. Date: 12 December 2011. In the case of The Prosecutor v. Omar Hassan Ahmad Al Bashir («Omar Al Bashir») // http: // www.icccpi.int/iccdocs/ doc/doc1013912.pdf

\section{Постановления Европейского суда по правам человека}

205. Постановление Европейского Суда по правам человека от 21 февраля 1975 г. по делу «Голдер против Соединенного Королевства» (Golder v. UK) / Series A, № 18, pp.13-18.

206. Постановление Европейского Суда по правам человека от 25 апреля 1978 г. по делу «Тайрер против Соединенного Королевства» (Tyrer v. UK) / Series A, № 36, §30.

207. Постановление Европейского Суда по правам человека от 2 марта 1987 г. по делу «Матье-Моэн (Mathieu-Mohin) и Клерфейт (Clerfayt) против Бельгии» // Европейский Суд по правам человека. Избранные решения: в 2 т. М.: Норма, 2000 .

208. Постановление Европейского Суда по правам человека от 5 ноября 2002 г. по делу «Алан против Соединенного Королевства» (Allan v. UK) (№ 48539/99) // Бюллетень Европейского Суда по правам человека. Российское издание. 2003. № 4.

209. Постановление Европейского суда по правам человека от 30 марта 2004 г. «Дело Херст (Hirst) против Соединенного Королевства» (Hirst v. United Kingdom) (№ 74025/01) // Бюллетень Европейского Суда по правам человека. Российское издание. 2006. № 4.

210. Постановление Европейского Суда по правам человека от 22 июня 2004 г. по делу «Брониовский против Польши» (Broniowski v. Poland), № 31443/96 // Бюллетень Европейского Суда по правам человека. Российское издание. 2004. № 11 .

211. Постановление Европейского Суда по правам человека от 29 марта 2006 г. по делу «Скордино против Италии» (Scordino v. Italy) (№ 36813/97) // Бюллетень Европейского Суда по правам человека. Российское издание. 2006. № 11 .

212. Постановление Европейского Суда по правам человека от 6 февраля 2007 г. по делу «Дойл против Соединенного Королевства» (Doyle v. UK) // Бюллетень Европейского Суда по правам человека. Российское издание. 2007. № 8 .

213. Постановление Европейского Суда по правам человека от 8 апреля 2010 г. по делу «Фродль против Австрии» (Frodl v. Austria) (жалоба №20201/04) // Информационный бюллетень по прецедентной практике Европейского Суда по правам человека. 2010, № 129. 
214. Постановление Европейского Суда по правам человека от 17 мая 2010 г. по делу «Кононов против Латвии» (Kononov v. Latvia), № 36376/04. // Бюллетень Европейского Суда по правам человека. Российское издание. 2010. № 8 .

215. Постановление Европейского Суда по правам человека от 7 октября 2010 г. по делу «Константин Маркин против Российской Федерации» (Konstantin Markin v. Russia), (жалоба № 30078/06), judgment of 7 October 2010; Grand Chamber judgment of 22 March 2012 // Бюллетень Европейского Суда по правам человека. Российское издание. 2012. № 6.

216. Постановление Европейского Суда по правам человека от 18 марта 2011 г. по делу «Лаутси и другие против Италии» (Lautsi and others v. Italy), № 30814/06. // Бюллетень Европейского Суда по правам человека. Российское издание. 2011. № 6.

217. Постановление Европейского Суда по правам человека от 22 мая 2012 г. по делу «Скоппола против Италии» (Scoppola v. Italy) (жалоба № 74025/01) // Бюллетень Европейского Суда по правам человека. Российское издание. 2012, № 11.

218. Постановление Европейского Суда по правам человека от 4 июля 2013 г. по делу «Анчугов и Гладков против России» (Anchugov and Gladkov v. Russia), №№ 11157/04, 15162/05 // Бюллетень Европейкого Суда по правам человека. Российское издание. 2014. № 2.

\section{Постановления высших органов конституционного правосудия и судов общей юрисдикции иностранных государств}

219. Постановление Федерального Конституционного Суда ФРГ от 12 октября 1993 г. Maastricht-Urteil des Bundesverfassungsgerichtes vom 12.10.1993 // http: //www.europarl.europa.eu/brussels/website /media /Basis /Vertraege /Pdf/Maastricht_Urteil_1993.pdf (дата обращения 08.09.2014).

220. Постановление Конституционного Суда Венгерской Республики от 22 января 1997 г. HUN-1997-1-001 http: //www.codices.coe.int/gateway.dll/ codices/full/eur/hun/ger/hun-1997-1-001 (дата обращения 10.10.2015).

221. Judgment of the Supreme Court of Canada Concerning Certain Questions Relating to the Secession of Quebec from Canada, 1998, para. 130. http://scc.lexum.org/decisia-scc-csc/scc-csc/scc-csc/en/item/1643/index.doc (дата обращения 08.09.2014).

222. Постановление Федерального Конституционного Суда ФРГ от 14 октября 2004г. Пергюлю http://www.bundesverfassungsgericht.de/en/decisions/rs20041014_2bvr148104en. html (дата обращения 09.10.2015).

223. Постановление Конституционного Суда Итальянской Республики от 19 ноября 2012 г. Judgment No. 264. 19 November 2012 // http: // www.cortecostituzionale.it/ documenti/ download/ doc/recent_judgments/ S2012264_Quaranta_Morelli_en.pdf (дата обращения 08.09.2014).

\section{Судебные постановления судов общей юрисдикции РФ (СССР)}

224. Постановление Пленума Верховного Суда СССР от 21 сентября 1977 г. № 11 «Об изменении и дополнении постановления Пленума Верховного Суда СССР от 18 марта 1970 г. № 4 «Об исчислении срока погашения судимости». [Текст не опубликован.] 
225. Постановление Пленума Верховного Суда РФ от 31 октября 1995 г. № 8 «О некоторых вопросах применения судами Конституции Российской Федерации при осуществлении правосудия» // Бюллетень Верховного Суда РФ. 1996. № 2 .

226. Постановление Пленума Верховного Суда РФ от 10 октября 2003 г. № 5 «О применении судами общей юрисдикции общепризнанных принципов и норм международного права и международных договоров Российской Федерации» // Бюллетень Верховного Суда РФ. 2003. № 12.

227. Постановление Пленума Верховного Суда РФ от 15 июня 2010 г. (с изм. от 9 февраля 2012 г.) № 16 «О практике применения судами Закона Российской Федерации «О средствах массовой информации» // Бюллетень Верховного Суда РФ. 2010. № 8.

228. Постановление Пленума Верховного Суда РФ от 27 июня 2013 г. № 21 «О применении судами общей юрисдикции Конвенции о защите прав человека и основных свобод от 4 ноября 1950 г. и Протоколов к ней» // Бюллетень Верховного Суда РФ. 2013. № 8.

229. Решение Верховного Суда РФ от 14 февраля 2003 г. № ГКПИ 03-116 «О признании террористическими организаций «Высший военный Маджлисуль Шура Объединенных сил моджахедов Кавказа», «Конгресс народов Ичкерии и Дагестана», «База» («Аль-Каида»), «Асбат аль-Ансар», «Священная война» («Аль-Джихад» или «Египетский исламский джихад»), «Исламская группа» («Аль-Гамаа аль-Исламия»), «Братья-мусульмане» («Аль-Ихван альМуслимун»), «Партия исламского возрождения» («Хизб ут-Тахрир альИслами»), «Лашкар-И-Тайба», «Исламская группа» («Джамаат-и-Ислами»), «Движение Талибан», «Исламская партия Туркестана» (бывшее «Исламское движение Узбекистана»), «Общество социальных реформ» («Джамият аль-Ислах аль-Иджтимаи»), «Общество возрождения исламского наследия» («Джамият Ихья ат-Туразаль аль-Ислами»), «Дом двух святых» («Аль-Харамейн») и запрещении их деятельности на территории РФ.

230. Решение Верховного Суда РФ от 2 июня 2006 г. № ГКПИ 06-531 «О признании организаций «Джунд аш-Шам» и «Исламский джихад - Джамаат моджахедов» террористическими и запрете их деятельности на территории Российской Федерации».

231. Решение Верховного суда РФ от 13 ноября 2008 г. № ГКПИ 08-1956 «О признании международной организации «Аль-Каида в странах исламского Магриба» террористической и запрете еe деятельности на территории Российской Федерации».

232. Решение Верховного Суда РФ от 7 мая 2009 г. № ГКПИ 09-525 «О признании международного религиозного объединения «Таблиги Джамаат» экстремистским и запрете его деятельности на территории Российской Федерации».

233. Решение Верховного Суда РФ от 8 февраля 2010 г. № ГКПИ 09-1715 «O признании международной организации «Имарат Кавказ» («Кавказский Эмират») террористической и запрете ее деятельности на территории Российской Федерации».

234. Решение Верховного Суда РФ от 15 сентября 2010 г. № ГКПИ 10-848 «О признании международного религиозного объединения «Ат-Такфир ВальХиджра» экстремистским и запрете его деятельности на территории Российской Федерации». 
235. Решение Верховного Суда РФ от 17 ноября 2014 г. № АКПИ 14-1292 С «О признании украинских организаций «Правый сектор», «Украинская национальная ассамблея - Украинская народная самооборона» (УНА-УНСО), «Украинская повстанческая армия» (УПА), «Тризуб им. Степана Бандеры», «Братство» экстремистскими и запрете их деятельности на территории Российской Федерации».

236. Решение Верховного Суда РФ от 29 декабря 2014 г. № АКПИ 14-1424 $\mathrm{C}$ «O признании международных организаций «Исламское государство» и «Джебхат ан-Нусра» террористическими и запрете их деятельности на территории Российской Федерации».

\section{Литература}

237. Абашидзе A., Солниеев A. Международный Суд $\mathrm{OOH}$ и одностороннее провозглашение независимости Косово // Обозреватель Observer. 2010. № 8., № 10.

238. Авакьян C.A. Конституция России: природа, эволюция, современность. М.: Рос. юрид. изд. Дом, 1997. 512 с.

239. Акимиева Я.В. Формы защиты государственного суверенитета / Проблемы современного российского права. Сб. статей междунар. науч.практ. конф. Челябинск, 2009.

240. Алексеев С.С. Государство и право. М.: Проспект, 2015.

241. Алешин B.B. Интернирование и вооруженный конфликт // Международное публичное и частное право. 2006. № 3.

242. Алешин B.B. Правовые основы применения режима чрезвычайного положения и режима контртеррористической операции // Современное право. 2006. № 4.

243. Алешин В.В., Остроухов Н.В. Теоретические и методологические основы использования основных правовых режимов в период вооруженных конфликтов. М.: Юрлитинформ, 2008. 134 с.

244. Ананьева E. Проблемы гуманитарной интервенции и защиты граждан за рубежом // Международная жизнь. 2009. № 7.

245. Багдасарян В.Э. Государственная идеология как фактор национального суверенитета / Государственная идеология и современная Россия. Мат-лы Всерос. науч. - обществ. конф. М.: Наука и политика, 2014.

246. Барциц И.Н. Институт федерального вмешательства: потребность в разработке и система мер // Государство и право. 2001 . № 5.

247. Бжезинский 3. Великая шахматная доска. Господство Америки и его геостратегические императивы. М.: Международные отношения, 1998. $256 \mathrm{c}$.

248. Бжезинский 3. Выбор: мировое господство или глобальное лидерство. М.: Международные отношения, 2010. 264 с.

249. Бжезинский 3. Стратегический взгляд: Америка и глобальный кризис. М.: Астрель, 2012. 285 с.

250. Бордачев T.B. «Новый интервенционизм» и современное миротворчество. М., 1998. 159 с.

251. Борисов И.Б. Электоральный суверенитет. М.: РОИИП, 2010.

252. Будылин С.Л. Конвенция или Конституция? Международное право и пределы государственного суверенитета // Закон. 2013. № 12 . 
253. Бьюкенен $A$. Сецессия. Право на отделение, права человека и территориальная целостность государства. М.: Рудомино, 2001. 238 с.

254. Ведерников Н.Т., Петренко Д.С. Конституционное правосудие (теоретические, исторические и организационные основы) : Монография. М.: РГТЭУ, 2009. $323 \mathrm{c}$.

255. Венгеров А.Б. Теория государства и права. М.: Омега-Л, 2014. 607 c.

256. Внешняя политика России. Теория и практика / Под общей ред. С.В. Смульского, О.Д. Абрамовой М.: Книга и бизнес, 2013. 543 с.

257. Глигич - Золотарева М.В. Проблема суверенитета: на стыке права и политики // Федерализм. 1999. № 3.

258. Глигич - Золотарева М.В. Институт федерального вмешательства в системе конституционно-правовой ответственности / Конституционноправовая ответственность: проблемы России, опыт зарубежных стран. М., 2001.

259. Голинков Д.Л. Крушение антисоветского подполья в СССР. Книга 1. М.: Изд-во полит. лит-ры, 1986. 333 с.

260. Голинков Д.Л. Крушение антисоветского подполья в СССР. Книга 2. М.: Изд-во полит. лит-ры, 1986. 397 с.

261. Горюнов B.B. Государственный суверенитет как конституционноправовая конструкция // Академический юридический журнал. 2005. № 4.

262. Джагарян A.A. Концепция суверенной демократии в конституционном измерении / Суверенная демократия в конституционноправовом измерении. Сб. статей и материалов. М.: Рос. газ., 2007.

263. Доклад Международного Суда 1 августа 2009 г. - 31 июля 2010 г. Генеральная Ассамблея. Официальные отчеты. 65 сессия. Дополнение № 4. Нью-Иорк, OOH, 2010. URL: http://www.icj-cij.org/homepage/ru/reportes/report (дата обращения 11.09.2015)

264. Дугин А. Основы геополитики. Геополитическое будущее России. Мыслить пространством. М., 1999. 928 с.

265. Зорькин В.Д. Об угрозах конституционного строя в ХХІ веке и необходимости проведения правовой реформы в России // Журнал российского права. 2004. № 6.

266. Зорькин В. Предел уступчивости // Рос. газ. 2010. 29 октября.

267. Зорькин В.Д. Конституция против криминала // Рос. газ. 2010. 10 декабря.

268. Зорькин В.Д. Право в условиях глобальных перемен : Монография. М.: Норма, 2013. 496 c.

269. Зорькин В.Д. Право против хаоса. М.: Редакция «Российской газеты», 2016. Вып. 13. 176 с.

270. Иванов C. Сепаратизм - угроза государственности или борьба за независимость? // Зарубежное военное обозрение. 2015. № 8.

271. Исследование деструктивных технологий «цветных революций» и профилактика возможности их применения в Российской Федерации. М.: ВНИИ МВД России, 2014. 86 с.

272. Кара-Мурза С.Г. Экспорт революции. Ющенко, Саакашвили... М.: Изд-во Алгоритм, 2005. 
273. Карапетян Г.М. Грани суверенитета и самоопределение народов // Государство и право. 1993. № 1.

274. Карташкин B.A. Соотношение принципов уважения прав человека и государственного суверенитета // Юрист-международник. 2006. № 1.

275. Карташкин B.A. Права человека: международная защита в условиях глобализации. М., 2009. 288 с.

276. Керимов А.Д. Современное государство: вопросы теории. М.: Норма, 2007. $144 \mathrm{c.}$

277. Керимов А.Д. Государственная организация общественной жизнедеятельности. Вопросы теории. М.: Норма, 2014. 192 с.

278. Князев С.Д. Конституционный Суд в правовой системе Российской Федерации // Журнал российского права. 2013. № 12.

279. Ковалев A.A. Глобализация и вопрос трансформации государственного суверенитета // Евразийский юридический журнал. 2012. № $11(54)$.

280. Козырев A.А. Проблемы соотношения государственного суверенитета Российской Федерации и государственной власти ее субъектов // Право и политика. 2003. № 5.

281. Кокошин A.A. Реальный суверенитет в современной мирополитической системе. М.: Европа, 2006. 180 с.

282. Колосова Н.М. Конституционная ответственность в Российской Федерации: Монография. М.: Городец, 2000. 192 с.

283. Колосова H.M. Право каждого на международную судебную защиту и государственный суверенитет // Народовластие и права человека. Материалы IV Междунар. науч.-практ. конф. М.: РАП, 2012.

284. Комментарий к Конституции Российской Федерации / Под ред. В.Д. Зорькина, Л.В. Лазарева. М.: Эксмо, 2009. 1056 с.

285. Конуров А.И. Государственный суверенитет в условиях глобализации. Автореферат дис. ...докт. полит. наук. М., 2012. 45 с.

286. Конуров А.И. Предпосылки зарождения и формирования государственного суверенитета // Право и образование. 2015. № 2 .

287. Красинский B.B. Правовое обеспечение защиты конституционного строя России в избирательном процессе. Монография. М.: Новый индекс, 2010. 340 с.

288. Красинский B.B. Организованная преступность на выборах и в российских органах власти. М.: Юрлитинформ, 2014. 224 с.

289. Кремянская E.A. Вопросы суверенитета в практике Конституционного Суда Российской Федерации // Право и власть. 2002. № 2.

290. Крылов Б.С. Государственный суверенитет: современные проблемы // Конституционное и муниципальное право. М.: Юрист, 2008. № 6 .

291. Кукушкина С.M. Влияние глобализации на государственный суверенитет: положительные и отрицательные моменты // Пробелы в российском законодательстве. М.: Медиа-ВАК, 2011. № 1.

292. Малько А.В., Ньикков В.В., Шундиков К.В. Теория государства и права. М.: Норма: Инфра-М, 2014. 432 с. 
293. Мамонов В.В. Государственный суверенитет и территориальная целостность - главные принципы современной российской государственности // Государство и право. 2004. № 4.

294. Марченко Е.И. Идея суверенитета в государственно-правовых учениях российских консерваторов второй половины XIX - XX вв. Автореф. дис. ... канд. юрид. наук. Ростов-на-Дону, 2009. 28 с.

295. Марченко М.Н. Государственный суверенитет: проблемы определения понятия и содержания // Правоведение. СПб.: Изд-во С.Петербург. ун-та, 2003. № 1.

296. Матузов Н.И., Малько А.В. Теория государства и права. М.: РАНХиГС, 2014. 528 с.

297. Международное право / под ред. А.А. Ковалева, С.В. Черниченко. М.: Омега - Л, 2006. 832 с.

298. Международное публичное право / под ред. К.А. Бекяшева. М.: ТК Велби, Проспект, 2007. 784 с.

299. Мелешкина T.C. Политико-правовые механизмы защиты суверенитета российского государства. Дис. ... канд. юрид. наук. Ростов-наДону, 2008.

300. Мелков Г.M. Гуманитарное вмешательство (международноправовые аспекты) // Московский журнал международного права. 2000. № 3 (39).

301. Мордовиев А.Ю. Единство и суверенитет государственной власти в отечественной политико-правовой доктрине XI-XVI веков // Философия права. Ростов-на-Дону: Изд-во Рост. юрид. ин-та МВД России, 2012. № 2.

302. Морозова А.С., Карасев А.Т. Некоторые подходы к пониманию государственного суверенитета // История государства и права. 2014. № 2.

303. Николаев А.М. Решения Европейского Суда по правам человека и государственный суверенитет Российской Федерации // Права человека и национальная безопасность: материалы междунар. науч.-практ. конф. М.: Изд-во Моск. гуманит. ун-та, 2011.

304. Носов С.И. Суверенитет государства в условиях глобализации: новые угрозы и вызовы // Право и образование. 2015. № 3.

305. Пастухова Н.Б. Международная интеграция и государственный суверенитет // Государство и право. М.: Наука, 2006. № 10.

306. Пастухова Н.Б. Проблемы государственного суверенитета М.: Норма, 2006. 288 с.

307. Пастухова Н.Б. Суверенитет и федеративная организация российского государства в условиях глобализации: конституционноправовые аспекты. Дис. ...докт. юрид наук. М.: РАГС, 2010.

308. Поветкина H.A. Проблемы правовой квалификации золотовалютных резервов (запасов) Российской Федерации и их роль в обеспечении финансовой устойчивости государства // Законодательство и экономика. 2016. № 2.

309. Понкин И.В. Технологии «мягкой силы» как средство дисфункционализации и разрушения государства // Право и образование. 2014. № 12 .

310. Проблема суверенности современной России / Мат-лы Всерос. научн. - общ. конф. М.: Центр научной политической мысли и идеологии, 2014. $617 \mathrm{c}$. 
311. Радько Т.Н. Теория государства и права. М.: Проспект, 2015.

312. Рияд Т.Ш. Соотношение международного и внутригосударственного (национального) права: теоретические аспекты. Дис. ...канд. юрид. наук. М.: РУДН, 2003.

313. Романова Ю.В. Национально-государственный суверенитет и международный порядок // Вестник Челябинского государственного университета. Челябинск: Изд-во ЧелГУ, 2009, Вып. 19. № 15.

314. Сеидов A.B. Международное право в эпоху глобализации. Эволюция концепции государственного суверенитета. М.: Научная книга, 2005. $154 \mathrm{c}$.

315. Сивков K. Профилактика «цветного» недуга // Военнопромышленный курьер. 2013. № 18 (486).

316. Советское государственное право. М.: Высшая школа, 1978. 439 с.

317. Сундиев И.Ю., Смирнов А.А., Кундетов А.И., Федотов В.П. Теория и практика информационного противодействия экстремистской и террористической деятельности : монография. М.: ВНИИ МВД России, 2014. $247 \mathrm{c}$.

318. Тарасова Л.Н. К дискуссии о правомерности гуманитарной интервенции // Вестник Волгоград. гос. ун-та. Сер. 5, Юриспруд. 2011. № 1.

319. Теория государства и права / Под ред. д-ра юрид. наук профессора В.Н. Струнникова. М.: ВКШ КГБ СССР., 1987.392 с.

320. Тихомиров Ю.А. Суверенитет в условиях глобализации // Право и политика. 2006. № 11.

321. Ткаченко Д.В. Юридические механизмы противодействия сепаратизму в современной России : Дис. ...канд. юрид. наук. Ростов н/Д, 2007.

322. Троиикая A.A. Государственный суверенитет: ограничение или трансформация содержания // Конституционное и муниципальное право. 2006. № 10 .

323. Ушаков Н.A. Суверенитет в современном международном праве. М.: Изд-во Ин-та междунар. отношений, 1963. 272 с.

324. Ушаков Н.A. Невмешательство во внутренние дела государства. М.: Международные отношения, 1971. 168 с.

325. Черняк Л.Ю. Общетеоретические проблемы государственного суверенитета. Дис. ... канд. юрид. наук. Челябинск, 2007.

326. Черняк Л.Ю. Теории отрицания государственного суверенитета: основные подходы //Академический юридический журнал. Иркутск, 2008, № $1(31)$.

327. Черняк Л.Ю. Общетеоретические проблемы государственного суверенитета в федеративных государствах. Иркутск: Институт законодательства и правовой информации им. М.М. Сперанского, 2009. 164 c.

328. Чиркин B.E. Пределы ведения федерации и ее субъектов: разграничение, сотрудничество, субсидиарность // Государство и право. 2002. № 4 .

329. Чиркин B.E. Государствоведение. М.: МПСУ, Воронеж, 2012. 480 c. 
330. Чобан А.А. Государственный суверенитет: теоретико-правовые аспекты. Дис. ... канд. юрид. наук. М., 1993. 166 с.

331. Шевиов В.C. Государственный суверенитет. Вопросы теории. М.: Наука, 1979. 300 c.

332. Шуберт T.Э. Имплементация решений ЕСПЧ в национальном законодательстве // Журнал российского права. 2015. № 6.

333. Эбзеев Б.С. Личность и государство в России: взаимная ответственность и конституционные обязанности. М.: Норма, 2011. 384 с.

334. Экстремизм: стратегия противодействия и прокурорский надзор: монография / П.В. Агапов, С.В. Борисов и др. М.: Акад. Ген. прокуратуры $\mathrm{P} \Phi, 2015.428 \mathrm{c}$.

\section{Иностранная литература}

335. Bradley A. Enforcing the Avena decision in US courts [URL] // http://www.law.harvard.edu/students/orgs/jlpp/Vol30_No1_Bradleyonline.pdf (дата обращения: 05.08.2015).

336. Freedman L. Military intervention in european conflicts. L., 1994.

337. Gene Sharp. The politics of nonviolent action. Boston, Porter Sargent, 1973.

338. Greenwood Ch. Is there a right of humanitarian intervention // The World today. 1993. № 2. 02.02.2000.

339. Mayntz G. Geheime Pflege junger Demokratien // Rheinische Post.

340. Mercer P. Unease Grows over New Australian DUAL Citizenship Rules // BBC. 2015. June 1.

341. Nye. J. Soft Power. The means to success in world politics. New York: Public Affairs, 2004. P.10.

342. Renate Flottau, Erich Follath, Uwe Klussman, Georg Mascolo, Walter Mayr, Christian Neef. Die Revolutions-GmbH: Helden unserer Zeit - wie eine neue Generation autokratische Regime in Osteuropa und Zentralasien stuerzt // Der Spiegel. 14.11.2005.

343. Supervision of the execution of judgments and decisions of the European Court of Human Rights, Committee of Ministers' Annual report, 2011 [URL] // Council of $\quad$ Europe. Http://www. int $/ /$ dghl/monitoring/execution/Source/Publications/CM_annreport2011_en. pdf. (дата обращения: 02.08.2015).

344. Way L. The real causes of the color revolutions // Journal of Democracy, July 2008, Vol. 19, No. 3.

345. Weiss Th., Thakur R. The UN and Global Governance An Idea and its Prospects. University of Indiana Press, 2003. 


\section{Приложение 1.}

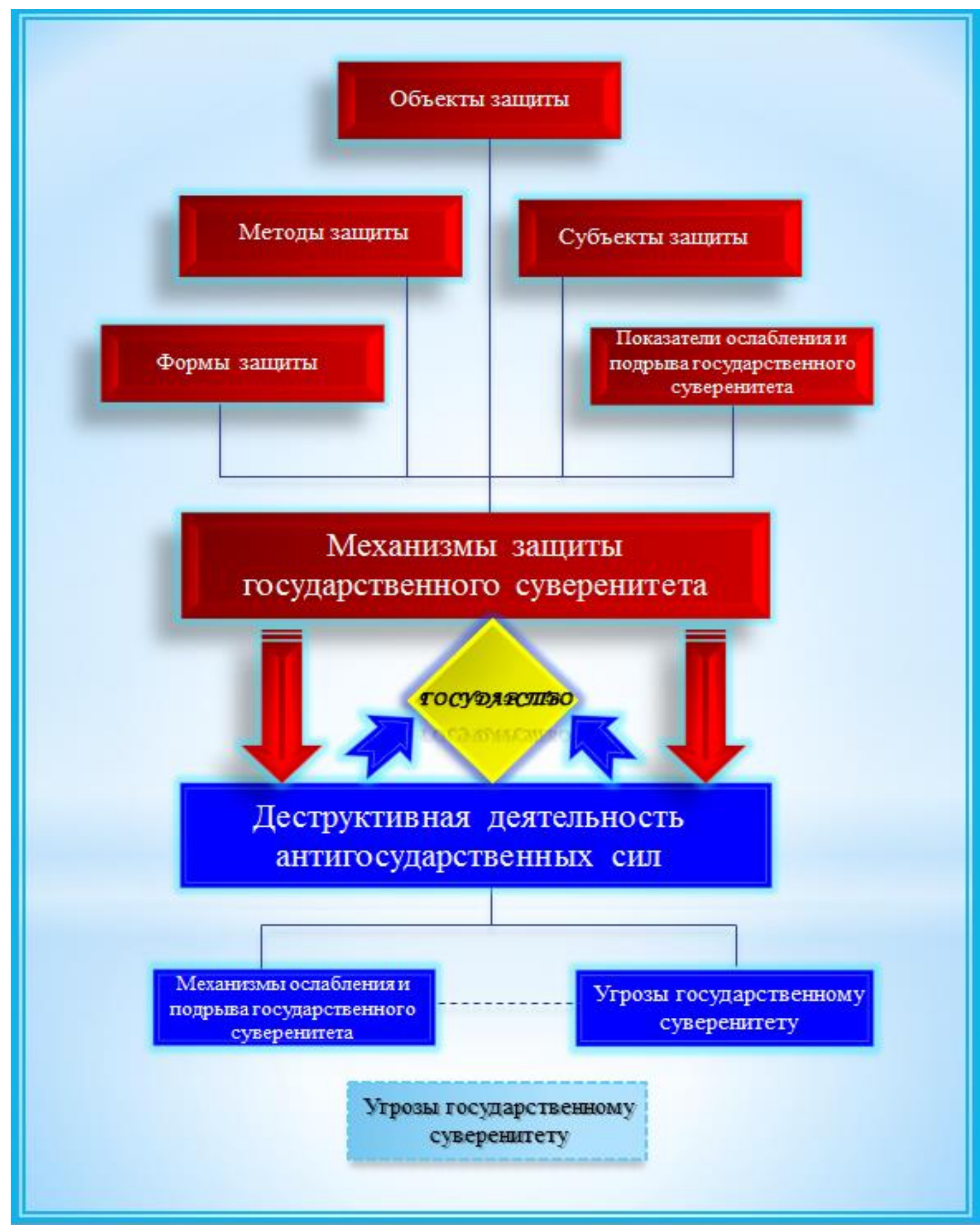


Приложение 2.

\section{МЕХАНИЗМЫ ОСЛАБЛЕНИЯ И ПОДРЫВА ГОСУДАРСТВЕННОГО СУВЕРЕНИТЕТА}

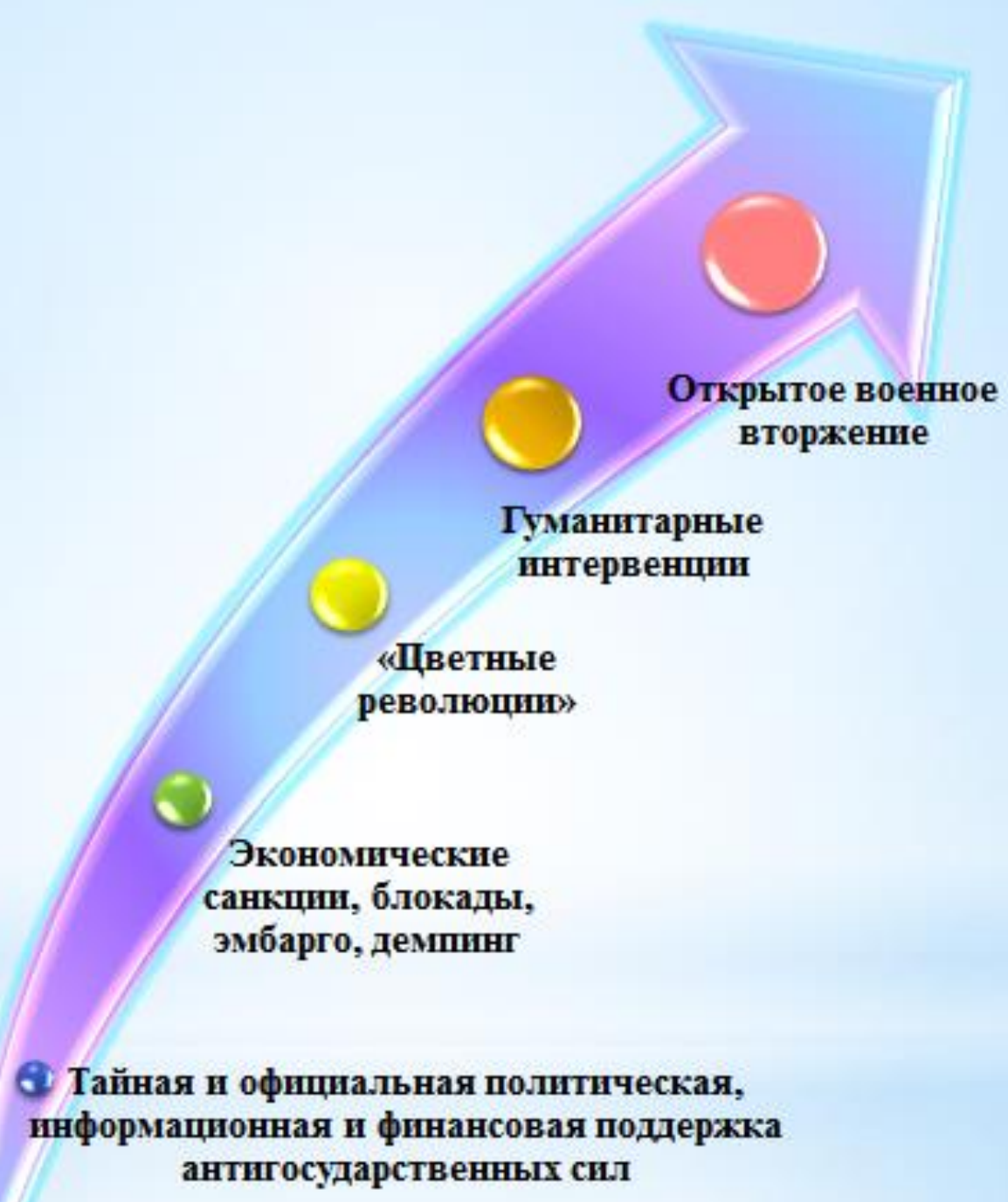


Приложение 3.

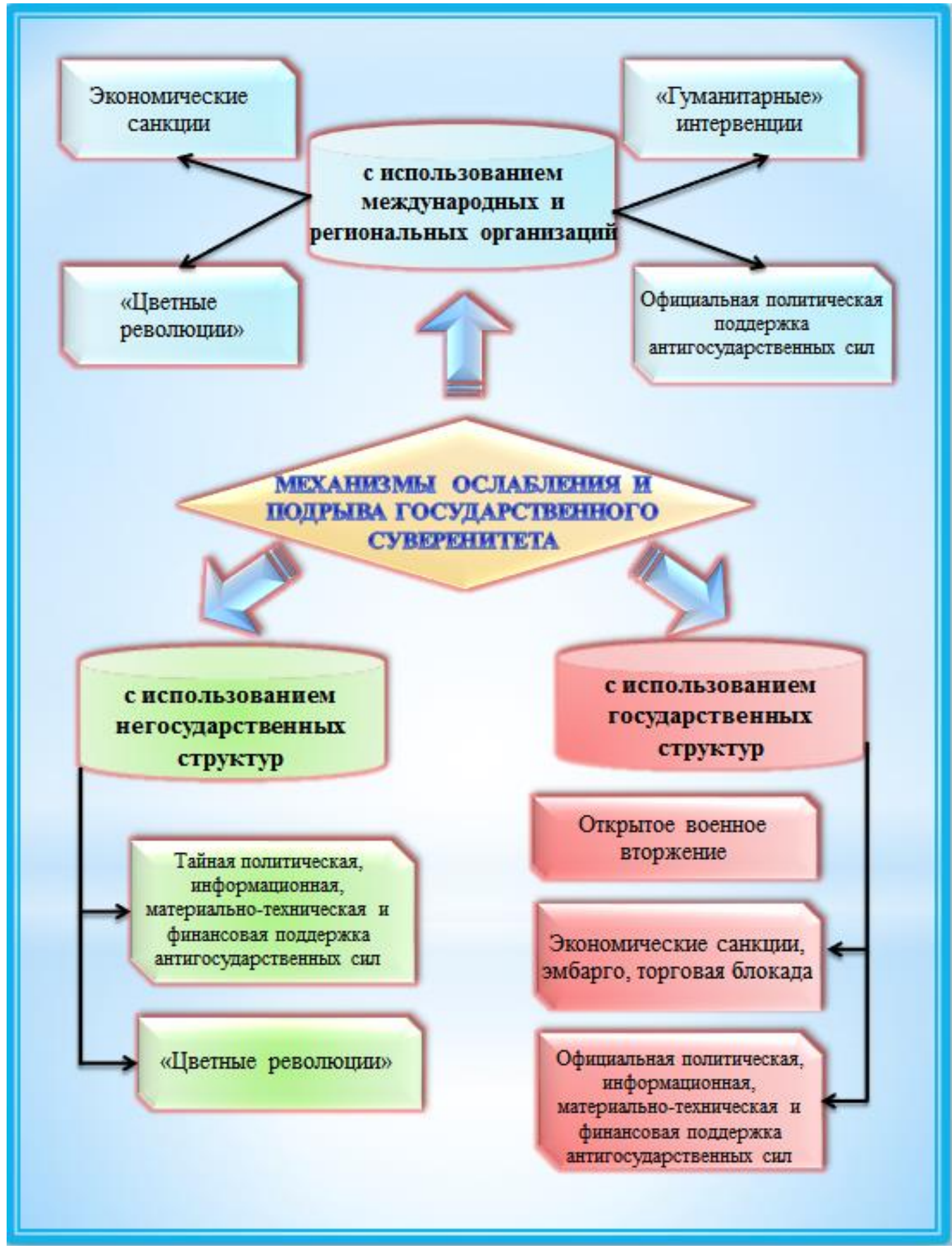


Приложение 4.

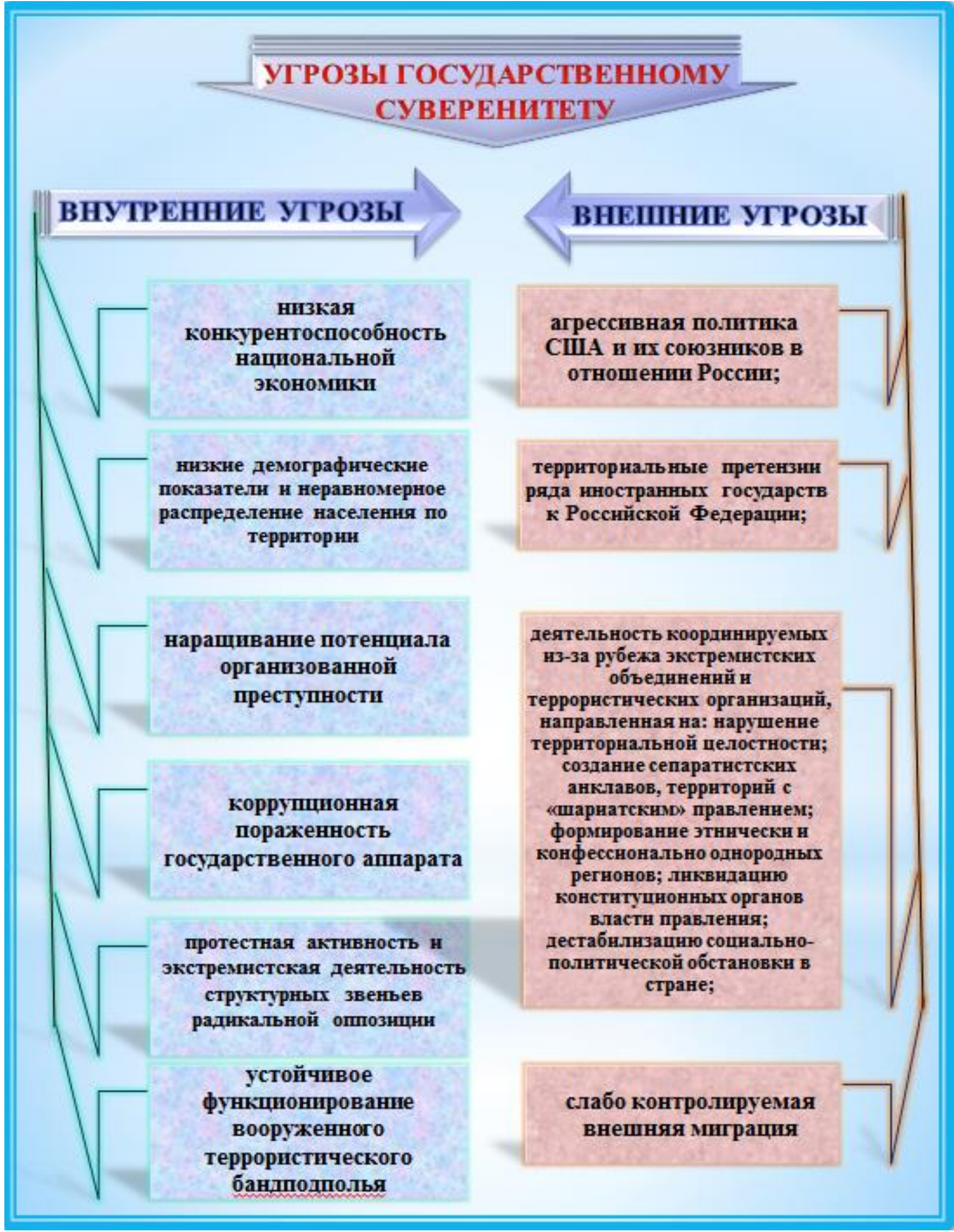




\section{Приложение 5.}

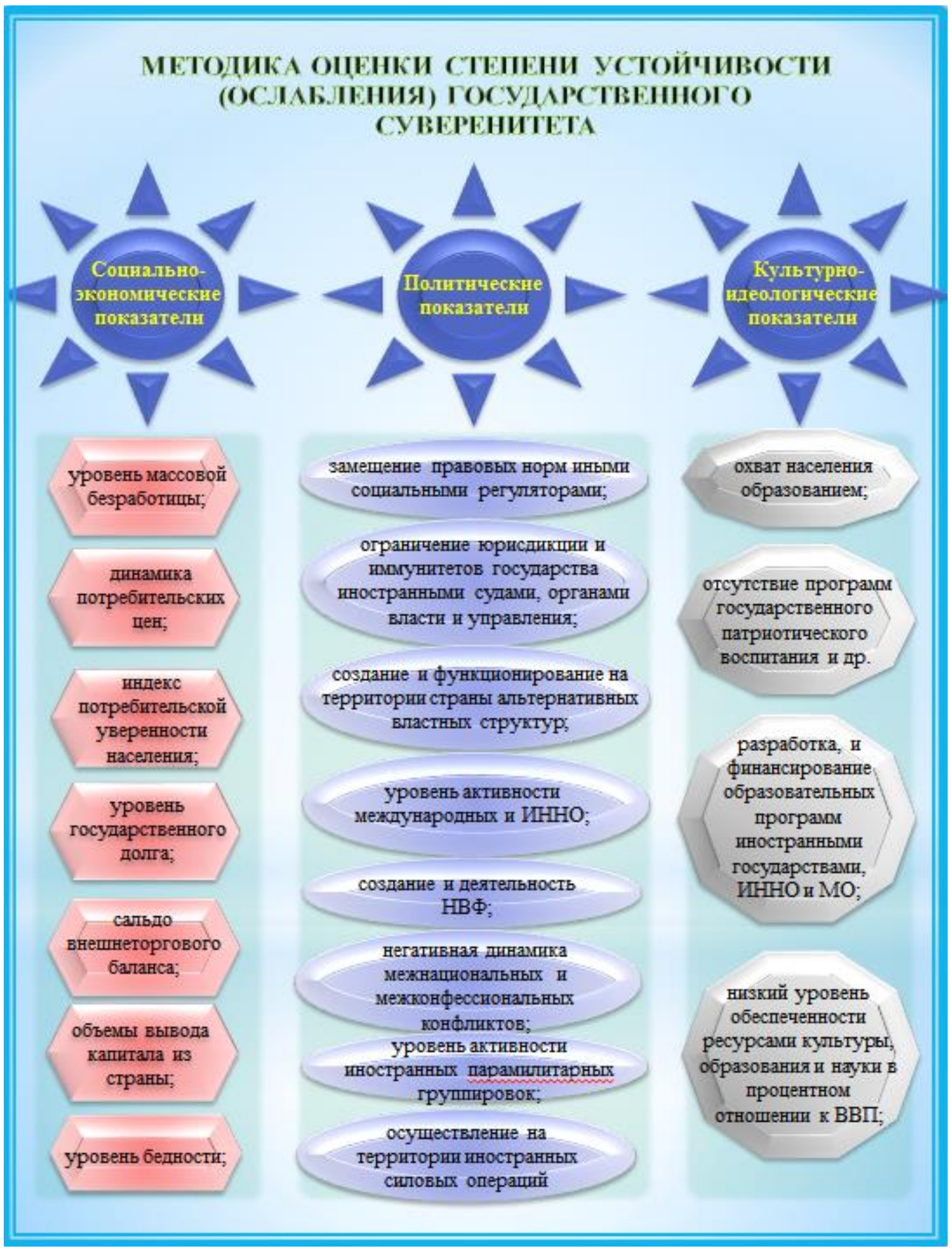




\section{Приложение 6.}

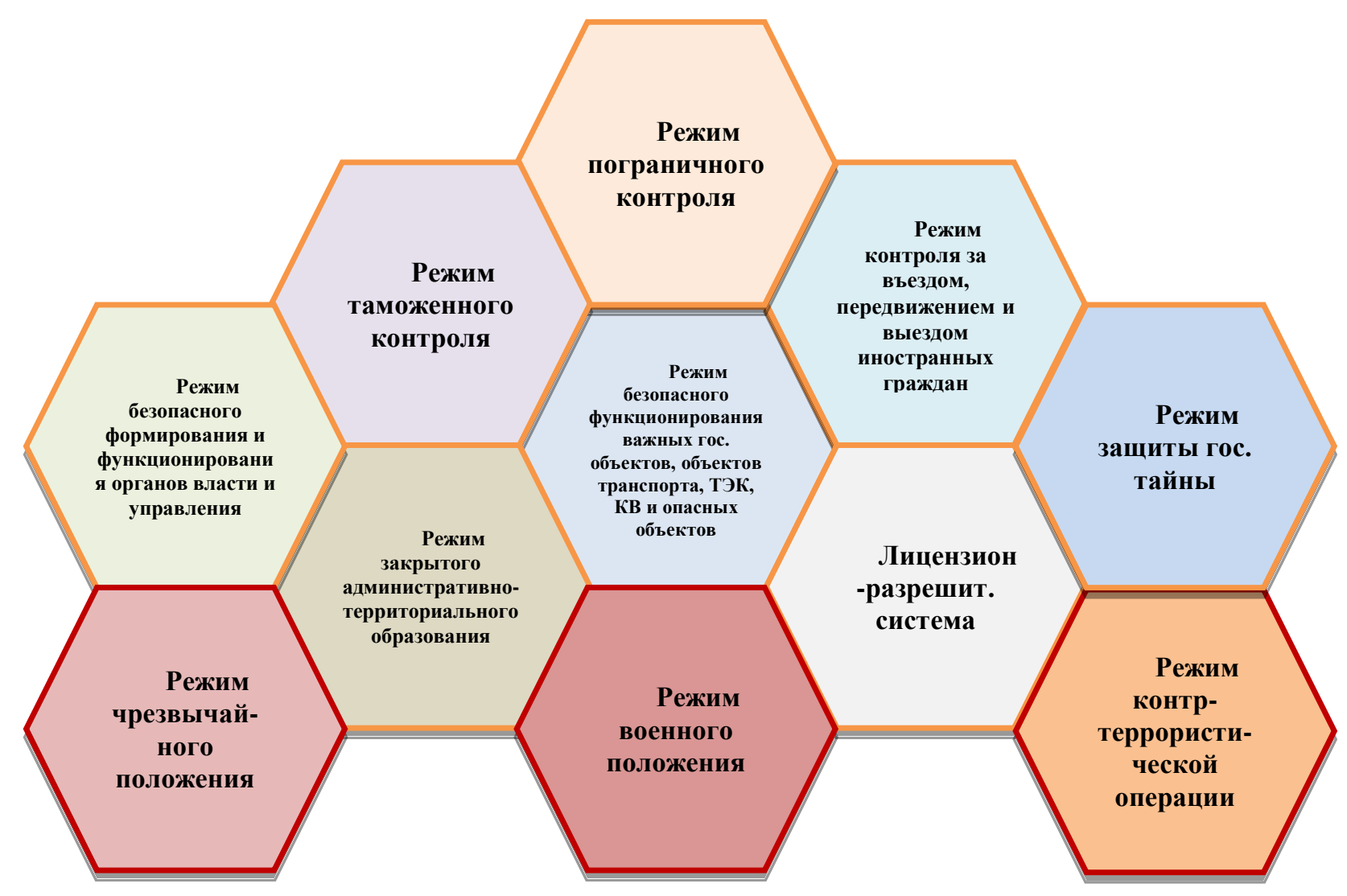

Комплексный правовой режим защиты государственного суверенитета 